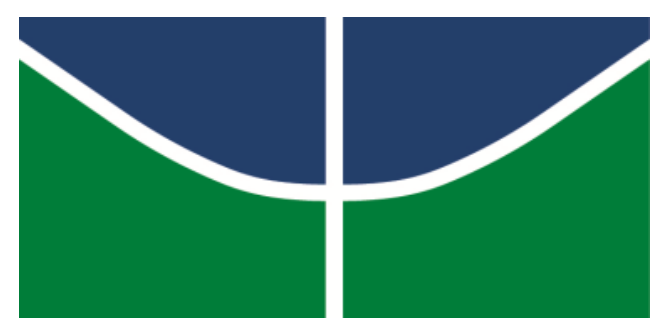

UNIVERSIDADE DE BRASÍLIA

PROGRAMA DE PÓS-GRADUAÇÃO EM HISTÓRIA - PPGHIS

REPRESENTAÇÕES DISCURSIVAS SOBRE O FEMINISMO NA I CONFERÊNCIA NACIONAL DE POLÍTICAS PARA AS MULHERES (2004)

ISABEL ESCOBAR CRESCENCIO

BRASÍLIA 


\title{
REPRESENTAÇÕES DISCURSIVAS SOBRE O FEMINISMO NA I CONFERÊNCIA NACIONAL DE POLÍTICAS PARA AS MULHERES
} (2004)

\author{
Dissertação apresentada à Banca Examinadora do \\ Programa de Pós-Graduação em História, da \\ Universidade de Brasília, como exigência para \\ obtenção do título de Mestra em História. \\ Orientadora: Prof ${ }^{\mathrm{a}}$. Dr ${ }^{\mathrm{a}}$. Susane Rodrigues de \\ Oliveira.
}

\section{BRASÍLIA}


FOLHA DE APROVAÇÃO

ISABEL ESCOBAR CRESCENCIO

\section{REPRESENTAÇÕES DISCURSIVAS SOBRE O FEMINISMO NA I CONFERÊNCIA NACIONAL DE POLÍTICAS PARA AS MULHERES (2004)}

Dissertação de Mestrado apresentada no Programa de Pós-Graduação em História da Universidade de Brasília como parte dos requisitos necessários à obtenção do grau de Mestra em História.

Aprovada em: 16 de Dezembro de 2016

\section{BANCA EXAMINADORA}

Prof $^{\mathrm{a}}$. Dr ${ }^{\mathrm{a}}$. Susane Rodrigues de Oliveira - PPGHIS - UnB

(Presidente)

Prof $^{a}$. Dr ${ }^{a}$. Diva do Couto Gontijo Muniz - PPGHIS - UnB

Prof ${ }^{a}$. Dr ${ }^{a}$. Maria Célia Orlato Selem - ADM/FACE/UnB

Prof. Dr ${ }^{\mathrm{a}}$. Liliane Maria Macedo Machado - FAC - UnB 
Em memória de Orlando, meu pai, a quem almejo orgulhar com cada passo do meu percurso de lutas e conquistas. 


\section{AGRADECIMENTOS}

Sou grata à minha orientadora, a professora $\operatorname{Dr}^{\mathrm{a}}$ Susane Rodrigues de Oliveira, pelo interesse e atenção direcionados ao tema desta dissertação, pela confiança em mim depositada, pelos conhecimentos que a mim foram transmitidos, pelo rigor acadêmico e pelo estímulo e apoio em todos os momentos para chegar ao fim deste trabalho.

Às professoras Dr ${ }^{\mathrm{a}}$ Diva do Couto Gontijo Muniz e Dr ${ }^{\mathrm{a}}$ Maria Célia Orlato Selem, por terem aceitado o convite para participar da Banca Examinadora deste trabalho, o que me causou imenso sentido de felicidade e de realização.

À coordenação e aos funcionários do Programa de Pós-Graduação em História da Universidade de Brasília, Rodolfo e Jorge, sempre foram atenciosos e prestativos com as burocracias do cotidiano.

Ao CNPQ (Conselho Nacional de Desenvolvimentos Cientifico e Tecnológico) pela concessão de bolsa de estudo fundamental para a realização desta pesquisa.

À Biblioteca Nacional de Brasília por disponibilizar o acervo do CFEMEA (Centro Feminista de Estudos e Assessoria), sem maiores obstáculos e contribuindo, significativamente, para o desenvolvimento desta pesquisa.

Às amigas da pós-graduação que caminharam comigo no laborioso percurso do mestrado, Renata Melo Barbosa do Nascimento, Jéssyca Lorena e Anne Caroline de Souza Quiangala João, pelos momentos vivenciados, pelas sugestões, vocês me ensinaram a virtude da humildade e resignificaram o sentido de companheirismo na vida acadêmica.

Aos amigos Victor Batista Maia Chaves e Juliana Machado, pela amizade de longa data, por desempenharem, com bastante satisfação, o papel de incentivadores, pois, por meio do seu apoio, me encorajaram à certeza da realização da pesquisa proposta neste trabalho. E, ainda, foram responsáveis por, em vários momentos estressantes, me proporcionar boas conversas, debates e risadas.

Aos professores Dr. Deusdedith Alvez Rocha Junior e Dr $^{\mathrm{a}}$ Cristiane de Assis Portela, pela amizade, por todo o conhecimento a mim proporcionado, pelo incondicional incentivo. Vocês, certamente, marcaram o meu percurso pelo conhecimento histórico.

À Joseane Rotatori Couri, pelo apoio incondicional em todos os momentos mais difíceis, pelas longas horas de conversas acerca dos feminismos e da história das mulheres, pela compreensão de minhas ausências e por compartilhar um pouco de minhas angústias e alegrias. 
Ao meu irmão Cláudio Escobar Crescencio, pela amizade e pelo apoio.

Por fim, agradeço à minha mãe, Marilda Escobar Crescencio, por, sempre, ter me apoiado, incentivado e acreditado em mim. Seus ensinamentos de vida me fazem acreditar e lutar por um mundo melhor, justo e equânime para nós, mulheres. 
Em toda sociedade machista e patriarcal, como a sociedade brasileira, as mulheres têm sido, historicamente, relegadas à invisibilidade e ao silêncio. Confinadas nos espaços privados, elas ficaram quase sempre fora dos espaços públicos, submersas no silêncio e na invisibilidade da vida privada, dedicadas à família e pouco conscientes do próprio valor e do seu papel na sociedade. Aos poucos, essa invisibilidade e esse silêncio se rompem e as mulheres começam a emergir e a ocupar espaços públicos, antes reservados exclusivamente aos homens, tanto no mundo do trabalho como nos demais campos da vida em sociedade.

Luiza Erundina (2008, p. 40). 


\section{RESUMO}

Essa dissertação apresenta uma análise das representações discursivas sobre o feminismo na I Conferência Nacional de Políticas para as Mulheres, realizada no ano de 2004 no Brasil. Privilegiaram-se, como fonte de pesquisa, os Anais dessa Conferência, que contêm as transcrições das falas pronunciadas por representantes do governo e de movimentos feministas e de mulheres durante esse evento. Os Anais da Conferência apresentam 18 falas, destas 12 mencionam o feminismo, das quais foram selecionadas 9 para análise. Trata-se de uma análise dos sentidos, significados, funções e implicações do feminismo em um espaço de debates, negociações e proposições de políticas para mulheres. Nesse caminho, foi necessário investigar as condições de produção da Conferência, bem como os valores, interesses, concepções, práticas, discursos, lugares sociais de fala (em termos de classe, raça e filiação institucional/grupal), normas, modos de interação e comunicação que informam as representações do feminismo. Desse modo, observou-se que o feminismo, ainda, continua a embasar os debates de políticas para as mulheres. Em boa parte das falas, o movimento feminista aparece como protagonista de um longo processo histórico, conferindo historicidade e anterioridade às lutas pelos direitos das mulheres, dando fundamento e dimensão às lutas que continuam no presente. Além disso, o feminismo aparece como uma perspectiva política, especialmente porque alguns movimentos têm reposicionado o feminismo, reconhecendo em suas pautas políticas as lutas, também, contra o racismo, a discriminação étnico-racial e sexual, dentre outras.

PALAVRAS-CHAVES: representações discursivas; feminismo; conferências nacionais; políticas públicas; mulheres. 


\begin{abstract}
This dissertation presents an analysis of the discursive representations about feminism at the I Conferência Nacional de Políticas para as Mulheres, held in 2004 in Brazil. The Annals of this Conference, which contains the transcriptions of the statements pronounced by representatives of the government and of feminist and women's movements during this event, were privileged as research source. The Conference's Annals present 18 lines, of which 12 mention feminism, from which 9 were selected for analysis. It is an analysis of the meanings, functions and implications of feminism in a space of debates, negotiations and propositions of public policies for women. In this way, it was necessary to investigate the Conference's production conditions, as well as the values, interests, conceptions, practices, discourses, social places of speech (in terms of class, race and institutional / group affiliation), norms and communication that inform the feminism's representations. Thus, it has been noted that feminism still continues to inform policy debates for women. The biggest part of the speech, the feminist movement appears as the protagonist of a long historical process, conferring historicity and priority to the struggles for women's rights, giving foundation and dimension to those struggles that continue in the present. In addition, feminism appears as a political perspective, especially since some movements have repositioned feminism, recognizing in their political guidelines, the struggles against racism, ethnic-racial and sexual discrimination, among others.
\end{abstract}

KEYWORDS: discursive representations; feminism; National conferences; public policy; women. 


\section{LISTA DE TABELAS}

Tabela 1: Menções ao termo "feminismo(s)" nos Anais da I CNPM ...................................... 21

Tabela 2: Quem menciona o termo "feminismo(s)" nos Anais da I CNPM ........................... 21

Tabela 3: Menções ao termo "feminista(s)" nos Anais da I CNPM ......................................... 22

Tabela 4: Quem menciona o termo "feminista(s)" nos Anais da I CNPM............................... 22

Tabela 5: Total de grupos e entidades declaradamente feministas........................................ 23

Tabela 6: Grupos e entidades que participaram da I CNPM ................................................ 24 


\section{LISTA DE FIGURAS}

Figura 1: Distribuição das pessoas que responderam ao questionário por origem geográfica. 64 Figura 2: Distribuição dos municípios representados na Conferência no total de municípios da região e dos país e distribuição das pessoas que responderam ao questionário por município de origem 65

Figura 3: Distribuição das pessoas que responderam ao questionário por características sócio demográficas

Figura 4: Distribuição das(os) delegadas(os) que responderam à pesquisa, segundo o tipo do curso superior que concluíram

Figura 5: Distribuição das pessoas que responderam ao questionário por características da sua situação familiar

Figura 6: Distribuição das pessoas que responderam ao questionário por características da sua atuação no mercado de trabalho 71

Figura 7: Distribuição das pessoas que responderam à pesquisa, segundo indicadores de instrução e rendimento. 72

Figura 8: Distribuição das pessoas que responderam ao questionário por características de atuação política e de representação na I CNPM 


\section{LISTA DE QUADROS}

Quadro 1: Distribuição das(os) delegadas(os) previstas(os) que responderam à pesquisa e do painel de amostra mínimo por UF 63

Quadro 2: Distribuição percentual das delegações previstas para a Conferência e das que responderam à pesquisa segundo região geográfica e/ou administrativa da representação ...... 66 


\section{LISTA DE ABREVIATURAS E SIGLAS}

ABMCJ

AMN

ANMTR

BPW/BRASIL

Brasil

$\mathrm{CECF} / \mathrm{SP}$

CEPAL

CEPIA

CGT

$\mathrm{CMB}$

CNDM

CNTE

CONAMI

CONTAG

CUT

FENATRAD

Geledés

I CNPM

I PNPM

IBAM

II CNPM

II PNPM

III CNPM

III PNPM

IV CNPM

MAMA

MMM

$\mathrm{OAB}$

ONG

PT

PUC
Associação Brasileira de Mulheres de Carreira Jurídica

Articulação de Mulheres Negras

Articulação Nacional de Mulheres Trabalhadoras Rurais

Federação das Associações de Mulheres de Negócios e Profissionais do

Conselho Estadual da Condição Feminina

Comissão Econômica para a América Latina e para o Caribe

Cidadania, Estudos, Pesquisa, Informação e Ação

Confederação Geral dos Trabalhadores

Confederação das Mulheres do Brasil

Conselho Nacional dos Diretos da Mulher

Confederação Nacional dos Trabalhadores em Educação

Conselho Nacional de Mulheres Indígenas

Confederação Nacional dos Trabalhadores na Agricultura

Central Única dos Trabalhadores

Federação Nacional das Trabalhadoras Domésticas

Instituto da Mulher Negra

I Conferência Nacional de Políticas para as Mulheres

I Plano Nacional de Políticas para as Mulheres

Instituto Brasileiro de Administração Municipal

II Conferência Nacional de Políticas para as Mulheres

II Plano Nacional de Políticas para as Mulheres

III Conferência Nacional de Políticas para as Mulheres

III Plano Nacional de Políticas para as Mulheres

IV Conferência Nacional de Políticas para as Mulheres

Movimento Articulado de Mulheres do Amazonas

Marcha Mundial de Mulheres

Ordem dos Advogados do Brasil

Organização não governamental

Partido dos Trabalhadores

Universidade Católica de São Paulo 
SEDIM

SEMULHER

SEPM

SEPPIR

$\mathrm{SOF}$

SOS Corpo

SPM

SUS

TO

UBM

USP

UNB

UFRJ

UERJ

UFMS
Secretaria de Estado dos Direitos da Mulher

Secretaria da Mulher do Governo do Estado de Alagoas

Secretaria Especial de Políticas para as Mulheres

Secretaria Especial de Políticas de Promoção da Igualdade Racial

Sempreviva Organização Feminista

Instituto Feminista para a Democracia

Secretária de Políticas para as Mulheres

Sistema Unificado de Saúde

Teatro do Oprimido

União Brasileira de Mulheres

Universidade de São Paulo

Universidade de Brasília

Universidade Federal do Rio de Janeiro

Universidade Estadual do Rio de Janeiro

Universidade Federal do Mato Grosso do Sul 


\section{SUMÁRIO}

INTRODUÇÃO .............................................................................................................. 13

CAPÍTULO 1 - AS CONDIÇÕES DE PRODUÇÃO DA I CONFERÊNCIA NACIONAL DE POLÍTICAS PARA AS MULHERES .............................................32

1.1 AS CONFERÊNCIAS NACIONAIS DE POLÍTICAS PÚBLICAS NO BRASIL........... 33

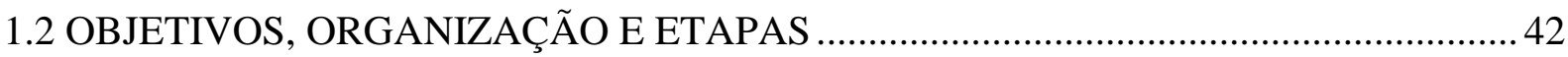

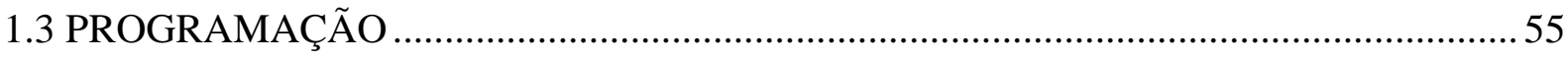

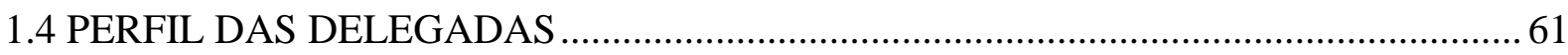

CAPÍTULO 2 - O FEMINISMO NAS FALAS DE ABERTURA DA I CONFERÊNCIA NACIONAL DE POLÍTICAS PARA AS MULEHRES.......................................................... 77

2.1 ESPETÁCULOS, HOMENAGENS E APROVAÇÃO DO REGULAMENTO ............... 77

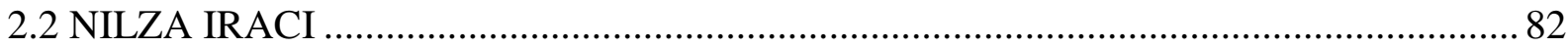

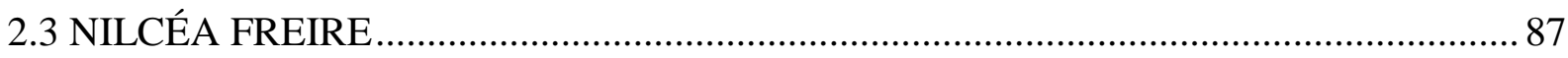

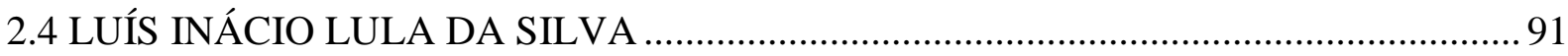

CAPÍtULO 3 - O FEMINISMO NAS AVALIAÇÕES DAS POLÍTICAS REALIZADAS E COMPROMISSOSASSUMIDOS PELO ESTADO BRASILEIRO ... 94

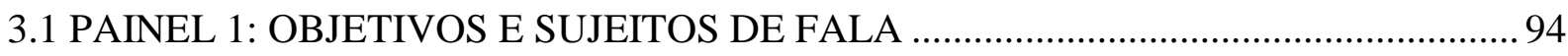

3.2 JACQUELINE PITANGUY: O FEMINISMO NA HISTÓRIA DAS LUTAS PELOS

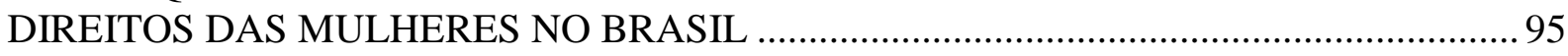

3.3 SUELI CARNEIRO: ENEGRECENDO O FEMINISMO ........................................... 106

3.4 JOSÉ DIRCEU: PAUTA E AVANÇOS DAS LUTAS FEMINISTAS ......................... 114

CAPÍTULO 4 - O FEMINISMO NAS PROPOSTAS DE CONSTRUÇÃO DO PLANO NACIONAL DE POLÍTICAS PARA AS MULHERES................................................118

4.1 PAINEL 2: OBJETIVOS E SUJEITOS DE FALA …................................................... 118

4.2 MARIA BETÂNIA ÁVILA: A TRANSFORMAÇÃO DO ESTADO EM UMA

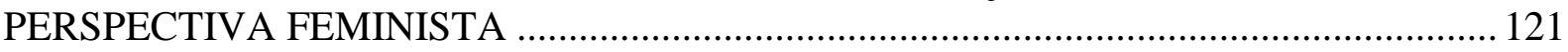

4.3 MATILDE RIBEIRO: AS DIVERSAS FORMAS DE ORGANIZAÇÃO FEMINISTA128

4.4 NALU FARIA: O FEMINISMO COMO INTRODUTOR DE QUESTÕES

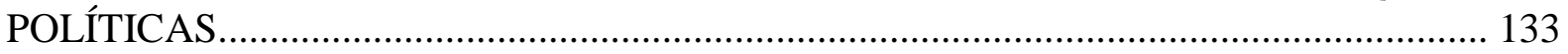

4.5 MARIA LAURA SALES PINHEIRO: DIÁLOGOS DO GOVERNO COM OS MOVIMENTOS DE MULHERES E FEMINISTAS ................................................... 135

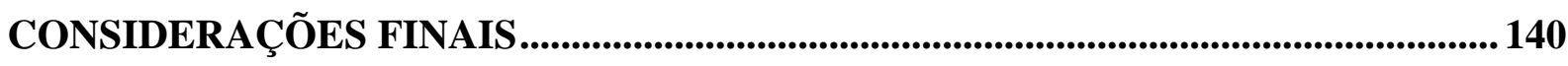


CORPUS DOCUMENTAL ................................................................................................. 146

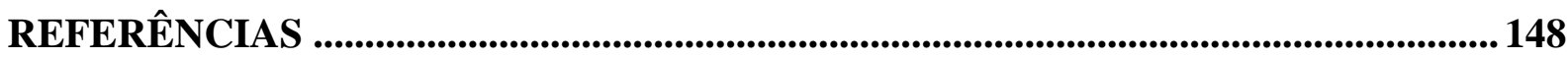

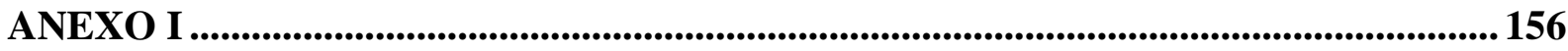




\section{INTRODUÇÃO}

A presente dissertação tem como tema de estudo as representações discursivas sobre o feminismo na I Conferência Nacional de Políticas para as Mulheres (I CNPM), realizada no ano de 2004 no Brasil. Trata-se dos resultados de uma pesquisa que se inscreve no campo da história das mulheres e que encontra o seu aporte teórico-metodológico nos estudos feministas e de gênero e na abordagem discursiva das representações (FOUCAULT, 1999; SPINK,2000; HALL, 1997).

É comum ouvirmos na mídia brasileira e nas conversas em nosso cotidiano que o feminismo acabou. Essa concepção sobre o fim dos feminismos acompanha a visão de que as mulheres já conquistaram todos os seus direitos e que não há mais a necessidade de ser feminista ou de evocar o feminismo como movimento de luta pelos direitos das mulheres. Nessa perspectiva, qualquer evocação ao feminismo pode ser vista como algo absurdo, ridículo ou radical. Tais discursos sobre o feminismo, em muitos casos, revelam imagens que associam a figura da feminista com a lesbianidade, a histeria, a incapacidade de ser amada por um homem e com o chamado "machismo ao contrário" (DINIZ, 2012, p. 103). Essas imagens sobre o feminismo e de suas militantes foram construídas, ao longo do tempo, com a participação de vários setores da sociedade, inclusive progressistas (ZANETTI, 2008, p. 4-5; DINIZ, 2012, p. 103). A historiadora Navarro-Swain (2001), em análise de revistas femininas produzidas nas últimas décadas, notou que o "ufanismo discursivo da igualdade de oportunidades" (2001, p. 68) tende a tornar os movimentos feministas desnecessários e obsoletos no tempo presente. Assim, afirma que:

[...] os movimentos feministas em sua prática social se veem desautorizados e desmotivados diante da afirmação generalizada de que "o feminismo acabou" e que sobretudo, o feminismo é uma prática anacrônica já que finalmente, "a igualdade já não foi alcançada?" (NAVARRO-SWAIN, 2001, p. 68).

A aversão e o ódio ao pensamento e à prática dos feminismos no Ocidente são herdeiros de um longo processo histórico de inferiorização, estigmatização, exclusão e opressão de mulheres que ousaram questionar e transformar a ordem binária, patriarcal e androcêntrica que impõe uma divisão generizada do mundo e, por conseguinte, as desigualdades entre homens e mulheres (NAVARRO-SWAIN, 2001, p. 17). Segundo Ferreira 
(1996), ao final do século XIX, os discursos masculinos sobre o feminismo, em revistas e jornais, difundiam a imagem de que

[...] a feminista estaria ultrapassando os limites "naturais", tentando medir forças, competir com o homem, imitá-lo. (...) O combate à "praga" se deu, de maneira geral, através da difusão de imagens negativas. Tachar a feminista de tola, histérica, ridícula, feia, masculinizada ou mal amada, ou ainda, tratar o feminismo de maneira satírica, "carnavalizá-lo", são práticas que tiveram e têm como efeito a despersonalização, a descaracterização e a diluição do caráter político do movimento (FERREIRA, 1996, p. 158).

Como observou Oliveira (2015), desde então, as feministas vêm causando profundos impactos na cultura, chocando-se com os interesses

[...] daqueles que desejam manter intactas as estruturas patriarcais de poder que excluem, inferiorizam e dominam as mulheres. Assim se proliferam os discursos que buscam apagar a força e importância histórica dos feminismos. Ficam assim os silêncios e uma enorme lacuna no entendimento da história das mulheres no tempo presente (OLIVEIRA, 2015, p. 15).

Os movimentos feministas, apesar de discutidos e analisados nos meios acadêmicos, ainda permanecem pouco explorados pelos(as) historiadores(as), no entanto pode-se encontrar estudos históricos que têm como tema o feminismo no Brasil. O livro de Céli Regina Pinto (2003), ainda, é um dos mais conhecidos sobre a história dos movimentos feministas brasileiros. Já os artigos da socióloga Ana Alice de Alcântara (2005) também constituem referências importantes sobre a história do feminismo no Brasil, assim como os textos de Sonia Alvarez (2003), Lourdes Bandeira (2010), Hildete Pereira (2010), Mirla Cisne (2005, 2008 e 2011), Sueli Gomes Costa (2009), Maria da Glória Gohn (2007), Maria Lygia Quartim de Moraes (1990, 2012) e Maria Amélia Telles (1993). No campo da história tem-se alguns estudos sobre as representações do feminismo no Brasil como os de Tania Navarro-Swain (2001), Verônica Ferreira (1996), Margareth Rago (1996, 2003 e 2004), Rachel Soihet (2007), Joana Maria Pedro (2006, 2010 e 2012), Cristina Scheibe Wolff (2010) e Carla Bassanezi Pinsky (2012).

Em paralelo, observei, nas redes sociais, o crescimento de grupos de mulheres jovens que discutem os feminismos e que se dizem feministas. Tais grupos enfrentam uma série de acusações, depreciações e injúrias que se configuram como violências simbólicas ${ }^{1}$. Os

\footnotetext{
${ }^{1}$ Violência simbólica é um conceito social criado pelo sociólogo francês Pierre Bourdieu no qual aborda uma maneira de violência exercida sob o corpo sem coação física, em que causa danos psicológicos e morais. É uma maneira de coação que se sustenta no reconhecimento de uma imposição determinada, seja esta econômica, social ou cultural (CUNHA, 2007). Esse conceito se funda na elaboração contínua de crenças no processo de socialização, que induz o indivíduo a se posicionar no espaço social seguindo padrões e critérios do discurso dominante.
} 
feminismos, em suas mais diversas vertentes, são, ainda, mal compreendidos. A simples menção ao feminismo nas práticas discursivas cotidianas é capaz de despertar conflitos, debates, agressões de todo tipo, ódio e a ira de muitos homens e mulheres. Diante disso, atentei para a necessidade de compreender os usos e apropriações do feminismo em falas institucionais, de representantes do governo e dos movimentos feministas e de mulheres ${ }^{2}$, na I CNPM. Trata-se de falas em um espaço político e de poder que se configura em uma "conferência nacional" - lugar onde emergem orientações, diretrizes e planos governamentais de políticas públicas. Não existe uma única definição para o conceito de política pública, mas, de forma geral, pode ser entendida

[...] como o campo do conhecimento que busca, ao mesmo tempo, "colocar o governo em ação" e/ou analisar essa ação (variável independente) e, quando necessário, propor mudanças no rumo ou curso dessas ações (variável dependente). A formulação de políticas públicas constitui-se no estágio em que os governos democráticos traduzem seus propósitos e plataformas eleitorais em programas e ações que produzirão resultados ou mudanças no mundo real (SOUZA, 2006, p. 26).

Teoricamente, as políticas públicas governamentais são construídas por meio da interação e do diálogo entre a sociedade civil e o Estado, e tem repercussão na sociedade (SOUZA, 2006). Elas se modificam ou se organizam com base em regras e em procedimentos que (re)constroem a realidade, a partir das relações/mediações entre agentes da sociedade civil e do Estado (BRASIL, 2012). Historicamente, alguns grupos mais privilegiados exerceram poder na orientação de políticas públicas no Brasil, especialmente grupos provenientes das elites políticas e econômicas, constituída por homens brancos, heterossexuais, escolarizados, com forte concentração de renda. Até então, as vozes e experiências sociais de grupos marginalizados politicamente não eram consideradas no processo de construção de políticas públicas. Até a segunda metade do século XX, as mulheres pouco ou raramente estiveram presentes nas discussões de políticas públicas no Brasil. Não por acaso, a articulação de políticas públicas com a perspectiva de gênero, com o objetivo de ampliar e efetivar a cidadania das mulheres no Brasil é recente (BANDEIRA; ALMEIDA, 2004). Nesse sentido, a presença e a participação de movimentos feministas e de mulheres na I CNPM têm grande importância histórica no Brasil, já que se trata de um espaço

\footnotetext{
2 Optei aqui pelo uso do termo "movimentos feministas e de mulheres", considerando as diferenças políticas que existem entre eles. Além disso, porque os Acordos Gerais definidos na Plenária Final da I CNPM estabelecem que "Para visibilidade da diversidade: procurar usar de forma associada: movimento de mulheres e feminista” (BRASIL, 2004a, p. 103).
} 
político e, portanto, de poder, centrado no diálogo, na discussão e proposição de políticas públicas que deveriam exercer efeitos na vida das próprias mulheres.

Como historiadora, meu interesse é fazer emergir um relato histórico que desvele a historicidade das representações do feminismo em discursos políticos, expondo, assim, o seu caráter histórico e cultural, seus processos de constituição de sentidos, suas funções enunciativas, significados, conceitos, interesses, valores e efeitos nas comunicações e diálogos travados em um espaço de negociação e protagonismo político, como é o da I CNPM.

Sigo nesta dissertação a mesma trilha de Scott (1994, p. 81 - 83), para quem a história das mulheres possui uma força política potencialmente crítica que desafia e desestabiliza os princípios disciplinares estabelecidos, principalmente porque esse tipo de história questiona o privilégio dado à "história do homem", em objeção à "história da mulher", e questiona qualquer relato histórico de pretensão universal. A história das mulheres, a partir de uma perspectiva pós-estruturalista, rompe com uma epistemologia evolucionista e androcêntrica ao relativizar a identidade "mulheres" e desnaturalizar as noções de sexo/gênero, mas também ao deslocar-se para a análise da linguagem e da produção social dos significados, ao considerar os conceitos como acontecimentos históricos que necessitam de explicações (SCOTT, 1991, p. 192). Em vez de demonstrar a diversidade de concepções e práticas em torno do feminismo nas últimas décadas, me interessa analisar o modo como se constroem os sentidos e significados para o feminismo. É assim que pretendo historicizar os significados do feminismo na I CNPM.

Entendo que fazer história seria, sobretudo, dialogar com o tempo, procurando no passado aquilo que o faz diferente do presente, assim como suas ressonâncias (BRITO, 2007, p. 12). Neste sentido, interpelo se o feminismo, ainda, é capaz de fortalecer os debates e reivindicações das mulheres na contemporaneidade? Que grupos de mulheres se identificam como feministas ou mencionam o feminismo em seus discursos políticos? Qual o significado do feminismo para esses grupos? São essas questões que suscitaram o meu interesse em investigar as representações discursivas do feminismo na I CNPM. Esse interesse é resultado, também, de uma vontade política de conferir visibilidade e dizibilidade às mulheres na história, haja vista o contínuo desinteresse da historiografia em mostrar as mulheres como sujeitos históricos. A maior parte das falas proferidas e analisadas na I CNPM são de mulheres, as únicas falas masculinas identificadas são a do presidente então Luiz Inácio Lula da Silva e do ministro José Dirceu. Nesse sentido, as fontes priorizadas nesta dissertação são, em sua quase totalidade, de autoria de mulheres. 
A I CNPM foi realizada nos dias 15, 16 e 17 de julho de 2004 na cidade de Brasília (Distrito Federal) e reuniu cerca de 1.787 mulheres da esfera governamental e civil. A convocação dessa I Conferência se deu por meio de decreto presidencial, publicado no dia 18 de dezembro de 2003, assinado pelo presidente Luiz Inácio Lula da Silva. Seu regimento foi aprovado em 02 de dezembro de 2003 pelo Conselho Nacional dos Diretos da Mulher (CNDM), e estabelecia, para o evento, o tema "Políticas para as Mulheres: um desafio para a igualdade numa perspectiva de gênero", com o objetivo central de propor diretrizes e propostas para a fundamentação do I Plano Nacional de Políticas para as Mulheres (I PNPM).

A II Conferência Nacional de Políticas para as Mulheres (II CNPM) foi convocada, por decreto presidencial, no dia 17 de janeiro de 2007, com o objetivo de avaliar e aperfeiçoar o I PNPM, e teve como título "Desafios para a construção da igualdade na perspectiva da implementação do PNPM e avaliação das ações e políticas propostas no PNPM. E a participação das mulheres nos espaços de poder”. Essa II Conferência ocorreu entre os dias 17 e 20 de agosto de 2007 e reuniu cerca de 2.800 mulheres. Já a III Conferência Nacional de Políticas para as Mulheres (III CNPM), convocada pelo decreto presidencial de 15 de março de 2011, teve como objetivo qualificar as diretrizes e normativas diversas da Política Nacional para Mulheres e ficou estabelecida com o seguinte título "Avaliação e aprimoramento das ações e políticas que integram o II Plano Nacional de Políticas para as Mulheres e definição de prioridades". Essa III Conferência foi realizada entre os dias 12 e 15 de dezembro de 2011 e reuniu cerca de 2.125 delegadas.

A IV Conferência Nacional de Políticas para as Mulheres (IV CNPM) foi convocada pela presidenta Dilma Rousseff em 30 de março de 2015, a ser realizada no período de 10 a 13 de maio de 2016, com o objetivo central de fortalecer a Política Nacional para as Mulheres e teve como título "Mais direitos, participação e poder para as mulheres". Essa IV Conferência propôs-se a discutir as estratégias de fortalecimento das políticas para as mulheres e a democratização da participação das mulheres nas diversas esferas institucionais e federativas. Devo ressaltar que esse evento foi realizado em um momento político conturbado, que incluiu o afastamento da presidenta Dilma, o que fez insurgir como lema, na aberta da IV CNPM, a frase: "não permitir retrocessos"”. Desse modo, Elaine Cutis, secretária da Mulher da Contraf-CUT, que participou da IV CNPM, afirmou:

[...] temos que defender o que já conquistamos e avançar ainda mais. Diante de um governo golpista, que não valoriza a mulher, temos que ampliar nosso

\footnotetext{
3 Disponível em: <http://www.brasil.gov.br/governo/2016/05/dilma-participa-da-abertura-da-4a-conferencianacional-de-politica-para-as-mulheres> Acesso em 04 Nov. 2016.
} 
poder de mobilização e manter a luta para que as conferências continuem e que as mulheres sejam respeitadas, com políticas públicas que ampliem o empoderamento feminino e promovam a equidade de gênero ${ }^{4}$.

Desse modo, a IV CNPM (2016) foi realizada em meio a sentimentos de que provavelmente esta seria a última, tendo em vista que o novo governo instaurado, após o impeachment da presidenta Dilma Rousseff, p não compactuar com boa parte das políticas e formas de diálogos (do governo) que vinham sendo estabelecidos com os movimentos sociais a partir das conferências nacionais nos governos do Partido dos Trabalhadores (PT) ${ }^{5}$. Diante disso, considero extremamente importante trazer para o campo da história a memória da Conferência Nacional de Políticas para as Mulheres, porque se trata de um momento político relevante onde os movimentos feministas e de mulheres tiveram oportunidades significativas de estabelecer diálogos com o governo, revelar suas atuações, proposições, avaliações, reivindicações e posicionamentos diante de políticas para as mulheres no Brasil. Esse evento não pode cair no esquecimento. Sua presença na história abre possibilidades de continuação futura desses debates e diálogos na arena política nacional.

A I CNPM foi fundamental na construção do I PNPM e, consequentemente, um marco nas conquistas históricas dos movimentos feministas no Brasil (OLIVEIRA, 2012, p. 03), por representar o primeiro "conjunto de políticas públicas articuladas em um plano cujo objetivo primário é a efetivação dos direitos das mulheres" (BRASIL, 2006, p. 11). Para Bandeira (2011),

o PNPM representa a ruptura com a condição de sujeito assujeitado das mulheres, estabelecendo uma nova relação de cidadania com o Estado/espaço público, fruto do acúmulo de lutas, reivindicações e anseios emancipatórios de mulheres, desde o início do século XX (BANDEIRA, 2011, p. 23).

A I CNPM foi organizada por uma comissão composta por membros da Secretária de Políticas para as Mulheres (SPM) ${ }^{6}$, que representaram o governo, e do Conselho Nacional de

\footnotetext{
4 Disponível em: <http://cut.org.br/noticias/4-conferencia-nacional-das-mulheres-exige-manutencao-dasconquistas-de-genero-270b/> Acesso em 04 Nov. 2016.

5 O repúdio ao processo de impeachment da presidenta Dilma Rousseff e o temor de retrocessos nas políticas públicas e sociais marcaram o processo de realização da IV CNPM, como mostrado da reportagem do site do Portal Brasil, publicada em 10/05/2016. Disponível em: <http://www.brasil.gov.br/cidadania-ejustica/2016/05/temor-de-retrocessos-sociais-marca-abertura-da-conferencia-de-politicas-para-as-mulheres $>$ Acesso em 23 Nov. 2016.

6 A SPM foi um órgão criado em 2003, no governo do presidente Lula. Surge da transformação da Secretaria de Estado dos Direitos da Mulher (SEDIM), ligada ao Ministério da Justiça, em Secretária Especial de Políticas para as Mulheres (SPM), tornando-se integrante da Presidência da República, com o status de ministério. Em maio de 2016, a nova estrutura organizacional da Presidência da República e dos Ministérios, oficializou a extinção do Ministério das Mulheres, da Igualdade Racial, da Juventude e dos Direitos Humanos, que havia sido criado em 13 de outubro de 2015, e desse modo a SPM foi extinta. (Cf. <http://www.spm.gov.br/sobre/a-
} 
Direitos da Mulher (CNDM), que representaram a sociedade civil em âmbito governamental. O CNDM é um órgão de instância nacional, que orienta, de forma direta, o poder Executivo com propostas de políticas públicas para as mulheres, sendo seu principal objetivo o de representar os interesses da sociedade civil, mais especificamente, dos movimentos feministas e de mulheres e, também, o de fomentar a participação desses junto à administração pública (PIMENTA, 2010).

As ações e articulações do CNDM e da SPM evidenciam a forte movimentação dos movimentos feministas e de mulheres e a abrangência de suas lutas, pautas e conquistas em âmbito civil e governamental, no período de 2003 a 2016. A atuação da SPM foi marcada pela realização das quatro Conferências Nacionais de Políticas para as Mulheres. Em cada uma delas foram aprovadas resoluções e diretrizes que deram origem, respetivamente, ao I, II e III Plano Nacional de Políticas para as Mulheres, redigidos por um Grupo de Trabalho Interministerial (OLIVEIRA, 2012).

Neste trabalho optei por tratar somente da I CNPM, devido ao tamanho da documentação para análise referente às outras Conferências e o limite de tempo disponível para a realização do mestrado. A abordagem discursiva das representações impõe certas restrições ao número de documentos a serem analisados, porque se trata de uma investigação mais minuciosa dos sentidos e das funções de cada representação no seu contexto de fala (HALL, 1997). Assim, elegi como fonte de pesquisa os Anais impressos, produzidos após a I CNPM, documento que contém as transcrições de falas pronunciadas durante a I Conferência por representantes de entidades da sociedade civil e do governo.

Devo ressaltar que as perguntas feitas às fontes históricas dependem das condições de possibilidade na qual se inscrevem o(a) historiador(a). Afinal de contas, não se podem elaborar todas as perguntas. Logo, toda história "comunica" um pouco sobre o passado - no qual se inscreve o objeto - e também as próprias condições de possibilidade do(a) historiador(a) que a produziu. Esse fato se relaciona, diretamente, com as escolhas arbitrárias das fontes, temas, teorias e metodologias que vão também ao encontro dos interesses e formação do(a) pesquisador(a). Assim, como bem afirma Eleonora Zicari Costa de Brito, concordo que a história é a "captação de sentido. Os sentidos são as formas que encontramos no passado, como no presente, de dar significado à realidade vivida e, nela, às relações que

secretaria> Acesso em 04 Nov. 2016). A nova reforma administrativa fez com que a SPM perdesse seu status de ministério e ficasse na condição de Secretaria Especial de Políticas para as Mulheres (SEPM), passando a ser vinculada novamente ao Ministério da Justiça e Cidadania. Apesar de vivenciar um momento de desmonte político, a SEPM tem ainda como objetivo principal "promover a igualdade entre homens e mulheres e combater todas as formas de preconceito e discriminação herdadas de uma sociedade patriarcal e excludente" (Citação retirada do site da SPM, atual SEPM: <http://www.spm.gov.br/sobre/a-secretaria> Acesso em 04 Nov. 2016.) 
estabelecemos" (2007, p. 14). Desse modo, cabe ao(a) historiador(a) a tarefa de buscar os sentidos que as perguntas possíveis de elaborar permitem apreender. Pode parecer pouco, no entanto, não é visto que nenhuma história é capaz de dar contar da totalidade de acontecimentos em um determinado tempo e espaço.

Os Anais (BRASIL, 2004a) da I CNPM possuem tamanho relativamente extenso, com um total de 164 páginas. Seu formato, de modo geral, é rígido e a sua estrutura contêm os seguintes aspectos: apresentação, programação, abertura, painel 1, painel internacional, painel 2, resoluções, nota metodológica, acordos gerais, natureza, princípios, diretrizes, eixos temáticos, moções, regulamento interno, homenagem às mulheres brasileiras, perfil das delegadas, créditos e patrocínios. Esses Anais estão disponíveis publicamente em formato digital no site da $\mathrm{SPM}^{7}$, haja vista que tiveram a função pública de subsidiar a elaboração do I Plano Nacional de Políticas para as Mulheres (I PNPM).

Na leitura inicial dos Anais da I CNPM, realizei um fichamento dos enunciados discursivos que faziam menção aos termos "feminismo(s)" e "feminista(s)". Nesse trabalho observei que o feminismo aparecia como "ator político na esfera pública", "movimento social", "plataforma política", "força revolucionária e transformadora", "proposta inovadora", "perspectiva", "discurso", "teoria" e "luta de mulheres", dentre outros. Nessa documentação, o termo "feminismo(s)" aparece, no total, 10 vezes, sendo mencionado por quatro palestrantes (Tabelas 1 e 2, p. 21). Já o termo "feminista(s)" aparece, no total, 38 vezes, sendo 22 vezes citado em discursos, e é mencionado por dez palestrantes (Tabelas 3, 4 e 5, p. 22 - 23). O termo "feminista(s)" também aparece, 16 vezes, nos nomes de grupos da sociedade civil, nos acordos gerais, princípios, diretrizes, moções e na homenagem às mulheres brasileiras. Participaram da I CNPM o total de 33 grupos e entidades provenientes da sociedade civil e da esfera governamental (Tabela 6, p. 24 - 26). Dentre eles, observei que 19 eram representantes da sociedade civil e 11 eram representantes do governo e 03 de mulheres "com notório conhecimento das questões de gênero" no Brasil. Pude constatar que estiveram presentes na I Conferência seis grupos e entidades da sociedade civil declaradamente feminista, são eles: Articulação de Mulheres Brasileiras (AMB), Articulação de ONGs de Mulheres Negras Brasileiras, Movimento Articulado de Mulheres do Amazonas (MAMA), Marcha Mundial das Mulheres (MMM), Rede Nacional Feminista de Saúde, Direitos Sexuais e Direitos Reprodutivos e o Instituto Feminista para Democracia (SOS Corpo) . As mulheres que se autodeclaram feministas na I Conferência contabilizaram o total de treze. Entre essas, nove

\footnotetext{
7 Site da SPM: www.spm.gov.br
} 
proferiram falas e quatro foram homenageadas, a saber: Jacqueline Pitanguy, Sueli Carneiro, Beatriz Paredes Rangel, Nalu Faria, Nilza Iraci, Nilcéa Freire, Virgínia Gúzman, Maria Betânia Ávila, Matilde Ribeiro, Gracíliana Selestino Wakanã, Zuleika Alambert, Rose Marie Muraro e Heloneida Studart.

Tabela 1: Menções ao termo "feminismo(s)" nos Anais da I CNPM

Número total de páginas nos Anais da I CNPM

164

Número total de ocorrências do termo "Feminismo(s)"

Número total de falas transcritas nos Anais da I CNPM

Número total de falas que mencionaram o termo

"Feminismo(s)"

Fonte: Elaborado pela autora com base nos Anais da I Conferência Nacional de Políticas para as Mulheres. Brasília: SPM, 2004.

Tabela 2: Quem menciona o termo "feminismo(s)" nos Anais da I CNPM

\begin{tabular}{ccc}
\hline $\begin{array}{c}\text { Quem mencionou o termo } \\
\text { "Feminismo(s)" nos Anais da I } \\
\text { CNPM }\end{array}$ & $\begin{array}{c}\text { Número total de ocorrência em } \\
\text { cada fala do termo } \\
\text { "Feminismo(s)" }\end{array}$ & $\begin{array}{c}\text { Número total de } \\
\text { falas transcritas } \\
\text { nos Anais da I } \\
\text { CNPM }\end{array}$ \\
\hline JACQUELINE PITANGUY & 6 & 18 \\
SUELI CARNEIRO & 1 & 1 \\
BEATRIZ PAREDES & 2 \\
\hline NALU FARIA & Brasília: SPM, 2004.
\end{tabular}

Brasília: SPM, 2004. 
Tabela 3: Menções ao termo "feminista(s)" nos Anais da I CNPM

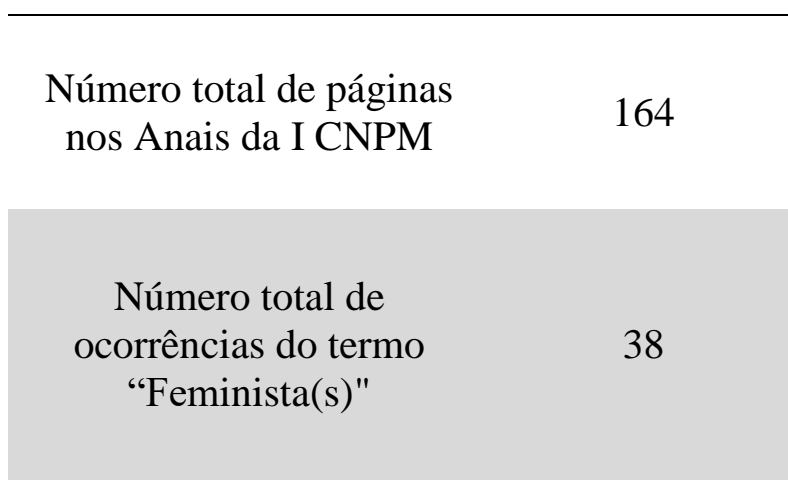

Número total de falas transcritas nos Anais da I 18 CNPM

\section{Número total de falas que mencionaram o termo "Feministas(s)"}

Fonte: Elaborado pela autora com base nos Anais da I Conferência Nacional de Políticas para as Mulheres. Brasília: SPM, 2004.

Tabela 4: Quem menciona o termo "feminista(s)" nos Anais da I CNPM

\begin{tabular}{ccc}
$\begin{array}{c}\text { Quem mencionou } \\
\text { o termo } \\
\text { "Feministas(s)" } \\
\text { nos Anais da I } \\
\text { CNPM }\end{array}$ & $\begin{array}{c}\text { Número total de } \\
\text { ocorrência em } \\
\text { cada fala do } \\
\text { termo } \\
\text { "Feministas(s)" }\end{array}$ & $\begin{array}{c}\text { Número total } \\
\text { de falas } \\
\text { transcritas nos } \\
\text { Anais da I } \\
\text { CNPM }\end{array}$ \\
\hline $\begin{array}{c}\text { Nilza Iraci } \\
\text { Nilcéa Freire }\end{array}$ & 1 & 18 \\
Jacqueline & 1 & \\
Pitanguy & 4 \\
Sueli Carneiro & 5
\end{tabular}




\begin{tabular}{|c|c|}
\hline José Dirceu & 1 \\
\hline Ariadna Reis & 1 \\
\hline Virgínia Guzman & 1 \\
\hline $\begin{array}{c}\text { Maria Betânia } \\
\text { Ávila }\end{array}$ & 2 \\
\hline $\begin{array}{c}\text { Matilde Ribeiro } \\
\text { Maria Laura Sales } \\
\text { Pinheiro }\end{array}$ & 3 \\
\hline
\end{tabular}

Fonte: Elaborado pela autora com base nos Anais da I Conferência Nacional de Políticas para as Mulheres. Brasília: SPM, 2004.

Tabela 5: Total de grupos e entidades declaradamente feministas

\begin{tabular}{l}
$\begin{array}{c}\text { Número total de grupos e entidades que } \\
\text { participaram da I CNPM }\end{array}$ \\
$\begin{array}{l}\text { Número total de grupos e entidades } \\
\text { representantes da sociedade civil }\end{array}$ \\
$\begin{array}{c}\text { Número total de grupos e entidades } \\
\text { representantes do governo que } \\
\text { participaram da I CNPM }\end{array}$ \\
$\begin{array}{c}\text { Número total de mulheres com "notório } \\
\text { conhecimento das questões de gênero" } \\
\text { no Brasil }\end{array}$ \\
$\begin{array}{c}\text { Número total de grupos e entidades } \\
\text { declaradamente feministas que } \\
\text { participaram da I CNPM }\end{array}$ \\
\hline
\end{tabular}

Fonte: Elaborado pela autora com base nos Anais da I Conferência Nacional de Políticas para as Mulheres. Brasília: SPM, 2004. 
Tabela 6: Grupos e entidades que participaram da I CNPM

\begin{tabular}{|c|c|c|}
\hline $\begin{array}{l}\text { REPRESENTANTES DO } \\
\text { GOVERNO }\end{array}$ & $\begin{array}{c}\text { REPRESENTANTES DE } \\
\text { ENTIDADES DA SOCIEDADE } \\
\text { CIVIL }\end{array}$ & $\begin{array}{c}\text { MULHERES } \\
\text { COM } \\
\text { "NOTÓRIO } \\
\text { CONHECIM } \\
\text { ENTO DAS } \\
\text { QUESTÕES } \\
\text { DE } \\
\text { GÊNERO" }\end{array}$ \\
\hline $\begin{array}{l}\text { 01. Secretária Especial de } \\
\text { Políticas para as Mulheres } \\
\text { Presidenta do Conselho: } \\
\text { Nilcéa Freire Assessora } \\
\text { Técnica: Maria Laura Sales } \\
\text { Pinheiro }\end{array}$ & $\begin{array}{l}\text { 01. Articulação de Mulheres } \\
\text { Brasileiras/ AMB } \\
\text { Titular: Schuma Schumaher (Maria } \\
\text { Aparecida Schumaher) } \\
\text { Suplente: Analba Brazão Teixeira }\end{array}$ & $\begin{array}{l}\text { 01. Rose } \\
\text { Marie Muraro }\end{array}$ \\
\hline $\begin{array}{l}\text { 02. Ministro de Estado do } \\
\text { Planejamento, Orçamento e } \\
\text { Gestão: Guido Mantega } \\
\text { Assessora Técnica: Mariana } \\
\text { Meirelles Nemrod } \\
\text { Guimarães }\end{array}$ & $\begin{array}{l}\text { 02. Articulação Nacional de Mulheres } \\
\text { Trabalhadoras Rurais/ ANMTR } \\
\text { Titular: Justina Inês Cima } \\
\text { Suplente: Lúcia de Fátima Félix da } \\
\text { Silva }\end{array}$ & $\begin{array}{l}\text { 02. Clara } \\
\text { Charf }\end{array}$ \\
\hline $\begin{array}{l}\text { 03. Ministro de Estado da } \\
\text { Saúde: Humberto Sergio } \\
\text { Costa Lima } \\
\text { Assessora Técnica: Maria } \\
\text { José de Oliveira Araújo }\end{array}$ & $\begin{array}{l}\text { 03. Articulação de ONGs de Mulheres } \\
\text { Negras Brasileiras } \\
\text { Titular: Nilza Iraci Silva } \\
\text { Suplente: Givania Maria da Silva }\end{array}$ & $\begin{array}{l}\text { 03. Albertina } \\
\text { de Oliveira } \\
\text { Costa }\end{array}$ \\
\hline $\begin{array}{l}\text { 04. Ministro de Estado da } \\
\text { Educação: Tarso Genro } \\
\text { Assessora Técnico: Lúcia } \\
\text { Helena Lodi }\end{array}$ & $\begin{array}{l}\text { 04. Associação Brasileira de Mulheres } \\
\text { de Carreira Jurídica/ ABMCJ } \\
\text { Titular: Gisela Zilsch } \\
\text { Suplente: Maria Dirce Mendonça } \\
\text { Fonseca }\end{array}$ & \\
\hline $\begin{array}{l}\text { 05. Ministro de Estado do } \\
\text { Trabalho e Emprego: } \\
\text { Ricardo Berzoni } \\
\text { Assessora Técnica: Rita de } \\
\text { Cássia Munck }\end{array}$ & $\begin{array}{l}\text { 05. Central Única dos Trabalhadores/ } \\
\text { CUT } \\
\text { Titular: Maria Ednalva Bezerra de } \\
\text { Lima } \\
\text { Suplente: Carmen Helena Ferreira Foro }\end{array}$ & \\
\hline $\begin{array}{l}\text { 06. Ministro de Estado da } \\
\text { Justiça: Márcio Thomaz } \\
\text { Bastos } \\
\text { Assessora Tecnina: Myriam } \\
\text { Brea Honorato de Souza }\end{array}$ & $\begin{array}{l}\text { 06. Confederação Geral dos } \\
\text { Trabalhadores/ CGT } \\
\text { Titular: Maria Lúcia Alves Dias } \\
\text { Suplente: Eliana Fernandes da Cruz } \\
\text { Malfarage }\end{array}$ & \\
\hline
\end{tabular}


07. Ministro de Estado do Desenvolvimento Agrário: Miguel Soldatelli Rosseto Assessora Técnica: Andréa Lorena Butto Zarzar

08. Ministro de Estado da Cultura: Gilberto Passos Gil Moreira

Assessora Técnica: Flávia Gomes de Galiza

09. Ministro de Estado de Desvolvimento Social e Combate à Fome: Patrus Ananias Assessora Tecnina: Hildézia Alves Medeiros

10. Secretária Especial de
Políticas de Promoção da
Igualde Racial: Matilde
Ribeiro
Assessora Técnica: Denise
Antonia de Paulo Pacheco
11. Secretário Especial dos
Direitos Humanos: Nilmário
Miranda
Assessora Técnica: Isabel
Maria Madeiro Loureiro
Maior

10. Confederação Nacional dos Trabalhadores na Agricultura/ CONTAG

Titular: Raimunda Celestina de Mascena

Suplente: Simone Battestin

11. Federação das Associações de Mulheres de Negócios e Profissionais do Brasil/ BPW/BRASIL Titular: Ana Luisa Fernandes Gonçalves Suplente: Iria Martins

12. Federação Nacional das Trabalhadoras Domésticas/ FENATRAD

Titular: Creuza Maria Oliveira Suplente: Maria Noeli dos Santos

\section{Fórum de Mulheres do MERCOSUL}

Titular: Maria Elvira Salles Ferreira Suplente: Dalva Maria Thomaz Rocha

14. Movimento Articulado de Mulheres do Amazonas/ MAMA Titular: Maria da Conceição Maia de Oliveira

Suplente: Maria das Graças Lopes de Castro 


\begin{tabular}{l} 
15. Ordem dos Advogados do Brasil/ \\
OAB \\
Titular: Marilma Torres Gouveia de \\
Oliveira \\
Suplente: Maria Avelina Imbiriba \\
Hesketh \\
16. Secretária Nacional da Marcha \\
Mundial das Mulheres \\
Titular: Nalu Faria Silva \\
Suplente: Eleutéria Amora da Silva \\
17. Secretaria Nacional de Políticas \\
para Mulher da Força Sindical \\
Titular: Neuza Barboza Lima \\
Suplente: Helena Ribeiro da Silva \\
18. União Brasileira de Mulheres/ \\
UBM \\
Titular: Eline Jonas \\
Suplente: Mary Garcia Castro \\
19. Rede Nacional Feminista de Saúde, \\
Direitos Sexuais e Direitos \\
Reprodutivos \\
Titular: Ana Maria da Silva Soares \\
Suplente: Lia Zanotta Machado \\
\hline
\end{tabular}

Fonte: Elaborado pela autora com base nos Anais da I Conferência Nacional de Políticas para as Mulheres. Brasília: SPM, 2004.

Os Anais da I CNPM apresentam a transcrição de dezoito falas, pronunciadas na abertura, painel 1, painel internacional e painel 2. Destas optei por não analisar apenas as do painel internacional, mesmo identificando a menção, em alguma delas, ao termo "feminismo(s)" e "feminista(a)", porque se tratavam de falas de palestrantes estrangeiras, baseadas em experiências fora do Brasil, em outros países da América Latina. Sendo assim, doze falas fazem menção ao feminismo, das quais selecionei nove para análise.

$\mathrm{Na}$ análise das falas, busquei compreender os sentidos, significados, funções e implicações do feminismo no contexto de debates e proposições de políticas para mulheres viabilizado pela I CNPM. Nesse caminho, busquei historicizar as representações detectadas nas práticas discursivas, a fim de compreender suas condições de produção e circulação, observando assim as relações que a sua emergência e difusão guardavam com os valores, interesses, práticas, imaginários, inserção social dos agentes (em termos de sua posição e filiação grupal) e com o contexto sociohistórico de sua enunciação/comunicação. Além disso, 
busquei identificar e analisar as diferenças e semelhanças, as convergências e divergências nas representações do feminismo proferidas por diferentes agentes na I CNPM.

Os Anais são considerados, segundo Wood (1984), publicações não convencionais, ou seja, um tipo de literatura que não está disponível em canais comerciais. São enquadrados ainda na categoria de grey literature, termo proposto, segundo Bichteler (1991), entre os bibliotecários britânicos. A grey literature, ou literatura cinzenta, segundo Población (1992), faz referência a publicações não convencionais e incorpora relatórios técnicos, teses, dissertações e documentos governamentais. Dessa forma, uma das características dos Anais, a que se referem Poindron (1962) e Ogawa (1989), está relacionada à maneira como os trabalhos, textos ou discursos são publicados nestes documentos, às vezes com conteúdo completo ou resumidos. A publicação de resumos, ao invés de conteúdos completos, pode vir a implicar omissões de informações e conhecimentos muitas vezes importantes para aqueles que não assistiram as apresentações. Apesar disso, esses resumos não devem ser subestimados, pois, em muitos casos, são os únicos meios de informação disponível para a recuperação de trabalhos ou falas apresentadas em um evento. Nesse sentido, entende-se os Anais como uma memória do evento, pela função de registro da organização, estrutura e trabalhos/discursos/debates apresentados.

Os Anais da I CNPM, enquanto registro das falas pronunciadas durante a I Conferência, são aqui apreendidos como um conjunto de práticas discursivas que permitem o acesso às representações do feminismo incorporadas aos debates, avaliações e reivindicações em torno das políticas públicas para as mulheres no Brasil, ou seja, permitem o acesso à produção de sentidos para o feminismo e as feministas no cenário da I CNPM.

Neste trabalho optei por usar o termo práticas discursivas em preferência ao termo discurso, no entanto, há a preservação do termo discurso para exprimir a utilização institucionalizada da linguagem e de sistemas de sinais do tipo linguístico (DAVIES \& HARRÉ, 1990). Com isso, essa proposta permite fazer a distinção entre as práticas discursivas — "as maneiras pelas quais as pessoas, por meio da linguagem, produzem sentidos e posicionam-se em relações sociais cotidianas" (SPINK, 2010, p. 27) - e a utilização institucionalizada da linguagem — "quando falamos a partir de formas de falar próprias a certos domínios de saber" (SPINK, 2010, p. 27).

As práticas discursivas põem em circulação os discursos, ou seja, um "sistema de representações" (HALL, 1997) que, de acordo com Foucault (2009), constituem o poder, aquilo pelo qual lutamos, aquilo que circula, transmite, conserva, institui "verdades", que têm 
valor; em suma, aquilo que tentamos nos apropriar (FOUCAULT, 1986). Assim, encontro apoio na noção difundida por Foucault (2009), para quem o discurso atravessa a experiência e está em todo conjunto de formas de comunicação, qualquer que seja a linguagem à qual pertença. Segundo o autor, mais importante que o conteúdo dos discursos, é o papel que eles desempenham na ordenação do mundo (FOUCAULT, 2009). Os discursos como "ordenação dos objetos", são entendidos não apenas como grupos de signos, mas como relações de poder, na medida em que são regidos por "normas" compartilhadas por determinados grupos (O’BRIEN, 2001, p. 48). Uma das importantes contribuições de Foucault à nova história cultural "encontra-se na importância que ele atribui à linguagem/discurso enquanto meio de apreender as transformações. A sua análise de discurso teve o seu maior impacto no estudo das instituições, em especial o asilo e a prisão, mas ainda conserva o potencial para aplicações mais gerais" ('O'BRIEN, 2001, p. 59).

O estudo das práticas discursivas se faz com base no interesse de uma abordagem teórica e metodológica da linguagem em uso e do seu papel nas interações sociais. Sendo assim, ressalta as maneiras pelas quais os agentes produzem sentido e posicionam-se nas relações sociais cotidianas. De acordo com Spink (2010),

as práticas discursivas têm como elementos constitutivos: a dinâmica (que são os enunciados, orientados por vozes), as formas ou speech genres (que, para Bakhtin, são formas mais ou menos fixas de enunciados) e os conteúdos, os repertórios lingüísticos (SPINK, 2010, p. 27).

É importante ressaltar que, em relação à análise das práticas discursivas da I CNPM, a noção de contexto é abordada em vários níveis, especialmente no contexto de produção das falas em foco. Assim, parti-se do pressuposto de que os sujeitos que falam podem expressarse de formas variadas, a depender de "onde estão, com quem estão falando, o que foi dito e qual a forma de interação". Com isso, busca-se compreender "por que as pessoas falam certas coisas num determinado momento" (SPINK, 2010, p. 27).

O sentido dos enunciados veiculados nas práticas discursivas é aqui entendido enquanto construção social, um empreendimento coletivo e interativo, por meio do qual os agentes, em suas dinâmicas das relações sociais, culturalmente localizadas e historicamente datadas, produzem os termos por meio dos quais entendam e lidam com os fenômenos e situações a sua volta (SPINK, 2010). Segundo Spink (2010),

situamos o sentido como uma construção social, e enfatizamos que tal construção se dá num contexto, numa matriz que atravessa questões 
históricas e culturais e que é essa construção que permite lidar com situações e fenômenos do mundo social. (SPINK, 2010, p. 35).

No estudo das práticas discursivas, trata-se o sentido como interativo. Ainda segundo Spink (2010),

os processos de produção de sentidos implicam a existência de interlocutores variados cujas vozes se fazem presentes. As práticas discursivas estão sempre atravessadas por vozes; são endereçadas e, portanto, supõem interlocutores. Obviamente, isso gera dificuldades consideráveis quando analisamos material discursivo, porque as pessoas, numa entrevista, por exemplo, estão falando com você e de repente a fala passa a ser endereçada a outrem. Por exemplo, "não sei...porque meu pai dizia que..." O interlocutor passou a ser o pai. É um trabalho instigante esse de tentar identificar estas mudanças de interlocutores. Numa pequena entrevista de cinco minutos aparece vários interlocutores, imaginem então uma entrevista de uma hora! (SPINK, 2010, p. 35-36).

Essa noção permite perceber a importância de não descontextualizar trechos das práticas discursivas na análise, pois, ao se retirar uma sentença do enunciado que lhe dá suporte, pode lhe roubar o sentido. Por isso, para compreender os processos de interações das práticas discursivas, é preciso incorporar, na análise, os diversos elos da cadeia de comunicação: "levar em consideração não só o que a pessoa falou, mas também o que precedeu essa fala [...]. Essas trocas, também, constituem o contexto de produção de sentidos” (SPINK, 2010, p. 29). Assim, compreende-se a produção de sentidos como ato incorporado ao contexto mais amplo de perguntas, respostas e interações que lhe dão suporte (SPINK, 2010). A linguagem em uso é tomada neste trabalho como prática social e isso implica trabalhar a interface entre os âmbitos performáticos da linguagem (quando, em que condições, com que intenção e de que modo) e as condições de produção (tanto no contexto social e interacional) (SPINK, 2010).

As representações discursivas são aqui compreendidas como formas de produção de sentidos, que se assentam em conceitos que são internalizados pela cultural, e, também, em virtude da(s) linguagem(ens) que lhes dá(dão) sustentação. É a conexão entre a linguagem e os conceitos que nos permitem referenciar ao mundo 'real' das pessoas, objetos e eventos, assim como ao mundo imaginário destes (HALL, 1997). Nesse sentido, as representações são "parte essencial do processo pelo qual o sentido é produzido e trocado entre membros de uma cultura. Ela envolve o uso da linguagem, de signos e de imagens que respondem por ou representam coisas" (HALL, 1997, p. 01).

Esta dissertação está estruturada em quatro capítulos, além desta introdução e das considerações finais. No primeiro capítulo abordou-se as condições de produção da I CNPM, 
como parte introdutória para a compreensão dos fundamentos emergentes e constitutivos das representações do feminismo que emergem nas falas proferidas ao longo da I Conferência. Na primeira parte desse capítulo, apresentou-se o cenário geral das conferências nacionais de políticas públicas no Brasil, a fim de entender o que são e qual a real relevância desse tipo de evento no país. Na segunda parte, tratou-se da dinâmica organizativa da I CNPM, sua estrutura, tema, objetivos, formato, formas de participação e diretrizes, para com isso entender o processo de produção de seus sentidos, as práticas discursivas proferidas e o posicionamento social e políticos de seus sujeitos.

No segundo capítulo apresentou-se a análise das representações do feminismo nas práticas discursivas da Abertura da I CNPM. Inicialmente, nesse capítulo, abordou-se as condições de produção e organização dessa cerimônia, destacando seus objetivos, programação, discursos e sujeitos de fala. Em seguida, analisou-se as representações do feminismo presente nas falas de Nilza Irazi, representante do Conselho Nacional de Direitos da Mulher (CNDM) e de Nilcéia Freire, então ministra de Estado da Secretaria Especial de Políticas para as Mulheres (SPM).

No terceiro capítulo tratou da análise das representações do feminismo nas palestras proferidas no Painel 1: Análise da realidade brasileira, avaliando as políticas realizadas e os compromissos assumidos pelo Estado brasileiro da I CNPM. Para isso, apresentou-se, inicialmente, as condições de produção e de organização desse Painel, ressaltando seus objetivos, discursos e sujeitos de fala. Em seguida, realizou-se a análise das representações do feminismo nas falas de Jacqueline Pitanguy,Diretora da Cidadania, Estudos, Pesquisa, Informação e Ação (CEPIA), Sueli Carneiro, Diretora do Instituto da Mulher Negra (Geledés) e da Articulação de Mulheres Negras (AMN) e de José Dirceu, Ministro Chefe da Casa Civil da Presidência da República.

No quarto e último capítulo tratou-se do Painel 2: Apresentação de propostas de diretrizes para a construção do Plano Nacional de Políticas para as Mulheres da I CNPM. Assim como no capítulo anterior, inicialmente discutiu-se as condições de produção e de organização desse Painel. Em seguida analisou-se as representações do feminismo nas falas de Maria Betânia Ávila, Coordenadora Geral do Instituto Feminista para a Democracia (SOS Corpo) e membro do Articulação de Mulheres Brasileiras, de Matilde Ribeiro, Ministra da Secretaria Especial de Políticas de Promoção da Igualdade Racial da Presidência da República (SEPPIR), de Nalu Faria, Coordenadora da Marcha Mundial de Mulheres, (MMM) e de Maria Laura Sales Pinheiro, Secretária Adjunta da Secretaria Especial de Políticas para as Mulheres da Presidência da República (SPM). 
Espero com esse estudo contribuir, de alguma forma, na escrita da história das mulheres, a partir de uma perspectiva feminista. Consoante Muniz (2010),

sob as rubricas "História da Mulher", "História das Mulheres", "Estudos de Gênero" e/ou "Estudos Feministas" evidencia-se o projeto comum de tornar visível e dizível, isto é, inteligível, o pensamento/ação das mulheres. Ou, conforme a perspectiva, em tornar inteligíveis as histórias dos sujeitos, as experiências que constituem aquelas como tais, como sujeitos históricos (MUNIZ, 2010, p. 75).

Nessa perspectiva, estou, também, de acordo com Perrot (1995) quando diz que escrever uma história das mulheres:

[...] significa levá-la a sério, querer superar o espinhoso problema das fontes ("Não se sabe nada das mulheres", diz-se em tom de desculpa). Também significa criticar a própria estrutura de um relato apresentado como universal, nas próprias palavras que o constituem, não somente para explicitar os vazios e os elos ausente, mas para sugerir uma outra leitura possível. Ambiosa, com certeza, esta pesquisa tem se desenvolvido no mundo ocidental há vinte anos (PERROT, 1995, p. 9).

A história das mulheres não exige uma narrativa linear, mas uma narrativa complexa, que considere, ao mesmo tempo, "a posição variável das mulheres na história, o movimento feminista e a disciplina da história" (SCOTT, 1992, p. 65). Assim, considero que a escrita da história das mulheres é um esforço altamente político que desafia não apenas os discursos dominantes e patriarcais que circulam na academia, mas também as formas de escrita da história.

Diante do processo histórico de pluralização dos feminismos e de construção/difusão de um imaginário negativo em torno dos movimentos feministas e das próprias feministas, espero que este estudo contribua para a compreensão da historicidade das representações do feminismo e das relações de poder que estruturam os conhecimentos sobre ele. Assim, por me incomodar diante das frequentes representações negativas que, ainda, circulam sobre os feminismos em nossa sociedade, busco nesta dissertação compreender os significados que o feminismo assume para grupos e organizações que, ainda, participam ativamente de lutas e de debates políticos pelos direitos das mulheres no Brasil. 


\section{CAPÍTULO 1}

\section{AS CONDIÇÕES DE PRODUÇÃO DA I CONFERÊNCIA NACIONAL DE POLÍTICAS PARAAS MULHERES}

Este capítulo trata das condições de produção da I Conferência Nacional de Políticas para as Mulheres (I CNPM), como parte fundamental e inicial para o entendimento das representações do feminismo nas falas pronunciadas durante a I Conferência. Na primeira parte deste capítulo apresenta-se um panorama das conferências nacionais de políticas públicas no Brasil, observando seus objetivos, características e formas de organização. Entender o significado e importância das conferências nacionais no país se faz necessário para a compreensão do funcionamento e papel da I CNPM. Na segunda parte deste capítulo, aborda-se o surgimento, objetivos e modos de organização da I CNPM, a fim de compreender suas condições de produção, ou seja, o contexto social e interacional de sua realização (SPINK, 2010, p. 26). Neste trabalho busca-se identificar o modo, o local e o processo de organização, estruturação, objetivos, modos de participação e realização do evento.

Neste capítulo, as obras de Avritzer (2013), Pogrebinschi (2012) e Santos (2011) foram usadas no entendimento das conferências nacionais. O corpus documental utilizado, para compreender as condições de produção da I CNPM, contém os decretos presidenciais de convocação da I CNPM, II CNPM, III CNPM e IV CNPM, os Anais da I CNPM, II CNPM e da III CNPM, o texto base da I CNPM e da IV CNPM, o boletim informativo da I CNPM, o regimento interno da I CNPM, o regulamento interno da I CNPM, o balanço da I CNPM, o I Plano Nacional de Política para as Mulheres, a Plataforma Política Feminista e a Carta de princípios provenientes da I Conferência Nacional de Mulheres Brasileiras, a pesquisa intitulada de "Perfil das Delegadas e Perspectivas de Atuação" realizada pela SPM e pelo Instituto Brasileiro de Administração Municipal (IBAM)”, os relatórios e textos elaborados pela SPM "Compromissos do Governo Federal 2003: políticas públicas para as mulheres", "Ano da Mulher no Brasil - I Conferência Nacional de Políticas para as Mulheres", "Relatório de Implementação 2005 - Plano Nacional de Políticas para as Mulheres", "Políticas públicas para as mulheres", "Proposta de Diretrizes para uma Política Nacional para as Mulheres. I Conferência Nacional de Políticas para as Mulheres - Documento para os Grupos de Trabalho", as resoluções da II CONAPIR, os textos da AMB "Boletim Articulando", "Políticas Públicas para as mulheres no Brasil: Balanço nacional cinco anos 
após Beijing”, “Articulando a luta feministas nas políticas públicas” e o estudo do Instituto Ipea intitulado de "Ampliação da Participação na Gestão Pública: um estudo sobre conferências nacionais realizadas entre 2003 e 2011".

\subsection{AS CONFERÊNCIAS NACIONAIS DE POLÍTICAS PÚBLICAS NO BRASIL}

As conferências nacionais, para os debates e propostas de políticas públicas, existem no Brasil desde a década de 1930, quando foram convocadas por Getúlio Vargas as primeiras conferências de saúde e de educação. A primeira delas foi a I Conferência de Saúde, que ocorreu em 30 de janeiro de 1941. Porém, a partir de 2003, no governo do presidente Luiz Inácio Lula da Silva, as conferências nacionais ganharam maior espaço e importância, ampliando a participação de movimentos sociais nos debates e propostas de políticas públicas em âmbito estatal (AVRITZER, 2013). Desde a criação das conferências nacionais de políticas públicas, se alcançou a marca de 115 conferências. Dentre estas 74 aconteceram ao longo do governo do presidente Lula, o que demonstra a centralidade de seu governo nas políticas participativas.

Nos últimos vinte anos, foram realizadas oitenta conferências em diversas áreas temáticas: 21 na área da saúde; vinte no tema das minorias; seis de meio ambiente; 22 sobre Estado, economia e desenvolvimento; dezessete sobre educação, cultural, assistência social e esporte; e onze sobre direitos humanos (Dulci, 2011). Assim, sob o ponto de vista do governo, a questão ressaltada é o aumento quantitativo das conferências nacionais mostrando que, de fato, existe hoje uma política participativa no nível federal de governo centrada nas conferências nacionais (AVRITZER, 2013, p. 126).

Sabe-se que, a partir de 2004, novos temas relativos a grupos sociais minoritários foram introduzidos como objeto das conferências nacionais, somando-se às habituais conferências de saúde, de direitos humanos e de diretos da criança e do adolescente que são realizadas desde a década de 1990 em caráter anual e bianual, respectivamente (POGREBINSCHI, 2012). Em relação a essa nova inclusão temática, Pogrebinschi (2012) ressalta a diversidade de temas abordados nas conferências nacionais:

Em 2004 passam a integrar o universo temático das conferências nacionais as políticas públicas para mulheres, seguidas, em 2005, das políticas de promoção da igualdade racial, e em 2006, das políticas para idosos, pessoas deficientes e povos indígenas, e em 2008, das políticas para gays, lésbicas, bissexuais, transexuais e travestis, e também para a juventude (POGREBINSCHI, 2012, p. 40). 
Dessa maneira, tendo como referência o começo do governo Lula, pode-se dizer que as conferências nacionais "inobstante o seu caráter consultivo e não vinculante, assumem feição propriamente participativa, deliberativa, normativa e representativa" (POGREBINSCHI \& SANTOS, 2011, p. 262). As conferências nacionais são consideradas participativas, pois estão abertas à participação social em suas etapas e, sistematicamente, obedecem a um formato que presume uma organização bipartite - no qual, geralmente, a sociedade civil possui $60 \%$ dos delegados e o governo $40 \%$ desses - a, ou ainda, uma organização tripartite — nos casos em que os trabalhadores constituem uma terceira categoria de delegação —, e ganham, paulatinamente, a adesão massiva das instituições da sociedade civil interessadas nas políticas debatidas nas conferências (POGREBINSCHI \& SANTOS, 2011).

As conferências nacionais, também, possuem caráter deliberativo, no sentido de estarem direcionadas à formação de consensos provenientes de espaços de voz da sociedade civil e do governo na esfera pública. Com isso, englobam seus representantes em um processo de "justificação pública de argumentos que se espera racionalmente motivados" (POGREBINSCHI \& SANTOS, 2011, p. 263). Além disso, as conferências nacionais difundem um determinado procedimento deliberativo ${ }^{8}$ que concorre na aprovação de um documento final, que contenha as diretrizes para as políticas públicas (POGREBINSCHI \& SANTOS, 2011).

Portanto, as conferências nacionais assumem um caráter normativo, uma vez que suas deliberações culminam, conclusivamente, na produção de um documento final, discutido, votado e aprovado perante diferentes estratégias e métodos de associação das preferências e dos interesses dos grupos e movimentos sociais envolvidos. Com isso, as conferências nacionais concebem expectativas não apenas cognitivas, mas também normativas para aqueles agentes envolvidos em seus processos, como também para aqueles que são afetados por suas eventuais consequências (POGREBINSCHI \& SANTOS, 2011). Pogrebinschi e Santos (2011) indicam diversos aspectos que reafirmam o caráter propriamente representativo pertinente às conferências nacionais, enquanto espaços de participação e deliberação, como:

O formato participativo de composição e organização das conferências nacionais, a dimensão deliberativa de seus grupos de trabalho, painéis e plenárias finais, e o caráter normativo dos relatórios finais que condensam as

\footnotetext{
${ }^{8} \mathrm{O}$ procedimento deliberativo possibilitado pela dinâmica das conferências nacionais "segue não apenas um fluxo de deliberações que começam no plano local e passam pelo estadual antes de atingir o nacional, mas também internamente envolvendo etapas deliberativas que envolvem grupos de trabalho, painéis, plenárias e outras instâncias" (POGREBINSCHI \& SANTOS, 2011, p. 263).
} 
resoluções, diretrizes e moções debatidas e aprovadas por maioria após o cumprimento de um conjunto de regras estruturadas na forma de um procedimento que busca garantir a legitimidade de seu resultado, independentemente de seu conteúdo (POGREBINSCHI E SANTOS 2011, p. 263).

As conferências nacionais de políticas públicas constituem atualmente o "mais inovador experimento participativo realizado no Brasil" (POGREBINSCHI, 2012, p. 07) e muito tem contribuído, ao lado das experiências do orçamento participativo e dos conselhos municipais, para comprovar a vocação do país para as "práticas democráticas de empoderamento da cidadania e de formas socialmente compartilhadas de gestão da coisa pública" (POGREBINSCHI, 2012, p. 07). Assim como as demais inovações democráticas brasileiras, utilizam as já conhecidas gramáticas da representação, da participação e da deliberação, mas não as empregam sem algumas singularidades, as quais, devidamente, assumem pelo seu papel inovador e democrático.

Em primeiro lugar, as conferências são como o seu nome indica, nacionais, desafiando, assim, o conhecido pressuposto de que a participação só é possível em pequena escala, isto é, no nível local (PATEMAN, 1970; DAHL, 1971; MANSBRIDGE, 1980; PRZEWORSKI, 2010). Não somente as conferências nacionais ultrapassam as fronteiras geográficas do espaço local como também superam os seus limites substantivos. Ao propiciar que a participação se exerça em âmbito nacional, as conferências nacionais possibilitam que os interesses nelas representados também o sejam, o que assegura que o procedimento conduza ao seu principal objetivo: "a formulação de diretrizes para políticas públicas nacionais" (POGREBINSCHI, 2012, p. 08).

Por outro lado, consentindo que é no espaço local que os agentes se encontram e que é de lá, consequentemente, que suas reivindicações surgem, as conferências nacionais não constituem, senão, o ponto alto de um processo que começa nos municípios (com as conferências municipais), passando pelos Estados (com as conferências estaduais) e, também, em muitos casos, envolvendo etapas que ultrapassam quaisquer divisões geopolíticas (com as conferências livres e virtuais) (POGREBINSCHI, 2012). Assim, as conferências nacionais têm a "potencialidade de fazer de problemas locais soluções nacionais" (POGREBINSCHI, 2012, p. 08).

As conferências nacionais fazem, assim, parte de um conjunto de processos de interação entre o Estado e a sociedade $\operatorname{civil}^{9}$, utilizadas pelo governo para ampliar a

\footnotetext{
${ }^{9}$ Neste trabalho o entendimento de sociedade civil dialoga com a definição apresentada por Gramsci, segundo Coutinho (2011, p. 25): “'sociedade civil’ designa o conjunto das organizações responsáveis pela elaboração
} 
participação social nas decisões sobre políticas públicas, assim como no acompanhamento e no controle social-democrático de sua implantação e implementação. São caracterizadas como espaços amplos e democráticos de discussão e de articulações coletivas sobre estratégias e propostas de organização. Por isso, não constituem um processo democrático isolado, mas um amplo processo de democratização da gestão pública.

Em segundo lugar, as conferências nacionais constituem experiências participativas que se originam, se desenvolvem e se consumam no cerne de instituições representativas, “desafiando, assim, o argumento de que participação e representação são conceitos antagônicos que apontam para modelos democráticos incompatíveis ou mesmo concorrentes" (BARBER, 1984; SANTOS, 2007; PRZEWORSKI, 2010). Convocadas pelo Poder Executivo por meio de seus ministérios, secretarias ou conselhos nacionais, e organizadas em parceria com a sociedade civil por meio de comissões, grupos de trabalho ou fóruns, as conferências se concluem ao direcionar as suas reivindicações aos poderes Executivo e Legislativo na forma de diretrizes com caráter administrativo e legislativo ${ }^{10}$.

Assim, as diretrizes administrativas objetivam produzir material de orientação, nas três esferas da administração pública, que verse sobre os atos, atitudes, condutas e comportamentos divergentes, com vista a informar a população sobre a aplicação de leis e os contatos dos ministérios públicos federal e estaduais, e os órgãos de segurança pública (II CONAPIR, 2009). Já as diretrizes legislativas pretendem propor aos legislativos estaduais e municipais a elaboração de leis, constituindo conselhos estaduais e municipais, vinculados às secretarias que desenvolvam as referidas políticas públicas (II CONAPIR, 2009). De modo geral, enquanto as diretrizes de caráter administrativo conclamam por políticas pontuais como a "elaboração de campanha maciça, sistemática e permanente, em todas as mídias, contra qualquer forma de preconceito, estimulando o valor e o respeito à diversidade — incluindo a diversidade religiosa e cultural” (POGREBINSCHI, 2012, p. 22), as diretrizes de caráter legislativo podem ser tão genéricas quanto “criar um Programa Nacional de Enfrentamento à Intolerância Religiosa e Discriminação Étnico-Racial” (POGREBINSCHI, 2012, p. 22).

e/ou difusão das ideologias, compreendendo o sistema escolar, os parlamentares, as Igrejas, os partidos políticos, as organizações profissionais, os sindicatos, os meios de comunicações, as instituições de caráter científico e artístico etc. Ao contrário do que fazem hoje muitos pensadores liberais e social-democratas, Gramsci não trata a sociedade civil como uma zona neutra situada 'para além do Estado e do mercado'. Ao contrário, ele a considera como parte do Estado, como uma decisiva arena da luta de classes, na qual os diferentes grupos sociais lutam para conservar ou conquistar hegemonia".

${ }^{10}$ As diretrizes das conferências nacionais podem ser classificadas, quanto à sua forma, em dois tipos: “i) diretrizes administrativas, que expressam demandas cuja efetivação se insere no campo de competências do Poder Executivo; e ii) diretrizes legislativas, as quais apontam para competências legislativas e requerem, a fim de que se cumpra, manifestação do Poder Legislativo" (POGREBINSCHI, 2012, p. 17). 
Ressalta-se que as diretrizes administrativas e legislativas se desdobram em inclusivas, específicas ou gerais $^{11}$, entretanto não é necessário aprofundar aqui nesta divisão, mas destacar que, de modo geral, nas conferências nacionais há uma tendência à prevalência de diretrizes de caráter administrativo sobre as de caráter legislativo. Um dos fatores que melhor explica esse predomínio de diretrizes de caráter administrativo diz respeito ao fato de que nos grupos sociais presentes nas conferências nacionais a grande maioria conta com o que chamamos de "uma representação participativa nos conselhos nacionais de políticas públicas" (POGREBINSCHI, 2012, p. 26).

Dessa forma, os conselhos nacionais de políticas públicas possuem papel determinante nas conferências nacionais e estas, dificilmente, podem ser inteiramente entendidas sem ser levado em conta o papel daqueles. Assim, os conselhos nacionais — inúmeros deles constituídos e reformulados a partir das reivindicações apresentadas em conferências nacionais — atuam ligados às causas e aos efeitos das conferências:

por fazerem parte da estrutura dos ministérios e secretarias que as convocam, os conselhos frequentemente participam de sua organização e seus membros têm papel ativo em sua realização; por terem caráter muitas vezes deliberativo, atuam na formulação, implementação e monitoramento das políticas públicas demandadas nas conferências nacionais (POGREBINSCHI, 2012, p. 27).

Os conselhos nacionais de políticas públicas, portanto, são esferas que dão continuidade ao trabalho realizado nas conferências nacionais durante os seus intervalos, para assegurar que as reivindicações nelas apresentadas transformem-se em políticas, por meio de moções de apoio a projetos de leis, de providências para a execução destas, de reuniões, de comissões internas e grupos de trabalho.

\footnotetext{
${ }^{11}$ Para ser compreendida, de modo geral, essa divisão deve ser evidenciada a explicação de Tamy Pogrebinschi: "Tomemos como exemplo as conferências nacionais de promoção da igualdade racial, que, das conferências de minorias, são as que, em média, aprovam mais diretrizes em suas plenárias finais. A I Conapir, em 2005, aprovou cerca de 1.068 diretrizes. Dentre elas, encontramos como diretrizes inclusivas, por exemplo, 'criar lei que garanta o ensino de culturas indígenas nas escolas públicas' (I Conapir, 2005) ou 'criar programas de saúde, conscientização e prevenção de doenças voltados para mulheres negras e comunidades tradicionais vítimas de violência' (II Conapir, 2009). Nos dois casos, o objetivo da diretriz parece ser a inclusão dos grupos em políticas setoriais de educação e saúde - em muitos casos, mas nem sempre, já existentes. Já das diretrizes específicas seriam, por exemplo, 'criar cotas para as populações negras, indígenas e remanescentes quilombolas em todos os concursos públicos (I Conapir, 2005) ou 'instituir 20 de novembro, Dia da Consciência Negra, feriado nacional (I Conapir, 2005). O que se encontra em jogo aqui são claramente políticas que visam promover ou ampliar interesses específicos dos grupos em questão. Quanto às diretrizes gerais, temos exemplos tão variados quanto 'promover a preservação do meio ambiente natural e a descontaminação das nascentes' (II Conapir, 2009) ou 'tornar obrigatória a disciplina de informática nos ensinos fundamental e médio' (I Conapir, 2005). Os dois exemplos ilustram diretrizes para políticas públicas em geral, ou seja, expressam demandas que escapam aos interesses dos grupos - e, portanto, transcendem ao tema objeto da conferência" (POGREBINSCHI, 2012, p. 17).
} 
Se a função dos conselhos nacionais explica, em certa medida, a prevalência de diretrizes de caráter administrativo, é possível, também, entender que este é um indício do qual a própria natureza das conferências nacionais é a verdadeira causa. Isso porque as conferências nacionais são espaços participativos e deliberativos destinados a providenciar diretrizes para a formulação de políticas públicas para o país, possuindo como ponto de partida o Poder Executivo, que as convoca por meio de decretos presidenciais e atos normativos de seus ministérios e secretarias, as conferências nacionais o têm também como seu natural ponto de chegada. Assim, se é o Executivo o poder do Estado encarregado por elaborar e implementar políticas públicas, e se ele convoca e estrutura as conferências nacionais propriamente com essa finalidade, parece ser natural que "as diretrizes aprovadas tendam a demandar mais a ação do Executivo a fim de serem cumpridas" (POGREBINSCHI, 2012, p. 28).

Desse modo, as conferências nacionais necessitam de esforços diferenciados, tanto na mobilização social quanto na mobilização governamental, para que haja a construção de um diálogo entre o governo e os movimentos sociais interessados na definição de agendas para determinadas políticas públicas (FARIA, PETINELLI, LINS, 2012). Os órgãos responsáveis pela convocação e realização das conferências nacionais, ao regulamentá-las, detalham os temas, os objetivos e as suas comissões organizadoras. Também definem os cronogramas e os regulamentos para implantação de reuniões municipais, estaduais e nacionais, e para as eleições dos delegados, dos representantes de entidades sociais e de pessoas que devem participar da conferência (SOUZA, 2011). Assim, as conferências nacionais são organizadas tematicamente e dispõem, em regra, da participação paritária de representantes do governo e da sociedade civil.

Ao elencar a deliberação pública como seu mecanismo de participação, as conferências nacionais transfiguram-se em instâncias participativas, possibilitando que ideias, preferências, opiniões e interesses que fogem aos limites do perímetro eleitoral sejam vocalizados, além de "externados diretamente àqueles que, eleitos pelo voto, podem convertêlos em leis e políticas" (POGREBINSCHI, 2012, p. 08). Ao serem suscetíveis às reivindicações e demandas das conferências nacionais, os poderes Executivos e Legislativos se fortificam, exercitando uma representação política mais democrática. "As conferências nacionais têm, assim, a vocação de fazer da participação representação" (POGREBINSCHI, 2012, p. 08).

Em terceiro lugar, as conferências nacionais possibilitam a participação direta de grupos sociais que galgaram ter seus interesses minoritários representados quando 
transformados em políticas públicas, provocando, assim, o pressuposto de que os agentes só se devem fazer representados em instituições políticas individualmente, por meio de eleições, ou coletivamente, por meio de grupos de interesse ou de lobbies. Com isso, ao consentir que as mulheres vocalizem as reivindicações de mulheres, que os indígenas explicitem as preferências de indígenas e que os negros advoguem aos interesses de negros, as conferências nacionais devem assegurar que uma representação mais justa seja atingida por meio de uma presença que parece não caber nos moldes dos partidos políticos ou nas cotas dos parlamentos. Desse modo, Pogrebinschi (2012) observou, com certo otimismo, como ocorre a participação direta que possibilita a inclusão de grupos sociais, ditos minoritários, nas conferências nacionais:

[...] ao facultar que mulheres índias deliberem sobre políticas de saúde na condição de mulheres e de índias, ou que negros jovens deliberem sobre políticas de educação na condição de negros e de jovens, as conferências nacionais propiciam que a inclusão não seja objeto de barganha, não tenha valor de moeda, nem tenha o custo da cooptação. Ao permitir que mulheres, índios ou negros afirme a sua identidade como grupos, por meio do compartilhamento de experiências, perspectivas e valores que transcendem divisões de classe ou cisões ideológicas, as conferências nacionais redefinem o sentido e a prática da igualdade política (POGREBINSCHI, 2012, p. 09).

Essas três singularidades não dissipam a potência progressista e democrática presente nas conferências nacionais de políticas públicas. Assim, as conferências nacionais não estabelecem uma experiência completamente nova na história política brasileira. No entanto, pode-se afirmar que, mesmo não sendo novas, as conferências nacionais são inovadoras, na medida em que possibilitam uma participação em âmbito nacional e uma deliberação de políticas públicas pelos agentes interessados juntamente ao governo.

Dessa maneira, as conferências nacionais adquirem contornos participativos e deliberativos mais nítidos e tornam-se, significativamente, mais amplas, abrangentes, inclusivas e frequentes. Tornam-se amplas por compreenderem um número, cada vez maior, de agentes, seja participando de forma direta como delegados ${ }^{12}$, na etapa nacional, seja de forma indireta, nas etapas municipais ou estaduais que a precedem, ou ainda de forma paralela, nas chamadas conferências (ou etapas) livres ${ }^{13}$ ou de forma virtual

\footnotetext{
12 Os delegados podem ser divididos entre delegados governamentais e não governamentais e são caracterizados por possuírem direito a voz e a voto nas conferências. Além disso, existem os delegados denominados de natos na etapa nacional das conferências, ou seja, "considera-se delegado nato aquela pessoa que, por ocupar determinado cargo, não necessita de eleição para participar como delegado da etapa nacional" (SOUZA; CRUXÊN; ALENCAR; LIMA; RIBEIRO, 2013, p. 63)

${ }_{13}$ As conferências nacionais possuem como uma de suas características fundamentais a realização por etapas. Esse formato permite que os debates e propostas realizadas em diferentes níveis sirvam de subsídios para a etapa
} 
(POGREBINSCHI, 2012). Além disso, tornam-se abrangentes por incorporarem um número, cada vez maior, de temas e de áreas de políticas, deixando de ser uma prática limitada à área da saúde - como indicado anteriormente, foi onde se originou o processo conferencial ainda na década de 1940 — , e às áreas de assistência social e direitos humanos, que estão se institucionalizando, gradativamente, a partir da década de 1990. Portanto, as conferências nacionais são abrangentes com o intuito de cobrir uma grande pluralidade de novas áreas em políticas públicas, e para isso passaram a ser deliberadas por diversos setores marcados por suas peculiaridades, mas também passaram a ser unidas pela transversalidade de temáticas de algumas (POGREBINSCHI \& SANTOS, 2011).

As conferências nacionais tornam-se inclusivas em consequência do aumento de sua amplitude e abrangência de grupos sociais que anteriormente não possuíam locus específico para a vocalização de suas reivindicações, interesses e demandas. Segundo Pogrebinschi \& Santos (2011), a inclusão é viabilizada nas conferências nacionais,

por reunirem um conjunto cada vez mais diverso e heterogêneo de grupos sociais, sobretudo aqueles representativos da sociedade civil, distribuídos entre ONGs, movimentos sociais, sindicatos de trabalhadores, entidades empresariais e outras entidades, profissionais ou não (POGREBINSCHI \& SANTOS, 2011, p. 262).

Tornam-se, por fim, frequentes, as conferências nacionais, por possuírem entre as suas diretrizes a demanda pela reprodução periódica. Tal demanda encontra apoio nas políticas dos ministérios, secretarias, conselhos nacionais ou grupos de trabalho envolvidos na convocação e na organização, e, em alguns casos, na própria legislação, que garante a periodicidade das conferências nacionais (POGREBINSCHI \& SANTOS, 2011).

Portanto, ao se tornarem mais amplas, abrangentes e inclusivas, as conferências nacionais declaram-se como "experimentos democráticos" (POGREBINSCHI, 2012, p. 42) nos quais aparentam ser possível não somente impulsionar a participação de agentes divergentes da sociedade, mas também permitir que suas demandas sejam representadas nas

nacional. "Estas etapas podem ser de diferentes tipos: municipais, estaduais, setoriais, livres etc."(SOUZA; CRUXÊN; ALENCAR; LIMA; RIBEIRO, 2013, p. 34). Assim, pode-se entender que "as etapas virtuais são aquelas mediadas pela internet. Os participantes não se encontram presencialmente, mas podem participar das discussões e da elaboração de propostas a partir de fóruns e plataformas virtuais. A interação virtual, possivelmente, oportuniza, o envolvimento de pessoas que não participariam de outra forma de processo de discussão de políticas públicas. Observa-se, no entanto, que este é um recurso ainda pouco utilizado, dado que apenas $9 \%$ das conferências típicas realizaram etapas virtuais. As conferências livres são aquelas organizadas pelos próprios participantes e que exigem o mínimo de formalidade (apenas registrar a discussão e a presença dos participantes no modelo proposto). Os próprios participantes escolhem os temas que serão discutidos com base nas orientações gerais e elaboram propostas relacionadas a estes temas, sem a necessidade de debater todos os eixos temáticos da conferência. Entre as conferências típicas, 12\% previram a realização deste tipo de etapa" (SOUZA; CRUXÊN; ALENCAR; LIMA; RIBEIRO, 2013, p.36). 
instituições políticas formais. Assim, seja por delegação concedida do Poder Executivo, que as convoca, seja por delegação resultante do Poder Legislativo, que as recepciona, pode-se perceber que as conferências nacionais, indubitavelmente, adensam o grupo de práticas de pluralização da representação política ${ }^{14}$ (GURZA LAVALLE, 2006), constituindo a denominada "nova ecologia da representação", e reunindo uma modalidade de "representação informal" (CASTIGLIONE E WARREN, 2006), ou ainda de "representação giroscópica" ou "representação sub-rogativa" (MANSBRIDGE, 2003).

Consequentemente, entende-se que a dinâmica participativa das conferências nacionais estimula a representação de agentes tradicionalmente marginalizados no Brasil, atestando que desenhos democráticos participativos e representativos não são apenas agregados na teoria, mas também complementares na prática (POGREBINSCHI, 2010a e 2010b; POGREBINSCHI; SANTOS, 2011; POGREBINSCHI, 2012). Por isso, as conferências nacionais podem impactar as diversas fases do ciclo de políticas públicas e, pode-se afirmar que transfigura a maneira de fazer - formular, implementar e controlar - as políticas públicas no país.

Os modos como às conferências nacionais incidem na agenda de políticas públicas no Brasil necessitam de uma análise mais rigorosa e aprofundada. Entretanto, pode-se indicar que as práticas participativas e deliberativas das conferências nacionais que encontram repercussão no Poder Executivo foram, cada vez mais, inclusivas e responsivas às demandas dos grupos sociais, pois remodelaram, institucionalmente, o processo de formular, implementar e monitorar as políticas públicas, especialmente durante o período do primeiro governo Lula, em que se insere a I CNPM. Nesse sentido, desde 2003, com a chegada do Partido dos Trabalhadores (PT) ao poder, o governo federal adotou uma orientação

\footnotetext{
${ }^{14}$ A representação política como categoria dentro das democracias extraem sua legitimidade por meio da realização de eleições periódicas, nas quais os eleitores escolhem os seus representantes que ocuparão os cargos políticos nas instituições que compõem as várias esferas de poder. O governo representativo está inserido em um contexto histórico muito peculiar e se diferencia de outras maneiras de exercício do poder político. Por um lado, o governo representativo se difere do modelo de democracia direta que foi sistema de governo existente nas cidades-estados gregas da antiguidade e no qual, teoricamente, não existia diferença entre governantes e governados. Por outro lado, também se difere dos sistemas autocráticos de governo nos quais os súditos não têm acesso e nem controle sobre as decisões políticas, por exemplo, nos regimes absolutistas. Em vista disso, conclui-se que o princípio da representação política está ligado a uma modalidade de controle regular do poder governamental por parte daqueles que não podem exercê-lo pessoalmente, transferindo para outros essa função. Segundo, Debora Cristina Rezende de Almeida (2008, p 4): "De acordo com Urbinati (2006b, p. 192), a ideia de governo representativo como algo singular produziu duas escolas de pensamento, referidas a um modelo representativo e a um modelo eleitoral de democracia. O primeiro destes modelos é visto pela autora como mais democrático, na medida em que a representação se funda na teoria do consentimento, que vê a eleição como a expressão do direito de participar em algum nível da produção das leis, não como um método de transferência de preferências das pessoas para os profissionais. Autores como Condorcet e Paine propuseram situar a representação dentro de um misto de deliberação e voto, autorização e informal que envolvia representantes e representados".
} 
participativa, que implicou a forte expansão das conferências nacionais e dos conselhos nacionais, o que revelou certa centralidade nas políticas participativas desse período (AVRITZER, 2013) e, consequentemente, se mostrou mais inclusivo ao constituir, gradualmente, mais espaços de participação para os grupos sociais — "o que pode ser medido pelo número crescente de conferências nacionais voltadas especificamente à deliberação de políticas para minorias instauradas a partir de 2003" (POGREBINSCHI, 2012, p. 32). A partir do primeiro governo Lula, passaram os grupos sociais marginalizados a terem um olhar mais atento, "revelando-se beneficiários privilegiados dos novos espaços participativos nacionais" (POGREBINSCHI, 2012, p. 42). Por isso, não apenas as conferências nacionais ampliaram-se em número, mas também houve um alargamento na compreensão das demandas de diversos grupos e entidades sociais.

A introdução das reivindicações e demandas dos grupos sociais no processo políticodecisório no Brasil, como as conferências nacionais, devem ser consideradas de maneira quantitativa e qualitativamente. No entanto, por mais significativo que seja o número de decretos presidenciais que promulgaram nos últimos anos políticas públicas concorrentes com as reivindicações explicitadas nas conferências nacionais, sabe-se que grande parte desses decretos são, excessivamente, abrangente e não contemplaram de forma eficaz todas as demandas sociais.

\subsection{OBJETIVOS, ORGANIZAÇÃO E ETAPAS}

A I Conferência Nacional de Políticas para as Mulheres (I CNPM) foi realizada nos dias 15, 16 e 17 de julho de 2004 na cidade de Brasília (Distrito Federal) ${ }^{15}$ e reuniu cerca de 1.787 mulheres da esfera governamental e civil. A convocação dessa I Conferência se deu por meio do decreto presidencial, publicado no dia 18 de dezembro de 2003, assinado pelo então presidente Luiz Inácio Lula da Silva. Esse decreto estabeleceu que a coordenação da I CNPM seria realizada pela Secretaria Especial de Políticas para as Mulheres da Presidência da República (SPM) e pelo Conselho Nacional dos Direitos da Mulher (CNDM), com o objetivo de propor diretrizes para a construção do I Plano Nacional de Políticas para as Mulheres (I PNPM).

Como indicado no decreto, a I CNPM teve como tema "Políticas para as Mulheres: um desafio para a igualdade numa perspectiva de gênero", o qual foi tratado a partir dos

\footnotetext{
${ }^{15} \mathrm{Na}$ Academia de Tênis Resort, Setor de Clubes Esportivos Sul, Trecho 4 - Conj. 05 - Lote 1 - B.
} 
seguintes eixos temáticos: I - Análise da realidade brasileira: social, econômica, política, cultural e os desafios para a construção da igualdade; II - Avaliação das ações e políticas públicas desenvolvidas para as mulheres nas três instâncias de governo: municipal, estadual e federal frente aos compromissos internacionais - acordos, tratados e convenções; III Proposição de diretrizes da Política Nacional para as mulheres numa perspectiva de gênero, apontando as prioridades dos próximos anos ${ }^{16}$.

A I CNPM foi convocada em caráter consultivo e deliberativo pelo Poder Executivo, e o decreto presidencial de convocação trouxe a temática aos debates e indicou os órgãos responsáveis pela organização do processo, como acontecia de modo geral nas demais conferências nacionais já mencionadas. Assim, a I CNPM foi organizada em torno de um tema central e de eixos temáticos que objetivaram orientar o conteúdo de seus discursos e das deliberações realizadas pelos grupos de trabalho. O tema central, portanto, expõe qual o principal assunto ou as ideias principais que a conferência pretende pautar e enfatizar ${ }^{17}$. Por sua vez, os eixos temáticos detalham os assuntos a serem debatidos por meio do tema central, e surgem, em geral, alinhados à estruturação de grupos de trabalhos que possibilitam a discussão mais aprofundada de cada eixo. Assim como o tema central, os eixos temáticos são definidos já no ato convocatório ou no seu regimento interno.

A I CNPM surge, assim, com o objetivo de promover a articulação entre o governo e a sociedade civil, para que ocorresse a instituição de um conjunto de propostas baseadas na perspectiva do respeito às diferenças e no combate as diversas desigualdades vivenciadas pelas mulheres. Posteriormente, o documento final da III Conferência Nacional de Políticas para as Mulheres (III CNPM) deixou explícita a perspectiva que permeou todos os eventos: “do respeito às diferenças e no enfrentamento e superação de múltiplas desigualdades vividas pelas mulheres, ao mesmo tempo em que se compromete e defende os direitos e princípios de igualdade e equidade" (BRASIL, 2011, p. 90). Tais objetivos se relacionam, amplamente, com os anseios e as lutas dos movimentos feministas que, desde sua "segunda onda", na segunda metade do século XX, vem contribuindo com a conquista e legitimação dos direitos e da autonomia das mulheres perante o Estado e a sociedade (PEDRO, 2012). Desse modo, a I

\footnotetext{
${ }^{16}$ Art. $2^{\circ}$ do decreto presidencial de convocação da I CNPM:

<http://www.ipea.gov.br/participacao/images/pdfs/conferencias/Mulheres/regimento_1_conferencia_politicas_pa ra_mulheres.pdf > Acesso em 25 Nov. 2016.

${ }^{17}$ Exemplos de temas centrais são: "SUAS - Plano 10: Estratégias e Metas para Implementação da Política Nacional de Assistência Social", tema da $5^{\circ}$ Conferência de Assistência Social; "Educação Profissional como Estratégia para o Desenvolvimento e a Inclusão Social", tema da $1^{\circ}$ Conferência de Aprendizagem Profissional e Tecnológica; "O Direito às Formas de Organização Econômica Baseada no Trabalho Associado, na Propriedade Coletiva, na Cooperação e na Autogestão, Reafirmando a Economia Solidária como Estratégia e Política de Desenvolvimento", tema da $2^{\circ}$ Conferência de Economia Solidária.
} 
CNPM encontrou-se, também, imbricada na trajetória histórica dos feminismos no Brasil. Disso resulta que, por meio de deliberações públicas, a Conferência Nacional de Políticas para as Mulheres transformou-se nas duas últimas décadas em um espaço de discussão participativo, deliberativo e representativo para esses movimentos, ao possibilitar que seus interesses, reivindicações, denúncias, opiniões, valores e representações sociais fossem vocalizados e reconhecidos também pelo governo como relevantes na proposição de políticas públicas para as mulheres.

Os movimentos feministas e de mulheres no Brasil estão conscientes de que a participação em conferências nacionais pode fortalecê-los "como sujeito na cena política nacional" (COSTA, 2005, p. 25). Segundo Margareth Rago (2003), nos anos 1980, no processo de abertura de diferentes canais de participação social e política no Brasil, os movimentos feministas iniciaram um diálogo com o Estado, especialmente a partir de 1982, data de criação do Conselho Estadual da Condição Feminina, em São Paulo.

Assim, as entidades da sociedade civil que participaram da I CNPM estavam atentas, também, para os riscos de serem "instrumentalizados para efeito de uma participação meramente ilustrativa, com poucos resultados concretos sobre as definições” de políticas públicas que seriam de fato postas em prática pelo governo (AMB, Boletim Articulando, 2004). Para que isso fosse evitado, articularam-se estratégias de participação e intervenção destes movimentos, desde as conferências municipais e estaduais, direcionando-as para garantir um maior número de delegadas $(\mathrm{os})^{18}$, representantes vinculadas aos movimentos sociais, para assegurar a incorporação de suas demandas às pautas de debate. Essa estratégia de participação e de intervenção foi articulada na organização e realização da I CNPM.

O Conselho Nacional dos Direitos da Mulher (CNDM), um dos órgãos responsáveis pela organização e realização da I CNPM, tem caráter nacional e orienta o Poder Executivo com propostas de políticas públicas para as mulheres. Foi criado em 29 de agosto de 1985 por meio da lei $n^{\circ}$ 7.353. Enquanto instância institucional, o CNDM surgiu com "os objetivos de representar os interesses dos movimentos feministas e de mulheres e estimular a participação da sociedade civil juntamente à administração pública” (PIMENTA, 2010, p. 36).

A criação do CNDM foi o resultado de diálogos e negociações de longos anos entre os movimentos feministas e o governo. O VII Encontro Nacional Feminista, realizado na cidade

\footnotetext{
${ }^{18}$ Delegadas são as representantes dos órgãos e instituições governamentais e da sociedade civil que participam das conferências, possuindo direito de voto e de voz.
} 
de Belo Horizonte (MG), em 1985, no governo de José Sarney ${ }^{19}$, se constituiu em um desses espaços de debates e diálogos desses movimentos com o governo. Nesse encontro, coordenado por Ruth Escobar ${ }^{20}$, onde houve a discussão de uma proposta de criação do Conselho, algumas feministas se manifestaram contrárias à sua criação, alegando que esse processo de institucionalização seria antidemocrático. Como afirmou Schumaher (1993),

Estamos conscientes de que o sistema, através dos órgãos oficiais do Estado, reconhecendo a importância e o alcance das idéias feministas e de nossa militância e não podendo mais ignorar-nos, vem por isso assumindo nosso discurso ideológico. [...] Sabemos, entretanto, que é uma utopia acreditar que as idéias feministas sejam assumidas pelas entidades do Estado ("Carta de B.H” apud SCHUMAHER, 1993, p. 354).

No entanto, a maioria das participantes deste encontro foi favorável à proposição de uma formalização do Conselho por meio de um documento intitulado de "Carta de B.H.", produzido ao final do encontro. Essas exigências destacavam que a composição do Conselho deveria ser fundamentada na trajetória feminista de suas integrantes. Schumaher expõe algumas outras reivindicações presentes na "Carta de B.H”:

- Criação da CNDM mediante projeto de lei, como forma de garantir ampla participação da sociedade civil e das mulheres;

- Atribuição de dotação orçamentária própria;

- Identificação do órgão com a luta contra a discriminação e opressão da mulher;

- Qualquer parlamentar que venha a ocupar o cargo no Conselho deve licenciar-se de seu mandato;

- Viabilização da participação do movimento de mulheres na elaboração, execução e acompanhamento das políticas oficiais;

19 O Governo de José Sarney, de 15 de março de 1985 à 15 de março de 1990, foi um período que corresponde à posse de José Ribamar Ferreira Araújo da Costa Sarney na Presidência da República, até a sua sucessão por Fernando Collor. Sarney assumiu o governo após a internação de Tancredo Neves, e definitivamente em 21 de abril de 1985, após a morte do qual foi o primeiro presidente civil após mais de vinte anos de regime militar no Brasil.

Quando tomou posse, Sarney afirmou que mudanças viriam ao longo do processo de redemocratização. As primeiras delas vieram em 8 de maio de 1985, quando foi aprovada a emenda constitucional que estabeleceu eleições diretas para presidente, prefeito e governador. Os analfabetos tiveram pela primeira vez o direito ao voto $\mathrm{e}$ os partidos comunistas foram legalizados. <http://noticias.r7.com/brasil/noticias/confira-a-cronologia-das-eleicoes-diretas-20091115.html>

Acesso em 24 Jan. 2017. Além disso, em 1985, criou o Conselho Nacional de Direitos das Mulheres.

${ }^{20}$ Ruth Escobar é uma atriz e produtora cultural, tornou-se uma das mais importantes produtoras culturais do Brasil e destacada personalidade do teatro brasileiro, empreendedora de muitos projetos culturais especialmente comprometidos com a vanguarda artística. O Teatro Ruth Escobar foi um espaço para a realização de inúmeros seminários, congressos e encontros, como o I Congresso da Mulher Paulista, em 8 de março de 1979, o Encontro Brasileiros de Homossexuais, em abril de 1980, e o Fórum Debate sobre a Mulher, que de março a novembro de 1980 reuniu quinzenalmente mulheres militantes na discussão da condição feminina. Ruth Escobar foi uma das idealizadoras e a primeira presidenta do Conselho Nacional de Direitos da Mulher (CNDM), criado em agosto por proposta do governo Sarney. O Conselho foi 'entidade-símbolo, na época, da luta das mulheres brasileiras pela construção de sua cidadania em meio à Nova República. (SCHUMAHER; BRAZIL, 2000) 
- O Conselho deve expressar as reivindicações do movimento de mulheres sem pretender representá-lo ou substituí-lo ("Carta de B.H” apud SCHUMAHER, 1993, p. 355).

Já a Secretaria de Políticas para as Mulheres (SPM), o outro órgão responsável pela I CNPM, foi criada por meio da medida provisória $\mathrm{n}^{\circ} 103$, de $1^{\circ}$ de janeiro de 2003 , pelo presidente Luiz Inácio Lula da Silva que realizou a deliberação da transformação da Secretaria de Estado dos Direitos da Mulher (SEDIM), ligada ao Ministério da Justiça, para Secretária Especial de Políticas para as Mulheres (SPM) ${ }^{21}$ tornando-a um órgão integrante da Presidência da República, ou seja, um órgão com status de ministério ${ }^{22}$. Nesse processo o CNDM foi transferido para a SPM ${ }^{23}$. No entanto, a SPM não é legatária do CNDM e, muito menos uma instância na qual o Conselho é subordinado. Conforme Pimenta (2010),

a Secretaria vem preencher uma demanda que o movimento feminista brasileiro sempre fez ao Estado, que era obter uma institucionalidade com reais funções executivas que permitisse transformar a pauta feminista em uma agenda de política pública (PIMENTA, 2010, p. 173-174).

Para haver essa diferenciação, a Lei n 10.683 , de 28 de maio de 2003, conferiu à SPM e ao CNDM as seguintes atribuições:

Art. 22. À Secretaria Especial de Políticas para as Mulheres compete assessorar direta e imediatamente o Presidente da República na formulação, coordenação e articulação de políticas para as mulheres, bem como elaborar e implementar campanhas educativas e antidiscriminatórias de caráter nacional, elaborar o planejamento de gênero que contribua na ação do governo federal e demais esferas de governo, com vistas na promoção da igualdade, articular, promover e executar programas de cooperação com os organismos nacionais e internacionais, públicos e privados, voltados à implementação de políticas para as mulheres, promover o acompanhamento da implementação de legislação de ação afirmativa e definição de ações públicas que visem ao cumprimento dos acordos, convenções e planos de ação assinados pelo Brasil, nos aspectos relativos à igualdade entre mulheres e homens e de combater à discriminação, tendo como estrutura básica $o$

\footnotetext{
${ }^{21}$ Essa deliberação foi destacada no discurso do presidente Luiz Inácio Lula da Silva, no Ato de Prestação de Contas do Ano de 2003, em que afirmou: "Demos status de Ministério à Secretaria Especial de Políticas para as Mulheres, vinculando-a diretamente à Presidência da República. A democracia contemporânea não pode se limitar aos direitos econômicos e políticos. A igualdade de gênero é uma dimensão inalienável da justiça social no mundo de hoje".

22 "A Secretaria se diferencia do Ministério porque não tem a estrutura deste; é um órgão mais enxuto, que normalmente dispõe de um quadro de pessoal 'emprestado' dos Ministérios. Diferentemente dos Ministérios, as Secretarias fazem parte da estrutura da Presidência da República, assim como a Casa Civil, o Gabinete de Segurança Institucional, entre outros, como prevê a Lei $\mathrm{N}^{\circ} 10.683$, de 28 de maio de 2003, que dispõe sobre a organização da Presidência da República e dos Ministérios”. (PIMENTA, 2010, p. 173) Este ministério foi extinto no ano de 2015.

${ }^{23}$ Assim estabelece o Art. 31. "São transformados: IV - a Secretaria de Estado dos Direitos da Mulher, do Ministério da Justiça, em Secretaria Especial de Políticas para as Mulheres da Presidência da República;(...) Art. 33. São transferidos: V - o Conselho Nacional dos Direitos da Mulher, do Ministério da Justiça para a Secretaria Especial de Políticas para as Mulheres da Presidência da República” (Lei n 10.683, de 28 de maio de 2003).
} 
Conselho Nacional dos Direitos da Mulher, o Gabinete e até três Subsecretarias (BRASIL, 2003).

Com essas transformações, a SPM adquiriu liberdade orçamentária e autonomia na elaboração, negociação e monitoramento de políticas públicas para as mulheres. Para isso contou com o apoio institucional do governo para a realização dos projetos e das políticas para as mulheres. A SPM tinha, assim, como objetivo planejar ações que implementassem a "transversalidade de gênero" (BANDEIRA; BITTENCOURT, 2005, p. 171) em todas as esferas políticas do governo federal e, consequentemente, promovessem a igualdade de gênero e combater a discriminação. De acordo com Oliveira (2012),

no Brasil, a estratégia de transversalização significou, portanto, a articulação entre diferentes órgãos na incorporação das questões de gênero em suas políticas. Devemos ressaltar que este tipo de gestão transversal só ganhou força política no país a partir de 2003 (OLVEIRA, 2012, p. 03).

Ainda segundo Oliveira (2012), a criação do CNDM e da SPM denota a forte mobilização dos movimentos feministas e de mulheres e o alcance de suas lutas e conquistas em âmbito governamental. Trata-se da conquista de espaços institucionais dedicados exclusivamente "à promoção da igualdade de gênero, com a missão de formular, coordenar e articular políticas para as mulheres no âmbito de todo o governo federal" (OLIVEIRA, 2012, p. 05).

A atuação da SPM foi marcada pela realização das quatro Conferências Nacionais de Políticas para as Mulheres, que deram origem ao I, II e III Plano Nacional de Políticas para as Mulheres. Essa Secretaria tinha ainda a função de monitorar e avaliar as políticas implementadas no Brasil, com o compromisso de manter o CNDM e a sociedade civil, periodicamente informada sobre a implementação dos Planos (OLIVEIRA, 2012; BRASIL, 2006, p. 11).

De modo geral, a comissão organizadora das conferências nacionais deve ser representativa de setores e grupos sociais envolvidos com as questões em debate (SOUZA, 2013), visto que a comissão organizadora é considerada um órgão colegiado temporário que discute as estratégias, ações e cronogramas a serem realizados por uma coordenação executiva, com dedicação exclusiva a tal tarefa e que também debate o regulamento que estabelece as etapas do processo, a forma de escolha dos representantes e as temáticas que entrarão em pauta. Assim, de forma geral, essa comissão estabelece o regimento que será apreciado na plenária inicial do evento, que indicará o funcionamento deste (SOUZA, 2013). 
A I CNPM foi sistematizada por uma comissão organizadora formada por 04 (quatro) membros da SPM, que representaram o governo ${ }^{24}$, e 04 membros do CNDM, que representaram a sociedade civil em âmbito governamental ${ }^{25}$. Esta comissão foi presidida pela então Ministra da SPM, Nilcéa Freire. Além disso, contou também com a coordenação executiva de Marlise Maria Fernandes e com a participação de Ângela Maria Mesquita Fontes, Eline Jonas, Maria Laura Sales Pinheiro, Nalu Faria, Nilza Iraci Silva, Maria Aparecida Schuma Schumaher, Suely de Oliveira e Zuleide Araújo Teixeira. Essa comissão organizadora contou ainda com um Grupo de Apoio $^{26}$, designado pela SPM e referendado

${ }^{24}$ Os representantes do governo, indicados pela SPM são: a própria Secretaria de Políticas para as Mulheres como Presidenta do Conselho Nilcéa Freire e como assessora técnica Maria Laura Sales Pinheiro; o Ministro de Estado do Planejamento Orçamento e Gestão Guido Mantega e a assessora técnica Mariana Meirelles Nemrod Guimarães; o Ministro de Estado da Saúde Humberto Sergio Costa Lima e a assessora técnica Maria José de Oliveira Araújo; o Ministro de Estado da Educação Tarso Genro e a assessora técnica Lúcia Helena Lodi; o Ministro de Estado do Trabalho e EmpregonRicardo Berzoni e a assessora técnica Tita de Cássia Munck; o Ministro de Estado da Justiça Márcio Thomaz Bastos e a assessora técnica Myriam Brea Honorato de Souza; o Ministro de Estado do Desenvolvimento Agrário Miguel Soldatelli Rosseto e a assessora técnica Andréa Lorena Butto Zarzar; o Ministro de Estado da Cultura Gilberto Passos Gil e a assessora técnica Flávia Gomes de Galiza; o Ministro de Estado de Desenvolvimento Social e Combate à Fome Patrus Ananias e a assessora técnica Hildézia Alvez Medeiros; a Secretaria Especial de Políticas de Promoção da Igualdade Racial Matilde Ribeiro e a assessora técnica Denise Antonia de Paulo Pacheco; o Secretário Especial dos Direito Humanos Nilmário Miranda e a assessora técina Isabel Maria Madeiro Loureiro Maior.

${ }^{25}$ Os representantes da sociedade civil, indicados pelo CNDM são: Articulação de Mulheres Brasileiras - AMB, titular Shuma Schumaher (Maria Aparecida Schumaher) e suplente Analba Brazão Teixeira; Articulação Nacional de Mulheres Trabalhadoras Rurais - ANMTR, titular Justina Inês Cima e suplente Lúcia de Fátima Félix da Silva; Articulação de Ongs de Mulheres Negras Brasileiras, titular Nilza Iraci Silva e suplente Givania Maria da Silva; Associação Brasileira de Mulheres de Carreira Jurídica - ABMCJ, titular Gisela Zilsch e suplente Maria Dirce Mendonça Fonseca; Central Única dos Trabalhadores - CUT, titular Maria Ednalva Bezerra de Lima e suplente Carmen Helena Ferreira Foro; Confederação Geral dos Trabalhadores - CGT, titular Maria Licia Alvez Dias e suplente Eliana Fernandes da Cruz Malfarage; Confederação das Mulheres do Brasil CMB, titular Márcia de Campos Pereira e suplente Edna Maria Costa; Conselho Nacional de Mulheres Indígenas - CONAMI, titular Dirce Cavalheiro Veron e suplente Maria do Socorro Pinheiro de Carvalho; Confederação Nacional dos Trabalhadores em Educação - CNTE, titular Raquel Felau Guisoni e suplente Luzia Aparecida de Oliveira; Confederação Nacional dos Trabalhadores na Agricultura - CONTAG, titular Raimunda Celestina de Mascena e suplente Simone Battestin; Federação das Associações de Mulheres de Negócios e Profissionais do Brasil - BPW/BRASIL, titular Ana Luisa Fernandes Gonçalves e suplente Iria Martins; Federação Nacional das Trabalhadoras Domesticas - FENATRAD, titular Creuza Maria Oliveira e suplente Maria Noeli dos Santos; Fórum de Mulheres do MERCOSUL, titular Maria Elvira Salles Ferreira e suplente Dalva Maria Thomaz Rocha; Movimento Articulado de Mulheres do Amazonas - MAMA, titular Maria da Conceição Maia de Oliveira e suplente Maria das Graças Lopes de Castro; Ordem dos Advogados do Brasil - OAB, titular Marilma Torres Gouveia de Oliveira e suplente Maria Avelina Imbiriba Hesketh; Secretaria Nacional da Marcha Mundial das Mulheres, titular Nalu Faria Silva e suplente Eleutéria Amora da Silva; Secretaria Nacional de Políticas para Mulher da Força Sindical, titular Neuza Barboza Lima e suplente Helena Ribeiro da Silva; União Brasileira de Mulheres - UBM, titular Eline Jonas e suplente Mary Garcia Castro; Rede Nacional Feminista de Saúde, Direitos Sexuais e Direitos Reprodutivos, titular Ana Maria de Silva Soares e suplente Lia Zanotta Machado. Além desses dois âmbitos representativos na I CNPM, há também a participação de Rose Marie Muraro, Clara Charf e Albertina de Oliveira Costa, como mulheres com "notório conhecimento" das questões de gênero.

${ }^{26}$ O Grupo de Apoio trabalhou junto com a Comissão Especial de Regimento e Regulamento e deve as seguintes competências:

I - Assessorar e garantir a execução e implementação das ações necessárias a realização das decisões tomadas pela Comissão Organizadora e Comissões Especiais.

II - Articular e viabilizar a execução de tarefas específicas de cada atividade estabelecida pela Comissão Organizadora. 
pelo CNDM. De modo geral, a comissão organizadora teve como competências as seguintes atribuições:

I - Organizar, acompanhar e avaliar a realização da I Conferência Nacional de Políticas para as Mulheres.

II - Deliberar sobre:

a) A metodologia de elaboração do relatório da $1^{\circ}$ Conferência;

b) As mesas centrais; temas e critérios de escolha das (os) expositoras (ES);

c) Os critérios para participação e a definição de convidadas (os) nacionais e internacionais;

d) As propostas de elaboração de termos de referência para o tema central e eixos temáticos, visando subsidiar a apresentação das (os) expositoras (es) das mesas;

e) A ampliação da articulação com as Conferências Nacionais de outras áreas, no sentido de inclusão do tema de gênero, e a transversalidade.

III - Definir e acompanhar a disponibilidade e organização da infraestrutura, inclusive orçamento para a etapa nacional.

IV- Designar as (os) integrantes das Comissões Especiais podendo ampliar a composição destas, sempre que houver necessidade.

V - Providenciar a publicação do relatório da I Conferência Nacional de Políticas.

VI- Debater e deliberar em relação a todas as questões julgadas pertinentes sobre a I Conferência Nacional de Políticas para as Mulheres e não previstas no regimento e no regulamento (REGIMENTO, 2003, p. 4).

Com a finalidade de ser mais eficaz em seu trabalho, a comissão organizadora da I CNPM contou com a designação de diferentes subcomissões. Estas instâncias seriam responsáveis por determinadas tarefas necessárias para a organização e realização da I Conferência (SOUZA; CRUXÊN; ALENCAR; LIMA; RIBEIRO, 2013). Em primeiro lugar foi constituída a Comissão Especial Temática e de Relatoria, que teve por competência propor os eixos temáticos de discussão, visando organizar as falas e debates na I Conferência. Tal Comissão ficou também responsável pela proposição de palestrantes para cada mesa temática e, consequentemente, ficou responsável pela elaboração da relação de sub-temas e roteiros para os grupos de trabalho. Com isso, encarregou-se de formular a metodologia da I Conferência além de coordenar a consolidação dos relatórios dos grupos. Por fim, elaborou, organizou e acompanhou a publicação do relatório final da I CNPM, junto a Comissão Especial de Comunicação (BRASIL, 2003c, p. 4). Esta Comissão Especial teve integrantes provenientes da SPM, dentre Suely de Oliveira, como Coordenadora, Ângela Maria Mesquita Fontes, Sônia Malheiros Miguel, Liège Rocha e Cleide Silva. Como integrantes provenientes

III - Apoiar os trabalhos operacionais da I Conferência Nacional de Políticas para as Mulheres, desde seu planejamento, até conclusão do processo de avaliação.

IV - Propor e organizar as pautas das reuniões da Comissão organizadora. 
do CNDM teve Clara Araújo, Iáris Ramalho Cortes, Lúcia Xavier, Márcia Camargo, Maria Lúcia da Silveira e Silvia Camurça (BRASIL, 2004a, p. 03).

Em seguida, foi organizada a Comissão Especial de Comunicação, que teve como atribuições a definição de instrumentos e de mecanismos de divulgação da I Conferência, assim como a divulgação do Regimento e a orientação das atividades de comunicação social da I CNPM. Seu principal objetivo era o de "promover os registros e coberturas dos principais momentos das três etapas da Conferência, visando a divulgação bem como o arquivamento da memória da I Conferência Nacional de Políticas para as Mulheres" (BRASIL, 2003c, p. 4). Concomitantemente, institui-se a Comissão Especial de Infraestrutura, que objetivou propor as condições necessárias de infraestrutura, "referentes ao local, instalar equipamentos, audiovisuais, reprografia, comunicações, hospedagem, transporte, alimentação e outras" para a realização da I Conferência, e também “avaliar, juntamente com a Comissão Organizadora, a prestação de contas de todos os recursos destinados à realização da Conferência" (BRASIL, 2003c, p. 5).

Ainda, organizou-se uma Comissão Especial de Articulação e Mobilização que contou com a participação de Dirce Margarete Grosz, Maria Elisabete Pereira, Liège Santos Rocha e Teresa Cristina Nascimento Sousa. Com o objetivo de estimular a organização e realização das etapas preliminares a I CNPM, como também articular, de forma ágil, o encaminhamento dos relatórios das conferências estaduais à comissão organizada da I CNPM e "mobilizar os governos estaduais e municipais, bem como as(os) delegadas(os) eleitas(os) nas Conferências Estaduais para sua participação efetiva na etapa nacional da Conferencia” (BRASIL, 2003c, p. 5).

Por fim, constituiu-se uma Comissão Especial de Regimento e de Regulamento que teve por competência a proposição e o acompanhamento do cumprimento do Regimento da I CNPM e a apresentação do Regulamento da Conferência, a ser votado em sua abertura (BRASIL, 2003c, p. 5). Em vista disso, o Regimento da I CNPM foi aprovado em 02 de dezembro de 2003, pelo CNDM e estabeleceu como temática do evento "Políticas para as Mulheres: um desafio para a igualdade numa perspectiva de gênero", com o objetivo de propor diretrizes para a fundamentação do I Plano Nacional de Políticas para as Mulheres (I PNPM). O Regimento, ainda, indicou os eixos básicos que deviam ser abordados na I Conferência, os quais também foram indicados no decreto de convocação, como assinalado no início do texto.

A I CNPM foi planejada como um espaço de deliberação, com elementos como discussão, construção de consenso, cooperação entre sujeitos, resolução de conflitos e tomada 
de decisão nas políticas públicas destinadas para as mulheres. Observar os diversos momentos da I CNPM e as suas regras de deliberação ajuda a compreender a dinâmica das suas atividades, sua organização, troca de experiências e formulação de propostas.

A partir da proposição do diálogo entre a esfera governamental e a sociedade civil, sabe-se que a organização e realização de uma conferência nacional se tornam um processo complexo, porém importante para a concretização de políticas públicas para áreas, em muitos casos, marginalizadas. Dessa maneira, antes da realização da etapa nacional I CNPM, foi promovida uma série de encontros regionais com o objetivo de realizar debates e propor diretrizes para que servissem de subsídios na etapa nacional. Tais encontros constituíram as etapas preliminares da I CNPM, tidas como preparatórias do grande evento nacional e que aconteceu em âmbitos municipais, regionais e estaduais. Em cada um destes encontros ocorreram deliberações prévias, feitas por representantes do governo local e por representantes provenientes de grupos e movimentos da sociedade civil, de temas relacionados com os objetivos da I CNPM.

As etapas preliminares da I CNPM podem ser dividas, segundo o Relatório de Pesquisa sobre a Ampliação da Participação na Gestão Pública ${ }^{27}$ em: "I) etapas territoriais, que se caracterizam por mobilizar pessoas de uma localidade específica; II) etapas não territoriais, que se caracterizam por mobilizar os participantes em torno de possibilidades que não são determinadas pelo território" (2013, p. 34). Esse Relatório afirma, ainda, que, as etapas territoriais:

[...] seguem uma lógica escalonar, ou seja, são realizadas etapas municipais que selecionam propostas que serão discutidas na etapa seguinte e elegem delegados para o nível estadual. As etapas intermunicipais surgem como alternativas para pequenos municípios que podem se ver sobrecarregados com os custos de organização de uma etapa municipal. Além disso, podem ter a finalidade de reunir participantes de municípios muitos próximos, que possuem demandas comuns relacionadas ao tema da conferência. Em seguida, organizam-se etapas estaduais, com vistas à formulação de propostas e eleição de delegados para a etapa nacional. A previsão de convocação de etapas municipais ou estaduais pela sociedade civil é um mecanismo que permite que organizações e movimentos sociais participem do processo mesmo quando as autoridades públicas municipais estaduais não se interessam pela realização desta (SOUZA; CRUXÊN; ALENCAR; LIMA; RIBEIRO, 2013, p. 34-35).

Em vista disso, entende-se que as etapas preliminares à I CNPM possuíram múltiplas bases territoriais, e nas etapas estaduais foram escolhidos os representantes e estabelecida a prévia das pautas para a etapa nacional. As discussões nesses momentos fundantes foram

\footnotetext{
${ }^{27}$ Um estudo sobre conferências nacionais realizadas entre 2003 e 2011.
} 
orientadas por textos-base, "que podem ser provocadores de debates ou apresentarem as propostas do governo para aquele setor" (SOUZA, 2013, p. 58). As etapas preliminares da I CNPM foram assim realizadas em plenárias ou em grupos temáticos, sendo o debate orientado por práticas de assembleia em que "o texto-base é lido e discutem-se os pontos em que há destaques que podem suprimir, modificar ou adicionar algum aspecto do texto; por fim, vota-se cada um dos destaques, realizando-se emendas ao texto inicial" (SOUZA, 2013, p. 58).

Na I CNPM, ao longo de suas etapas preliminares, as assembleias foram constituídas por debates, nos quais, além da tarefa imprescindível de estimular o diálogo entre suas participantes e as agentes do governo, deu-se um sentido mais amplo para a participação política, o de "captar onde as mulheres vivem seu cotidiano e a enorme diversidade que constitui a maior riqueza do nosso país" (BRASIL, 2004a, p. 19). Essa diversidade, presente tanto nos debates realizados quanto na composição de suas participantes, nas etapas preliminares, pôde ser visualizada através das propostas e diretrizes que foram encaminhas para a etapa nacional. Nesses eventos também houve espaço para as moções que deram voz aos manifestos de apoio ou de repúdio a questões que não entraram na pauta principal de debate.

O texto-base ${ }^{28}$ apresentado para a etapa nacional da I CNPM objetivou servir de contribuição para os debates realizados nas conferências municipais, regionais e estaduais e, assim, estimular as discussões sobre os possíveis caminhos para as políticas públicas para as mulheres na conferência nacional. A esse documento foram agregadas contribuições, resultantes das reflexões e dos debates realizados nas plenárias municipais e regionais pelos entes governamentais e pelos movimentos feministas e de mulheres. Estruturado em três partes, o texto-base expôs: um breve diagnóstico da situação das mulheres brasileiras; um conjunto de compromissos internacionais do Estado brasileiro para com as mulheres e algumas políticas efetivadas para a realização desses compromissos; e, por fim, propôs princípios que deveriam nortear as políticas para as mulheres e apontou algumas diretrizes que fundamentariam o I Plano Nacional de Políticas para as Mulheres (I PNPM).

Durante o processo de mobilização das conferências municipais, regionais e estaduais, foram debatidas as propostas de diretrizes que orientariam a constituição do I Plano Nacional de Políticas para as Mulheres (I PNPM). Além disso, buscou-se nesse processo compreender

\footnotetext{
${ }^{28}$ Disponível em

<http://www.ipea.gov.br/participacao/images/pdfs/conferencias/Mulheres/texto_base_1_conferencia_politicas_p ara_mulheres.pdf > Acesso em 25 Nov. 2016.
} 
os papéis das diversas esferas governamentais para a efetivação das plataformas e convenções internacionais sobre os direitos das mulheres, as quais o Brasil é signatário.

Com o I PNPM, buscou-se contemplar algumas áreas estratégicas de atuação, como a "autonomia, igualdade no mundo do trabalho e cidadania; educação inclusiva e não sexista; saúde das mulheres, direitos sexuais e direitos reprodutivos; e, enfrentamento à violência contra as mulheres" (BRASIL, 2004c, p. 13). Estas deveriam ser aprofundadas e desenvolvidas em prol de mudanças qualitativas e quantitativas na vida das mulheres brasileiras. A gestão e o monitoramento do I PNPM foram um desafio, pois teve como fundamento a transversalidade de gênero, proposta até então nova no âmbito da política nacional. Dessa forma, o I PNPM, por ser um instrumento governamental de aplicação das propostas e diretrizes para políticas públicas para as mulheres, objetivou reafirmar o compromisso do governo federal, e dos seus demais entes. E assim, integrar a perspectiva de gênero e raça nas políticas públicas (BRASIL, 2004c).

Quem ficou a cargo de convocar as plenárias municipais e regionais, preferencialmente, foi o prefeito(a) municipal de cada região. Caso isso não ocorresse pela prefeitura, uma Comissão Organizadora poderia tê-lo feito, desde que fosse representativa de todos os setores relacionados ao tema. Seguindo essa mesma lógica, as conferências estaduais deveriam ser convocadas pelo(a) governador(a) de cada Estado, a quem caberia a responsabilidade de organizar tais conferências, vinculado com organismos governamentais e não governamentais, como o Conselho Estadual da Mulher, Coordenadorias da Mulher, Movimentos e Organizações Feministas e de Mulheres, Movimentos Sociais e Populares e, essencialmente, todas(os) as pessoas comprometidas com o tema.

As plenárias municipais e regionais foram realizadas no período entre 05 de janeiro a 04 de abril de 2004; já as conferências estaduais foram realizadas no período entre 05 de abril a 16 de maio de 2004; consecutivamente, foi realizada a conferência nacional no período de 15 a 17 de julho de 2004. Durante as plenárias municipais e regionais, foram trabalhadas temáticas que serviram de embasamento para os debates nas conferências estaduais momento em que foram eleitas(os) as(os) delegadas(os) para a etapa nacional e, consequentemente, aprovados os relatórios que foram encaminhados à Comissão Organizadora da I CNPM. Nesses processos estiveram envolvidos cerca de 2.000 (dois mil) municípios e houve a participação de todas as 27 (vinte e sete) unidades da federação brasileira. As etapas preliminares da I CNPM contaram, assim, com a participação de cerca de 120 mil mulheres. 
Os relatórios finais das etapas preliminares foram elaborados tendo como base os eixos temáticos da I CNPM, e as contribuições das plenárias municipais e regionais. As comissões organizadoras das etapas municipais e estaduais deviam encerar os relatórios finais e os encaminhar à comissão organizadora da I CNPM até o dia 20 de maio de 2004 para subsidiar o relatório da etapa nacional. Os relatórios finais das etapas preliminares foram apresentados em versão resumida de no máximo 10 (dez) laudas e encaminhados à comissão organizadora da I CNPM por meio eletrônico ${ }^{29}$, o que não dispensou o envio via correio postal, registrado, em formato impresso, e uma cópia em disquete para a Secretaria Especial de Políticas para as Mulheres ${ }^{30}$.

Entende-se que a realização das etapas preliminares, assim como a etapa nacional da I CNPM, foi efetuada em um momento que o Brasil possuía à sua frente o desafio de executar profundas e concretas transformações na estrutura da sociedade, reivindicadas pela população ao eleger, no ano de 2002, um governo de cunho democrático e popular. No entanto, de acordo com a SPM, essas transformações não ocorreriam de maneira repentina no cerne da sociedade. Nesse sentido, a SPM afirmou:

[...] não tínhamos a ilusão de que essas transformações iriam ocorrer de forma instantânea e milagrosa, de um momento para o outro, acreditamos em uma mudança concretada coletivamente, por isso a proposta de realização desta I Conferência Nacional” (BRASIL, 2004b, p. 33)

Nessa perspectiva, entende-se que o diálogo deliberado nas diferentes regiões do país e articulado entre os organismos responsáveis por executar as políticas públicas e os movimentos sociais interessados nos direitos das mulheres, considerando toda a sua diversidade, representou uma oportunidade única para a constituição e o aprofundamento das propostas de diretrizes que orientariam políticas públicas para as mulheres na esfera municipal, estadual e federal.

As etapas preliminares foram importantes na organização e na realização da etapa nacional da I CNPM, porque, além de realizar a tarefa de estimular o debate político, estimularam o sentimento de representatividade em suas participantes perante o Estado. Em consequência desse processo preparatório, foi estabelecido, nas diretrizes gerais da etapa nacional da I CNPM, que essa conferência deveria ocorrer, preferencialmente, a cada três

\footnotetext{
${ }^{29}$ No endereço eletrônico:

<conferenciamulheres@spmulheres.gov.br <mailto:conferenciamulheres@spmulheres.gov.br> Acessado em 17 Jan. 2016.

${ }^{30}$ No endereço: Esplanada dos Ministérios, Bloco L - Ed. Sede - $2^{\circ}$ andas - sala 200 - CEP 70047-900 Brasília - DF.
} 
anos e que deveria ser precedida de etapas preliminares, onde seriam definidos os conteúdos que formalizariam as diretrizes da I Conferência (BRASIL, 2004, p. 110).

O processo de organização e de realização da I CNPM superou as expectativas em números de participantes, pois foram cerca de, 1.787 (mil setecentas e oitenta e sete) delegadas e mais de 700 (setecentas) observadoras e convidadas, que vieram de todas as unidades da federação e da América Latina e Caribe, com o desafio de apontar diretrizes que subsidiariam o I Plano Nacional de Política para as Mulheres (I PNPM) (BRASIL, 2004ª).

\subsection{PROGRAMAÇÃO}

A programação da I CNPM foi dividida ao longo de três dias e, além do apoio proveniente do governo federal representado pela SPM e do apoio da sociedade civil representado pelo CNDM, a I Conferência contou com a colaboração de diversas empresas e órgãos governamentais, com especial destaque para as que demonstraram sensibilidade e comprometimento com as questões das mulheres, a saber: Avon; Banco do Brasil, com a área de tecnologia Cobra Tecnologia; Infraero; Petrobras; Caixa Econômica Federal; Eletrobrás; Itaipu Nacional; SENAC Distrito Federal; Conselho Nacional da Indústria (CNI); FURNAS; Nestlé; e, Senado Federal (BRASIL, 2004a, p. 163).

Após as etapas preliminares locais, a comissão especial de regimento e de regulamento da I CNPM, equipe indicada pela comissão organizadora da I Conferência, sistematizou as contribuições de cada uma das etapas e elaborou um texto com as propostas que seriam discutidas na etapa nacional. Trata-se de um documento que estabelecia o regulamento do evento. No primeiro dia da I CNPM, esse regulamento foi entregue a todos os representantes de grupos e entidades presentes para que pudessem entender a organização e a orientação das discussões.

Durante a etapa nacional da I CNPM, as discussões seguiram o modelo de assembleias, e, quando foi o caso, existiu um momento para a eleição de representantes para o conselho de políticas de determinado setor. Nessas assembleias, as delegadas vindas das etapas preliminares eram denominadas de "delegadas natas" e possuíam direito a voz e a voto $^{31}$. A realização da I CNPM teve a seguinte programação: a) plenária de abertura, b) painéis, c) grupos temáticos ou de trabalho e d) plenária final (BRASIL, 2004a, p. 147). De acordo com o Relatório de Pesquisa do Ipea, as Plenárias na I CNPM “[...] são os momentos

\footnotetext{
31 "Integrantes do conselho temático" (SOUZA, 2013, p. 58).
} 
deliberativos em que todos os participantes se reúnem para aprovação do regulamento, das propostas recebidas dos grupos de trabalho (quando houver) e das moções" (SOUZA; CRUXÊN; ALENCAR; LIMA; RIBEIRO, 2013, p. 40). Ainda nesse mesmo Relatório, as Palestras se caracterizam como:

[...] momentos em que todos os participantes se reúnem para discussões conceituais nos diversos formatos: palestra, seminário, painel ou mesa redonda. Elas trazem subsídios para a discussão acerca do tema da conferência, bem como podem auxiliar a construção das propostas (SOUZA; CRUXÊN; ALENCAR; LIMA; RIBEIRO2013, p. 40).

Já os Grupos de Trabalho seriam compostos por um número menor de participantes, com a função de discutir subtemas da conferência, além de construir e aprovar propostas a serem encaminhas às plenárias (SOUZA; CRUXÊN; ALENCAR; LIMA; RIBEIRO, 2013, p. 40).

Nos termos gerais de seu Regimento, a I CNPM teve a sua temática desenvolvida com base em dois grandes painéis:

1. Análise da realidade brasileira, avaliando as políticas realizadas e os compromissos assumidos pelo Estado Brasileiro;

2. Apresentação de propostas de diretrizes para a construção do Plano Nacional de Políticas para as Mulheres (BRASIL, 2004a, p. 147).

Nesses painéis a temática foi abordada por palestrantes indicadas pela comissão organizadora da I Conferência. Estabeleceu-se um tempo máximo de vinte minutos para cada palestra, onde deveriam expor discursos, avaliações, propostas e reivindicações. Entretanto, ao término de cada painel, as delegadas e as convidadas poderiam ainda manifestar-se verbalmente ou por escrito, sendo que o tempo destinado para cada intervenção era de três minutos, improrrogáveis. Coube à mesa organizadora de cada painel a definição do número de inscrições para as intervenções, considerando o tempo limite para a continuidade da programação. As falas, tanto das palestrantes quanto das intervenções, foram gravadas em fita magnética $^{32}$ com o objetivo de divulgação nos Anais da I Conferência (BRASIL, 2004a, p. 147). No entanto, nos Anais constam, apenas, as falas dos palestrantes na Abertura e nos Painéis, além do Regulamento e das Resoluções aprovadas na I Conferência.

Ao longo da realização da I CNPM, o processo de criação das diretrizes para o I PNPM se deu por meio da discussão do documento "Propostas de Diretrizes para uma Política Nacional para as Mulheres", documento este que é o resultado das 3.844 (três mil oitocentos e

${ }^{32}$ Art. $7^{\circ}$ - As exposições serão registradas em fita magnética com vistas a sua divulgação nos Anais da I Conferência Nacional de Políticas para as Mulheres (BRASIL, 2003c). 
quarenta e quatro) propostas provenientes dos relatórios finais das etapas preliminares (BRASIL, 2004a, p. 20). Essas discussões foram realizadas nos 20 grupos de trabalhos formados durante a I Conferência, todos esses grupos discutiram a parte geral do documento, denominada de "Natureza, princípios e diretrizes da Política Nacional para as Mulheres na perspectiva da igualdade de gênero, considerando a diversidade de raça e etnia" (BRASIL, 2004a, p. 100). Portanto, os cinco eixos temáticos que fizeram parte desse documento foram discutidos, cada um, por quatro grupos de trabalhos. Os eixos temáticos foram indicados na Nota Metodológica da I CNPM da seguinte forma:

Eixo Temático 1 - Enfrentamento da pobreza: geração de renda, trabalho, acesso ao crédito e a terra.

Eixo Temático 2 - Superação da violência contra a mulher: prevenção, assistência e enfrentamento.

Eixo Temático 3 - Promoção do bem-estar e qualidade de vida para as mulheres: saúde, moradia, infraestrutura, equipamentos sociais e recursos naturais.

Eixo Temático 4 - Efetivação dos direitos humanos das mulheres: civis, políticos, sexuais e reprodutivos.

Eixo Temático 5 - Desenvolvimento de políticas de educação, cultura, comunicação e produção do conhecimento para a igualdade (BRASIL, 2004a, p. 100).

Nessa perspectiva, os grupos de trabalho foram constituídos levando em consideração as escolhas feitas pelas inscritas no pré-credenciamento da etapa nacional da I CNPM. Devese ressaltar que os grupos em sua prática procuraram abordar as temáticas em uma perspectiva "não sexista, não racista, não homofóbica, incorporando a diversidade étnica" (BRASIL, 2004a, p. 148). Assim, a composição dos grupos de trabalho se deu por delegadas que tinham o direito a voz e voto, por convidadas com direito a voz e por observadoras, em um número de até cem por grupo. Além disso, os grupos de trabalho contaram com uma coordenadora, indicada pela comissão organizadora da I Conferência, que tinha a função de coordenar as discussões, controlar o tempo de fala e estimular a participação, seguindo o roteiro previamente recebido. Tais grupos contaram, também, com uma relatora indicada pela comissão organizadora, e uma sub-relatora indicada pelo próprio grupo de trabalho, que foram responsáveis pelo relatório do grupo e pela sua consolidação juntamente aos demais grupos do mesmo eixo temático. Tendo em vista essa dinâmica de composição dos grupos de trabalho, as delegadas desses grupos possuíam direito "a aprovar, suprimir, mudar a redação ou incluir propostas em forma de diretrizes pertinentes ao tema, contidas nos relatórios dos Estados, e que não foram contempladas no documento-base” (BRASIL, 2004a, p. 149). 
A elaboração da sistematização das discussões dos grupos de trabalho foi feita com a participação das coordenadoras e relatoras de cada um dos grupos, e foi orientada pela comissão especial temática e de relatoria. Essa organização teve por base os relatórios contendo as propostas e diretrizes provenientes das etapas preliminares. Dessa maneira, os relatórios das discussões dos grupos de trabalho foram compatibilizados, sendo destacado "os itens que foram aprovados $(50 \%+1)$ pelos 4 grupos nos respectivos eixos temáticos" (BRASIL, 2004a, p. 101), assim as diretrizes, que foram aprovadas pela maioria dos grupos de trabalho, também foram compatibilizadas.

Com base nas discussões realizadas nos grupos de trabalho, foi organizado um "bloco de questões conceituais", as quais foram discutidas no primeiro momento da Plenária Final no terceiro dia da I Conferência - e que, depois de aprovadas pelas delegadas, seriam usadas em todo o documento final da Conferência (BRASIL, 2004a, p. 101). Assim, as propostas de diretrizes que passaram por alguma alteração no trabalho dos grupos foram separadas em dois grandes blocos, como indicado na Nota Metodológica da Conferência:

[...] o primeiro bloco aglutinou as diretrizes aprovadas na íntegra e as propostas de diretrizes que receberam emendas de redação, que não alteravam o conteúdo da proposta e sim melhoravam ou clareavam o texto sugerido. O segundo bloco aglutinou as emendas que sugeriram novos conteúdos (BRASIL, 2004a, p. 101).

Por recomendação da comissão especial temática e de relatoria, foram discutidas na Plenária Final da I CNPM, as sugestões das emendas contidas no segundo bloco, como descrito acima, pois exigiram um posicionamento das delegadas. Já o primeiro bloco foi levado à Plenária Final apenas para referendum.

Após esse longo processo de deliberações, foi aprovado um documento final da I CNPM intitulado "Natureza e diretrizes da Política Nacional para as Mulheres na perspectiva da igualdade de gênero, considerando a diversidade de raça e etnia”. Tal documento foi estruturado da seguinte forma: uma parte geral, contendo sete itens; uma parte de princípios, contendo treze, nos quais são abordados temas como: igualdade, autonomia das mulheres, Estado laico, universalidade, participação e equidade; e, uma parte das diretrizes gerais, contendo vinte e dois itens. Ainda, nesse Documento, são apresentados os cinco eixos temáticos e as suas respectivas diretrizes trabalhadas ao longo da I Conferência.

A dinâmica da organização da I CNPM, de modo geral, contou, também, com duas principais plenárias, a Plenária de Abertura, que teve como função principal aprovar o Regulamento da I Conferência e deliberar sobre eventuais recursos, e a Plenária Final que 
teve como funções discutir e debater as propostas de diretrizes e as moções apreciadas pelos grupos de trabalhos.

As sessões das plenárias foram realizadas por uma mesa formada por integrantes da comissão organizadora e por pessoas indicadas por ela. Coube assim à mesa informar ao plenário o número de delegadas, convidadas e de observadoras inscritas na I CNPM; encaminhar para a aprovação o Regulamento da I Conferência e, por fim, conduzir os trabalhos das plenárias.

Ainda, na Plenária Final da I CNPM, realizou-se a apreciação dos relatórios consolidados por eixos temáticos e das moções ${ }^{33}$ apresentadas por alguns grupos, movimentos e entidades presentes. Neste momento, houve no plenário a aprovação das propostas encaminhadas para votação final, sendo consideradas aprovadas as que obtiveram metade (50\%) mais 1 (um) dos votos das(os) delegadas(os) presentes. Dessa maneira, como ficou

\footnotetext{
${ }^{33}$ No momento final da I Conferência foram apresentadas algumas moções, por meio escrito e encaminhadas para secretaria da I CNPM, "até as 19h do dia 16" (BRASIL, 2004, p. 151). Para que cada moção fosse aprovada deveriam ser assinadas por, no mínimo duzentas delegadas. No processo de aprovação das moções, caso houvesse alguma divergência, poderia haver uma intervenção a favor e uma contra, de no máximo três minutos e, consequentemente, assim como no processo de aprovação das diretrizes, foram consideradas aprovadas as moções que obtiveram 50\% mais 1 (um) dos votos das delegadas presentes. Ao final, foram aprovadas dezoito moções, a saber: 1) Moção de Repúdio a publicação do livro Manual da Incompetência Feminina, do autor Paulo Mundim Prazeres, que contou com 325 assinaturas; 2) Repúdio ao Governador Jarbas Vasconcelos, que se mostrou indiferente à importância do processo das conferências para as mulheres, descumprindo o seu papel de garantir que todas as Delegadas eleitas na I Conferência Estadual de Políticas para as Mulheres pudessem participar do pleno da I Conferência Nacional de Políticas para Mulheres, realizado em Brasília/DF, de 15 a 17 de julho de 2004, esta redação teve 200 assinaturas; 3) Moção de apoio à liminar do Supremo Tribunal Federal sobre a arguição de descumprimento de preceito fundamental apresentada pela Confederação Nacional dos Trabalhadores na Saúde, com assessoria técnica da ANIS (Instituto de Bioética, Direitos Humanos e Gênero), que contou com 411 assinaturas; 4) Moção de apoio à liminar concedida pelo Ministro Marco Aurélio de Mello, do Superior Tribunal Federal - STF, favorável à realização de aborto em casos de gravidez de fetos anencéfalos (sem cérebro), que não possuem chance de sobrevivência, causando enorme sofrimento às mulheres, contou com 313 assinaturas; 5) Moção de protesto contra a legalização do aborto, que contou com 224 assinaturas; 6) Moção de defesa da legalização do aborto, esta redação foi retirada pelo tema já ter sido debatido e aprovado na Conferência; 7) Moção de apoio a emenda constitucional PEC 385/2001, que dá direito a aposentadoria para donas de casa, esta redação teve 244 assinaturas; 8) Moção de recomendação às candidatas e candidatos as Prefeituras de todos os municípios brasileiros, pela criação de Secretarias da Mulher, com status de $1^{\circ}$ escalão, em seus futuros governos, esta redação teve 538 assinaturas; 9) Moção de repúdio à proposta de desvinculação das verbas constitucionais destinadas à saúde e a educação em estudo no Ministério da Fazenda, atendendo as exigências do FMI, esta redação teve 244 assinaturas; 10) Moção de recomendação para o reconhecimento e promoção do projeto de Promotoras Legais Populares como uma Política Pública em parceria entre o Estado e a Sociedade Civil, para a defesa e promoção dos direitos das mulheres e garantia de acesso à justiça, esta redação teve 453 assinaturas; 11) Moção que visa reconhecer o papel das mulheres na democratização e na construção de uma cultura da paz, esta redação teve 214 assinaturas; 12) Moção de apoio a mulher indígena e a Terra Raposa Serra do Sol, esta redação teve 233 assinaturas; 13) Moção de homologação das terras indígenas com demarcação continuada - esta redação teve 200 assinaturas; 14) Moção de apoio à candidatura de Silvia Pimentel ao CEDAW, esta redação teve 231 assinaturas; 15) Moção de repúdio a todos os atos de violação dos direitos das mulheres, nos processos de guerra, esta redação teve 239 assinaturas; 16) Moção de apoio a casaabrigo de Juiz de Fora, esta redação teve 418 assinaturas; 17) Moção sobre abuso e exploração sexual de crianças e adolescentes, esta redação teve 235 assinaturas; e por fim, 18) Moção de apoio para a resolução do caso Maria da Penha, esta redação teve 201 assinaturas.
} 
indicado no Regulamento Interno da I Conferência as propostas aprovadas tiveram o seguinte destino:

Parágrafo $2^{\circ}$ - As propostas que obtiveram aprovação nos quatro grupos do mesmo eixo temático, serão consideras aprovadas pela conferência, mediante referendo do plenário.

Parágrafo $3^{\circ}$ - As propostas aprovadas em 1 (um) ou mais grupos do mesmo eixo temático e as não aprovadas, mas que obtiverem no mínimo de $20 \%$ da votação nos grupos, serão deliberadas em plenário, com o seguinte encaminhamento:

a) as propostas apresentadas em plenário e não destacas serão consideradas aprovadas.

b) as propostas destacadas terão uma intervenção a favor e uma intervenção contra, com o tempo máximo de 3 (três) minutos para cada. Caso o plenário não se sinta devidamente esclarecido, será aberta uma nova rodada de intervenção, sendo uma a favor e outra contra.

c) após a discussão serão submetidas à votação no plenário e aprovadas aquelas que obtiverem $50 \%$ (cinquenta por cento) mais 1 (um) dos votos das (os) delegadas (os) presentes (BRASIL, 2004a, p. 150)

Desse modo, os acordos gerais definidos na Plenária Final configuram, ao todo, nove diretrizes:

1) onde couber, mencionar categorias estruturais: gênero, raça, etnia e classe social, quando estivermos nos referindo às desigualdades estruturais.

2) conferir visibilidade e afirmar todas as expressões da diversidade em relação à livre orientação sexual, às jovens, às idosas e às mulheres com deficiência.

3) conferir visibilidade e afirmar a diversidade de inserção social e regional: mulheres trabalhadoras urbanas e rurais, profissionais do sexo, mulheres vivendo com HIV/AIDS, refugiadas e mulheres em situação de encarceramento.

4) igualdade e equidade: adotar, sempre que se aplicar, a equidade de gênero em associação com igualdade, nos termos indicados pelos grupos.

5) para visibilidade da diversidade: procurar usar de forma associada: movimento de mulheres e feministas.

6) ao citar grupos específicos de mulheres, além de negras e índias, incluir, sempre que adequado e nos termos propostos: as jovens, idosas, populações tradicionais, mulheres lésbicas, mulheres bissexuais, mulheres que fazem sexo com mulheres, mulheres vivendo com AIDS, profissionais do sexo, mulheres com deficiência, mulheres privadas de liberdade e refugiadas;

7) dar visibilidade a desigualdades regionais, adotando esta referência nos casos propostos nos grupos, ao tratar de desenvolvimento.

8) adotar a menção as perspectivas não sexista, antirracista, não lesbofóbica e não homofóbica nos casos indicados.

9) como regra geral usar mulheres em situação de violência. Onde couber referência à garantia de direitos, reparação, indenização e punição, usar mulheres vítimas de violência (BRASIL, 2004a, p. 103. Grifos nossos).

Já se pode notar neste acordo geral, no item 5, o modo como o termo "feministas" deveria ser usado em associação ao termo "movimento de mulheres". Um acordo feito com a 
intenção de contemplar a diversidade dos movimentos que participam da I CNPM. Esse acordo esteve presente nas falas de muitas palestrantes que durante o evento tenderam a tratar de "movimentos de mulheres e feministas", considerando as interlocutoras presentes. No entanto, como será visto na análise das falas, em relação a essa estratégia e acordo discursivo de menção aos movimentos, o feminismo e a feminista, assim como os "movimentos de mulheres", ganham sentidos particulares em cada fala.

Por fim, a redação do relatório final da I CNPM ficou a cargo da comissão especial de relatoria, coordenada pela SPM. Esse documento teve o prazo de no máximo 45 (quarenta e cinco) dias após o término da I CNPM para ser redigido (BRASIL, 2004a, p. 151). Portanto, o relatório final da I CNPM foi referendado pelo CNDM, antes de sua divulgação, respeitandose a aprovação na plenária final da I Conferência.

O processo de organização e de realização da I CNPM foi bastante complexo, em que as condições de produção favoráveis tiveram que ser trabalhadas de maneira atenta e plural. Ressalta-se que, ao longo desse processo, além da presença das(os) delegadas(os), palestrantes e observadoras, estiveram presentes mulheres convidadas pela comissão organizadora com "notório conhecimento das questões de gênero"(BRASIL, 2004a), cuja presença objetivou contribuir no processo de construção política da I Conferência. Outro ponto importante a ser destacado é o destino das deliberações e resoluções provenientes da I CNPM: coube aos órgãos responsáveis pela I Conferência, SPM e CNDM, pós-conferência, a dar encaminhamento a estas, bem como pela constituição do I Plano Nacional de Políticas para as Mulheres (I PNPM).

\subsection{PERFIL DAS DELEGADAS}

As delegadas participantes da I CNPM foram fundamentais para que o objetivo de propor diretrizes para o I Plano Nacional de Políticas para as Mulheres (I PNPM) fosse alcançado, pois tinham por função aprovar, suprimir, mudar ou incluir diretrizes provenientes dos relatórios das etapas preliminares. Tendo em vista esse relevante papel das delegadas, a SPM e o Instituto Brasileiro de Administração Municipal (IBAM) firmaram um convênio em 1 de julho de 2004 para execução de uma pesquisa (BRASIL, 2005) com o objetivo de traçar o perfil das delegadas que participaram da I Conferência. Essa pesquisa resultou em um relatório final, publicado no ano de 2005 sob o título "I Conferência Nacional de Políticas para as Mulheres - Perfil das delegadas e perspectivas de atuação". Esse relatório contribuiu para uma melhor compreensão dos arranjos políticos-institucionais instaurados por meio da 
identificação do perfil das delegadas que participaram da I CNPM. Além disso, tal relatório traz uma avaliação do processo de construção e de realização da I Conferência, além de um destaque às possibilidades de efetivação das resoluções aprovadas nesse evento.

O processo de estruturação da I CNPM mobilizou uma vasta rede social constituída por técnicos governamentais, gestores e mediadores de políticas públicas, militantes dos movimentos feministas e de mulheres, representantes de ONGs, lideranças comunitárias, trabalhadoras rurais e urbanas etc. A implementação de políticas públicas construídas sob a ótica de uma gestão democrática e popular solicita o esforço de diálogo e escuta juntamente aos inúmeros segmentos da sociedade civil e governamentais que pretendem construir uma sociedade marcada por relações de gênero igualitárias. A concepção do I PNPM, resultante dos trabalhos da I CNPM, consistiu em um instrumento de políticas públicas que forneceu subsídios para as três esferas de governo no que diz respeito ao planejamento, à implementação e ao monitoramento de projetos, programas e ações direcionais a redução das desigualdades de gênero no país.

A pesquisa sobre o perfil das delegadas da I CNPM foi organizada a partir de um questionário no qual suas respostas foram sistematizadas. O painel de amostra final foi composto por 900 delegadas, "o que significa 50\% do total das(os) delegadas(os) que efetivamente compareceram ao evento" (BRASIL, 2005, p. 08) (Figura 1, p. 64). O número alcançado foi considerado mais que suficiente para este estudo quantitativo, já que as informações apresentaram a qualidade necessária (Figura 2, p. 65). Essa pesquisa é, também, "fruto complementar do trabalho de supervisão dos questionários, evitando-se assim a perda de informações para a construção do Banco de Dados" (BRASIL, 2005, p. 08).

O Quadro1 ${ }^{34}$ (p. 63) apresenta uma comparação entre o número previsto de delegadas(os), das(os) que responderam à pesquisa, e o painel de amostras mínimo calculado em $30 \%$, por UF. Como o Governo Federal tinha uma cota em separado, assim entrou no painel de amostra (BRASIL, 2005, 16).

\footnotetext{
${ }^{34}$ Foram mantidos os títulos originais da pesquisa.
} 
Quadro 1: Distribuição das(os) delegadas(os) previstas(os) que responderam à pesquisa e do painel de amostra mínimo por UF

\begin{tabular}{l|c|c|c|c} 
UF & $\begin{array}{l}\text { N.* Previsto } \\
\text { de delegadas(os) }\end{array}$ & $\begin{array}{c}\text { Painel de amostras } \\
\text { mínimo (30\%) }\end{array}$ & $\begin{array}{c}\mathbf{N .} \text { de delegadas(os) } \\
\text { pesquisadas(os) }\end{array}$ & $\begin{array}{c}\text { \% do total } \\
\text { previsto }\end{array}$ \\
\hline AC & 26 & 8 & 9 & 35 \\
AL & 41 & 12 & 23 & 56 \\
AM & 37 & 11 & 14 & 38 \\
AP & 27 & 8 & 12 & 44 \\
BA & 101 & 30 & 57 & 56 \\
CE & 68 & 20 & 33 & 49 \\
DF & 36 & 11 & 18 & 50
\end{tabular}

\begin{tabular}{|c|c|c|c|c|}
\hline UF & $\begin{array}{l}\text { N. }{ }^{\circ} \text { Previsto de } \\
\text { delegadas(os) }\end{array}$ & $\begin{array}{l}\text { Painel de amostras } \\
\text { mínimo (30\%) }\end{array}$ & $\begin{array}{l}\text { N. }{ }^{\circ} \text { de delegadas(Os) } \\
\text { pesquisadas(os) }\end{array}$ & $\begin{array}{l}\% \text { do total } \\
\text { previsto }\end{array}$ \\
\hline ES & 42 & 13 & 34 & 81 \\
\hline GO & 54 & 16 & 36 & 67 \\
\hline MA & 57 & 17 & 23 & 40 \\
\hline MG & 129 & 39 & 67 & 52 \\
\hline MS & 36 & 11 & 19 & 53 \\
\hline MT & 39 & 12 & 25 & 64 \\
\hline PA & 49 & 15 & 20 & 41 \\
\hline PB & 44 & 13 & 21 & 48 \\
\hline PE & 71 & 21 & 32 & 45 \\
\hline PI & 41 & 12 & 19 & 46 \\
\hline PR & 80 & 24 & 42 & 53 \\
\hline $\mathrm{RJ}$ & 109 & 33 & 78 & 72 \\
\hline $\mathrm{RN}$ & 40 & 12 & 17 & 43 \\
\hline RO & 29 & 9 & 17 & 59 \\
\hline RR & 25 & 8 & 5 & 20 \\
\hline RS & 84 & 25 & 30 & 36 \\
\hline SC & 56 & 17 & 28 & 50 \\
\hline SE & 35 & 11 & 18 & 51 \\
\hline$S P$ & 243 & 73 & 127 & 52 \\
\hline TO & 31 & 9 & 10 & 32 \\
\hline GF & 363 & 109 & 64 & 18 \\
\hline Sem & & & & \\
\hline Informação & - & - & 2 & - \\
\hline TOTAL & 1.993 & 599 & 900 & 45 \\
\hline
\end{tabular}

Fonte: Regimento Interno da I CNPM. Diário Oficial da União, edição número 247 de 19 de dezembro de 2004. 
Figura 1: Distribuição das pessoas que responderam ao questionário por origem geográfica

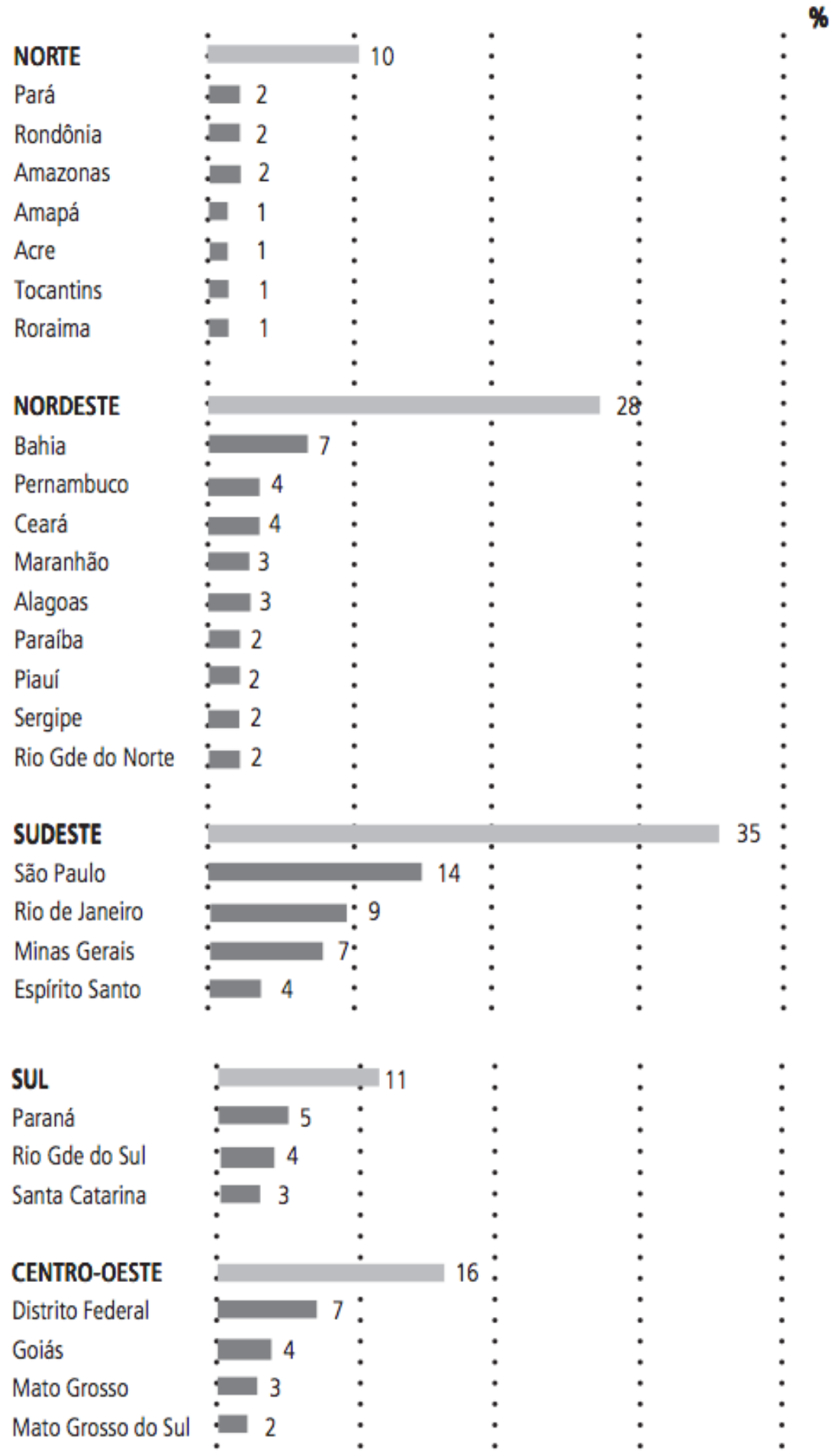

Fonte: I Conferência Nacional de Politicas para as Mulheres: Perfil das Delegadas e Perspectivas de Ação. IBAM/SPM, 2004. 
Figura 2: Distribuição dos municípios representados na Conferência no total de municípios da região e dos país e distribuição das pessoas que responderam ao questionário por município de origem

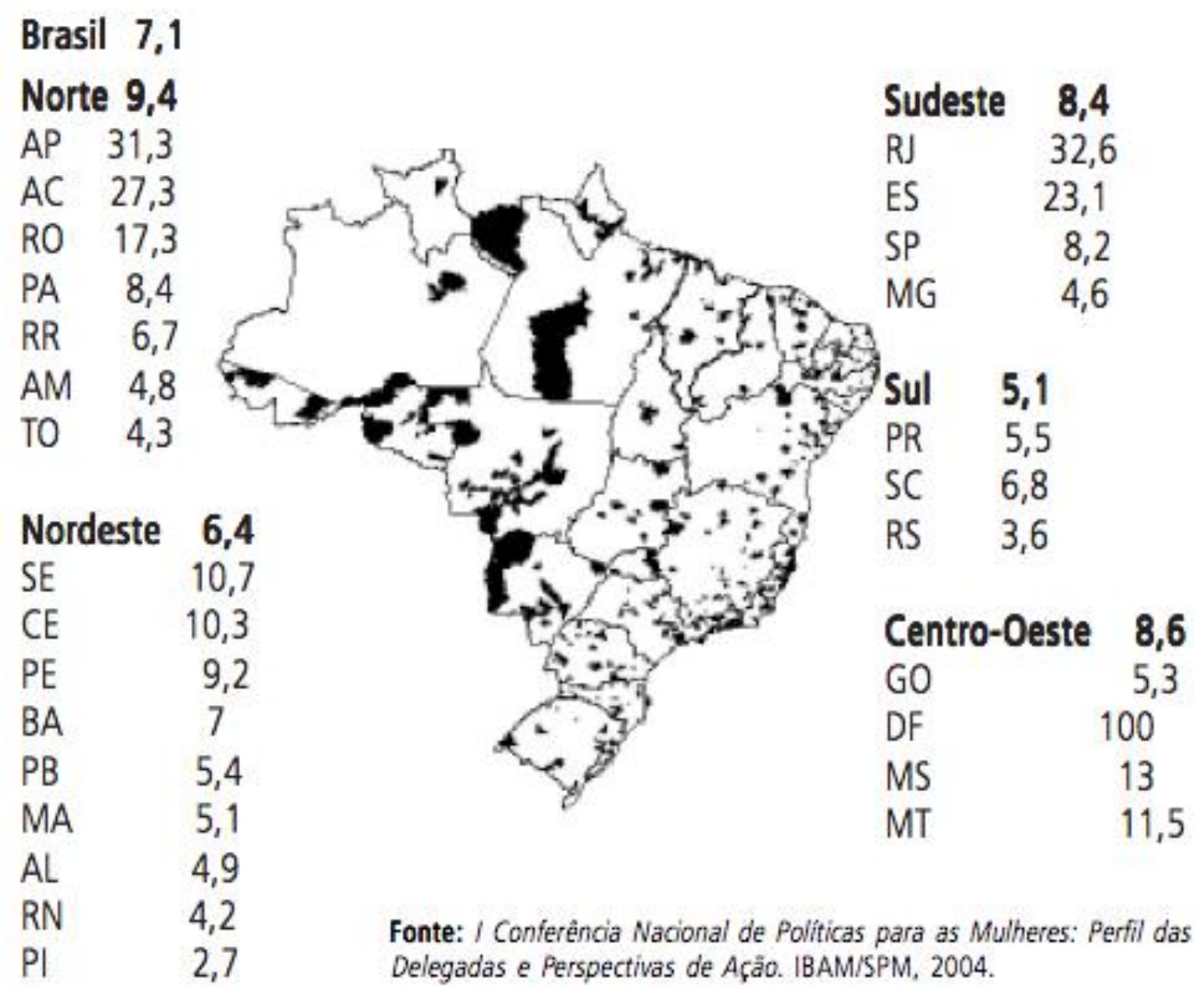

A metodologia utilizada na pesquisa foi a quantitativa, tendo como instrumento de coleta de dados o questionário que respondido pelas delegadas. Tendo em vista esse procedimento, o universo da pesquisa constituiu-se em 1.993 delegadas, cujo comparecimento à I CNPM estava previsto de acordo com o regimento interno da I Conferência. Entretanto, apenas $48 \%$ das delegadas devolveram a ficha ${ }^{35}$ preenchida dentro do prazo previsto. Por esse motivo, na pesquisa, optou-se por tomar como referência o número de delegadas previsto no regimento. Tinha-se como intenção atingir um painel de amostras de, no mínimo, 30\% do total de participantes, respeitando a distribuição de cada uma por Unidade da Federação (UF). O monitoramento dos questionários preenchidos só deixou de ser realizado após o cumprimento dessa meta que, como foi dito, foi ultrapassada com "folga".

\footnotetext{
35 As fichas previamente respondidas foram as das delegações dos seguintes Estados: Amazonas, Amapá, Tocantins, Paraíba, Sergipe, Piauí, Alagoas, Rio Grande do Norte, Rio de Janeiro, Rio Grande do Sul, Santa Catarina, Goiás, Distrito Federal, Mato Grosso do Sul e a delegação do Governo Federal (BRASIL, 2005, p. 11).
} 
Contudo, tem-se razões para acreditar que a amostra é ainda mais ampla do que se demonstra aqui, uma vez que o número de delegadas(os) que efetivamente compareceu é distinto do previsto, aqui tomado como base. O número total de pessoas que estiveram na I Conferência foi de 1.785 e não de 1.993, segundo informações posteriormente fornecidas pela SPM (BRASIL, 2005, p. 18).

O Quadro 2 (p. 66) permite corroborar o ótimo nível de representatividade obtido pela pesquisa, como também observar o sentido assumido pela autosseleção. No entanto, há que levar em consideração que o parâmetro de comparação está sendo o número e a distribuição previstos no Regimento Interno da I Conferência e não a lista das pessoas que de fato compareceram à I CNPM, para as quais somente o número total é conhecido: 1.785 (BRASIL, 2005). Assim, pode ter havido variações entre o número de representantes previsto por UF/região e o número que de fato esteve presente à conferência.

Quadro 2: Distribuição percentual das delegações previstas para a Conferência e das que responderam à pesquisa segundo região geográfica e/ou administrativa da representação

\begin{tabular}{lccc} 
Região & Delegações previstas & Delegações na amostra & Diferencial \\
\hline Norte & 11 & 10 & -1 \\
\hline Nordeste & 25 & 27 & +2 \\
\hline Sudeste & 27 & 34 & +7 \\
\hline Sul & 11 & 11 & 0 \\
\hline Centro-Oeste & 8 & 11 & +3 \\
\hline Governo Federal & 18 & 7 & -11 \\
\hline Total & 100 & 100 & - \\
Fonte: Regimento Interno da I Conferência Nacional de Políticas para as Mulheres. Diário Oficial da \\
União. Edição número 247 de 19 de dezembro de 2004. I Conferência Nacional de Políticas para as \\
Mulheres: Perfil das Delegadas e Perspectivas de Ação. IBAM/SPM, 2004.
\end{tabular}

O questionário foi composto, basicamente, por perguntas fechadas, totalizando 114 variáveis divididas em quatro conjuntos temáticos e, ainda, um espaço, ao final, para o registro de quaisquer opiniões e impressões. Como foi indicado no relatório final da pesquisa:

- Perfil socioeconômico das(os) participantes: constituindo-se das variáveis de praxe (sexo, idade, naturalidade, posição na família, instrução condição de atividade, religião etc.);

- Atuação política e tipo de representação na Conferência; 
- Avaliação do processo que antecedeu à Conferência e da realização propriamente dita do evento;

- Expectativas quanto à efetividade das proposições da Conferência: relativas à elaboração do Plano Nacional de Políticas Públicas para as Mulheres e às condições concretas de execução das políticas propostas pelo encontro $\mathrm{cm}$ fruto do processo nacional que o antecedeu (BRASIL, 2005, p. $14)$.

Quanto à distribuição por sexo, registrou-se que $99 \%$ das pessoas que responderam à pesquisa, sobre o perfil das(os) delegadas(os), eram mulheres, sendo apenas sete homens, possivelmente em número proporcional à presença na I CNPM na condição de delegados ${ }^{36}$ : "um na delegação do Governo Federal, dois nas delegações dos Governos Estaduais, um nas delegações dos Governos Municipais, e três nas delegações da Sociedade Civil” (BRASIL, 2005, p. 21) (Figura 3, p. 67 - 68).

Figura 3: Distribuição das pessoas que responderam ao questionário por características sócio demográficas

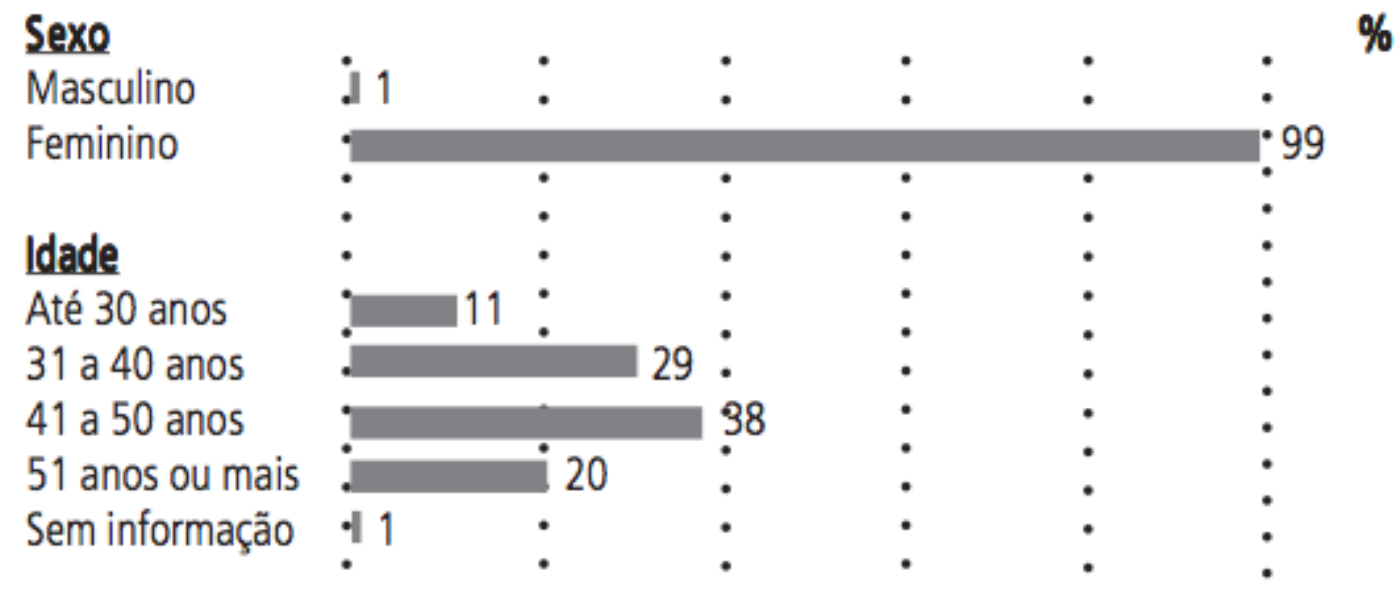

\footnotetext{
36 "Havia homens participando também na condição de observadores, de convidados e de pessoa de apoio" (BRASIL, 2005, p. 21).
} 


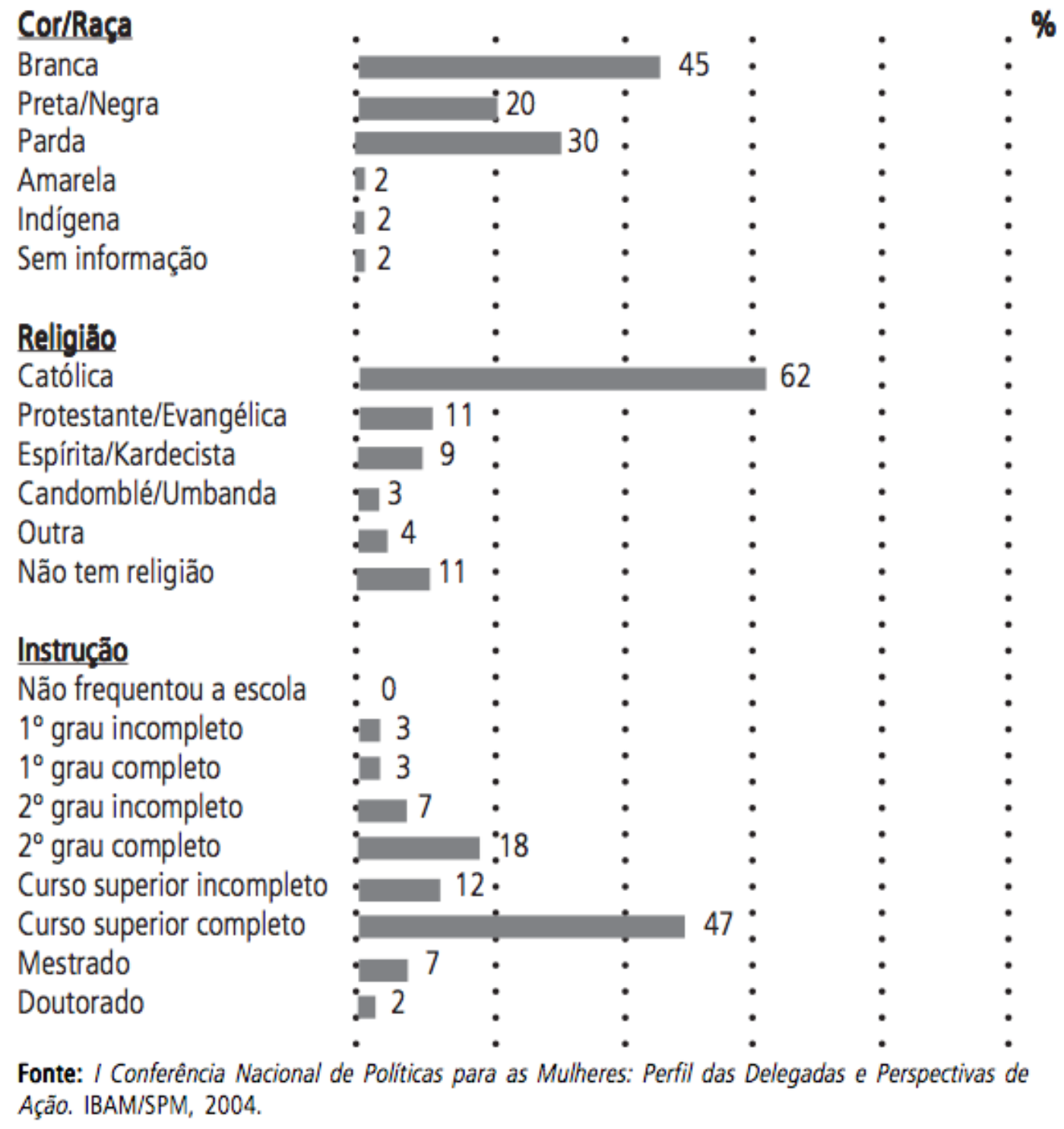

A idade média das entrevistadas era de 42,77 anos, "praticamente igual à da mediana (43 anos) " (BRASIL, 2005, p. 21). Segundo a cor ou raça, a distribuição concentrou-se nas pessoas que se declararam brancas (45\%), seguidas pelas pardas $(30 \%)$ e, por último, as negras (que corresponderam a $20 \%$ ); no entanto, se considerarmos a soma ${ }^{37}$ das entrevistadas que se declararam pardas e negras, observa-se que ocorre um predomínio dessas sobre as brancas. O restante da distribuição corresponde às pessoas que se declararam indígenas, amarelas e às que não responderam ao critério cor ( $2 \%$ de cada). Quanto à religião, houve

\footnotetext{
37 "Vale lembrar que a investigação da cor na pesquisa foi feita segundo o critério clássico de autodeclaração, adotado pelos Censos Demográficos brasileiros e também que, como já foi insistentemente repetido na avaliação destes Censos, a existência de preconceito social promove um branqueamento da população. Contudo, considerando-se constituírem as(os) entrevistadas(os) um grupo politizado e, em grande parte, com escolaridade e renda média elevadas, e havendo alta correlação entre cor branca e melhores condições socioeconômicas, não há que questionar a alta proporção de brancos no grupo, ao lado de significativa parcela que se declarou não branca: mais da metade: (BRASIL, 2005, p. 22).
} 
entre as entrevistadas uma forte predominância das que se declararam católicas (62\%), seguidas das protestantes (11\%) e das espíritas (9\%) e também das que se declararam não possuir religião $(11 \%)^{38}$.

Em relação à escolaridade, a maior parte das delegadas declaram possuir curso superior, o que correspondia a $47 \%$ das delegadas. A quantidade de delegadas que declarou possuir mestrado e doutorado superou a quantidade das que afirmaram possuir o segundo grau completo, respectivamente $9 \%$ e $7 \%$ (Figura 4, p. 69).

Figura 4: Distribuição das(os) delegadas(os) que responderam à pesquisa, segundo o tipo do curso superior que concluíram

\begin{tabular}{llc} 
Cursos & Número & $\%$ \\
\hline Serviço/Assistência social & 61 & 15 \\
Pedagogia & 56 & 14 \\
Direito & 55 & 14 \\
Letras & 34 & 9 \\
Ciências Sociais & 28 & 7 \\
Psicologia & 27 & 7 \\
& & \\
Cursos (cont.) & Número & $\%$ \\
História & 17 & 4 \\
ComunicaçãoSocial & 15 & 4 \\
Administração de Empresas & 12 & 3 \\
Enfermagem & 12 & 3 \\
Educação Física & 11 & 3 \\
Biologia & 11 & 3
\end{tabular}

Fonte: I Conferência Nacional de Políticas para as Mulheres: Perfil das Delegadas e Perspectivas de Ação. IBAM/SPM, 2004.

A compreensão da composição familiar das entrevistadas foi possibilitada através do conhecimento do estado conjugal, da posição ocupada na família e do número de filhos. Houve predomínio de delegadas em união estável (legal 36\% e consensual 13\%) ${ }^{39}$, seguidas

\footnotetext{
38 Essas são "bastante atípicas se considerada a população feminina brasileira em geral onde somente $6 \%$ admitem não professar qualquer religião" (BRASIL, 2005, p. 22-23).

39 "Vale notar que o conceito de estado conjugal diz respeito à situação de fato das pessoas e não de direito e, assim sendo, as informações citadas revelam que metade da população entrevistada, quase que exclusivamente
} 
por solteiras (27\%), separadas, desquitadas ou divorciadas (19\%) e, por fim, viúvas (4\%). Quanto à posição familiar das entrevistadas, houve um grande percentual (52\%) que se declararam "chefes" ou "a pessoa de referência" no âmbito familiar; esse alto valor dá margem para algumas reflexões sobre mudanças nos papéis tradicionais de gênero, assim como as respostas dadas na alternativa "outro", entre as quais predominaram a afirmação de que "na sua família há divisão total das responsabilidades entre os parceiros" (BRASIL, 2005, p. 26). Por fim, é significativa a quantidade de delegadas que declarou não possuir filhos, porém entre as delegadas que declararam possuir filhos a média é baixa, de 1,92 crianças $^{40}$ (Figura 5, p. 70).

Figura 5: Distribuição das pessoas que responderam ao questionário por características da sua situação familiar

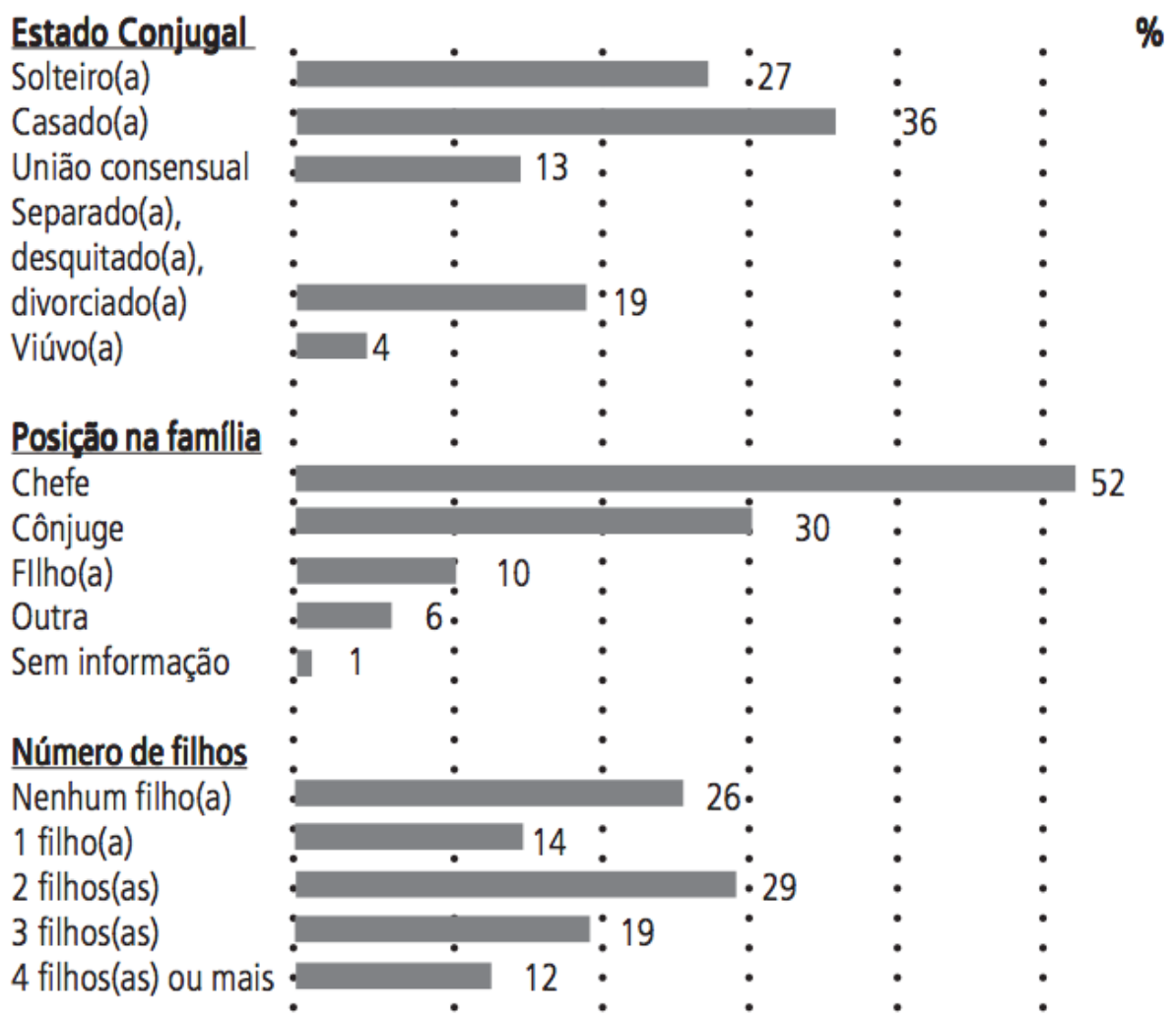

Fonte: I Conferência Nacional de Políticas para as Mulheres: Perfil das Delegadas e Perspectivas de Ação. IBAM/SPM, 2004.

Quanto à inserção no mercado de trabalho, a maioria das entrevistadas $(80 \%)$ declarou estar empregadas no momento da I Conferência e, somente, $9 \%$ se declararam aposentadas.

feminina, vive sem um(a) parceiro(a) estável. Na população feminina brasileira como um todo, esta proporção é de $52 \%$ do total das mulheres de 10 anos e mais e seria muito menor se restringisse a base de cálculo às mulheres de 19 anos e mais (BRASIL, 2005. p. 25).

40 "É possível inferir que as mulheres presentes à Conferência apresentam um padrão distinto da população brasileira cuja média é de 3,4 (filhos vivos em 2000 das mulheres de 20 anos e mais) (BRASIL, 2005, p. 25). 
Houve predominância de funcionárias públicas (52\%), seguidas de empregadas com ou sem carteira assinada (respectivamente, 17\% e 11\%) (Figura 6, p. 71 - 72). Os resultados da pesquisa mostraram que a participação por classes de salários mínimos foi bastante equilibrada, com reduzida participação de pessoas com rendimentos muito baixos (menores que 1 salário mínimo), e com significativa participação de mulheres com rendimentos salariais mais altos (acima de 10 salários mínimos) ${ }^{41}$ (Figura 7, p. 72).

Figura 6: Distribuição das pessoas que responderam ao questionário por características da sua atuação no mercado de trabalho

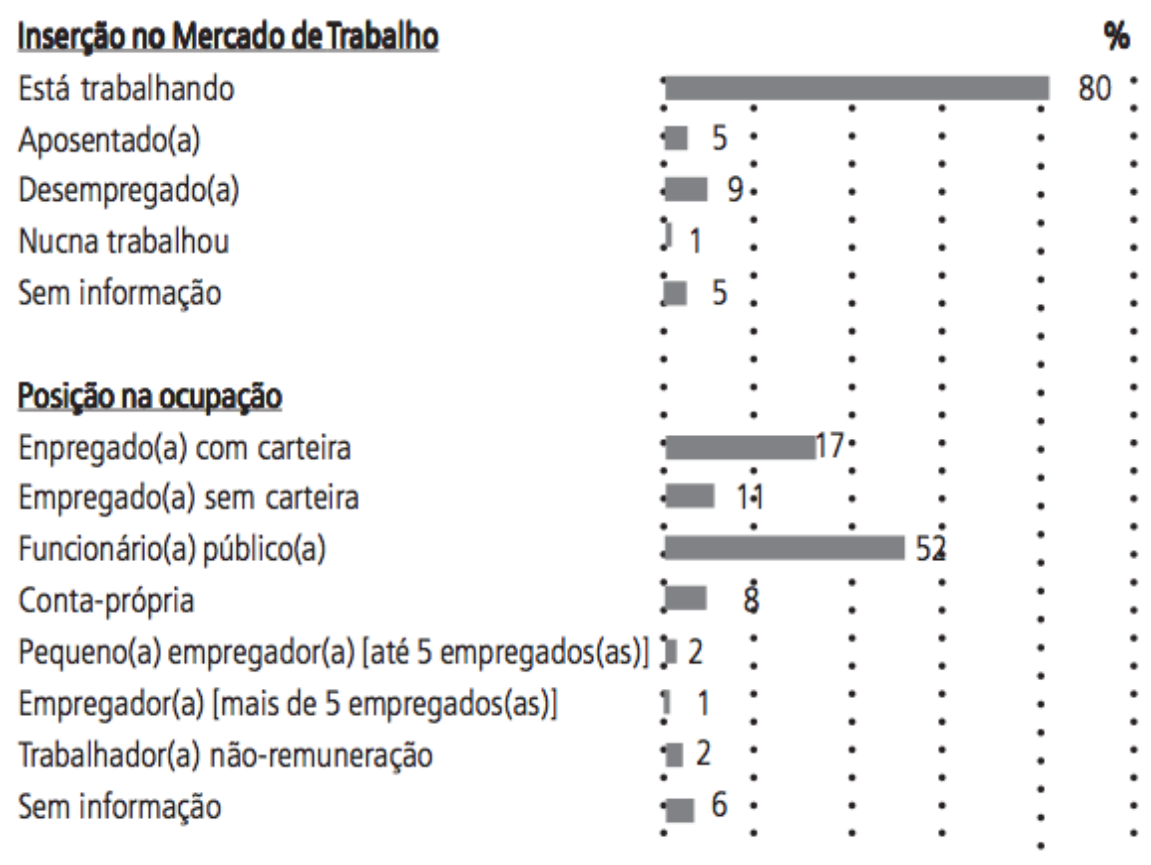

41 “O valor médio fica em $\mathrm{R} \$ 1819,83$, e o mediano em $\mathrm{R} \$ 1250,00$, o valor mínimo é zero (19 pessoas) e o máximo de $\mathrm{R} \$ 38.268,00$ (valor conferido e confirmado pela única respondente que declarou este valor, uma pequena empregadora do setor serviços)" (BRASIL, 2005, p. 28). 


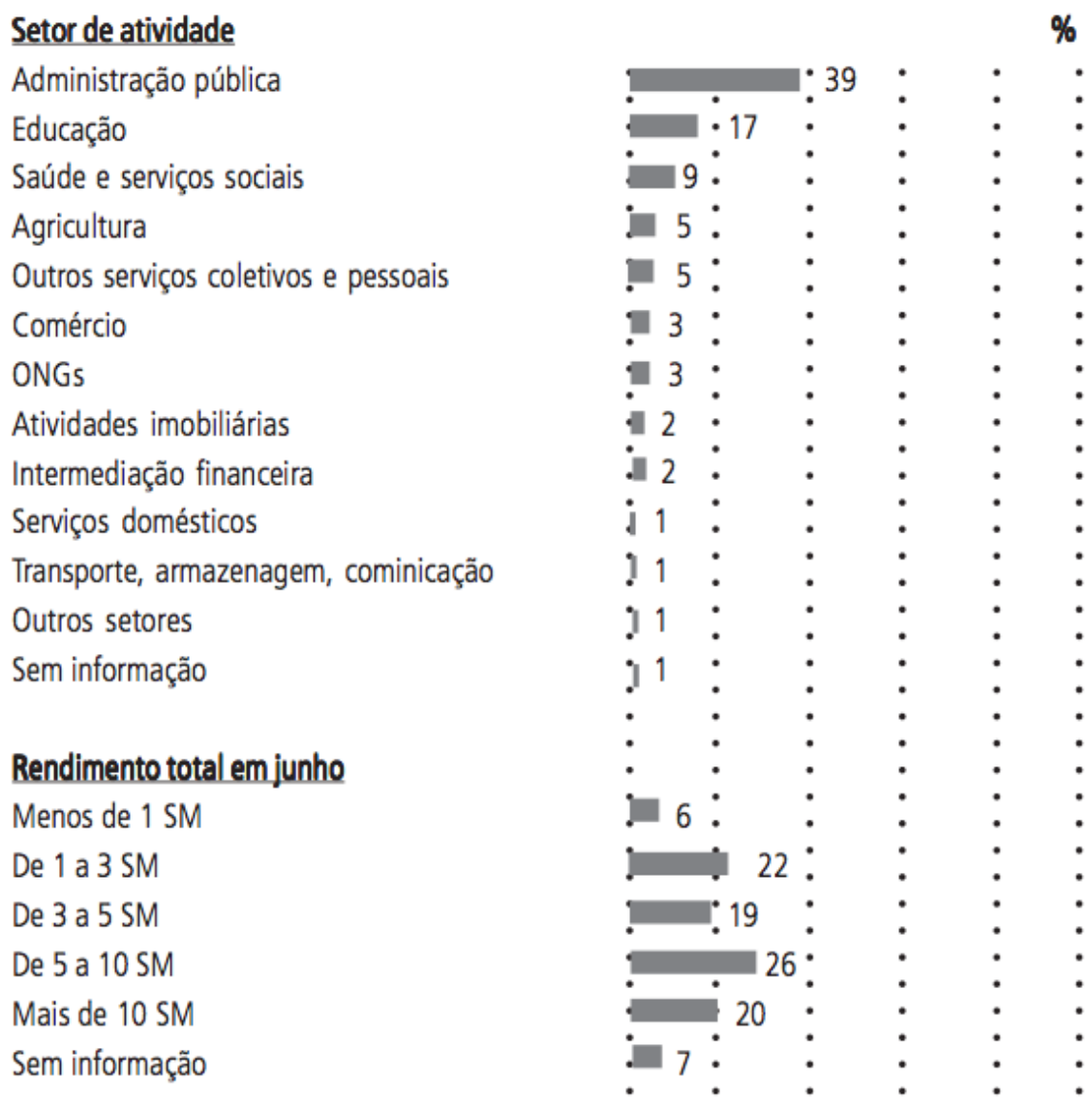

Fonte: I Conferência Nacional de Políticas para as Mulheres: Perfil das Delegadas e Perspectivas de Ação. IBAM/SPM, 2004.

Figura 7: Distribuição das pessoas que responderam à pesquisa, segundo indicadores de instrução e rendimento

\begin{tabular}{|c|c|c|c|c|}
\hline \multicolumn{5}{|c|}{ Indicadores Cor ou Raça } \\
\hline Branca & Negra & Parda & Amarela(*) & Indígena $\left({ }^{*}\right)$ \\
\hline \multicolumn{5}{|c|}{ Níveis de Instrução (\%) } \\
\hline \multicolumn{5}{|c|}{ Até $2^{\circ}$ grau incompleto } \\
\hline 6 & 16 & 23 & 20 & 43 \\
\hline \multicolumn{5}{|c|}{$2^{\circ}$ grau completo } \\
\hline 23 & 44 & 34 & 20 & 29 \\
\hline \multicolumn{5}{|c|}{ Superior completo } \\
\hline 59 & 37 & 39 & 33 & 21 \\
\hline \multicolumn{5}{|c|}{ Pós graduação } \\
\hline 12 & 3 & 4 & 27 & 7 \\
\hline \multicolumn{5}{|c|}{ Rendimento em junho de 2004 (R\$) } \\
\hline \multicolumn{5}{|c|}{ Média } \\
\hline $2.249,62$ & $1.114,22$ & $1.672,60$ & $1.773,08$ & 666,67 \\
\hline \multicolumn{5}{|l|}{ Mediana } \\
\hline $\begin{array}{l}1.600,00 \\
\text { (*) Poucos ca } \\
\text { Fonte: I Conf } \\
\text { de Ação. IBA }\end{array}$ & $\begin{array}{l}925,00 \\
\text { ên na amostra. } \\
\text { ência Naciona } \\
\text { ISPM, 2004. }\end{array}$ & $\begin{array}{l}1.100,00 \\
\text { al de Políticas } p\end{array}$ & $1.500,00$ & $\begin{array}{l}600,00 \\
\text { das Delegadas e Perspectivas }\end{array}$ \\
\hline
\end{tabular}


Chama atenção a grande presença de delegadas da sociedade civil (57\%), corroborando, portanto, a estimativa inicial prevista no regimento interno da I CNPM de que o evento seria realizado com $60 \%$ de representantes da sociedade civil e $40 \%$ dos governos; seguiu-se, em ordem decrescente, as delegações municipais, estaduais e federais. Tal disposição aponta para a consecução do objetivo de construir a I Conferência a partir das bases.

Do ponto de vista da atuação política, a pesquisa mostrou o tipo de participação das delegadas, destacando-se os movimentos sociais em geral (55\%), os partidos políticos (49\%), as ONGs (34\%) e as organizações governamentais (31\%), como os principais locus de atuação política (Figura 8, p. 74). Mesmo que não tenha sido muito claramente formulado em termos de sua distinção com a pergunta anterior, o levantamento das organizações onde as delegadas atuam destaca, bem à frente das demais, o movimento de mulheres (58\%), seguido pelo movimento popular, movimento feminista e o movimento sindical (com porcentagens entre $21 \%$ e $30 \%)$. 
Figura 8: Distribuição das pessoas que responderam ao questionário por características de atuação política e de representação na I CNPM
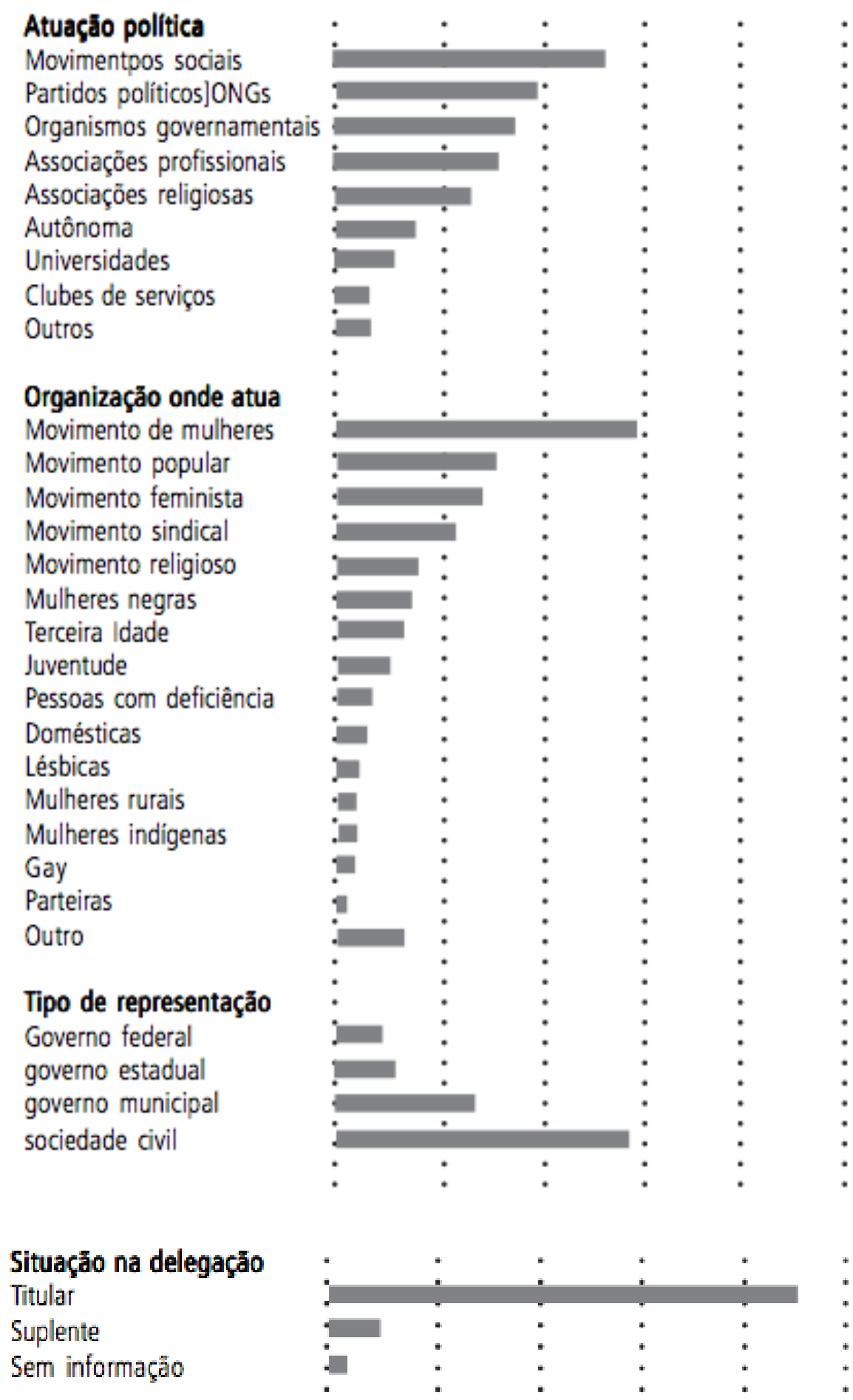

Fonte: I Conferência Nacional de Politicas para as Mutheres: Perfil das Delegadas e Perspectivas de Açäo. IBAM/SPM, 2004.

Essas informações gerais expostas na segunda parte da pesquisa permitiram afirmar que as delegadas que participaram da I CNPM eram, em sua maioria, mulheres de mais idade, 
escolarizadas em nível universitário, com altos rendimentos salariais e com menor número de filhos, comparado à média nacional para as mulheres. Tais elementos permitiram a essas mulheres uma maior mobilização e melhores condições de acesso para integrar a rede social que foi estabelecida a partir dos processos municipais e estaduais que possibilitaram participação na I Conferência, assim como permitiram discutir a representação das mulheres neste evento.

Esta representativa feminina se deu ao longo do primeiro governo do Presidente Luiz Inácio Lula da Silva, que foi eleito no ano de 2002 com mais de 58 milhões de votos e exerceu o mandato, primeiramente, nos anos de 2003 a 2006. Esse governo caracterizou-se pala estabilidade econômica, favorecendo o investimento e o crescimento do país. Lula conseguiu diminuir a dívida externa, em cerca de 168 bilhões de reais, porém acabou aumentando a dívida interna. Seu governo foi marcado por políticas e ações de caráter social, auxiliando a parcela mais humilde da população. O governo, entretanto, no ano de 2005, recebeu denúncias de um esquema que ficou conhecido como "Mensalão", além do escândalo dos correios.

A pesquisa trata seus dados de forma genérica, visto que, nos critérios presentes no questionário, respondido pelas delegadas, não foram especificados os nomes de grupos e entidades que cada uma pertencia. Tal fato, especialmente no âmbito da atuação política, mostrou que as delegadas se identificaram como pertencentes, em primeiro lugar, aos movimentos de mulheres, seguido do movimento popular, dos movimentos feministas, do movimento sindical etc. Nos Anais da I CNPM, entre os dezenove grupos representantes de entidades da sociedade civil, apenas seis possuem explicitamente um caráter feminista, a saber: Articulação de Mulheres Brasileiras (AMB), a Articulação de Ongs de Mulheres Negras Brasileiras, a Marcha Mundial das Mulheres (MMM), a Rede Nacional Feminista de Saúde, Direitos Sexuais e Direitos Reprodutivos e o Instituto Feminista para a Democracia (SOS Corpo) .

Ainda segundo o relatório (BRASIL, 2005), os movimentos de mulheres e os movimentos feministas são apreendidos como espaços distintos, frente aos quais as mulheres devem se posicionar e decidir entre um ou outro. A pesquisa, ao mostrar a maior identificação das delegadas nos movimentos de mulheres, indica que nem todas definem-se como parte dos movimentos feministas. Aliás, a presença feminista é pouca dentro da I CNPM, e difícil de se saber ao certo, já que o relatório não se preocupa em apresentar o número de movimentos feministas representados, ao incluí-los na porcentagem geral de movimentos "outros", junto aos sindicais e populares. Diante desses dados, notamos que, embora sejam todas mulheres 
lutando pelas mulheres, depreende-se que existe, ainda, muito desconhecimento, algumas desconfianças para se autodeclarar feminista. Por isto, tende-se a considerar o feminismo como parte do movimento de mulheres, mas não como sendo a mesma coisa. São feministas aquelas mulheres e organizações que se definam assim. 


\section{CAPÍtULO 2}

\section{O FEMINISMO NAS FALAS DE ABERTURA DA I CONFERÊNCIA NACIONAL DE POLÍTICAS PARAAS MULHERES}

Neste capítulo apresenta-se uma análise das representações do feminismo nos pronunciamentos realizados durante a Abertura da I Conferência Nacional de Políticas para as Mulheres (I CNPM). Inicialmente, apresenta-se as condições de produção e organização desse momento de abertura do evento, destacando seus objetivos, programação e sujeitos de fala. Em seguida, analisa-se as representações do feminismo nas falas de Nilza Irazi, Nilcéia Freire e Luiz Inácio Lula da Silva. Para compreender essas representações, é necessário analisar as condições de produção das práticas discursivas onde emergem, ou seja, é necessário considerar as dimensões de sua exterioridade, para compreendê-las em relação àconjuntura sócio histórica em que foram produzidas (FOUCAULT, 1993). Nesse sentido, procura-se, inicialmente, compreender o contexto social e interacional (SPINK; MEDRADO, 2000, p. 44) onde emergem estas representações. Para isso, são identificados os acontecimentos, os interlocutores presentes ou presentificados, as finalidades, o espaço e o tempo desse ato inaugural de debates e proposições de políticas para mulheres, aspectos que incidem de alguma forma nos sentidos, significados, usos, funções e apropriações dos termos “feminismo(s)" e "feminista(s)" nas falas consideradas para análise.

\subsection{ESPETÁCULOS, HOMENAGENS E APROVAÇÃO DO REGULAMENTO}

A Abertura da I Conferência Nacional de Políticas para as Mulheres (I CNPM) foi realizada no dia 15 de julho de 2004, em uma quinta-feira. Esse evento, assim como o processo de realização da I Conferência, superou as expectativas em números de participantes, compareceram cerca de 1.787 delegadas(os) e mais de 700 observadoras (es) e convidadas(os) de todas as unidades da federação e também de alguns países da América Latina e Caribe (BRASIL, 2004a).

A mesa de Abertura contou com o nove representantes governamentais, a saber: Luiz Inácio Lula da Silva (Presidente da República), Nilcéa Freire (Ministra de Estado da Secretaria de Políticas para as Mulheres), Marisa Letícia Lula da Silva (Primeira-dama), 
Dilma Rousseff (Ministra de Estado de Minas e Energia), Marina Silva (Ministra de Estado do Meio Ambiente), Matilde Ribeiro (Ministra de Estado da Secretaria Especial de Políticas de Promoção da Igualdade Racial), Senadora Serys Slhessarenko (Presidenta da Comissão Especial do Ano da Mulher no Senado Federal), Deputada Federal Jandira Feghali (Presidenta da Comissão Especial do Ano da Mulher na Câmara dos Deputados) e Nilza Irari (Representante do Conselho Nacional dos Direitos da Mulher). A presença desses agentes denota a importância do governo e de seus representantes na Abertura da I CNPM. Fica explícito nesse momento os agentes que legitimam o evento e com os quais os movimentos feministas e de mulheres, ali presentes, dialogarão na proposição de políticas públicas para as mulheres.

A programação teve início às 8 h30 com a apresentação do elenco "Os Curingas" do Centro de Teatro do Oprimido(TO $)^{42}$, com o teatro-fórum ${ }^{43}$ "Coisas do Gênero". A Abertura teve como mestre de cerimônia Zezé Motta que é uma atriz e cantora, uma das mais importantes artistas negras do Brasil, por interpretar papéis que colaboraram para que o protagonismo das mulheres negras no teatro brasileiro fosse evidenciado positivamente. Além disso, ela encorajou a realização de discussões sobre o papel dos negros na teledramaturgia. Já o TO consiste em uma metodologia teatral criada por Augusto Boal ${ }^{44}$ nos anos 1960, que depois de exilado pelo regime militar se dedicou a pesquisar e conceber formas teatrais que pudessem ser utilizadas para pessoas caracterizadas como oprimidas. Boal pretendeu utilizar o teatro como instrumento de trabalho político, social, ético e estético, cooperando para a

\footnotetext{
${ }^{42}$ Os principais objetivos do Teatro do Oprimido são a democratização dos meios de produção teatral, o acesso das classes sociais menos favorecidas - restituindo o seu direito à palavra - e a transformação da realidade por meio do diálogo - assim como Paulo Freire pensou a Educação - e do teatro. Concomitantemente, ofereceu toda uma nova técnica para a preparação do ator. Partindo da encenação de uma situação real, o TO procura estimular a troca de experiências entre atores e espectadores, por meio da intervenção direta da ação teatral, objetivando a análise e a compreensão da estrutura representada e a investigação de ferramentas concretas para ações efetivas que provoquem a transformação daquela realidade. Basicamente, o TO se baseia no princípio de que o ato de transformar é transformador. Segundo Boal: "Aquele que transforma as palavras em versos transforma-se em poeta; aquele que transforma o barro em estátua transforma-se em escultor; ao transformar as relações sociais e humanas apresentadas em uma cena de teatro, transforma-se em cidadão" (Trecho do filme Augusto Boal e o Teatro do Oprimido)

43 "A dramaturgia simultânea era uma espécie de tradução feita por artistas sobre os problemas vividos pelo povo. Até o dia em que uma mulher, no Peru, não aceitou a tradução e ousou subir ao palco para dizer com sua voz e através de seu corpo qual seria a alternativa para o problema encenado. Aí nasceu o Teatro-Fórum, onde a barreira entre palco e plateia é destruída e o Diálogo implementado. Produz-se uma encenação baseada em fatos reais, na qual personagens oprimidos e opressores entram em conflito, de forma clara e objetiva, na defesa de seus desejos e interesses. No confronto, o oprimido fracassa e o público é estimulado, pelo Curinga (o facilitador do Teatro do Oprimido), a entrar em cena, substituir o protagonista (o oprimido) e buscar alternativas para o problema encenado". Disponível em: < http://ctorio.org.br/novosite/arvore-do-to/teatro-forum/> Acesso em: 10 Mai. 2016.

${ }^{44}$ Augusto Boal nasceu em 1931 no Rio de Janeiro e faleceu nesta mesma cidade em 2009. Primeiramente, tornou-se engenheiro químico e, posteriormente, tornou-se tetatrólogo, diretor, dramaturgo, ensaísta e, essencialmente, criador do Teatro do Oprimido. Ainda foi professor na New York University, na Harvard University e na Université de La Sorbonne-Nouvelle.
} 
transformação social. Cada uma das técnicas do TO refere-se a uma resposta encontrada por Boal e pelos atores-colaboradores para realizar uma transformação por meio da arte, tal fato justifica a apresentação do teatro-fórum "Coisas do Gênero" na abertura da I CNPM.

Este espetáculo foi realizado em uma linguagem, exclusivamente, não verbal e com um repertório musical inédito, onde apresentou a história de uma mulher que desde o seu nascimento até a maturidade lutou para ser reconhecida em casa e no trabalho. Tal peça discutiu a relação entre gêneros, onde a mulher para sair da situação de oprimida precisaria conquistar seu espaço próprio, respeito e independência. $\mathrm{O}$ espetáculo contou com a direção geral de Helen Sgrapeck e com a direção musical de Roni Valk ${ }^{45}$.

Esse espetáculo, desde a abertura com a dança dos Orixás, uma saudação à Mãe Terra, que representou uma celebração ao feminino e ao masculino na criação da vida, objetivou introduzir a discussão sobre seres que nascem do mesmo ventre, mas são separados pela ação da sociedade que os transforma em "Mulher" e em "Homem". Pode-se perceber que, ao longo do espetáculo, o processo do crescimento, descoberta e explosão da paixão são incorporados/enquadrados no ritual do casamento que, consequentemente, constrói a família e a vida doméstica, essencialmente, desgastante. Assim, a mulher, agora, esposa, passa a procurar atividade profissional fora do lar e começa a vivenciar a pressão da dupla jornada de trabalho - "sua vida se torna um tormento" 46 . Ela tenta sair dessa situação, mas não consegue. Precisa então, da ajuda dos espectadores que são convidados a entrar na peça, para em seu lugar tentar sair da opressão.

Além da apresentação teatral ocorreram, na Abertura da I Conferência, o show da cantora Margareth Menezes ${ }^{47}$ e uma solenidade de homenagens a quatorze mulheres, tidas como relevantes para a história e as lutas das mulheres brasileiras. Esta homenagem ocorreu por meio da leitura de um texto ${ }^{48}$, pela mesa de abertura, que procurou ilustrar a diversidade

\footnotetext{
${ }^{45} \mathrm{O}$ roteiro deste espetáculo encontra-se na publicação da SPM intitulada de Ano da Mulher no Brasil - I Conferência Nacional de Políticas para as Mulheres. (BRASIL, 2004b, p.239).

46 Disponível em < https://carlosscomazzon.wordpress.com/2009/10/07/centro-de-teatro-do-oprimido-promovecoisas-do-genero/>Acesso em 30 Jan. 2016.

47 Margareth Menezes nasceu em Salvador, Bahia, em 1962. É uma cantora, compositora, produtora e atriz brasileira. É referência da música negra no Brasil e lidera o movimento "Afropop Brasileiro", que objetiva preservar e promover a cultura afro-brasileira. Ela criou a "Fábrica Cultural", uma organização não governamental que ajuda crianças e adolescentes carentes. Conquistou, ainda, 02 (dois) troféus Caymmi, 02 (dois) troféus Imprensa, 04 (quatro) troféus Dodô e Osmar, e também foi indicada para o Grammy Awards e Grammy Latino. Foi considerada pelo jornal estadunidense Los Angeles Times como a "Aretha Franklin brasileira". Além disso, todos os anos, a cantora leva seu trio elétrico, um dos mais tradicionais, às ruas de Salvador no carnaval.

${ }^{48}$ Este texto foi intitulado de "Homenagem às Mulheres Brasileiras" e pode ser encontrado na parte final dos Anais da I Conferência de Políticas para as Mulheres, nas páginas 153 a 156.
} 
de trabalhos e de esforços que estas brasileiras homenageadas empenharam ao longo de suas carreiras para a melhoria de toda a sociedade ${ }^{49}$.

Um vídeo ${ }^{50}$ produzido, também, em homenagem às mulheres que lutaram de alguma forma pelos direitos das mulheres foi exibido em grande tela para o público da I Conferência. Com duração de 13:35 minutos mostrou imagens e mencionou mulheres que aderiram a luta em prol da equidade entre mulheres e homens e que colaboraram, de alguma forma, no combate a preconceitos e estereótipos que acometem as mulheres ${ }^{51}$.

Esse momento de abertura deixa claro sua característica de reconhecimento e valorização da diversidade das mulheres brasileiras, sejam elas negras, indígenas, cientistas, acadêmicas etc. Já a homenagem realizada confere fundamento histórico e uma identidade à I CNPM, ressaltando, com isso as lutas empreendidas historicamente por diferentes mulheres no Brasil. Dentre as homenageadas podemos notar a presença também de mulheres que se autodenominavam "feministas" como: Gracíliana Selestino Wakanã, Zuleika Alambert, Rose Marie Muraro e Heloneida Studart. Desse modo, as feministas, ao lado de mulheres de outros movimentos e grupos, são homenageadas e rememoradas, nesse momento de Abertura da I Conferência, o que denota a consideração aos movimentos feministas como parte das lutas pelos direitos das mulheres até o presente. Não se trata de uma luta exclusiva dos feminismos,

\footnotetext{
${ }^{49}$ Dentre elas, oito estavam presentes à cerimônia de Abertura, são elas: Lenira Maria de Carvalho (alagoana e fundadora da Associação das Empregadas Domésticas), Raimunda Gomes da Silva (maranhense, conhecida como Raimunda dos Cocos, criou a Federação Interestadual das Quebradeiras de Coco e a Associação das Quebradeiras de Coco), Graciliana Selestino Wakanâ (do povo indígena Xucuru-Kariri, uma das mais atuantes líderes do movimento em defesa dos povos indígenas); Zuleika Alambert (escritora, feminista e ativista política e fundadora do Grupo de Mulheres Brasileiras em Paris), Benedita da Silva (a primeira senadora negra no Brasil, eleita vereadora, deputada federal, senadora, vice-governadora e governadora do Estado do Rio de Janeiro), Heleieth Saffioti (socióloga, professora, pesquisadora e primeira teórica brasileira a tratar da questão da violência contra as mulheres), Clara Charf (viúva de Carlos Mariguella que viveu exilada em Cuba por nove anos, e é hoje membro do Conselho Nacional dos Direitos da Mulher e coordenadora do Comitê Brasileiro 1000 Mulheres para o Prêmio Nobel da Paz de 2005), e, Enid Backes (socióloga, militante do Movimento Feminino pela Anistia e fundadora da primeira Coordenadoria da Mulher no Rio Grande) (BRASIL, 2004b, p. 231). As outras seis homenageadas que não estivam presentes na solenidade de Abertura da Conferência, são elas: Rose Marie Muraro (escritora e uma das pioneiras do movimento feminista no Brasil, formada em Física e Economia e uma das mais brilhantes intelectuais do nosso tempo), Heloneida Studart (escritora e feminista, foi deputada estadual em 1978 pelo antigo MDB e fundadora do Centro da Mulher Brasileira), Elizabete Teixeira (líder das Ligas Camponesas), Ruth de Souza (atriz brasileira), Ana Montenegro (uma das fundadoras do Partido Comunista no Brasil); e a Mãe Estela de Oxossi (ialorixá e herdeira do axé do candomblé Axé Opô Afonjá) (BRASIL, 2004b, p. 231).

${ }^{50}$ OBSERVATÓRIO DA MULHER. Mulheres do Brasil, Presente!. Disponível em : <https://www.youtube.com/watch?v=s_95rDEQjpA. > Acesso em: 30 Jan. 2016.

${ }^{51}$ As mulheres apresentadas no vídeo são: Benedita da Silva, Heloneida Studart, Clara Charf, Heleieth Saffioth, Almeida (primeira eleitora brasileira), Ana Montenegro, Rose Maria Muraro, Raimunda dos Cocos, Zuleika Alambert, Elizabeth Teixeira, Graciliana Wakanã, Lenira Maria de Carvalho, Enid Backes, Ângela Borba, Antonieta de Barros, Beatriz Nascimento, Bertha Lutz, Beth Lobo, Carmem da Silva, Carmem Portinho, Carolina Maria de Jesus, Cida Kopcak, Clementina de Jesus, Cora Coralina, Eliane de Grammont, Helenina Resende, Lélia Abramo, Lélia Gonzalez, Márcia Dangremont, Margarida Alves, Marta, Miriam Botassi, Nise da Silveira, Nísia Floresta, Olga Benário, Patrícia Galvão (Pagu), Regina Stella, Rosely Roth, Rosinha do Cim, Trindade, Vânia Araújo, Wilma Lessa e Zuzu Angel.
} 
mas várias outras mulheres cujas lutas são também marcadas, não só por questões de gênero, mas também de raça, classe, étnica, religião, orientação sexual, região, dentre outras.

Assim a I CNPM parece se abrir no reconhecimento, inclusão, diálogo e interação entre mulheres de diversas perspectivas e experiências políticas. Desse modo, pode-se perceber o lugar e a importância histórica do feminismo na I CNPM. Fica claro que o feminismo se configura como uma das perspectivas ali presentes, ou seja, não é a única, mas se coloca junto a outras interessadas nas políticas públicas para as mulheres. Essa concepção está em sintonia também com os acordos gerais (BRASIL, 2004a, p. 103) que irão aparecer na plenária final da I Conferência, onde se estabelece o uso do termo "movimentos de mulheres e feministas" nas resoluções aprovadas.

A Plenária de Abertura, também, teve como função aprovar o Regulamento Interno da I CNPM e deliberar sobre eventuais recursos. Nesse sentido, trata-se de um espaço cujas falas e participações são produzidas dentro de um contexto normatizado. A aprovação do Regulamento Interno foi realizada das $14 \mathrm{~h}$ às $15 \mathrm{~h} 30$, sendo a última ação realizada no evento de abertura. Esse Regulamento Interno teve por finalidade definir as normas de funcionamento da I Conferência. Nesta Plenária participaram: “a) as(os) delegadas(os), com direito a voz e voto; b) as(os) convidadas(os) com direito a voz; e, c) as(os) observadoras(es)" (CNPM, 2004g, p. 149). Esta sessão da Plenária foi coordenada por uma mesa constituída por integrantes da Comissão Organizadora e por pessoas por ela indicadas, coube à mesa: “a) informar ao plenário o número de delegadas(os), convidadas(os) e observadoras(es) inscritas(os) na Conferência; b) encaminhar para aprovação o Regulamento Interno da Conferência; c) conduzir os trabalhos das plenárias” (CNPM, 2004g, 2004, p. 150). Essa mesa foi composta por: Maria Laura Sales Pinheiro (Secretária Adjunta da Secretaria Especial de Políticas para as Mulheres/SPM), Marlise Fernandes (Subsecretária de Articulação Institucional da Secretaria Especial de Políticas para as Mulheres/SPM), Schuma Schumaher (Representante da Articulação Brasileira de Mulheres e integrante do Conselho Nacional dos Direitos das Mulheres/CNDM), Maria Ednalva Bezerra Lima (Representante da Central Única dos Trabalhadores e componente do Conselho Nacional dos Direitos das Mulheres/ CNDM), Eline Jonas (Representante da Central Única dos Trabalhadores e Componente do Conselho Nacional dos Direitos das Mulheres/CNDM), Mari Machado (Representante Governamental do Ministério de Ciência e Tecnologia/MCT) e Liège Rocha (Gerente de Projetos da Secretaria Especial de Políticas para as Mulheres/SPM).

Ainda, na Abertura da I Conferência, às 9h30, discursaram Nilza Iraci (Representante do Conselho Nacional dos Direitos da Mulher/CNDM), Nilcéa Freire (Ministra da Secretaria 
Especial de Políticas para as Mulheres/SPM) e o então presidente do Brasil Luiz Inácio Lula da Silva. Estes sujeitos de fala trataram das expectativas do governo em relação à I Conferência. A seguir apresento uma análise das falas proferidas nessa Abertura por esses representantes do governo federal.

\subsection{NILZA IRACI}

O primeiro discurso de Abertura da I Conferência foi realizado por Nilza Iraci, então Representante do Conselho Nacional dos Direitos da Mulher (CNDM). Nilza Iraci é uma mulher negra de meia idade, formou-se em Comunicação Social com especialização pela Universidade de Brasília (UnB), foi presidente e coordenadora de comunicação do Instituto da Mulher Negra (Geledés) e coordenou a Articulação de ONG's de Mulheres Negras Brasileiras. Além disso, fazer parte do Conselho Deliberativo do Instituto Patrícia Galvão, do Comitê Internacional do Fórum Social Mundial e do Conselho Consultivo do Observatório de Gênero. Trata-se de uma mulher que possui um lugar de fala bastante representativo, devido à sua liderança e participação em instituições governais e grupos sociais de lutas pelos direitos de mulheres negras.

Nilza Iraci tem uma longa militância em prol dos direitos das mulheres, já que esteve presente nos principais eventos e lutas feministas e antirracistas nos últimos trinta anos, assim como no processo de redemocratização do país. Participou de Conferências da ONU, chamando atenção para questões de gênero e raça. Seu ativismo lhe rendeu também, no ano de 2001, a coordenação do Comitê Internacional da Conferência das Américas, preparatória para a Conferência de Avaliação da Implementação da Declaração e do Plano de Ação de Durban. Desde o ano de 1988, se dedica a projetos de formação e de capacitação de mulheres negras em Tecnologias da Informação e Comunicação (TICs), Comunicação, Mídia e Advocacy, com inúmeros artigos publicados sobre o assunto.

Ao iniciar a sua fala fez agradecimentos às autoridades governamentais e as(os) convidadas(os) presentes. No entanto, teceu um cumprimento especial "as nossas irmãs índias" que há pouco tempo haviam realizado "a sua I Conferência Nacional" (BRASIL, 2004a, p. 16). A partir disso, ressaltou que "não é nenhuma novidade um encontro reunindo tantas mulheres" (BRASIL, 2004a, p. 16), mas que a novidade e, consequentemente, o objetivo da I CNPM era o acolhimento do Presidente da República, a quem saudou pela "coragem de convocar as mulheres para esta Conferência e ouvir o que elas têm a dizer e a propor sobre políticas e diretrizes para a construção de um plano de igualdade que vai 
beneficiar não apenas as mulheres, mas toda a sociedade" (BRASIL, 2004a, p. 17). Desse modo, Iraci como representante do governo destaca a presença e ação do presidente Lula, conferindo a ele os créditos pela abertura desse espaço de diálogos e proposição de políticas para as mulheres.

Ainda segundo Iraci, as mulheres brasileiras são as protagonistas de relevantes mudanças sociais no país no último século, especialmente, "na casa, na rua e na política" (BRASIL, 2004a, p. 16). Ao elencar esses espaços de atuação, expressou que elas não só mudaram sua postura perante as suas experiências, mas também ampliaram os espaços de atuação feminina, contribuindo assim para os avanços da sociedade. Segundo ela, essas transformações possibilitaram uma "luta permanente para mudar o Brasil e por um mundo fraterno, solidário, sem violência, sem preconceito, sem sexismo, sem racismo e com justiça social" (BRASIL, 2004a, p. 16). Nesse sentido, afirmou que "fomos nós, mulheres, que pavimentamos o caminho para o enfrentamento do medo pela sociedade brasileira. Fomos nós, as mulheres, que mostramos que a esperança pode vencer o medo" (BRASIL, 2004a, p. 16). Relembrando, com isso, o slogan "a esperança vai vencer o medo" 52 utilizado ao longo da campanha política até a vitória final de Lula nas eleições de 2002, para o seu primeiro mandato.

Iraci destacou ainda, de certa forma idealizada, o protagonismo das mulheres brasileiras em sua diversidade, ao mencionar que as mulheres negras romperam com "uma estrutura racista e patriarcal, que lhes negava a humanidade" (BRASIL, 2004a, p. 16); que as lésbicas romperam com "os padrões hegemônicos dos donos de sentimentos e demonstrar[am] que não existe uma única maneira de amar e de serem amadas" (BRASIL, 2004a, p. 16); que as agricultoras remexem a terra e "semeiam e colhem mais do que alimentos cotidianos, nos devolvem esperança" (BRASIL, 2004a, p. 16); e que "as feministas [...] demonstraram que os direitos das mulheres são direitos humanos e que a autonomia é fundamental para que possamos governar nossas vidas, nossos corpos, nossa sexualidade, nosso país" (BRASIL, 2004a, p. 16).

$\mathrm{Na}$ fala de Iraci as feministas se localizam dentre os grupos de mulheres que foram protagonistas de mudanças políticas e sociais. Assim como as negras, lésbicas e agricultoras, as feministas são destacadas dentre outras que colaboraram nas lutas e conquistas dos direitos das mulheres. Iraci em sua fala, de forma didática e exemplificativa, divide as mulheres por

\footnotetext{
52 < http://www1.folha.uol.com.br/folha/brasil/ult96u41584.shtml> Acesso em 24 Jan. 2017.
} 
suas características, como visto anteriormente, porém isso não revela que a palestrante compreenda que uma característica anule outra.

Essa visão das lutas feministas pelos direitos das mulheres como direitos humanos se insere no contexto de lutas pela cidadania plena das mulheres. Os direitos das mulheres foram, pela primeira vez, reconhecidos como direitos humanos na Declaração e no Programa de Ação da Conferência Mundial de Direitos Humanos, realizada em Viena, no ano de 1993, pela Organização das Nações Unidas (ONU). Em Viena, a ONU reconheceu que "a promoção e a proteção dos direitos humanos das mulheres devem ser questões prioritárias para a comunidade internacional. Consolidou-se, dessa forma, um longo caminho iniciado em 1948, quando da Declaração Universal dos Direitos Humanos"53 (BARSTED, 2001, p. 03). Nesse sentido, a Conferência Mundial de Direitos Humanos, no artigo 18 de sua Declaração, reconheceu que:

Os direitos humanos das mulheres e das meninas são inalienáveis e constituem parte integrante dos direitos humanos universais (...). A violência de gênero e todas as formas de assédio e exploração sexual (...) são incompatíveis com a dignidade e o valor da pessoa humana e devem ser eliminadas (...). Os direitos humanos das mulheres devem ser parte integrante das atividades das Nações Unidas (...), que devem incluir a promoção de todos os instrumentos de direitos humanos relacionados à mulher (OLIVEIRA, 1996, p. 100 - 102),

Compreende-se que a noção de direitos humanos, de modo geral, teve origem na busca de limites aos abusos estatais, assegurando-se aos agentes determinados direitos como fundamentais. Habitualmente, era essa a abordagem que tinha predomínio nas relações políticas, especialmente nos países desenvolvidos. O que se observa, no entanto, em especial na América Latina, é uma mudança de foco, um alargamento do conceito, de maneira a se resguardar direitos aos agentes não somente em relação ao Estado, mas também em relação à própria sociedade.

Atualmente é experimentado o desafio da reconstrução da agenda dos direitos humanos. Uma mudança conceitual que explique a função da sociedade enquanto possível agente desrespeitador dos direitos e que, consequentemente, estabeleça novas estratégias de

\footnotetext{
53 No ano de 1948, a Assembleia Geral da ONU ratificou a Declaração Universal dos Direitos Humanos, documento que devotaria ter a mais ampla divulgação e cumprimento por parte dos Estados Membros pelo seu atributo de compromisso aos princípios mínimos de respeito à dignidade da pessoa humana. $\mathrm{O}$ preâmbulo dessa Declaração determina que: “(...) os povos reafirmaram, na Carta, sua fé nos direitos humanos fundamentais do homem, na dignidade e no valor da pessoa humana, e na igualdade de direitos do homem e da mulher, e decidiram promover o progresso social e melhores condições de vida em sua liberdade mais ampla". A despeito dessa Declaração fazer referência direta à igualdade de direitos entre mulheres e homens, ao longo de anos, a avaliação acerca do cumprimento dos direitos humanos não abarcou especificamente das violações aos direitos humanos das mulheres.
} 
enfrentamento (PIMENTAL \& PANGJIARJIAN, 2000). Com essa mudança conceitual é possível estabelecer condições para abordar, de forma direta, a questão dos "direitos humanos das mulheres versus os aspectos androcêntricos, patriarcais e machistas da sociedade" (PIMENTAL \& PANDJIARJIAN, 2000). Segundo Pitanguy e Miranda (2006) afirmam que:

\begin{abstract}
Ao mesmo tempo em que os direitos humanos se universalizavam, ocorria um processo de especificação desses direitos. Eles passaram a conjugar-se não mais a partir de um conceito abstrato de humanidade, e sim baseados no reconhecimento da diversidade em função, principalmente, de gênero, raça e etnia, idade, orientação sexual, dentre outros. Esse conceito plural de sujeitos de direitos (mulheres, crianças, grupos étnicos e raciais) está na base da nova linguagem dos direitos humanos, que também reconhece e incorpora novas dimensões, como a sexualidade, a reprodução, o meio ambiente e a luta contra a violência doméstica. (PITANGUY \& MIRANDA, 2006, p. 17).
\end{abstract}

Entretanto, os movimentos feministas expressam certa inquietação e desconforto quanto se trata de discutir os direitos humanos de modo geral, pois lhes parece discriminar as mulheres. Isto ocorre, porque os direitos humanos que nasceram sob a proteção do princípio da igualdade experimentam a dualidade conflitiva entre as garantias estabelecidas nos acordos e instrumentos formais de proteção e a realidade consubstanciada na prática social (KATO, 1998, p. 06). A experiência histórica tem evidenciado tal descompasso, pois, de modo geral, evidencia os modelos de exclusão e de discriminação sob o rótulo de "direitos humanos". O documento do CLADEM (Comitê Latino Americano e do Caribe para a Defesa dos Direitos da Mulher) sob o título "Direitos Humanos para o Século XXI: Contribuições ao $50^{\circ}$ aniversário da Declaração Universal dos Direitos Humanos”, enfatiza a concepção generalizada quanto a ideia de o sujeito titular dos chamados direitos de primeira geração (direitos civis e direitos políticos), que identificam como "o ser humano ocidental, varão, adulto, heterossexual e possuidor de patrimônio". Dessa perspectiva histórica resultou a exclusão, a restrição e a ineficácia dos direitos humanos em relação às mulheres e meninas. Daí porque a Declaração de Viena de 1993, o artigo 11 é especifico sobre direitos humanos das mulheres.

Segundo as Declarações Internacionais, os seres humanos nascem dignos e com igualdade de direitos. No entanto, aumenta o número dos excluídos. Por esse motivo, a inclinação contemporânea é sair do conceito genérico para especificar os direitos concretos como o de liberdade de imprensa, de opinião, de reunião, etc, assim como acolher instrumentos diferenciados de proteção, centrados nas especificidades (KATO, 1998). A moderna concepção de direitos humanos põe como princípios informativos desses direitos a universalidade, indivisibilidade e interdependência, o que atrapalha a possibilidade do 
fracionamento de tais direitos. Assim, os movimentos feministas, em suas lutas e embates, almejam uma sociedade em que não seja necessário clamar por direitos humanos, mas que eles já estejam naturalmente inseridos nas relações sociais e culturais.

Na concepção de Iraci, as feministas aparecem relacionadas também com as lutas pela "autonomia" das mulheres, pelo governar de suas vidas, corpos e sexualidade (BRASIL, 2004a, p. 16). Entende-se que essa reivindicação das feministas encontra um fundamento histórico nas lutas pela libertação e autonomia das mulheres em relação aos homens.

Essa evocação do feminismo funciona como instrumento exemplificativo dos avanços alcançados pelas mulheres tanto na esfera privada, quanto na pública. Entretanto, avançar no sentido de maior igualdade de gênero em nossa sociedade requer mudanças profundas no pensar e agir, implica em alargar as concepções que temos das atividades, dos lugares, das relações sociais e das próprias convicções relacionadas às mulheres e homens. Implica, portanto, questionar, desestabilizar e redefinir valores, estruturas, definiçõos que servem como base da organização social vigente (GONZALEZ, 2014). Por isso, a autonomia das mulheres, ressaltada na fala de Iraci, serve para reconhecer que apesar das vitórias alcançadas, ainda há obstáculos que impedem a conquista de novos horizontes, principalmente, das mulheres negras, pobres e mães que enfrentam não apenas o patriarcado, mas também o machismo e o racismo, formas contemporâneas perversas e silenciosas de exclusão (BRASIL, 2004a).

Nilza Iraci encerrou o discurso ressaltando a sua expectativa, como Representante do CNDM, para as ações resultantes da I Conferência, e assim disse: "Estaremos, [...], construindo mais um capítulo da História. As mulheres esperam que todos, governantes e sociedade, se juntem a nós nessa árdua empreitada de construir um mundo mais feliz, mais humano, mais solidário, mais digno" (BRASIL, 2004a, p. 17). Ao destacar que se trata de "mais um capítulo da História”, Iraci parece apontar para a ideia das lutas das mulheres por seus direitos como um processo. Não por acaso, fica claro em sua fala o modo como as mulheres em sua diversidade de pautas e lutas (negras, lésbicas, agricultoras e feministas) vem contribuindo nesse processo e que assim a I Conferência se integra também nesse processo, como parte dessa história ainda em construção pelos direitos das mulheres. 


\subsection{NILCÉA FREIRE}

O segundo discurso de Abertura da Conferência foi proferido por Nilcéa Freire, então Ministra $^{54}$ da Secretaria Especial de Políticas para as Mulheres (SPM). Trata-se de uma mulher que têm relevante história também no âmbito acadêmico. Graduou-se em medicina pela Faculdade de Ciências Médicas da Universidade do Rio de Janeiro (UFRJ), em 1978, tornando-se médica e, posteriormente, também professora universitária. Possui pós-graduação em Residência Médica pela FCM/UERJ, nos anos de 1979 e 1980, e mestrado em Zoologia no Museu Nacional da UFRJ, de 1985 a 1987. Além disso, foi militante do movimento estudantil. Ocupou diferentes cargos de representação política entre os docentes na UERJ, sendo eleita Reitora da Universidade Estadual do Rio de Janeiro (UERJ), de 2000 a 2003, tornando-se a primeira mulher a ocupar esse cargo em uma universidade pública no estado do Rio de Janeiro. Presidiu, em 2002, o Conselho de Educação do Estado do Rio de Janeiro e vivenciou a experiência pioneira da implantação do sistema de cotas para os alunos de escolas públicas e afrodescentes. Também, foi a delegada brasileira frente à Conferência Regional sobre a Mulher Latino-Americana e Caribenha (CEPAL-ONU), na qual fez parte da mesa diretiva e delegada titular do Brasil na Comissão Interamericana de Mulheres (OEA), a qual presidiu de outubro de 2004 a dezembro de $2006^{55}$.

Ao iniciar o discurso e logo após os agradecimentos direcionados aos presentes e à mesa de Abertura, Nilcéa Freire citou um pequeno verso no qual demonstrou que acredita na força da coletividade e no poder da memória para construir as discussões e resoluções da I CNPM. Assim disse: "É preciso ter força, é preciso ter garra, é preciso ter memória!" (BRASIL, 2004a, p. 18). Tendo o termo memória como central em sua fala, objetivou criar uma linha discursiva cronológica que fizesse referência ao passado das lutas, dos encontros e dos congressos de mulheres brasileiras. Para isso elencou dados e fatos históricos que

\footnotetext{
${ }^{54}$ As competências do cargo de Ministra da SPM objetivavam: assessorar e imediatamente o Presidente da República na formulação, coordenação e articulação de políticas públicas para as mulheres; elaborar e implementar campanhas educativas e não discriminatórias de caráter nacional; elaborar o planejamento de gênero que contribua na ação do governo federal e das demais esferas de governo; promover a igualdade de gênero; articular, promover e executar programas de cooperação com organismos nacionais e internacionais, públicos e privados, voltados à implementação de políticas para as mulheres; promover o acompanhamento da implementação de legislação de ação afirmativa e definição de ações públicas que visem ao cumprimento dos acordos, convenções e planos de ação assinados pelo Brasil, nos aspectos relativos à igualdade entre mulheres e homens e de combate à discriminação, tendo como estrutura básica o Conselho Nacional dos Direitos da Mulher, o Gabinete e três Subsecretarias. (http://www.diap.org.br/images/stories/secretaria_especial_de_polticas_para_as_mulheres.pdf).

$55<$ https://www.diap.org.br/images/stories/secretaria_especial_de polticas_para_as mulheres.pdf $>$ Acesso em 24 Jan. 2017.
} 
recordassem pontos relevantes nos percursos das lutas pelos direitos das mulheres no Brasil e, assim, justificou em seu discurso a organização e a realização da I CNPM.

Nilcéa Freire, ao discorrer sobre o processo de realização da I CNPM, destacou como aconteceram às etapas preliminares das conferências municipais e estaduais. As quais, segundo a ministra, tiveram a função imprescindível de estimular o debate, e também de "captar onde as mulheres vivem seu cotidiano e a enorme diversidade que constitui a maior riqueza do nosso país" (BRASIL, 2004a, p. 19). Ao mencionar a diversidade das mulheres, a ministra da SPM ressaltou que o sentido da I CNPM foi o de "inscrever definitivamente na estrutura política do nosso país a perspectiva da igualdade entre homens e mulheres" (BRASIL, 2004a, p. 19).

No início do discurso, a ministra faz um recuo ao passado e refere-se ao ano de 1988, ano em que caravanas de mulheres vieram a Brasília para participar da Constituinte e "garantir que nossos direitos estivessem inscritos na Constituição do Brasil" (BRASIL, 2004a, p. 18). Em seguida, fez alusão a quatro "encontros feministas e de mulheres" que aconteceram no Brasil, em 1997, 2000, 2002, 2003. Esta menção é a única referência que ela faz em seu discurso ao feminismo. Desse modo a ministra localiza as feministas na trajetória de lutas das mulheres por seus direitos. Em sua fala, as feministas e as mulheres são promotoras de encontros e eventos fundamentais na conquista de direitos das mulheres. É nessa trajetória que, na perspectiva da ministra, se insere a I CNPM.

As datas e locais dos encontros feministas mencionados pela ministra correspondem, em 1997 ao XII Encontro Nacional Feminista em Salvador (Bahia); em 2000 ao XIII Encontro Nacional Feminista em João Pessoa (Paraíba); em 2002 à Conferência Nacional de Mulheres Brasileiras em Brasília onde foi aprovada a Plataforma Política Feminista; e, em 2003 ao XIV Encontro Nacional Feminista que ocorreu em Porto Alegre (Rio Grande do Sul). Esses encontros propuseram intervenções dos movimentos feministas e de mulheres para que houvesse o reconhecimento da diversidade feminina e também a criação de políticas públicas para as mulheres junto ao Estado. Também possibilitaram a constatação das experiências subjetivas das mulheres, apartando-as de seu encerramento na esfera da vida privada (TELLES, 1999). E, ainda, expuseram e reprovaram as inúmeras maneiras de discriminação que ainda acometem muitas mulheres na sociedade contemporânea.

Os encontros feministas se constituíram em espaços sociais que possibilitaram uma configuração peculiar de diálogos e de relações entre a sociedade civil e o Estado. Nilcéa Freire faz referência a estes espaços sociais não apenas ao mencionar os encontros feministas, mas também, ao citar as etapas municipais e estaduais que constituíram a I CNPM. Nesses 
espaços sociais, a diversidade das mulheres é um elemento de destaque, que de acordo com a ministra esta é uma característica que confere sentido a I Conferência de "inscrever definitivamente na estrutura das políticas do nosso país a perspectiva da igualdade entre homens e mulheres" (BRASIL, 2004a, p. 19). Assim, entende- se que é por meio da diversidade das mulheres e de suas pautas que a I CNPM se abre como um espaço heterogêneo onde deve emergir múltiplas vozes advindas de movimentos feministas e de mulheres.

Os encontros feministas realizados nas últimas décadas buscam formas de negociação e articulações com o Estado na construção de políticas para as mulheres. Valente (2000) ressalta que os movimentos feministas têm forçado os Estados a dialogar e construir novas maneiras de institucionalização e de mediação para com os interesses dos seus agentes. Em vista disso, entende-se que "o diálogo dos movimentos feministas com o Estado tem propiciado a criação de ambientes institucionais e políticas públicas que estão formalmente incumbidas de garantir os direitos das mulheres" (MIRANDA, 2014, p. 03), tal fato pode ser percebido, de certa forma, por meio de tentativas ao longo dos anos do governo PT, assim como no processo de realização das conferencias nacionais. Assim, políticas públicas para as mulheres procuram traduzir a busca pela igualdade por meio do reconhecimento das diferenças, ou seja, o entendimento das necessidades específicas das mulheres e a transformação em políticas públicas e sociais. De acordo com Freire,

políticas públicas para as mulheres significam para nós a busca da igualdade na reafirmação das diferenças. Significam incorporar as necessidades e demandas específicas das mulheres e lançar o seu olhar sobre todas as políticas de todas as esferas do governo (BRASIL, 2004a, p. 47).

Dessa forma, os encontros feministas são espaços de reunião, de compromisso, de reflexão e de construção de estratégias e alternativas políticas, essencialmente direcionadas às demandas das mulheres, no que compete ao viver melhor cotidianamente. Assim, com o crescente incremento de preconceitos e estereótipos na sociedade em geral, os encontros feministas procuram construir, no âmbito social, alternativas autônomas válidas, por meio de protocolos, debates, ações e de informações a fim de facilitar o acesso das mulheres a espaços de poder, de fala e de visibilidade, em condições de igualdade e segurança.

As feministas e seus encontros são evocados na trajetória histórica e na rememorização do processo de lutas das mulheres no discurso da ministra, conferindo, assim, visibilidade e importância aos encontros e congressos feministas e de mulheres realizados no Brasil, como parte fundamental de uma trajetória que abriga, também, a CNPM. 
De acordo com Le Goff (1990), a memória, por conservar certas informações, colabora para que o passado não seja totalmente esquecido, pois ela acaba por habilitar o sujeito a atualizar expectativas ou informações passadas, permitindo que a história se perpetue na consciência humana. O passado permanece "vivo" apenas por meio de trabalhos de associação da memória, que nos possibilitam a oportunidade de revivê-lo a partir do instante em que o sujeito passa a compartilhar suas experiências, tornando assim a memória "viva" (ALBERTI, 2004, p. 15).

Ainda que algumas vezes se compreende a memória como um fenômeno particular, de acordo com Halbwanchs (1990), ela deve ser entendida, também, como um fenômeno coletivo e social. E os elementos que compõem a memória, tanto no aspecto individual quanto no coletivo, são primeiramente aqueles episódios que aconteceram pessoalmente e aqueles vivenciados pelo grupo no qual a pessoa se relaciona (POLLAK, 1992). De acordo com Pollak (1992), a memória pode ser categorizada como seletiva, pois nem tudo por completo fica registrado. Ela sofre algumas alterações que acontecem como "consequência do momento em que ela está sendo articulada. Com isso pode-se dizer que a memória é construída, podendo ser essa construção consciente ou não" (ROCHA, 2012, p. 03).

Sendo assim, estudar e compreender a constituição da memória é imprescindível ao entendimento do processo de lutas das mulheres, porque está intimamente conectada à concepção de identidade que se perpetuar no presente. A memória é um elemento importante no que se refere à estruturação de identidades, porque com base nela podemos identificar os acontecimentos passados e também preservar as informações que nos são relevantes conservar, tanto na memória coletiva quanto na individual (KRAISCH, 2007). Ainda segundo Le Goff (2007), a memória estabelece um "vínculo" entre as gerações humanas e o "tempo histórico que as acompanha”. Esse vínculo que se transfigura em afetivo permite que determinados grupos se vejam como "sujeitos da história", que têm, assim, participação e responsabilidade efetiva na construção da vida política e social do presente.

Ao entender que a memória, evocada no discurso de Nilcéa Freire, faz menção breve às feministas, porém não exclusivamente a elas, mas a vários movimentos de mulheres, confere fundamentação histórica a I CNPM. Assim, admite-se que a importância da memória das lutas feministas é "historicamente construído e conjuga o sentimento de pertencimento dos indivíduos a um ou mais grupos" (PELEGRINI, 2007, p.3), sentimento esse que assegura uma identidade para as lutas por políticas para mulheres no Brasil. 


\subsection{LUÍS INÁCIO LULA DA SILVA}

O discurso do então presidente Lula encerrou a Abertura da I Conferência em um tom informal de oratória. O presidente ressaltou os avanços governamentais realizados até então no campo referente aos direitos e políticas para as mulheres. Destacou a parceria estabelecida entre governo federal e os movimentos de mulheres, ao dizer que desde que assumiu a Presidência da República, se empenhou em tomar medidas efetivas, para mudar a situação das mulheres, em parceria com os "movimentos de mulheres" (BRASIL, 2004a, p. 25).

Lula, ao longo de seu discurso, travou diálogo indireto com as falas de Nilza Iraci e de Nilcéa Freire. Em seu discurso, Nilza Iraci destacou, como já mencionado, a coragem do Presidente de convocar as mulheres para a I Conferência e, dessa forma, ouvir o que elas têm a falar sobre políticas para as mulheres, melhorando, assim, toda a sociedade. Já a ministra da SPM Nilcéa Freire destacou, em sua fala, o papel do Presidente na convocatória da I Conferência como uma ação de confiança para as mulheres brasileiras e ressaltou que a “ousadia maior é a de Vossa Excelência convocar Conferências em todas as áreas de governo, sendo esta mais uma, no mais inédito e amplo processo de consulta popular que já aconteceu neste país" (BRASIL, 2004a, p. 20). Em contrapartida Lula, ao cumprimentar essas duas representantes em seu discurso, destacou o protagonismo das mulheres ao afirmar que "a conquista dos espaços políticos das mulheres e que a liberdade que tanto as mulheres buscavam, não seria obra de nenhum governo e muito menos dádiva, mas seria conquista da organização das próprias mulheres" (BRASIL, 2004a, p. 28).

Nesse caminho Lula disse, ainda, que "a maior obra que um governante pode deixar para seu povo não é a quantidade de asfalto que ele fez ou a quantidade de salas de aula. Mas é a relação que o Estado estabelece com a sociedade e a relação que a sociedade estabelece com o Estado" (BRASIL, 2004a, p. 22). Ainda segundo o presidente, o estabelecimento dessa relação entre sociedade civil e Estado fez, de forma direta, com que transformações acontecessem na vida das mulheres e nos seus espaços de atuação.

Assim, as mudanças sociais para as mulheres, de acordo com Lula, ocorreriam devido à mobilização coletiva das próprias mulheres. Como bem disse, "principalmente graças à mobilização das próprias mulheres, que em diferentes espaços da sociedade, lutaram, ao longo da história, para conquistar direitos e a consciência política da nossa população" (BRASIL, 2004a, p. 23). Não por acaso, Lula destaca e reconhece o protagonismo e capacidade de luta política das mulheres, já que as falas anteriores de suas interlocutoras destacaram o protagonismo de lutas dos movimentos feministas e de mulheres. Os direitos das mulheres, 
segundo Lula, não são assim conquistas que vieram como dádivas ou concessões do governo ou de políticos poderosos, mas sim fruto de lutas históricas e de negociações das mulheres com o governo. Apesar de não mencionar em sua fala os feminismos e as feministas, fato que a princípio pode ser entendido por Lula possuir lugar de fala como gestor do governo federal e por ter trajetória sindical, diferente das demais palestrantes que possuem trajetória feminista militante e acadêmica, entretanto o presidente não deixa de destacar os "movimentos de mulheres". A preferência de Lula pelo termo "movimentos de mulheres" está de acordo com seu plano governamental e partidário, em que o governo federal deveria mostrar os avanços sociais em pautas que não explicitassem radicalização e que estivessem, diretamente, ligadas ao cotidiano das mulheres, pois, caso contrário, poderia evocar questões e pautas tradicionalmente feministas, consideradas tabus na sociedade, como os direitos reprodutivos, o direito ao corpo e o direito ao aborto.

Busquei nesta análise trazer o discurso do presidente para destacar o modo como ele fala das lutas pelos direitos das mulheres e reconhece os protagonismos dos "movimentos de mulheres", mas sem fazer qualquer menção ao movimento feminista. Tal silêncio é bastante significativo e problemático, capaz de gerar muitos debates. Quando as lutas pelos direitos das mulheres são abordadas no mais alto escalão da política, há um silêncio em torno do protagonismo feminista nesse processo. Tratar de "movimentos de mulheres" apresenta-se como a saída política menos radical no reconhecimento das demandas e agentes políticos relacionados às lutas pelos direitos das mulheres, a partir de um lugar de fala político e de negociação que ainda se faz sob a égide do patriarcado, apesar de apoiar a I CNPM. Nesse discurso o feminismo parece se diluir ou até mesmo desaparecer em uma espécie de movimento homogêneo de base biológica, já que o termo mulheres abriga uma diversidade enorme de identidades. Nessa mesa de Abertura da I Conferência, Nilza Irazi e Nilcéia Freire não silenciam a presença e importância histórica do feminismo na trajetória de lutas pelos direitos das mulheres no Brasil, já que as experiências políticas, o lugar social de fala e a trajetória acadêmica dessas mulheres reconhece o protagonismo de suas interlocutoras, ali também presentes.

Como bem observou Descarries (2002) $)^{56}$, o termo "movimentos de mulheres" indica um grande conjunto de coalizões e práticas, continuas ou não ao longo do tempo, que tiverem e ainda têm como objetivo, modificar a situação socioeconômica e política das mulheres e a

\footnotetext{
56 DESCARRIES, Francine. "Um feminismo em múltiplas vozes, um movimento em atos: os feminismo no Quebéc". In: Labrys, estudos feministas. Brasília: UnB, número 1-2, julho/dezebro, 2002. < http://www.labrys.net.br/labrys1_2/francine1.html> Acesso em 10 Mai. 2016.
} 
redefinição de seu papel/função na sociedade, sem obrigatoriamente questionar os padrões e mecanismos reprodutores da divisão social dos sexos (DESCARRIES, 2002). Já os "movimentos feministas", ainda segundo a mesma autora, são associados a um conjunto mais restrito de práticas e de discursos que possuem como prioridade a luta das mulheres e que sugerem "um projeto de sociedade alternativa e colocam como objetivo a abolição, ou mesmo a transformação profunda da ordem patriarcal e de seu poder regulador em nome dos princípios de igualdade, de equidade e de justiça social (DESCARRIES, 2002).

Os "movimentos feministas" são parte importante da dinâmica dos "movimentos de mulheres", mas que não englobam necessariamente todos estes movimentos. É preciso, sobretudo, ter em mente que os projetos teóricos e militantes dos femininos modificam-se sensivelmente e tornam-se mais complexos ao longo dos anos, enquanto que as concepções de igualdade e de liberdade se multiplicam e até divergem-se (DESCARRIES, 2002). Isto posto, compreende-se que a escolha de Lula pela utilização do termo "movimentos de mulheres", em vez do termo "movimentos feministas", se fundamenta na concepção de que os "movimentos de mulheres" sugerem algo mais amplo, uma identidade coletiva capaz de englobar a diversidade de movimentos de mulheres, dentre eles os feministas. $\mathrm{O}$ discurso inaugural de Lula denota a importância da I Conferência como espaço de diálogo dos movimentos de mulheres, entre si, e, com o governo, um espaço democrático, capaz de desencadear políticas para mulheres. Trata-se, portanto, de um espaço revelador do protagonismo desses movimentos nas conquistas pelos direitos das mulheres diante do governo federal. Assim, as lutas e conquistas das mulheres com pautas especificamente feministas ao não serem verbalizadas, mencionadas ou rememoradas são deslocadas para o patamar de lutas secundárias, em que o essencial é a melhoria da sociedade como um todo, sem evidenciar as especificidades dos grupos sociais.

Destaca-se que a não utilização do termo "feminismo(s)" e/ou "feminista(s)" por Lula reforça uma omissão na história das mulheres e de suas lutas. Nessa perspectiva, considero que a abordagem das lutas das mulheres, assim como a utilização do termo "feminismo(s)" e "feminista(s)" em espaços de poder, constitui um esforço altamente político que desafia não apenas os discursos dominantes e patriarcais que circulam, tanto nos espaços cotidianos quanto nos políticos e acadêmicos, mas também as formas de escrita, de fala e de expressão. 


\section{CAPÍTULO 3}

\section{O FEMINISMO NAS AVALIAÇÕES DAS POLÍTICAS REALIZADAS E COMPROMISSOS ASSUMIDOS PELO ESTADO BRASILEIRO}

Neste capítulo apresenta-se uma análise das representações do feminismo nas palestras proferidas no Painel 1: Análise da realidade brasileira, avaliando as políticas realizadas e os compromissos assumidos pelo Estado brasileiro, realizadas no primeiro dia (15/07/2004) da I Conferência Nacional de Políticas para Mulheres (CNPM). Inicialmente trata-se das condições de produção e de organização desse Painel, ressaltando seus objetivos, discursos e sujeitos de fala. Em seguida apresenta-se uma análise das falas de Jacqueline Pitanguy, Sueli Carneiro e José Dirceu.

\subsection{PAINEL 1: OBJETIVOS E SUJEITOS DE FALA}

O Painel 1 teve por objetivo analisar a realidade brasileira na área social, econômica, política, cultural e os desafios enfrentados para a construção da igualdade e da equidade de gênero no Brasil. Os palestrantes desse painel, de certa forma, procuraram realizar um diagnóstico e análise dos problemas a serem enfrentados por projetos ou programas mais duradouros em torno de políticas públicas para as mulheres no Brasil. Nesse espaço de debate, buscou-se, também, comparar e avaliar em que medida as intenções políticas se concretizaram em iniciativas, programas e ações que estiveram sob a responsabilidade do governo, além da abrangência de tais iniciativas e o enfoque de seus trabalhos. Levou-se em conta as avaliações de políticas governamentais, já apresentadas em encontros feministas e outras conferências de mulheres. Particularmente, destacou-se a Plataforma Política Feminista, retirada da Conferência Nacional de Mulheres Brasileiras, realizada em 2002. Por último, foram abordados no Painel alguns compromissos retificados pelo Estado brasileiro. O maior destaque foi dado às proposições de diretrizes de políticas públicas para mulheres que contivessem uma perspectiva de gênero, e apontassem prioridades para os próximos anos.

O Painel 1 foi coordenado por Wanda Menezes (Secretária da Mulher do Governo do Estado de Alagoas/SEMULHER) e contou com quatro palestrantes: Jacqueline Pitanguy (Diretora da Cidadania, Estudos, Pesquisa, Informação e Ação/CEPIA), Sueli Carneiro (Diretora do Instituto da Mulher Negra/Geledés e da Articulação de Mulheres Negras/AMN), 
Nilcéa Freire (Ministra da Secretaria Especial de Políticas para as Mulheres da Presidência da República/SPM) e José Dirceu (Ministro Chefe da Casa Civil da Presidência da República). As palestras tiveram duração média de $20 \operatorname{minutos}^{57}$ e, ao final, as(os) delegadas(os) e as(os) convidadas(os) puderam manifestar-se verbalmente ou por escrito. Cada manifestação posterior às palestras teve duração de três minutos, improrrogáveis (BRASIL, 2004a, p. 147). Coube à mesa organizadora do Painel a definição do número de inscrições para este espaço de debate, para não comprometer o andamento da programação da I Conferência.

Dentre as palestras proferidas nesse Painel, apenas a ministra Nilcéa Freire não faz menção alguma aos termos "feminismo(s)" e/ou "feminista(s)". Sua fala, de forma pontual, abordou como o governo federal compreendeu as políticas públicas para as mulheres e, também, como ele atuou para diminuir a distância entre a igualdade formal e a realidade cotidiana vivenciada pelas mulheres brasileiras. Para isso, ressaltou a importância de travar diálogos entre os poderes instituídos e a sociedade civil, pois, dessa maneira, seria permitida a maior participação das mulheres junto ao Estado. Nilcéa Freire ainda destacou com bastante detalhe, o processo de organização, constituição e elaboração da I CNPM.

No discurso de Jacqueline Pitanguy, o termo "feminismo(s)" aparece seis vezes, enquanto o termo "feminista(s)" quatro vezes. Já no discurso de Sueli Carneiro, o termo "feminismo(s)" aparece uma vez e o termo "feminista(s)" seis vezes. José Dirceu chegou a mencionar o termo "feminista" apenas uma vez em sua palestra. Tais discursos evidenciam o modo como o feminismo é evocado e/ou associado às políticas públicas até então implementadas pelo governo brasileiro, já que se trata de uma situação discursiva cujo objetivo é o de avaliar tais políticas.

\subsection{JACQUELINE PITANGUY: O FEMINISMO NA HISTÓRIA DAS LUTAS PELOS DIREITOS DAS MULHERES NO}

A primeira palestra do Painel 1 foi pronunciada por Jacqueline Pitanguy como diretora do CEPIA (Cidadania, Estudos, Pesquisa, Informação e Ação). Ela se graduou em Ciências Sociais na Universidade de Louvain, em 1968. Em 1972 fez mestrado na Escola de Sociologia da Universidade Católica do Chile, onde vivenciou importantes acontecimentos políticos como a eleição de Salvador Allende e os primeiros anos do governo democrático de projeto

\footnotetext{
57 “Art. 60 - O temário da I Conferência Nacional de Políticas para as Mulheres será abordado por painelistas indicadas(os) pela Comissão Organizadora que disporão de 20 (vinte) minutos para as suas exposições." (BRASIL, 2004a, p. 147).
} 
socialista. Anos depois, já na década 1990, doutorou-se pela Universidade de São Paulo (USP) e, fundou a organização não governamental (ONG) Cidadania, Estudos, Pesquisa, Informação e Ação (CEPIA) . Atuou, também, como presidente do Conselho Nacional de Direitos da Mulher (CNDM), ao longo de quatro anos que coincidiram com a formulação da nova Constituição brasileira, de 1984 a 1988.

A CEPIA, desde a sua criação, está comprometida com a realização de projetos que contribuam para a ampliação e efetivação dos direitos humanos e, consequentemente, para o fortalecimento da cidadania de grupos sociais que, ao longo da história do Brasil, foram tradicionalmente excluídos e invisibilizados. Nesse sentido, a ONG busca desenvolver estudos, pesquisas, projetos de educação e de intervenção social, tendo o cuidado de difundir os resultados, compartilhando-os com amplos setores da sociedade. Assim, vem atuando, também, na proposição, no acompanhamento e na avaliação de políticas públicas, estabelecendo diálogos com agentes sociais diversos, segundo o site da organização ${ }^{58}$.

Ao iniciar o seu discurso, Pitanguy agradeceu o convite da SPM para que ela participasse da I CNPM. Cumprimentou todas(os) as(os) delegadas(os) e representantes de movimentos presentes no momento de sua fala. Em meio a cortesias e saudações iniciais, de forma inusitada, ela destacou o poder da fala como instrumento de comunicação, ao dizer: "sinto-me honrada em usar a palavra em um momento como este" (BRASIL, 2004a, p. 30), por se tratar de um momento de avaliação, análise e debate de políticas públicas para mulheres, que de alguma forma elege e privilegia determinados sujeitos de fala.

Conforme Foucault (2009), a utilização da fala e, consequentemente, a elaboração de discursos variados na sociedade constituem uma ação

[...] ao mesmo tempo controlada, selecionada, organizada e redistribuída por certo número de procedimentos que têm por função conjurar seus poderes e perigos, dominar seus acontecimentos aleatório, esquivar sua pesada e temível materialidade (FOUCAULT, 2009, p. 9).

Em vista disso, entende-se que a fala, longe de ser um elemento transparente ou neutro, pode ser considerada um lugar de poder, por isso há um controle sobre a fala, não é qualquer pessoa que pode falar o que pensa em qualquer lugar, já os discursos são capazes de expor, idealizar e criar realidades. Segundo Foucault, “o discurso não é simplesmente aquilo que traduz as lutas ou os sistemas de dominação, mas aquilo por que, pelo que se luta, o poder do qual nós queremos apoderar" (FOUCAULT, 2009, p. 10). Não por acaso, a I CNPM tem,

\footnotetext{
${ }^{58}$ Informações sobre a CEPIA (Cidadania, Educação, Pesquisa, Informação e Ação) ver o site da organização: <http://www.cepia.org.br/ > Acesso 13 Jun. 2016.
} 
também, seus sujeitos de fala privilegiados, cujos discursos ganham espaço e legitimidade a partir das experiências e identidades que assumem frente às questões que são postas em debate. Como há um controle e seleção das falas, não é qualquer pessoa que pode falar, já que se trata de um espaço de representação política e, portanto, de poder, onde as falas privilegiadas podem servir de parâmetros para a construção de propostas e diretrizes de políticas públicas para as mulheres. Desse modo, os sujeitos de fala são eleitas pelas(os) organizadoras(os) da I CNPM e reconhecidas também por suas(seus) interlocutoras(os) como qualificadas e experientes para isso. Não por acaso, Pitanguy agradece pelo lugar de fala na I Conferência e compreende que:

[...] este é um momento de celebração, por estarmos juntas aqui, nesse cenário de poder somando forças, apoiadas em nossa memória coletiva de lutas, conquistas e desafios, reconhecendo nossa diversidade e construindo estratégias conjuntas (BRASIL, 2004a, p. 30).

Nesse sentido, segundo Pitanguy, a I CNPM se constitui em um espaço de reflexão sobre as políticas públicas já implementadas, em que as discussões, diretrizes e estratégias traçadas deveriam incorporar aspectos que colaboraram para o reconhecimento e para o desdobramento das ações e das reivindicações das mulheres no Brasil. Ainda segundo a palestrante, trata-se de:

[...] um momento de reflexão sobre os caminhos percorridos para que as diretrizes e estratégias que vão emergir desta Conferência incorporem nosso passado não como uma recordação saudosista e sim como um elemento fundamental na construção do futuro (BRASIL, 2004a, p. 30).

Para isso, deixa claro em sua fala que pretende "traçar, de forma breve, os percursos do feminismo no Brasil, as principais estratégias seguidas pelos movimentos de mulheres, e deixar algumas perguntas, que nos assombram neste novo milênio” (BRASIL, 2004a, p. 30). Para falar dos "caminhos percorridos", Pitanguy organiza sua fala em torno de três momentos:

Gostaria de distinguir alguns momentos que caracterizam o movimento de mulheres e as políticas de gênero, ressaltando que não significa que não haja justaposições entre estes momentos, pois, como sabemos, a história não se escreve de forma linear. Estes momentos seriam:

1 - No contexto da ditadura o surgimento do Feminismo como ator político na esfera pública - 1975-1982;

2 - A redemocratização e a agenda de políticas públicas para a mulher 1983-1990;

3 - A internacionalização das agendas: globalização econômica, universalização dos direitos humanos, conferências das Nações Unidas; 4 - O novo século: nós, aqui, hoje (BRASIL, 2004a, p. 32). 
Nesse discurso observa-se que o "feminismo" é evocado para conferir historicidade à trajetória de lutas e conquistas pelos direitos das mulheres no Brasil. Na visão da palestrante, o feminismo aparece no início dessa trajetória como "ator político" na esfera pública dos anos setenta. Ao tratar das características marcantes desse primeiro período, afirma que

No Brasil o feminismo irrompe na arena política nos anos 70, década caracterizada por intensa mobilização contra a ditadura e pelo surgimento de movimentos sociais no cenário público. Estes movimentos, que continuam a atuar ao longo dos anos 80, ampliaram o campo do político, alargando a compreensão das contradições sociais para além do estritamente econômico, revelando a existência de outras formas de exercício do poder. Tais movimentos trouxeram o individual para o campo do político, tornando-o coletivo, demonstrando que além das relações de classe também as relações de gênero, raça e etnia se concretizam numa distribuição desigual de poder. É neste momento histórico de autoritarismo, de contestação e de luta que o feminismo ressurge como um movimento organizado, que passa a se constituir em inegável força política, com enorme potencial de transformação social. Surgem, neste contexto, inúmeras organizações, que atuam como núcleos congregando grande número de mulheres, desenvolvendo atividades diversas, grupos de trabalho, pesquisas, debates, cursos, publicações - e participando das campanhas que levaram as mulheres às ruas dando visibilidade as suas reivindicações específicas, ao lado das reivindicações pelos direitos civis e políticos e pelo fim do regime militar (BRASIL, 2004a, p. 32. Grifos nossos).

Nesse enunciado, o feminismo ganha contornos de um "movimento organizado", assim como outros que irrompem no cenário da Ditadura Militar. No contexto do regime militar (1964-1985), que se instituiu no país por meio de um golpe de Estado embasado por setores dominantes e pela política externa dos Estados Unidos, e de uma crise econômica a qual resultou em alta dos índices de desemprego e subemprego, assim como o arrocho salarial e o corte de gastos sociais (SAFA, 1990), o feminismo, também, aparece como um protagonista na esfera pública. Pois, ainda que as mulheres brasileiras tenham conquistado o sufrágio em 1932, resultado principalmente de um lobby de mulheres escolarizadas vinculadas às camadas ricas junto a políticos simpáticos à causa (MACAULEY, 2006), os movimentos feministas brasileiros, ao reflexo dos feminismos latino-americano, se consolidaram enquanto movimentos sociais em meados da década de 1970, nesse contexto de intensos embates políticos.

Na visão da palestrante, é nesse momento histórico de lutas e mobilizações políticas que o feminismo "ressurge", o que denota o entendimento de que esse movimento vem também de uma trajetória anterior, mas é nesse momento que ele ganha uma "força política inegável, com enorme potencial de transformação", se constituindo assim como "ator político" por introduzir no campo da política as discussões sobre outras formas de poder que 
afetam as mulheres e que estão presentes nas relações de gênero, classe, raça e etnia. Nesse sentido, a palestrante afirma que estes movimentos "trouxeram o individual para o campo do político, tornando-o coletivo". Trata-se de uma visão que se sustenta na concepção de que para o feminismo “o pessoal é político", expressão utilizada pela primeira vez por Carol Hanisch $^{59}$, em 1969, presente nas críticas feministas dos anos 1970 à dicotomia público/privado (doméstico), coletivo/individual (pessoal), que acabava por excluir as questões relacionadas às mulheres ao universo pessoal, privado e doméstico onde não caberia a intervenção de políticas públicas.

O slogan "o pessoal é político" se tornou sinônimo da segunda onda ${ }^{60}$ dos movimentos feministas no Ocidente. As feministas, movidas por essa concepção, observaram as desigualdades culturais e políticas das mulheres como resultados de uma cultural política sexista e patriarcal. Com isso se propuseram a estimular as mulheres a compreenderem a opressão e desigualdade que viviam no seio de suas famílias e também na sociedade como resultados de uma estrutura social e política de poder que privilegiava os homens em detrimento das mulheres.

Afirmar que "o pessoal é político" foi fundamental para estabelecer a possibilidade da construção de uma "nova intimidade", de acordo com Giddens (1993) ${ }^{61}$, em um processo eminentemente histórico e social. Assim, a objetivação de uma nova experiência subjetiva, que o feminismo permitiu em um processo necessariamente coletivo, possibilitou que esta experiência tivesse uma existência e um significado social e, com isso, pudesse formular uma nova referência de ser mulher. Segundo Sartir, este é o "sentido radical do movimento feminista como manifestação coletiva das mulheres, formulado como politização do mundo privado" (SARTI, 2001, p. 45).

\footnotetext{
${ }^{59}$ HANISCH, Carol. Women's Liberation Movement, 1969. Tradução:

$<$ https://we.riseup.net/assets/190219/O+Pessoal\%2B\%C3\%A9\%2BPol\%C3\%ADtico.pdf >. Acesso em 17 Jun. 2016.

${ }^{60}$ Dependendo do momento histórico, da cultura e do país, as mulheres se mobilizaram por diferentes causas e objetivos, em consequência disto diversas feministas e acadêmicas, ao longo do tempo, tenderam a dividir a história dos movimentos feministas em três "ondas". A primeira onda faz referência principalmente ao sufrágio feminino, movimento que ganhou força no século XIX e no começo do século XX. A segunda onda faz referência às ideias e ações interligadas com os movimentos de liberação feminina iniciados na década de 1960, que reivindicavam a igualdade legal e social das mulheres. E, por fim, a terceira onda, iniciada na década de 1990, que seria uma continuação e também uma reação às falhas da segunda onda. Sobre a divisão em "ondas" da história dos movimentos feministas cf. KROLOKKE, C.; SCOTT, A. Three waves of feminism: from suffragettes to girls. In: KROLOKKE, C.; SCOTT, A. Gender communication theories and analyses: from silence to performance. Thousand Oaks: SAGE, 2006. p. 1-24.

61 GIDDENS, Anthony. A transformação da intimidade: sexualidade, amor e erotismo nas sociedades modernas. São Paulo, UNESP, 1993.
} 
Deve-se notar que Pintaguy percebe, nos movimentos feministas dos anos 1970, preocupações com as questões de raça, classe e etnia, na base de suas concepções de que o individual é político, e, portanto, coletivo. No entanto, não há um consenso sobre isso, já que alguns grupos "feministas dissidentes" 62 vem se empenhando em mostrar o quanto o feminismo dos anos 1970 atentava apenas para as desigualdades de gênero impostas por um patriarcado hegemônico, excluindo de suas preocupações as diferenças raciais, étnicas e de classe social que atingem as mulheres na sua pluralidade de experiências e identidades (CURIEL; FALQUET; MASSON, 2005).

Ao mencionar as preocupações de raça, etnia e classe, o discurso de Pintaguy sobre o feminismo parece entrar em sintonia com os interesses diversos de suas interlocutoras na I CNPM, já que se trata de uma fala dirigida às representantes de movimentos feministas e de mulheres bastante diversificados e atentos às interseccionalidades de gênero, raça, etnia e classe na proposição de políticas públicas para mulheres. No entanto, sua fala, também, encontra fundamento nas diversas práticas e discursos do feminismo na cena política dos anos 1970, possibilitando a visibilidade e o reconhecimento da presença dessa discussão, o que não exclui ou ausenta o feminismo dos debates sobre as interseccionalidades, já que o ressurgimento dos movimentos feministas nos anos 1970 trouxe consigo um conjunto de pautas direcionadas para os processos mais amplos de democratização e igualdade de gênero.

Segundo Lourdes Bandeira (2005), os movimentos feministas propagaram, nesse momento dos anos 1970, uma forma de "ser mulher" (ocidental, heterossexual, branca, classe média) e, a partir dessa "mulher", definida no singular, defendeu-se uma solidariedade intragênero estruturada, exclusivamente, em uma identidade biológica comum, "esquecendo-

\footnotetext{
${ }^{62}$ A concepção do feminismo como um movimento hegemônico nos anos 1970 sofreu críticas de algumas feministas negras, indígenas e outras através de "emergentes vozes dissidentes", ou seja:

"El movimiento feminista de la "segunda ola" se expresó en varias ciudades de América Latina y del Caribe a partir de la década de los setenta. Igual que en Europa, este movimiento provenía principalmente de mujeres de clase media; se organizó al inicio según un modelo autogestivo e independiente y era generalmente constituido por pequeños grupos de auto-conciencia. En los años ochenta, las corrientes feministas se diversifican y surge un movimiento amplio de mujeres (MAM) que se deslinda, en parte, del feminismo, para desarrollar un trabajo con mujeres de sectores populares y hacer alianzas con los partidos de la izquierda y organizaciones de la lucha armada. El caso de Centroamérica es un ejemplo en este sentido. Del MAM nacieron las primeras ONGs de mujeres impulsadas por la cooperación internacional. En la década de los 90, el movimiento feminista se academiza y se institucionaliza: llega el tiempo de las políticas oficiales de "equidad de género", de los encuentros de mujeres financiados por la ONU y de los programas de micro-crédito del Banco Mundial para las pobres. (...) En estos años, más voces disidentes emergieron: de las lesbianas, las mujeres afrodescendientes y las mujeres indígenas. Las lesbianas aparecen públicamente ya desde los setenta, aunque en medio de la represión y la clandestinidad. En los años ochenta, su movimiento se fortalece a través de encuentros continentales, en los cuales se organiza una respuesta al hetero-feminismo y desde donde denuncian de manera articulada el sistema patriarcal y la heterosexualidad obligatoria. Es hasta los noventa que esta lucha empieza a ser reconocida, al tiempo que se institucionalizan más como movimiento" (CURIEL, Ochy; FALQUET, Jules; MASSON, Sabine. Feminismos disidentes en América Latina y el Caribe. NQF, vol. 4, n 2, 2005, p. 7).
} 
se das diferenças e desigualdades entre mulheres de distintos lugares sociais, experiências religiosas, pertença racial, orientação sexual, etc” (RODRIGUES, 2013, p. 07). Alguns movimentos feministas dos anos 1970, focados nas desigualdades de gênero e no combate ao patriarcado, acabaram por não perceber outras formas de poder sobre a diversidade das mulheres, onde o racismo e sexismo colocavam as mulheres negras, por exemplo, em uma situação inferior à das mulheres brancas, escolarizadas e classe média alta (RODRIGUES, 2013, p. 01). Por isso, a suposta igualdade preconizada dentro dos movimentos feministas nos anos 1970, levaram muitas mulheres a lutarem por suas especificidades, produzindo alguns conflitos e rupturas com o feminismo.

O conceito de interseccionalidade, formulado, inicialmente, por Kimberlé Williams Crenshaw em 1991, concede visibilidade às múltiplas formas de ser "mulher" sem cair no reducionismo de um princípio unificador comum, mas sem, contudo, "resvalar para um relativismo que desloca as relações de poder envolvidas nas diversas formas de opressão, transformando-as em mero objeto de disputa discursiva" (RODRIGUES, 2013, p. 06). Nesse sentido, Patricia Hill Collins (1998, p. 201) aconselha a não esquecer que o "posicionamento de um grupo em meio a relações de poder hierárquicas produz um desafio compartilhado pelos indivíduos destes grupos". A partir de tal enunciação, entende-se que as estratégias individuais devem ser compreendidas sem perder de vista que as opressões incidem sobre a coletividade de formas diversas.

A interseccionalidade pode ser considerada, a depender de quem e de como se usa a terminologia, uma ferramenta heurística, um conceito ou até uma teoria. No entanto, um ponto de vista comum das feministas que tratam das interseccionalidades refere-se à tentativa de evidenciar em que medida gênero, raça e classe interagem na realidade sóciomaterial da vida das mulheres na (re)produção e transformação de relações de poder. Assim, utilizar-se da interseccionalidade, como pretende Pitanguy ao reconhecer as diferenças de gênero, raça e classe, é essencial para escapar de interpretações reducionistas e ou essencialistas do feminismo que chocam-se com os interesses de suas interlocutoras na I CNPM.

A imagem do feminismo como um movimento preocupado, já no passado, com questões de gênero, raça e classe, parece integrá-lo/acomodá-lo, também, na trajetória e nas causas dos movimentos presentes e representados na I CNPM. Colocando o feminismo no início de uma trajetória de lutas e conquistas de políticas para mulheres, que já levava em conta outras formas de exercício do poder sobre as mulheres, relacionadas à raça, classes e etnia, a palestrante consegue articular o feminismo dos anos 1970 a uma trajetória histórica de lutas que se articula com os interesses presentes na I Conferência. 
Ainda segundo Pitanguy, o movimento feminista, como "ator político":

[...] trouxe para o interior dos partidos políticos a questão da mulher, pois uma característica que marca desde os anos 1970 este movimento é o seu investimento em influenciar o governo, buscando interlocução com o legislativo (Código Civil 1976), apresentando demandas aos partidos nas eleições de 1979 (Alerta Feminista) e a partir da vitória da oposição em 1982 em Minas e São Paulo e Rio de Janeiro, reivindicando e construindo espaços institucionais a nível estadual como os conselhos, e as delegacias especializadas (BRASIL, 2004a, p. 33. Grifos nosso).

O movimento feminista como "ator político" ganha reconhecimento, força e valor como protagonista nas negociações com o governo. Desse modo, Pitanguy confere sentido e importância política aos movimentos feministas pela capacidade de influenciar o governo, de dialogar com o legislativo, partidos políticos e instituições. Trata-se de uma imagem do feminismo que reconhece seu lugar e importância na história das lutas pelos direitos das mulheres no Brasil. Não por acaso, Pitanguy destaca que as contribuições do feminismo são “inegáveis".

No entanto, ao tratar dos anos 1980 e 1990, caracterizando os outros três momentos históricos a que se refere, Pitanguy fala de "feministas e movimento de mulheres", sinalizando para uma concepção de que essas lutas e conquistas não são exclusivas das feministas. Desse modo, a palestrante faz menção aos diálogos nos anos 1980 (1985-89) do Conselho Nacional de Direitos da Mulher (CNDM) com as "feministas e movimentos de mulheres" na proposição de políticas para as mulheres no Brasil. Fica claro, que na trajetória histórica narrada por Pitanguy, os movimentos feministas tem “inegável” importância e contribuição, mas que ele não é o único ator político nesse processo, já que também atribui aos chamados "movimentos de mulheres" um papel fundamental. Dada à diversidade de pautas e perspectivas políticas das mulheres, algumas em divergência com as feministas, ao falar da trajetória histórica de lutas e conquistas pelos direitos das mulheres, faz-se fundamental destacar o feminismo ao lado dos movimentos que não se intitulam feministas, mas que também atuaram nessas lutas. Ao longo da I CNPM, essa distinção aparece em vários discursos quando se trata de "movimentos feministas e de mulheres". Na fala de Pitanguy, o feminismo tem um lugar histórico importante e específico, já que, nos anos 1970, são precursores das lutas políticas, mas que se destaca e se coloca de modo paralelo aos "movimentos de mulheres".

A palestrante deixa, ainda, entrever diferenças entre os movimentos feministas e de mulheres no campo da ação política, após os anos 1970. Desse modo, fala de uma diversidade 
que caracteriza o movimento de mulheres, em que o feminismo aparece como um dos diversos "campos de ação". Segundo Pitanguy:

[...] além destas pautas diversas há que se ver a colcha de retalhos e a diversidade deste movimento que, cada vez mais, especifica demandas e dá visibilidade a segmentos da população feminina brasileira destacando-se, por exemplo, a contribuição fundamental do movimento de mulheres negras (BRASIL, 2004a, p. 34).

Considerando a diversidade dos movimentos de mulheres, Pitanguy busca ressaltar as diferenças, quando diz:

Cabe, no entanto, ressaltar que o campo de ação política e a agenda do movimento de mulheres comportam temáticas cuja legitimidade social é bastante diversa. Desde uma perspectiva ampla, o campo de ação política do feminismo é o das relações de gênero. Este campo, que se constrói também no nível imaginário e simbólico, se desdobra em esferas específicas tais como: violência doméstica, direitos sexuais, direitos reprodutivos, mercado de trabalho, educação, participação política, e que não gozam da mesma legitimidade social nem da mesma capacidade de informar políticas publicas. Assim é que a luta contra a violência doméstica, presente nas plataformas do movimento de mulheres desde seus primórdios, sempre alcançou maior aceitação na sociedade brasileira do que aquela travada pelo respeito aos direitos reprodutivos (BRASI, 2004a, p. 34. Grifos nossos).

A palestrante destaca a existência da diversidade de pautas que o movimento de mulheres suporta e, em seguida, aponta para a ação política do feminismo. Em sua visão, o feminismo está dentro da diversidade dos movimentos de mulheres, por consequência, nesse discurso percebe-se uma identificação do feminismo com questões relativas aos direitos reprodutivos que tocam especialmente na questão do direito aborto. É nesse sentido que as pautas feministas encontram resistência na sociedade e dentro de alguns movimentos de mulheres. De acordo com Pitanguy,

Nesta última frente de ação o movimento sempre encontrou a pressão contrária de setores mais conservadores e seu avanço tem sido mais lento, pois é mais sinuoso o caminho percorrido para incorporar questões ligadas a sexualidade, a contracepção, a contracepção de emergência e ao abortamento no debate social e em políticas públicas (BRASIL,2004a, p. 34. Grifos nossos).

Trata-se, portanto, de pautas que se identificam com o feminismo e que, segundo a palestrante, encontram dificuldades em informar políticas públicas, por isso não tem a mesma "legitimidade social". Ou seja, o feminismo toca em questões que tendem a modificar mais a fundo as relações de gênero, especialmente ao reivindicar o direito ao aborto como um direito de escolha e decisão das mulheres sobre seu próprio corpo, questão ainda combatida por 
setores religiosos e mulheres na cena política, mulheres estas que também estavam presentes na I CNPM e que contribuíram para que a "Moção de Protesto contra a Legalização do Aborto" tivesse 224 assinaturas e expusesse como conteúdo o seguinte protesto:

[...] contra qualquer proposta em prol da LEGALIZAÇÃO SO ABORTO, reiterando o princípio legal de que TODOS TÊM O DIREITO A VIDA, conforme previsto no art. $5^{\circ}$ da Constituição Federal, pois a partir da concepção, uma nova vida foi gerada, não cabendo a nós o direito de decidir sobre ela. Alertando também sobre a importância de um programa de acompanhamento de crianças, adolescentes e jovens, que precocemente estão entrando na atividade sexual sem estarem totalmente cientes das suas consequências e responsabilidades, gerando um aumento no número de adolescentes grávidas ou com problemas de DST/AIDS (BRASIL, 2004a, p. 141).

Pitanguy revela que os movimentos feministas e de mulheres possuem pautas comuns como a luta contra a violência doméstica, mas quando se trata de direitos reprodutivos há diferenças fundamentais. Assim, o que o diferencia o feminismo dos outros "movimentos de mulheres" é o seu "campo de ação política".

Finalizando a sua fala, Pintaguy declara que:

Ao tratar desta temática e ao refazer o longo caminho trilhado por tantas de nós até hoje, me vem à cabeça a estória de Alice no país das Maravilhas. Há uma passagem em que os personagens correm e correm e correm, mas permanecem no mesmo lugar. Acho que nossa história é diferente. Corremos e corremos, ora na sociedade civil, ora no governo, acertamos muitas vezes e freqüentemente não avançamos porque estamos defendendo espaços conquistados no território da política caracterizado por embates, tensões, alianças, negociações. Neste território não permanecemos no mesmo lugar, como na estória de Alice, pois atualmente o debate sobre políticas públicas de gênero ocupa, no cenário nacional e internacional, uma posição diversa daquela que detinha em 75 quando a ONU inaugura o Ano Internacional da Mulher e o movimento feminista organizado desponta no Brasil.[...] Neste ano de 2004, decretado como Ano da Mulher pelo Presidente da República e no espaço desta grande Conferencia Nacional de Políticas para as Mulheres cabem novas perguntas, próprias a uma agenda de gênero que construída na história, não comporta visões unilaterais nem verdades absolutas. Muito obrigada! (BRASIL, 2004a, p. 38)

Nesse enunciado, a palestrante deixa entrever que as lutas e conquistas das mulheres não seguem uma trajetória linear de avanços, já que nesse percurso encontram também entraves nas negociações e nos diálogos com o governo. A concepção de uma "agenda de gênero que construída na história, não comporta visões unilaterais nem verdades absolutas", encontra fundamento da trajetória histórica narrada pela palestrante onde se faz presente a diversidade de movimentos feministas e de mulheres com interesses e pautas variadas. A narrativa histórica de Pitanguy aponta para os desafios que se colocam no presente na 
construção de políticas para mulheres que levem em conta essa história de diversidade, de interesses e de pautas que caracterizam os movimentos feministas e de mulheres, para não haver benefícios apenas unilaterais, mas que possam abarcar a multiplicidade das mulheres.

Para Jorn Rüsen (2010), a necessidade de usar a história deriva da vida prática cotidiana. Portanto, é diante da imprevisibilidade de agir que cada sujeito recorre às experiências vividas e representações do sentido do tempo. Essa ideia funda a reflexão sobre si e os outros no tempo (um conceito amplo de "história"), como o princípio fundamental da produção do saber sobre a história, que alcança várias características segundo a época e a cultura dos sujeitos. Entender a função da história do feminismo no presente, especialmente no contexto de proposição da avaliação de políticas públicas para as mulheres, representa uma mudança profunda em pensamentos enraizados sobre as mulheres há muitos anos, justificados em vasta literatura de ordem discursiva patriarcal de filósofos e cientistas, especialmente homens, apropriados por um sistema político e econômico que lucra e se aproveita dessas diferenças. Jorn Rüsen destaca que a "consciência histórica" não deve ser compreendida somente como um "simples conhecimento do passado", mas antes de tudo como um "meio de entender o presente e antecipar o futuro" (2010, p. 57). Ela é, de maneira sucinta, um "conjunto coerente de operações mentais que definem a peculiaridade do pensamento histórico e a função que ele exerce na cultura humana" (RUSEN in BARCA et al. 2010, p. 3637).

Entende-se que Pitanguy, ao traçar, de forma breve, um certo percurso das lutas pelos direitos das mulheres no Brasil, buscou conferir historicidade às lutas e às conquistas das mulheres, para, assim, fundamentar as ações e propostas políticas no presente, que se colocaram na I CNPM. Dessa forma, compreende-se, a partir de sua fala, que a história, neste cenário, pode ser compreendida como um instrumento para legitimar as ações das mulheres no tempo presente. Nesse passado reconstruído e idealizado pela narrativa histórica os movimentos feministas são relembrados e re-significados ganhando um papel fundamental, ao lado dos "movimentos de mulheres", no processo de lutas e conquistas pelos direitos das mulheres. 


\subsection{SUELI CARNEIRO: ENEGRECENDO O FEMINISMO}

A segunda palestra do Painel 1 foi proferida por Sueli Carneiro, então diretora do Instituto da Mulher Negra (Geledés) e da Articulação de Mulheres Negras (AMN). Ela se formou em filosofia na Universidade de São Paulo (USP) e na mesma instituição obteve também o título de Doutora em Educação $(2002-2005)^{63}$. É reconhecida como teórica da questão da mulher negra e é responsável por criar um programa de orientação na área da saúde física e metal específico para mulheres negras, onde mais de trinta mulheres são atendidas semanalmente por psicólogos e assistentes sociais ${ }^{64}$.

Na década de 1980, período importante para o surgimento de novas organizações sociais, assim como para a ampliação da participação das mulheres em diferentes espaços institucionais, Sueli Carneiro, ao lado de outras mulheres negras, fundou, em 1982, o Coletivo de Mulheres Negras de São Paulo. Um ano depois, surgiu em São Paulo o Conselho Estadual da Condição Feminina (CECF/SP), cuja composição chamou atenção, pois dentre as 32 conselheiras eleitas para sua composição nenhuma era negra. Diante desse fato, a radialista Marta Arruda começou uma campanha, associada a ações enérgicas de algumas lideranças de mulheres negras, entre elas Sueli Carneiro, com o objetivo de que uma das vagas fosse aberta a uma representante das mulheres negras. Com essa interferência e participação de Carneiro e de outras militantes negras no corpo técnico do CECF/SP, incentivou-se o debate sobre a realidade das mulheres negras e também a introdução da questão sobre a opressão racial ao conjunto de ações do órgão, resultando na criação da Comissão da Mulher Negra. Essas conquistas alcançadas em São Paulo foram propagadas nacionalmente, desenvolvendo, assim, políticas públicas de temáticas raciais na esfera federal ${ }^{65}$.

No ano de 1988, durante o Centenário da Abolição, o Conselho Nacional dos Direitos da Mulher (CNDM) criou, sob a coordenação de Sueli Carneiro, o Programa da Mulher Negra que, entre outras funções, realizou um conjunto de atividades em parceria com a Comissão de Mulheres Negras do CECF/SP e também com a Comissão da Mulher Advogada da OAB em São Paulo. Nesse mesmo ano, Carneiro ajudou a fundar em São Paulo a organização não governamental Instituto da Mulher Negra (Geledés), primeira organização negra e feminista do país. O Instituto desenvolveu, inicialmente, trabalhos nas áreas de saúde, política e

\footnotetext{
63 Informação presente no site do "Geledés - Instituto da Mulher Negra" < http://www.geledes.org.br/suelicarneiro-coordenacao-executiva-portal-geledes-app-plp2-0/\#gs.p8cpLrg> Acesso em 30 Jun. 2016.

${ }^{64}$ Informação presente no site da Fundação Cultural Palmares <http://www.palmares.gov.br/?p=26674> Acesso em 30 de Jun. 2016.

${ }^{65}$ Informação presente no site "Mulher 500 anos atrás dos panos":

<http://www.mulher500.org.br/acervo/biografia-detalhes.asp?cod=859> Acesso em: 05 Jul. 2016.
} 
jurídica, objetivando, com isso, a melhoria da situação da população negra no Brasil, em especial, das mulheres negras. Atualmente, o Instituto atua também na área de educação, onde conta com um projeto de capacitação de jovens de baixa renda ${ }^{66}$.

A atuação de Carneiro colaborou, de forma decisiva, para o estabelecimento de um elo entre as questões feministas e raciais no Brasil. E como consequência, no ano de 1990, através de uma iniciativa do Geledés, pela primeira vez no país, o Sistema Unificado de Saúde (SUS) do município de São Paulo passou a registrar o item cor nas fichas de entrada dos pacientes ${ }^{67}$. No ano de 1995, Carneiro contribuiu para a elaboração das metas para o Grupo de Trabalho Interministerial, que determinou políticas para a valorização da população negra no país. Consequentemente, em 1996, convidada pelo governo federal, por meio do Ministério da Justiça, ela assessorou a redação do capítulo referente à população negra no Programa Nacional de Direitos Humanos ${ }^{68}$.

Diante de toda essa experiência, analisou-se a presença do feminismo na fala de Carneiro. Sua palestra traz em si vivências da militância e da academia, pois a fala encontra fundamento nas experiências de sua militância, especialmente junto aos direitos de mulheres negras no Brasil. Inicialmente, ela agradeceu às autoridades governamentais e convidadas(os) presentes. Mas apresentou um agradecimento especial a então ministra Nilcéa Freire, ao destacar a "honra de poder estar aqui, falando nesta Plenária extraordinária" (BRASIL, 2004a, p. 38-39). Além disso, ressaltou a I CNPM como "extraordinária iniciativa" que já apresentava "sucesso" "para o conjunto das mulheres brasileiras" (BRASIL, 2004a, p. 39).

No momento inicial de sua fala, Carneiro foi interpelada pela fala de Jaqueline Pitanguy, ao dizer que, como ela, falaria "um pouco dos nossos paradoxos". Assim diz, "creio que nós mulheres, temos enfrentado conjunturas difíceis, tempos muito difíceis, no que diz respeito à consolidação e à manutenção dos nossos direitos, nos novos direitos que vimos conquistando, ao longo de nossa luta" (BRASIL, 2004a, p. 39). A partir disso, fala sobre as lutas e conquistas de políticas para as mulheres no Brasil, e destaca enfaticamente as permanências e dificuldades nessas lutas, ao mencionar a persistência de “ideologias autoritárias, fascismos, neofascismos, diferentes variações do machismo, do racismo e suas múltiplas formas de discriminação étnica e racial, pelos fundamentalismos religiosos ou econômicos, pelo neoliberalismo ou pelas globalizações” (BRASIL, 2004a, 39). Além disso, mencionou a mercantilização dos corpos femininos, os baixos salários e o assédio sexual que

\footnotetext{
${ }^{66}$ Idem <http://www.mulher500.org.br/acervo/biografia-detalhes.asp?cod=859> Acesso em: 05 Jul. 2016.

${ }^{67} \mathrm{Idem}<\mathrm{http} / / /$ www.mulher500.org.br/acervo/biografia-detalhes.asp?cod=859> Acesso em 05 Jul. 2016.

${ }^{68} \mathrm{Idem}<\mathrm{http}$ ://www.mulher500.org.br/acervo/biografia-detalhes.asp?cod=859> Acesso em 05 Jul. 2016.
} 
ainda sofrem as mulheres no mercado de trabalho; a persistência da impunidade diante da violência doméstica e sexual; a expansão do fundamentalismo religioso como fator de retrocesso nas conquistas das mulheres; e o racismo e discriminação que sofrem mulheres negras e indígenas.

Nessa observação dos problemas e avaliação das políticas públicas para mulheres no Brasil, Carneiro mencionou a palavra "feminista(s)" seis vezes, e o termo "feminismo(s)" uma vez. A primeira menção ao termo aparece no seguinte enunciado:

Lutamos contra o racismo e a discriminação racial. Sumariamente, podemos afirmar que o protagonismo político das mulheres negras tem se constituído em força motor para determinar as mudanças nas concepções e no reposicionamento político feministas no Brasil.

As ações políticas das mulheres negras vêm promovendo o reconhecimento da falácia da visão universalizante da mulher, o reconhecimento das diferenças intragênero, o reconhecimento do racismo e da discriminação racial, como fatores de produção e reprodução das desigualdades sociais experimentadas pelas mulheres, no Brasil. O reconhecimento do privilégio que essa lógica produz, para as mulheres do grupo racial hegemônico. $\mathrm{O}$ reconhecimento da necessidade de políticas específicas para as mulheres negras, para a equalização das oportunidades sociais. (BRASIL, 2004a, p. 40. Grifos nossos).

Na visão da palestrante, as ações das mulheres negras têm se caracterizando como um elemento essencial para estabelecer transformações nas concepções políticas do feminismo, ao atentar para o racismo e discriminação racial que ainda impede que mulheres negras tenham as mesmas oportunidades sociais que outras. Trata-se da introdução do reconhecimento das "diferenças intragênero", ou seja, das diferenças entre as mulheres, nas concepções políticas feministas que estiveram centradas numa visão universalizante das mulheres, sem reconhecimento das diferenças de raça e de etnia que se articulam nas desigualdades experimentadas por mulheres negras e indígenas no Brasil.

Nas últimas décadas, organizações autônomas de mulheres negras, dentre elas o próprio Geledés e a AMN, ambas fundadas por Sueli Carneiro, encontraram por meio de suas ações coletivas, maneiras diversas de atuar, lutar e romper com obstáculos e invisibilidade sociais. As "mulheres negras se expressam, emitem suas próprias opiniões e visões de mundo, por meio da produção intelectual, ação e representação política" (ALMEIDA, 2010, p. 6). Com isso, elas vêm assumindo no Brasil um papel importante diante dos movimentos feministas e do governo, em busca da visibilidade das mulheres negras e da atenção às especificidades e diversidade das mulheres na construção de políticas para mulheres. 
É nessa perspectiva que, ao enfatizar os problemas decorrentes do racismo, enfrentados pelas mulheres negras, Carneiro afirma, ainda, a necessidade do:

[..;] reconhecimento da dimensão racial que a pobreza tem, no Brasil e, consequentemente, a necessidade do corte racial, na problemática da feminização da pobreza. $O$ reconhecimento da violência simbólica e a opressão, e a brancura como padrão estético privilegiado e hegemônico exerce sobre as mulheres não brancas. Apesar de todo o vitalismo do movimento de mulheres, as práticas discriminatórias permanecem impunes, e as desigualdades raciais inalteradas (BRASIL, 2004a, p. 40-41).

Para Carneiro, as "políticas econômicas neoliberais" vêm aprofundando esse fenômeno da "feminização da pobreza", graças à "precariedade das políticas sociais, o desemprego estrutural, a migração forçada dos homens em busca de trabalho, a perda da capacidade de investimento dos Estados no desenvolvimento social e econômico dos nossos países” (BRASIL, 2004a, p. 41). Tais situações, em virtude não apenas do sexo, mas também da raça e da classe social, segundo ela, afastam a possibilidade das mulheres se apossarem da riqueza, limitando-as ao patrimônio familiar. Após essas considerações, Carneiro, ainda, afirma que:

Do mergulho nesse mar de contradições nós, mulheres brasileiras, emergimos sempre mais fortes, ousando ofertar um projeto de radicalização democrática ao Estado e à sociedade brasileira. Radicalização democrática que tem como princípios fundamentais a igualdade, a diversidade, a participação, a solidariedade e a liberdade.

É isso que vimos construindo, programaticamente, enquanto movimento social e que equivale a uma verdadeira revolução cultural e um projeto político para um novo país. Estou tomando como referência dessa análise apenas um dos consensos e pactos que formos capazes de consagrar, da nossa trajetória de lutas: a plataforma política feminista, gestação coletiva, em 2002, aqui em Brasília, pela maioria de nós, que aqui estamos, na Conferência Nacional das mulheres Brasileiras.

Essa plataforma feminista representou, para as mulheres negras, o coroamento de quase duas décadas de luta, pelo reconhecimento e incorporação do racismo, da discriminação racial e das desigualdades de gênero e raça que eles geram (BRASIL, 2004a, p. 41. Grifos nossos).

Ao tratar da trajetória de lutas por um projeto de radicalização democrática do Estado e da sociedade, Carneiro confere destaque à Plataforma Política Feminista, que foi construída sobre uma base de mobilização de 5.200 (cinco mil e duzentas) ativistas dos movimentos feministas e de mulheres. A Plataforma foi um documento aprovado na Conferência Nacional de Mulheres Brasileiras, realizada em Brasília nos dias 6 e 7 de junho de 2002, que contou com a participação de 2.000 (duas mil) mulheres pertencentes aos vinte e seis estados brasileiros mais o Distrito Federal. O principal objetivo desse documento foi criar condições 
para que os movimentos estabelecessem posições autônomas e estratégicas perante o contexto eleitoral de $2002^{69}$.

O processo de construção da Plataforma foi longo, começou em março de 2001, quando foi difundido o desafio de reunir variados segmentos dos movimentos feministas e de mulheres na elaboração conjunta de uma Plataforma Política Feminista, a ser aprovada na referida Conferência. Naquela oportunidade, um grupo de feministas de diferentes articulações e redes nacionais motivou a articulação da Comissão Organizadora da Conferência Nacional de Mulheres Brasileiras e trabalhou na constituição de consensos e pactos para a preparação dessa Conferência.

O primeiro desses pactos foi a Carta de Princípios, que delimitou os compromissos políticos distintos da Conferência Nacional e da Plataforma, e se tornou em uma espécie de “mapa político de navegação no qual os movimentos de mulheres encontraram o norte para tecer suas parcerias e alianças nos planos estadual e nacional", como também em "estabelecer os termos do diálogo e mobilizar para o debate centenas de outras ativistas" (CNMB, 2002b, p. 01).

O segundo pacto refere-se à metodologia utilizada, visto que a Primeira Versão da Plataforma teve seus eixos estruturados a partir do diálogo entre os movimentos feministas e de mulheres; diálogo este que foi realizado nas Conferências estaduais e nacional, organizadas como espaços públicos de reflexão e de deliberação das diferenças e dos consensos que permearam a elaboração desse documento (CNMB, 2002b, p. 01).

Já a Segunda Versão da Plataforma surgiu a partir da compilação e síntese dos processos estaduais, e na Conferência Nacional foi revisada, enriquecida, criticada e negociadas em alguns de seus parágrafos. Ao final, seu texto foi aprovado e com ele os movimentos feministas e de mulheres reafirmaram seu potencial de contestação, mobilização e de elaboração política e, estrategicamente, "posicionam coletivamente os conteúdos de seus discursos plurais frente ao contexto político brasileiro, reafirmando sua autonomia de pensamento, projeto e ação" (CNMB, 2002b, p. 02).

A Plataforma Política Feminista, portanto, é um documento extenso, denso, propositivo e de conteúdo amplo e diversificado, elaborada a partir de uma perspectiva feminista "de questionamento da sociedade e de se repensar como sujeito político" (CNMB, 2002b, p. 02). Sendo assim, esse documento é a expressão de um conjunto relevante das

\footnotetext{
${ }^{69}$ Disponível em: <http://www.institutobuzios.org.br/documentos/PLATAFORMA\%20POLITICA\%20FEMINISTA.pdf > Acesso em: 05 Jul. 2016.
} 
mulheres brasileiras que integram variados movimentos sociais e afirma, também, a diversidade e a capacidade de aliança entre as feministas.

Essa Plataforma, na visão de Sueli Carneiro, portanto, institui, na atualidade, "um dos eixos centrais da luta das mulheres no Brasil”, pois com a sua publicação abre um novo ciclo no processo de debates sobre políticas públicas para as mulheres ao incorporar as orientações e diretrizes colocadas pelas mulheres negras, em torno do racismo e da discriminação racial, selando, como disse Carneiro, "um pacto de solidariedade e corresponsabilidade entre as mulheres negras e brancas, na luta pela superação das desigualdades persistentes entre as mulheres, no Brasil" (BRASIL, 2004a, p. 41). A Plataforma constitui um instrumento dos movimentos feministas e de mulheres para o diálogo, crítico e provocativo, para o confronto e negociação com as diversas forças políticas e sociais no Brasil, com vistas ao reconhecimento das diferenças e dos novos movimentos de mulheres, assim como à conquista da igualdade, da redistribuição de riquezas e da justiça social. Carneiro afirma que a Plataforma reorientou os conceitos para uma "verdadeira justiça social no Brasil" (BRASIL, 2004a, p. 41). Não por acaso ela cita Guacira César de Oliveira ${ }^{70}$, que na época participava, também, da Articulação de Mulheres Brasileiras e foi uma das integrantes da Comissão Organizadora da Conferência que deu origem a essa Plataforma (CARNEIRO, 2003), quando diz que:

Com a Plataforma Feminista, reafirmamos que, os movimentos de mulheres e feministas querem radicalizar a democracia, deixando claro que ela não existirá enquanto não houver igualdade, que não haverá igualdade sem distribuição das riquezas. E não há distribuição das riquezas sem o reconhecimento das desigualdades entre homens e mulheres, sem o reconhecimento das desigualdades entre brancos e negros, entre urbanos e rurais, contradições que hoje estruturam a pobreza no Brasil (Apud BRASIL, 2004a, p. 41-42. Grifos nossos).

Carneiro destaca o protagonismo das mulheres negras na constituição dessa Plataforma Política Feminista, já que, a partir delas, as diferenças de classe e raça são articuladas também ao projeto político feminista de transformação social. Desse modo destaca a atuação histórica das mulheres negras no processo de lutas e construção de uma proposta política feminista mais atenta à diversidade e diferenças entre as mulheres. Segundo Carneiro, as mulheres negras vêm trabalhando para que haja o "reconhecimento da dimensão racial", constata-se que a luta contra o racismo e o desmascaramento do mito da democracia racial tem conquistado o envolvimento e o comprometimento de setores da sociedade civil e do

\footnotetext{
${ }^{70}$ Segundo Sueli Carneiro, em seu artigo "Mulheres em Movimento" (2003), "esses comentários foram,
} originalmente, publicados no jornal na Coluna Opinião do Jornal Correio Braziliense de 14/6/2002". 
Estado, o que faz das mulheres negras importantes agentes na construção socioeconômica e cultural do país e na conquista dos direitos das mulheres brasileiras.

Ainda sobre essa Plataforma, Carneiro fala:

Não almejamos a mera inversão dos papéis, mas um novo marco civilizatório. Dessa perspectiva, daquela Conferência, nós, mulheres brasileiras, negras, indígenas, brancas, lésbicas, nortistas, nordestinas, urbanas, rurais, sindicalizadas, quilombolas, jovens, de terceira idade, portadoras de necessidades especiais, de diferentes vinculações religiosas e partidárias, nos detivemos, criticamente, sobre as questões mais candentes da conjuntura nacional e internacional, nos obstáculos contemporâneos persistentes para a realização da igualdade de gênero e nos desafios e mecanismos para a sua superação.

A partir desse diagnóstico, reafirmamos os nossos compromissos para com a autonomia e autodeterminação dos movimentos sociais de mulheres. Com a crítica ao modelo neoliberal injusto, predatório, insustentável, do ponto de vista econômico, social, ambiental e ético; com a defesa dos direitos econômicos, sociais, culturais e ambientais das mulheres; com a defesa dos princípios de igualdade e justiça econômica social; com o direito universal à educação, à saúde e à Previdência; com a luta pelo direito à terra e à moradia; com a luta anti-racista e a defesa dos princípios equidade racial e étnica; com a luta contra as formas de discriminação de gênero e com o combate à violência, maus tratos, assédio e exploração de mulheres e meninas; com a luta contra a discriminação à lésbicas e gays; com a luta pela assistência integral à saúde das mulheres e pela defesa dos direitos sexuais e reprodutivos; com o direito das mulheres de ter ou não ter filhos, com acesso de qualidade à concepção e/ou contracepção; com o direito de livre exercício sexual de travestis e transgêneros; com a descriminalização do aborto, como um direito de cidadania e uma questão de saúde pública, tal como expressamos através das jornadas brasileiras pelo direito ao aborto legal e seguro que hoje realizamos (BRASIL, 2004a, p. 42).

Portanto, essa plataforma política que se nomeia como "feminista" representa os interesses dos movimentos feministas e de mulheres, ou seja, interesses e reivindicações coletivos que sob essa denominação passaram a abarcar também as lutas contra o racismo, as desigualdades de classe e o neoliberalismo, dentre outras. Assim, a grande diversidade de pontos elencados por Carneiro, faz com que a Plataforma seja apreendida como um documento de gestão coletiva que, em sua visão, está atento às questões das mulheres negras. Essa perspectiva aparece também em textos e artigos escritos por Sueli Carneiro nas últimas décadas, onde vem difundindo a necessidade do "enegrecimento do feminismo". A expressão "enegrecendo o feminismo" é utilizada por Sueli Carneiro nestes trabalhos, para designar a trajetória e, principalmente, as ações, lutas e conquistas das mulheres negras no âmago dos movimentos feministas e de mulheres no Brasil.

As mulheres negras possuem pautas e demandas específicas que, fundamentalmente, não devem ser abordadas, exclusivamente, sob a ótica da questão de gênero se esta não 
considerar as especificidades que definem o ser mulher neste e naquele caso. Essas visões particulares têm exigido, gradativamente, práticas igualmente variadas e complexas que ampliem as concepções e práticas políticas feministas na sociedade brasileira. Tal posicionamento releva o combate ao racismo como fator prioritário para as mulheres negras, alegação que segundo Sueli Carneiro em um artigo publicado em 2003 foi enfatizada por Lélia Gonzalez ao afirmar que: "a tomada de consciência da opressão ocorre, antes de tudo, pelo racial" (GONZALEZ apud BAIRROS, 2000, p. 56). Nesse sentido, Carneiro, em sua fala, propõe que seja feita uma reparação perante a invisibilidade histórica das mulheres negras, ao afirmar que:

A nossa ambição é que as perspectivas de promoção de igualdade de gênero, de uma perspectiva racial que para aqui trazemos, possa realizar o milagre da reparação que é devida, historicamente, às mulheres negras destes país. (...) E, tendo em vista a invisibilidade histórica das mulheres negras, nas políticas públicas sonhamos que essa reparação se dará, em letras garrafais, nas diretrizes e, sobretudo, nas metas fiscais, financeiras e nos indicadores de monitoramento de execução de políticas de promoção e equiparação social das mulheres negras brasileiras (BRASIL, 2004a, p. 4344).

Não por acaso, Carneiro finaliza sua fala se dirigindo à ministra Nilcéia Freire, ressalta o papel das mulheres negras, assim como a importância da Plataforma Política Feminista, no enegrecimento dos movimentos feministas e de mulheres, e por fim enfoca a necessidade de enegrecer as "políticas públicas", ao afirmar que:

Senhora Ministra,

Como apontei, através da plataforma política feminista, consagrada pelos movimentos de mulheres em 2002, nós, mulheres negras, vimos enegrecendo o feminismo e o movimento de mulheres brasileiras, em suas propostas e seus fóruns. Nossa presença maciça nessa Conferência é a expressão desse protagonismo político crescente das mulheres negras brasileiras (BRASIL, 2004a, p. 43. Grifos nossos).

Na fala de Sueli Carneiro, o feminismo ganha destaque na menção à Plataforma Política Feminista que, por fim revela um enegrecimento do feminismo e do movimento de mulheres no Brasil, pois reposiciona a luta feminista no Brasil, sendo construída coletivamente por mulheres negras, indígenas, brancas etc., que se detiveram, criticamente, sobre questões relevantes da conjuntura nacional e internacional e nos obstáculos persistentes para a realização da igualdade de gênero. A Plataforma Política Feminista é fruto de um diálogo mais profícuo que amplia as frentes de luta do feminismo, incorporando e reconhecendo o racismo, o que de fato tem efeitos entre suas interlocutoras na I CNPM, já 
que se trata de uma plataforma política relevante e em sintonia com os interesses da diversidade de mulheres ali representadas. Ao mencionar o enegrecimento do feminismo e reafirmar os compromissos da Plataforma Política Feminista, Carneiro traz, para a I CNPM, uma perspectiva feminista mais abrangente da diversidade de interesses das mulheres, conferindo às propostas políticas feministas um lugar importante em meio aos debates de avaliação das políticas públicas para mulheres. A Plataforma Política Feminista representa o coroamento de quase duas décadas de luta pelo reconhecimento e incorporação do racismo, da discriminação racial e das desigualdades de gênero e raça nas pautas feministas. Tal posicionamento constitui-se em um dos eixos centrais da luta das mulheres negras brasileiras. Ao incorporar esse princípio, segundo Sueli Carneiro, sela um pacto de solidariedade e de corresponsabilidade entre as mulheres brasileiras na luta pela superação das desigualdades de gênero, por isso, "redefine os termos de uma verdadeira justiça social no Brasil" (CARNEIRO, 2003, p. 127).

A Plataforma Política Feminista oferece à sociedade a contribuição para a formação de uma sociedade mais democrática e socialmente justa, em que, pode-se afirmar, de acordo com Carneiro, que "o protagonismo político das mulheres negras tem se constituído em força motriz para determinar as mudanças nas concepções e o reposicionamento político feminista no Brasil” (CARNEIRO, 2003, p. 129).

\subsection{JOSÉ DIRCEU: PAUTA E AVANÇOS DAS LUTAS FEMINISTAS}

A última palestra proferida no Painel 1 foi de José Dirceu, então ministro Chefe da Casa Civil da Presidência da República. Sua fala chama atenção, já que se trata de um representante do governo e do sexo masculino, um ministro que estava envolvido nas formulações de políticas públicas no Brasil como figura central na articulação entre o Estado e a sociedade civil. Em sua fala, fica explícito o cuidado de não falar "pelas mulheres", mas sim "com as mulheres", afirmando com isso que acredita que "ninguém mais do que a mulher sente os efeitos da situação em que o país se encontra", e nesse sentido ressalta que "é muito importante nos darmos conta do que mudou no Brasil" (BRASIL, 2004a, p. 51).

Trata-se de uma palestra que põe em funcionamento um discurso institucional e governamental, com abordagens de questões econômicas, já que procura ressaltar, de maneira positiva, os avanços governamentais, destacando a relevância dos bancos públicos para o país. Esta palestra teve por objetivo, primeiramente, oferecer um panorama da política de governo em relação às mulheres, para isso o ministro deixa claro em sua fala que pretendia "prestar 
contas da política do governo, do nosso governo, do governo do presidente Lula, com relação às mulheres, à luta pela igualdade de gênero" (BRASIL, 2004a, p. 51).

Porém, ao ouvir anteriormente Jacqueline Pintaguy, Sueli Carneiro e a ministra Nilcéa Freire, o ministro mudou o direcionamento do seu discurso para abordar um pouco mais sobre o que o governo Lula havia feito em termos de políticas para as mulheres no Brasil, destacando avanços e conquistas que ocorreram durante o seu governo. Mas deve-se destacar que como representante do governo federal seu papel é o de avaliar, sempre, positivamente as ações e propostas, portanto Dirceu teve o cuidado, assim como o presidente Lula teve na Abertura da I Conferência, de destacar o protagonismo político das próprias mulheres nestas conquistas. Assim ele disse que iria falar um pouco do que acreditava que poderia dar como uma contribuição maior para esta I Conferência (BRASIL, 2004a, p. 51).

Ao focalizar mais nas ações governamentais em prol de uma política para as mulheres, José Dirceu procurou mostrar que o país, por meio de uma perspectiva construída e vivenciada pelas mulheres, tem a oportunidade de transformar os altos níveis de desigualdade, de violência e de desemprego que persistem na sociedade. Assim, disse o ministro,

O nosso país se encontra em um momento especial e tem uma oportunidade única pela frente, e, a partir da perspectiva de vocês, das mulheres, é fácil identificar que o país não consegue mais conviver com os níveis de desigualdade, de violência e de desemprego que hoje enfrentamos. E acredito que ninguém mais do que a mulher sente os efeitos da situação em que o país se encontra. Por isso, é muito importante nos darmos conta do que mudou no Brasil (BRASIL, 2004a, p. 51).

É somente ao final da sua fala, ao se referir às lutas das mulheres, que menciona a palavra "feminista". Assim, diz o ministro:

Eu quero registrar, para além do otimismo pela realização desta Conferência, a presença de todas aqui em Brasília, a pauta e o avanço das lutas feministas, das mulheres em nosso país, a agenda, a incorporação pela sociedade, apesar de resistência, do conservadorismo. A sociedade brasileira tem avançado de maneira extraordinária do ponto de vista de consciência dos direitos e do papel da mulher, e a mulher tem avançado na nossa sociedade. Basta que cada um se referencie na própria família, nas nossas mães, irmãs e filhas para ver o avanço que a sociedade brasileira produziu nesses últimos anos. Mas nós também sabemos da gravidade da situação de preconceito, desigualdade e desobediência da lei, de falta de recursos e instituições. Temos muito para avançar (BRASIL/, 2004a, p. 55. Grifos nossos).

Essa acepção sobre "a pauta e os avanços das lutas feministas" se baseia na ideia de que todo movimento de mulheres é feminista, uma vez que as mulheres lutam por direitos para as mulheres. Entretanto, sabe-se que no âmbito social e nos enfrentamentos políticos nem 
todos os grupos e organizações dos movimentos de mulheres se autodeclaram como parte dos movimentos feministas. Visto que, nem todas as mulheres estão interessadas em denunciar a desigualdade de gênero (DESCARRIES, 2002), mas em constituir conjuntos de práticas e coalizões, permanentes ou não ao longo do tempo, que possuem por objetivo transformar a situação socioeconômica e política das mulheres e também a redefinição de seu papel social, porém não necessariamente questionam os mecanismos reprodutores da divisão social dos sexos (DESCARRIES, 2001).

As falas anteriores contribuíram para que o discurso de Dirceu estruturasse de forma breve um certo reconhecimento da movimentação das mulheres na sociedade em prol da luta por direitos, por mudanças, por igualdade, por justiça, ressaltando obviamente o trabalho realizado pelo governo federal. Neste sentido, faz referência direta à ministra Nilcéa Freire e a todas as participantes presentes, para reiterar o compromisso governamental com a luta das mulheres. Assim, diz:

O que eu quero reiterar aqui para a nossa ministra Nilcéa, para todas, é o nosso compromisso, o compromisso do presidente Lula - que não é só compromisso de governo, é um compromisso de vida, de militância. Não estamos no governo lutando pelo direito das mulheres; estamos continuando no governo a luta histórica pelos direitos das mulheres. Eu quero reafirmar, neste momento, a minha fé e o meu otimismo na nossa luta e, em primeiro lugar, na capacidade de luta do povo brasileiro. Eu sempre digo que o nosso povo é muito melhor que as elites brasileiras e ele já deu provas disso várias vezes, porque sempre é o povo brasileiro que começa as lutas e muda a correlação de forças, embora nem sempre acabe ganhando, vencendo. Em muitas fases da história brasileira, o povo iniciou na luta, mas as elites fizeram considerações, acordos e desorganizaram o status quo (BRASIL, 2004a, p. 55).

Ao deixar entrever em sua fala o compromisso governamental de continuidade da "luta histórica pelos direitos das mulheres", faz desse pacto de governo uma ação coletiva, na qual o elemento essencial para a sua realização seria a "capacidade de luta do povo brasileiro". Assim, as lutas feministas na fala de Dirceu ganham uma dimensão ampliada e tornam-se ações não somente restritas às mulheres e aos seus interessados, mas também ao "povo brasileiro" que, segundo o palestrante, inicia as lutas e modifica as correlações de forças. Por isso, compreende-se que ao redimensionar as ações em prol de uma política para as mulheres, Dirceu não intentou propagar uma análise das suas contradições estruturais, mas pretendeu destacar a luta de classes e nela inserir as lutas das mulheres, e assim assinalar as ações coletivas não somente das mulheres, mas de toda a população e com isso ressaltar a 
relevância que o governo federal teve nesse âmbito. Dirceu fez esse destaque de forma e política para expressar os interesses governamentais.

Em vista disso, destaca-se que Dirceu, ao longo de sua fala, não propõe nenhuma estratégia para modificar o locus social para as mulheres, muito menos propõe formas de construir e desenvolver as pautas feminista, mas apenas cita, brevemente, o interesse do governo em ter essa esfera desenvolvida. Sendo assim, ao fazer isso generaliza as especificidades das lutas feministas.

Finalizando a sua fala, Dirceu declara que:

É no pluralismo, é no debate, é na disputa política que a democracia se consolida e o país avança. Por isso fiz questão de vir aqui hoje (mesmo com o presidente tendo comparecido na abertura, com ministros), para, em nome do governo, em nome da Casa Civil, da coordenação do governo, reiterar não o nosso apoio à luta das mulheres, mas a nossa militância com vocês pelos direitos das mulheres. Muito obrigado (BRASL, 2004a, p. 56).

Assim, Dirceu reafirma o seu lugar de fala como ministro diante às mulheres ali presentes, pois acredita no pluralismo e destaca que mesmo com a fala do Presidente da República sentiu necessidade de se expressar para mostrar sua solidariedade em prol de uma luta que apenas pode apoiar e integrar em colaboração. Por meio do discurso de Dirceu podese compreender a importância de ser evidenciada a construção da identidade coletiva das mulheres feministas, pois a partir delas as mulheres, principalmente na esfera pública como é o caso da I CNPM, não são silenciadas e suas falas e opiniões são evidenciadas com maior expressividade, mesmo quando pronunciadas em um contexto de fala junto de um ministro da Casa-Civil. 


\section{CAPÍTULO 4}

\section{O FEMINISMO NAS PROPOSTAS DE CONSTRUÇÃO DO PLANO NACIONAL DE POLÍTICAS PARA AS MULHERES}

Neste capítulo apresenta-se uma análise das representações do feminismo nas palestras proferidas no Painel 2: Apresentação de propostas de diretrizes para a construção do Plano Nacional de Políticas para as Mulheres, realizadas no segundo dia (16/07/2004) da I Conferência Nacional de Políticas para Mulheres (I CNPM). Inicialmente, discute-se as condições de produção e de organização desse Painel, ressaltando seus objetivos, sujeitos de fala e práticas discursivas. Em seguida apresenta-se uma análise das representações do feminismo presentes nas práticas discursivas de Maria Betânia Ávila, Matilde Ribeiro, Nalu Faria e Maria Laura Sales Pinheiro.

\subsection{PAINEL 2: OBJETIVOS E SUJEITOS DE FALA}

O Painel 2 da I CNPM teve como objetivo apresentar sugestões, princípios e propostas de diretrizes para integrar a construção do I Plano Nacional de Políticas para as Mulheres (I PNPM). Considerando proposições do plano plurianual e incorporando programas ministeriais específicos, além de proposições arroladas em outros documentos nacionais e internacionais e por alguns movimentos feministas e de mulheres, este Painel apresentou um elenco de diretrizes e de debates a partir dos cinco eixos temáticos trabalhados na I Conferência pelos grupos de trabalho que mencionamos no capítulo 1 dessa dissertação. Nesse Painel, as discussões realizadas para a construção do I PNPM apresentaram, ao mesmo tempo, uma perspectiva propositiva e operativa. Ou seja, propositiva por apresentar em seu conteúdo de falas diversas propostas que representariam, caso aderidas, ganhos para os grupos sociais interessados e, também, operativa por possuir um potencial de produzir efeitos na sociedade, principalmente em longo prazo.

O Painel foi coordenado por Mara Vidal (Secretária de Estado da Mulher do Governo do Acre) e contou com cinco palestrantes, que expuseram seus discursos na seguinte ordem: Dirce Veron (Representante do Conselho Nacional das Mulheres Indígenas no Conselho Nacional dos Direitos da Mulher/CNDM), Maria Betânia Ávila (Coordenadora Geral do, Instituto Feminista para a Democracia/SOS Corpo e da Articulação de Mulheres 
Brasileiras/AMB), Matilde Ribeiro (Ministra da Secretaria Especial de Políticas de Promoção da Igualdade Racial da Presidência da República/SEPPIR), Nalu Faria (Coordenação da Marcha Mundial de Mulheres/MMM), Maria Laura Sales Pinheiro (Secretária Adjunta da Secretaria Especial de Políticas para as Mulheres da Presidência da República/SPM). Assim como no Painel 1, cada palestra teve uma duração média de vinte minutos.

Dentre as palestrantes desse Painel, observa-se que apenas Dirce Veron não fez menção alguma ao termo "feminismo(s)" e "feminista(s)". Sua fala, de modo geral, ressalta a busca pelo reconhecimento do lugar da mulher indígena no âmbito social, nas tomadas de decisões e, também, nos processos de demarcações de terras, ressaltando a importância da participação e presença de representantes indígenas na I Conferência. Assim, diz a palestrante:

Quero dizer que nós estamos mesmo audaciosas, nós estamos com muita ousadia mesmo, nós saímos de trás do cocar, agora nós estamos ao lado dos nossos caciques, o que nossos caciques ainda não fizeram nós estamos buscando agora. $\mathrm{O}$ que eles não fizeram, o que até agora eles não encontraram o meio, nós mulheres vamos encontrar, porque nós somos, ao lado das mulheres negras, as mais sofridas do Brasil (BRASIL, 2004a, p. 77).

Dirce Veron é bacharel em Direito e aluna de Ciências Sociais e Humanas na Universidade Federal do Mato Grosso do Sul (UFMS). Envolveu-se na militância em defesa dos Kaiowá-Guarani, principalmente depois do assassinato de seu pai, Ava Taperendy (Marcos Veron), um funcionário público aposentado que abraçou a luta pela demarcação das terras indígenas, se juntando às demais lideranças indígenas para reaver as regiões tomadas ${ }^{71}$. O crime ocorreu em 13 de janeiro de 2003, em uma emboscada que segundo Veron teve a participação de mais de vinte homens. No entanto, somente três foram formalmente acusados e levados a júri popular em 2011. Esses foram considerados culpados, condenados a 12 anos e 3 meses de reclusão, pena que cumprem em liberdade por terem passado 4 anos presos antes do julgamento. "É o que prevê a lei" ${ }^{\prime 72}$, comentou Dirce em uma entrevista sobre o caso.

Em vista dessa vivência, Veron, também, ressaltou em sua fala, a necessidade de se respeitar o jeito de viver e a diversidade étnica das mulheres indígenas, para que diminuam as situações constrangedoras e preconceituosas em suas experiências diárias. Ela ressaltou também a necessidade de as mulheres indígenas continuarem participando de espaços de poder, elaborando seus próprios documentos para que os indígenas, de modo geral, tenham

\footnotetext{
${ }^{71}$ Disponível em: <http://pib.socioambiental.org/pt/noticias?id=112847> Acesso em 06 Set. 2016.

${ }^{72}$ Disponível em: < http://pib.socioambiental.org/pt/noticias?id=112847> Acesso em 06 Set. 2016.
} 
suas culturas e modos de vida respeitados. Ao final de sua fala, indicou diretrizes e ações contidas em um documento elaborado pelas mulheres indígenas para a incorporação ao conjunto das propostas apresentadas no processo de construção do I PNPM. Assim, propôs:

Políticas afirmativas que visam incluir as mulheres índias no enfrentamento a pobreza, geração de renda, trabalho, acesso ao crédito e a terra, humanização da atenção e a saúde da mulher índia com atendimento diferenciado, inclusão de uma área temática específica para as mulheres índias dentro da Secretaria de Políticas Públicas para Mulheres e da Secretaria de Promoção da Igualdade Racial, e quando houver essa inclusão que esteja a índia lá dentro participando. Garantia da educação escolar para as mulheres índias nos três níveis, fundamental, médio e superior. Punição em forma de lei específica para qualquer tipo de discriminação à mulher índia (BRASIL, 2004a, p. 79).

Dirce Veron traz propostas diferentes, marcadas pelos interesses coletivos indígenas e pela necessidade de as mulheres indígenas conquistarem espaços dentro das instituições que representam o interesse político das mulheres, como a SPM. A ausência do termo "feminismo(s)" e/ou "feminista(s)" em sua fala tem relação com o distanciamento dos movimentos de mulheres indígenas em relação aos movimentos feministas urbanos e de classe média, cujas pautas não levam em consideração as demandas específicas de mulheres indígenas que são mais coletivas, não só contra o patriarcado e o machismo, mas também contra o preconceito e a discriminação étnica e social dos índios no Brasil. A falta de sensibilidade cultural frente aos seus problemas específicos e concepções de mundo dificultou muitas vezes o diálogo entre estes movimentos (CASTILLO, 2014). No entanto, a I CNPM revela um esforço importante no diálogo entre estes movimentos para a construção de propostas políticas que contemplem a diversidade das mulheres.

Já na fala de Maria Betânia Ávila, o termo "feminista(s)" aparece duas vezes, porém apenas uma vez em um enunciado que comporta com sentido e significado para análise. $\mathrm{Na}$ fala de Matilde Ribeiro aparece três vezes, na de Maria Laura Sales Pinheiro o termo aparece duas vezes e na de Nalu Faria o termo "feminismo(s)" aparece duas vezes. Tais práticas discursivas, de forma dialógica, evidenciam o modo como o feminismo é evocado e/ou associado às propostas de diretrizes para a construção de um plano nacional de políticas públicas para as mulheres, já que se trata de uma situação discursiva cujo objetivo é propor orientações, normas e ações políticas. 


\subsection{MARIA BETÂNIA ÁVILA: A TRANSFORMAÇÃO DO ESTADO EM UMA PERSPECTIVA FEMINISTA}

Maria Betânia Ávila, coordenadora geral do Instituto Feminista para a Democracia (SOS Corpo) foi a segunda palestrante no Painel 2. Ela iniciou a sua fala fazendo referência às conferências municipais e estaduais que antecederam a I CNPM, como locais próprios e legítimos que conformaram as diretrizes trabalhadas e discutidas na Conferência Nacional. A importância das conferências municipais e estaduais fez com que Ávila salientasse a relevância do movimento que criou a I CNPM, pois, como disse, são em processos como esse, perpassados por tensões e contradições, que fazem avançar a democracia. Desse modo, ela inicia sua fala:

[...] quero salientar a importância desse movimento que construiu a Conferência Nacional, com dificuldades, alegrias, tensões e contradições. Em processos como esse, não lidamos só com convergências, ao contrário são as lutas em torno das contradições que fazem avançar a democracia. Sendo essa a primeira conferência nacional de políticas públicas para as mulheres, ela se constitui em um marco histórico (BRASIL, 2004a, p.80).

A I Conferência fundamenta-se como um marco histórico, porque, segundo Ávila, é o “divisor de águas" nas proposições e realizações dos debates para a construção de políticas públicas para as mulheres no país. De acordo com a palestrante, a I CNPM é uma "marca na nossa história política, mas também uma marca na real possibilidade de transformar a vida cotidiana das mulheres" (2004, p. 80). Ela afirma, ainda, que:

Essa marca que se constrói aqui, para ganhar força e capacidade de ação,
exigirá dos governos um compromisso nunca antes concretizado na prática,
que é aquele com transformação real desse país. E exigirá de nós,
movimento de mulheres, muita organização, capacidade de luta e nenhuma
paciência ou condescendência com um sistema produtor de exploração e
desigualdade (BRASIL, 2004a, p. 80 ).

Ao se dirigir às suas interlocutoras, Ávila usa o termo "movimento de mulheres" para tratar de um compromisso e luta que se faz de forma coletiva. Trata-se de estratégia discursiva que tem seus efeitos na medida em que interpela todas as mulheres ali presentes para as questões de organização e lutas que ela deseja ressaltar. O movimento de mulheres emerge em sua fala como "sujeito político estratégico". A historiadora Linda Nicholson (1999) sugere que o sentido de "mulher" seja usado como um mapa de semelhanças e diferenças que se cruzam, no qual o corpo não desaparece, mas transforma-se em uma variável historicamente especifica cujo sentido e importância são revelados como potencialmente diferentes em 
contextos históricos variáveis. Essa sugestão implica, portanto, que a percepção do feminismo como um "sujeito político estratégico" acarreta em um esforço coletivo a ser feito por muitas mulheres e em constante diálogo. Assim, pode-se pensar que a estratégia discursiva utilizada por Ávila propicia uma união daquelas mulheres presentes que querem trabalhar em torno das reivindicações das “mulheres”. Isso resulta, em uma "política de coalizão", pois este tipo de política permite que as identidades coletivas evocadas comportem sentidos diversos como atos políticos que refletem os contextos sociais e culturais que as mulheres pertencem (NICHOLSON, 1999).

No entanto, o feminismo, também, se revela em sua fala:

Políticas públicas para as mulheres devem se constituir em uma política de Estado. Uma política que deve ser um elemento estrutural da configuração de um estado democrático. É neste sentido que os resultados dessa conferência devem referenciar os valores e os conteúdos da ação estatal com vistas à superação da desigualdade de gênero relacionada às desigualdades de classe, raça e etnia. Igualdade, autonomia e liberdade esses são termos que referenciam movimentos de mulheres na busca da emancipação. São esses termos também que qualificam o conflito em torno da transformação do estado em uma perspectiva feminista. A realização dessa conferência deve fortalecer a legitimidade do movimento de mulheres como um sujeito político estratégico para a transformação da sociedade brasileira (BRASIL, 2004a, p. 80. Grifos nossos).

Nesse enunciado observa-se que a "perspectiva feminista" ganha o sentido de prática política capaz de orientar as diretrizes de construção do I PNPM. Além disso, trata-se de uma perspectiva que referencia também os "movimentos de mulheres" já que se pauta em termos como igualdade, autonomia e liberdade. Deve-se ressaltar que essa proposta de uma perspectiva feminista encontra também fundamento na experiência política de Ávila enquanto militante e componente do SOS Corpo, organização declaradamente feminista e uma das únicas desse tipo representadas na I CNPM. A palestrante traz assim a perspectiva feminista para as proposições de políticas para as mulheres, na medida em que associa os termos "igualdade, autonomia e liberdade" a um projeto político feminista. Essa perspectiva coloca o feminismo como referência importante para as propostas políticas que seriam delineadas na I CNPM.

Maria Betânia Ávila, é, sem dúvida, um exemplo de atuação em prol da luta por espaços de poder para que as mulheres possam promover a eliminação da dominação patriarcal, visto que ela atua, principalmente, em temas como feminismo, mulheres, direitos reprodutivos, trabalho, participação política e movimento de mulheres, além de ser graduada e 
doutora em Ciências Sociais ${ }^{73}$. O Instituto SOS Corpo, do qual é representante na I CNPM tem por objetivo central, de acordo com a descrição presente no site $^{74}$ da organização, a emancipação das mulheres, propondo-se:

[...] a contribuir para a construção de uma sociedade democrática e igualitária com justiça socioambiental. A ação do SOS CORPO tem como fundamento a ideia de que os movimentos de mulheres, como movimentos sociais organizados que lutam pela transformação social, são sujeitos políticos que provocam mudanças nas condições de vida das mulheres em geral. Para o SOS CORPO, a luta contra a pobreza, o racismo e a homofobia são dimensões fundamentais do feminismo da transformação social para o enfrentamento do sistema capitalista e patriarcal, produtor de desigualdades e sofrimento humano (SOS Corpo, Instituto Feminista para Democracia) ${ }^{75}$.

Nesse sentido, percebe-se que a experiência da autora está imbricada com a proposta de transformação social por meio de uma perspectiva feminista, visto que, além de sua atuação acadêmica que versa sobre temas correlacionados com esta proposta, ela trabalha em um instituto que busca em suas práticas e ações a conformação em sua base de uma intervenção social, a partir da articulação de vários agentes, para o enfrentamento de problemas que são de caráter público. Assim, Ávila ao propor uma perspectiva feministas visa galgar maior força política para o campo do movimento de mulheres e feminista, já que a participação política é uma prerrogativa do trabalho institucional para a construção de políticas públicas.

A "perspectiva feminista", no enunciado acima, se relaciona à uma política de transformação social. Trata-se do modo como é analisada e vivenciada determinada situação ou objeto da experiência das mulheres na esfera política. A perspectiva feminista, mencionada pela palestrante, não só exige novas posturas e compromissos por parte do governo, mas também exige dos movimentos de mulheres mais organização, capacidade de luta e enfrentamento ao sistema que reproduz as desigualdades e impede a sua transformação.

A transformação social, de acordo com Ávila, deve ser qualificada por três termos que orientam os movimentos de mulheres na busca da emancipação: igualdade, autonomia e liberdade. Sabe-se que há uma grande discussão no interior dos movimentos feministas acerca da questão da igualdade, porque há diversas abordagens e concepções. Mesmo considerando essa diversidade de debates, a proposta de igualdade, inserida nessa perspectiva feminista, não

\footnotetext{
73 O título da tese é "O tempo do trabalho das empregadas domésticas: tensões entre dominação/exploração e resistência". Esteve sob orientação da professora Dra. Josefa Salete Barbora Cavalcanti. Disponível em: <http://repositorio.ufpe.br/bitstream/handle/123456789/9427/arquivo4226_1.pdf?sequence=1\&isAllowed=y > Acesso em 13 Jul. 2016.

${ }^{74}$ Disponível em: <http://soscorpo.org/quem-somos/> Acesso em 13 Jul. 2016.

${ }^{75}$ Disponível em http://soscorpo.org/ Acesso em 29 Nov. 2016.
} 
possui como idealização o modelo clássico de igualdade, inteiramente produzido pelos homens e para uma parcela dos homens. Pelo contrário, a possibilidade de as mulheres atingirem a igualdade implica em ações de desconstrução e transformação desse modelo de igualdade pautado na ideia de um sujeito universal que acaba por ocultar e invisibilizar as mulheres. Essa questão é explicada, com muita relevância, pela filósofa e feminista Bonacchi $(1988)^{76}$, quando afirma que:

[...] a crítica feminista desmascarou esse universalismo aparente, mostrou o caráter particular desse sujeito que se pretendia universal: o ponto de vista oculto por trás do ser abstrato da metafísica é, na realidade, o ponto de vista extremamente concreto do homem ocidental adulto, branco e proprietário (BONACCHI, 1988, p. 01).

O feminismo rompeu com as evidências que sustentavam a naturalização das desigualdades entre os sexos (BOURDIEU, 1996). Para o feminismo, portanto, a construção da esfera privada como espaço de liberdade e de igualdade e o acesso das mulheres à esfera pública são uma questão dialética e indissociável para um projeto de construção de cidadania e democracia. Pois, se a chegada das mulheres na esfera pública amplia e reestrutura o projeto democrático, o envolvimento dos homens nas tarefas e na transformação da vida privada é igualmente necessário. A igualdade, enquanto um ideal de convivência humana, só pode ser buscada se as influências igualadoras se estenderem a todas as instâncias da vida social (GIDDENS, 1992). Nesse sentindo, a percepção da vida privada como um lugar de destino é desfeita. E essa ruptura coloca, instantaneamente, para o feminismo o problema da autonomia como requisito primordial para o exercício da liberdade. Assim a reconstrução da vida privada, lugar que esteve associado às mulheres é, de fato, um caminho essencial para a construção de uma proposição de autonomia para as mulheres enquanto um projeto coletivo de libertação.

De acordo com Ávila, a I CNPM deve colaborar para que os movimentos de mulheres sejam legitimados "como um sujeito político estratégico", o que revela que a construção da igualdade passa, justamente, pela desestruturação da ordem social que hierarquiza as diferenças, transformando-as em desigualdades. Sendo assim, considera-se que a relação igualdade-diferença deve ser compreendida, na fala da palestrante, não em termos antagônicos, mas como um dilema a ser encarado como parte do processo dialético da transformação social.

\footnotetext{
76 BONACCHI, Gabriela. Entrevista, Caderno Mais, Folha de S. Paulo. São Paulo, 23 de agosto, 1998. Disponível em: <http://www1.folha.uol.com.br/fsp/mais/fs23089814.htm> Acesso 19 Set. 2016.
} 
Os movimentos feministas realizaram algumas conquistas fundamentais em termos de igualdade de gênero, como o direito ao voto, a educação, ao trabalho e também colocou as mulheres como sujeito político do processo de transformação social. A partir da fala de Ávila, entende-se que a construção desse sujeito político resultou em uma ruptura com a heteronímia do papel social tradicionalmente destinados as mulheres, oferecendo a possibilidade de romper a situação de vítimas ou de protegidas e com a imobilidade de uma identidade imposta para o locus social. A partir dessa ruptura, abre-se a oportunidade de as mulheres se transformarem em sujeitos, o que significa ter existência própria dotada de autonomia e direitos, participando, assim, das lutas, negociações e debates inerentes à democracia. Considerando a situação política vivenciada no país no ano de 2004, Ávila assinala,

Reconhecemos que vivemos em uma democracia política, mas que essa democracia tem que avançar, pois ainda é plena de desigualdades. E que as possibilidades atuais são produto de uma história de luta que nos garantiu liberdade de expressão e organização política. E neste sentido é relevante compreender a importância dessa conferência como parte de um processo de participação política no âmbito do poder executivo o qual deve trazer novos sentidos e novas práticas que façam avançar a democratização do estado. E nesse sentido que façam avançar a participação das mulheres nos espaços de poder de decisão (BRASIL, 2004a, p. 81).

Ávila destaca, ainda, em sua fala, o rompimento do poder patriarcal proporcionado pela Constituição Federal de 1988, visto que procura em seu discurso propõe que em uma democracia política deve haver avanços para que as desigualdades sejam eliminadas. Poder este que é um processo de construção social contra as mulheres, sendo expresso tanto em formas de violência física, moral, psicológica como também simbólica que se reitera ao longo da história. Como diz Bourdieu (2007, p. 07-08), esse processo, a primor de subordinação resulta em uma violência simbólica. Não uma violência física, mas uma violência invisível, suave às suas próprias vítimas, que é exercida pelos caminhos simbólicos do conhecimento e da comunicação e, também, pela aceitação, por elas mesmas, da dominação masculina. Portanto, essa violência simbólica não consiste em algo concreto, mas em uma violência que se manifesta de forma subjetiva e nas representações socioculturais.

Assim o rompimento do poder patriarcal, segundo a palestrante, é uma parte da conquista dos movimentos das mulheres que bravamente lutaram nos espaços de decisões. Assim diz:

Achamos importante salientar que a Constituição Federal de 1988 rompeu com a institucionalização do poder patriarcal. Conquista sem dúvida nenhuma do movimento de mulheres que acirradamente lutou no espaço da Assembléia Nacional Constituinte. Mas, reconhecemos que as práticas do 
estado e da sociedade ainda estão impregnadas da cultura de dominação masculina herdeira do poder patriarcal e que ainda se expressa com bastante vigor. Políticas culturais são imprescindíveis para superação da dominação no campo simbólico. Esse poder esteve historicamente vinculado a exploração de classe e à discriminação de raça. $\mathrm{O}$ patriarcado e a escravidão no Brasil são realidades históricas inextricáveis. Essa herança colonial ainda não superada é uma herança de violência que pesa também sobre o povo índio. Lembrar sempre é preciso, para que a história não se repita em forma de barbárie. (BRASIL, 2004a, p. 81. Grifos nossos.)

Nesse enunciado pode-se entender que Ávila percebe o Estado atual como patriarcal, violento, classista e racista, daí compreende-se o seu argumento em favor de uma "transformação do Estado em uma perspectiva feminista", o que implica no investimento em políticas públicas para superação dessa dominação. O trabalho na esfera pública e a luta pela igualdade no âmbito da produção traduzem-se em bandeiras de luta para a plena emancipação das mulheres em seus espaços de vivência. As mulheres pouco a pouco foram conquistando seus direitos civis e ocupando o espaço público, antigo domínio masculino. A emancipação feminina inverte os valores sociais tradicionais e coloca em cheque o papel do homem. A ascensão feminina ao espaço público torna-se assim uma ameaça à identidade do sujeito universal e a sua posição de poder hegemônico é posta em questão.

A desintegração do poder patriarcal, portanto, não é resultante somente da redefinição do papel da mulher na sociedade. Mas, também, tem a ver com as transformações históricas ocorridas que modificam a dinâmica das relações sociais e também colocam em questão o mito da masculinidade em razão de uma nova forma de definição de ser homem, pautada em conflitos no âmbito da subjetividade e da intimidade.

No entanto, assim como indicou a Ávila, a herança patriarcal ainda não superada, é uma presença marcante nas práticas do Estado e da sociedade, visto que formas particulares continuam a rebaixar os salários femininos, a incluir as mulheres em um número restrito de ocupações e a negar-lhes acesso a funções de poder, apesar de importantes mudanças culturais.

Na visão da palestrante, se compreende que o sentido de transformação do estado em uma perspectiva feminista deve ser realizado em combate à ordem social dominante estruturada pelo poder patriarcal e na reflexão crítica que leva à libertação dessa ordem. Para que assim o Estado seja conduzido a criar condições de vida social mais democrática.

Finalizando a sua fala, Ávila declara que:

O caminho da nossa emancipação e da nossa igualdade atravessa as linhas tortuosas que conectam as desigualdades entre nós mesmas. Por isso na defesa de políticas públicas que configurem um estado democrático e 
produtor de justiça social temos, que ter consciência crítica sobre a realidade social, compromisso para transformá-la e solidariedade no olhar de nós sobre nós mesmas. (BRASIL, 2004a, p. 83)

Nesse enunciado, a palestrante deixa entrever que para ocorrer à construção de políticas públicas, em prol de um Estado democrático, é necessário que seja desenvolvida consciência crítica sobre a realidade social. Pois, é pela formação da consciência crítica que o ato e o compromisso de propor políticas, como produto de justiça social, conduz a transformação da sociedade, combatendo assim a alienação de seus agentes através da compreensão de si próprio, desenvolvendo suas potencialidades e solidarizando-se no exercício da responsabilidade que tem frente às mudanças sociais.

Para se pensar uma transformação social em uma perspectiva feminista, portanto, é importante refletir sobre o acesso aos espaços de vocalização, deliberação e luta, caso contrário, a desigualdade e as discriminações permanecerão de forma estrutural na sociedade. Nesse sentido, entende-se que as políticas públicas estão sempre em processo de construção, de vir a ser, pois são fruto de diversas leituras de mundo, realizadas por diferentes sujeitos sociais que estão inseridos em um contexto contínuo de interpretações e reinterpretações de mundo. Essa forma de enxergar a construção de políticas públicas para as mulheres possibilita refletir sobre como os diferentes sujeitos políticos, no contexto da I CNPM os membros da sociedade civil e do governo, exercem um papel ativo no processo de interpretação e reinterpretação destas. Assim, as políticas públicas para as mulheres sempre serão criadas e interpretadas de acordo com a história, experiência, valores, interesses e propósitos das pessoas envolvidas em seu contexto.

A proposta de uma "perspectiva feminista de transformação do Estado", exposta por Ávila, deve ser radical no seu confronto com o sistema patriarcal, pois possibilita o enfrentamento das estruturas que reproduzem as desigualdades que se sobrepõem. Esse embate requer uma grande capacidade de organização, solidariedade e generosidade entre os movimentos de mulheres, assim como uma capacidade crítica para combater, entre as próprias mulheres, as desigualdades e as formas de agir, herdadas do poder patriarcal e das tradições políticas autoritárias. Em vista disso, negar este conflito apenas fragiliza a luta e diminui a capacidade de organização coletiva das mulheres.

Ao traçar propostas e diretrizes para o I Plano Nacional de Políticas para as Mulheres (I PNPM), objeto do Painel 2, Ávila ressalta a importância de uma perspectiva feminista em uma democracia política, fato que exige uma nova forma para repensar os métodos utilizados 
no estabelecimento da autonomia a das relações não hierárquicas dentro dos movimentos de mulheres, reafirmando assim a pluralidade de seus sujeitos.

\subsection{MATILDE RIBEIRO: AS DIVERSAS FORMAS DE ORGANIZAÇÃO FEMINISTA}

A terceira palestra proferida no Painel 2 foi de Matilde Ribeiro, então Ministra da Secretaria Especial de Políticas de Promoção da Igualdade Racial da Presidência da República (SEPPIR). Em sua fala, a palavra "feminista" foi mencionada três vezes. Ela inicia a sua fala com a frase - "E elas nunca se cansam..." (BRASIL, 2004a, p. 84) - exibida em um vídeo da $9^{\circ}$ Conferência Regional sobre a Mulher da América Latina e do Caribe, promovida pela CEPAL (Comissão Econômica para a América Latina e para o Caribe), no ano de 2004, no México, e que retrata a organização feminista na América Latina e no Mundo desde 1975, Ano Internacional da Mulher, instituído pela ONU. Segundo Ribeiro,

\footnotetext{
Analisando esta frase e pensando nas diversas formas de organização feminista, verifico alguns fatores que contribuem para que as mulheres façam a diferença e deixem suas marcas: a persistência, a obstinação e, acima de tudo, a crença em um mundo melhor. Sei que muitas vezes elas se cansam. Mas também sei que elas não desistem facilmente! (BRASIL, 2004a, p. 84. Grifo original)
}

Na fala de Ribeiro a "organização feminista" aparece como um movimento de mulheres marcado pela diversidade. Isso deixa claro que, na sua visão, não há na contemporaneidade uma forma única de organização feminista, mas uma diversidade de organizações que, de modo geral, persistem incansavelmente no "ideal coletivo de igualdade, liberdade e justiça" (BRASIL, 2004a, p. 85), sempre repondo as mulheres que integram essa luta. Como disse, se por "motivos diversos uma ou outra mulher se retira da luta, novas surgem, tocando adiante esse ideal coletivo" (BRASIL, 2004a, p. 85). Trata-se de uma concepção importante que ao reconhecer a diversidade das organizações feministas, percebe também nessas organizações a presença de um ideal coletivo que possibilita o diálogo entre vários movimentos de mulheres na luta por políticas públicas. Segundo Ribeiro, essa persistência na luta é fundamental, pois "foi assim na conquista da abolição da escravidão, na luta pelo direito ao divórcio, na inserção dos direitos das mulheres na reforma constitucional e na ampliação da representação da mulher em todos os espaços políticos e sociais" (BRASIL, 2004a, p. 85).

É analisando essa diversidade da "organização feminista" que ela focaliza sua fala nos movimentos de mulheres negras e na sua proposta de transversalidade de gênero e raça nas 
políticas públicas para as mulheres. Nessa argumentação, ressalta que mulheres negras e indígenas vivem situações de maior vulnerabilidade em relação às mulheres brancas e que, desse modo, "as desigualdades sociais impostas às mulheres não atingem a todas na mesma dimensão (BRASIL, 2004a, p. 85). Assim, diz a palestrante:

A transversalidade entre gênero e raça é fundamental não apenas para a
elaboração de políticas voltadas para a população mais vulnerável, quanto
para aliar os conhecimentos dos movimentos sociais que lidam com a
exclusão e que, de certa forma, já reuniram um cabedal de conhecimento
importantíssimo para o poder público (BRASIL, 2004a, p. 87).

Para tratar de tal proposta, a palestrante indica que a perspectiva da transversalidade de gênero e de raça deve ir ao encontro da "quebra da invisibilidade historicamente imposta às mulheres negras, invisibilidade criada e mantida pelo machismo e pelo racismo, as formas contemporâneas mais perversas e silenciosas de exclusão" (BRASIL, 2004a, p. 85). Partindo da diversidade de organizações feministas, Ribeiro destaca a proposta política produzida pelas organizações de mulheres negras. Ela mesma, também enquanto mulher negra é consciente da necessidade da transversalidade de gênero e raça no âmbito das propostas políticas de organizações feministas e de mulheres.

Tais propostas se articulam plenamente com sua experiência, já que foi militante do movimento negro e do feminismo. Graduou-se em Serviço Social na PUC de São Paulo. Nasceu em uma família de baixa renda e se filiou ao Partido dos Trabalhadores (PT). Após participar da equipe da campanha vitoriosa nas eleições presidenciais do ano de 2002, foi convidada pelo então Presidente da República, Luiz Inácio Lula da Silva, para compor o primeiro-escalão do governo, em março de $2003^{77}$. Assim, ocupou até o ano de 2008 a presidência da Secretaria Especial de Políticas de Promoção da Igualdade Racial (SEPPIR), cargo no qual participou no ano de 2004 da I CNPM. Em vista disso, entende-se que por participar de organizações feministas e de mulheres negras, e por estar inserida em um espaço público onde são trabalhadas políticas para as mulheres, a palestrante acredita no potencial coletivo de luta das mulheres em que é preservado, o já mencionado, "ideal coletivo pela igualdade, liberdade e justiça” (BRASIL, 2004a, p. 85). Assim, observa que a luta de mulheres negras e indígenas por esse ideal passa pela consideração do racismo como aspecto fundamental que articulado ao gênero, marcam as desigualdades sociais experimentadas pelas mulheres.

\footnotetext{
${ }^{77}$ Disponível em: <http://g1.globo.com/Noticias/Politica/0,,MUL11020-5601,00.html> Acesso em 27 Jul. 2016.
} 
No Brasil, a diversidade das organizações feministas se expressa, portanto, nessa consideração de outros eixos de opressão, como a raça, etnia, classe, religião, orientação sexual, idade, etc., que articulados às diferenças de gênero são enfatizados por diferentes grupos de mulheres em suas lutas cotidianas. É desse modo que os movimentos de mulheres negras se aliam também com os movimentos negro e feminista no interesse comum de luta contra o racismo e o patriarcado. Os movimentos de mulheres negras e indígenas são reveladores, portanto, dessa diversidade das organizações feministas, já que suas lutas são marcadas por interesses que vão mais além daqueles de mulheres brancas, urbanas, escolarizadas e de classe média alta. Tais movimentos lutam pela incorporação das questões de étnico-raciais nos debates sobre a igualdade de gênero, e nos propósitos internacionais de combate a desigualdade (BRASIL, 2004a, p. 88), em que as diferentes condições econômicas e sociais das mulheres, em muitos casos, resultantes de processos culturais excludentes, são pontos convergentes tanto na exploração profissional e econômica das mulheres, quanto na feminização da pobreza.

Para falar da participação dos movimentos de mulheres em espaços que objetivam a elaboração de políticas públicas para as mulheres, Ribeiro ressalta o trabalho coletivo de movimentos sociais, perpassados pela "mobilização, o protagonismo e o acompanhamento das formulações normativas e políticas”. Assim, diz:

A participação do movimento de mulheres em diversas conferências tem
permitido a elaboração de documentos e subsídios para a formulação
conjunta de políticas de combate à pobreza, trazendo à tona as reais
condições das mulheres em relação ao exercício pleno de cidadania e de
conquista de direitos. Importante salientar que a mobilização, o
protagonismo, e o acompanhamento das formulações normativas e políticas
nacionais e internacionais, reafirmam que os Movimentos Negros e de
Mulheres Negras, têm desempenhado, no processo de formação da nação
brasileira, um papel fundamental na denúncia do mito da democracia racial e
na elaboração de propostas de políticas públicas que contribuam para a
alteração do quadro de desigualdade e opressão, não apenas racial, mas
também de gênero (BRASIL, 2004a, p. 88).

Nesse sentido, observa-se que, o discurso de Ribeiro, entra em conformidade com o que foi escrito em seu livro "Políticas de Promoção da Igualdade Racial no Brasil (19862010) ", lançado em 2014. Trata-se de um livro baseado em sua tese de doutorado, realizada no Programa de Estudos Pós-Graduados em Serviço Social da Pontifícia Universidade Católica de São Paulo (PUC-SP), no ano de 2013, em que refletiu sobre a realidade brasileira a partir do reconhecimento, por parte do Estado, da existência do racismo e das perspectivas 
para sua superação ${ }^{78}$. Dessa forma, a sua tese parte do pressuposto de que o movimento negro e as organizações de mulheres negras têm sido, nas últimas décadas, no Brasil, referências estratégicas para a implantação de canais de negociações entre a sociedade civil e o Estado, o que tem permitido o desenvolvimento das políticas de igualdade racial, sob a forma de ações afirmativas, objetivando atender às necessidades históricas da população negra brasileira. Também, na tese, em documentos nacionais e internacionais sobre as políticas de igualdade racial, Ribeiro indica as perspectivas articulatórias dos movimentos sociais que ressaltam a reflexão sobre as estratégias e as formas de atuação do Movimento Negro e das organizações das mulheres negras em suas relações com o Estado.

Pode-se notar que, no Brasil, tem sido ampliado o campo de pesquisas acerca das relações raciais e do racismo, a partir de esforços de mulheres e de homens em sua maioria ativistas negras/os que, em geral, ingressam na academia e desenvolvem pesquisas voltadas para a temática, como a palestrante Matilde Ribeiro. No entanto, não podemos afirmar que ocorre a consolidação da institucionalização de práticas discursivas que possuem como marco central a questão étnica-racial ou, como Ribeiro propõe, a transversalidade entre gênero e raça nas políticas públicas, pois são muitas as dificuldades estruturais e orçamentárias, e, ainda, existem fortes conflitos políticos entre posições tradicionais sobre as relações raciais e de gênero no Brasil - embasadas no mito da democracia racial, — se opondo às posturas mais progressistas. Considerando tais pontos de sua tese, e sem apagar as esparsas, porém importantes mudanças sociais e políticas que indicam maior conquista de direitos quanto à promoção de justiça social, Ribeiro trata em sua fala na I CNPM das dificuldades de implantar uma perspectiva de gênero nos assuntos políticos de decisão, o que impede, de forma direta, o estabelecimento de uma política equitativa. Desse modo, argumenta:

[...] as maiores dificuldades em relação à conquista de políticas equitativas estão na relação da incorporação da perspectiva de gênero nos assuntos de decisão políticas, com a falta de respaldo jurídico institucional e o cumprimento de normas e tratados em âmbito internacional. $\mathrm{O}$ marco jurídico para enfrentamento da discriminação de gênero, deve estar aliado à participação do Brasil em tratados e convenções internacionais de diferentes matrizes. Somente assim é possível promover a equidade de gênero com recortes para raça, etnia, localidade, orientação sexual, condição civil, etc. Considerando as condições das mulheres em relação ao mercado de trabalho, à educação, à saúde (o eixo contemplado com 923 propostas aprovadas no processo das conferências estaduais, considerado um campo onde as mulheres mais acumularam na discussão das políticas públicas) a busca por

\footnotetext{
${ }^{78}$ Ver tese de doutorado de Matilde Ribeiro, "Institucionalização das Políticas de Promoção da Igualdade Racial no Brasil: Percursos e Estratégias - 1986 a 2010”. Disponível em:

<https://sapientia.pucsp.br/bitstream/handle/17640/1/Matilde\%20Ribeiro.pdf>. Acesso em 17 Set. 2016.
} 
uma gestão democrática e equânime tem sido, sem dúvida, o maior dos compromissos dos movimentos de mulheres em qualquer que seja área de atuação: feministas, negras, indígenas, quilombolas... (BRASIL, 2004a, p. 88).

Deve-se notar que nesse enunciado, a ideia de organização feminista cede espaço para a ideia de movimentos de mulheres como denominação mais abrangente. Desse modo o feminismo acaba figurando como um dos seus componentes, ao lado dos movimentos de mulheres negras, indígenas e quilombolas. Aqui fica claro o seu posicionamento de que o feminismo não é algo comum a todas as mulheres, que nem todas as organizações são feministas. Deve-se também notar que Ribeiro fala na I CNPM para um público diversificado, interessado em propostas de políticas públicas para as mulheres que contemplem também essa diversidade de interesses.

Quanto à proposta de estabelecimento de uma política em que predomine a transversalidade de gênero e raça, Ribeiro finaliza a sua fala afirmando que:

A partir do momento em que as políticas de governo se fortalecem, e isso somente é possível a partir de aliança, principalmente com ações dos movimentos sociais organizados, pode-se articular o empoderamento das mulheres. Embora a demanda seja maior que a estrutura, somente alianças pautadas nas experiências práticas e educativas podem propor, em um período menor de tempo, a alteração da cultura machista e racista (BRASIL, 2004a, p. 89).

O fortalecimento de políticas de governo que operem em favor do empoderamento das mulheres só será possível a partir de alianças baseadas nas experiências práticas e educativas, principalmente com ações dos movimentos sociais organizados (LOBO, 1987). Para isto deve haver uma forte dinâmica social entre mulheres e o Estado, visando demonstrar à sociedade civil e aos setores do governo as suas reivindicações, cumprindo, assim, o papel articulatório dos movimentos de mulheres.

A fala de Ribeiro faz ecoar os discursos dos movimentos de mulheres negras, bem como a sua experiência política e acadêmica no tema da igualdade racial e de gênero. É a partir disso que traça propostas e diretrizes para o I Plano Nacional de Políticas para Mulheres (I PNPM), objeto de discussão no Painel 2. Para isso, Ribeiro menciona a importância das organizações de mulheres negras e do Movimento Negro nas últimas décadas no Brasil como referência central para a construção de canais de comunicação entre a sociedade civil e o Estado, o que possibilitará o estabelecimento de políticas de igualdade racial e de gênero. 


\subsection{NALU FARIA: O FEMINISMO COMO INTRODUTOR DE QUESTÕES POLÍTICAS}

A quarta palestra foi realizada por Nalu Faria, coordenadora da Marcha Mundial de Mulheres (MMM), psicóloga que atua, desde o ano de 1986 na Sempreviva Organização Feminista (SOF), onde desenvolve atividades de assessoria e formação feminista com grupos de mulheres, ONGs e gestores públicos. Ela também coordenou várias publicações ${ }^{79}$ da SOF, como o boletim Mulher e Saúde (1993 a 2002), a coleção Cadernos Sempreviva (desde 1997) e o boletim Folha Feminista (desde 1999) e participou da Marcha Mundial de Mulheres (MMM) como coordenadora, cargo, que lhe garantiu espaço de fala representativo na I CNPM.

Em sua fala a palavra "feminismo(s)" é mencionada duas vezes, logo na introdução. Em conformidade com os objetivos do Painel apresenta algumas diretrizes para a construção de políticas para mulheres no Brasil. Logo no início, reconhece a importância do feminismo e da própria I CNPM, para em seguida fundamentar as críticas que conduzem às suas propostas políticas. Assim, disse a palestrante,

O primeiro aspecto que quero ressaltar é o papel da luta das mulheres e do feminismo para a nossa presença aqui, ou seja, para que esteja acontecendo neste momento essa conferência. Foi a partir do feminismo que emergiu como questão política a situação de opressão vivida por nós mulheres e trouxe para a esfera pública e para o campo dos direitos várias questões até então consideradas apenas questão individual, parte da vida privada. (...) Como parte desse processo foi questionada a suposta neutralidade do Estado e também explicitou o funcionamento do mercado e sua relação com a estrutura de família, houve a denúncia intransigente de todas as formas de preconceito, discriminação e violência. Foram colocadas em questão e para serem repensadas nossa subjetividade, nossa percepção e nossas práticas. Nós mulheres nos tornamos sujeitos de transformação em todos os campos da vida pública e privada. E isso está inteiramente ligado como nossa autoorganização por autodeterminação, por autonomia e por igualdade. (...) Entre os resultados, podemos celebrar que as mulheres saíram da invisibilidade e hoje nos expressamos em nossa pluralidade como mulheres negras, brancas, urbanas, rurais, quilombolas, indígenas, de diferentes idades e em nossa diversidade de exercício da sexualidade (BRASIL, 2004a, p.90. Grifos nossos).

Neste sentido, percebemos que Faria atribui ao feminismo uma anterioridade e responsabilidade pela inclusão das questões relacionadas à opressão das mulheres na esfera pública e no campo dos direitos. A própria existência da I CNPM situa-se no campo de

\footnotetext{
${ }^{79}$ Em parceria com Sonia Alvarez e Miriam Nobre, organizou o dossiê "Feminismos no Fórum Social Mundial" para a Revista Estudos Feministas, publicada em 2003. É autora de diversos artigos sobre o movimento de mulheres, entre eles "O feminismo latino-americano e caribenho: perspectivas diante do neoliberalismo". E ainda, foi integrante do Conselho Diretor da Fundação Perseu Abramo de 1996 a 2004.
} 
trajetórias e conquistas não só do feminismo, mas também das mulheres. Nesse sentido, a I Conferência ganha significado e identidade não só nas lutas feministas, mas nas lutas dos movimentos mais amplos de mulheres que não se denominam feministas, mas que colaboraram para a construção deste espaço de debate sobre políticas públicas para mulheres na I CNPM. Isso denota também o quanto o feminismo constitui um movimento específico, mas que de alguma forma referencia todos os movimentos de mulheres que persistem na luta por autonomia e igualdade.

Ao longo de sua fala, Faria revela esse entendimento da pluralidade das mulheres "como mulheres negras, brancas, urbanas, rurais, quilombolas, indígenas, de diferentes idades e em nossa diversidade de exercício da sexualidade" (BRASIL, 2004a, p. 90). Não por acaso, há uma tendência dentro da I CNPM em se reconhecer o papel do feminismo, sempre ao lado dos movimentos de mulheres na construção de espaços de debate e negociação com o governo. No entanto, observa-se na fala de Faria que o feminismo, mesmo compartilhando com os movimentos de mulheres esse papel fundamental na construção da I CNPM, ganha um status de precursor dessas lutas, já que é tido como o introdutor das questões políticas relacionadas à opressão das mulheres no campo da esfera pública e do direito. É a partir do feminismo que emerge a importância do privado (pessoal) como questão política. O feminismo, na fala de Faria, acaba por conferir identidade e historicidade à própria I Conferência, aspecto fundamental para a sua legitimidade como espaço que comporta toda uma carga de experiência que nasce com o movimento feminista.

Embora Faria não argumente amplamente sobre as perspectivas políticas feministas em sua fala, fica claro que reconhece o feminismo como fundamento das questões que levanta. Desse modo, situa o feminismo no passado, como precursor/influenciador das lutas pelos espaços públicos e direitos das mulheres, mas também no presente como um movimento específico que é colocado dentro e fora, ao mesmo tempo, dos movimentos de mulheres.

A partir dessas colocações iniciais, onde reconhece também a importância da I CNPM no presente, como espaço de debate e formulação de políticas para as mulheres, apresenta críticas ao contexto neoliberal, a globalização econômica, as políticas de ajuste e aos conservadorismos que fizeram retroceder os avanços que, em décadas anteriores, foram duramente conquistados. Assim ela propõe a superação dessa lógica econômica por meio de políticas redistributivas e de garantia de direitos sociais de caráter "universal". Além disso, reforça a crítica introduzida pelo feminismo, à persistência da divisão entre público (produtor) e privado (reprodutor), propondo "repensar as políticas sociais e exercer um papel ativo para que as tarefas domésticas sejam compartilhadas por homens e mulheres" (BRASIL, 2004a, 
92). Em suma, fala de três níveis de políticas especificas como forma de garantir autonomia das mulheres e "políticas universais" que devem levar em conta a diversidade das mulheres:

O primeiro é a autonomia pessoal e econômica, ou seja, o direito ao emprego, a igualdade salarial, o acesso à terra, ao crédito, à profissionalização e à educação igualitária. O segundo é a atuação do Estado para alterar essa divisão sexual do trabalho em casa e no mercado, quer dizer, a construção de creches, a escola em período integral e uma política cultural e um trabalho educativo de incentivo à divisão do trabalho doméstico. A terceira diretriz é que se garanta autonomia sobre o corpo das mulheres. Nesse tema colocamos todas as questões da saúde, dos direitos reprodutivos e sexuais e do direito a viver sem violência (BRASIL, 2004a, p. 92).

Nesse sentido, ela fala de "políticas universais" que deem conta da dinâmica que caracteriza a sociedade brasileira na atualidade, baseada em hierarquias de gênero, raça, classe e outras formas de opressão como geração, sexualidade, deficiência, contextos regionais (BRASIL, 2004a, p. 90). Nessa direção finaliza a sua fala:

Pensar igualdade para as mulheres passa por políticas universais para o modelo de desenvolvimento e políticas específicas de ações afirmativas que levem em conta a diversidade da situação das mulheres. Não somos apenas brancas, somos mulheres brancas e negras; somos urbanas e rurais; somos indígenas, somos jovens e velhas; somos heterossexuais e homossexuais. Isso tem definido condições e discriminações diferenciadas. Portanto, nessas políticas universais e específicas devem levar em consideração esse conjunto. Para isso, é extremamente importante que espaços de debates e de participação estejam sempre abertos (BRASIL, 2004a, p. 93).

Nesse sentido, considera-se a experiência política feminista de Faria na base também de sua produção de sentidos para o feminismo no contexto de sua fala. $\mathrm{O}$ feminismo introduz, no passado, questões fundamentais que ainda estão em debate e que foram ampliadas pelos movimentos de mulheres na atualidade, e é nesse sentido que ela fala de "políticas universais" que abarcam os interesses da pluralidade de movimentos de suas interlocutoras na I CNPM. Estratégia de fala fundamental que não exclui o feminismo e consegue abarcar a diversidade de interesses das mulheres na atualidade por políticas públicas.

\subsection{MARIA LAURA SALES PINHEIRO: DIÁLOGOS DO GOVERNO COM OS MOVIMENTOS DE MULHERES E FEMINISTAS}

A quinta e última palestra no Painel 2 foi proferida por Maria Laura Sales Pinheiro, então Secretária Adjunta da Secretária Especial de Políticas para as Mulheres da Presidência da República (SPM). Em sua fala o termo "feminista(s)" aparece duas vezes. Enquanto 
representante do governo Pinheiro se mostrou interessada em revelar a importância do governo do presidente Lula, tanto na construção da I CNPM, como no comprometimento com políticas para a igualdade de gênero, raça e etnia no Brasil. Falou da importância da realização das Conferências no âmbito deste governo, como instrumento de gestão que prioriza a participação dos movimentos sociais. Nesse sentido, destacou a importância da SPM na institucionalização das propostas construídas na I CNPM, tendo em vista "a ampliação e institucionalização, nos Governos estaduais e municipais, de mecanismos que gerem políticas para as mulheres, em diversos níveis" (BRASIL, 2004a, p. 98).

Os "movimentos feministas" emergem em sua fala ao lado dos "movimentos de mulheres", seguindo assim as normas e acordos estabelecidos no início da I Conferência, de tratar sempre de "movimentos de mulheres e feministas". Assim diz a palestrante:

A Secretaria Especial de Políticas para Mulheres, em nome do Governo Lula, se dirigiu a todos os Governadores e Governadoras, Prefeitos e Prefeitas deste país, convocando-os a assumir, juntos, o desafio de construir esta Conferência. Ao mesmo tempo em que propôs como estratégia esta forma de parceria com a sociedade: movimentos de mulheres e feministas, o fez pela convicção de que nesse processo era fundamental o diálogo com os organismos governamentais, que são os responsáveis, ou virão a ser, pela execução das políticas públicas que serão tiradas nesta Conferência (BRASIL, 2004a, p.96. Grifos nossos).

Nessa fala, Pinheiro assinala a presença e importância dos movimentos feministas como parte da "sociedade", também composta por "movimentos de mulheres" que dialogam com o governo por meio da I CNPM. Os movimentos feministas, presentes na I CNPM, participam assim de diálogos fundamentais com os organismos responsáveis por políticas públicas para as mulheres. Esse espaço de diálogo entre a sociedade civil e o governo, oferecido na I Conferência, é visto como uma importante estratégia política de gestão do que ela chama de "nosso governo" (BRASIL, 2004a, p. 96), o do presidente Lula. Em seguida os movimentos feministas aparecem em outro enunciado:

É também importante destacar que o reforço, a criação e o fortalecimento dos Conselhos de Direitos das Mulheres, como espaços de participação das mulheres e de controle social são fundamentais para que os organismos executivos tenham, de fato, a possibilidade de adotar também a construção de políticas, considerando o acúmulo da luta das mulheres e dos movimentos feministas (BRASIL, 2004a, p. 97. Grifos nossos).

Nesse enunciado, Pinheiro trata da necessidade de reforçar os espaços institucionais como os Conselhos de Direitos das Mulheres, como espaços de participação e de controle, capazes de considerar o acúmulo das lutas das mulheres e dos movimentos feministas na 
construção de políticas implementadas por organismos executivos. O que parece em questão é a presença/reforço de órgãos institucionais que, como a SPM, podem cobrar e fiscalizar as políticas para mulheres, tais órgãos devem atuar como representativos dos movimentos feministas e de mulheres.

Pinheiro, enquanto representante da SPM, deixa claro sua proposta no Painel, a de reforçar e criar espaços institucionais, dentro do Estado, que devem atuar como representantes de movimentos feministas e de mulheres no âmbito do governo, para que possam fiscalizar/controlar a construção e implementação de políticas para as mulheres. Como representante do governo, ela reforça e acredita no diálogo destes movimentos com o governo, por meio de suas instituições e da I CNPM, que afinal é também produzida por um órgão governamental, a SPM, e que tem a função de promover a participação dos movimentos sociais em diálogo com o governo, na construção de políticas para as mulheres.

Nos anos 1980, os movimentos feministas e de mulheres encararam muitos dilemas e embates, já que na década anterior os movimentos se haviam centrado no trabalho de organização, na luta contra a ordem social, política e econômica. Os avanço destes movimentos fizeram do eleitorado feminino um alvo do interesse partidário e de seus candidatos, que deram início à incorporação das demandas das mulheres aos seus programas e plataformas eleitorais. Não por acaso surgem departamentos femininos dentro de estruturas partidárias. No entanto, a perspectiva de relação com o Estado no projeto de transformação feminista não havia sido apresentada. Foi somente com a eleição de partidos políticos de oposição para alguns governos estaduais e municipais que as feministas foram forçadas a repensarem sua posição perante o Estado, na medida em que a possibilidade de avançar em termos de política feminista era uma realidade. Nos dois primeiros anos (1980-1982), as velhas divisões políticas e partidárias voltaram à cena. Como afirma Elizabete Lobo,

[...] a reorganização partidária começou a descaracterizar as práticas autônomas dos movimentos, os grupos se dividiram e se desmancharam. $\mathrm{Na}$ divisão muitas feministas se concentraram nos partidos, outras permaneceram somente no movimento. Os discursos feministas invadiram os discursos partidários, mas as práticas autônomas se reduziram (LOBO, 1987, p. 50).

Percebe-se que a atuação dos movimentos feministas e de mulheres em nível institucional, ou seja, na relação com o Estado, nesse e em outros momentos, como é o caso da I CNPM, não foi um processo fácil de ser assimilado no interior dos movimentos. Visto que, de modo geral, duas posições polarizaram as discussões nesses espaços: "de um lado, as que se propunham ocupar os novos espaços governamentais, e de outro, as que insistiam na 
exclusividade dos movimentos como espaços feministas" (LOBO, 1987, p. 64). No entanto, a perspectiva de atuar no âmbito do Estado representou, para muitas mulheres, uma brecha na luta pela autonomia dos movimentos feministas e de mulheres.

Os movimentos feministas não puderam deixar de reconhecer a capacidade do Estado moderno para influenciar a sociedade civil como um todo, não somente de maneira coercitiva com medidas punitivas, mas por meio das leis, de políticas sociais e econômicas, de ações de bem-estar, de mecanismos reguladores da comunicação pública e da cultura, portanto um aliado fundamental na transformação dos tradicionais papeis atribuídos às mulheres (MOLYNEUX, 2003, p. 68). Também não puderam deixar de reconhecer os limites da política feminista no sentido da mudança cultural sem o acesso a mecanismos mais amplos de comunicação. Desse modo, deviam combater a resistência constante de um aparelho patriarcal, classista e racista como o Estado. Caberia, assim, ao feminismo, enquanto movimento social organizado, articulado com outras esferas da sociedade brasileira, fiscalizar, pressionar e buscar influenciar esse aparelho, por meio dos seus numerosos organismos, para alcançar a definição de metas sociais apropriadas aos interesses das mulheres e o desenvolvimento de políticas públicas e sociais que garantissem a equidade de gênero.

Os movimentos feministas na I CNPM, enquanto movimentos sociais, extrapolaram os limites do seu status e do próprio conceito, pois conseguiram expor suas demandas e enfrentar a pressão política na defesa de seus interesses específicos. Na I Conferência, as perspectivas feministas estão presentes, de alguma forma, nas falas institucionais de suas representantes na SPM.

Entende-se com isso que os resultados provenientes da I CNPM, enfatizam a proposta de criação de espaços institucionais dentro do Estado, evocada por Pinheiro, pois o momento da I Conferência demonstrou a força, a capacidade de mobilização e a articulação de novas alianças entre sociedade e governo em torno de propostas e diretrizes transformadoras que seriam expressas no I PNPM.

A I CNPM não representa um ponto final para os movimentos feministas, mas uma vitória, que faz surgir novas demandas e novos enfrentamentos. Sendo assim, o feminismo está longe de ser um consenso na sociedade brasileira, já que a implantação de políticas públicas para as mulheres enfrenta ainda hoje resistências políticas e culturais de ordem patriarcal. Por isso, a atuação dos movimentos feministas em espaços institucionalizados, como a SPM e a I CNPM, significa uma redefinição do poder político e da forma de entender a política ao colocar novas demandas e interesses. Assim, sua força está em recolocar a forma de entender a política e o poder, de questionar o conteúdo formal que se conferiu ao poder e 
as formas em que é exercido. Então, ao trazer novas questões para o âmbito público, o feminismo traz também a necessidade de constituir novas condutas, novas práticas, conceitos e dinâmicas, esse é o seu caráter subversivo (LEON, 1994, p. 14). 


\section{CONSIDERAÇÕES FINAIS}

Ao percorrer os momentos de organização e de realização da I Conferência Nacional de Políticas para as Mulheres (I CNPM), realizada no ano de 2004, busquei compreender os sentidos, significados, funções e implicações das representações do feminismo evocadas no contexto de debates sobre políticas públicas para as mulheres na I Conferência. Meu interesse em investigar as representações do feminismo é fruto de uma vontade política de conferir visibilidade e dizibilidade às mulheres na história.

Nas falas proferidas na Abertura e nos Painéis 1 e 2 da I Conferência somente em dois discursos os termos "feminismo(s)" e "feminista(s)" não foram mencionados. A fala do então Presidente da República, Luiz Inácio Lula da Silva, não menciona a palavra "feminismo(s)", mas dá preferência pela utilização do termo "movimentos de mulheres". Esse silenciamento evidência, a partir de seu plano governamental e partidário, que o governo federal deveria mostrar os avanços sociais nas pautas que não explicitem radicalização. Por isso, prefere-se a utilização das identidades coletivas de mulheres, em detrimento do reconhecimento de uma identidade feminista, pois pode evocar questões consideradas tabus na sociedade, como o direito ao corpo, a sexualidade, os direitos reprodutivos e ao aborto. Com isso, compreendi que não há dificuldades em admitir que vivemos em um sistema capitalista que oprime, principalmente, as mulheres, tanto cultural, economica e socialmente. Entretanto, ainda há resistências em se admitir que a luta contra esse sistema é também desempenhada pelos movimentas feministas ao proporem um novo projeto de que tem como objetivo a transformação profunda da ordem patriarcal e de seu poder regulador, em nome da igualdade, de equidade e de justiça social (DESCARRIES, 2001).

Os termos "feminismo(s)" e "feminista(s)", também, não aparecem na fala de Dirce Veron, Representante do Conselho Nacional das Mulheres Indígenas no Conselho Nacional dos Direitos da Mulher (CNDM). Veron ressaltou em sua fala a necessidade de se respeitar o estilo de vida e a diversidade étnica das mulheres indígenas. Com isso, Veron ao expor propostas marcadas pelos interesses coletivos indígenas, não faz menção ao feminismo em sua fala, já que sua experiência é marcada por um certo distanciamento dos movimentos feministas, urbanos e de classe média, cujas pautas não consideram as reivindicações específicas das mulheres índigenas no Brasil. Entretanto, a não menção dos termos "feminismo(s)" e "feminista(s)" na fala de Veron não significa uma postura anti feminista, 
mas que os interesses e pautas das mulheres indígenas alargam a concepção clássica do feminismo.

Apesar de o feminismo não aparecer em grande parte das falas na I CNPM, observa-se que ele ainda é referência nos debates entre as mulheres e o governo em prol de políticas públicas para as mulheres no Brasil. Os movimentos feministas são vistos e reconhecidos em seu protagonismo histórico nas lutas pelos direitos das mulheres no Brasil. Nas falas de Nilcéa Freire, Jacqueline Pitanguy e Nalu Faria o feminismo aparece como parte de um processo histórico que culmina na realização da I CNPM. Desse modo, o feminismo ganha espaço nos discursos que analisados, já que não é totalmente silenciado ou negado, pois há a consideração de sua importância e atuação histórica nas lutas pelos direitos das mulheres no país. O feminismo, ao ser evocado em discursos que denotam a historicidade às lutas pelos direitos das mulheres, aparece assim com a função de conferir identidade e memória a essas lutas em um longo processo.

$\mathrm{Na}$ Abertura da I CNPM, algumas feministas tanto do passado quando do presente foram homenageadas e rememoradas enquanto protagonistas e integrantes das lutas pelos direitos das mulheres no país. As feministas, como exposto por Nilza Iraci, demostraram que os direitos das mulheres são direitos humanos e que a autonomia é elemento central para que as mulheres governem suas vidas, corpos e desejos. Iraci enquanto representante de grupos sociais em prol dos direitos das mulheres negras, envolvidos nas lutas feministas e antirracistas nos últimos anos, reconhece o feminismo como um instrumento central dos avanços alcançados pelas mulheres tanto na esfera privada quanto na pública.

No Painel 1, as palestrantes procuraram realizar um diagnóstico e análise dos problemas a serem enfrentados pelas propostas e diretrizes para políticas públicas para as mulheres no Brasil. Em vista disso, Jacqueline Pitanguy indicou que a I CNPM se constituiu em um espaço de reflexão sobre as políticas públicas já implementadas, onde os debates e as diretrizes elaboradas deveriam incorporar elementos que colaborassem para o reconhecimento e realização das pautas das mulheres brasileiras. Para isso, buscou, em sua fala, traçar, brevemente, os percursos do feminismo no Brasil. Nesse percurso, Pitanguy atribuiu "inegável” importância e contribuição aos movimentos feministas, mas considera que estes movimentos não foram os únicos atores políticos, já que os chamados "movimentos de mulheres" aparecem também como fundamentais.

Dada à diversidade de pautas e perspectivas políticas das mulheres na I CNPM, algumas em divergência com as feministas, ao falar da trajetória histórica de lutas e conquistas pelos direitos das mulheres, parece fundamental destacar o feminismo ao lado dos 
movimentos que não se intitulam feministas, mas que também atuaram nessas lutas. Ao longo da I Conferência, essa distinção foi ressaltada ao aparecer em vários discursos quando se tratou de "movimentos de mulheres e de feministas". Neste sentido, Pitanguy deixou entrever que as lutas e conquistas das mulheres não seguiram uma trajetória linear de avanços, já que encontram, também, entraves nas negociações e diálogos entre si e com o governo.

A narrativa histórica do feminismo de Pitanguy apontou para os desafios que se colocavam no presente do ano de 2004, especialmente na construção de políticas públicas para mulheres brasileiras, levando em conta a história de diversidade de interesses e de pautas que caracterizaram os movimentos feministas e de mulheres, para que dessa forma não ocorresse benefícios unilaterais somente, mas que essas prerrogativas abarcassem a diversidade das mulheres. Portanto, no contexto de debates do Painel 1, Pitanguy relembrou e ressignificou a narrativa histórica dos movimentos feministas, ao lado dos "movimentos de mulheres", conferindo protagonismo a todos esses movimentos nas lutas e conquistas das mulheres no Brasil.

Ainda no Painel 1, Sueli Carneiro conferiu destaque ao protagonismo das mulheres negras, pois em sua visão as ações dessas mulheres foram fundamentais na transformação das concepções políticas do feminismo no país, ao atentar para o racismo e a discriminação racial, introduzindo assim o reconhecimento das "diferenças intragênero", isto é, as diferenças entre as mulheres, não mais centradas numa visão universalizante das mulheres. Neste sentido, evidenciou a Plataforma Política Feminista, pois de acordo com a sua fala a publicação desse documento abriu um novo ciclo no processo de debates sobre políticas públicas para as mulheres, ao incorporar as orientações e diretrizes colocadas pelas mulheres negras em torno do racismo e da discriminação racial. Com isso, entende-se que a Plataforma Política Feminista constituiu um instrumento dos movimentos feministas e de mulheres para o diálogo, crítico e provocativo, e também para o confronto e a negociação com as diversas forças políticas e sociais no Brasil. Objetivando assim o reconhecimento das diferenças e dos novos movimentos de mulheres, assim como à conquista da igualdade, da redistribuição de riquezas e da justiça social.

Na fala de Sueli Carneiro o feminismo ganhou destaque na menção à Plataforma Política Feminista, pois reposicionou a luta feminista no Brasil, construída coletivamente por mulheres negras, indígenas, brancas, etc. Assim, ao mencionar o enegrecimento do feminismo e ao reafirmar os compromissos estabelecidos pela Plataforma Política Feminista, Carneiro trouxe para o debate da I CNPM uma perspectiva feminista mais abrangente da diversidade dos interesses das mulheres ali presentes, conferindo a proposta política feminista presentes 
na Plataforma Política Feminista um lugar importante em meio aos debates de avaliação das políticas públicas para mulheres.

O Painel 2 foi um espaço utilizado para apresentação de sugestões, princípios e propostas de diretrizes para integrar a construção do I Plano Nacional de Políticas para as Mulheres (I PNPM). Neste sentido, Maria Betânia Ávila tratou da implementação de uma perspectiva feminista para contribuir na transformação social, na medida em que associou os termos "igualdade, autonomia e liberdade" a um projeto político para as políticas públicas. A perspectiva feminista, mencionada por Ávila, não só ressalta a necessidade de novas posturas e compromissos por parte do governo, mas também pelos dos movimentos de mulheres. Para que isso ocorresse Ávila afirmou que os movimentos feministas e de mulheres deveriam ter mais organização, capacidade de luta e de enfrentamento o sistema que reproduz as desigualdades e impede a sua transformação. Na visão de Ávila, o sentido de transformação social por uma perspectiva feminista deveria ser realizado em combate à ordem social dominante, estruturada pelo poder patriarcal e na reflexão crítica. Para que dessa forma o Estado fosse conduzido a criar condições de uma vida social mais democrática. Logo, esta proposta, colocou o feminismo como referência importante para as diretrizes políticas que seriam delineadas na I CNPM.

Ávila, ainda, ressaltou a importância de se refletir sobre o acesso aos espaços de voz, de deliberação e de luta, pois sem essa reflexão as discriminações presentes em atos verbais e físicos permaneceriam de forma estrutural na sociedade. Neste sentido, compreendeu-se que as políticas públicas estão em constante processo de (re)construção, visto que são o resultado de diversas leituras de mundo, realizadas por diferentes agentes sociais. Esse entendimento acerca da construção de políticas públicas para as mulheres possibilitou a reflexão sobre como os agentes políticos, da sociedade civil e do governo, exercem papel ativo no processo de interpretação e reinterpretação destas. Assim, a proposta exposta por Ávila deveria ser enfática no confronto com o sistema patriarcal, pois possibilitaria o enfrentamento das estruturas que reproduzem as desigualdades sociais que perpassam a vida das mulheres.

Na fala da Ministra Matilde Ribeiro o feminismo aparece na menção as "organizações feministas" enquanto movimentos de mulheres marcado pela diversidade. Em sua visão, não há na atualidade uma única forma de organização feminista, mas uma variedade de organizações que, de modo geral, persistem incansavelmente no "ideal coletivo de igualdade, liberdade e justiça". Ao destacar a gama de organizações feministas, Ribeiro direcionou sua fala para os movimentos de mulheres negras e propôs com isso a transversalidade de gênero e raça nas políticas públicas para as mulheres. Em sua argumentação, não deixou de ressaltar 
que as mulheres negras e indígenas vivem situações de maior vulnerabilidade em relação às mulheres brancas na sociedade brasileira. E ao destacar as ações e práticas produzidas pelas organizações de mulheres negras e, consequentemente, mostrar, de forma consciente, a necessidade da implementação da transversalidade de gênero e raça no âmbito das políticas públicas, Ribeiro faz ecoar os discursos dos movimentos de mulheres negras.

$\mathrm{Na}$ fala de Nalu Faria, destacou-se, também, o reconhecimento da pluralidade das mulheres. Isso não ocorreu por acaso, já que na I CNPM existiu uma tendência de reconhecer o papel do feminismo ao lado dos movimentos de mulheres, nos espaços de debate e de negociação com o governo. Porém, observou-se, na fala de Faria, que o feminismo, mesmo compartilhando com os movimentos de mulheres papel fundamental na construção da I Conferência, teve um status de precursor das lutas das mulheres, já que foi considerado introdutor das questões políticas relacionadas à opressão das mulheres no campo da esfera pública e do direito. O feminismo, na fala de Faria, conferi assim identidade e historicidade à própria I CNPM, aspecto fundamental para a legitimidade do evento como espaço que comportou toda uma carga de experiência proveniente dos movimentos feministas. Ao introduzir o feminismo como elemento do passado, elencou questões fundamentais que ainda estão em debate e que foram ampliadas pelos movimentos feministas e de mulheres na atualidade. É nesse sentido que Faria abordou as políticas universais que abarcaram os interesses da diversidade dos movimentos de suas interlocutoras na I CNPM.

O Painel 2 foi finalizado com a fala de Maria Laura Sales Pinheiro. Ela assinalou a presença e importância dos movimentos feministas como parte da sociedade civil, composta por "movimentos de mulheres" que dialogaram com o governo por meio da I CNPM. Segundo Pinheiro, os movimentos feministas presentes na I Conferência, participaram de diálogos fundamentais com os organismos responsáveis por políticas públicas para as mulheres. Esse espaço de diálogo entre a sociedade civil e o governo, oferecido na I Conferência, foi visto como uma importante estratégia política de gestão, denominando tal contexto de "nosso governo". Abordou, com isso, a necessidade de reforçar os espaços institucionais como locus de participação e de controle, capazes de considerar o acúmulo das lutas dos movimentos feministas e de mulheres na elaboração de políticas efetivadas por organismos executivos. Pinheiro, enquanto representante da SPM, deixou claro que a sua proposta para o Painel 2 era a de reforçar as funções dos espaços institucionais do Estado que deveriam atuar como representantes de movimentos feministas e de mulheres, para que esses fiscalizassem e controlassem a organização e implementação de políticas para as mulheres. 
Reforçou com isso a crença no diálogo desses movimentos com o governo, por meio de suas instituições e da I CNPM.

Diante dos discursos analisados na I CNPM e, consequentemente, dos sentidos e das funções apreendidas do feminismo, percebi que mesmo não sendo amplamente exposto nas falas pronunciadas na Abertura e nos Painéis 1 e 2, o feminismo aparece como referência fundamental nos debates políticos pelos direitos das mulheres. Desse modo, o feminismo, ainda, continua a embasar os debates de políticas para as mulheres. Especialmente, porque alguns movimentos tem o reposicionado, reconhecendo também as lutas contra o racismo, a discriminação étnica-racial e sexual, entre outros eixos de opressão contra as mulheres. Nas falas de Sueli Carneiro e de Matilde Ribeiro, o feminismo aparece associado às lutas das mulheres negras e indígenas, o que amplia o foco de luta antes centrado somente no patriarcado. Sendo assim, é a partir desse reposicionamento do feminismo e de seu projeto político, ou mesmo de seu "enegrecimento" como bem disse Sueli Carneiro, que ele continua a fazer sentido nos debates e lutas por políticas públicas para as mulheres no Brasil.

Além disso, observei que o feminismo é, também, evocado em falas para conferir historicidade às lutas pelos direitos das mulheres, verificando com isso anterioridade a essas lutas, dando fundamento e dimensão à sua continuidade no presente. Dessa forma, nota-se que na maioria das falas de mulheres representantes do governo, o feminismo aparece somente como parte de um processo histórico, mas que se dissolve no presente nos movimentos de mulheres. Já o feminismo como perspectiva política manifesta-se, especialmente, nas falas das mulheres que possuem forte militância política, em grupos, instituições e entidades denominadas feministas.

Considero, portanto, que o feminismo, ainda, é referência política e social no âmbito de debates e de proposições de políticas públicas para as mulheres brasileiras. Compreendi que o feminismo possui protagonismo histórico nas lutas pelos direitos das mulheres e que também, na atualidade, é perpassado por um reposicionamento para abarcar a diversidade de interesses das mulheres no Brasil, especialmente, as negras, indígenas, lésbicas e pobres. 


\section{CORPUS DOCUMENTAL}

BRASIL. Presidência da República. Secretaria Especial de Políticas para as Mulheres. Compromissos do Governo Federal 2003: políticas públicas para as mulheres. Brasília: $2003 a$.

BRASIL. Decreto de 18 de dezembro de 2003. Convoca a I Conferência Nacional de Políticas para as Mulheres. Diário Oficial da União. Brasília, 18/12/2003b.

BRASIL. Decreto de 17 de janeiro de 2007. Convoca a II Conferência Nacional de Políticas para as Mulheres. Diário Oficial da União. Brasília, 17/01/2007b.

BRASIL. Decreto de 15 de março de 2011. Convoca a III Conferência Nacional de Políticas para as Mulheres. Diário Oficial da União. Brasília, 15/03/2011b.

BRASIL. Decreto de 3 de fevereiro de 2016. Convoca a IV Conferência Nacional de Políticas para as Mulheres. Diário Oficial da União. Brasília, 03/02/2016.

BRASIL. Presidência da República. Secretaria Especial de Políticas para as Mulheres. Regimento Interno. I Conferência Nacional de Políticas para as Mulheres. Brasília: SPM/CNDM, 02/12/2003c.

BRASIL. Presidência da República. Secretaria Especial de Políticas para as Mulheres. Anais da Conferencia. Brasília: Secretaria Especial de Políticas para as Mulheres, 2004a.

BRASIL. Presidência da República. Secretaria Especial de Políticas para as Mulheres. Anais da Conferencia. Brasília: Secretaria Especial de Políticas para as Mulheres, 2007a.

BRASIL. Presidência da República. Secretaria Especial de Políticas para as Mulheres. Anais da Conferencia. Brasília: Secretaria Especial de Políticas para as Mulheres, 2011a.

BRASIL. Presidência da República: Secretaria Especial de Políticas para as Mulheres. Ano da Mulher no Brasil. I Conferência Nacional de Políticas para as Mulheres. Brasília, 2004b.

BRASIL. Presidência da República: Secretaria Especial de Políticas para as Mulheres. I Plano Nacional de Políticas para as Mulheres. Brasília: SPM, 2004c.

BRASIL. Presidência da República: Secretaria Especial de Políticas para as Mulheres. Contribuição da Secretaria Especial de Políticas para as Mulheres para as Conferências Estaduais. Documento Base - I Conferência Nacional de Políticas para as Mulheres. Brasília: SPM, 2004d.

BRASIL. I Conferência Nacional de Políticas para as Mulheres. Perfil das Delegadas e Perspectivas de Atuação. Brasília: IBAM/SPM, 2005.

BRASIL. Presidência da República. Secretária Especial de Políticas para as Mulheres. Relatório de Implementação 2005. Plano Nacional de Políticas para as Mulheres. Brasília: SPM, 2006.

BRASIL. Presidência da República. Secretaria Especial de Políticas de Promoção da Igualdade Racial (SEPPIR). Resoluções da II CONAPIR. Brasília: Secretaria Especial de Políticas de Promoção da Igualdade Racial, 2009.

BRASIL. Presidência da República. Secretária Especial de Políticas para as Mulheres. Políticas públicas para as mulheres. Brasília: SPM, 2012.

BRASIL. Presidência da República. Secretaria Especial de Políticas para as Mulheres. Proposta de Diretrizes para uma Política Nacional para as Mulheres. I Conferência 
Nacional de Políticas para as Mulheres. Documento para os Grupos de Trabalho. Brasília: Secretaria Especial de Políticas para as Mulheres, 2004h.

BRASIL. Presidência da República. Secretaria Especial de Políticas para as Mulheres. $4^{\text {a }}$ Conferência Nacional de Políticas para as Mulheres. Texto Base. Brasília: SPM/CNDM, 2015.

CONFERENCIA NACIONAL DE POLÍTICAS PARA AS MULHERES, 1., 2004, Brasília. Balanço. Brasília: [s.n.], 2004e.

CONFERENCIA NACIONAL DE POLÍTICAS PARA AS MULHERES, 1., 2004, Brasília. Boletim informativo. n. 1. Brasília: [s.n.], $2004 \mathrm{f}$.

CONFERÊNCIA NACIONAL DE POLÍTICAS PARA AS MULHERES, 1., 2004, Brasília. Regulamento Interno. Aprovado na Plenária do dia 15 de julho. 2004g.

ARTICULAÇÃO de mulheres brasileiras (AMB). Boletim Articulando, Recife, n. 90, jul. 2004a.

ARTICULAÇÃO de mulheres brasileiras (AMB). Boletim Articulando, Recife, n. 94, set. 2004b.

ARTICULAÇÃO de mulheres brasileiras (AMB). Políticas Públicas para as mulheres no Brasil: Balanço nacional cinco anos após Beijing. Brasília: ABM, 2000a.

ARTICULAÇÃO de mulheres brasileiras (AMB). In: Articulando a luta feminista nas políticas públicas. Recife: [s.n.], 2004b. (Texto para discussão)

CONFERENCIA NACIONAL DE MULHERES BRASILEIRAS, 1., 2002, Brasília. Carta de princípios. Brasília: [s.n.], 2002a.

CONFERENCIA NACIONAL DE MULHERES BRASILEIRAS, 1., 2002, Brasília. Plataforma política Feminista. Brasília: [s.n.], jun, 2002b.

SOUZA, Clóvis Henrique Leite de.; CRUXÊN, Isadora Araíjo.; ALENCAR, Joana Luiza Oliveira.; LIMA, Paula Pompeu Fiuza; RIBEIRO, Uriella Coelho. Ampliação da Participação na Gestão Pública: um estudo sobre conferências nacionais realizadas entre 2003 e 2011. Relatório de Pesquisa. Brasília: Ipea - Instituto de Pesquisa Econômica Aplicada, 2013. 


\section{REFERÊNCIAS}

ALBERTI, Verena. Ouvir e contar: textos em história oral. Rio de Janeiro: Editora FGV, 2004.

ALMEIDA, Lady Christina de. Protagonismo e autonomia de mulheres negras, a experiência das organizações: GELÉDES e Criola. Fazendo Genero 9 - Diásporas, Diversidade e Deslocamento. Florianópolis, 2010.

ALMEIDA, Tânia Mara C. de.; BANDEIRA. Lourdes. Políticas públicas destinadas ao combate da violência contra as mulheres - por uma perspectiva feminista, de gênero e de direitos humanos. In: BANDEIRA, Lourdes.; ALMEIDA, Tânia Mara et. Ali. (Orgs.). Violência contra as mulheres: a experiência de capacitação das DEAMs da Região CentroOeste. Brasília, Cadernos AGENDE, n. 5, dez/2004.

ÁLVAREZ, Sonia. La (trans)formación del (los) feminismo (s) y la política de gênero en la democratización del Brasil. In. LEON, Magdalena (Org.). Mujeres y participación política. Avances y desafios en América Latina. Bogotá: Tecer Mundo, 1994.

Los feminismos latino-americanos se globalizan: tendências de los años 90 y retos para un nuevo milênio. In:. DAGNINO, Evelina; ESCOBAR, Arturo (Org.). La política de las culturas y las culturas de la política: revisando los movimientos sociales latioamericanos. Bogotá: Taurus, 2001.

AVRITZER, Leonardo. Conferências nacionais: ampliando e redefinindo os padrões de participação social no Brasil. Brasília: Ipea, 2013.

BANDEIRA, Lourdes. Fortalecimento da Secretaria Especial de Políticas para as Mulheres: Avançar na transversalidade da perspectiva de gênero nas políticas públicas. Brasília: CEPAL/SPM, 2005a.

Importância do PNPM: contexto histórico das I e II Conferências e da formulação dos I e II Planos, eixos, principais propostas do II PNPM e situação atual. Brasília: SPM, 2011.

.; BITTENCOURT, Fernanda. Desafios da transversalidade de gênero nas políticas político-brasileiras. In. SWAIN, Tania Navarro; MUNIZ, Diva de Couto Gontijo (Org.). Mulheres em ação: práticas discursivas, práticas políticas. Florianópolis: Editora Mulheres, 2005b.

BARBER, Benjamin. Strong democracy: participatory politics for a new age. Berkeley: University of California Press, 1984.

BARCA, Isabel.; MARTINS, Estevão de Rezende.; SCHMIDT, Maria Auxiliadora. (Org.). Jorn Rüsen e o ensino de história. Curitiba: Ed. UFPR, 2010.

BARRIOS, Luiza. Lembrando Leila Gonzalez. In.: WERNECK, Jurema.; MENDONÇA, Maisa.; WHITE, Evelyn C. O livro da saúde das mulheres negras - nossos passos vêm de longe. Rio de Janeiro: Criola/Pallas, 2000.

BARSTED, Leila Linhares. Os direitos humanos na perspectiva de gênero. Texto produzido para o I Colóquio de Direitos Humanos. São Paulo, Brasil, 2001.

BICHTELER, Julie. Geologist and grat literature: acess, use and problems. In.Science \& Technology Li-braries. Binghamtom, N. Y., vol. 11, n 3, p. 39 - 50, 1991. 
BOURDIEU, Pierre. A dominação masculina. Tradução Maria Helena Kühner. 5. ed. Rio de Janeiro: Bertrand Brasil, 2007.

Novas reflexões sobre a dominação masculina. In: LOPES, Marta J. M.; MEYER, Dagmar E.; WALDOW, Vera Regina (Orgs.).Gênero e Saúde. Porto Alegre: Ed. Artes Médicas, 1996.

BRITO, Eleonora Zicari Costa de. Justiça e gênero: uma história da Justiça de menores em Brasília (1960-1990). Brasília: Editora Universidade de Brasília: Finatec, 2007.

CAMPELLO, Bernadete Santos; CAMPOS, Carlita Maria. Fontes de informação especializada: características e utilização. Belo Horizonte: UFMG/PROED, 1993.

CARDOSO, Ciro Flamarion. O uso, em história, da noção de representações sociais desenvolvida na psicologia social: um recurso metodológico possível. In. Psicologia e Saber Social. Vol. 1, n 1, p. 40-52, 2012.

CARNEIRO, Sueli. Mulheres em movimento. In.: Estudos Avançados. v. 17. n 49, 2003.

CASTIGLIONE, Dario.; WARREN, Mark. Rethinking democratic representation: eight theoretical issues. Trabalho apresentado no Centre for the Study of Democratic Institutions, University of British Comlumbia, 2006.

CASTILHO, Rosalva Aída Hernández. Feminismos poscoloniales: reflexiones desde el Sur del Río Bravo. In: CASTILLO, Rosalva Aída Hernández Castillo; NAVAZ, Liliana Suárez (orgs.). Descolonizando el Feminismo: Teorías y Prácticas desde los Márgenes. Espanha: Cátedra, 2008.

CERTEAU, Michel de. A cultura plural. Paris: UGE, 1974.

A escrita da história. Rio de Janeiro: Forense Universitária, 2011.

CHARTIER, Roger. O mundo como representação. In. Estudos Avançados. Vol. 11, n ${ }^{\circ}$, 1991.

COLLINS, Patricia Hill. It's all in the family: intersections of gender, race and nation. In.: Hypatia. v.13. $\mathrm{n}^{\circ}$. 3. Border Crossings: Multicultural and Postcolonial Feminist Challenges to Philosophy. p. $62-82,1998$.

COSTA PINHEIRO, Ana Alice. Avances y definiciones del movimento feminista em Brasil. Dissertação (Mestrado em Sociologia) - Facultad de Ciências Políticas y Sociales, México, 1981.

COSTA, Ana Alice de Alcântra. O movimento feminista no Brasil: dinâmicas de uma intervenção política. In Niterói. Vol, 5, n 2, p. 9 - 35, 2005.

DAHL, Robert. Polyarchy: participation and opposition. New Haven: Yale University Press, 1971.

DAVIES, B.; HARRÉ,R. Positioning: the discursive production of selves. Journal for the Teory os Social Behaviour. v. 20. n¹. P. 43-63, 1990.

DESCARRIES, Francine. Teorias feministas: liberação e solidariedade no plural. In. Textos de História. Dossiê Feminismo: teoria e perspectiva. Brasília: UnB, vol. 8, n 1/2, p. 09-46, 2000 .

Um feminismo em múltiplas vozes, um movimento em atos: os

feminismos no Quebéc. In.: Labrys, estudos feministas. Brasília: UnB. nº 12, julho/dezembro 2002. 
DINIZ, Antony Henrique Tomaz. Mulheres ilhadas: representações do feminismo entre jovens mulheres universitárias em Belo Horizonte. In. Primeiros Estudos. São Paulo, n 2, p. $98-118,2012$.

FARIA, Claudia Feres.; PETINELLI, Viviane; LINS, Isabela Lourenço. Conferências de políticas públicas: um sistema integrado de participação e deliberação? In. Revista brasileira de ciência política. $n^{\circ}$ 7, p. 249 - 284, 2012.

FERREIRA, Elizabeth F. Xavier. Mulheres - militância e memória. Rio de Janeiro: Fundação Getúlio Vargas, 1996.

FERREIRA, Verônica C. Entre emancipadas e Quimera - Imagens do feminismo no Brasil. In Cadernos AEL. Campinas, n 3/4, 1995/1996.

FOUCAULT, Michel. Arqueologia do poder. Rio de Janeiro: Forense Universitária, 1986. A ordem do discurso. São Paulo: Loyola, 2009.

As palavras e as coisas: uma arqueologia das ciências humanas. 8. Ed. São Paulo: Martins Fontes, 1999.

Microfísica do poder. Rio de Janeiro: Graal, $1993 .$.

GIDDENS, Anthony. A transformação da intimidade: sexualidade, amor e erotismo nas sociedades modernas. São Paulo, UNESP, 1993.

GONZALEZ, Débora de Fina. Entre público, privado e político: avanços das mulheres e machismo velado no Brasil. Cadernos de Pesquisas. v. 44. n . 151. P. 228 - 247, 2014.

GURZA LAVALlE, Adrian. Democracia, Pluralização da Repressentação e Sociedade Civil. Lua Nova. n67, 2006.

HALBWANCHS, Maurice. A memória coletiva. São Paulo: Vértice, 1990.

HALL, Stuart. The Work of Representation. In.: HALL, Stuart (Org.). Representation: Cultural Representations and Signifying Practices. Sage/Open University: London/Thousand Oaks/New Delhi, 1997.

HANISCH, Carol. Women's Liberation Movement, 1969

JODELET, Denise. Representações sociais: um domínio em expansão. In. ARRUDA, Angela (Org.). As representações sociais. Rio de Janeiro, EDUERJ, 2001.

KATO, Shelma Lombardi de. Direitos humanos e direitos das mulheres. Palestra em Comemoração aos 50 anos da Declaração dos DDHH, 1998.

KOSELLECK, Reinhart. Futuro passado: contribuição à semântica dos tempos históricos. Rio de Janeiro: Contraponto: PUC - Rio, 2006.

KRAISH, Adriana. M.P.O. O patrimônio arqueológico como elemento do patrimônio cultural. In.: ANPUH, 2007.

KROLOKKE, C.; SCOTT, A. Three waves of feminism: from suffragettes to girls. In: KROLOKKE, C.; SCOTT, A. Gender communication theories and analyses: from silence to performance. Thousand Oaks: SAGE, 2006. p. 1-24.

LAURETIS, Teresa. A tecnologia do gênero. In. Technologies of gender. Indiana University Press, p. 1 - 30, 1987.

LE GOFF, Jacques. História e memória. Campinas: Unicamp, 1990. 
Patrimônio histórico, cidadania e identidade cultural: o direito à memória. In.: BITTENCOURT, Circe (Org.). O saber histórico na sala de aula. São Paulo: Contexto, 2007.

LEON, Magdalena. Movimiento social de mujeres y paradojas de América Latina. In: LEON, Magdalena (Org.). Mujeres y participación politica. Avances y desafios en América Latina. Bogotá:Tercer Mundo, 1994.

LOBO, Elizabete Souza. Mulheres, feminismo e novas praticas sociais. Revista de Ciências Sociais. Porto Alegre, v. 1, n. 2, 1987.

MOLYNEUX, Maxine. Movimientos de mujeres en América Latina. Un estdio teórico comparado. Madrid: Catedra - Universidad de Valencia, 2003.

MACAULEY, Fiona. Gender politics in Brazil and Chile: the role of parties and national and local policymaking. Hampshire/New York: Palgrave Macmillan, 2006.

MANSBRIDGE, Jane. Beyond adversary democracy. Chicago: University of Chicago Press, 1980.

Rethinking representation. American Political Science Review. v.

97. $\mathrm{n}^{\circ} 4.2003$.

MÉNDEZ, Natalia Pietra. Feminismo, imprensa e poder no Brasil contemporâneo. In MÉTIS: história \& cultura. Caxias do Sul, vol. 6, n 12, p. 269 - 288, jul./dez., 2007.

MIRANDA, Cyntia Mara. Os movimentos feministas e a construção de espaços institucionais para a garantia dos direitos das mulheres no Brasil e no Canadá. IX ENCONTRO DA ABCP - Genero, Democracia e Políticas Públicas. Brasília, 2014.

MOSCOVICI, Serge. A representação social da psicanálise. Rio de Janeiro: Zahar Editores, 1978.

.; VIGNAUX, George. Le concept de thêmata. In. GUIMELLI, C.

(Org.). Structures et transformations des représentations sociales. Lausanne: Delachaux et Niestlé, p. 25 - 71, 1994.

MUNIZ, Diva do Couto Gontijo. Mulheres na historiografia brasileira: práticas de silêncio e inclusão diferenciada. In: STEVENS, Cristina et. al. Gênero e feminismos: convergências (in)disciplinares. Brasília: Editora Libris, 2010, p. 65-79.

NAVARRO-SWAIN, Tania. Feminismo e Representações Sociais: A invenção das mulheres nas Revistas "Femininas". In História: Questões \& Debates. Curitiba, n 34, p. 11 44, 2001.

O’BRIEN, Patrícia. A história da cultura de Michel Foucault. In. HUNT, Lynn (Org.). A nova história cultural. São Paulo: Martins Fontes, 2001.

OGAWA, Haruyuki.; MIDORIKAWA, Nobuyuki.; SAITO, Ken-ichiro., ITSUMURA, Hiroshi; KANEKO, Masatsugo; NIKI Emiko. How much of cited conference materials can be found using bibliographic tools? In. Journal of the American Society for Informatios Science. New York, vol. 40, n 5, p. 350 - 355, Sept. 1989.

OLIVEIRA, Rosiska Darcy de. O Século XXI começou em Pequim. In: IV Conferência Mundial sobre a Mulher - Beijing, China - 1995. Rio de Janeiro: FIOCRUZ, 1996.

OLIVEIRA, Susane Rodrigues de. Educação inclusiva e não-sexista: as políticas educacionais para a equidade de gênero no Brasil (2004-2007). In: ROSA, Renata de Melo; AVILA, Carlos 
F. Dominguez (Org.). Democracia, Desenvolvimento e Cidadania no Brasil: A construção de uma agenda de pesquisa em políticas públicas (volume 2). Curitiba: Editora CRV, 2012.

História das mulheres em plano de aula: mídias digitais

e saberes docentes na Internet. In Labrys. Estudos Feministas (Online). Brasília, 2015.

ORLANDI, Eni P. Análise de discurso: princípios e procedimentos. 5 ed. Campinas: Pontes, 2003.

PÁEZ, Dario. Características, funciones y proceso de formación de las representaciones sociales. In.__ et al. Pensamiento, individuo y sociedad: cognición y representación social. Madrid: Fundamentos, p. 297 - 317, 1987.

PATEMAN, Carole. Participation and democratic theory. Cambridge: Cambridge University Press, 1970.

PEDRO, Maria Joana. Narrativas fundadoras do feminismo: poderes e conflitos (1970 1978). In.: Revista Brasileira de História. São Paulo. v. 26. n 52. p. 249-272. 2006

; WOLFF, Cristina Sheibe (Org.). Gênero, feminismos e ditaduras no Cone Sul. Florianópolis: Ed. Mulheres, 2010.

PELEGRINI, Sandra. C. A. Cultura e natureza: os desafios das práticas preservacionistas na esfera do patrimônio cultural e ambiental. In.: Revista Brasileira de História. São Paulo. v. 26. $\mathrm{n}^{\circ}$ 51. p. $115-140,2006$.

PERROT, Michelle. Escrever uma história das mulheres: relato de uma experiência. In. Cadernos Pagu. Vol. 4, p. 9 - 28, 1995.

PESAVENTO, Sandra Jatahy. História e História Cultural. Belo Horizonte: Autêntica, 2004.

PIMENTA, Fabrícia Faleiros. Políticas feministas e os feminismos na política: o Conselho Nacional dos Direitos da Mulher (1985 - 2005). Tese de doutorado apresentada no Programa de Pós-graduação em História da Universidade de Brasília. Brasília, 2010

PIMENTAL, Sílvia.; PANDJIARJIAN, Valéria. Direitos humanos a partir de uma perspectiva de Gênero. Revista da Procuradoria Geral do Estado de São Paulo. ${ }^{\circ}$ 53. p. 107 $-139,2000$.

PINSKY, Carla Bassanezi \& PEDRO, Maria Joana (Org.). Nova História das Mulheres. São Paulo: Contexto, 2012.

PINTO, Celi Regina. Uma história do feminismo no Brasil. São Paulo: Fundação Perseu Abramo, 2003.

PITANGUY, Jacqueline.; MIRANDA, Dayse. As mulheres e os direitos humanos. In.: O progresso das mulheres no Brasil. UNIFEM/FORD FOUNDATION/ CEPIA - Cidadania, Estudo, Pesquisa, Informação e Ação. Brasília, 2006.

POBLACIÓN, Dinah Aguiar. Literatura cinzenta ou não convencional: um desafio a ser enfrentado. In. Ciência da Informação. Brasília, vol. 21, n 3, p. 243-246, Set./Dez., 1992.

POGREBINSCHI, Thamy. Conferências Nacionais e Políticas Públicas para Grupos Minoritários. Rio de Janeiro:Ipea - Instituto de Pesquisa Econômica Aplicada, 2012.

Democracia pragmática. Pressupostos de uma teoria empiricamente orientada. Dados - Revista de Ciências Sociais. Rio de Janeiro. v. 53. n ${ }^{\circ} 3$. $2010 b$. 
. Entre representação e participação: as conferências nacionais e o experimentalismo democrático brasileiro. Brasília: Ministério da Justiça, 2010a (Série Pensando o Direito).

. Participatory policymaking and political experimentalism in Brazil. In: KRON, S.; COSTA, S.; BRAIG, M. (Ed.). Democracia y reconfiguraciones contemporáneas del derecho en America Latina. Frankfurt \& Madrid: Vervuert, 2012.

; SANTOS, Fabiano. Participação como Representação: o impacto das conferências nacionais de políticas públicas no Congresso Nacional. Dados Revista de Ciências Sociais. Rio de Janeiro. v. 54. n 3. p.259 - 305, 2011.

POINDRON, Paul. The content, influence and value of scientific conference papers and proceedings. In. UNESCO Bulletin for Libraries. Paris, vol. 16, n 3, p. 113-126, May., 1962.

POLLACK, Michael. Memória e identidade social. In.: Estudos Históricos. Rio de Janeiro. v.5. $\mathrm{n}^{\circ} .10,1992$.

PRZEWORSKI, Adam. Democracy and the limits of self-government. Cambridge: Cambridge University Press, 2010.

RAGO, Margaret. A "mulher cordial": feminismo e subjetividade. In Verve. São Paulo, vol. 6, p. 279-296, 2004.

Adeus ao Feminismo? Feminismo e (Pós)Modernidade no Brasil. In Cadernos AEL. Campinas, n 3/4, 1995/1996.

Epistemologia feminista, gênero e história. In. PEDRO, Joana Maria;

GROSSI Miriam (Org.). Masculino, feminino, plural. Florianópolis: Editora Mulheres, 1998.

Os feminismos no Brasil: dos "anos de chumbo" à era global. In Labrys, Estudos Feministas. №3, Jan./Jul., 2003.

ROCHA, Thaíse Sá Freire. Refletindo sobre memória, identidade e patrimônio: as contribuições do programa de Educação Patrimonial do MAEA-UFJF. XVIII Encontro Regional (ANPUH-MG). Mariana-MG, 2012.

RODRIGUES, Cristiano. Atualidade do conceito de interseccionalidade para a pesquisa e prática feminista.In.: FAZENDO GÊNERO10, 2013.

RÜSEN, Jörn. Razão histórica: teoria da história - fundamentos da ciência histórica. $1^{\text {a }}$ reimpressão. Brasília: Editora UnB, 2010.

SAFA, Helen Icken. Women's social movements in Latin America. In.: Gender ans Society. v. 4. n³. Special Issue: Women and Development in the Third World. p. 354 - 369, 1990.

SANTOS, Wanderley Guilherme dos. O paradox de Rousseau. Uma interpretação democrática da vontade geral. Rio de Janeiro: Rocco, 2007.

SARTI, Cynthia Andersen. O feminismo brasileiro desde os anos 1970: revisitando uma trajetória. In. Revista Estudos Feministas. Florianópolis, vol. 12, n² 2, p. 35-50, 2004.

SCHUMAHER, Maria Aparecida; VARGAS, Elizabeth. Lugar no governo: álibi ou conquista? In. Revista Estudos Feministas. Florianópolis, n² 2, Nov., 1993.

; BRAZIL, Érico Vital (Org.). Dicionário Mulheres do

Brasil: de 1500 até a atualidade. Rio de Janeiro: Jorge Zahar Ed., 2000. 
SCOTT, Joan W. El problema de la invisivilidad. In. ESCANDÓN, C. R. (Org.). Gênero e História. México: Instituto Mora/UAM, 1989.

Gênero: Uma categoria útil para a análise histórica. Traduzido pela SOS: Corpo e Cidadania. Recife, 1990.

História das Mulheres. In. BURKE, Peter (Org.). A escrita da história: novas perspectivas. São Paulo: UNESP, p. 63-95, 1992.

Campinas/SP, 1994.

Preface a gender and politics of history. In.:Cadernos Pagu. $\mathrm{n}^{\circ} 3$.

The evidence of experience. In.: Critical Inquiry. Vol. 17, n. 4, p. 773-

797. 1991.

SOIHET, Rachel. Preconceitos nas charges de $\boldsymbol{O}$ Pasquim: mulheres e a luta pelo controle do corpo. In ArtCultura. Uberlândia, vol. 9, n 14, p. 39-53, Jan./Jun. 2007.

SOUZA, Celina. Políticas Públicas: uma revisão da literatura. Sociologias, Porto Alegre, ano $8, n^{\circ} 16$, jul/dez 2006, p. $20-45$.

SOUZA, Clóvis Henrique Leite de. A que vieram as conferências nacionais? Uma análise dos objetivos dos processos realizados entre 2003 e 2010. In. AVRITZER, Leonardo; SOUZA, Clóvis Henrique Leite de. Conferências Nacionais: atores, dinâmicas participativas e efetividade. Brasília: Ipea, 2013

Conferências e os desafios metodológicos de seu estudo.

In. PIRES, R. R. C. (Org.). Efetividade das instituições participativas no Brasil: estratégias de avaliação. Brasília: Ipea, 2011.

SPINK, Mary Jane (Org.). Práticas discursivas e produção de sentidos no cotidiano: aproximações teóricas e metodológicas. $2^{\mathrm{a}}$ ed. São Paulo: Cortez, 2000.

Linguagem e produção de sentidos no cotidiano. Rio de Janeiro: Centro Edelstein de Pesquisas Sociais, 2010.

.; MEDRADO, Benedito. Práticas de sentido no cotidiano: uma abordagem dircursiva. In.: SPINK, Mary Jane (Org.). Práticas discursivas e produção de sentidos no cotidiano. São Paulo: Cortez, 2000, p. 41 - 61.

STERBACH, Nancy Saporta; ARANGUREN, Marysa Navarro; CHUCHRYK, Patrícia e ÁLVAREZ, Sonia. Feminismo en América Latina: de Bogotá a San Bernardo. In. LEON, Magdalena (Org.). Mujeres y participación política. Avances y desafios en América Latina. Bogotá: Tecer Mundo, 1994.

TEIXEIRA, Ana Claudia Chaves; SOUZA, Clóvis Henrique Leite de.; LIM, Paula Pompeu Fiuza de. Conselhos e Conferências Nacionais: o que são, quantos existem e para que servem. In.: Arquitetura da Participação. Brasília: Inesc Instituto de Estudos Socioeconômicos e Instituto Pólis. 2010/2011.

TELLES, Vera da Silva. Direitos sociais: afinal do que se trata? Belo Horizonte: UFMG, 1999.

VALDÉS, Teresa. De lo social a lo político. La acción de lãs mujeres latino-americanas. Santiago: Lom Editora, 2000.

VALENTE, Virginia Vargas. Presupuestos sensibles al género: las experiencias en America Latina. Documento apresentado no Painel de Direito Internacional "Presupuestos nacionales para la equidad". Quito, 2000. 
VEYNE, Paul. Como se escreve a História. Foucault revoluciona a história. Brasília: Editora Universidade de Brasília, 1982.

VILLS BÔAS, Lúcia Pintor Santiso. Uma abordagem da historicidade das representações sociais. In. Cadernos de Pesquisa. Vol. 40, n 140, p. 379 - 405, Maio/Ago. 2010.

WOOD, D. N. The collection, bibliographic control and acessibility of grey literature. In. IFLA Journal. Wetherby, vol. 10, n³ 3, p. 278 - 282, Aug., 1984.

ZANETTI, Julia. Jovens Feministas: um estudo sobre a participação juvenil no feminismo. In Revista Fazendo Gênero. Florianópolis, n 8, 2008. 
ANEXO I 


\section{Conferência Nacional de Políticas para as Mulheres \\ ANAS}

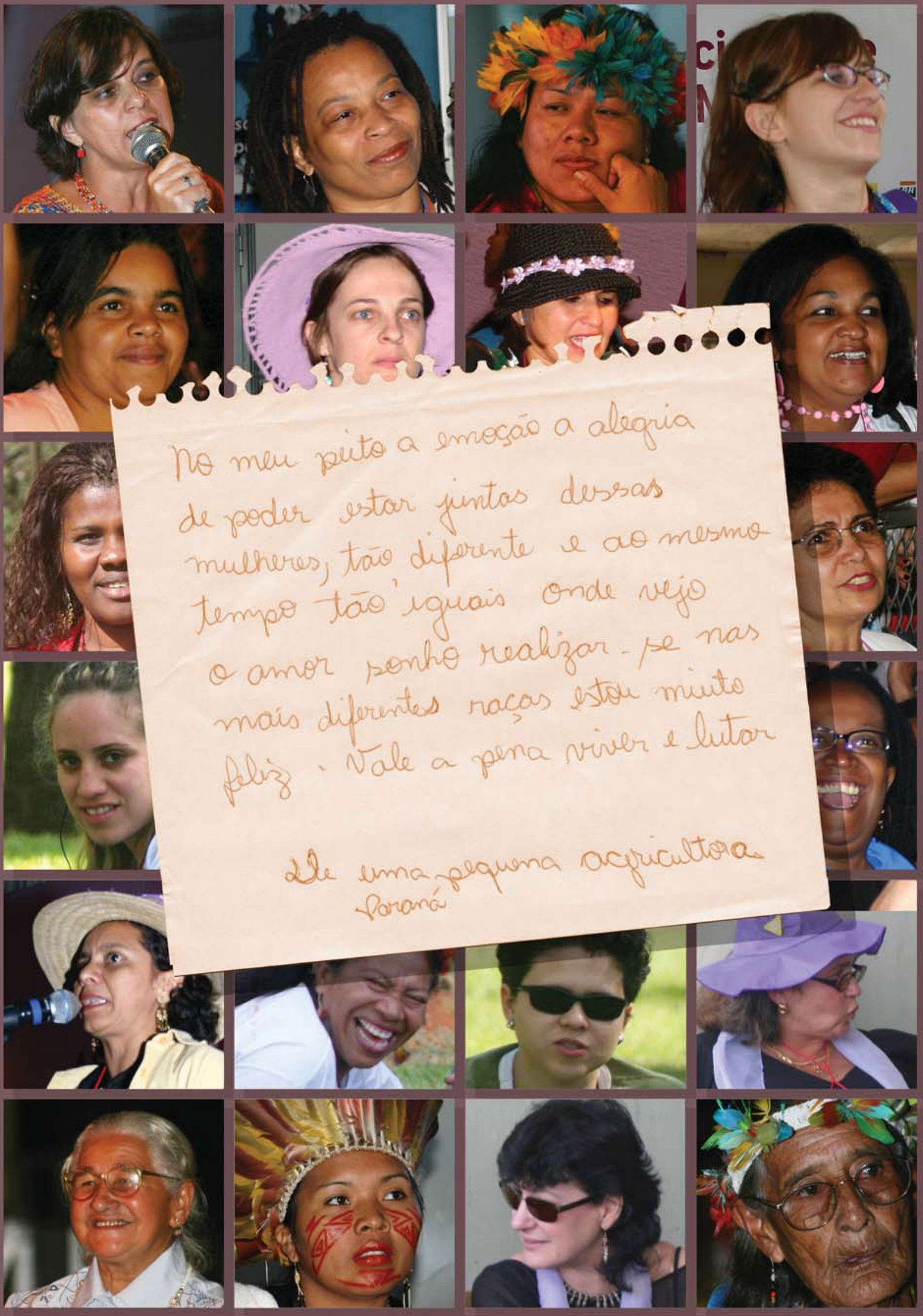

Presidência da República

Secretaria Especial de Políticas para as Mulheres 


\section{Conferência Nacional de Políticas para as Mulheres $\mathrm{AIN}$}




\section{Comissão Organizadora da I Conferência Nacional de Políticas para as Mulheres}

Nilcéa Freire - Presidenta

Marlise Maria Fernandes - Coordenadora Executiva

Angela Maria Mesquita Fontes, Eline Jonas, Maria Laura Sales Pinheiro, Nalu Faria, Nilza Iraci Silva, Maria

Aparecida Schuma Schumaher e Suely de Oliveira.

\section{Comissão de Mobilização}

Dirce Margarete Grosz, Maria Elisabete Pereira, Liège Santos Rocha e Teresa Cristina Nascimento Sousa.

\section{Comissão Especial Temática e de Relatoria}

Integrantes da Secretaria Especial de Políticas para as Mulheres

Suely de Oliveira - Coordenação, Angela Maria Mesquita Fontes, Sônia Malheiros Miguel, Liège Rocha e Cleide Silva.

Integrantes da Sociedade Civil indicadas pelo Conselho Nacional dos Direitos da Mulher

Clara Araújo, láris Ramalho Cortes, Lúcia Xavier, Márcia Camargo, Maria Lúcia da Silveira e Silvia Camurça.

\section{Equipe de Produção}

Patrícia Silva - Produção Executiva

Caíque Santiago, Eclesina Oliveira, Luisa Sena, Raphael Homem e Renata Correia - Assistentes de Produção.

\section{Secretaria Especial de Políticas para as Mulheres - Presidência da República}

Nilcéa Freire - Secretária Especial de Políticas para as Mulheres

Maria Laura Sales Pinheiro - Secretária Adjunta

Elisabete Matar Freire de Carvalho - Chefe de Gabinete

Teresa Cristina Nascimento Sousa - Assessora Especial

Angela Maria Mesquita Fontes - Subsecretária de Planejamento de Políticas para as Mulheres

Marlise Maria Fernandes - Subsecretária de Articulação Institucional

Suely de Oliveira - Subsecretária de Monitoramento de Programas e Ações Temáticas

\section{Conselho Nacional dos Direitos da Mulher}

\section{Representantes do Governo}

I - Secretaria Especial de Políticas para as Mulheres

Presidenta do Conselho: Nilcéa Freire

Assessora Técnica: Maria Laura Sales Pinheiro

II - Ministro de Estado do Planejamento Orçamento e Gestão: Guido Mantega

Assessora Técnica: Mariana Meirelles Nemrod Guimarães

III - Ministro de Estado da Saúde: Humberto Sergio Costa Lima

Assessora Técnica: Maria José de Oliveira Araújo

IV - Ministro de Estado da Educação: Tarso Genro

Assessor Técnico: Lúcia Helena Lodi

V - Ministro de Estado do Trabalho e Emprego: Ricardo Berzoini

Assessora Técnica: Rita de Cássia Munck

VI - Ministro de Estado da Justiça: Márcio Thomaz Bastos Assessora Técnica: Myriam Brea Honorato de Souza
VII - Ministro de Estado do Desenvolvimento Agrário: Miguel Soldatelli Rosseto

Assessora Técnica: Andréa Lorena Butto Zarzar

VIII - Ministro de Estado da Cultura: Gilberto Passos Gil Moreira

Assessora Técnica: Flávia Gomes de Galiza

IX - Ministro de Estado de Desenvolvimento Social e Combate à Fome: Patrus Ananias

Assessora Técnica: Hildézia Alves Medeiros

X - Secretaria Especial de Políticas de Promoção da Igualdade Racial: Matilde Ribeiro

Assessora Técnica: Denise Antonia de Paulo Pacheco

XI - Secretário Especial dos Direitos Humanos: Nilmário Miranda

Assessora Técnica: Isabel Maria Madeiro Loureiro Maior 


\section{Representantes de Entidades da Sociedade Civil}

01. Articulação de Mulheres Brasileiras - AMB Titular: Schuma Schumaher (Maria Aparecida Schumaher) Suplente: Analba Brazão Teixeira

02. Articulação Nacional de Mulheres Trabalhadoras Rurais - ANMTR

Titular: Justina Inês Cima

Suplente: Lúcia de Fátima Félix da Silva

03. Articulação de Ongs de Mulheres Negras Brasileiras Titular: Nilza Iraci Silva

Suplente: Givania Maria da Silva

04. Associação Brasileira de Mulheres de Carreira Jurídica ABMCJ

Titular: Gisela Zilsch

Suplente: Maria Dirce Mendonça Fonseca

05. Central Única dos Trabalhadores - CUT

Titular: Maria Ednalva Bezerra de Lima

Suplente: Carmen Helena Ferreira Foro

06. Confederação Geral dos Trabalhadores - CGT

Titular: Maria Lúcia Alves Dias

Suplente: Eliana Fernandes da Cruz Malfarage

07. Confederação das Mulheres do Brasil - CMB

Titular: Márcia de Campos Pereira

Suplente: Edna Maria Costa

08. Conselho Nacional das Mulheres Indígenas - CONAMI Titular: Dirce Cavalheiro Veron

Suplente: Maria do Socorro Pinheiro de Carvalho

09. Confederação Nacional dos Trabalhadores em Educação

- CNTE

Titular: Raquel Felau Guisoni

Suplente: Luzia Aparecida de Oliveira

10. Confederação Nacional dos Trabalhadores na Agricultura - CONTAG

Titular: Raimunda Celestina de Mascena

Suplente: Simone Battestin
11. Federação das Associações de Mulheres de Negócios e Profissionais do Brasil - BPW/BRASIL

Titular: Ana Luisa Fernandes Gonçalves

Suplente: Iria Martins

12. Federação Nacional das Trabalhadoras Domésticas FENATRAD

Titular: Creuza Maria Oliveira

Suplente: Maria Noeli dos Santos

13. Fórum de Mulheres do Mercosul

Titular: Maria Elvira Salles Ferreira

Suplente: Dalva Maria Thomaz Rocha

14. Movimento Articulado de Mulheres do Amazonas - MAMA Titular: Maria da Conceição Maia de Oliveira

Suplente: Maria das Graças Lopes de Castro

15. Ordem dos Advogados do Brasil - OAB

Titular: Marilma Torres Gouveia de Oliveira

Suplente: Maria Avelina Imbiriba Hesketh

16. Secretaria Nacional da Marcha Mundial das Mulheres Titular: Nalu Faria Silva

Suplente: Eleutéria Amora da Silva

17. Secretaria Nacional de Políticas para Mulher da Força Sindical

Titular: Neuza Barbosa Lima

Suplente: Helena Ribeiro da Silva

18. União Brasileira de Mulheres - UBM

Titular: Eline Jonas

Suplente: Mary Garcia Castro

19. Rede Nacional Feminista de Saúde, Direitos Sexuais e Direitos Reprodutivos

Titular: Ana Maria de Silva Soares

Suplente: Lia Zanotta Machado

\section{Mulheres com "notório conhecimento das questões de gênero"}

20. Rose Marie Muraro

21. Clara Charf

22. Albertina de Oliveira Costa 


\section{Conferência Nacional de Políticas para as Mulheres

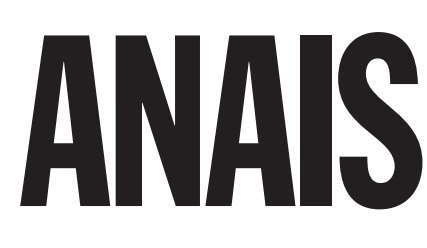

Secretaria Especial de Políticas para as Mulheres

Presidência da República

Brasília 2004 


\section{2004 Presidência da República \\ Secretaria Especial de Políticas para as Mulheres}

Elaboração, distribuição e informações:

Secretaria Especial de Políticas para as Mulheres - Presidência da República

Esplanada dos Ministérios, Bloco L, Edifício Sede, $2^{\circ}$ andar, Sala 200

70047-900 - Brasília - DF

Telefones: (55-61) 2104-9377 e 2104-9381

Fax: (55-61) 2104-9362 e 2104-9355

spmulheres@spmulheres.gov.br

www.presidencia.gov.br/spmulheres

\section{Edição}

Heloisa Frossard

Preparação de originais

Marlise Fernandes

Capa

Felipe Lopes

Fotos

Cláudia Ferreira

Distribuição gratuita

Tiragem: 5.000 exemplares

É permitida a reprodução total ou parcial desta publicação, desde que citada a fonte.

Apoio: UNFEME Fundo de Desenvolvimento das Nações Unidas para a Mulher

Dados Internacionais de Catalogação da Publicação

Brasil. Presidência da República. Secretaria Especial de Políticas para as Mulheres

Brasil. Presidência da República. Secretaria Especial de Políticas para as Mulheres.

Anais da Conferência - Brasília: Secretaria Especial de Políticas para as Mulheres,

2004. 164 p. (Série Documentos) 1.

1. Políticas Públicas. 2. Conferência de Mulheres. 3. Conselho Nacional dos Direitos da Mulher.l. Título. II. Série.

CDU 396

\section{4}




\section{Sumário}

$\begin{array}{ll}\text { Apresentação } & 9\end{array}$

$\begin{array}{ll}\text { Programação Geral } & 11\end{array}$

$\begin{array}{ll}\text { Abertura } & 15\end{array}$

$\begin{array}{ll}\text { Painel } 1 & 30\end{array}$

Análise da realidade brasileira, avaliando as políticas realizadas e os compromissos assumidos pelo Estado brasileiro

\section{Painel Internacional}

Diálogo Interativo sobre experiências internacionais com ministras e representações

internacionais

\section{Painel 2}

Apresentação de propostas de diretrizes para a construção do Plano Nacional de Políticas para as Mulheres

Resoluções da I Conferência Nacional de Políticas para as Mulheres 100 $\begin{array}{ll}\text { Anexos } & 146\end{array}$

Regulamento da I Conferência Nacional de Políticas para as Mulheres 146

Homenagem às mulheres brasileiras $\quad 153$

I Conferência Nacional de Políticas para as Mulheres: perfil das delegadas e perspectivas 157 de atuação - pesquisa realizada pelo Instituto Brasileiro de Administração Municipal (IBAM) Créditos 163

$\begin{array}{ll}\text { Patrocinadores } & 164\end{array}$ 


\section{Apresentação}

O Presidente da República ao convocar a I Conferência Nacional de Políticas para as Mulheres, através da Secretaria Especial de Políticas para as Mulheres SPM e do Conselho Nacional dos Direitos da Mulher - CNDM, no Ano da Mulher no Brasil, reafirmou o compromisso do governo com a construção da igualdade entre homens e mulheres em nosso país.

Consolidar a igualdade de gênero e igualdade racial não depende só da vontade política de um governo, mas depende, sobretudo da construção de uma política de gênero no país, com atribuições claras e bem definidas para as três esferas de governo, ou seja, municípios, estados e união, bem como para os poderes legislativo e judiciário, dialogando e construindo a com os poderes constituídos, e com a sociedade civil como um todo, especialmente com os movimentos de mulheres e os movimentos feministas.

Neste sentido, foram convidados pelo Governo Federal a participar do processo da conferência os municípios, os estados, os diferentes poderes constituídos e a sociedade civil. Cabe ressaltar o importante papel que desempenhou a Comissão Organizadora da I Conferência que contou com a ativa participação de integrantes da Secretaria Especial de Políticas para as Mulheres e dos movimentos de mulheres e feminista, através da sua representação no Conselho Nacional dos Direitos da Mulher.
Acreditamos que a Conferência foi repleta de êxito, na medida em que seu processo de elaboração envolveu mais de 120 mil pessoas nas plenárias municipais e nas conferências estaduais. Cerca de dois mil municípios realizaram suas plenárias e todas as unidades da Federação realizaram conferências estaduais.

0 processo da Conferência foi um rico exercício de democracia, de diálogo e de cooperação, vivenciado tanto pela sociedade civil quanto pelos governos. Algumas vezes um exercício dolorido e sofrido, mas que resultou em importantes avanços na perspectiva de concretizar políticas públicas para as mulheres. A partir da experiência do processo de construção da I Conferência Nacional de Políticas para as Mulheres, podemos dizer que ele foi pedagógico.

Durante três dias, em Brasília, reuniram-se 1.787 delegadas governamentais e da sociedade civil que assistiram painéis de debates, apresentações artísticas e participaram de muitas discussões, principalmente nos trabalhos de grupo, que indicaram as propostas de diretrizes que foram objeto de votação na plenária final e que compõem as resoluções finais desta I Conferência Nacional de Políticas para as Mulheres.

Para consolidar uma política nacional para as muIheres, estamos aprofundando a discussão a partir 
das diretrizes resultantes da Conferência através da formulação de um Plano Nacional de Políticas para as Mulheres, avançando na consolidação e ampliação dos direitos das mulheres, bem como na construção da igualdade de gênero.

0 compromisso com a igualdade, além de ser um compromisso de governo, deve ser um compromisso incondicional de cada brasileiro e de cada brasileira.
Segundo o presidente Luiz Inácio Lula da Silva, "a democracia contemporânea não pode se limitar aos direitos econômicos e políticos. A igualdade de gênero é uma dimensão inalienável da justiça social no mundo de hoje". Assim, apresentamos os anais da I Conferência Nacional de Políticas para as MuIheres e confiamos que este processo tenha contribuído de maneira decisiva para a construção de um Brasil solidário para homens e mulheres em toda sua diversidade.

Nilcéa Freire Secretária Especial de Políticas para as Mulheres Presidenta do Conselho Nacional dos Direitos da Mulher 


\section{Programa}

\section{Programação}

\section{Conferência Nacional de Políticas para as Mulheres}

\section{5 de julho de 2004, quinta-feira 8 h30 - 9h30 - Teatro do Oprimido}

\section{$9 \mathrm{~h} 30$ - 10h - Abertura}

Composição da Mesa - Senhor Luiz Inácio Lula da Silva, Presidente da República; Senhora Nilcéa Freire, Ministra da Secretaria Especial de Políticas para as Mulheres; Senhora Marisa Letícia Lula da Silva, Primeira-dama; Senhora Dilma Rousseff, Ministra de Estado de Minas e Energia; Senhora Marina Silva, Ministra de Estado do Meio Ambiente; Senhora Matilde Ribeiro, Ministra da Secretaria Especial de Políticas de Promoção da Igualdade Racial; Senadora Serys Slhessarenko, Presidenta da Comissão Especial do Ano da Mulher no Senado Federal; Deputada Federal Jandira Feghali, Presidenta da Comissão Especial do Ano da Mulher na Câmara dos Deputados; Senhora Nilza Iraci, Representante do Conselho Nacional dos Direitos da Mulher.

\section{Homenagens}

\section{Show da Cantora Margareth Menezes}

\section{4h - 15h30 - Aprovação do Regulamento}

Composição da Mesa - Sra Maria Laura Sales Pinheiro, Secretária Adjunta da Secretaria Especial de Políticas para as Mulheres - SPM; Sra Marlise Fernandes, Subsecretária de Articulação Institucional da Secretaria Especial de Políticas para as Mulheres SPM; Sra Schuma Schumaher, Representante da Articulação Brasileira de Mulheres e integrante do Conselho Nacional dos Direitos das Mulheres - CNDM; Sr ${ }^{a}$ Maria Ednalva Bezerra de Lima, Representante da Central Única dos Trabalhadores e componente do Conselho Nacional dos Direitos das Mulheres - CNDM; Sra Liège Rocha, Gerente de Projetos da Secretaria Especial de Políticas para as Mulheres - SPM.
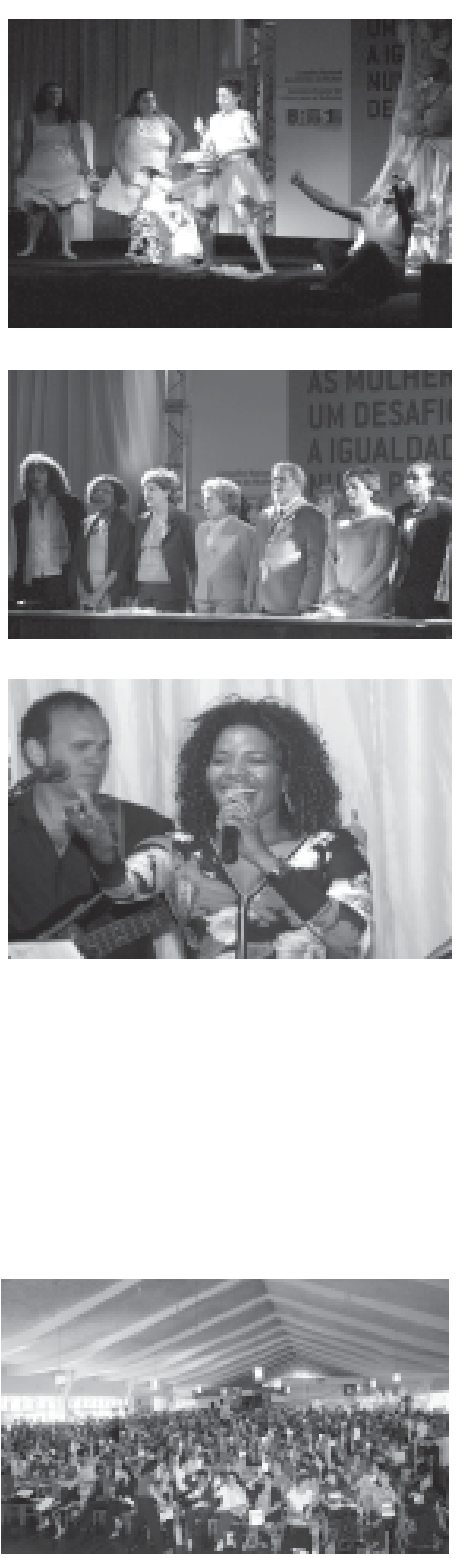


\section{5h30 - 17h - Painel 1}

Análise da realidade brasileira, avaliando as políticas realizadas e os compromissos assumidos pelo Estado Brasileiro.

Coordenação da Mesa - Sra Wanda Menezes, Secretária da Mulher do Governo do Estado de Alagoas

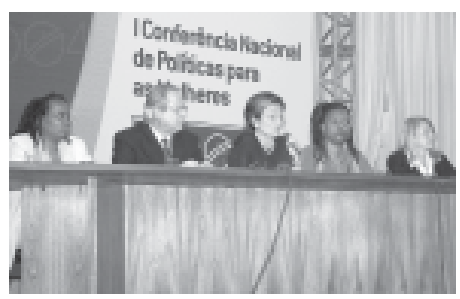

Palestrantes - Ministra Nilcéa Freire, Secretária Especial de Políticas para as Mulheres - SPM; Ministro José Dirceu, Chefe da Casa Civil da Presidência da República; Sra Sueli Carneiro, Coordenadora Executiva do Geledés - Instituto da Mulher Negra; Sra Jacqueline Pitanguy, Diretora da CEPIA - Cidadania, Estudo, Pesquisa, Informação e Ação.

\section{7h -18h - Debate}

\section{8h - 19h30 - Painel Internacional}

Diálogo Interativo sobre Experiências Internacionais com Ministras e representações internacionais

Coordenação da Mesa - Ministra Nilcéa Freire, Secretária Especial de Políticas para as Mulheres - SPM; Sra Márcia de Campos Pereira, Representante da Federação Internacional das Mulheres e componente do Conselho Nacional de Direitos da Mulher - CNDM.

Composição da Mesa - Ministra Patrícia Espinosa, Presidente do Instituto da Mulher do México; Sra Amélia Paiva, Presidenta da Comissão para a Igualdade e pelos Direitos das Mulheres, Portugal; Deputada Nérida Quintero, Cuba; Deputada Biatriz Paredes, Presidenta da Fundação Colosio, México; Sra Ariadna Reyes, Representante do Conselho Nacional da Mulher do Equador; Sra Virgínia Gúzman, Consultora da Comissão Econômica para a América Latina - CEPAL-ONU.

\section{6 de julho de 2004, sexta-feira}

\section{8 h30 - 9h30 - Painel 2}

Apresentação de propostas de diretrizes para a construção do Plano Nacional de Políticas para as Mulheres.

Coordenação da Mesa - Sr ${ }^{a}$ Mara Vidal, Secretaria da Mulher do Governo do Estado do Acre.

Palestrantes - Ministra Matilde Ribeiro, Secretaria Especial de Políticas de Promoção da Igualdade Racial - SEPPIR; Sra Maria Laura Sales Pinheiro, Secretária Adjunta da Secretaria Especial de Políticas para as Mulheres - SPM; Sra Maria Bethânia Ávila Socióloga e Coordenadora Geral do SOS Corpo (Instituto Feminista para a Democracia); Sra Nalu Faria, Coordenação da Marcha Mundial de Mulheres; Sr ${ }^{a}$ Dirce CavaIheiro Veron, Representante do Conselho Nacional das Mulheres Indígenas - CONAMI, no Conselho Nacional de Direitos da Mulher - CNDM. 


\section{0h - 12h - Grupos de trabalho}

1. Enfrentamento da pobreza: geração de renda, trabalho, acesso ao crédito e a terra.

2. Superação da violência contra a mulher: prevenção, assistência, combate e políticas de segurança.

3. Promoção do bem-estar e qualidade de vida para as mulheres: saúde, moradia, infra-estrutura, equipamentos sociais, recursos naturais.

4. Efetivação dos direitos humanos das mulheres: civis, políticos, sexuais e reprodutivos.

5. Desenvolvimento de políticas de educação, cultura, comunicação e produção do conhecimento para a igualdade.

\section{4h - 15h30 - Grupos de trabalho}

1. Enfrentamento da pobreza: geração de renda, trabalho, acesso ao crédito e a terra.

2. Superação da violência contra a mulher: prevenção, assistência, combate e políticas de segurança.

3. Promoção do bem-estar e qualidade de vida para as mulheres: saúde, moradia, infra-estrutura, equipamentos sociais, recursos naturais.

4. Efetivação dos direitos humanos das mulheres: civis, políticos, sexuais e reprodutivos.

5. Desenvolvimento de políticas de educação, cultura, comunicação e produção do conhecimento para a igualdade.

\section{2h - Show da cantora Elba Ramalho}

\section{7 de julho de 2004, sábado}

\section{8 h30 - 12h - Plenária Final}

Composição da Mesa - Sra Maria Laura Sales Pinheiro, Secretária Adjunta da Secretaria Especial de Políticas para as Mulheres - SPM; Marlise Fernandes, Subsecretária de Articulação Institucional da Secretaria Especial de Políticas para as Mulheres - SPM; Sra Maria Ednalva Bezerra de Lima, Representante da Central Única dos Trabalhadores - CUT no Conselho Nacional dos Direitos das Mulheres - CNDM; Sra Eline Jonas, Representante da União Brasileira de Mulheres - UBM no Conselho Nacional dos Direitos das Mulheres - CNDM; Sra Mari Machado, representante governamental, Ministério de Ciência e Tecnologia -MCT.

\section{4h - 18h - Plenária Final}

Composição da Mesa - Sra Maria Laura Sales Pinheiro, Secretária Adjunta da Secretaria Especial de Políticas para as Mulheres - SPM; Sra Marlise Fernandes, Subsecretária de Articulação Institucional da Secretaria Especial de Políticas para as Mulheres - SPM; Sra Maria Ednalva Bezerra de Lima, Representante da Central Única dos
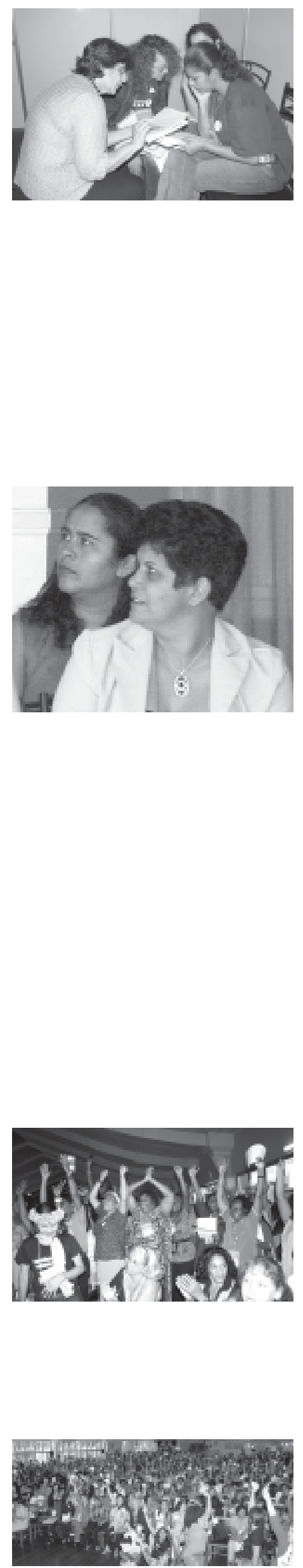
Trabalhadores - CUT no Conselho Nacional dos Direitos das Mulheres - CNDM; Sra Eline Jonas, Representante da União Brasileira de Mulheres - UBM no Conselho Nacional dos Direitos das Mulheres - CNDM; Sra Mari Machado, representante governamental, Ministério de Ciência e Tecnologia - MCT. 


\section{5 de julho de 2004}

\section{AbERTURA \\ I Conferência Nacional de Políticas para as Mulheres}

\section{Mesa de Abertura}

Sr. Luiz Inácio Lula da Silva, Presidente da República

Sra Nilcéa Freire, Ministra de Estado da Secretaria Especial de Políticas para as Mulheres

Sr ${ }^{a}$ Marisa Letícia Lula da Silva, Primeira-dama

$\mathrm{Sr}^{\mathrm{a}}$ Dilma Rousseff, Ministra de Estado de Minas e Energia,

$\mathrm{Sr}^{\mathrm{a}}$ Marina Silva, Ministra de Estado do Meio Ambiente

$\mathrm{Sr}^{\mathrm{a}}$ Matilde Ribeiro, Ministra de Estado da Secretaria Especial de Políticas de Promoção da Igualdade Racial

Senadora Serys Slhessarenko, Presidenta da Comissão Especial do Ano da Mulher no Senado Federal

Deputada Federal Jandira Feghali, Presidenta da Comissão Especial do Ano da Mulher na Câmara dos Deputados

Sra Nilza Iraci, Representante do Conselho Nacional dos Direitos da Mulher
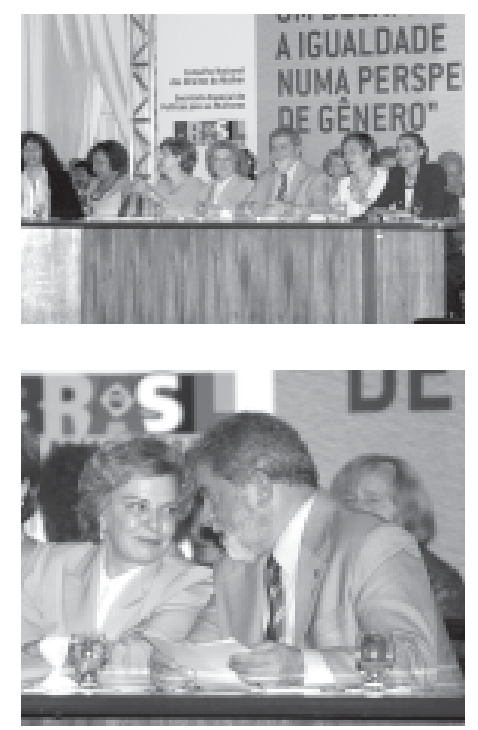

Mestre de Cerimônias: Sra Zezé Mota

\section{Transcrição das falas da Abertura}

\section{Sra Nilza Iraci - Representante do Conselho Nacional dos Direitos da Mulher:}

Bom dia a todas

Excelentíssimo Senhor Presidente da República, Luiz Inácio Lula da Silva, Senhora Marisa Letícia, Senhora Ministra Nilcéa Freire, Presidenta do Conselho Nacional dos Direitos da Mulher, em nome de quem eu cumprimento todas as minhas queridas Conselheiras,

Senhoras e senhores Ministros,

Demais autoridades,

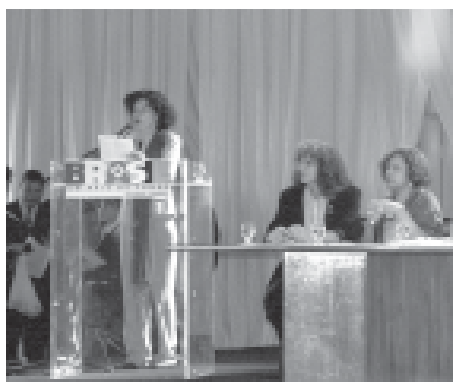




\section{5 de jullho de 2004}

Senhoras, senhores,

E queridas mulheres, que atravessaram este país, de norte a sul, leste a oeste, de barco, ônibus, avião, a pé, para juntar as suas vozes a esse belíssimo coro, que vai entoar e compor uma belíssima canção, que vai ecoar por todo o Brasil.

Quero cumprimentar, especialmente, as nossas irmãs índias, que acabaram de realizar a sua I Conferência Nacional.

Nós, mulheres brasileiras, fomos protagonistas de importantes mudanças no país, no último século: na casa, na rua e na política. Não somos mais as mesmas. Mudamos e contribuímos para os avanços da sociedade. Estamos na luta permanente para mudar o Brasil e por um mundo fraterno, solidário, sem violência, sem preconceito, sem sexismo, sem racismo e com justiça social.

Nós, mulheres brasileiras, há muito afirmamos que políticas públicas para as mulheres devem ser pensadas com integralidade, ou seja, na junção das políticas econômicas com as políticas sociais.

Senhor Presidente,

Senhoras e senhores,

Temos a convicção de que fomos nós, as mulheres, que pavimentamos o caminho para o enfrentamento do medo pela sociedade brasileira. Fomos nós, as mulheres, que mostramos que a esperança pode vencer o medo.

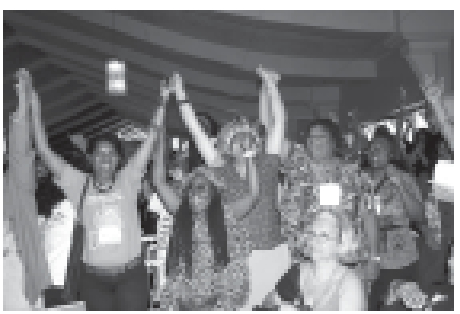

As mulheres negras venceram o medo e tiveram a coragem de romper com uma estrutura racista e patriarcal, que thes negava a humanidade. As lésbicas tiveram a coragem de romper com os padrões hegemônicos dos donos dos sentimentos e demonstrar que não existe uma única maneira de amar e serem amadas.

As agricultoras, que revolvem a terra, semeiam e colhem mais que nossos alimentos cotidianos, nos devolvem esperança. As feministas, que demonstraram que os direitos das mulheres são direitos humanos e que a autonomia é fundamental para que possamos governar nossas vidas, nossos corpos, nossa sexualidade, nosso país.

Não é nenhuma novidade um encontro reunindo tantas mulheres. A novidade é que estejamos aqui atendendo a um chamado do Presidente da República, a quem que- 


\section{5 de Julho de 2004}

ro cumprimentar pela coragem de convocar as mulheres para esta Conferência e ouvir o que elas têm a dizer e a propor sobre políticas e diretrizes para a construção de um plano de igualdade que vai beneficiar não apenas as mulheres, mas a toda a sociedade.

Em nome do Conselho Nacional dos Direitos da Mulher, quero saudar a todas e a cada uma das mulheres que estão aqui, mensageiras de tantas outras que não dos Direitos da Mulher puderam estar presentes neste momento, mas que deram enorme contribuição para que ele acontecesse. A elas também as nossas homenagens. E o compromisso, a certeza de que vamos levar de volta, para cada estado, cada município deste país, a boa nova de que a esperança que venceu o medo pode, também, vencer as barreiras que ainda hoje impedem a igualdade e a autonomia das mulheres.

Estaremos, nos próximos dois dias, construindo mais um capítulo da História. As mulheres esperam que todos, governantes e sociedade, se juntem a nós nessa árdua empreitada de construir um mundo mais feliz, mais humano, mais solidário, mais digno.

Que as nossas ancestrais africanas, que as deusas das florestas nos iluminem nessa tarefa de construir o mundo que queremos.

Bem-vindas a todas e bem-vindos a todos, à nossa I Conferência Nacional de Políticas para as Mulheres.

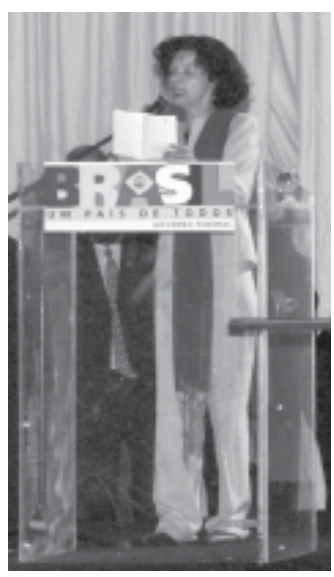




\section{5 de julho de 2004}

Sr ${ }^{a}$ Nilcéa Freire - Ministra da Secretaria Especial de Políticas para as Mulheres

Bom dia a todas e a todos.

Excelentíssimo Senhor Presidente da República, Luiz Inácio Lula da Silva,

Exma Senhora Marisa Letícia,

Minhas queridas companheiras ministras Dilma Rousseff, Marina Silva e Matilde Ribeiro,

Minhas caras companheiras, parceiras de trabalho, Deputada Jandira Feghali e Sena-

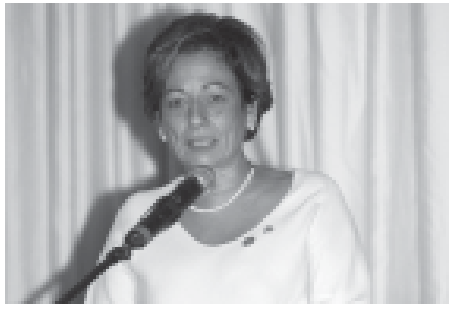
dora Serys Slhessarenko, presidentas, respectivamente, das Comissões do Ano da MuIher na Câmara dos Deputados e no Senado Federal,

Minha querida companheira do Conselho Nacional dos Direitos da Mulher, Nilza Iraci, representando neste ato a sociedade civil.

$$
\begin{aligned}
& \text { É preciso ter força, } \\
& \text { é preciso ter garra, } \\
& \text { é preciso ter memória! }
\end{aligned}
$$

Em 1988, caravanas de mulheres vieram a Brasília no movimento da Constituinte para garantir que nossos direitos estivessem inscritos na Constituição do Brasil.

Em 1997, 2000, 2002, 2003, em Salvador, na Paraíba, em Brasília, no Rio Grande do Sul, encontros feministas e de mulheres aconteceram.

Em 1997 e 1999, saímos do Brasil e fomos para o Chile, para a Costa Rica, fomos também para Washington e para Nova York dizer NÃO a todas as formas de violência e discriminação contra as mulheres.

Fizemos o "Planeta Fêmea" na Eco-92 e, em 1993, em Viena, finalmente, conseguimos que os direitos das mulheres fossem reconhecidos como direitos humanos. Estivemos no Cairo, em 1994 e, em 1995, tivemos uma participação histórica na Conferência de Beijing. Em Durban, reunimos a maior delegação de mulheres negras presentes àquela Conferência.

As mulheres negras se organizaram em encontros nacionais, em 1988, 1992 e 2001. Prepararam-se também, em seminários específicos para Cairo e Beijing. Organizaram, em 2004, um Fórum Nacional e, hoje, representam, nesta Conferência, cerca de $46 \%$ das delegadas. 


\section{5 de Julho de 2004}

As mulheres índias, ao longo de todo o ano de 2003, fizeram encontros regionais. E, nesta semana, segunda e terça-feira, fizeram a $1^{\text {a }}$ Conferência Nacional das Mulheres Índias, mostrando a força da sua organização nascente.

0 ano de 2004, Ano da Mulher no Brasil, instituído por força de Lei pelo Congresso Nacional, por indicação do Deputado Maurício Rabelo, e sancionada pelo Presidente Luiz Inácio Lula da Silva, marca uma inflexão positiva, na luta de tantas e tantas mulheres que estão aqui conosco, e daquelas que aqui não podem estar, porque ainda não conquistaram o direito a ter sua voz ouvida. Este ano marca também 0 reconhecimento de muitas outras mulheres que dedicaram suas vidas à causa da LIBERDADE E DA JUSTIÇA e que, lamentavelmente, já nos deixaram, como a querida Ângela Borba, que hoje, coincidentemente, é aniversário de sua morte.

Nesse momento de abertura da nossa Conferência, quero render uma homenagem especial à ex-Ministra Emília Fernandes que, no ano de 2003, iniciou seu processo de convocação.

Foram muitas plenárias municipais, mais de dois mil municípios as realizaram. Os 26 estados da Federação e o Distrito Federal, fizeram as etapas estaduais da Conferência. Fomos 120 mil mulheres a participando diretamente desse processo.

120 mil mulheres

Queria pedir às minhas companheiras do Conselho Nacional dos Direitos da Mulher que se levantassem, porque juntamente com a Secretaria Especial de Políticas das Mulheres, foram responsáveis pela convocação e realização desta Conferência. Aplausos para elas!

Durante as etapas municipais e estaduais dizíamos que, para além da tarefa imprescindível de estimular o debate, havia um sentido mais amplo na nossa participação nos Estados: captar onde as mulheres vivem seu cotidiano e a enorme diversidade que constitui a maior riqueza do nosso país. Esta diversidade está expressa aqui, através das diretrizes e propostas encaminhadas pelas conferências estaduais.

Estivemos juntas, mulheres profissionais liberais, mulheres donas de casa, mulheres trabalhadoras rurais, mulheres extrativistas e da floresta, mulheres índias, mulheres lésbicas, mulheres de todos os credos religiosos, mulheres urbanas, enfim, mulheres que entendiam o sentido dessa conferência: inscrever definitivamente na estrutura das políticas do nosso país a perspectiva da igualdade entre homens e mulheres. 
0 resultado desses encontros traduziu-se em 3.844 propostas. Senhor Presidente, estas propostas foram consolidadas em diretrizes que, a partir de amanhã, estaremos discutindo em grupos de trabalho e sessões plenárias. Diretrizes que convergem com a perspectiva de inclusão do nosso governo e ratificam que é na afirmação das diferenças que vamos garantir a igualdade.

Senhor Presidente, eu estou muito emocionada. Foram cinco meses até chegarmos a este momento, período que mais ou menos coincide com o convite que, com muita honra e muito orgulho, recebi de Vossa Excelência para integrar sua equipe de trabalho à frente da Secretaria Especial de Políticas para as Mulheres. Durante este tempo, todos os dias, diante das dificuldades que por vezes enfrentávamos, me lembrava do que Vossa Excelência havia me dito em seu gabinete, no dia da minha posse e dos novos componentes do seu ministério. Quando Ihe perguntei o que Vossa Excelência esperava de mim, ouvi: espero que a Secretaria, sob a sua liderança, represente a todas as mulheres brasileiras e mais: que você tenha ousadia.

Temos tentado seguir sua recomendação e corresponder a sua confiança. Mas devemos dizer, ousadia maior é a de Vossa Excelência convocar Conferências em todas as áreas de governo, sendo esta mais uma, no mais inédito e amplo processo de consulta popular que já aconteceu neste país. A ousadia e a coragem de nos submetermos à avaliação e para, através do diálogo com a sociedade que vos elegeu, construirmos juntos uma plataforma concreta de trabalho. A ousadia e a persistência que corresponde ao espírito de todas as brasileiras, que corresponde ao espírito de todas as patriotas e todos os patriotas aqui presentes.

Eu vou pedir perdão às companheiras dos 14 estados onde pude, pessoalmente, acompanhar as Conferências Estaduais e vou repetir uma parte do discurso que fiz naquelas solenidades de abertura, quando ao homenagear as mulheres ali presentes, fazia uma pequena homenagem particular a uma grande brasileira: a escritora e poetisa Lya Luft.

Então, para todas as mulheres aqui presentes, alguns versos de Canção das Mulheres, de Lia Luft.

"Que o outro saiba quando estou com medo e me tome nos braços sem fazer perguntas demais. 


\section{5 de Julho de 2004}

Que o outro note quando preciso de silêncio e não vá embora batendo a porta, mas entenda que não o amarei menos porque estou quieta.

Que se eu, eventualmente, perco a paciência, perco a graça e perco a compostura, o outro ainda assim me ache linda e me admire.

Que o outro — filho, amigo, amante, marido — não me considere sempre disponível, sempre necessariamente compreensiva, mas me aceite quando não estou podendo ser nada disso.

Que, finalmente, o outro entenda que mesmo se às vezes me esforço, não sou, nem devo ser, a mulher-maravilha, mas apenas uma pessoa: vulnerável e forte, incapaz e gloriosa, assustada e audaciosa - uma mulher".

Um grande abraço a todas as mulheres aqui presentes, um grande abraço para as minhas companheiras da Secretaria Especial de Políticas para Mulheres.

Bem vindas à I Conferência Nacional de Políticas para as Mulheres!

Muita força companheiras e vamos à luta!

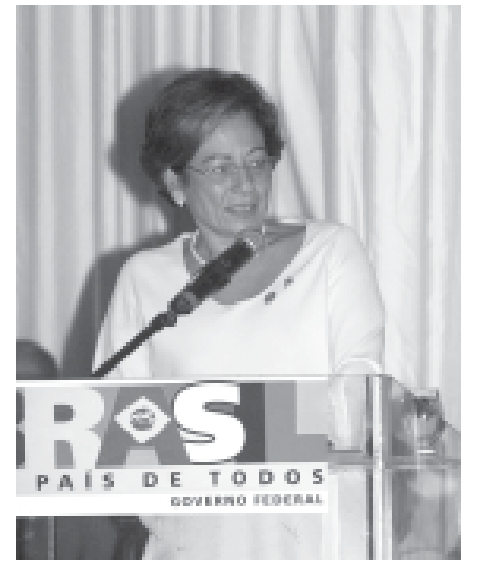




\section{Sr. Luiz Inácio Lula da Silva - Presidente da República}

Minha querida companheira Nilcéa Freire, Secretária Especial de Políticas para as Mulheres,

Minha querida companheira Marisa,

Senhores embaixadores estrangeiros presentes neste ato,

Meus companheiros ministros e ministras,

Quero dizer para vocês que não tiveram a oportunidade de ver o espetáculo que eu vi, que nós vimos daqui da frente, os ministros sentadinhos aí, pela primeira vez se sentindo minoria absoluta num plenário, batendo palmas envergonhados, querendo dançar, mas com vergonha de dançar. Eu espero que eles comecem a aprender, senão a ser minoria, pelo menos a serem iguais, porque não estávamos habituados a sermos iguais e sim a sermos maioria absoluta em tudo que fazíamos.

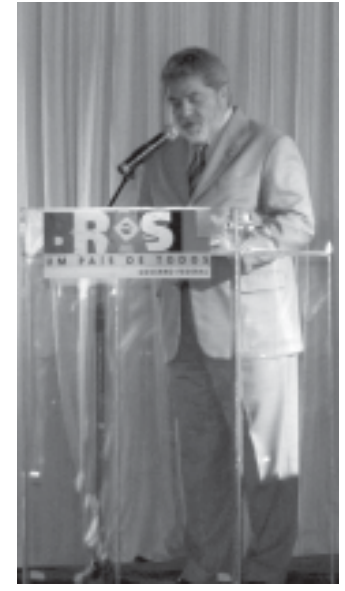

conferências
Minha querida Zezé Mota, minhas queridas companheiras Benedita da Silva e Emília Fernandes, minha querida companheira Clara Charf, em nome de quem eu quero homenagear as mulheres aqui presentes e todas as homenageadas. Eu acho que a Clara Charf tem uma especial participação na luta das mulheres em nosso país. Quero cumprimentar a nossa querida Serys, senadora, presidente da Comissão Especial do Ano da Mulher, no Senado Federal. Quero cumprimentar a companheira Jandira Feghali, presidente da Comissão Especial do Ano da Mulher, na Câmara dos Deputados. Quero cumprimentar os deputados federais, deputados estaduais, prefeitos. Quero cumprimentar a senhora Nilza Iraci, representante do Conselho Nacional dos Direitos da Mulher e, sobretudo, quero cumprimentar as delegadas que vieram para este Encontro.

Esta é a nona conferência de que eu participo nesses 18 meses. Algumas, como esta, significam a primeira conferência nacional. E não fazemos isso apenas porque gostamos de participar de conferência, fazemos isso porque - eu dizia em toda a minha vida sindical e minha vida política - a maior obra que um governante pode deixar para o seu povo não é a quantidade de asfalto que ele fez ou a quantidade de salas de aula. Mas é a relação que o Estado estabelece com a sociedade e a relação que a sociedade estabelece com o Estado.

legislação

Por isso, essas conferências são extremamente necessárias, porque o que for decidido por vocês e o que for transformado em projetos, em leis, decretos ou medidas provisórias, amanhã ninguém poderá dizer que é uma obra desse ou daquele cidadão ou dessa ou daquela cidadã, mas terá que dizer que é o resultado de uma conferência 


\section{5 de jullho de 2004}

que trouxe a experiência de centenas de conferências que vocês fizeram nas cidades, dezenas nos estados e que, portanto, vai balizar o comportamento de todo o conjunto do governo, através da nossa ministra Nilcéa, para que a gente possa aperfeiçoar as políticas de gênero no nosso país.

Portanto, abrir esta Conferência Nacional é uma experiência que me orgulha e me alegra, porque renova o compromisso que assumi, desde meus tempos de líder sindical, com a luta das mulheres.

Eu me lembro como se fosse hoje, o primeiro Congresso das Mulheres Metalúrgicas que realizamos em janeiro de 1978, em São Bernardo do Campo. Aqui neste evento podemos contar mais de duas mil mulheres que fazem dos movimentos sociais, das entidades sindicais, das organizações não-governamentais ou dos diferentes órgãos do governo em que trabalham um espaço para a conquista de seus direitos.

Vocês trazem até Brasília o que foi debatido em mais de duas mil plenárias municipais ou regionais, e também nas conferências realizadas em todas as 27 unidades da Federação. Trazem, acima de tudo, resultados de uma discussão da qual participaram mais de 120 mil mulheres em todo o território nacional. É por essa intensa mobilização, por essa vontade de contribuir com a elaboração de uma política pública para a questão de gênero, que vejo em vocês uma capacidade extraordinária para reverter a dívida histórica que o Brasil tem com a mulher brasileira.

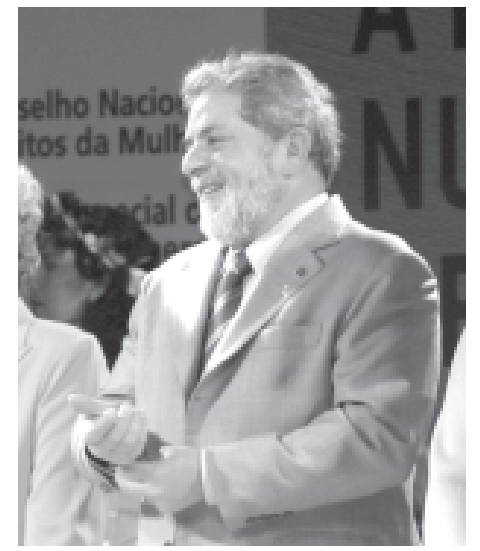

Várias gerações de brasileiras e brasileiros foram educados segundo uma cartilha que relegava a papel secundário, ou a nenhum papel, as mulheres do nosso país. Felizmente essa mentalidade já mudou e mudou muito.

E mudou principalmente graças à mobilização das próprias mulheres que em diferentes espaços da sociedade, lutaram, ao longo da história, para conquistar direitos e ampliar a consciência política da nossa população.

Na luta contra a escravidão, por exemplo, nós tivemos destacadas abolicionistas como Chiquinha Gonzaga. No início do século XX, uma greve de costureiras deflagrou uma série de movimentos em favor da jornada de 8 horas de trabalho no nosso país.

Em 1917, as mulheres conquistaram o direito de ingressar no serviço público. Em 1919, a Conferência do Conselho Feminino da OIT aprovou o salário igual para 


\section{5 de julho de 2004}

trabalho igual, destacando-se a participação de duas brasileiras no evento: Bertha Lutz e Olga de Paiva Meira.

voto feminino

luta contra a ditadura e pela anistia
Em 1933, Carlota Pereira Queiroz tornou-se a primeira deputada brasileira. Um ano mais tarde, a Assembléia Constituinte assegurou o princípio da igualdade entre os sexos, o direito ao voto feminino, a regulamentação do trabalho da mulher e a equiparação salarial com os homens.

Isso para não falar da luta contra a ditadura, principalmente o forte movimento pela Anistia, que contou com intensa participação e liderança de valorosas mulheres brasileiras.

Sei que praticamente todas vocês aqui presentes desempenharam, e desempenham, papéis importantíssimos nessas batalhas, fazendo a sociedade e o Estado reconhecerem suas conquistas.

Minhas amigas, minhas queridas companheiras de luta.

É preciso ter sempre em mente qual é a situação da mulher brasileira hoje. Importantes espaços nas empresas privadas e na vida pública já deixaram de ser exclusividade masculina. Ao contrário de antes, por exemplo, as mulheres passam mais anos estudando do que os homens.

Há, contudo, graves problemas que continuam atingindo negativamente as brasileiras do Oiapoque ao Chuí. Mesmo quando têm igual escolaridade, o salário médio das mulheres é bem inferior ao dos homens. $E$, se a mulher for negra, o salário é menor ainda.

Infelizmente, também encontramos empregadores que, a esta altura da história, preferem funcionários do sexo masculino somente porque as mulheres podem ficar grávidas.

Temos hoje, de acordo com dados do IBGE, 15 milhões de lares chefiados por mulheres. Em apenas 1 milhão e meio desses lares, ou seja, um em cada dez, as mulheres contam com a ajuda de um companheiro para o sustento da família. Nos demais casos, elas dependem apenas da própria fibra para realizar o verdadeiro milagre que é encontrar um modo de sobrevivência digno para si e sua família. 


\section{5 de Julho de 2004}

Ao mesmo tempo, as mulheres continuam sendo vítimas constantes da violência.

Pesquisa da Fundação Perseu Abramo apontou, em 2001, dados estarrecedores sobre este tema.Mostrou que uma em cada três brasileiras já havia sofrido, ao menos uma vez na vida, algum tipo de violência física. E que na grande maioria dos casos, 0 agressor estava dentro de sua própria casa. Eram maridos, ex-maridos, namorados ou ex-namorados, entre outros.

Minhas amigas,

Desde que assumi a Presidência da República, tenho me empenhado, tomando medidas efetivas, para mudar essa situação, em parceria com os movimentos de mulheres. Nestes 18 meses, conseguimos alguns avanços significativos, entre os quais vou destacar os seguintes.

Nossa primeira ação foi transformar a Secretaria de Estado dos Direitos da Mulher, que era vinculada ao Ministério da Justiça, em Secretaria Especial de Políticas para as Mulheres, diretamente subordinada à Presidência da República e com status de Ministério.

No que se refere à questão da violência, criamos no ano passado o Programa de Prevenção, Assistência e Combate à Violência Contra a Mulher. Por meio dele, buscamos não apenas punir o agressor, mas, principalmente, criar mecanismos de conscientização que previnam e evitem a agressão.

Em relação à violência doméstica, criamos em março passado um grupo de trabalho interministerial, que está atuando intensamente, envolvendo as Secretarias de Políticas para Mulheres, a Secretaria de Direitos Humanos e a Secretaria de Segurança Pública, entre outros órgãos do governo federal.

Sancionei também, no final de 2003, uma lei que obriga todas as unidades de serviços notificação compulsória de saúde, públicas ou privadas, a notificarem os casos atendidos de violência contra a mulher. Na verdade, eu hoje de manhã tive a preocupação de ligar para o meu ministro Humberto Costa, e essa lei já foi regulamentada, não foi publicada porque teve alguns erros. Disse-me o ministro Humberto Costa, que ela está na Casa Civil para fazer os acertos e ser publicada, mas que todos os formulários já estão prontos para que, na área da saúde, esse problema seja efetivamente solucionado. 
Em parceria com 5 estados brasileiros, já capacitamos 2 mil profissionais de 150 delegacias especializadas no atendimento à mulher. Ao mesmo tempo, estamos olhando com especial atenção para as mulheres que vivem e trabalham no campo. Lançamos em maio o Programa Nacional de Documentação da Mulher Trabalhadora Rural.

Com ele, as assentadas da reforma agrária e as agricultoras familiares estão conquistando o direito de ter seus documentos básicos, como certidão de nascimento, CPF, carteiras de identidade e de trabalho.

Esse tipo de ação é extremamente importante. Ter os próprios documentos é uma das conquistas básicas da cidadania. Sem eles, as pessoas não conseguem existir oficialmente, tornam-se praticamente invisíveis para o Estado brasileiro. No caso específico das mulheres do campo, a documentação permitirá também o acesso aos benefícios sociais do governo, principalmente políticas sociais como o Bolsa Família.

Com o PRONAF-Mulher, as agricultoras familiares podem pegar financiamentos do governo federal para investir na produção e pagá-los em até 8 anos. Agora, não é só o marido que pode pegar o crédito. Mesmo que ele já tenha um financiamento, a mulher pode obter outro para fazer o seu próprio investimento na produção.

É importante Nilcéa, e é importante vocês ficarem atentas, porque nós criamos isso no ano passado e, possivelmente, não teremos feito a comunicação adequada. $E$ nós não tivemos a procura, no Banco do Brasil, no BNB e no Basa, que nós imaginávamos que fôssemos ter. $E$, possivelmente, o erro esteja em nós mesmos, talvez esteja no próprio movimento sindical rural, porque a gente não orientou corretamente a família de como proceder para que tanto o homem quanto a mulher, ou o filho de 18 anos, pudessem ter acesso ao financiamento do Pronaf.

Vocês sabem que na safra 2003/2004, nós liberamos $83 \%$ do dinheiro que nós colocamos à disposição. Foi a primeira vez que o PRONAF virou nacional, sobretudo na região Norte e Nordeste, onde praticamente as pessoas não tinham acesso ao dinheiro, porque muitas vezes os gerentes dos bancos não estavam preparados para atender 0 trabalhador mais humilde. E nós, este ano, colocamos 7 bilhões à disposição e nós queremos que os 7 sejam contratados, e eu disse, num encontro com os dirigentes sindicais, que não faltará dinheiro para financiar a agricultura familiar, que é responsável por grande parte da produção dos alimentos que nós comemos neste país. 


\section{5 de Julho de 2004}

O governo também inovou, em outubro de 2003, ao reconhecer direitos da mulher assentada em projetos de reforma agrária que antes vinham sendo ignorados. Criamos, por exemplo, a titularidade conjunta da terra. Quando uma família é, hoje, beneficiada com um lote em assentamento rural, a escritura sai em nome do marido e da mulher, e não apenas em nome do marido, como era antes.

0 compromisso do Brasil em relação às questões de gênero também está presente na nossa política externa.

O nosso país é signatário, desde 1974, da Convenção sobre a Eliminação de Todas as Formas de Discriminação Contra a Mulher, aprovada pela ONU. Ela é uma verdadeira Carta Magna dos Direitos das Mulheres.

Mas foi só em 2003, durante nosso governo, que o Brasil enviou ao Comitê da Convenção o seu primeiro relatório de ações no sentido de cumprir a pauta da convenção. Com isso, demonstramos a todo o mundo que o tema é parte central da agenda do nosso governo.

Minhas queridas companheiras,

Minhas queridas amigas,

O Plano Nacional de Políticas para as Mulheres, que todas vocês estão ajudando a construir aqui neste momento, vai significar um grande salto de qualidade nessa caminhada.

Esse plano estabelecerá um conjunto de ações permanentes, tornando ainda mais eficaz a política de gênero em todos os ministérios e outros órgãos do governo federal.

Quero dar os meus parabéns à companheira ministra Nilcéa Freire pelo trabalho que vem desenvolvendo à frente da Secretaria Especial de Políticas para as Mulheres, e a todas vocês que construíram esse belo momento.

E quero também dar um destaque especial a uma decisão que, certamente, tem 0 Bolsa família dedo das mulheres brasileiras. 0 programa Bolsa Família que distribui o projeto Fome Zero e Bolsa Escola num único projeto. Hoje, 93\% de todo o dinheiro do Bolsa 
Família é entregue diretamente para as mulheres, porque nós partimos do pressuposto de que quando o dinheiro chega na mão da mulher, será cuidado com mais carinho e gasto com mais eficácia, sem desvio, para que ele cumpra a sua finalidade.

Eu quero desejar a vocês que esta Conferência possa contribuir de forma muito concreta para avançarmos nessa luta, que é libertar as mulheres, na verdade, libertar a todos nós.

A Nilcéa falou de uma conversa que nós tivemos, quando eu pedi ousadia. Eu me lembro que em 1978, quando fizemos o primeiro congresso das metalúrgicas, eu disse que a conquista dos espaços políticos das mulheres e que a liberdade que tanto as mulheres buscavam, não seria obra de nenhum governo e muito menos dádiva, mas seria conquista da organização das próprias mulheres.

Conferência Nacional de Políticas para as Mulheres
Esta Conferência, além de juntar gente do Brasil inteiro, gente com as mais diferentes experiências nos poderes Executivo, no Legislativo, no movimento sindical, no movimento social, nas igrejas, em tantos outros organismos institucionais e não institucionais, precisa sair daqui com uma consciência muito maior, sobretudo, vocês mulheres, que aprenderam muito mais do que nós e que sabem ter paciência.

As mulheres não precisam nem gritar, as mulheres, diferentemente de nós, não precisam nem esbravejar, porque todos nós, por mais bravos que sejamos, sabemos que de vez em quando precisamos reconhecer que, na maioria das vezes, as nossas companheiras têm razão no relacionamento que têm conosco.

É essa paciência que precisa encontrar em vocês a certeza de que o que nós estamos fazendo no Brasil neste momento, é tentando construir as bases para que a gente possa fazer as profundas coisas de que o Brasil precisa. E quero dizer para vocês que muitas coisas não podem ser feitas em 18 meses, muitas coisas não podem ser feitas em 4 anos, e, possivelmente, tenha outras coisas que não possam ser feitas em mais anos.

0 que é importante é que estejamos dando passos, por menores que eles sejam, para que a gente possa estabelecer uma nova relação entre Estado e a sociedade. 


\section{5 de Julho de 2004}

Eu quero desejar para vocês, minha querida companheira Nilcéa, que vocês tenham a ousadia de uma Rigoberta Menchú, que se dependesse da lógica dos homens, certamente, não teria ganhado o Prêmio Nobel da Paz.

Não é a lógica de governo que tem que prevalecer e muito menos a lógica dos homens. 0 que tem que prevalecer nessa relação é a lógica da consciência, é a lógica do amadurecimento, é a lógica da convivência democrática na diferença e nas adversidades. 0 que tem que prevalecer é essa aula de democracia que vocês estão dando ao Presidente da República e ao Brasil com a realização desta Conferência.

Vão em frente e boa luta para vocês!

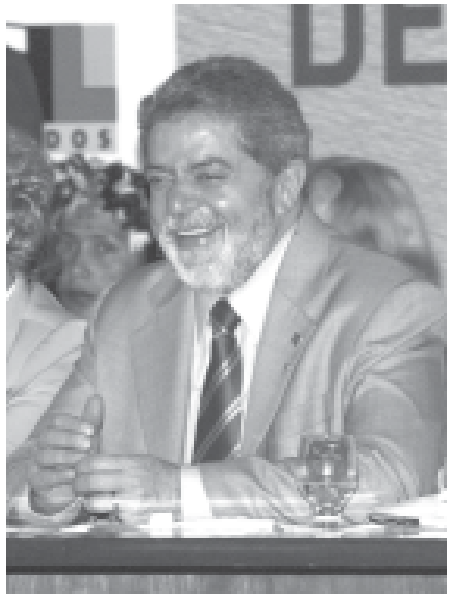




\section{Dia 15.07.2004}

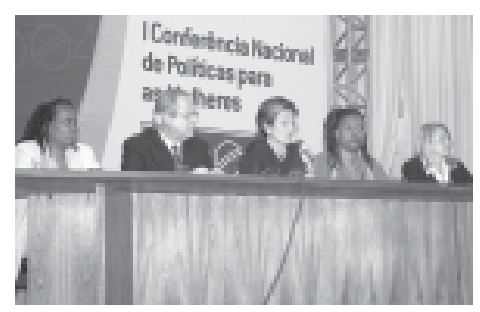

\section{Painel 1}

\section{Análise da realidade brasileira, avaliando as políticas realizadas e os compromissos assumidos pelo Estado Brasileiro}

\section{Palestrantes:}

Sr ${ }^{a}$ Jacqueline Pitanguy, diretora da CEPIA - Cidadania, Estudos, Pesquisa, Informação e Ação

Sra Sueli Carneiro, diretora do Instituto da Mulher Negra - Geledés e Articulação de Mulheres Negras - AMN

Sra Nilcéa Freire, ministra da Secretaria Especial de Políticas para as Mulheres da Presidência da República - SPM

Sr. José Dirceu, ministro Chefe da Casa Civil da Presidência da República

\section{Coordenação:}

Sr ${ }^{a}$ Wanda Menezes, Secretária da Mulher do Governo do Estado de Alagoas SEMULHER

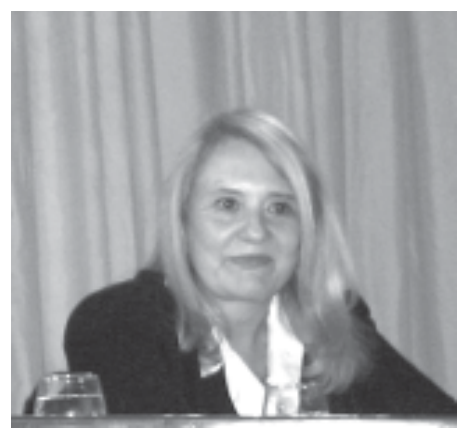

\section{$\mathrm{Sr}^{\mathrm{a}}$ Jacqueline Pitanguy}

Agradeço o convite da Secretaria de Políticas para a Mulher para participar desta relevante Conferência. Sinto-me honrada em usar a palavra em um momento como este, e cumprimento a Ministra Nilcéa Freire, ao Ministro José Dirceu, a companheira Suely Carneiro e a todas as delegadas presentes.

Este é um momento de celebração, por estarmos juntas aqui, neste cenário de poder, somando forças, apoiadas em nossa memória coletiva de lutas, conquistas e desafios, reconhecendo nossa diversidade e construindo estratégias conjuntas.

Este é também um momento de reflexão sobre os caminhos percorridos para que as diretrizes e estratégias que vão emergir desta Conferência incorporem nosso passado não como uma recordação saudosista e sim como um elemento fundamental na construção do futuro.

Nesta apresentação, pretendo traçar, de forma breve, os percursos do feminismo no Brasil, as principais estratégias seguidas pelos movimentos de mulheres, e deixar algumas perguntas, que nos assombram neste novo milênio. 


\section{5 de Julho de 2004}

Gostaria de começar ressaltando que no Brasil as mulheres são titulares de direitos tardios, que ainda não foram suficientemente absorvidos no imaginário social. Excluídas até 1932 do direito ao sufrágio, uma das características da participação política da mulher no Brasil tem sido a sua escassa presença nos partidos políticos e em cargos eletivos e sua forte participação em movimentos e associações diversos. A participação da mulher no legislativo federal tem sido extremamente limitada. Em 1933 foi eleita a primeira deputada federal e, nos 70 anos seguintes somente 143 mulheres se elegeram para a Câmara dos Deputados no Congresso Federal, em comparação com 6.619 homens sendo que 116 destas se elegeram a partir do final dos anos 80 quando o debate sobre 0 acesso da mulher ao poder político já havia ganhado espaço na sociedade.

Apesar de que nossa Constituição de 1988 afirma a igualdade de todos perante a lei há uma distância muito grande entre esta declaração formal e a percepção social desta igualdade, percepção esta que ainda interpenetra o Legislativo, o Executivo, 0 Judiciário, e as diversas instâncias da vida social. Apesar dos inegáveis avanços do movimento de mulheres o imaginário social brasileiro ainda é, em grande parte, marcado pela visão da mulher como uma cidadã de segunda categoria.

É, portanto, necessário que se realize um exercício cotidiano de ação pedagógica junto ao Estado e à sociedade. As Conferências Municipais e Estaduais de Políticas para as Mulheres assim como este grande encontro nacional, além de traçarem diretrizes e estabelecerem prioridades de ação política, são também uma ação pedagógica visando a sensibilização de interlocutores diversos para que incorporem a idéia de que os direitos das mulheres são direitos humanos e que, enquanto tal, devem ser respeitados em seu aspecto normativo e traduzidos em políticas públicas adequadas, de maneira que seja possível vivenciar no cotidiano direitos adquiridos no plano formal.

Estamos aqui reunidas, a partir de espaços governamentais e da sociedade civil, para traçar políticas de gênero. Gostaria de ressaltar que o desenvolvimento de tais políticas encontra os seus limites e possibilidades nos contextos nacional e internacional e que sua dinâmica obedece a bagagem histórica já acumulada e aos desafios das novas conjunturas. Por esta razão, vou apresentar de forma resumida considerações sobre a história recente do movimento de mulheres e sua interlocução com 0 poder público. Falarei também sobre a agenda dos direitos da mulher nos anos 1990, marcados pela internacionalização dos movimentos sociais. Gostaria também de 


\section{5 de jullho de 2004}

refletir sobre as implicações da transformação sofrida pelo conceito de direitos humanos, tanto em termos de significado, quanto de seu alcance para as políticas públicas de gênero.

Gostaria de distinguir alguns momentos que caracterizam o movimento de mulheres e as políticas de gênero, ressaltando que não significa que não haja justaposiç̧ões entre estes momentos, pois, como sabemos, a história não se escreve de forma linear. Estes momentos seriam

1- No contexto da ditadura o surgimento do Feminismo como ator político na esfera pública-1975-1982;

2-A redemocratização e a agenda de políticas públicas para a mulher - 1983-1990;

3- A internacionalização das agendas: globalização econômica, universalização dos direitos humanos, conferências das Nações Unidas;

4- 0 novo século: nós, aqui, hoje.

Falarei brevemente sobre algumas características mais marcantes destes períodos.

No Brasil o feminismo irrompe na arena política nos anos 70, década caracterizada por intensa mobilização contra a ditadura e pelo surgimento de movimentos sociais no cenário publico. Estes movimentos, que continuam a atuar ao longo dos anos 80, ampliaram o campo do político, alargando a compreensão das contradições sociais para além do estritamente econômico, revelando a existência de outras formas de exercício do poder. Tais movimentos trouxeram o individual para o campo do político, tornandoo coletivo, demonstrando que alem das relações de classe também as relações de gênero, raça e etnia se concretizam numa distribuição desigual de poder.

É neste momento histórico de autoritarismo, de contestação e de luta que o feminismo ressurge como um movimento organizado, que passa a se constituir em inegável força política, com enorme potencial de transformação social.

Surgem, neste contexto, inúmeras organizações, que atuam como núcleos congregando grande número de mulheres, desenvolvendo atividades diversas, grupos de trabalho, pesquisas, debates, cursos, publicações - e participando das campanhas que levaram as mulheres às ruas dando visibilidade as suas reivindicações específicas, ao lado das reivindicações pelos direitos civis e políticos e pelo fim do regime militar. 


\section{5 de Julho de 2004}

Estas organizações tinham em comum, o fato de se colocarem de forma autônoma frente aos partidos políticos, pois suas agendas ultrapassavam os limites das diferentes correntes partidárias. Isto não significava que rejeitassem os partidos, expressão política fundamental do processo democrático. Ao contrário, buscavam interlocução com estes, no sentido de influenciar suas plataformas. De fato, o movimento feminista trouxe para o interior dos partidos políticos a questão da mulher, pois uma característica que marca desde os anos 1970 este movimento é o seu investimento em influenciar o governo, buscando interlocução com o legislativo (Código Civil 1976), apresentando demandas aos partidos nas eleições de 1979 (Alerta Feminista) e a partir da vitória da oposição em 1982 em Minas e São Paulo e Rio de Janeiro, reivindicando e construindo espaços institucionais a nível estadual como os conseIhos, e as delegacias especializadas.

A criação de Conselhos Estaduais voltados para o desenvolvimento de políticas para as mulheres inaugura o segundo momento deste nosso caminhar onde se destaca 0 ano de 1985 quando o CNDM inaugura uma agenda de políticas públicas a nível federal. Este período coincide com a redemocratização das instituições políticas e a elaboração de uma nova constituição.

No plano legislativo, a Constituição de 1988 traça um marco normativo igualitário para homens e mulheres no âmbito da sociedade conjugal, reconhece a violência intrafamiliar como questão de governo, afirma o direito a livre escolha no âmbito da reprodução, avança na garantia de Direitos específicos na esfera do trabalho, incluindo o trabalho doméstico, da previdência, da mulher rural, dentre outros.

Eu tive a oportunidade histórica e a honra de presidir o Conselho Nacional de Direitos da Mulher por quatro anos, durante o processo Constituinte. Com muitas companheiras aqui presentes, em um trabalho conjunto, conseguimos articular esse grande processo de interlocução política com as diversas faces do movimento de mulheres e com o Congresso Nacional, que foi chamado de o "lobby do batom". Cabe também reconhecer a importância da bancada feminina que se constituiu na Assembléia Nacional Constituinte onde as parlamentares conseguiram, apesar das suas diferenças político-partidárias, trabalharem em conjunto. 0 Conselho Nacional enviou, ao Congresso naquela época, mais de 100 propostas, emendas substitutivas e constitutivas.

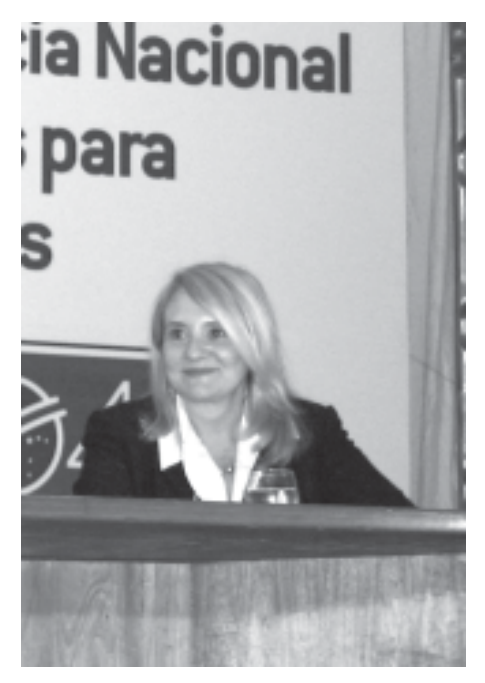

Conselho Nacional dos Diretios da Mulher

Constituição de 1988

A Constituição brasileira é um documento que me emociona profundamente porque 
foi escrito efetivamente por uma luta política que as mulheres, a partir do governo e da sociedade civil, escreveram conjuntamente. 0 sucesso do CNDM, entre 1985-89, deveu-se ao desenvolvimento de uma ação programática eficiente, e a sua capacidade de interlocução enquanto um ator forte e legitimo, com outros órgãos de estado, particularmente com o legislativo e com conselhos estaduais, com a academia através de apoio a programas de pesquisa, com a mídia, com grupos de juristas e, sobretudo, com feministas e movimentos de mulheres com os quais mantinha uma permanente comunicação, estreitando os laços entre sociedade civil e estado, rotos durante mais de 21 anos.

Durante estes anos, atuando em consonância com o Conselho Nacional dos Direitos da Mulher e com Conselhos locais o movimento de mulheres teve a capacidade de articular demandas e estabelecer estratégias de encaminhamento de propostas constitucionais e de políticas publicas.

Cabe, no entanto, ressaltar que o campo de ação política e a agenda do movimento de mulheres comportam temáticas cuja legitimidade social é bastante diversa. Desde uma perspectiva ampla, o campo de ação política do feminismo é o das relações de gênero. Este campo, que se constrói também no nível imaginário e simbólico, se desdobra em esferas específicas tais como: violência doméstica, direitos sexuais, direitos reprodutivos, mercado de trabalho, educação, participação política, e que não gozam da mesma legitimidade social nem da mesma capacidade de informar políticas publicas. Assim é que a luta contra a violência doméstica, presente nas plataformas do movimento de mulheres desde seus primórdios, sempre alcançou maior aceitação na sociedade brasileira do que aquela travada pelo respeito aos direitos reprodutivos.

Nesta última frente de ação o movimento sempre encontrou a pressão contrária de setores mais conservadores e seu avanço tem sido mais lento, pois é mais sinuoso 0 caminho percorrido para incorporar questões ligadas a sexualidade, a contracepção, a contracepção de emergência e ao abortamento no debate social e em políticas públicas. Além destas pautas diversas há que se ver a colcha de retalhos e a diversidade deste movimento que, cada vez mais, especifica demandas e dá visibilidade a segmentos da população feminina brasileira destacando-se, por exemplo, a contribuição fundamental do movimento de mulheres negras.

Tendo presente que existem diferenças no campo do feminismo, gostaria agora de fazer um paralelo entre a luta política das mulheres e a plataforma dos direitos 


\section{5 de Julho de 2004}

humanos que é um fator fundamental para a efetivação e sustentabilidade de políticas de igualdade. Esta plataforma sofreu profundas transformações neste período.

Durante a ditadura havia um divórcio entre sociedade civil, que monopolizava a agenda dos direitos humanos, e o Estado autoritário, violador desses direitos. A redemocratização levou a que essa plataforma de Direitos Humanos fosse incorporada também pelo Estado através de Planos de Direitos Humanos, dos Conselhos, das Comissões Parlamentares e das Secretarias Especiais. Paralelamente a esta ampliação do espaço institucional também o conceito de direitos humanos se expande, incorporando novos sujeitos como as mulheres, os povos indígenas, grupos étnicos e raciais, crianças e adolescentes, idosos, e novas dimensões da vida como o meio ambiente, a reprodução, a sexualidade, dentre outros, em um movimento caracterizado por Bobbio como de universalização e especificação dos direitos humanos.

0 que eu gostaria de ressaltar é que existe uma inter-relação entre as esferas nacionais e internacionais e que o movimento de mulheres brasileiro vem atuando em ambas as esferas. Os avanços na linguagem internacional de Direitos Humanos respondem a transformações ocorridas nos cenários nacionais e ao mesmo tempo contribuem para a sua afirmação e legitimidade tanto frente a governos nacionais, quanto a organizações internacionais.

Ao falar sobre este processo de universalização dos direitos humanos, estou na realidade já me referindo ao terceiro momento de nossa historia, que é o período correspondente aos anos 90.

Para o movimento de mulheres, este período se inicia com a desestruturação do CNDM que, já em 1989, ainda no governo Sarney, sofre inúmeras pressões e restrições que levaram à renuncia coletiva do seu colegiado, da sua presidência e sua diretoria. Com a eleição de Collor de Mello e seu projeto de redução do estado, 0 CNDM recebe mais um golpe perdendo sua autonomia administrativa e financeira extinguindo-se, em seguida, o Fundo dos Direitos da Mulher que garantia autonomia financeira a este órgão. A propósito deste esvaziamento do CNDM, a Articulação Nacional de Mulheres afirma que naquele momento fechou-se um dialogo do com 0 movimento de mulheres.

Buscando reverter este processo, em 1994, ano eleitoral, mais de 200 organizações de mulheres subscreveram um Programa para a Igualdade e Direitos da Mulher, apresentado aos candidatos. Entretanto, no governo Fernando Henrique, o CNDM 


\section{5 de jullho de 2004}

continuou a ser um órgão de caráter apenas deliberativo, subordinado ao Ministro da Justiça, situação em que permaneceu até o ultimo ano desse governo quando finalmente se cria a SEDIM, Secretaria dos Direitos da Mulher. No governo Lula este órgão passa a ser a Secretaria Especial de Políticas para as Mulheres e permanecendo o CNDM como órgão deliberativo. A reflexão sobre este processo nos permite constatar mais uma vez que a historia não é linear e que os direitos são uma conquista permanentemente ameaçada.

Do ponto de vista da sociedade civil, os anos noventa se caracterizam também como os anos de internacionalização das agendas dos movimentos de mulheres e são anos fundamentais para 0 avanço dos direitos humanos onde se reafirma de forma transnacional uma plataforma de direitos humanos das mulheres. Nesta plataforma a violência doméstica passa a ser reconhecida como uma violação de direitos humanos (Viena, 1993), as questões ligadas à reprodução deslocam-se da matriz demográfica para a matriz dos direitos reprodutivos, (Cairo, 1994), os direitos sexuais bem como uma ampla plataforma de direitos das mulheres são reafirmados, (Beijing, 1995) e a

Viena

Cairo

Beijin

Durban Belém do Pará questão do racismo e formas correlatas de xenofobia são explicitadas em Durban, 2001. Importantes Convenções como a do Belém do Pará, Convenção Regional sobre a Violência contra Mulher, datam também dos anos 1990.As plataformas de direitos econômicos, sociais e culturais, as DESC afirmadas desde a década de 60 e fortalecidas na década de 90, contam também com uma importante participação das mulheres que apontam para feminizaçao da pobreza e as desigualdades sociais e étnico-raciais.

A década de noventa é também a década da proliferação das ONGs, das redes nacionais, da articulação de mulheres, da articulação de mulheres negras, de visibilidade e fortalecimento das mulheres rurais como a Marcha das Margaridas, de redes de mulheres soro positivas, dos movimentos pelo reconhecimento dos direitos sexuais das mulheres lésbicas, e de outras formas de organização da sociedade civil.

Mesmo sem um espaço relevante governamental de interlocução e implementação de políticas de gênero a nível federal, como o que temos agora, com a Secretaria Especial, esta agenda continuou a ser impulsionada, desde a sociedade civil, e em articulação com outros Ministérios, como o da Saúde.

A partir desses processos políticos globais e nacionais foram instituídos no país, na década de 90, legislação e políticas públicas importantes como a Lei do Planejamento 


\section{5 de Julho de 2004}

Familiar, a lei da união estável, a lei do assédio sexual, as importantes Normas Técnicas para o Atendimento de Mulheres Vítimas de Violência Sexual, os Comitês de Mortalidade Materna, os Centros de Atenção a Mulher Vítima de Violência Sexual no âmbito da saúde pública, a lei de quotas eleitorais. Iniciou-se o questionamento da eficácia da lei 9.099, no que diz respeito a violência intra-familiar que esperamos, venha a levar a uma lei de violência doméstica que garante as mulheres o direito a segurança.

Nesta década investiu-se também na formação de profissionais de saúde e de segurança, procurou-se sensibilizar o judiciário sobre a tese da legitima defesa da honra, alcançando importante vitória em 1991 quando o Superior Tribunal de Justiça em decisão histórica repudia esta tese, não reconhecendo seu valor legal. 0 judiciário é também acionado pelos movimentos de mulheres com relação à questão do abortamento em casos de anomalia fetal grave e irreversível, como a anencefalia, dentre outras iniciativas.

Apesar de nos anos 90 a capacidade de resposta dos mecanismos institucionais vigentes no âmbito federal se viu prejudicada pelo esvaziamento do CNDM, esta foi uma década de grandes avanços no âmbito internacional em termos da ampliação dos direitos humanos, do reconhecimento de seu caráter indivisível e universal e da afirmação, neste contexto, dos direitos humanos das mulheres. Ao mesmo tempo, 0 processo de "advocacy" desenvolvido pelos movimentos de mulheres garantiu avanços importantes no plano nacional.

Neste novo milênio, em termos institucionais, ressaltamos a importância da Secretaria Especial de Políticas para a Mulher e da Secretaria Especial de Políticas de Promoção da Igualdade Racial, sinalizando a incorporação pelo governo federal de agendas políticas acordes com a gramática atual dos direitos humanos, onde sexo e raça constituem eixos fundamentais.

Nos anos 2000, do ponto de vista legal, ressaltamos as mudanças no código civil, que regulamentam a igualdade entre os cônjuges, enunciada na Constituição, a lei que determina a notificação compulsória à vigilância sanitária dos casos de violência sexual e domestica contra mulheres, a criação de inciso no código penal (artigo 129) estipulando que se considera crime de violência domestica a lesão corporal praticada no âmbito das relações familiares, e a recente liminar de Ministro do Supremo Tribunal Federal autorizando a interrupção da gravidez em feto anencefálico. 


\section{5 de jullho de 2004}

Entretanto gostaria de finalizar ressaltando mais uma vez as dificuldades e desafios que nos assombram. Vou deixar algumas destas indagações com vocês, esperando que as considerem ao discutirem nos workshops as diretrizes das políticas publicas que serão traçadas aqui.

A agenda dos direitos das mulheres sem dúvida influenciou o discurso político do Brasil e desencadeou políticas públicas. Cabe agora responder simultaneamente ao desafio de consolidar conquistas e avançar em sua implementação. Neste novo milênio continuamos ainda lutando pelas demandas antigas. Ainda não impactamos a maioria da população feminina, constituída, sobretudo, por mulheres pobres e dentre estas, pelas mulheres negras. Enfrentamos retrocessos no mercado de trabalho com uma crescente informalidade que afeta, sobretudo, as mulheres. Neste sentido temos uma dupla jornada política pela frente: defender as conquistas dos anos 80 consolidando os avanços dos anos noventa enfrentando, ao mesmo tempo, retrocessos e desafios como a crescente desigualdade social e os fundamentalismos religiosos e culturais.

Ao tratar desta temática e ao refazer o longo caminho trilhado por tantas de nós até hoje, me vem à cabeça a estória de Alice no país das Maravilhas. Há uma passagem em que os personagens correm e correm e correm, mas permanecem no mesmo lugar. Acho que nossa história é diferente. Corremos e corremos, ora na sociedade civil, ora no governo, acertamos muitas vezes e freqüentemente não avançamos porque estamos defendendo espaços conquistados no território da política caracterizado por embates, tensões, alianças, negociações. Neste território não permanecemos no mesmo lugar, como na estória de Alice, pois atualmente o debate sobre políticas públicas de gênero ocupa, no cenário nacional e internacional, uma posição diversa daquela que detinha em 75 quando a ONU inaugura o Ano Internacional da Mulher e o movimento feminista organizado desponta no Brasil.

Neste ano de 2004, decretado como Ano da Mulher pelo Presidente da República e no espaço desta grande Conferencia Nacional de Políticas para as Mulheres cabem novas perguntas, próprias a uma agenda de gênero que construída na história, não comporta visões unilaterais nem verdades absolutas.

Muito obrigada!

\section{Sra Sueli Carneiro}

Boa tarde a todas e a todos.

Eu quero, também, inicialmente, agradecer à ministra Nilcéa Freire, pela honra e pelo 
privilégio de poder estar aqui, falando nesta Plenária extraordinária. E quero cumprimentar a Ministra pela extraordinária iniciativa e pelo sucesso que esta Conferência já representa, para o conjunto das mulheres brasileiras. Quero cumprimentar o Ministro José Dirceu, a Secretária Vanda Menezes e a minha cara Jacqueline Pitanguy, amiga e companheira de todas as lutas. E acho que, como a Jacqueline, vou começar falando um pouco dos nossos paradoxos.

Creio que nós, mulheres, temos enfrentado conjunturas difíceis, tempos muito difíceis, no que diz respeito à consolidação e à manutenção dos nossos direitos, nos novos direitos que vimos conquistando, ao longo de nossa luta. Direitos que estão sempre sendo colocados em perigo, por diferentes ideologias autoritárias, fascismos, neofascismos, diferentes variações do machismo, do racismo e suas múltiplas formas de discriminação étnica e racial, pelos fundamentalismos religiosos ou econômicos, pelo neoliberalismo ou pelas globalizações.

Ideologias que, invariavelmente, colocam em risco as conquistas das mulheres. Autoritarismos que se reciclam ou se renovam permanentemente, se apropriam de nossas lutas, subvertem nossos sonhos e nossas conquistas.

Lutamos para que as mulheres pudessem estudar, ter uma carreira, e trabalhassem fora de casa. As mulheres entraram para o mercado de trabalho e novas contradições se colocaram. E passamos a nos defrontar com a desigualdade dos salários das mulheres, em relação aos dos homens, mesmo quando apresentamos as mesmas habilitações, desenvolvemos as mesmas tarefas e temos índices superiores de educação, como ocorre atualmente, no Brasil.

Enfrentamos o veto nas promoções, especialmente para os cargos de chefia. 0 assédio sexual a que muitas têm que se submeter para manter o emprego ou conseguir uma promoção. A ausência de creches para assegurar a guarda dos filhos, para nos mantermos no mercado de trabalho, a falta de solidariedade dos maridos e companheiros, na divisão das tarefas domésticas e em relação à educação dos filhos. Mais recentemente, a informalidade que, como já notou a Jacqueline, é outro fantasma a nos perseguir.

Lutamos por liberdade sexual, pelo direito de ter controle sobre os nossos corpos. Submeteram esses corpos que se supunham, enfim, livres, a um processo brutal de mercantilização, que resulta, hoje, no espetáculo grotesco de exibição narcisista de corpos siliconados e de nádegas expostas a granel, destinadas a vender de tudo:

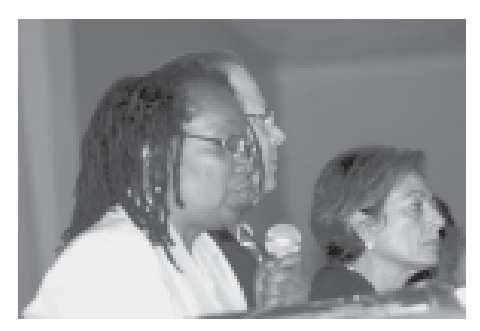

direitos da mulher

desigualdade salarial 
sabonete, sexo, carros de luxo, cigarros, bebidas e o que mais vier. Um grau de reificação do corpo feminino, jamais imaginado por nós, nos nossos piores pesadelos.

Alteramos padrões de comportamento, ao retirar a questão da violência doméstica e sexual do plano privado do casal ou da família para a esfera pública. Recusamos a máxima "em briga de marido e mulher ninguém mete a colher". Metemos a colher, sim, e transformamos a questão da violência contra a mulher em questão pública, objeto de políticas públicas.

No entanto, a impunidade é uma chaga que permanece cúmplice da violência contra a mulher. Hoje, uma nova legislação acena com a possibilidade de punição da violência contra a mulher. E esperamos que o tempo nos mostre a sua eficácia.

Assistimos, nesse momento, a expansão de diferentes fundamentalismos religiosos. Eles, em geral, professam a conversão ou reconversão das mulheres a valores conservadores. Impedir que a intolerância religiosa seja um fator de retrocesso nas conquistas das mulheres, é mais uma árdua tarefa, nesse cenário de expansão dos fundamentalismos religiosos.

Lutamos contra o racismo e a discriminação racial. Sumariamente, podemos afirmar que o protagonismo político das mulheres negras tem se constituído em força motor para determinar as mudanças nas concepções e no re-posicionamento político feminista no Brasil.

As ações políticas das mulheres negras vêm promovendo o reconhecimento da falácia da visão universalizante da mulher, o reconhecimento das diferenças intragênero, o reconhecimento do racismo e da discriminação racial, como fatores de produção e reprodução das desigualdades sociais experimentadas pelas mulheres, no Brasil. 0 reconhecimento do privilégio que essa lógica produz, para as mulheres do grupo racial hegemônico. 0 reconhecimento da necessidade de políticas específicas para as mulheres negras, para a equalização das oportunidades sociais.

0 reconhecimento da dimensão racial que a pobreza tem, no Brasil e, conseqüentemente, a necessidade do corte racial, na problemática da feminização da pobreza. 0 reconhecimento da violência simbólica e a opressão, e a brancura como padrão estético privilegiado e hegemônico exerce sobre as mulheres não brancas. Apesar de 


\section{5 de Jullho de 2004}

todo o vitalismo do movimento de mulheres, as práticas discriminatórias permanecem impunes, e as desigualdades raciais inalteradas.

Como agravante de todas essas contradições, as políticas econômicas neoliberais vêm aprofundando o fenômeno da feminização da pobreza, especialmente nos países não desenvolvidos. Graças à precariedade das políticas sociais, o desemprego estrutural, a migração forçada dos homens em busca de trabalho, a perda da capacidade de investimento dos Estados no desenvolvimento social e econômico dos nossos países.

Porém, do mergulho nesse mar de contradições nós, mulheres brasileiras, emergimos sempre mais fortes, ousando ofertar um projeto de radicalização democrática ao Estado e à sociedade brasileira. Radicalização democrática que tem como princípios fundamentais a igualdade, a diversidade, a participação, a solidariedade e a liberdade.

É isso o que vimos construindo, programaticamente, enquanto movimento social e que equivale a uma verdadeira revolução cultural e um projeto político para um novo país. Estou tomando como referência dessa análise apenas um dos consensos e pactos que fomos capazes de consagrar, da nossa trajetória de lutas: a plataforma política feminista, gestação coletiva, em 2002, aqui em Brasília, pela maioria de nós, que aqui estamos, na Conferência Nacional das Mulheres Brasileiras.

Essa plataforma política feminista representou, para as mulheres negras, o coroamento de quase duas décadas de luta, pelo reconhecimento e incorporação do racismo, da discriminação racial e das desigualdades de gênero e raça que eles geram.

Tal concepção constitui-se, hoje, em um dos eixos estruturais da luta das mulheres brasileiras. A plataforma, ao incorporar essas orientações e diretrizes, selou um pacto de solidariedade e co-responsabilidade entre mulheres negras e brancas, na luta pela superação das desigualdades de gêneros e das desigualdades persistentes entre as mulheres, no Brasil.

A plataforma redefiniu os termos de uma verdadeira justiça social no Brasil. Como afirmou, na ocasião, Guacira César de Oliveira "com a plataforma feminista, reafirmamos que, os movimentos de mulheres e feministas querem radicalizar a democracia, deixando claro que ela não existirá enquanto não houver igualdade, que não haverá igualdade sem distribuição das riquezas. E não há distribuição das riquezas sem 0 reconhecimento das desigualdades entre os homens e mulheres, sem o reconheci- 


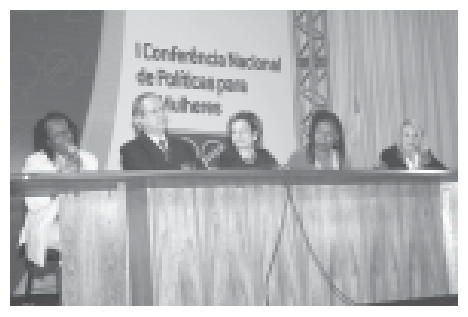

neoliberalismo

políticas públicas

\section{5 de Julho de 2004}

mento das desigualdades entre brancos e negros, entre urbanos e rurais, contradições que hoje estruturam a pobreza no Brasil".

Não almejamos a mera inversão dos papéis, mas um novo marco civilizatório. Dessa perspectiva, daquela Conferência, nós, mulheres brasileiras, negras, indígenas, brancas, lésbicas, nortistas, nordestinas, urbanas, rurais, sindicalizadas, quilombolas, jovens, de terceira idade, portadoras de necessidades especiais, de diferentes vinculações religiosas e partidárias, nos detivemos, criticamente, sobre as questões mais candentes da conjuntura nacional e internacional, nos obstáculos contemporâneos persistentes para a realização da igualdade de gênero e nos desafios e mecanismos para a sua superação.

A partir desse diagnóstico, reafirmamos os nossos compromissos para com a autonomia e autodeterminação dos movimentos sociais de mulheres. Com a crítica ao modelo neoliberal injusto, predatório, insustentável, do ponto de vista econômico, social, ambiental e ético; com a defesa dos direitos econômicos, sociais, culturais e ambientais das mulheres; com a defesa dos princípios de igualdade e justiça econômica social; com o direito universal à educação, à saúde e à Previdência; com a luta pelo direito à terra e à moradia; com a luta anti-racista e a defesa dos princípios equidade racial e étnica; com a luta contra as formas de discriminação de gênero e com 0 combate à violência, maus tratos, assédio e exploração de mulheres e meninas; com a luta contra a discriminação à lésbicas e gays; com a luta pela assistência integral à saúde das mulheres e pela defesa dos direitos sexuais e reprodutivos; com o direito das mulheres de ter ou não ter filhos, com acesso de qualidade à concepção e/ou contracepção; com o direito de livre exercício sexual de travestis e transgêneros; com a descriminalização do aborto, como um direito de cidadania e uma questão de saúde pública, tal como expressamos através das jornadas brasileiras pelo direito ao aborto legal e seguro que hoje realizamos.

Porém, essa vitalidade, esse sentido de responsabilidade cívica que o movimento de mulheres expressa em suas lutas, essa crença na possibilidade de radicalização da agenda democrática do país, não tem encontrado contrapartida efetiva no Estado brasileiro, sobretudo no que diz respeito às políticas públicas destinadas a promover a equidade de gênero entre as mulheres.

E nossa presença nessa Conferência é mais uma demonstração de nossa perseverança, de nosso compromisso ético e político, de nossa busca incessante de sensibilizar os governos e o Estado brasileiro para a reconhecer e acolher, de maneira efetiva, a agenda de reivindicações desse sujeito político e estratégico que são as mulheres, de 


\section{5 de jullho de 2004}

cuja inclusão, promoção e emancipação depende a possibilidade de mudar esse país para melhor.

Não vou me deter nos números das desigualdades de gênero e de raça. Eles estão amplamente divulgados em todos os documentos que suportam os debates em torno dessa Conferência. Basta reafirmar que, em relação às mulheres negras, metade da população feminina do país, os indicadores conhecidos configuram um verdadeiro matriarcado da miséria, tal a magnitude da exclusão. E, no entanto, desconhece-se uma única política específica voltada para alterar as condições de vida dessa população.

Por outro lado, não há indicadores desagregados, por sexo e raça, para se avaliar o alcance dos programas em execução, sobre as mulheres negras. Porém, essa Conferência é mais uma oportunidade para essa correção de rota.

Para isso, é necessário que o plano de ação de promoção da igualdade de gênero, que deva decorrer das diretrizes que serão aqui aprovadas, articule um conjunto de políticas de diferentes naturezas, como políticas compensatórias, políticas de ação afirmativa e focalização nos segmentos mais vulneráveis, como as mulheres negras e indígenas, um conjunto de políticas capazes de realizar, a um só tempo, a promoção da igualdade de gênero e a erradicação das desigualdades raciais entre as mulheres.

Senhora Ministra,

Como apontei, através da plataforma política feminista, consagrada pelos movimentos de mulheres, em 2002, nós, mulheres negras, vimos enegrecendo o feminismo e 0 movimento de mulheres brasileiro, em suas propostas e seus fóruns. Nossa presença maciça nessa Conferência é a expressão desse protagonismo político crescente das mulheres negras brasileiras.

É chegada a hora de enegrecer as políticas públicas. Para isso, construímos a nossa contribuição para os debates desta Conferência. É o Manual para fazer a Diferença, elaborado pelo Fórum de Mulheres Negras de São Paulo e pela coordenação da articulação de ONGs de mulheres negras, onde aprofundamos as linhas de ação que consideramos estratégicas, para a promoção da igualdade de gênero e intragênero.

A nossa ambição é que as perspectivas de promoção de igualdade de gênero, de uma perspectiva racial que para aqui trazemos, possa realizar o milagre da reparação que é devida, historicamente, às mulheres negras deste país. 


\section{5 de jullho de 2004}

E, tendo em vista a invisibilidade histórica das mulheres negras, nas políticas públicas, sonhamos que essa reparação se dará, em letras garrafais, nas diretrizes e, sobretudo, nas metas físicas, financeiras e nos indicadores de monitoramento de execução de políticas de promoção e equiparação social das mulheres negras brasileiras.

Muito obrigada. 


\section{5 de jullho de 2004}

\section{Ministra Nilcéa Freire.}

Boa Tarde a todas e a todos.

Quero especialmente cumprimentar e agradecer a presença nesta mesa de debates ao ministro José Dirceu, às companheiras Jacqueline Pitangy, Suely Carneiro e a nossa moderadora, a Secretária da Mulher de Alagoas, Wanda Menezes.

Antes de iniciar minha breve exposição gostaria de recuperar um fato que talvez tenha passado desapercebido na cerimônia de abertura pela manhã. E este fato foi a assinatura pelo Presidente Lula de uma Portaria que reafirma o seu compromisso com as diretrizes emanadas desta Conferência, que constituirão as bases do Plano Nacional de Políticas para as Mulheres.

Essa Portaria institui um Grupo Interministerial, com a participação da sociedade civil, através da representação do Conselho Nacional dos Direitos da Mulher e a participação de representação dos órgãos executivos estaduais e municipais encarregados do desenvolvimento de políticas para as mulheres, com o objetivo de elaborar nosso Plano Nacional e propor medidas para sua implementação e acompanhamento.

Passando a minha intervenção, vou tentar a partir de alguns dados da realidade das mulheres no nosso país mostrar como nosso governo entende as políticas para as mulheres e como vem atuando no sentido de diminuir a distância existente entre a igualdade formal prevista em nosso ordenamento jurídico e a realidade cotidiana de desigualdade e exclusão em que vivem ainda milhões de brasileiras.

Quem somos nós?

O Brasil segue sendo um país predominantemente urbano. Nos últimos vinte anos houve um acentuado processo de migração para os grandes centros urbanos. De 1980 a 2000, segundo os dois últimos censos, a população urbana passou de 67.5 para $81.25 \%$, enquanto a população rural passou de 32.41 para $18.75 \%$.

O Brasil ainda é um país predominantemente jovem, mas é um país jovem de cabelos brancos, a nossa expectativa de vida tem aumentado, com vantagem para as mulheres.

Somos $51,2 \%$ da população, $46 \%$ de nós se auto declaram pretas e pardas, vivemos predominantemente em áreas urbanas, nossa taxa de fecundidade vem caindo ano a ano mas cresce o número de jovens que precocemente engravidam. 


\section{5 de Jullho de 2004}

população economicamente ativa

ensino

desigualdades duráveis
Constituímos 42,7\% da PEA (População Economicamente Ativa), e somos mais escolarizadas que a população masculina (temos em média 6,6 anos de estudo enquanto os homens têm 6,3). Enquanto a taxa de desocupação entre os homens em 2003 era de 7,8\% a nossa chegava a 12,3\% e recebemos em média 70\% dos seus rendimentos. Portanto, muito embora o nosso nível de escolaridade venha aumentando, esta condição por si só não nos tem garantido igualdade de oportunidades no mundo do trabalho.

Hoje representamos cerca de $62 \%$ daqueles que concluem o ensino superior, mas quanto maior o nível de escolaridade maior a discrepância salarial entre homens e mulheres, chegando uma mulher com onze anos ou mais de estudo a receber $58 \%$ do salário dos homens.

Apenas 9\% dos cargos executivos das 500 maiores empresas brasileiras são ocupados por nós (Instituto Ethos, setembro de 2004) e ainda nos fazemos representar por apenas 9\% de mulheres entre a Câmara e o Senado Federal.

Estes dados confirmam um padrão de desigualdade que pode enquadrar-se naquilo que os sociólogos chamam de desigualdades duráveis. Ou seja, mesmo que se obtenha uma melhoria das condições gerais de vida na sociedade tanto para homens como para mulheres isto não se traduz necessariamente em maior equidade de gênero, 0 mesmo fenômeno acontecendo também para a condição racial. Assim, ser mulher neste país, é por si só uma condição que exclui. E na mulher negra encontraremos nela a representação da base da pirâmide social.

A persistência dessas variáveis como operadoras de exclusão somadas ao desequilíbrio de poder historicamente construído entre homens e mulheres se expressa em todas as relações sociais sejam elas no espaço público ou no espaço privado. A manutenção destes padrões de desigualdade certamente tem causado enormes prejuízos e distorções no processo de desenvolvimento econômico e social do nosso país.

Por que políticas para as mulheres?

Ao assumir a Secretaria ouvi muitas perguntas, de companheiros, de companheiras, de jornalistas, enfim de muita gente que não entendia porque uma Secretaria Especial de Políticas para as Mulheres. A alguns perdôo pela ignorância, pois pensam que isso é uma invenção do Governo Lula, que quis criar mais um espaço institucional com status de ministério inchando a máquina governamental. 0 que talvez ainda poucos saibam é que mecanismos institucionais como este já existem há muito em 


\section{5 de Julho de 2004}

outros países, só para mencionar três exemplos na América Latina, lembro o Paraguai, Chile e México sem citar aqui os existentes na Europa e na América do Norte. A outros, não lhes perdôo o preconceito e a falta de sensibilidade.

Em outros casos se colocava a criação da SPM dentro de uma falsa disjuntiva entre políticas de caráter universal ou políticas focalizadas. Defendemos o caráter universal das políticas no entanto temos convicção de que é preciso tratar afirmativamente as desigualdades de gênero e de raça. É preciso agir para equilibrar as relações de gênero e raça na sociedade em favor daqueles seguimentos que ao longo da história vem acumulando desvantagens.

Políticas públicas para as mulheres significam para nós a busca da igualdade na reafirmação das diferenças. Significam incorporar as necessidades e demandas específicas das mulheres e lançar o seu olhar sobre todas as políticas de todas as esferas de governo.

Desta forma quando nos indagam porque e para que políticas para as mulheres, respondemos com questões muito simples e práticas. A primeira delas é se já nos preocupamos em apurar o custo da não incorporação da perspectiva de gênero nas políticas públicas e o quanto se perde por não avaliar desde sua formulação como incidem diferentemente na vida de mulheres e de homens, por exemplo, políticas de transporte urbano, de iluminação pública ou a construção de uma barragem.

Como garantir a incorporação cidadã das mulheres, no desenvolvimento econômico do país, se o Estado, os governos e a sociedade não compartilharem das tarefas que garantem a reprodução do viver e que ainda hoje são quase que exclusivamente atribuídas a elas? Há que intervir na educação e na cultura combatendo estereótipos e atitudes que levam à divisão sexual do trabalho e ao mesmo tempo garantir a construção de equipamentos sociais como lavanderias comunitárias e o aumento da oferta de vagas na pré escola, só para citar algumas medidas.

E se ainda, depois de tudo isso, ainda me perguntam porque políticas para as mulheres respondo que perguntem a pelo menos uma mulher se esta não conhece, pelo menos mais uma, que tenha sofrido algum tipo de violência por parte de algum homem. Desde a agressão física às mais sutis violências psicológicas muitas vezes configuradas como cerceamento de liberdade e de escolhas.

Portanto, certamente cada uma de nós, sabe responder porque e para que políticas para as mulheres. 
0 que já estamos fazendo?

3.844 propostas

pobreza e geração de renda

PRONAF - Mulher

capacitação para o trabalho

empreendedorismo feminino

violência contra a mulher
Foi com muita alegria que ao recebermos as 3.844 diretrizes e propostas das conferências estaduais - nunca mais vou esquecer desse número - verificamos que muitas delas correspondiam a políticas, programas, ações já em execução ou planejadas em diferentes áreas, em vários Ministérios do nosso Governo.

Para enfrentar a pobreza no campo, estamos trabalhando com linhas de crédito específicas para as mulheres. Estamos aprofundando essa discussão, tanto com 0 Movimento de Mulheres Camponesas quanto com as mulheres da CONTAG (Confederação Nacional dos Trabalhadores na Agricultura), junto ao Ministério do Desenvolvimento Agrário, no sentido de avançar, em relação ao PRONAF-Mulher (Programa Nacional de Fortalecimento da Agricultura Familiar - Mulher). Ainda para enfrentar a pobreza e ampliar a autonomia econômica das mulheres, um dos eixos centrais de nossa ação posto que permite o enfrentamento dos demais desafios colocados nesta conferência, apoiamos programas de capacitação para o trabalho e acabamos de assinar um convênio com o SEBRAE nacional e a Associação de Mulheres de Negócios para estimular o empreendedorismo feminino e criar oportunidades de geração de trabalho e renda.

Para combater a violência uma de nossas prioridades tem sido o reaparelhamento e a ampliação dos serviços de atendimento às mulheres que vivem em situação de violência. Neste primeiro semestre apoiamos financeiramente projetos encaminhados por estados e municípios de implantação, adequação ou aparelhamento de casas

\begin{tabular}{|c|c|c|c|c|}
\hline Região & Quant. & Cidade/UF & Convenente & Total concedido \\
\hline Centro-Oeste & 06 & $\begin{array}{l}\text { Brasília/DF } \\
\text { Goiânia/GO } \\
\text { Campo Grande/MS }\end{array}$ & $\begin{array}{l}\text { Contag/DF } \\
\text { Cecria/DF } \\
\text { Prefeitura } \\
\text { Prefeitura } \\
\text { Prefeitura } \\
\text { Gov. estadual }\end{array}$ & $\begin{array}{l}100.000,00 \\
61.445,00 \\
25.000,00 \\
100.000,00 \\
150.000,00 \\
149.999,00 \\
586.444,00\end{array}$ \\
\hline Nordeste & 14 & $\begin{array}{l}\text { Campina Grande/PB } \\
\text { Natal/RN } \\
\text { Parnamirim/PB } \\
\text { Icapuí/CE } \\
\text { Fortaleza/CE } \\
\text { Aracaju/SE } \\
\text { Petrolina/PE } \\
\text { Olinda/PE } \\
\text { Orobó/PE } \\
\text { Recife/PE }\end{array}$ & $\begin{array}{l}\text { Prefeitura } \\
\text { Prefeitura } \\
\text { Prefeitura } \\
\text { Prefeitura } \\
\text { Gov. estadual } \\
\text { Prefeitura } \\
\text { Prefeitura } \\
\text { Prefeitura } \\
\text { Prefeitura } \\
\text { Rede Nac. Parteiras } \\
\text { Instuto PAPAl }\end{array}$ & $\begin{array}{l}40.000,00 \\
112.800,00 \\
113.501,60 \\
77.850,00 \\
52.252,00 \\
150.000,00 \\
115.296,98 \\
80.002,90 \\
32.478,60 \\
55.000,00 \\
49.945,00\end{array}$ \\
\hline
\end{tabular}




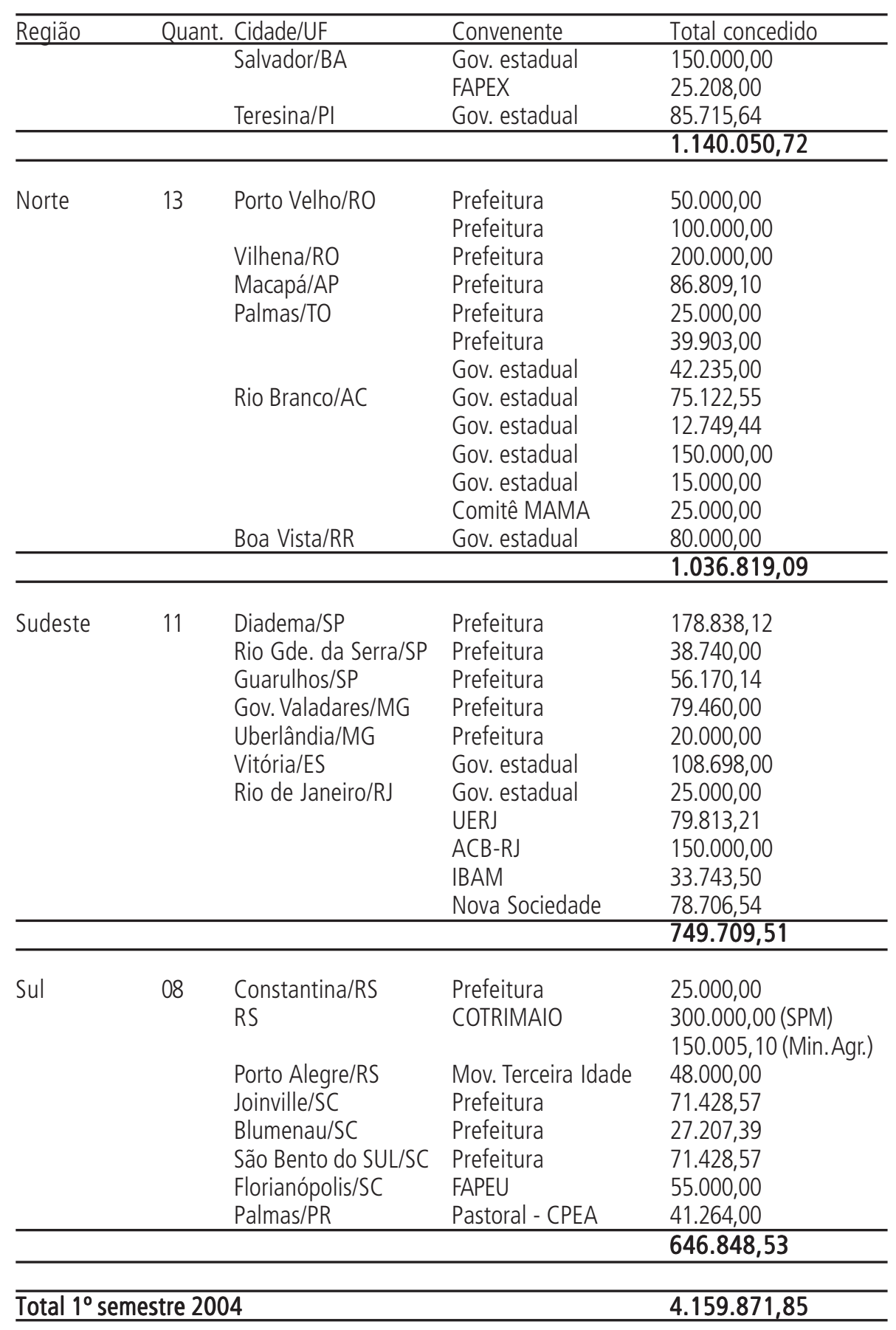

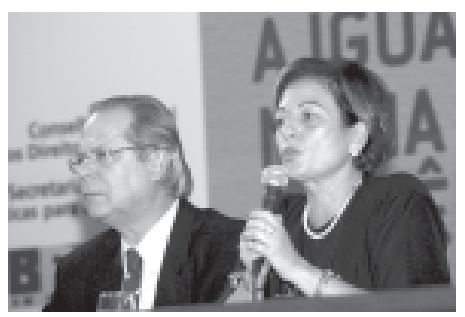

abrigo para mulheres em situação de risco e centros de referência como podemos ver na tabela.

Ainda com relação à violência estamos, em parceria com a Secretaria Nacional de Segurança Pública, trabalhando para introduzir na matriz curricular das academias de polícia, disciplinas que discutam as questões de gênero e violência contra a mulher. Estamos, também, ainda na mesma parceria e em outras organizações não governamentais, capacitando o pessoal das delegacias especializadas de atendimento à mulher. 


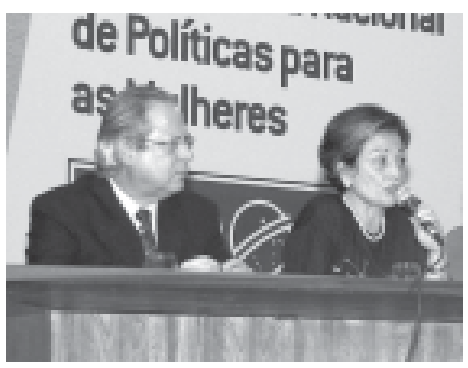

saúde e direitos sexuais

\section{5 de julho de 2004}

Ainda este ano, dentro desta profícua colaboração vamos reaparelhar 50 DEAMs, em todo o país, de forma que tenhamos pelo menos uma delegacia por estado dentro do padrão mínimo que entendemos como necessário. Este será um passo importante no processo de normatização e padronização das DEAMS.

E, finalmente ainda no âmbito da violência, estamos revisando a legislação que trata da violência doméstica contra a mulher e esperamos que, no segundo semestre, estejamos encaminhando ao Congresso Nacional um ante projeto de lei que teve como subsídio um projeto base elaborado por um consórcio de oito organizações não governamentais e que tem contado com o apoio e participação da comissão do ano da mulher no Senado e na Câmara. Nos últimos $1^{\circ}$ e 2 de julho, estivemos discutindo esse ante-projeto com estas organizações, com defensores públicos, com juízes de juizados especiais, com promotores e com profissionais da área de saúde.

Para garantir a saúde e os direitos sexuais reprodutivos, o Ministério da Saúde em colaboração com a SPM lançou o Pacto pela Redução da Mortalidade Materna e Neonatal. Entre as causas mais importantes de mortalidade materna estão colocadas aquelas provenientes de complicações nos casos de abortamento inseguro e, portanto, o pacto garante a ampliação do atendimento ao abortamento previsto em lei nas unidades do SUS e garante, por outro lado, a humanização do atendimento.

Enfim, na educação, na saúde, na geração de emprego e renda, na ampliação da autonomia das mulheres, na diminuição, portanto, das desigualdades, temos, nós da SPM, encontrado apoio e respaldo. Temos encontrado, também, e isso se reflete nessa Conferência, uma interlocução generosa, uma interlocução respeitosa com a sociedade civil, e com as companheiras que têm nos acompanhado nessa trajetória no Governo.

Finalmente, é preciso enfatizar que os caminhos para a construção da igualdade não estão ainda totalmente pavimentados. Seria uma ilusão achar que, com apenas desejo ou vontade, poderemos desconstruir o preconceito, a discriminação e a intolerância. É preciso muito trabalho e muita persistência.

Essa Conferência representa para nós, do executivo federal, a reafirmação do quanto nós precisamos trabalhar. A presença hoje, pela manhã, de praticamente todos os Ministros das pastas que têm uma intercessão mais direta com o nosso trabalho nos é muito cara, significa a possibilidade concreta da transversalidade de gênero em nosso Governo.

Quero mais uma vez agradecer a oportunidade de estar aqui, de estar aprendendo a cada dia com todas vocês e com os companheiros e companheiras de Governo.

Muito obrigada. 


\section{5 de jullho de 2004}

\section{Ministro José Dirceu}

Boa tarde a todos e a todas.

Quero agradecer esta oportunidade, cumprimentar a Sueli [Carneiro], a Wanda [Menezes], cumprimentar a nossa ministra [Nilcéa Freire], cumprimentar a Jaqueline [Pitanguy]. Quero cumprimentar de uma maneira especial e fazer uma referência especial a uma amiga e companheira que está presente aqui conosco e que, para mim, sempre representou mais do que um exemplo de militância, de combatente, um exemplo de dignidade, que é a Clara Charf. Eu vim para cá com um discurso escrito para prestar contas da política do governo, do nosso governo, do governo do presidente Lula, com relação às mulheres, à luta pela igualdade de gênero, mas, ouvindo a Jaqueline, ouvindo antes a Vanda, depois, a Sueli e a Nilcéa, e pela própria fala que o presidente fez aqui pela manhã, resolvi mudar e falar um pouco sobre o Brasil, falar um pouco do que acredito que posso dar como uma contribuição maior para esta Conferência.

O nosso país se encontra em um momento especial e tem uma oportunidade única pela frente, e, a partir da perspectiva de vocês, das mulheres, é fácil identificar que 0 país não consegue mais conviver com os níveis de desigualdade, de violência e de desemprego que hoje enfrentamos. $E$ acredito que ninguém mais do que a mulher sente os efeitos da situação em que o país se encontra. Por isso, é muito importante nos darmos conta do que mudou no Brasil.

Quando se cria a Secretaria Especial de Políticas para as Mulheres, isso não significa apenas que o Brasil assumiu, assimilou uma luta de muitas décadas das mulheres, significa que o Estado brasileiro voltou a ser Estado - quando a Jaqueline falava, ela lembrava da política da década de 90, do Estado mínimo, e, hoje, nós estamos recuperando (e muitos não enxergam isso) o papel do Estado brasileiro no planejamento. Sem planejamento, nenhuma nação, nenhum povo conseguiu se desenvolver. 0 papel do Estado, enquanto financiador do desenvolvimento do país, não é só pelo Orçamento — todos nós sabemos que é um orçamento contingenciado, é um orçamento de um ajuste fiscal —, mas, é, principalmente, pela retomada do papel dos bancos públicos.

O Brasil é um país privilegiado na América do Sul e na América Latina - e, mesmo, no Hemisfério Sul. Nós temos o Banco Nacional de Desenvolvimento Econômico e Social (BNDES), que é um banco que financia o investimento de longo prazo, porque todas aqui sabem que investimento no Brasil, quando o sistema bancário financia, é 


\section{5 de jullho de 2004}

inviável pelas taxas de juros e pelo prazo desse investimento. Não se constroem hidrelétricas, fábricas, não se constroem rodovias, portos, ferrovias, hidrovias e não se implantam setores de papel e papelão, siderúrgico, petroquímico ou mesmo indústrias de ponta sem crédito e investimento de longo prazo. 0 Brasil tem o BNDES, mas que tinha se tornado um banco comercial, e voltou a ser um banco de fomento, da exportação, dos investimentos de longo prazo, da reorganização do parque produtivo brasileiro, do mercado interno, da política de ciência e tecnologia, do financiamento a pequenas e microempresas. E temos o Banco do Brasil, que financia a agroindústria e a agricultura familiar brasileira. Temos a Caixa Econômica Federal, que financia o saneamento e a habitação, e temos o Fundo de Garantia do Tempo de Serviço (FGTS) e o FAT (Fundo de Amparo ao Trabalhador), que sustentam a política de enfretamento ao desemprego, de habitação e de saneamento, e temos o próprio BNDES.

Voltamos a ter esses bancos articulados, com uma visão estratégica de o país ter, novamente, uma política industrial, uma política de ciência e tecnologia, uma política de exportação. Porque somos um país que devemos ao exterior, mas, aqui dentro, temos uma dívida de $R \$ 1$ trilhão praticamente. Se nós pagamos 10\% de juros dessa dívida, pagamos $R \$ 100$ bilhões - que é aproximadamente o que iremos pagar neste ano - , e se tiramos do Orçamento a Previdência, o pessoal e os gastos obrigatórios, o governo na verdade tem $\mathrm{R} \$ 71$ bilhões (que é o que terá em 2005, para o que chamamos de "despesas discricionárias"), o que dá para ter uma idéia da gravidade desta dívida interna.

Se temos dívida externa, se temos que pagar juros sobre essa dívida e se temos déficit na balança de transporte - tínhamos na balança de turismo - isso significa que o país precisa não só de investimento externo, mas precisa de superávit comercial. Nós vamos ter um superávit de US\$30 bilhões neste ano, e, mais do que isso, vamos ter, pela segunda vez depois de quase 15 anos, um superávit na conta corrente de US\$ 3 bilhões a US\$ 5 bilhões. Assim, o país vai fazer reservas, vai parar de depender do mercado internacional de capitais, porque está, inclusive, recebendo investimentos externos.

Voltamos a investir na infra-estrutura de saneamento e de habitação. Em saneamento, investimos em 18 meses mais do que o governo anterior em sete anos; dobramos, praticamente, o financiamento de habitação. 0 governo triplicou os recursos do Bolsa Família, unificando os programas, sustentou o Programa Fome Zero por mais um ano e cuidou da agricultura familiar para além da reforma agrária. 


\section{5 de jullho de 2004}

Temos que fazer a reforma agrária, mas, no Brasil, antes, temos que garantir a agricultura familiar, porque não adianta assentar 100 mil famílias por ano e 100 mil famílias saírem do campo. É preciso sustentar a agricultura familiar porque não havia assistência técnica, porque 350 mil famílias assentadas nos últimos anos não tinham água, luz, crédito, segurança da venda dos seus produtos, seguro. A metade tinha quitação, porque a própria reforma agrária garante o crédito de habitação, mas só metade. É preciso levar luz para todas essas propriedades, crédito, financiamento, água, estradas. No primeiro ano do governo Lula, nós tivemos que cuidar disso basicamente, cuidar da agricultura familiar. No segundo ano, vamos assentar mais de cem mil famílias e cumprir o Plano de Reforma Agrária.

É preciso combater a pobreza, fazer reforma agrária, devolver ao Estado brasileiro o papel do desenvolvimento do país, retomar o projeto de desenvolvimento nacional, voltar a ter política industrial e tecnológica e investir na infra-estrutura. Todas aqui viajaram para Brasília e sabem qual é a situação das ferrovias e, principalmente, das rodovias brasileiras. Nós passamos dez anos sem investimentos na infra-estrutura, privatizamos os setores petroquímico, energético, de telecomunicações, além das rodovias e das ferrovias. Foram arrecadados US\$100 bilhões com as privatizações e, no entanto, hoje, a nossa sociedade, o povo brasileiro, paga onze pontos percentuais de impostos a mais do que em 1995, apesar de termos vendido US\$ 100 bilhões do nosso patrimônio. A nossa dívida pública praticamente dobrou. Na verdade era de pouco mais de $R \$ 150$ bilhões [em 1994] e hoje é de quase $R \$ 1$ trilhão, mas, atualizando pelo índice inflacionário, bastaria dizer que ela era 30\% da riqueza, do nosso Produto Interno Bruto [PIB], e hoje é 56\%.

O país ficou mais pobre, porque vendeu o que tinha, endividou-se lá fora e aqui dentro, acumulou 10 milhões de desempregados e precisa crescer 5\%,7\% ao ano — isso só para incorporar 1,5 milhão de jovens que chegam ao mercado de trabaIho. Neste primeiro semestre, já em maio, nós tínhamos criado 856 mil empregos com carteira assinada. Acredito que neste ano o país crescerá mais que 3,5\%.

Nós pegamos os juros do país a $25 \%$ ao ano e hoje ele está a 16\%, mas o país precisa de mais crédito, mais financiamento e de juros menores. Hoje, as famílias pagam quase um terço da sua renda em juros, impostos e tarifas públicas - a demanda do país está deprimida e a renda, além de concentrada, não cresce, porque o emprego não vinha crescendo. 


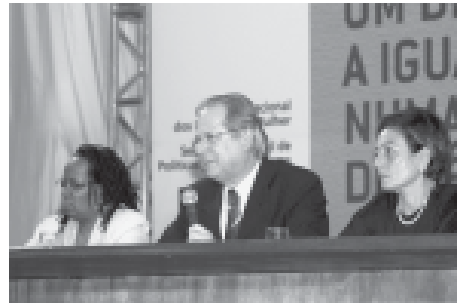

reformas
Para este país crescer, precisamos de mais investimento. 0 investimento é muito baixo no Brasil comparado com aquilo que o país necessita, que é de $24 \%$, 25\% do $\mathrm{PIB}$ - hoje, é de 17\%, 18\%. Para aumentar o investimento, é preciso tirar o recurso que a sociedade tem entesourado, rendendo juros, aplicado em títulos do governo indiretamente. Se o cidadão e a cidadã recebem menos no investimento, numa compra de ação, numa pequena empresa ou num trabalho autônomo do que deixando o dinheiro rendendo juros, acontece o que está acontecendo no Brasil: temos praticamente meio trilhão de reais rendendo juros, que não vão para a produção.

Para resolver esta equação é preciso tempo e, como todos e todas aqui sabem, o tempo político e social não é igual ao tempo econômico. A sociedade reivindica e pressiona. Faz greves, manifestações e ocupações. Esse contraditório, esse conflito é que faz o país avançar e que fez o Brasil chegar até aqui. Todas que estão aqui - nos conhecemos há 20, 30, 40 anos nas lutas sociais, contra a ditadura, na resistência, na construção da democracia e das nossas entidades e organizações, na construção das nossas pautas e dos nossos programas, das nossas políticas públicas, na construção do Estado brasileiro e das suas instituições -, vejam bem: neste ano o país fez uma reforma do Judiciário e vai ter que fazer uma reforma política. Neste ano, o país fez as reformas tributária e previdenciária, aprovou o Estatuto do Idoso, aprovou 0 Estatuto do Desarmamento e deve aprovar o Estatuto da Igualdade Racial, que vai para o Congresso. 0 país tem aprovado leis importantíssimas, como a Lei de Falências, que acabou de passar no Senado, mudou toda a legislação de crédito imobiliário. Isso significa que nós estamos consolidando a democracia brasileira, combatendo a pobreza e a miséria, melhorando a infra-estrutura social e econômica do país, meIhorando o país do ponto de vista tecnológico. Mas o tempo é curto e conspira contra nós.

O maior desafio pela frente é a agenda da Educação, porque a agenda da Saúde teve um avanço extraordinário no Brasil com o SUS — que tem recursos constitucionais garantidos, uma pauta, um avanço orçamentário e institucional. Nós temos 11 milhões de jovens fora do ensino médio. Desses, milhões não voltarão mais para 0 ensino médio, só para o supletivo. Mas, pelo menos 6 milhões, 7 milhões estão à espera. Este é o maior problema que o país tem hoje, porque eles querem também 0 ensino técnico-profissional, não só o ensino médio. Este desafio está ligado à questão da criminalidade e da violência, ligado à questão da cultura, à agenda da 
juventude, do emprego da juventude, do ensino técnico-profissional, do lazer da juventude. Praticamente, nós temos que ressocializar a juventude brasileira das grandes periferias, dos grandes centros metropolitanos. É a agenda, talvez, mais prioritária do país. As mulheres e as jovens estão sendo, talvez, as primeiras vítimas desta situação, porque é maior o desemprego, é maior a violência. Nós temos ainda a gravidez precoce como um problema gravíssimo.

Eu quero registrar, para além do otimismo pela realização desta Conferência, a presença de todas aqui em Brasília, a pauta e o avanço das lutas feministas, das mulheres em nosso país, a agenda, a incorporação pela sociedade, apesar da resistência, do conservadorismo. A sociedade brasileira tem avançado de maneira extraordinária do ponto de vista de consciência dos direitos e do papel da mulher, e a mulher tem avançado na nossa sociedade. Basta que cada um se referencie na própria família, nas nossas mães, irmãs e filhas para ver o avanço que a sociedade brasileira produziu nesses últimos anos. Mas nós também sabemos da gravidade da situação de preconceito, desigualdade e desobediência da lei, de falta de recursos e instituições. Temos muito para avançar.

0 que eu quero reiterar aqui para a nossa ministra Nilcéa, para todas, é o nosso compromisso, o compromisso do presidente Lula - que não é só compromisso de governo, é um compromisso de vida, de militância. Não estamos no governo lutando pelo direito das mulheres; estamos continuando no governo a luta histórica pelos direitos das mulheres. Eu quero reafirmar, neste momento, a minha fé e o meu otimismo na nossa luta e, em primeiro lugar, na capacidade de luta do povo brasileiro. Eu sempre digo que o nosso povo é muito melhor que as elites brasileiras e ele já deu provas disso várias vezes, porque sempre é o povo brasileiro que começa as lutas e muda a correlação de forças, embora nem sempre acabe ganhando, vencendo. Em muitas fases da história brasileira, o povo iniciou na luta, mas as elites fizeram considerações, acordos e desorganizaram o status quo.

Com o governo do presidente Lula, com a coalizão que governa o Brasil hoje — que tem o PT como partido principal, porque é o partido do presidente, mas há os partidos de esquerda que são nossos aliados - , estamos tendo uma oportunidade histórica de mudar o Brasil. As conferências que realizamos (de Meio Ambiente, de Educação, de Saúde e esta, da Mulher, além do Conselho de Desenvolvimento Econômico e Social), a parceria ideal que instituímos na sociedade e o respeito do governo com as manifestações e greves — neste governo não houve repressão a nenhuma atividade 


\section{5 de Jullho de 2004}

pública, seja da oposição, seja dos movimentos, seja da sociedade — são uma garantia e a nossa certeza de que nós podemos avançar. É no pluralismo, é no debate, é na disputa política que a democracia se consolida e o país avança. Por isso fiz questão de vir aqui hoje (mesmo com o presidente tendo comparecido na abertura, com ministros), para, em nome do governo, em nome da Casa Civil, da coordenação do governo, reiterar não o nosso apoio à luta das mulheres, mas a nossa militância com vocês pelos direitos das mulheres.

Muito obrigado. 


\section{5 de Jullho de 2004}

Dia 15.07.2004

Painel Internacional

Diálogo Interativo SObre EXPERiÊncias internacionais

com Ministras e representações Internacionais

\section{Palestrantes:}

Sra Patrícia Espinosa, Presidente do Instituto da Mulher do México.

Sra Amélia Paiva, Presidente de Comissão para a Igualdade pelos Direitos das Mulheres de Portugal

Sra Nérida Quintero, Deputada, representante da Federação das Mulheres Cubanas.

Sra Beatriz Paredes, Deputada, Presidente da Fundação Colosio, México.

$\mathrm{Sr}^{\mathrm{a}}$ Ariadna Reis, representante do Conselho Nacional da Mulher no Equador.

Sra Virgínia Gúzman, consultora da CEPAL/ONU

\section{Coordenação:}

Sra Nilcéa Freire, ministra da Secretaria Especial de Políticas para as Mulheres SPM, e Sra Márcia Campos, presidente da Federação Democrática Internacional de Mulheres - FEDIM, e integrante do Conselho Nacional dos Direitos da Mulher CNDM.

\section{Ministra Nilcéa Freire}

Boa tarde. Vamos trabalhar esse Painel com uma certa dose de informalidade, por isso chamamos de "Diálogo Interativo". Na verdade, nós estamos, aqui, abusando um pouco das nossas companheiras, das nossas convidadas internacionais, que atenderam ao nosso convite e que, à medida que estariam aqui, conosco, nós não poderíamos perder a oportunidade de ouvir um pouco das suas experiências.

Então, convidamos, também, a UNIFEM e a CEPAL para estarem aqui conosco, e a companheira Márcia Campos, que é do Conselho Nacional dos Direitos da Mulher e Presidenta da FDIM (Federação Democrática Internacional de Mulheres), para que faça a moderação dessa Mesa.

Eu vou passar a condução dos trabalhos, portanto, para a Márcia, para assistir, do Plenário, a intervenção das nossas companheiras aqui presentes, que eu passo a agradecer: a Ministra Patrícia Espinosa, Presidente do Instituto da Mulher do México; a Excelentíssima Senhora Cândida Celesta da Silva, Ministra da Família e Promoção da Mulher de Angola; Doutora Amélia Paiva, Presidente da Comunidade dos Países de Língua Portuguesa; a senhora Deputada Nérida Quintero, representante da Federação das Mulheres Cubanas; a senhora Deputada Beatriz Paredes, Presidente da Fundação Colossio, do México; Doutora Ariadna Reis, Representante do Conselho 


\section{5 de jullho de 2004}

Nacional da Mulher do Equador; Doutora Virgínia Gúzman, consultora da CEPAL Comissão Econômica para a América Latina e Caribe - grande parceira da nossa Secretaria e do Movimento de Mulheres Brasileiras, e Doutora Mônica Munhoz, representante da UNIFEM no Brasil.

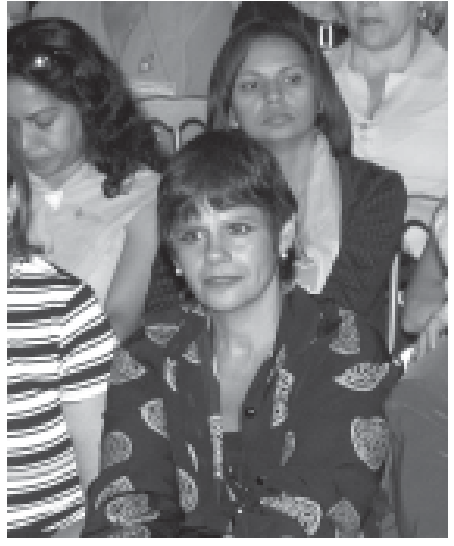

política norte-americana

Então, por favor, Márcia, passo a condução dos trabalhos para você.

\section{Sra Márcia Campos}

Boa noite a todas as companheiras que estão aqui, abrilhantando a nossa $1^{\text {a }}$ Conferência Nacional de Políticas para as Mulheres. Gostaria de dizer para cada companheira que está aqui presente, para todos e para todas, que o nosso país e o mundo vivem um momento muito grande de transformações.

Nós, hoje, percebemos a humanidade se somando, se indignando com políticas como as do governo dos Estados Unidos que, de forma cada vez mais unilateral, não leva em consideração os desejos da humanidade.

Essa Mesa vai expressar um pouco do esforço que a humanidade faz, por soberania, por desenvolvimento, por igualdade, para garantir a identidade de cada Nação, e para que cada vez mais, a cooperação entre as Nações, a integração entre as $\mathrm{Na-}$ ções possa vigorar no mundo.

O Presidente Luiz Inácio da Silva tem feito um esforço muito grande, desde que assumiu a Presidência da República, para buscar novos caminhos para a humanidade. É a relação que o Brasil vem desenvolvendo com a China que vai crescer, que vai gerar, para o nosso país, divisas, vai gerar emprego, vai gerar mais desenvolvimento para a Nação brasileira.

É o nosso país enfrentando, com dignidade, a tentativa norte-americana de impor uma ALCA, uma Área de Livre Comércio, que não interessa à Nação brasileira e aos demais países americanos. É o Presidente Lula se esforçando para que o Mercosul seja um caminho de desenvolvimento para os países latino-americanos e, hoje, também para o México, também para a Venezuela, o que é uma honra muito grande, porque estamos descobrindo o caminho do desenvolvimento de todas as Nações. É hora, efetivamente, de garantir a paz no mundo, de garantir a cooperação e de garantir a inclusão de todos os povos e Nações.

Eu quero registrar, saudar e resgatar neste momento o heroísmo do povo do Iraque, 


\section{5 de Julho de 2004}

o heroísmo do povo palestino, o heroísmo do povo de Cuba, que não vai se agachar perante os norte-americanos e vão defender a honra das suas Nações. É a isso que o povo brasileiro se soma aqui, nesta noite, e se soma aqui, neste momento.

Vamos agora ouvir a palavra de cada uma das nossas visitantes, que nós esperamos com tanta ansiedade, durante todo o período de preparação dessa Conferência.

Primeiro eu gostaria de fazer dois resgates nacionais: à companheira brasileira que coordenou em nosso país um trabalho muito bonito resgatando todas as mulheres guerreiras do nosso país em relação ao Prêmio Mundial da Paz. Queria agradecer à companheira Clara Charf, pelo brilhante trabalho que desenvolveu, em nome de todas as brasileiras. Vamos ganhar esse prêmio. Nós e as outras mil mulheres. Resgatar ainda o papel do Mercosul, esse trabalho tão importante para o povo brasileiro, e também para o povo latino-americano, o trabalho da companheira Maria Elvira, que é presidente do Fórum de Mulheres do Mercosul, também Conselheira juntamente com a Clara Charf do Conselho Nacional dos Direitos da Mulher.

\section{Ministra Patrícia Espinosa.}

Muito obrigada por me dar a oportunidade de poder falar aqui para vocês, por estar presente nesta conferência de mulheres brasileiras tão cheia de impactos. Vou falar em espanhol, espero que me entendam, mas a apresentação está em português para que fique mais claro. Desculpem por eu não falar português.

Quando me chegou o convite da ministra Nilcéa, decidimos compartilhar a experiência do México, já que o Instituto Nacional das Mulheres, que é o similar da Secretaria da Mulher aqui no Brasil, foi criado em 2001, já temos 3 anos e meioe vamos compartilhar a experiência da criação do Instituto.

Os Institutos no México não são Ministérios, são aquilo que chamamos de Gabinete Ampliado, que têm interlocução direta com todos os Secretários e os acordos são feitos diretamente com o Presidente da República. São uns dos avanços e das importantes conquistas para que as mulheres possam influenciar nas políticas públicas de nossos países.

O México, no relatório sobre o desenvolvimento humano do PNUD da ONU, se encontra no índice de desenvolvimento humano número 53 de 175 países. No índice de desenvolvimento relativo ao gênero, estamos no lugar 55 de 144 e no índice de 


\section{5 de Jullho de 2004}

potencialidade de gênero no número 42. Contamos com uma população de um pouco mais de 104.000 .000 (cento e quatro milhões) dos quais $50,25 \%$ somos mulheres e 49,75\% são homens; com uma esperança de vida das mulheres de quase 78 anos e dos homens de quase 73 anos. Temos 5 anos de diferença na média de vida. 0 México é uma República Federal com 31 estados e 1 distrito federal no país.

Entre os tratados e convênios internacionais quero destacar a assinatura da convenção

CEDAW

Belém do Pará

Plano Nacional de Desenvolvimento

Programa Nacional de Igualdade de Oportunidades e não Discriminação sobre a eliminação de todas as formas de discriminação contra a mulher, a CEDAW e também foi assinado o Protocolo Facultativo da mesma forma que a Convenção de Belém do Pará. 0 Instituto Nacional das Mulheres é o mecanismo nacional reitor na agenda de gênero, onde estamos trabalhando com todos os Ministérios do Governo Federal para conseguir transformar uma cultura masculina machista em uma cultura democrática entre homens e mulheres.

Para dar seguimento e cumprimento aos compromissos internacionais e regionais em matéria de gênero e conscientes dos objetivos do desenvolvimento do milênio; estes estão refletidos no Plano Nacional de Desenvolvimento deste governo de 2001 a 2006. Este plano estabelece como um dos objetivos centrais, conduzir de maneira democrática e participativa o processo de transição do país para uma sociedade mais justa e igualitária entre homens e mulheres. 0 plano estabelece uma nova relação entre o governo e a sociedade civil e postula novos paradigmas de desenvolvimento humano com equidade.

Portanto abaixo está o Programa Nacional para Igualdade de Oportunidades e não Discriminação, que conhecemos como Pró-Equidade, para cumprir com o seu compromisso tem como ponto de partida também os acordos de Beijing, da plataforma de ação de Beijing, que em seu parágrafo 197 fala a respeito da criação dos mecanismos. Antes do Instituto no México nós tivemos o programa nacional para o avanço das mulheres que teve vigência desde 1995 até 2000. Em 2001 foi criado 0 Instituto e o Programa Nacional para Igualdade de Oportunidades. Para a realização deste programa, vocês vêem em azul, temos um acordo nacional pela equidade. 0 Presidente Lula assinou o decreto para fazer a institucionalização da perspectiva de gênero em todas as políticas do governo.

No México assinamos um acordo nacional pela equidade entre homens e mulheres com o Presidente e todos os Secretários de Estado. Isso tem feito com que os Secretários atendam a agenda de gênero. Estamos trabalhando com todos os companheiros do governo. 0 Instituto Nacional das Mulheres conta com uma junta de governo, 


\section{5 de jullho de 2004}

que é o órgão mais alto dentro da instituição do Instituto. A junta do governo conta com 2 órgãos auxiliares. Um é o Conselho Consultivo e o outro é o Conselho Social. Estão aqui comigo duas conselheiras destes órgãos auxiliares, a companheira Olímpia Flores e Candelária Ochoa. 0 Conselho Consultivo é o órgão assessor e promotor das ações e o Conselho Social é o órgão de assessoria e consulta.

O Plano de Igualdade, como é chamado aqui, nós o chamamos de Pró-Equidade, pró-equidade teve um processo de elaboração através de um Fórum Nacional de Consulta, muito semelhante ao que vocês já fizeram aqui. Estivemos fazendo fóruns em todo o país, onde foram recebidas as propostas. Foram mais de 2000 propostas de trabalho e 0 Plano Nacional de Igualdades foi construído com uma participação muito ampla de toda a sociedade, dos conselhos, da academia, dos legisladores e dos funcionários.

O Pró-eqüidade tem como objetivo potencializar o papel das mulheres em todas as esferas da sociedade para a eliminação de todas as formas de discriminação. Tem nove objetivos fundamentais. 0 primeiro, que é um dos mais importantes, porque trabalha com a institucionalização da perspectiva de gênero nas políticas publicas. Conseguir com que os programas de políticas públicas do governo levem em consideração que mais da metade da população é de mulheres e que as mulheres não tem acesso a esses projetos e a essas políticas porque são projetados com outra visão. Em 3 anos nós já revisamos muitas dessas políticas dos programas, como funcionam as regras, a norma para que se possam ter acesso a elas.

0 Pró-eqüidade tem outros 8 temas que trabalhamos como impulsionar o marco jurídico, fomentar a igualdade de oportunidades econômicas, impulsionar as condições que incidem para terminar com a pobreza, sobre temas como política educacional, saúde integral, o combate à violência, a tomada de decisões por parte das mulheres. Tudo isso está em conformidade com o programa do nosso plano nacional. 0 nosso programa está na página do Instituto, para quem tem interesse em conhecêlo. Já o compartilhamos com a nossa contraparte.

Para conseguir tudo isso nós criamos uma série de mecanismos para vincular e coordenar todas as tarefas. São vários os mecanismos, mas eu apenas gostaria de ressaltar esses 4. A partir do acordo pela equidade cada titular da dependência federal designou um representante e criamos a mesa de conexões de gênero federais. Contamos com 55 agentes de ligação que estão trabalhando em cada um dos espaços do governo para poder influenciar nessas políticas e para conseguir com 
que a agenda de gênero seja realmente uma agenda de governo. Temos também um trabalho permanente, uma agenda de diálogo com as organizações da sociedade civil, com todos os estados e municípios. Temos nos 31 estados e no Distrito Federal, nas 32 entidades, uma instância da mulher. Nos municípios, que são 2.400, contamos com quase mais de quinhentas instâncias municipais com as quais já estamos trabalhando.

violência

0 tema da violência também é um tema que nos tem tomado tempo, criamos uma mesa institucional para coordenar ações para combater e erradicar a violência. Contamos com um programa e ações importantes como, um levantamento que fizemos sobre violência familiar, linha de orientação telefônica para vitimas, a rede de refúgios e uma série de indicadores. Há também outros grupos e outros mecanismos que são importantes a sua criação para se realizar estes objetivos.

Entre os instrumentos, ferramentas só quero ressaltar algumas, como é o acordo nacional por equidade, convênios de colaboração e também já assinamos mais de 20 acordos ou convênios com os titulares da administração pública, com 15 governadores, com 8 instituições acadêmicas, e muito mais com algumas organizações da sociedade civil. Outro ponto importante é a capacitação com uma ação multiplicadora, então levamos a cabo o trabalho institucional e transversal.

0 seguinte slide é somente um exemplo a respeito de como medimos os objetivos e metas do Pró-equidade. Colocamos metas de curto, médio e longo prazo e dos 9 objetivos vamos medindo como está o resultado, como se tem trabalhado, e a ponderação vai somar a cem que é o último item que trabalharíamos. Também nós medimos os avanços de metas do plano em cada um de nossos objetivos, porque se não contamos com indicadores como vamos fazer avaliação e medir o avanço e a incidência de cada uma das metas e dos objetivos; não saberemos como medir.

Entre os sistemas de medição contamos com o SISESIM que é um Sistema para o Seguimento da Situação da Mulher que nos dá indicadores para conhecer qual é a situação da mulher; temos um sistema interativo para dar prosseguimento a CEDAW, que se chama SICEDAW; temos um sistema estatal de indicadores de gênero; já temos 14 estados no país que tem seus sistemas de indicadores; também fizemos um levantamento nacional para saber a situação da violência entre casais, em mais de 52.000 moradias. É o único levantamento na América Latina desta dimensão, feito 
diretamente em moradias onde vivem mulheres de mais de 15 anos, com companheiros. A prevalência de violência foi de quase $50 \%$, sendo reconhecida pelas mulheres.

Para conseguir a transversalidade da perspectiva de gênero nós impulsionamos a capacitação tanto de funcionários dos poderes Executivo, Legislativo e Judiciário nos estados e municípios, como de integrantes da sociedade civil. Alguns dos programas são de capacitação, com uma metodologia, com indicadores de gênero.

Nós também temos um manual para desenvolver indicadores de avaliação com perspectiva de gênero. Outros exemplos, nós também capacitamos e fazemos workshops para procuradores de justiça e advogados. Temos um grande acervo de indicadores e estatísticas separadas por sexo.

Este é um resumo do trabalho que temos feito nestes 3 anos e meio no Instituto para conseguir transformar essa sociedade e conseguir com que as políticas públicas estejam voltadas para a perspectiva de gênero, para que ajudem a diminuir a discriminação e a lacunas. Muito obrigada!

\section{Doutora Amélia Paiva}

Muito obrigada a todas. Muito boa noite a todas e a todos. Eu sou, exatamente, presidente de Comissão para a Igualdade pelos Direitos das Mulheres em Portugal, e fui organizadora recentemente de um Seminário dos Países de Língua Portuguesa.

Foi com muita honra que aceitei o convite lançado pela senhora ministra da Secretaria Especial de Políticas para as Mulheres, Doutora Nilcéa Freire, para participar, nesta I Conferência Nacional de Políticas para as Mulheres, muito louvável e importante iniciativa do governo brasileiro, de reunir as mulheres brasileiras para construir com elas, e para elas, um Plano Nacional de Políticas para as Mulheres.

No ano em que se comemoram em Portugal os 30 anos do restabelecimento da democracia, vou me permitir partilhar convosco algumas reflexões sobre a evolução dos direitos das mulheres em Portugal, bem como sobre os dois planos, o Segundo Plano Nacional para a Igualdade, e o Segundo Plano Nacional contra a Violência Doméstica, que foram aprovados no Conselho de Ministros, no ano de 2003.

É forçoso reconhecer que os progressos alcançados em Portugal, em matéria de igualdade, entre mulheres e os homens foram, nos últimos 30 anos, progressos notáveis.

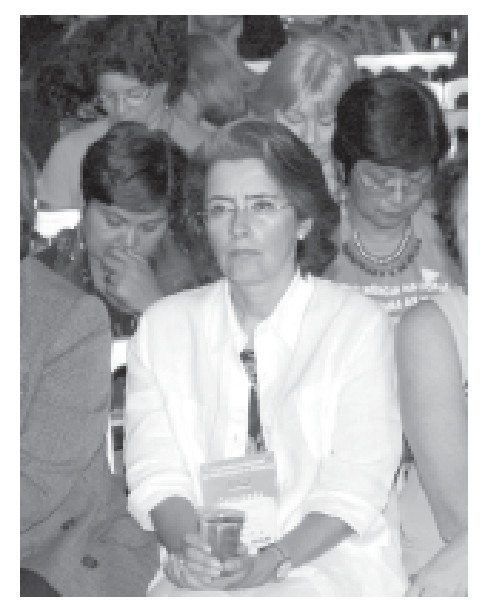

planos nacionais 
De fato, as mulheres portuguesas conquistaram autonomia jurídica. A maioria de vocês, aqui, como muitas vezes em Portugal me acontece perceber, não Ihes ocorre pensar que as mulheres portuguesas, antes de 25 de abril de 1964, não podiam viajar para o estrangeiro sem uma autorização do marido. E que apenas em novembro de 1974 foram abolidas todas as restrições, baseadas no sexo, quanto à capacidade eleitoral. E que só em 1966 foi abolido o direito do marido abrir a correspondência da mulher. E que só em 1968, com a entrada em vigor da revisão do Código Civil, a mulher casada deixa de ter um estatuto de dependência, para ter um estatuto de igualdade com o homem. E só, então, desaparece uma figura que ainda tanto se utiliza, na linguagem de todos os dias, a figura do chefe de família.

A mulher deixa, a partir de então, de precisar da autorização do marido para ser comerciante. E cada um dos cônjuges pode exercer qualquer profissão ou atividade, sem o consentimento do outro.

Também aproveito para dizer que só nessa altura terminou a impossibilidade das mulheres serem magistradas, juízas, ou serem diplomatas. Até essa altura, 1964, não era permitido às mulheres, em Portugal, desempenharem nenhuma dessas duas carreiras, a diplomacia ou a magistratura.

Hoje, as mulheres portuguesas caminham, felizmente, e progressivamente, no sentido da autonomia econômica. Obtiveram igualdade de direitos com os homens e entraram, em grande número, no mercado de trabalho. Todos os anos representam, já, a maioria dos jovens diplomados no ensino superior. São já $67,1 \%$ dos diplomados. No entanto, o maior número de desempregados com licenciatura, na procura do primeiro emprego, continuam a ser as mulheres.

Mas os progressos alcançados têm sido lentos. A igualdade formal já atingida não corresponde a uma igualdade de fato. E esta continua a não garantir que mulheres e homens tenham, efetivamente, as mesmas oportunidades. Permanece uma estreita ligação entre a função biológica das mulheres e a forma como os papéis sociais se encontram divididos, entre essa função e a discriminação contra as mulheres, na vida profissional e nas várias instituições da sociedade.

Se refletirmos sobre os cotidianos, sobre a vida de todos os dias, das mulheres e dos homens, constataremos, e como dizia a senhora ministra, na sua intervenção desta 
tarde, não vivem os mesmos problemas e, tampouco, têm acesso às mesmas oportunidades. Basta falar, por exemplo, do sistema de transportes. Daí decorrem, em grande parte, as diferenças significativas que subsistem entre ambos os sexos, em áreas fundamentais. As mulheres continuam a constituir, em Portugal, a maioria dos desempregados. A taxa de feminização do desemprego era de 53,6\% no primeiro trimestre deste ano.

São, freqüentemente, as únicas responsáveis pela assistência a filhos, idosos e a dependentes em geral. Ganham menos do que os homens. Em 2000, as mulheres portuguesas receberam $77,4 \%$ da remuneração média de base mensal. Possuem menos bens e trabalham o maior número de horas.

Efetivamente, de acordo com estudos recentes, as mulheres trabalham, em média, mais duas horas por dia, se tivermos em conta, além das responsabilidades profissionais, 0 trabalho familiar e doméstico. Isso as impede, muitas vezes, de ascender a outros domínios de participação cívica e política.

As mulheres são, também, mais expostas à violência e à exploração sexual. A pobreza continua a atingir, sobretudo, às mulheres. Mantém-se, por outro lado, a desigualdade entre as mulheres e os homens, no acesso efetivo à participação e à decisão política, econômica, social e cultural.

Estas desigualdades são contrárias ao princípio da democracia, que pressupõe que cada cidadão e cada cidadã participem, de forma ativa e plena, em todas as esferas da vida pública e privada.

Não quero, obviamente, dar-vos, aqui, uma lição de História recente de Portugal, mas relembrar que a construção de uma sociedade mais desenvolvida e mais democrática são grandes propósitos, inscritos na Constituição portuguesa. Sendo a igualdade entre mulheres e homens uma das tarefas fundamentais do Estado.

Neste quadro, a redução das desigualdades entre homens e mulheres é, de fato, uma das maiores revoluções ocorridas em Portugal, nas últimas décadas, e é parte da consolidação do sistema democrático. Sem igualdade entre homens e mulheres, nunca teremos uma sociedade justa, democrática, desenvolvida e respeitadora dos direitos humanos.

Como todas sabemos, e todos sabemos, as tarefas, no sentido da promoção da igualdade são muitas e variadas. Tanto mais quanto a sociedade continua a atribuir, 


\section{5 de jullho de 2004}

a mulheres e a homens, papéis sociais específicos e diferentes, que vão ter conseqüências nas suas escolhas escolares e profissionais, e que influenciam a forma como umas e outros desempenham funções, na esfera do público e do privado, da produção e da reprodução, funções essas que continuam, como todas sabemos, a ter valor e reconhecimento social, e até econômico, diferentes.

Passadas quase 3 décadas de democracia pode, por outro lado, afirmar-se que a participação das mulheres portuguesas, em termos igualitários, está, não obstante os grandes progressos, longe de ser desenvolvida. E, por essa razão, o Governo de Portugal considerou fundamental a adoção de dois instrumentos para atingir esses objetivos. São eles: o Segundo Plano Nacional para a Igualdade e o Segundo Plano Nacional contra a Violência Doméstica, de que vos falava há pouco.

Ambos os processos envolveram, à semelhança do que acontece no Brasil, os vários departamentos do Estado e a administração local. E ambos os processos tentam conseguir que as políticas e as medidas estruturais venham a integrar, efetivamente, a perspectiva de gênero em todas as atividades dos vários departamentos da Administração Pública, tanto ao nível do seu funcionamento interno, como no que se refere às iniciativas dirigidas aos públicos com os quais trabalham.

Trata-se de continuar a aplicar, com empenho redobrado, uma estratégia para alcançar a igualdade de oportunidades. Essa estratégia passa pelo desenvolvimento de um vasto número de atores, na intervenção sistemática de uma perspectiva de gênero em todos os processos de elaboração, implementação, avaliação e redefinição das políticas e das ações, tal como vem sendo recomendado pela União Européia, pelas Nações Unidas, pelo Conselho da Europa.

Assim, não basta o combate à discriminação e a criação de programas específicos para as mulheres, ou para mulheres e para homens, porque também consideramos que para atingir uma igualdade efetiva é cada vez mais fundamental que neste combate e nesta luta estejam envolvidas não apenas as mulheres, mas as mulheres e os homens. Aquilo que, normalmente, nesses programas de políticas chamamos as "ações positivas".

É necessário, sobretudo, que a perspectiva de gênero e a dimensão da igualdade sejam integradas em todas as políticas governamentais. 


\section{5 de Julho de 2004}

O Segundo Plano Nacional para a Igualdade, que vos falarei muito brevemente, tem como grandes medidas, medidas organizadas, medidas estruturantes, que são de caráter transversal, cuja implementação caberá a todos os Ministérios e medidas por grandes áreas de intervenção.

As principais áreas de intervenção - e vou, obviamente, abreviar - são: atividade profissional e vida familiar; trabalho, emprego e proteção da maternidade e paternidade; e conciliação da vida familiar e profissional; educação, formação e informação, e a área nuclear, neste capítulo, é a educação; cidadania e inclusão social onde, sub-capítulos importantes são o poder e a tomada de decisão, a pobreza e a inclusão social, as mulheres migrantes e as minorias étnicas e culturais. Portugal é, cada vez mais, um destino de imigração, e um sub-capítulo, neste outro, violência contra as mulheres, onde a questão do tráfico de mulheres e da prostituição são preocupações fundamentais.

E, por último, e por isso estou aqui, com muito gosto, em março fui anfitriã de um Seminário que pôde contar com a presença da Maria Laura, a cooperação dos países da CPLP.

Este Plano é um plano vasto. Mas há um segundo, que é um Plano dedicado exclusivamente às políticas de combate à violência doméstica. É um plano que está estruturado em sete grandes áreas de intervenção, num total de sete medidas, e as quais, e das mais importantes são: informação, a sensibilização e a prevenção; a formação dos profissionais que trabalham com as mulheres vítimas de violência doméstica; a proteção das vítimas, nomeadamente através das Casas-Abrigo; e a integração e a formação profissional dessas mulheres e, obviamente, as políticas de avaliação.

Vou terminar deixando-vos duas reflexões. A História tem nos ensinado que é muito mais fácil conceder direitos à mulher abstrata e ideal do que às mulheres concretas e reais, no exercício de um cotidiano, que foi construído sobre bases que têm como norma e como modelo o masculino. Não basta, por isso, mudar leis e princípios, há, também, que mudar modelos, hábitos e mentalidades. Há, ainda, uma batalha a ser ganha: a batalha a favor da paridade e dos direitos humanos.

Muito obrigada pela oportunidade.

Muito bons trabalhos. 


\section{5 de Jullho de 2004}

\section{Deputada Nérida Quintero.}

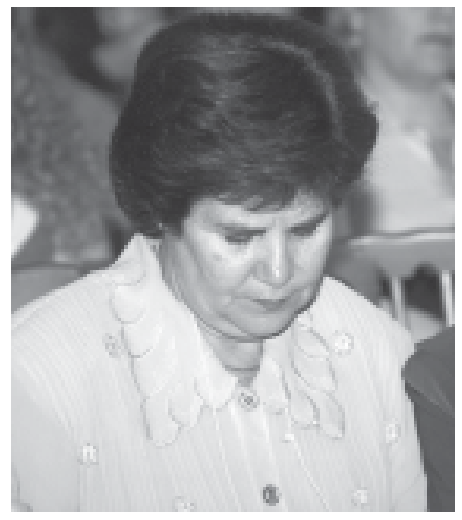

revolução cubana
Lamento muito não falar em português, porque me solidarizo com as palavras tão emotivas da amiga Márcia e hoje temos estado muito emocionadas porque realmente a vitalidade, a combatividade das milhares de mulheres reunidas neste dia de hoje, nos tem feito refletir sobre a força das mulheres e quando pensamos nos nossos antecedentes da índia indomável, da guerrilheira incansável não teremos mais nada a pensar. A força e a vitalidade que nós mulheres latino americanas colocamos em tudo o que fazemos. Realmente somos uma força pujante com a qual temos que contar.

Quero transmitir-Ihes um abraço em nome das quatro milhões de mulheres cubanas que represento, sou representante da Federação das Mulheres Cubanas que há 45 anos crescemos como mulheres. Podemos mostrar a vocês os progressos que temos conquistado num processo em revolução; revolução que mantém acesa sua chama que bate no coração junto com vocês e que temos conquistado nestes 45 anos, conquistas tão significativas para as mulheres cubanas que $66,1 \%$ de nossas mulheres cubanas pertencem ao setor técnico e cientifico, 48\% são cientistas e 66\% são mulheres em aulas universitárias e 99,8\% estão alfabetizadas. 0 grau médio de escolaridade do país é o nono grau. Realmente podemos mostrar ao mundo o que temos sido capazes de fazer através da implementação da transversalidade do gênero nas políticas públicas no nosso país.

No ano de 1997 foi aprovado por decreto lei do Conselho de Estado da República de Cuba o Plano de Ação Nacional para dar seguimento da quarta Conferência de Beijing Beijing, com 90 tarefas que checamos sistematicamente junto com a sociedade civil. Nossa organização de mulheres, junto com o estado cubano, temos conseguido melhoras incríveis para as mulheres em todos os setores da educação, da saúde. Hoje em Cuba 70\% dos médicos são mulheres, são professoras mais de $70 \%$ e hoje podemos mostrar o trabalho internacional feito pelas mulheres cubanas quando no mundo mais de $50 \%$ dos médicos que prestam assistência solidária são mulheres. $\mathrm{E}$ isso é um orgulho para nós, poder mostrar a vocês o que temos conseguido com 0 seguimento das políticas públicas no estado cubano e com as conquistas que temos tido.

Algumas amigas nos falavam das conquistas que tivemos na saúde sexual e reprodutiva, das conquistas que temos tido na mortalidade infantil em Cuba; 6,3 falecidos para cada 1000 nascidos vivos é a mortalidade infantil mais baixa da América Latina neste momento está em Cuba. É um país bloqueado há 45 anos. 
Homens e mulheres em Cuba lutam pela igualdade de oportunidades entre ambos e podemos mostrar conquistas significativas.

Eu agradeço em nome das minhas mulheres, em nome do meu povo, a possibilidade de me dirigir a vocês, a possibilidade de compartilhar estes lindos dias com vocês e crescer como mulher junto a vocês. Desejo a vocês muito sucesso no seu evento, muitas coisas lindas e cantar junto com vocês o samba brasileiro e a salsa cubana, que ambas, que cantemos em uníssono em uma dança, na qual somos muito apaixonadas, tanto vocês quanto nós. Convidamos vocês a ir a esta pequena ilha do Caribe de 11 milhões de cubanos que se sentem orgulhosos das conquistas nestes 45 anos de revolução. Muito sucesso! Muitas felicidades! Viva a primeira conferência! Saudações a todas!

Obrigada!

\section{Deputada Beatriz Paredes.}

Boa noite! Eu falo um pouquinho de português, mas falarei em espanhol bem devagar. Saudações a minha amiga de Cuba por sua paixão e sua emoção. Eu me perguntei muito, o que poderia dizer a vocês que fosse útil, que tivesse sentido nesta primeira conferência, neste feito memorável das mulheres brasileiras, principalmente porque admiro e conheço as conquistas do feminismo brasileiro e sei que as mulheres no Brasil têm contribuído para todo o avanço das mulheres na América Latina; mas também porque estou convencida que o Brasil está vivendo um momento histórico, porque eu tenho a certeza que a chegada do Presidente Lula ao governo do Brasil significa uma esperança não só para o Brasil, mas também para a América Latina e para o mundo.

De repente há processos de regressão que arrebatam as mulheres, o que é um produto de um enorme esforço coletivo. Conscientes dessas possíveis regressões e no âmbito de um processo histórico, como o qual vocês estão vivendo, eu acredito que a estratégia do Ministério da Mulher, do governo do Presidente Lula e do movimento massivo de mulheres, dos diversos movimentos de mulheres do Brasil tem saber distinguir o que é o importante, o que é o urgente e o que é o transcendente.

As mulheres da vida cotidiana estarão exigindo o que é urgente, ou seja, mais moradia, melhores serviços de saúde, maiores oportunidades de capacitação, respaldo para um programa para a mulher rural e tudo isso precisa ser atendido e atendido com grande eficiência. Ao mesmo tempo em que atendemos o que é urgente temos

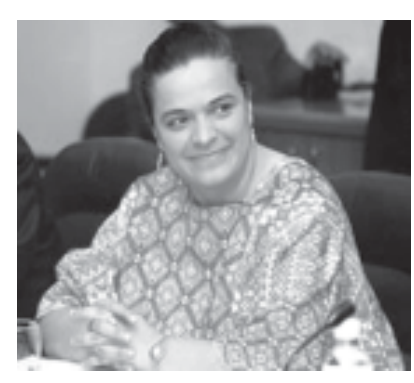

movimento feminista brasileiro 


\section{5 de Jullho de 2004}

que olhar também o que é transcendente e a experiência de revisão de vários dos projetos governamentais na América Latina faz com que eu compartilhe com vocês as seguintes considerações:

Primeiro: façam com que as verdadeiras conquistas sejam projetadas na legislação. A legislação é o que permite uma projeção de grande alcance, uma grande projeção ao longo dos anos e às vezes os dirigentes políticos, principalmente os dirigentes políticos da esquerda não dão toda a importância à legislação. Eles pensam finalmente que é a expressão de um status quo superado. Eu quero propor que seja feita uma proposta legislativa que seja negociada com os deputados e senadores dos diferentes partidos, que tenham um programa legislativo que possa ser realizado ao longo de toda a administração do Presidente Lula e que tenham a certeza, não somente de que sejam erradicadas todas as normas discriminatórias, mas também que sejam garantidas ações afirmativas em todos os sentidos e que deixem materializadas, no âmbito do legislativo, a institucionalização em favor das mulheres.

O segundo assunto está relacionado em como podem incidir na cultura e na percepção de homens e mulheres sobre o papel da mulher. Quando está começando uma administração federal, quando há possibilidades de alianças positivas é possível ter projetos ambiciosos. Eu me atrevo a sugerir que façam uma revisão dos programas de estudo e que consigam ter uma incidência no sistema educacional brasileiro para que o padrão educacional não reproduza cultura discriminatória, nem com relação às mulheres, nem com relação às raças. Eu acho que vocês estão em condições de tentar um processo de reforma educacional pela igualdade, que permita conceitualmente incidir na projeção dos programas de estudo em uma série de exercícios na prática escolar que possa erradicar a discriminação.

O terceiro assunto, que eu acho indispensável é que vocês façam um esforço monumental, massivo e contundente para a formação de quadros. Eu acho que a experiência que hoje nós tivemos quando escutamos que estavam presentes vereadoras de diferentes regiões do Brasil, percebemos que vocês podem fazer um esforço de formação enfocando o gênero das líderes comunitárias, das líderes de base, das vereadoras e de toda a estrutura de representação social brasileira. Seria possível fazer uma estratégia de capacitação que utilize os recursos informáticos e os meios eletrônicos. Eu me atrevo a sugerir que tenham uma rádio da mulher, que possa transmitir avisos, assuntos, programas e que seja um instrumento fácil de comunicação em um país com uma geografia tão extensa; onde as mulheres pobres para se informar, estão limitadas pela possibilidade de transporte. 0 rádio é um instrumento muito útil. 


\section{5 de jullho de 2004}

Acho indispensável esse processo de capacitação generalizada, porque o que importa no Brasil, como o que importa no mundo, não é que tenhamos, como tivemos hoje ao meio dia, um painel com uma qualidade extraordinária de Jacqueline Pitanguy, de Sueli, da ministra, mas precisamos que isso se reproduza por milhares, por miIhões; esse seria um esforço de capacitação popular, que permitiria dar continuidade à estratégia de equidade de gênero, independentemente das circunstâncias políticas e independentemente do peso institucional, porque a minha experiência, queridas amigas, é que o governo não é suficiente. É importante, mas não é suficiente.

Nas questões de transformar a discriminação, nas questões de sacudir a consciência, nas questões de mudar o mundo, somente a sociedade e o povo têm a última palavra e é indispensável gerar uma massa crítica que esteja atenta, que exija e que solicite a continuidade dos projetos.

Finalmente, eu gostaria de concluir assinalando a importância dos pactos. Quanto ao tema da luta contra a desigualdade nós não podemos ser rigorosos com relação as intensidades. Existem aqueles que lutam contra a desigualdade a partir da esfera acadêmica, aqueles que o fazem em uma palestra na Câmara dos Deputados, aqueles que o fazem em uma comunidade. 0 fundamental é que não haja um conflito entre todas aquelas e todos aqueles que queriam transformar a realidade brasileira. Vocês terão a solidariedade das suas amigas da América Latina e do mundo, eu tenho certeza.

Nós mexicanas temos a honra de sermos representadas no Brasil, por uma destacada mulher mexicana, a embaixadora Cecília Soto, a quem saúdo com muito prazer e que hoje nos acompanha. Nós estamos também disponíveis para compartilhar todas as nossas experiências.

Gostaria de dizer que eu aprendi muito com vocês, que vocês têm muitas coisas para ensinar ao mundo, que nós temos o que trocar com o Brasil, com os brasileiros. Fazer com que recuperemos a utopia que outro mundo é possível e como é dito em uma canção de Gonzaguinha: "Eu não sei se a vida é boa ou ruim, eu só sei que é bonita, é bonita e é bonita..." 


\section{Doutora Ariadna Reis.}

Desde já sejam bem vindas ao meu país no Fórum Social Mundial das Américas. Muito obrigada a ministra Nilcéa Freire por convidar o Conselho Nacional de Mulheres do Equador, ministras, autoridades e todas que nos acompanham aqui neste momento histórico como foi dito pela companheira do México. Estão dizendo que eu falo rápido, então falarei mais devagar. Eu gostaria de saudá-las pessoalmente em nome do Conselho Nacional das Mulheres do Equador, que é um órgão vinculado com a Presidência da República da mesma forma que no Brasil, e também em nome da nossa diretora executiva, a doutora Rocio Roseiro.

Eu gostaria de começar dizendo que esta manhã eu tive uma lição, uma aprendizagem de memória, uma aprendizagem da transcendência dos quadros de mulheres, das mulheres líderes que lutaram e que transformaram no Brasil e também em toda a América Latina e no mundo. Isto é o que nos une e é o que inclusive fez com que fosse possível que cada país tivesse o seu mecanismo institucional, o seu conselho, 0 seu ministério, o que faz parte também da conquista do movimento de mulheres mundial. Nós no Equador, no ano 2004, também estamos construindo o plano de igualdades e de oportunidades. Este é realmente o segundo plano de igualdades e de oportunidades porque nós, em 1995, o fizemos baseado em Beijing, na plataforma de Beijing. Eu asseguro que nós aprendemos muito com essa experiência. Eu gostaria de compartilhar alguns pontos muito breve do que foi este processo agora em 2004.

A primeira lição que tivemos é que a inclusão da diversidade das mulheres é um desafio construído com muita força, diariamente e que não é fácil. Passar da formalidade de dizer que somos diferentes porque pertencemos a uma classe, pela nossa diversidade étnica, pela nossa idade, pela nossa opção sexual ou se somos da cidade ou do campo a construir uma política pública para apoio a essa diversidade é muito complexo. É um desafio que precisa ser construído com o estado e também com a sociedade civil, realmente como construtoras do pacto de equidade de gêneros de cada país.

A segunda idéia e que também foi uma lição importante dos últimos 7 anos no Equador, é que a compreensão das lacunas da equidade precisa ser uma lição para o país, uma lição de governabilidade democrática e neste sentido não pode ser vista como um tema exclusivamente de mulheres, para mulheres, a partir de mulheres; ou 


\section{5 de Julho de 2004}

seja precisa ser uma prioridade nacional de todos e todas e uma obrigatoriedade para os cidadãos e as cidadãs e para o Estado que projeta as políticas públicas. Não somente do conselho e das secretarias, mas todos os órgãos do executivo, do legislativo e da administração da justiça.

A terceira idéia é porque nós vivemos e tivemos uma fraqueza nos últimos 3 anos com relação aos mecanismos institucionais públicos de gênero. 0 conselho, a secretaria ou o ministério, o que seja em cada país, e nós acreditamos que o plano de igualdades e oportunidades do ano de 2004 não pode começar com nenhum passo atrás das conquistas e lutas que estão consagradas nos instrumentos nacionais de direitos. Este é o ponto mínimo que nos propusemos no Equador. Estamos nesse processo de construção, precisamos ir mais além, não podemos nos permitir, ainda mais em um momento tão comovente internacionalmente pelo cumprimento das convenções e instrumentos internacionais, dar um passo atrás.

Finalmente eu gostaria de dizer que um dos grandes desafios de 2004 é recuperar a força transformadora e revolucionária do movimento feminista e de gênero do Equador. Nós estávamos dormindo um pouco no Equador. Apesar de ser politicamente complexo o país, nós acreditamos que se não recuperarmos essa força transformadora, eu gostaria de deixar isso para vocês, nas suas mentes, nos seus corações e nas suas mãos, será muito difícil continuar avançando.

Muito obrigada.

\section{Doutora Virgínia Gúzman.}

Em primeiro lugar eu estou muito agradecida e me sinto privilegiada de estar neste momento aqui com vocês. 0 que eu gostaria de fazer agora é simplesmente refletir em voz alta a partir do que eu escutei ao longo do dia e um pouco a partir do que eu vi na CEPAL em um projeto de governabilidade democrática e gênero que temos trabalhado no Brasil, com grande satisfação da minha parte. Eu tenho uma simpatia enorme, muito grande.

Eu acredito que uma primeira reflexão, são 4 ou 5, que foi bastante repetida é como esse momento é um momento de um processo histórico muito amplo, que foi conseguido graças a criação de força política, campos políticos, novas concepções e novas interpretações da realidade. Tem sido um processo muito questionador do que são ou o que eram as instituições que subordinavam as mulheres. Então eu acho que 


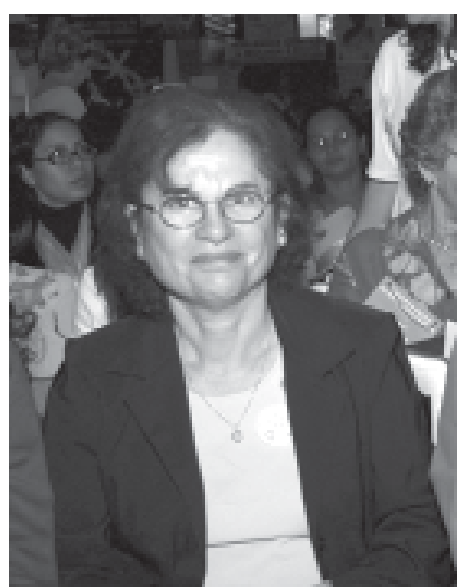

liberdade autonomia justiça social

\section{5 de julho de 2004}

essa força, esse caráter, não somente de mobilização política, mas de questionamento institucional para gerar novas instituições, acho muito importante que seja resgatado.

Outra idéia que a Beatriz mencionou agora e que a Jacqueline repetiu e que foi dito ao longo do dia, eu acho que também é importante ser assinalada, o movimento de mulheres, a luta pela igualdade de gênero não acontece no nada, acontece em contextos históricos, culturais muito específicos e esta área política, que em algum momento se consegue gerar, pode crescer ou pode se enfraquecer. Em um momento determinado, as conquistas podem aparecer muito enfraquecidas. É um trabalho permanente de consolidação e de manutenção porque eu sempre assinalo que o movimento feminista, a equidade de gênero, a igualdade, é uma mudança cultural e uma proposta inovadora.

Entretanto eu acredito que neste momento, no âmbito da América Latina, e eu acho que o Brasil tem um papel privilegiado neste caso, nós vivemos em um contexto de grandes oportunidades e de grandes riscos para a equidade de gênero. Grandes oportunidades por que? Porque esta ordem de gênero tão monolítico já foi enfraquecida, porque as mulheres ganharam autonomia, porque de alguma forma existe o reconhecimento do respeito ao estilo de vida diferente, onde de alguma forma é solicitado o protagonismo.

Contudo, poder exercer a liberdade e a autonomia passa pela obtenção dos recursos e das oportunidades para fazê-lo e neste sentido eu acho que o desafio atual é como articular o elemento de liberdade com justiça social. Eu acho que é a grande luta, porque a luta das mulheres é uma luta pela liberdade, pela autonomia e pela justiça social; e eu acho que o Brasil com os desafios da inclusão social tem neste tema a possibilidade de articular essas duas grandes dimensões, a justiça e a liberdade.

Por outro lado eu gostaria de tocar em um segundo ponto, que é o seguinte: 0 Presidente Lula disse esta manhã que este evento e esta política estão propondo uma nova relação entre o Estado e a sociedade. Agora, no momento atual as relações entre o Estado e a sociedade não são rígidas, ou seja, são bastante livres, ou seja, nós podemos encontrar correntes progressistas que vão desde a sociedade penetrando o Estado como correntes também atrasadas dentro do Estado e dentro da sociedade. Então eu acho este aspecto de fluidez de limites não bruscos, não rígidos é importante ser levado em consideração. 


\section{5 de jullho de 2004}

Acho que o Brasil, eu fico impressionada com a experiência de participação e de controle social que foi feito num momento de elaborar políticas comparando com outros países, acho que ainda fica um grande desafio que é o desafio da gestão das políticas, como eu construo uma institucionalização que efetivamente permita a elaboração e a manutenção de políticas e serviços de gênero.

Quando o que eu proponho, e isso eu acho que é muito importante, questiona a organização habitual do Estado, questiona a setorialidade, questiona os critérios de avaliação de sucesso e fracasso, questiona o tipo de distribuição de orçamento e etc. Então o tema de como introduzir a gestão, a Patrícia disse muito bem, alguns indicadores, algumas normas, alguns critérios que nos permitam dar seguimento as políticas. Eu acho que o tema da tecnologia é um tema que os mecanismos de gênero, as secretarias das mulheres, as novas tecnologias, é um grande tema para ser abordado.

Finalmente, acho que de alguma forma, a última reflexão que me veio neste dia é que estamos num momento não apenas numa relação, construindo uma relação nova entre o Estado e a sociedade, não só estamos questionando uma velha institucionalização, mas gerando uma nova institucionalização e isso a Beatriz falou, estamos num momento em que é necessário gerar um novo pacto social, um novo pacto social em torno da igualdade e equidade de gênero.

Muito obrigada.

\section{Ministra Nilcéa Freire.}

Obrigada, Virgínia. E, ao encerrar esse painel internacional, mais uma vez, quero agradecer a presença da companheira de Cuba, da companheira de Portugal, das mexicanas, da companheira do Equador, da companheira da CEPAL, e querdo dizer estamos aptas a construir um caminho diferente da guerra, da fome, da discriminação e da violência. Nós somos fortes o suficiente, e sairemos mais fortalecidas dessa Conferência, para firmar um caminho de paz e cooperação entre os povos e as nações. Um caminho de progresso e igualdade. Um caminho de soberania e de solidariedade entre todos os povos.

Muito obrigada a cada uma de vocês.

Obrigada a todas as companheiras. 
Dia 16.07.2004

Parte da Manhã

\section{Painel 2}

\section{Apresentação de propostas de diretrizes para a construção do Plano Nacional de Políticas para as Mulheres}

\section{Palestrantes:}

$\mathrm{Sr}^{\mathrm{a}}$ Dirce Veron, representante do Conselho Nacional das Mulheres Indígenas no Conselho Nacional dos Direitos da Mulher - CNDM

Sr ${ }^{a}$ Bethânia Ávila, Coordenadora Geral do SOS Corpo - Instituto Feminista para a Democracia e Articulação de Mulheres Brasileiras

Sra Matilde Ribeiro, ministra da Secretaria Especial de Políticas de Promoção da Igualdade Racial da Presidência da República - SEPPIR

Sra Nalu Faria, Coordenação da Marcha Mundial de Mulheres - MARCHA

$\mathrm{Sr}^{\mathrm{a}}$ Maria Laura Sales Pinheiro, Secretária Adjunta da Secretaria Especial de Políticas para as Mulheres da Presidência da República - SPM

\section{Coordenação:}

Sra Mara Vidal, Secretária de Estado da Mulher do Governo do Acre

\section{Sra Dirce Veron.}

Bom dia a todas e a todos. Quero saudar, inicialmente, na pessoa da ministra Matilde Ribeiro, Secretária Especial de Políticas de Promoção da Igualdade Racial, toda a

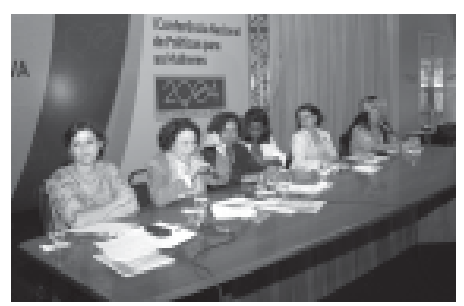

Esta Conferência Nacional das Mulheres Indígenas foi uma preparatória para essa Conferência onde estamos agora. Peço licença a todas por que nós temos no Brasil 195 línguas diferenciadas, por isso eu gostaria de cumprimentar a minha etnia, o povo a que eu pertenço na minha língua, peço licença a todos vocês, eu gostaria de estar cumprimentando elas e dizer também para os outros povos que nós estamos aqui 


\section{6 de jullho de 2004}

para lutar, para estar ao lado da mulher branca, da mulher negra, porque a gente acredita também que nós mulheres indígenas precisamos nos organizar, estamos nos organizando, e com muita ousadia mesmo é que estamos aqui.

(a Sra Dirce Veron cumprimenta as companheiras no idioma de sua etnia)

Gostaria de iniciar a minha fala informando a essa platéia, que nós mulheres índias saímos de uma conferência, da nossa conferência e queremos compartilhar com vocês, mas como vocês, penso eu que a maioria das senhoras que estão aqui presentes já tem conhecimento que nós indígenas somos vários povos neste Brasil, então nós já temos nossa cultura diferente, nós somos diferentes de uma etnia para outra, de um povo para outro, falamos línguas diferentes, de jeito diferente, por conta disso, nós pedimos o apoio para Secretaria Especial de Política para Mulheres para que nós fizéssemos nossa conferência.

Para que nós estivéssemos aqui mais preparadas, com nossas propostas, do jeito que nós queremos, nós mulheres índias cada uma se colocando, participar dessa conferência, de acordo com nossas necessidades, do jeito que cada uma quer participar, do jeito que as mulheres índias querem participar dessa Conferência, de um jeito que essas questões de gênero venham, de acordo com nossas necessidades, como a gente vive na nossa aldeia e nós estamos aqui.

Quero dizer que nós estamos mesmo audaciosas, nós estamos com muita ousadia mesmo, nós saímos de trás do cocar, agora nós estamos ao lado dos nossos caciques, o que nossos caciques ainda não fizeram nós estamos buscando agora. 0 que eles não fizeram, o que até agora eles não encontraram o meio, nós mulheres vamos encontrar, porque nós somos, ao lado das mulheres negras, as mais sofridas do Brasil.

Quando eu digo que nós somos as mais sofridas, nós que acompanhamos nossos maridos em demarcações de terra, nós é que compartilhamos a nossa vida $90 \%$ do tempo. Somos nós que fazemos as nossas aldeias, só que isso nunca foi reconhecido, nós queremos ser reconhecidas, nós queremos ser reconhecidas também ao lado dos nossos caciques. E nós estamos buscando isso, e é por isso que nós estamos aqui hoje. Estamos em pouco número ainda, mas eu acredito muito, eu acredito plenamente, tenho a esperança gigantesca que ainda eu vou ver uma boa parte de cocares, índias sentadas, aí na próxima conferência. 


\section{6 de Julho de 2004}

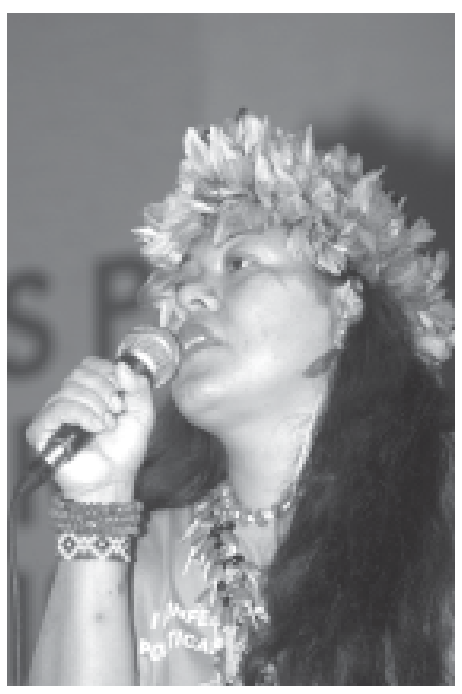

saúde e educação
Quero dizer também que nós mulheres indígenas gostaríamos que nos respeitassem mais do nosso jeito de viver, do nosso jeito de ser. Existe muita discriminação, até aqui mesmo a gente percebe isso. Muita discriminação com as mulheres indígenas, ainda. Eu acredito que é por que nós estamos tão audaciosas não é? Nós estamos com tanta ousadia que às vezes algumas nem acreditam que somos indígenas, nossa, estamos falando tão bem! "Nossa, como vocês estão com uma boa aparência"! Como eu disse que os nossos caciques não fizeram isso, nós vamos fazer, nós vamos lutar, nós estamos lutando. Nós temos as nossas diferenças sim de etnia para etnia, mas somos unidas sim, nós estamos nos unindo conforme as nossas condições também, conforme as condições que nos tem dado como movimento, como organização, como a gente tem brigado... Eu acredito muito, como eu já disse, que com o tempo a gente vai ver muito mais índia aqui sentada.

Eu vou dar uma lida aqui em alguns papéis que me chegaram.

Quero dizer que eu não sou muito de ler, eu vou falando, o que eu falo vem do meu coração, por isso quero dizer às minhas companheiras que elaboraram alguma coisa pra eu estar falando... eu sou assim, eu gosto de falar aquilo que vem, aquilo que eu vivo na minha aldeia, aquilo que eu vejo e o que eu acho que deve ser mudado, porque nós estamos numa fase de construção, para isso é que estamos aqui.

Penso que nós mulheres indígenas somos as verdadeiras mães da terra não é gente!? Por isso que nessa conferência a nossa maior briga, a nossa maior luta é para que nós tenhamos uma boa saúde, uma boa educação. Nós elaboramos nossas propostas, elaboramos nossos documentos que nós vamos estar entregando para a Secretária Adjunta Maria Laura, que eu tenho uma fé muito grande em que a gente já sentou, já conversou, tivemos uma pequena conversa com a ministra, onde ela colocou para a gente que elas estão de portas abertas, mas ela disse também que a gente tem que estar levando. Por que eu reconheço que o povo brasileiro não tem um reconhecimento muito profundo das causas indígenas, das questões indígenas por que as cartilhas nesse Brasil desde a época que eu me senti gente, quando eu pisei numa escola de branco, eu já vi lá como é que é escrito, às pinceladas.

Por isso que muitas vezes quando a gente chega aqui, quando a gente vai conversando, as pessoas vêm com cada pergunta, o que eu tenho recebido assim... Cada pergunta que eu fico horrorizada, achando que eu nem estou no Brasil. Porque às vezes 


\section{6 de Julho de 2004}

quando a gente está fora parece que povo de lá conhece muito mais do que o povo que está aqui, então eu fico assim, na maior tristeza, de ver, às vezes, companheiras fazendo umas perguntas pra mim, que eu falo gente, e eles acham cada coisa, eu vou respeitar porque eu sei que as pinceladas que foram passadas, somente mesmo aquelas pessoas que tem um carinho especial pela cultura indígena, somente mesmo algumas pessoas, muito pouquinha pessoas que vão à nossa aldeia, que visitam a gente que tem outra compreensão. Os estados que sabem que têm aldeia, que gostam verdadeiramente. Eu acho que não precisa nem gostar do índio, mas que respeitem a sua cultura, que respeitem que ele viva daquele jeito.

Por isso que eu ainda respondo às várias e tristes perguntas que chegam para mim, mas vai chegar uma hora que eu não vou responder mais não gente, quer saber, vai pra aldeia, vai lá ver também. Porque a gente está aqui na cidade, comprando roupa, fazendo uma série de coisas, então a gente paga imposto, vive aqui, então vá também lá, quer saber mais alguma coisa, não fica só querendo comprar cocarzinho, colarzinho para usar não, querem saber também o que ela significa, o que ela é pra nós.

Agora eu vou ler umas partes aqui mesmo, por isso nós propomos dentre outras diretrizes as ações contidas no documento das mulheres indígenas que solicitamos a incorporação ao conjunto de propostas apresentadas no processo de construção dessa conferência. Políticas afirmativas que visam incluir as mulheres índias no enfrentamento a pobreza, geração de renda, trabalho, acesso ao crédito e a terra, humanização da atenção e a saúde da mulher índia com atendimento diferenciado, inclusão de uma área temática específica para as mulheres índias dentro da Secretaria de Políticas Públicas para Mulheres e da Secretaria de Promoção da Igualdade Racial, e quando houver essa inclusão que esteja a índia lá dentro participando. Garantia da educação escolar para as mulheres índias nos três níveis, fundamental, médio e superior. Punição em forma de lei específica para qualquer tipo de discriminação à mulher índia.

Eu li esses cinco pontos por que são as que a gente achou bastante importante, a gente já passou isso aqui pra Secretaria e a gente já tirou várias cópias xerox desse documento que eu vou estar espalhando por aí. Peguem, distribuam e ajudem a gente.

E eu gostaria aqui, até vou levantar, eu gostaria de pedir mesmo para as mulheres negras, não querendo deixar as mulheres brancas de lado, mas para as mulheres negras, nós somos as mais discriminadas nesse país, vamos fazer um pacto, vamos nos levantar e vamos nos juntar porque eu acho que só assim que verdadeiramente as políticas públicas para a mulher vão ter mudança nesse país.

Muito obrigada!

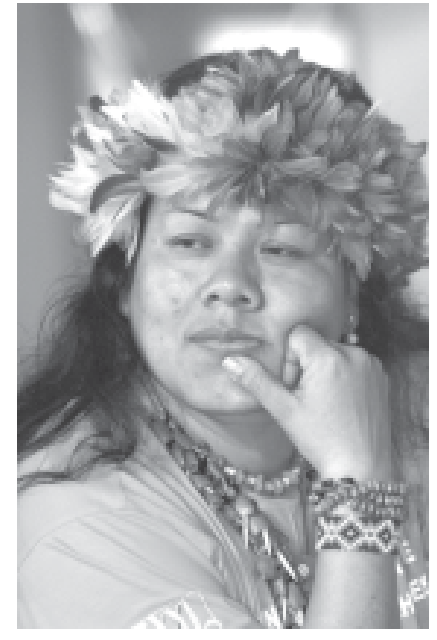

políticas afirmativas

SPM SEPPIR 


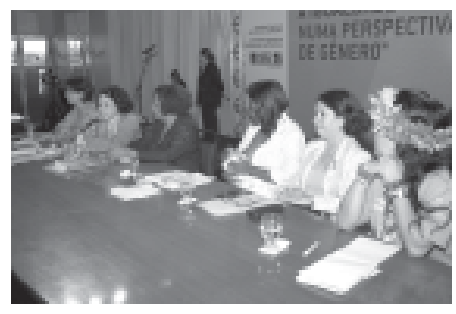

movimentos sociais

\section{Sra Maria Betânia Ávila.}

As conferências municipais e estaduais já definiram os conteúdos que devem conformar as diretrizes. esses foram os espaços próprios e legítimos que alimentam este momento nacional. Então quero salientar a importância desse movimento que construiu a Conferência Nacional, com dificuldades, alegrias, tensões e contradições. em processos como esse, não lidamos só com convergências, ao contrário são as luta em torno das contradições que fazem avançar a democracia. sendo essa a primeira conferência nacional de políticas públicas para as mulheres, ela se constitui em um marco histórico.

Esse marco compromete o Estado e seus poderes, compromete também os movimentos sociais com especial relevância o movimento de mulheres. Temos que fazer do marco uma marca na nossa história política, mas também uma marca na real possibilidade de transformar a vida cotidiana das mulheres, levando em conta as desigualdades que existem entre elas e nesse sentido a situação de pobreza a qual milhões de mulheres estão submetidas. Essa marca que se constrói aqui, para ganhar força e capacidade de ação, exigirá dos governos um compromisso nunca antes concretizado na prática, que é aquele com a transformação real desse país. E exigirá de nós, movimento de mulheres, muita organização, capacidade de luta e nenhuma paciência ou condescendência com um sistema produtor de exploração e desigualdade.

Políticas públicas para as mulheres devem se constituir em uma política de Estado. Uma política que deve ser um elemento estrutural da configuração de um estado democrático. É neste sentido que os resultados dessa conferência devem referenciar os valores e os conteúdos da ação estatal com vistas à superação da desigualdade de gênero relacionada às desigualdades de classe, raça e etnia. Igualdade, autonomia e liberdade esses são termos que referenciam movimentos de mulheres na busca da emancipação. São esses termos também que qualificam o conflito em torno da transformação do estado em uma perspectiva feminista. A realização dessa conferência deve fortalecer a legitimidade do movimento de mulheres como um sujeito político estratégico para a transformação da sociedade brasileira.

Reconhecemos que vivemos em uma democracia política, mas que essa democracia tem que avançar, pois ainda é plena de desigualdades. E que as possibilidades atuais são produto de uma história de luta que nos garantiu liberdade de expressão e organização política. E neste sentido é relevante compreender a importância dessa conferência como parte de um processo de participação política no âmbito do poder 


\section{6 de jullho de 2004}

executivo o qual deve trazer novos sentidos e novas práticas que façam avançar a democratização do estado. E neste sentido que façam avançar a participação das mulheres nos espaços de poder de decisão.

Achamos importante salientar que a Constituição Brasileira de 1988 rompeu com a institucionalização do poder patriarcal. Conquista sem dúvida nenhuma do movipoder patriarcal mento de mulheres que acirradamente lutou no espaço da Assembléia Nacional Constituinte. Mas, reconhecemos que as práticas do estado e da sociedade ainda estão impregnadas da cultura de dominação masculina herdeira do poder patriarcal e que ainda se expressa com bastante vigor. Políticas culturais são imprescindíveis para superação da dominação no campo simbólico. Esse poder esteve historicamente vinculado à exploração de classe e à discriminação de raça. 0 patriarcado e a escravidão no Brasil são realidades históricas inextricáveis. Essa herança colonial ainda não superada é uma herança de violência que pesa também sobre o povo índio. Lembrar sempre é preciso, para que a história não se repita em forma de barbárie.

Compreendemos que a questão econômica e a questão social são indissociáveis. Temos que ligar as políticas macroeconômicas às políticas sociais. 0 compromisso incontornável com a superação da perspectiva neoliberal que impõe políticas macroeconômicas, voltadas para os interesses do mercado e produtoras de pobreza e violência, é para nós uma diretriz sobre a qual devem estar delineadas as políticas públicas de curto e longo prazos.

As política sociais compensatórias impostas pelo ajuste estrutural, servem para manutenção da pobreza, pois nem sequer trazem alívio para a situação das populações pobres, porque como está constatado em dados sobre os impactos da globalização econômica e financeira, esta globalização trouxe mais concentração de riqueza e conseqüentemente aumento da pobreza e de sofrimento humano. Direitos sociais que assegurem políticas universais são imprescindíveis como diretriz que se contraponha a esse modelo e assegure a sua superação.

Neste contexto de conservadorismo imperialista e fundamentalismo religioso no qual se fazem guerras, violações terríveis aos direitos humanos e atos de repressão e violência sexual, a defesa de um estado laico é um bem inestimável para este país e para o mundo. 0 Estado brasileiro é um Estado laico. Neste sentido é importante resgatar que uma das conquistas primordiais da democracia moderna é o estado 


\section{6 de jullho de 2004}

laico. Na perspectiva das lutas de emancipação e do contexto mundial atual essa é uma premissa a ser recolocada sempre como valor e como condição básica da vida democrática.

divisão sexual do trabalho

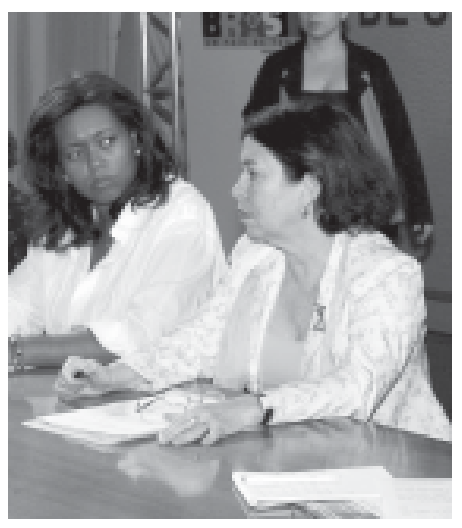

mulheres camponesas
0 trabalho das mulheres nas esferas produtiva e reprodutiva está marcado pela desigualdade da divisão sexual do trabalho. Consideramos que as política públicas devem garantir mudanças que tragam impactos a curto prazo na situação das trabalhadoras urbanas, rurais e domésticas e que apontem na direção da transformação dos fundamentos dessa divisão. Políticas públicas que incidam, sobre o desemprego e a falta de renda para as mulheres, sobre as relações trabalhistas para garantir os direitos, e sobre políticas sociais que assegurem instrumentos coletivos de suporte a vida cotidiana e que dado o estado atual de desigualdade de gênero afetam diretamente a autonomia das mulheres. Instrumentos que minorem o fardo da dupla jornada e assim liberem o tempo das mulheres para usufruir outras dimensões da vida social, inclusive que liberem o tempo das mulheres agir como sujeito político.

A terra para quem nela trabalha, é um direito das mulheres camponesas que ainda buscam para muitas a cidadania civil do acesso aos documentos que confere identidade pessoal e acesso às políticas, como crédito e posse da terra. Reforma agrária e reconhecimento como sujeito da transformação do campo neste país esse é um direito das mulheres camponesas e trabalhadoras rurais.

Direitos reprodutivos e direitos sexuais estão relacionados a autonomia e a integridade da pessoa humana, pois o nosso corpo é o lugar primeiro da nossa existência. É o lugar onde habita o nosso eu, portanto esses direitos devem se manter e avançar como parte de uma política de estado. Como meio de combater a violência sexual e doméstica e de garantir uma vida reprodutiva plena de igualdade, assegurando as mulheres o direito a concepção e anticoncepção. Assegurando uma vivência da maternidade com dignidade, bem estar e como expressão de uma sociabilidade transformada, assegurando ainda 0 acesso a uma prática integralmente legal e segura do aborto, com respeito a decisão das mulheres. Esses são aspectos imprescindíveis de uma ética verdadeiramente centrada em uma cidadania voltada para vida cotidiana.

Partindo dos direitos sexuais a liberdade de orientação sexual se institui como parte dos direitos humanos. Essa liberdade como premissa de uma vida social civilizada é sim um legado dos movimentos gay e lésbico e feminista à democratização das relações humanas. 


\section{6 de jullho de 2004}

As mulheres, profissionais do sexo, através de sua organização política tem trazido para a esfera pública a relação entre cidadania e a sexualidade com campo de trabalho remunerado.

Cabe ao Estado promover esses direitos como um valor coletivo que promova a superação dos preconceitos, das discriminações e da violência que eles causam.

É sobre a sexualidade e sobre o corpo das mulheres que se desenvolve com mais força a indústria da mercantilização do prazer e da banalização da exploração sexual. É também nesse terreno que a força repressiva das instituições conservadoras tem produzido controle e abusos em nome de princípios transcendentes.

Por fim quero trazer nossa defesa intransigente das políticas públicas para igualdade racial que possam garantir de imediato novas perspectivas na vida das mulheres negras, e que sejam definitivamente o caminho da superação do preconceito da desigualdade e da construção de um país verdadeiramente democrático. 0 preconceito de raça e a desigualdade que pesa sobre as mulheres negras é o signo de uma herança que queremos destruir.

0 caminho da nossa emancipação e da nossa igualdade atravessa as linhas tortuosas que conectam as desigualdades entre nós mesmas. Por isso na defesa de políticas públicas que configurem um estado democrático e produtor de justiça social temos que ter consciência crítica sobre a realidade social, compromisso para transformá-la e solidariedade no olhar de nós sobre nós mesmas. 


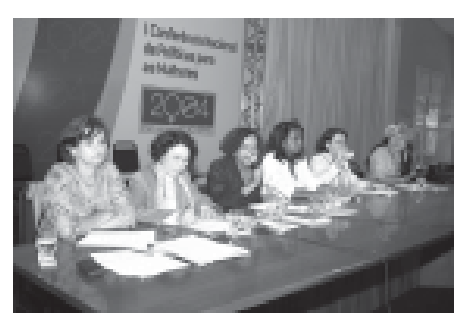

\section{Ministra Matilde Ribeiro.}

Bom dia a todas as pessoas presentes nesta Conferência.

Quero cumprimentar a ministra Nilcéa Freire e, na sua pessoa, cumprimento os demais componentes da mesa.

Gostaria também de saudar, neste momento, as mulheres de todos os cantos do Brasil, representadas pelas delegadas e outras participantes desta Conferência.

Cumprimento às parlamentares, gestoras, servidoras que fazem de seu exercício profissional a busca para políticas públicas de promoção da igualdade.

Gostaria de felicitar a organização do evento, sob responsabilidade da Secretaria Especial de Políticas para as Mulheres, mas que, com toda certeza, contou com mulheres e homens de diversas organizações, órgãos públicos e particulares, construindo a base da infra-estrutura dessa Conferência.

Também gostaria de cumprimentar os homens aqui presentes, e desejar que esse momento não seja ímpar em suas vidas...

E elas nunca se cansam...

Essa frase está contida num vídeo, exibido recentemente para mulheres da América Latina e do Caribe, e retrata a organização feminista na América Latina e no Mundo, desde 1975 - Ano Internacional da Mulher, instituído pela ONU. Aparentemente simples, esta frase sintetizou as várias formas de participação das mulheres e a continuidade na luta por seus direitos e por uma vida digna para toda a humanidade.

$9^{a}$ Conferência Regional sobre a Mulher - CEPAL
0 evento em questão foi a $9^{\text {a }}$ Conferência Regional sobre a Mulher da América Latina e do Caribe, promovida pela CEPAL (Comissão Econômica para a América Latina e para o Caribe) no período de 10 a 12 de junho, no México. Nesta conferência participaram mulheres representando governos e sociedade civil, levando suas experiências locais propositivas para a melhoria de vida das mulheres.

Analisando esta frase e pensando nas diversas formas de organização feminista, verifico alguns fatores que contribuem para que as mulheres façam a diferença e deixem suas marcas: a persistência, a obstinação e, acima de tudo, a crença em um mundo melhor. Sei que muitas vezes elas se cansam. Mas também sei que elas não desistem facilmente! 


\section{6 de Julho de 2004}

Se, por motivos diversos uma ou outra mulher se retira da luta, novas surgem, tocando adiante o ideal coletivo pela igualdade, liberdade e justiça. Foi assim na conquista da abolição da escravidão, na luta pelo direito ao divórcio, na inserção dos direitos das mulheres na reforma constitucional e na ampliação da representação da mulher em todos os espaços políticos e sociais.

As mulheres negras do mundo se encontraram na França, dias 01 e 02 de julho de 2004, no I Congresso Mundial da Mulher Negra Líder, evento que reuniu mulheres negras de diferentes partes do mundo e que, a partir de suas ações políticas e militantes somam ao mundo os seus protestos, suas reivindicações, mobilizações sociais, ações profissionais e conquistas políticas.

Esta perspectiva vai ao encontro da quebra da invisibilidade historicamente imposta às mulheres negras, invisibilidade criada e mantida pelo machismo e pelo racismo, as formas contemporâneas mais perversas e silenciosas de exclusão. Neste sentido, é necessário identificar que as desigualdades sociais impostas às mulheres não atingem a todas na mesma dimensão, pois as mulheres negras e indígenas vivem uma situação de maior vulnerabilidade em relação às mulheres brancas.

Sabemos que as desigualdades de gênero se tornam muito mas acentuadas quando somadas à vulnerabilidade da condição de vida dos grupos racial e historicamente discriminados. Isto aparece explícito no discurso de Kofi Annan, por ocasião da III Conferencias Mundial contra o Racismo, a Discriminação Racial, Xenofobia e Intolerância Correlatas, na África do Sul, em 2001:

Em todo o mundo, minorias étnicas continuam a serem desproporcionalmente pobres, afetadas pelo desemprego e menos escolarizadas do que os grupos dominantes. Estão sub-representadas nas estruturas políticas e super-representadas nas prisões. Têm menos acesso a serviços de saúde de qualidade e, conseqüentemente menor expectativa de vida. Estas e outras formas de injustiça racial são a cruel realidade do nosso tempo, mas não precisam ser inevitáveis no nosso futuro.

A afirmação de Koffi Anan foi direcionada às condições da população negra e de grupos outros étnicos discriminados, mas sem sombra de dúvida, reforça a frase que ouvi no México: "E elas nunca se cansam...". É grande a aposta em um futuro pauta- 


\section{6 de Julho de 2004}

do na justiça social e racial e, a lista de mulheres negras brasileiras que também fazem desse objetivo sua luta cotidiana, é enorme. Muitas delas fazem desse objetivo seu propósito, seja no exercício profissional, seja na militância, ou simplesmente na sua imagem. Aqui apresentamos algumas que se destacam:

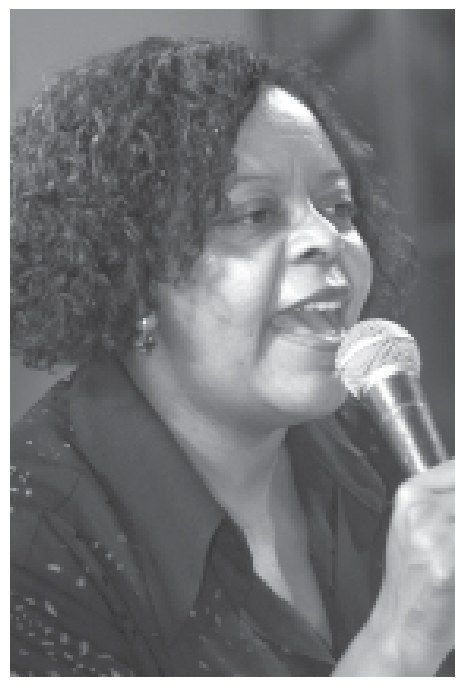

Ruth de Souza que teve sua primeira experiência artística no Teatro Experimental do Negro, nos anos 40, com a peça "O Imperador Jones". Foi a primeira atriz negra a pisar no palco do Teatro Municipal do Rio de Janeiro. Atuando nas primeiras radionovelas brasileiras, foi através de muita luta contra a discriminação racial que conseguiu ser uma das referencias da Tv Brasileira, exercendo papeis de destaque e concorrendo a prêmios internacionais. Um exemplo disso é sua indicação para o premio de melhor atriz, na edição do Festival de Veneza de 1954. Disputou o Leão de Ouro com monstros sagrados do cinema mundial, como comenta Ruth: "Concorri com Katharine Hepburn, Michele Morgan e Lili Palmer, para quem perdi por dois pontos. Mas só com a indicação já me senti "premiada'". Filha de lavadeira e lavrador, reproduz, com muito orgulho, as histórias que viveu, quando diziam-lhe que seu sonho era impossível: uma menina negra tornar-se artista de renome.

Laudelina de Campos Melo que nasceu em 12/10/1904 em Poços de Caldas, em Minas Gerais, e que ainda jovem integrou a Frente Negra Brasileira. Em 1936 criou uma Associação das Empregadas Domésticas, fechada em 1942, quando atividades políticas foram proibidas em função do Estado Novo. Mais adiante, em 1961 em Campinas, fundou a Associação Profissional Beneficiente das Empregadas Domésticas, para defesa dos direitos sociais e intermediação de conflitos entre patroas e empregadas, uma vez que não havia legislação trabalhista para a categoria. Em 1988, esta associação foi transformada em Sindicato dos Trabalhadores Domésticos. Laudelina morreu em maio de 1991, na cidade de Campinas.

Lélia de Almeida Gonzalez que também nasceu em Minas Gerais, filha de pai negro e mãe indígena, foi militante da causa da mulher e do negro. Historiadora e Filósofa, tornou-se mestre em Comunicação pela Universidade do Estado do Rio de Janeiro (UERJ) e Doutora em Antropologia Social pela Universidade de São Paulo (USP). Na condição de pesquisadora, explorou ao máximo o espaço acadêmico para desenvolver pesqui- 


\section{6 de Julho de 2004}

sas sobre mulheres e negros. Na vida política se destacou como participante, nos anos 70, da fundação do Movimento Negro Unificado (MNU). Foi membro do Instituto de Pesquisas das Culturas Negras (IPCN); do Coletivo de Mulheres Negras N'Zinga; e, Conselho Nacional dos Direitos da Mulher. Atuou, também, em partidos políticos como primeira suplente de Deputado Federal, pelo PT em 1982 e suplente de Deputado Estadual pelo PDT, em 1986. Lélia morreu nos anos 90 no Rio de Janeiro.

Benedita da Silva que é natural do Rio de Janeiro, começou a trabalhar cedo: vendeu limão e amendoim, foi operária fabril e entregava a roupa lavada e passada por sua mãe. Foi professora de escola comunitária, onde fundou a Associação das Mulheres do Chapéu Mangueira. Tornouse a primeira mulher negra a atingir os mais altos cargos eletivos da história do Brasil: vereadora (em 1982), deputada federal constituinte (1988), reeleita para um segundo mandato em 1990, senadora, em 1994, vice-governadora e, posteriormente governadora (2002). Seus mandatos foram marcados pela defesa das mulheres e negros. Em 2003 Benedita foi Ministra do Ministério de Assistência Social, no Governo LULA, onde teve a oportunidade de conciliar os conhecimento teóricos, a militância e o aprendizado parlamentar.

Essas brasileiras, incansáveis em suas ações, quebraram lógicas excludentes e apontaram novos rumos para a população negra, para as mulheres, e para os pobres. Independente de idade, escolaridade ou profissão, fizeram de suas histórias de vida exemplos de garra no combate ao machismo, ao racismo e à exclusão. Com isso, reafirmase a máxima de que "elas nunca se cansam" e de que "querem sempre mais"!

Elaborar um Plano Nacional é uma tarefa árdua. A transversalidade entre gênero e raça é fundamental não apenas para a elaboração de políticas voltadas para a população mais vulnerável, quanto para aliar os conhecimento dos movimentos sociais que lidam com a exclusão e que, de certa forma, já reuniram um cabedal de conhecimento importantíssimo para o poder público.

Consciente dessa necessidade, a SPM já trouxe, no Eixo Temático 5, "Desenvolvimento de políticas de educação, cultura, comunicação, e produção de conhecimento para a igualdade", a proposição de ações afirmativas. Ao atentar para a necessidade de "formular políticas de ações afirmativas que possam ser desenvolvidas de modo trans- 


\section{6 de jullho de 2004}

versal, estabelecendo parcerias com a Secretaria Especial de Políticas de Promoção da Igualdade Racial", SPM inova, em abrangência nacional, o que já vem sendo proposto em âmbito internacional.

raça e etnia

movimento de mulheres

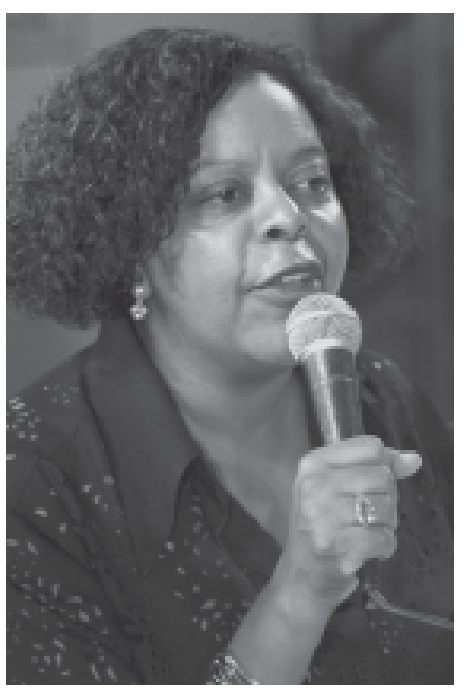

O Plano Nacional de Política para as mulheres, ao incorporar as questões de raça/ etnia, vai de encontro ao propósito internacional de combate à desigualdade. Recentemente, na $9^{a}$ Conferencia Regional sobre a Mulher da América Latina e Caribe, foram enfatizadas as diferentes condições econômicas e sociais das mulheres, muitas vezes resultantes de processos culturais excludentes, ponto convergente tanto na exploração profissional e econômica, quanto na feminização da pobreza.

A participação do movimento de mulheres em diversas conferências tem permitido a elaboração de documentos e subsídios para a formulação conjunta de políticas de combate à pobreza, trazendo à tona as reais condições das mulheres em relação ao exercício pleno de cidadania e de conquista de direitos. Importante salientar que a mobilização, o protagonismo, e o acompanhamento das formulações normativas e políticas nacionais e internacionais, reafirmam que os Movimentos Negros e de Mulheres Negras, têm desempenhado, no processo de formação da nação brasileira, um papel fundamental na denúncia do mito da democracia racial e na elaboração de propostas de políticas públicas que contribuam para a alteração do quadro de desigualdade e opressão, não apenas racial, mas também de gênero.

Porém, as maiores dificuldades em relação à conquista de políticas eqüitativas estão na relação da incorporação da perspectiva de gênero nos assuntos de decisão políticas, com a falta de respaldo jurídico institucional e o cumprimento de normas e tratados em âmbito internacional. 0 marco jurídico para enfrentamento da discriminação de gênero, deve estar aliado à participação do Brasil em tratados e convenções internacionais de diferentes matizes. Somente assim é possível promover a equidade de gênero com recortes párea raça, etnia, localidade, orientação sexual, condição civil, etc.

Considerando as condições das mulheres em relação ao mercado de trabalho, à educação, à saúde (o eixo contemplado com 923 propostas aprovadas no processo das conferências estaduais, considerado um campo onde as mulheres mais acumularam na discussão das políticas públicas) a busca por uma gestão democrática e equânime tem sido, sem dúvida, o maior dos compromissos dos movimentos de mulheres em qualquer que seja a área de atuação: feministas, negras, indígenas, negras, quilombolas... 


\section{6 de jullho de 2004}

Padrões culturalmente estabelecidos são um dos obstáculos da conquistas da equida-

de: a erradicação da pobreza e das péssimas condições de vida e cidadania das mulheres em situação de vulnerabilidade estão diretamente relacionadas a manutenção do estereótipo do poder. Também são as maiores dificuldades para a incorporação da transversalidade nas políticas públicas.

O Brasil tem suporte governamental: ministérios e secretarias especiais, bem como órgãos em nível estadual e municipal são bases para a superação da distância entre as leis e a efetivação dos direitos. 0 contexto de debilidade institucional e as dificuldades (morais e técnicas) de gestão impedem o cumprimento e o aumento do alcance das políticas afirmativas com recortes de gênero.

Durante todo o processo preparatório da Conferencia, verificam-se avanços políticos traduzidos na formulação dos eixos e diretrizes muitos bem fundamentados e abrangentes. Podemos notar, por exemplo, que a menção a relação de gênero, raça e etnia está presente em todos os eixos e diretrizes temáticas, aparecendo em diferentes espaços, em número considerável de vezes e, com apontamentos para as mulheres negras e indígenas, propondo acordos e pactos entre mulheres brancas, negras e indígenas.

Devo destacar a importância de instrumentos para o "controle social": a sinalização de ação planejada e sistematizada (proposição, execução e monitoramento), apontando para realização de conferência a cada três anos. Isso remonta a necessidade de elaboração de documento propositivo que incidirá no orçamento, reelaborando a definição de prioridades de governo. Com isso, temos o Estado reconhecendo a desigualdade de gênero e formulando, conjuntamente com o movimento social, ações para a justiça social.

A partir do momento em que as políticas de governo se fortalecem, e isso somente é possível a partir de aliança, principalmente com ações dos movimentos sociais organizados, pode-se articular o empoderamento das mulheres. Embora a demanda seja maior que a estrutura, somente alianças pautadas nas experiências práticas e educativas podem propor, em um período menor de tempo, a alteração da cultura machista e racista.

Desejo a todas um excelente evento. 


\section{6 de jullho de 2004}

movimento feminista

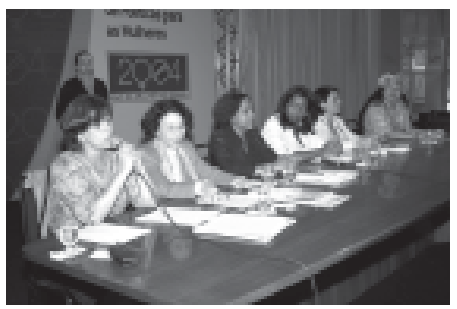

movimento social e governo

\section{$\mathrm{Sr}^{\mathrm{a}}$ Nalu Faria}

0 primeiro aspecto que quero ressaltar é o papel da luta das mulheres e do feminismo para a nossa presença aqui, ou seja, para que esteja acontecendo neste momento essa conferência. Foi a partir do feminismo que emergiu como questão política a situação de opressão vivida por nós mulheres e trouxe para a esfera pública e para o campo dos direitos várias questões até então consideradas apenas questão individual, parte da vida privada.

Como parte desse processo foi questionada a suposta neutralidade do Estado e também explicitou o funcionamento do mercado e sua relação com a estrutura de família, houve a denúncia intransigente de todas as formas de preconceito, discriminação e violência. Foram colocadas em questão e para serem repensadas nossa subjetividade, nossa percepção e nossas práticas. Nós mulheres nos tornamos sujeitos de transformação em todos os campos da vida pública e privada. E isso está inteiramente ligado como nossa auto-organização por autodeterminação, por autonomia e por igualdade.

Entre os resultados, podemos celebrar que as mulheres saíram da invisibilidade e hoje nos expressamos em nossa pluralidade como mulheres negras, brancas, urbanas, rurais, quilombolas, indígenas, de diferentes idades e em nossa diversidade de exercício da sexualidade.

Um segundo elemento a ser ressaltado é o sentido dessa Conferência e a importância de que em nesse momento ocorra o debate conjunto entre movimentos de mulheres e governo para a definição de um projeto para o conjunto da sociedade e que envolve a elaboração de políticas em todos os níveis do Estado. Afirmamos que consideramos como o horizonte desse processo a construção de uma sociedade em que coloque um fim para a exploração e que, portanto reforce a luta do movimento de mulheres por autonomia e igualdade para as mulheres.

A discussão sobre diretrizes para uma política para as mulheres deve ser proposta a partir do que é a dinâmica atual da sociedade brasileira. 0 Brasil tem como principal característica ser uma sociedade hierárquica, onde as desigualdades de classes são assentadas nas desigualdades de gênero, raça e outras formas de opressão como geração, sexualidade, deficiência, contextos regionais.

0 outro balizador é o contexto neoliberal que estamos vivendo e isso nos remete a olhar para mais de uma década atas e suas conseqüências. 0 neoliberalismo se 
implantou em um momento em que as mulheres estavam avançando nas suas reivindicações de cidadania ativa e, portanto de conquista de direitos em uma perspectiva de sujeitos de transformação. Nesse contexto a globalização econômica, as políticas de ajuste e conservadorismo em geral fizeram retroceder os avanços que estavam sendo duramente conquistados.

Esse processo foi legitimado pelos organismos multilaterais e colocou o paradoxo: enquanto se avançava na normalização e declaração de direitos nas Conferências da $\mathrm{ONU}$, o mercado organizava nossas vidas. Nunca é demais lembrar que foi no mesmo ano em 1995 quando se comemorava os avanços da IV Conferência da Mulher em Pequim que se criou a Organização Mundial do Comércio - OMC. E todas nós sabemos e experimentamos o significado da OMC no ataque aos nossos direitos e na garantia das transnacionais e, portanto, do livre mercado.

O que se coloca hoje é como conter a expansão do mercado sobre nossas vidas. Não é possível discutir isso sem abordar as relações imperialistas que têm imposto uma enorme transferência de recursos dos países do sul para os países do norte. Neste processo 0 EUA é o principal sugador como forma inclusive de suprir seu déficit público.

Dentro dessa perspectiva que querem incluir no âmbito da OMC a agricultura e os serviços. Na América Latina não temos a menor dúvida que esse é o sentido da proposta da ALCA, ou seja, a política de neo-colonialismo dos EUA. É essa lógica que tem privilegiado o capital financeiro e que os países da América Latina têm que manter o ajuste para gerar superávit primário e seguir pagando os juros da dívida eterna e já paga tantas vezes. Nós temos demonstrado que somos os credores de uma dívida social, de gênero, de raça e ambiental.

0 enfrentamento a essa lógica é fundamental para que as políticas nacionais possam promover mudanças estruturais que se orientem para a ruptura com o livre mercado e conter a expansão do mercado sobre nossas sociedades. A partir disso será possível recuperar o papel do Estado como indutor de um novo projeto de sociedade voltado para o mercado interno e para o consumo de massas, portanto de produtos básicos para o bem estar e para a garantia dos direitos de todas e todos.

A Conferência tem de ter um posicionamento radical sobre o que significa ter políticas para garantir a autonomia das mulheres e permitir a sua condição de sujeito nesse novo modelo de desenvolvimento. Isso pressupõe a combinação de políticas
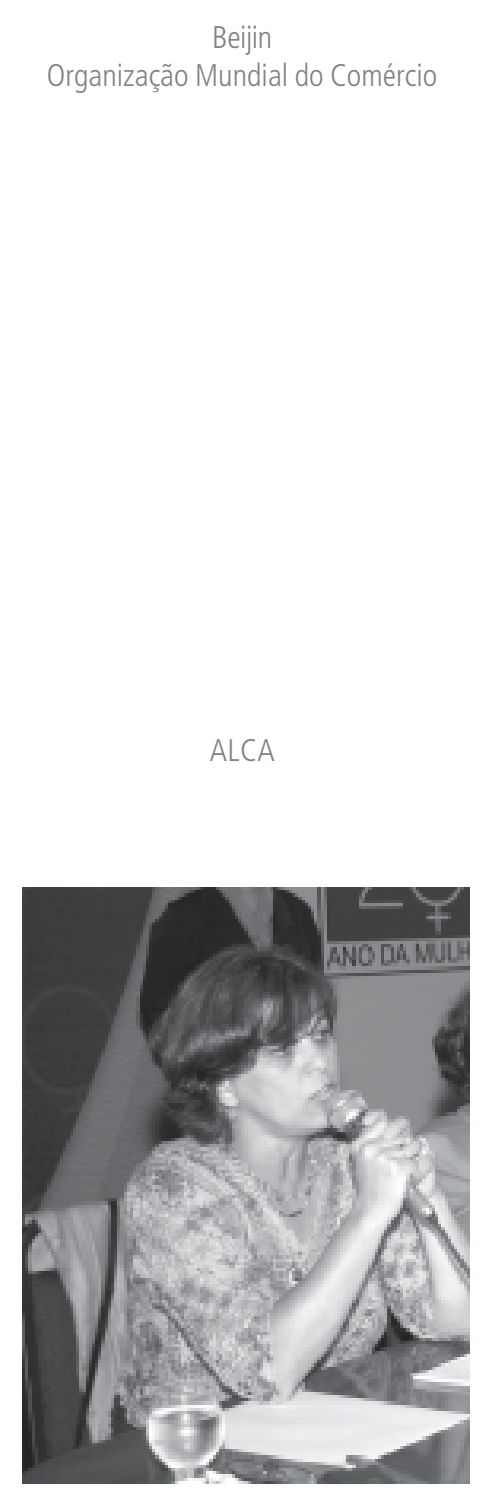

políticas para as mulheres 


\section{6 de julho de 2004.}

redistributivas e de garantia de direitos sociais de caráter universal, combinadas com políticas específicas voltadas para o combate à desigualdade das mulheres no sentido do rompimento com a suposta neutralidade do Estado.

público e privado

Um elemento central é o rompimento com a lógica de que divisão entre o público e o privado - e isso é ideológico, não confere com o cotidiano. Ainda vivemos sob a idéia de que as mulheres estão em casa e os homens estão no trabalho. Isso faz com que nada se modifique em casa quando as mulheres saem para trabalhar. Ao longo dos anos, 0 Estado acabou atuando como se as mulheres fossem um recurso interminavelmente disponível para complementar suas ações. Por isso, em nosso país, a educação em período integral e as creches nunca foram prioridade. Parece que sempre há uma mulher esperando a criança depois das suas 4 horas de aula.

Romper essa relação entre o público e o privado, que também é uma divisão entre a produção e a reprodução - e esta última está a cargo das mulheres - é repensar 0 paradigma da sociedade, é romper aquela lógica de mercado que mencionei anteriormente e colocar o cuidado com a reprodução da vida humana como centro da nossa atenção. Isso significa repensar as políticas sociais e exercer um papel ativo para que as tarefas domésticas sejam compartilhadas por homens e mulheres.

Para garantirmos autonomia às mulheres são necessárias políticas específicas voltadas para elas em três níveis. 0 primeiro é a autonomia pessoal e econômica, ou seja, o direito ao emprego, a igualdade salarial, o acesso à terra, ao crédito, à profissionalização e à educação igualitária. 0 segundo é a atuação do Estado para alterar essa divisão sexual do trabalho em casa e no mercado, quer dizer, a construção de creches, a escola em período integral e uma política cultural e um trabalho educativo de incentivo à divisão do trabalho doméstico.

A terceira diretriz é que se garanta autonomia sobre o corpo das mulheres. Nesse tema colocamos todas as questões da saúde, dos direitos reprodutivos e sexuais e do direito a viver sem violência. Sabemos que, no período do neoliberalismo, uma das coisas que aumentou foi o mercantilismo do corpo e da vida das mulheres. Não aumentou só o tráfico para os países europeus, a prostituição infantil e a utilização das mulheres nos tais trabalhos de entretenimento ou turismo sexual, mas também a imposição de um padrão de consumo para as mulheres. Isso faz com que tenhamos 


\section{6 de julho de 2004}

um mal-estar com o nosso corpo, querendo, em todo o momento, sermos outra coisa por meio da utilização dos intermináveis cosméticos, das lipoaspirações, das ginásticas, das cirurgias plásticas, das injeções de colágeno, dos botox, e assim por diante. Temos a idéia de que o nosso corpo, todo o tempo, está defeituoso e precisa de uma intervenção, e isso não pára apenas na questão do padrão de beleza estrito.

Há também a medicação. Em nome das novas tecnologias e da idéia de que os remédios não fazem mal, as mulheres voltaram a tomar, cada vez mais, antidepressivos, e a ver sua menstruação com interferências, como, na menopausa, as tais terapias de reposição hormonal (TRH). Hoje há pesquisas consistentes que demonstram justamente que aumentaram as doenças cardiovasculares que os médicos diziam que diminuíam. Temos também a supressão da menstruação nas jovens e a construção de uma TPM (Tensão Pré-Menstrual), sempre com a idéia de que o corpo da mulher falha e necessita de uma intervenção médica. Então, a nossa conferência deve também se posicionar quanto a isso, ou seja, desconstruir mitos e trabalhar com a sociedade uma nova visão sobre os temas.

Uma política de combate à violência passa por assistência às mulheres vítimas, por um trabalho de prevenção e informação e também pela revisão de questões legais.

Pensar igualdade para as mulheres passa por políticas universais para o modelo de desenvolvimento e políticas específicas de ações afirmativas que levem em conta a diversidade da situação das mulheres. Não somos apenas brancas, somos mulheres brancas e negras; somos urbanas e rurais; somos indígenas, somos jovens e velhas; somos heterossexuais e homossexuais. Isso tem definido condições e discriminações diferenciadas. Portanto, nessas políticas universais e específicas devem levar em consideração esse conjunto. Para isso, é extremamente importante que espaços de debates e de participação estejam sempre abertos.

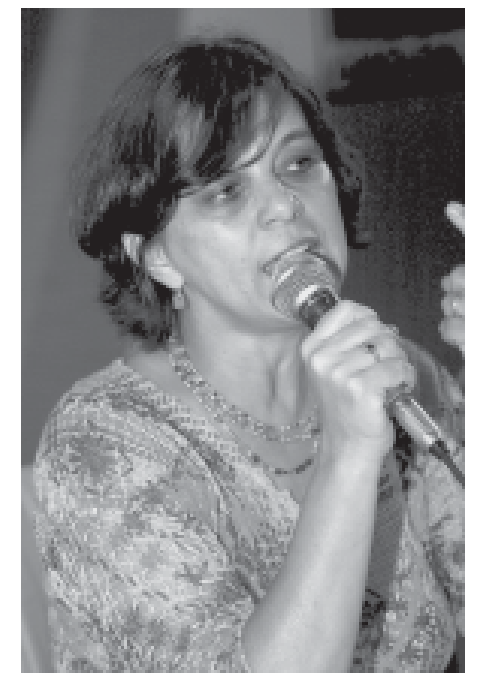

violência 


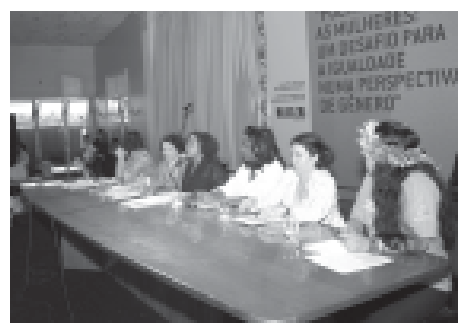

\section{Sra Maria Laura Sales Pinheiro.}

Bom dia. Bom dia à ministra Nilcéa Freire, aqui nossa delegada número um; às delegações estrangeiras; à delegação angolana, que não esteve conosco ontem, mas temos certeza absoluta que desde o momento em que vocês decidiram vir a esta Conferência, vocês já estavam conosco. Muito obrigada pela presença entre nós. Bom dia às minhas companheiras de Mesa: Dirce, Bethânia, Nalu, a ministra Matilde, que tem sido, desde o primeiro momento, uma grande parceira, como ela mesma diz, muito mais do que estratégica - é importante que o que é verdade a gente continue dizendo. Bom dia à Mara, nossa Secretária de Mulheres do Governo do Estado do Acre que está aqui com sua filhinha, a Maria, que completa hoje três meses, companheiras. Três meses faz a Maria, e a Mara já está nos ajudando a construir esse momento, o da nossa Conferência Nacional de Políticas para as Mulheres. A Mara está entre as Marias que, neste país, continuam a nossa luta e que não se cansará, ministra Matilde, tenho certeza.

Companheiras, delegadas, todas e todos que estão aqui presentes. Eu podia até ficar calada, podia não dizer mais nada, mas eu vou dizer. Podia não dizer nada porque eu sinto que há uma sintonia muito grande entre o que está sendo dito nos painéis, tanto de ontem como o de hoje.

No entanto, é importante a gente repetir, porque repetir é reafirmar. E reafirmar é mostrar o compromisso que nós temos. Por isso, algumas coisas vão ser repetidas, eu vou tentar somar nessa discussão que nós estamos fazendo aqui, que tem o objetivo de subsidiar as discussões que vão ser feitas nos grupos, que terão por base o que está neste caderno que a ministra Matilde mostrava, quando ele ainda estava xerocado. 0 caderninho que vai estar nos grupos é esse, bonitinho, com a nossa cor, e que é fruto do trabalho da Comissão de Relatoria da nossa Conferência, que contou com a presença da Secretaria Especial de Políticas para Mulheres e de representantes da sociedade civil, indicadas pelo Conselho Nacional dos Direitos da Mulher.

Companheiras, como juntar em um momento só a emoção que a gente está vivendo? Eu diria que a eleição de um operário para a Presidência da República é uma enorme conquista da sociedade, e já fala da particularidade do momento histórico que vive nosso país.

Esta Conferência é uma conquista. E eu ressalto esses elementos porque é nos apropriando dos avanços, das conquistas, das construções que são feitas na sociedade, que nós construímos e avançamos na nossa história. 


\section{6 de jullho de 2004}

0 nosso Governo, com o Presidente Lula, em apenas 18 meses de Governo, realiza a

I Conferência Nacional de Políticas para Mulheres no nosso país, nesse 2004, Ano da Mulher no Brasil. E a gente sabe que já se passaram 29 anos, desde o ano de 1975, quando, no México, aconteceu a $1{ }^{\text {a }}$ Conferência Mundial. Muitas mulheres brasileiras, que inclusive estão aqui hoje, além de outras que já se foram, participaram daquela Conferência.

Foi necessária muita história e muita luta para que nós chegássemos aqui, 29 anos depois, para realizar a nossa I Conferência Nacional. Parabéns a todas nós. Parabéns a todas por acreditar na História.

A criação da Secretaria Especial de Políticas para as Mulheres, da Secretaria Especial de Direitos Humanos e da Secretaria Especial de Políticas para a Promoção da Igualdade Racial para tratarem das questões de gênero, das questões de raça e das questões dos direitos humanos como referências para a construção das diversas políticas públicas, já é indicador do compromisso do Governo com a promoção e com a inclusão social, estabelecendo novos paradigmas, compreendendo a diversidade e a pluralidade. Indicando, portanto, outro rumo para a intervenção do Poder Público.

Nós vivemos sob um Governo que adota as Conferências como instrumento de gestão, valorizando experiências governamentais e o acúmulo de práticas dos movimentos sociais. Isso altera a lógica do planejamento. Isso gera, além da participação, legitimidade na construção, provoca a cumplicidade. E mesmo que os resultados concretos não sejam visíveis imediatamente, essa prática constrói uma nova forma de relação com a sociedade, uma nova forma de relacionamento de Estado e governos.

O Presidente Lula, ao abrir a Conferência dos Esportes, disse assim: "No meu Governo, o que é feito é tão importante quanto a maneira de fazer". Eu acho que essa questão coloca também para nós o significado da construção estratégica dessa Conferência. Nós também estamos em um Governo que compreende a autonomia dos movimentos sociais. A Nalu, em sua fala, nos dizia: "O nosso Governo...". Isso demonstra que os movimentos sociais sabem que apoiando o Governo, sentindo-se responsáveis pelo Governo, não perdem a liberdade de criticá-lo. Porque isso ajuda a construir as forças necessárias para que o Governo responda da forma mais positiva às necessidades e aos anseios da população. Neste Governo as demandas da sociedade, além de serem ouvidas, não são reprimidas. 


\section{6 de Jullho de 2004}

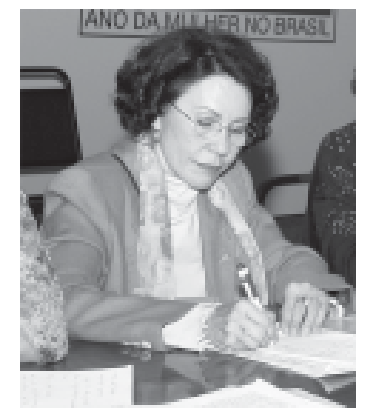

Eu fiquei coçando a língua, para ver se dizia isso aqui ou não. Mas eu lembro, como se fosse hoje, da primeira greve dos petroleiros neste país, no início do primeiro mandato do Governo que nos precedeu. As pessoas atentas àquele momento sabem a repressão que se abateu contra os petroleiros em greve no nosso país. Aquilo ali foi a sinalização para a forma como o Governo trataria os movimentos que ousassem, certamente, entrar em greve.

O Presidente Lula, ao convocar a I Conferência Nacional de Políticas para as Mulheres, deu uma demonstração clara de que, para efetivar a inclusão, como objetivo estratégico de Governo, é necessário que as políticas públicas incorporem as desigualdades de gênero, as desigualdades de raça - e nós vamos continuar repetindo e as desigualdades étnicas.

A Secretaria Especial de Políticas para Mulheres, em nome do Governo Lula, se dirigiu a todos os Governadores e Governadoras, Prefeitos e Prefeitas deste país, convocando-os a assumir, juntos, o desafio de construir esta Conferência. Ao mesmo tempo em que propôs como estratégia esta forma de parceria com a sociedade: movimentos de mulheres e feministas, o fez pela convicção de que nesse processo era fundamental o diálogo com os organismos governamentais, que são os responsáveis, ou virão a ser, pela execução das políticas públicas que serão tiradas nesta Conferência.

Eu acho que a estratégia adotada para a construção da Conferência, por si só, já indica qual é a estratégia de gestão do nosso Governo e que desdobramento nós queremos como resultado dessa Conferência.

Companheiras, delegadas e convidadas, ontem o ministro José Dirceu e o próprio Presidente Lula, além de outros, se referiam aos últimos 50 anos de nossa História recente e falavam dos avanços, dos recuos, e eu digo: das ditaduras, dos neoliberalismos - não é, Nalu? E, hoje, temos um Governo, e isso também o ministro José Dirceu disse ontem, que se apropria da concepção de que o que é dever do Estado e direito da cidadã e do cidadão, para serem efetivados, exigem políticas públicas.

Ouvimos o ministro José Dirceu ontem quando ele dizia que no nosso Governo o papel do Estado foi recuperado, como financiador do desenvolvimento. Nós dizemos também, e eu digo, com toda a certeza, que o nosso governo rompe com o modelo do Estado mínimo e que entende que cabe ao Poder Público garantir a universalida- 


\section{6 de Julho de 2004}

de dos direitos, alterando as desigualdades e ressalto que esta alteração precisa também ser considerada, do ponto de vista das relações de gênero, raça e etnia, modificando as relações de poder e acesso a direitos, em sua dimensão social e política.

"A apropriação de uma Política Nacional para Mulheres, em direção à igualdade de gênero, implica em reconhecer que a organização do Estado, especialmente a sua lógica de formulação de políticas, interfere na vida das mulheres reproduzindo ou alterando padrões de relações de gênero. E exige, também, uma nova institucionalização que absorve o diálogo entre distintas esferas de Governo e a presença das mulheres como protagonistas deste processo".

A efetivação da Política Nacional para Mulheres exige a institucionalização de organismos executivos, de articulação e implementação, ao nível dos estados e municípios: secretarias, coordenadorias, o que for possível construir dependendo da correlação de forças.

É também importante destacar que o reforço, a criação e o fortalecimento dos Conselhos de Direitos das Mulheres, como espaços de participação das mulheres e de controle social são fundamentais para que os organismos executivos tenham, de fato, a possibilidade de adotar também a construção de políticas, considerando 0 acúmulo da luta das mulheres e dos movimentos feministas.

Para a Secretaria Especial de Políticas para as Mulheres, a Política Nacional para as Mulheres orienta-se, entre outros princípios - e, aqui, eu vou repetir um rol de coisa - o da igualdade na adversidade, da universalidade dos direitos, da autonomia das mulheres. Estes, sem sombra de dúvida, são base para a construção dos planos governamentais - e aqui eu estou colocando no plural. No atual contexto de desigualdades, consideramos, também, necessárias, políticas afirmativas como instrumento para promover oportunidades que ao longo da História foram negadas às mulheres, às mulheres negras, às mulheres índias. Atender, de forma afirmativa as desigualdades, superando-as, é fundamental para construirmos a igualdade de oportunidades.

No entanto, sabemos que só por meio de políticas públicas efetivas, permanentes, estruturais e estruturantes poderemos de fato construir novos valores, rompendo padrões, e estabelecendo novos paradigmas.

As Conferências Estaduais - repito um dado que já foi dito aqui - produziram 3.844 


\section{6 de jullho de 2004}

propostas que são indicativas de programas, ações, projetos, sugeridos aos Governos municipais, estaduais e ao Governo Federal.

documento base

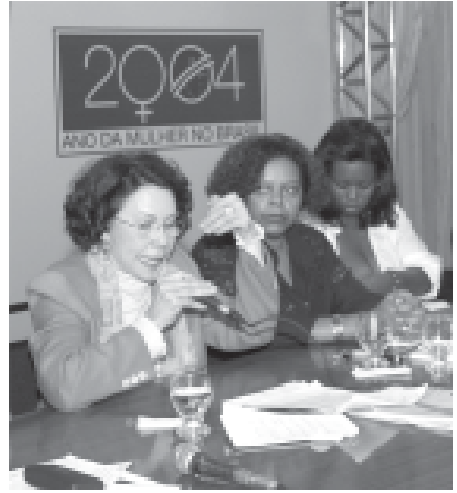

Plano Nacional de Políticas para as Mulheres
A Comissão de Relatoria produziu este documento que as delegadas desta Conferência vão analisar, tomando posições e decisões nos grupos e na Plenária Final. São 40 diretrizes pontuadas no eixo de enfrentamento da pobreza, geração de renda, trabaIho, acesso ao crédito e à terra.

No eixo que trata da superação da violência contra as mulheres, identificamos 16 diretrizes. Já o eixo sobre a promoção do bem-estar às mulheres, que abrange saúde, moradia, infra-estrutura, equipamentos sociais e recursos naturais, engloba 60 propostas de diretrizes. 0 que trata da efetivação dos direitos humanos das mulheres, dos direitos civis, políticos, sexuais e reprodutivos, contém 14 diretrizes. E o eixo de desenvolvimento das políticas de educação, cultura, comunicação e produção do conhecimento para a igualdade, gerou 33 diretrizes. 0 documento acrescenta princípios e diretrizes gerais - a própria ministra Matilde já se referiu a eles, também, como eu que vão nortear a discussão, nos grupos que vocês vão constituir daqui a pouquinho.

Então, é sobre esse material que as delegadas vão se debruçar e, democraticamente, deliberar, contribuindo, assim, ativamente, com a construção do Plano Nacional de Políticas para as Mulheres.

Nós observamos uma grande similaridade nas propostas, o que indica, e nos alegra, o acúmulo da sociedade sobre os temas e a maturidade do debate. Ao mesmo tempo, observamos que muitas dessas propostas, já estão sendo absorvidas pelo próprio Governo, mas nós temos certeza absoluta que elas serão reforçadas quando legitimadas nessa Conferência Nacional. E isso dá, cada vez mais, a dimensão da importância desse espaço nacional.

Para a Secretaria Especial de Políticas para as Mulheres a conseqüência desta Conferência é fundamental para a ampliação e institucionalização, nos Governos estaduais e municipais, de mecanismos que gerem políticas para as mulheres, em diversos níveis.

Institucionalizar significa criar Secretarias nos Estados e nos Municípios, incorporar os desafios a serem superados nos objetivos estratégicos dos governos, visando a construção da igualdade.

Na construção do Plano Plurianual 2004/2007 consta o desafio da promoção da 


\section{6 de Julho de 2004}

igualdade de gênero e de raça com programas e projetos que nosso Governo assumiu, estrategicamente. 0 que significa, incorporar as categorias de gênero e raça para a construção de indicadores no planejamento governamental dos Estados e Municípios; capacitar os gestores; construir mecanismos de monitoramento da execução das políticas, possibilitando a desagregação de indicadores. Significa também incorporar nas pesquisas e no Censo os indicadores de gênero nas diversas áreas de políticas públicas; significa explicitar, nos programas, projetos e ações dirigidos às mulheres, as metas físicas, as financeiras e os recursos orçamentários, porque nós sabemos que é dessa forma que nós vamos estar criando as condições para alterar o cotidiano da vida das mulheres.

Precisamos, também, criar elementos para monitorar, cada vez mais e melhor, o cumprimento dos acordos internacionais.

Portanto, companheiras delegadas, termino a minha fala dizendo que ao final do nosso Governo nós queremos saber quantas mulheres foram incorporadas no trabalho formal, quantas mulheres se integraram à Previdência Social, quantas jovens mulheres tiveram acesso ao primeiro emprego, quantas mulheres acessaram o PRONAF e outras linhas de crédito; quantos hospitais a mais foram habilitados para fazerem o aborto previsto em lei - hoje, ainda em número insuficiente; quantos Estados criaram Secretarias para as Mulheres, quantos Conselhos foram fortalecidos, quantas mulheres, com título de propriedade de terra, quantas mulheres com documentação.

Nós queremos conhecer a realidade do Brasil, porque nós temos certeza do nosso compromisso com a alteração dessa realidade. Nós estamos aqui, companheiras delegadas, ministra Nilcéa, ministra Matilde, delegações estrangeiras, estamos aqui, possibilitando a construção de um legado para a sociedade brasileira, e dando a nossa contribuiç̧ão para o mundo.

0 que esta Conferência decidir deverá ser apropriado pela sociedade, porque ela é muito mais ampla do que os Governos. Nós sabemos que os Governos são frutos de momentos históricos, de correlações de forças e que eles contêm, também, contradições. Temos certeza de que é necessário que, estrategicamente, se compreenda o momento que estamos vivendo e o significado de cada decisão que tomarmos.

Nós estamos certas de que, no Governo do Presidente Lula, fazemos a diferença na medida em que entendemos que a construção da História passa por tudo que nós vivemos e que nós estamos fazendo nesse momento. Muito obrigada. 


\section{Conferência Nacional de Políticas para as Mulheres Resultados da Plenária Final 17 de julho de 2004}

\section{Nota Metodolóqica}

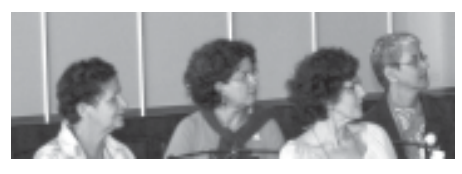

Durante a I Conferência Nacional de Políticas para as Mulheres, o processo de elaboração das diretrizes para uma Política Nacional para as Mulheres se deu a partir da discussão do Documento "Propostas de Diretrizes para uma Política Nacional para as Mulheres", nos 20 grupos de trabalho constituídos durante a Conferência.

Todos os 20 grupos discutiram a parte geral deste Documento "Natureza, princípios e diretrizes da Política Nacional para as Mulheres na perspectiva da igualdade de gênero, considerando a diversidade de raça e etnia".

Os cinco eixos temáticos que faziam parte do Documento foram discutidos, cada um deles, por 4 grupos.

Eixo Temático 1 - Enfrentamento da pobreza: geração de renda, trabalho, acesso ao crédito e a terra.

Eixo Temático 2 - Superação da violência contra a mulher: prevenção, assistência e enfrentamento.

Eixo Temático 3 - Promoção do bem-estar e qualidade de vida para as mulheres: saúde, moradia, infra-estrutura, equipamentos sociais e recursos naturais.

Eixo Temático 4 - Efetivação dos direitos humanos das mulheres: civis, políticos, sexuais e reprodutivos.

Eixo Temático 5 - Desenvolvimento de políticas de educação, cultura, comunicação e produção do conhecimento para a igualdade.

0 trabalho de sistematização das discussões dos grupos foi realizado com a participação das coordenadoras e relatoras de cada um dos grupos, e coordenado pela Comissão Especial Temática e de Relatoria. 


\section{7 de jullho de 2004}

Os relatórios das discussões dos grupos foram compatibilizados, sendo destacados os itens que foram aprovados $(50 \%+1)$ pelos 4 grupos nos respectivos eixos temáticos. E as diretrizes da parte geral do Documento que também foram aprovadas pela maioria dos grupos.

A partir das discussões levantadas nos grupos se estruturou um bloco de questões "conceituais" que foram definidas no primeiro momento da Plenária Final e que, depois de aprovadas pelas delegadas, seriam utilizadas em todo o documento.

As propostas das diretrizes que sofreram alguma modificação nos grupos foram separadas em dois grandes blocos. 0 primeiro bloco aglutinou as diretrizes aprovadas na íntegra e as propostas de diretrizes que receberam emendas de redação, que não alteravam o conteúdo da proposta e sim melhoravam ou clareavam o texto sugerido. 0 segundo bloco aglutinou as emendas que sugeriam novos conteúdos.

Por sugestão da Comissão Especial Temática e de Relatoria, acatada pela Plenária, foram discutidas na Plenária Final da I Conferência Nacional de Políticas para as Mulheres as sugestões de emendas deste segundo bloco, que exigiam um posicionamento das delegadas. 0 primeiro bloco foi levado à Plenária somente para referendum.

As propostas de diretrizes apresentadas à Plenária para serem referendadas obtiveram $50 \%+1$ dos votos nos grupos de trabalho.

Na parte geral do Documento foram aprovadas por maioria as diretrizes de número: $1,4,5,6,12,13,17,21,22,23,30,33$ e 40.

No Eixo Temático 1, foram aprovadas por maioria as diretrizes de número: 43, 44, $46,47,48,50,52,53,54,55,56,57,58,59,60,61,62,63,65,66,67,71,72,73$, $74,75,76,77,78,80,81,82$ e 83.

No Eixo Temático 2, foram aprovadas por maioria as diretrizes de número: 90, 91, 96, e 101.

No Eixo Temático 3, foram aprovadas por maioria as diretrizes de número: 120, 125, $127,128,132,133,147,153,155$ e 162. Da mesma forma foi aprovada por referendum a diretriz de número 130, que teve a proposta de alteração de texto aprovada nos 4 grupos deste eixo.

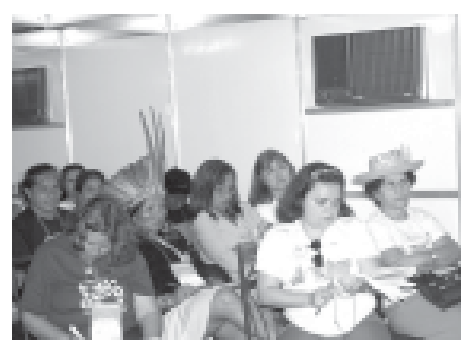

.




\section{7 de julho de 2004}

No Eixo Temático 4, foram aprovadas por maioria as diretrizes de número: 170, 171, 172, 173, 174, 175, 176, 177, 178, 179, 180, 181, 182 e 183.

No Eixo Temático 5, foram aprovadas por maioria as diretrizes de número: 189, 192, $200,203,207,208,220,221,222,223$ e 224.

Brasília, agosto de 2004.

Comissão Especial Temática e de Relatoria 


\section{7 de jullho de 2004}

\section{Acordos gerais definidos na Plenária Final}

Onde couber, mencionar categorias estruturais: gênero, raça, etnia e classe social, quando estivermos nos referindo às desigualdades estruturais.

Conferir visibilidade e afirmar todas as expressões da diversidade em relação à livre orientação sexual, às jovens, às idosas e às mulheres com deficiência;

Conferir visibilidade e afirmar a diversidade de inserção social e regional: mulheres trabalhadoras urbanas e rurais, profissionais do sexo, mulheres vivendo com HIVIAIDS, refugiadas e mulheres em situação de encarceramento;

Igualdade e equidade: adotar, sempre que se aplicar, a equidade de gênero em associação com igualdade, nos termos indicados pelos grupos.

Para visibilidade da diversidade: procurar usar de forma associada: movimento de mulheres e feminista;

Ao citar grupos específicos de mulheres, além de negras e índias, incluir, sempre que adequado e nos termos propostos: as jovens, idosas, populações tradicionais, mulheres lésbicas, mulheres bissexuais, mulheres que fazem sexo com mulheres, mulheres vivendo com Aids, profissionais do sexo, mulheres com deficiência, mulheres privadas de liberdade e refugiadas;

Dar visibilidade a desigualdades regionais, adotando esta referência nos casos propostos nos grupos, ao tratar de desenvolvimento.

Adotar a menção as perspectivas não sexista, anti-racista, não lesbofóbica e não homofóbica nos casos indicados.

Como regra geral usar mulheres em situação de violência. Onde couber referência à garantia de direitos, reparação, indenização e punição, usar mulheres vítimas de violência. 


\section{Natureza, princípios e diretrizes da Política Nacional para as Mulheres na perspectiva da iqualdade de gênero, considerando a diversidade de raça e etnia.}

1. A proposição de uma Política Nacional para as Mulheres na direção da igualdade e equidade de gênero - considerando raça e etnia e a livre orientação sexual - implica, em primeiro lugar, em reconhecer que a organização do Estado, especialmente a sua lógica de formulação de políticas, interfere na vida das mulheres determinando, sancionando, reproduzindo ou alterando padrões de relações de gênero, raça e etnia, e a liberdade de orientação sexual. E, na medida em que reconhecemos que essas relações têm um caráter sistêmico, o alcance de uma Política Nacional deve interferir no sentido das ações do Estado.

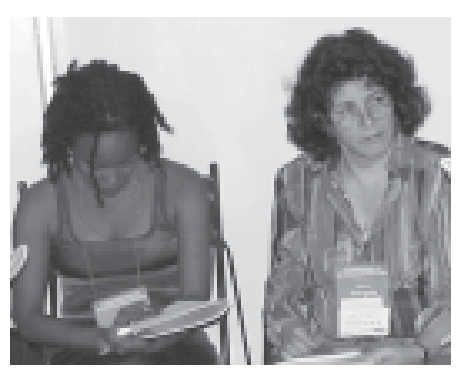

2. O desafio a ser enfrentado na implementação de políticas públicas é desmistificar a neutralidade do Estado como propositor e articulador de uma ação política. Cabe ao poder público garantir a universalidade, alterando as desigualdades sociais. Esta alteração precisa ser também considerada do ponto de vista das relações de gênero, raça e etnia, de geração, da diversidade de orientações sexuais e das necessidades específicas de pessoas com deficiência, modificando relações de poder e acesso a direitos em sua dimensão social, política, econômica e cultural. Possibilitando, assim, o rompimento da visão corrente e assumindo o pressuposto de que a definição de masculino e feminino é uma construção histórica, política, cultural e um componente estrutural das relações sociais e econômicas.

3. Esta Política estrutura diretrizes e princípios para intervenções governamentais, visando a inserção construtiva das mulheres nas ações do Estado, promovendo políticas concretas que efetivem a igualdade e equidade de gênero, raça e etnia e a livre orientação sexual, considerando as mulheres como sujeito e não apenas como apêndice da família ou recurso poupador de investimentos públicos.

4. 0 reconhecimento das mulheres como sujeitos de direitos e como sujeitos políticos, previstos na Constituição Federal de 1988, também é próprio desta Política Nacional, posto que considera importante promover seu maior acesso e participação nos espaços de poder e se torna essencial para democratizar o Estado e a sociedade.

5. Nesse sentido, a Política Nacional para Mulheres, reconhece e valoriza a contribuição dos movimentos feministas e de mulheres, para a construção dessa trajetória de 


\section{7 de Julho de 2004}

alteração da lógica tradicional de políticas para as mulheres no plano do Estado e das demais políticas que tradicionalmente não levam em conta as desigualdades de gênero, geração, raça e etnia.

6. A Política Nacional para Mulheres, por todos estes desafios, é uma estratégia de longo alcance no sentido da democratização do Estado e construção de uma nova institucionalização que exige a gestação de um processo articulado de diálogo entre os distintos sujeitos, dentre os quais as mulheres que, em suas múltiplas experiências e movimentos, vêm dando enorme contribuição ao país.

7. A institucionalização necessária a uma Política Nacional para as Mulheres, que seja efetiva e que altere as condições de desigualdades entre as mulheres e homens exige a criação de organismos executivos de articulação e implementação de políticas, indispensáveis para a construção de uma coerência nas ações do Estado. A criação de Secretarias de Políticas para as Mulheres, no primeiro escalão de governo nas esferas federal, estadual e municipal com poder político, administrativo e orçamentário é estratégica para a construção da igualdade. Para assegurar e garantir a construção de relações democráticas com o movimento feminista e de mulheres é importante a criação e fortalecimento de mecanismos institucionais que ampliem a participação popular e o controle social como as conferências, os conselhos de direitos das mulheres e a participação das mulheres na elaboração do orçamento participativo, além de outros mecanismos existentes de participação popular, contemplando a representação das mulheres indígenas, negras, lésbicas, idosas, deficientes, jovens, ciganas e profissionais do sexo.

\section{PRINCÍPIOS}

8. A Política Nacional para Mulheres, que fundamenta os planos governamentais, orientase pelos princípios da igualdade na diversidade, autonomia das mulheres, laicidade do Estado, universalidade, participação e solidariedade.

9. IGUALDADE. As políticas para mulheres, nos termos desta conferência, constituem um desafio para a igualdade e a equidade numa perspectiva de gênero. 0 princípio da igualdade deve ser por isto o parâmetro para uma política de Estado que se proponha a superar as desigualdades entre mulheres e homens, com recorte étnico e racial.

10. Políticas de ações afirmativas implicam em garantir a responsabilidade das esfe- 


\section{7 de julho de 2004}

ras governamentais (federal, estadual, municipal) na implementação de políticas públicas de promoção da igualdade com ação continuada e conjunta com os movimentos sociais: grupo de mulheres negras e indígenas, no intuito de corrigir práticas discriminatórias históricas.

11. 0 princípio da igualdade deve ser implementado com respeito e atenção a diversidade de situações, experiências e formas de inserção social de todas as mulheres e considerando as categorias de gênero, classe, raça, etnia, de geração, orientação sexual e mulheres com deficiência no diagnóstico, na formulação, na implementação, no monitoramento e na avaliação de políticas públicas.

12. No tocante ao respeito a diversidade na igualdade, garantir a presença do Estado, suas instituições e organismos, políticas públicas e serviços públicos nas distintas regiões do país, rurais e urbanas, de forma adequada às condições locais de moradia e territorialidade, preservando o meio ambiente e primando pelo desenvolvimento econômico sustentável.

13. AUTONOMIA DAS MULHERES. Implica na ampliação do poder de decisão das mulheres sobre suas vidas, seus corpos, sua comunidade e país, favorecendo o rompimento com o legado histórico, os ciclos e espaços de dependência, exploração, opressão e subordinação que constrangem as suas vidas no plano pessoal e da sua autonomia econômica, política e social.

14. ESTADO LAICO. 0 princípio da laicidade do Estado deve ser obedecido nas políticas públicas de forma a garantir a igualdade de todas e todos perante o Estado, assegurar a efetivação dos direitos já consagrados na Constituição Federal e nos diversos instrumentos internacionais como medida de proteção aos direitos humanos das mulheres e meninas.

15. UNIVERSALIDADE. A luta pela universalização das políticas públicas permanentes tem sido uma marca da luta das mulheres pelo acesso aos direitos sociais, econômicos, culturais e ambientais para todas as mulheres, rurais e urbanas, em sua diversidade de raça e etnia, de situações e experiências. É necessário que o Estado implemente ações neste sentido e garanta que elas se cumpram na sua integralidade.

16. 0 princípio da universalidade deve ser traduzido em políticas permanentes nas três esferas governamentais caracterizadas por sua indivisibilidade, integralidade e 


\section{7 de Julho de 2004}

inter setorialidade dos direitos, combinadas às políticas públicas de ações afirmativas, percebidas como transição necessária em busca da efetiva igualdade e equidade de gênero que considera a diversidade de raça e etnia.

17. Este é, portanto, um princípio de responsabilidade permanente do conjunto do governo, e não de alguma área da administração, o que exige esforço de integração entre as distintas políticas de governo.

18. PARTICIPAÇÃO. A Política Nacional para Mulheres, e quaisquer projetos, programas e planos governamentais dela decorrente, deve ter presente à necessidade de debater e elaborar com o segmento interessado que busca beneficiar, o que implica estabelecer um diálogo e uma parceria com os movimentos feministas e de mulheres, respeitando sua diversidade e ampliando a cidadania.

19. A discussão das políticas públicas junto ao segmento interessado só será instrumento de mudança se vier acompanhada de poder de decisão sobre elas, com controle social.

20. EQÜIDADE. Princípio que garante o acesso aos direitos universais, através de ações específicas e afirmativas a grupos historicamente discriminados. Tratar desigualmente os desiguais requer o pleno reconhecimento das subordinações e necessidades específicas dos diferentes grupos de mulheres, e é compreendida como fundamento das ações afirmativas e como instrumentos necessários no alcance ao pleno uso-fruto por mulheres e homens, de todos os direitos humanos.

\section{DIRETRIZES GERAIS}

21. Para concretizar estes princípios que nortearão a formulação de planos de políticas para igualdade estabelece-se as seguintes diretrizes gerais:

22. 0 Estado deverá garantir e assegurar a implementação dessa política pública, nas suas diferentes esferas, na superação das desigualdades de gênero, raça e etnia e na necessária formulação de políticas integradas para a construção da igualdade.

23. Possibilitar a ampliação das condições de autonomia pessoal e auto-sustentação das mulheres, reconhecendo e valorizando a contribuição coletiva das mulheres quanto ao bem estar e qualidade de vida de todas e todos.

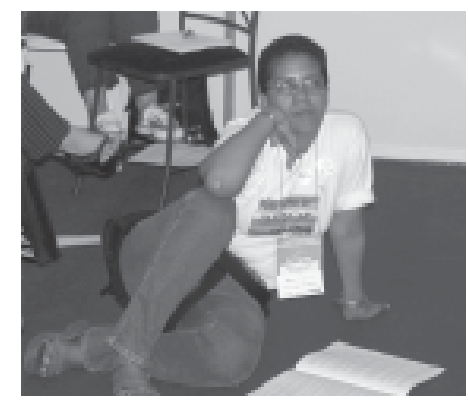




\section{7 de jullho de 2004}

24. Favorecer as condições do exercício dos direitos reprodutivos, dos direitos sexuais e a livre orientação sexual, descriminalizando o aborto, possibilitando autonomia e bem estar também neste campo, intervindo contra as distintas formas de apropriação mercantil do corpo e da vida das mulheres, tendo em vista também a exploração sexual, o tráfico de mulheres e o consumo de imagens da mulher.

25. Reconhecer a violência de gênero e raça/etnia como violência estrutural e histórica que expressa a opressão das mulheres e como questão de saúde pública. Isto exige responder as demandas que pressionam o cotidiano das mulheres, em particular a violência doméstica e sexual de que são vitimas, implementando e garantindo políticas permanentes de enfrentamento, assistência e prevenção.

26. 0 Estado tem a sua parte a cumprir na modificação da divisão sexual do trabalho: primeiro, reconhecendo a sua importância social e fundamental para as relações humanas e produção do viver; segundo, ampliando a oferta de equipamentos sociais e serviços correlatos; terceiro, contribuindo com a educação pública e construção social de novos valores que enfatizem a sua importância, e sensibilizando a todos, ao Estado, a mulheres e homens da necessidade de viabilizar novas formas de sua efetivação.

27. Garantir um desenvolvimento democrático e sustentável levando em consideração as diversidades regionais, com justiça social, assegurando que as políticas de desenvolvimento promovidas pelo Estado Brasileiro sejam direcionadas à superação das desigualdades econômicas e culturais, o que implica ações de caráter distributivo e desconcentrador de renda e riquezas.

28. Aperfeiçoar os mecanismos de participação, consolidando a relação com os movimentos populares e de mulheres e com as associações comunitárias de mulheres, incentivando e promovendo mecanismos de controle e participação popular aberto a todos os segmentos deste multifacetado movimento.

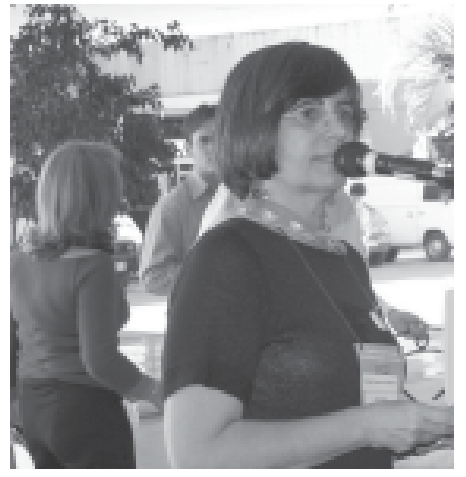

29. Garantir a soberania do Brasil nas políticas comerciais internacionais, assinando apenas acordos comerciais que promovam políticas econômica, agrícola e industrial, voltadas para o desenvolvimento sustentável e para a promoção da igualdade entre homens e mulheres.

30. Contribuir para a ampliação das políticas públicas voltadas para a melhoria de vida das mulheres, em todas as áreas de atuação governamental, garantindo redes de atuação inter-governamental desenvolvidas entre municípios, governos estaduais e governo federal. 


\section{7 de julho de 2004}

31. Garantir o cumprimento dos tratados, acordos e convenções internacionais firmados e ratificados pelo Estado brasileiro, que garantam os direitos humanos das mulheres.

32. Estabelecer estratégias que promovam equilíbrio de poder entre mulheres e homens, em termos de recursos econômicos, direitos legais, participação política e relações interpessoais.

33. Implantar e implementar políticas de ações afirmativas como instrumento necessário ao pleno usufruto de todos os direitos e liberdades fundamentais para distintos grupos de mulheres - negras, índias, jovens, idosas, populações tradicionais, mulheres lésbicas e bissexuais, mulheres que fazem sexo com mulheres, mulheres vivendo com HIVIAIDS, profissionais do sexo, mulheres com deficiência, mulheres privadas de liberdade - para corrigir práticas discriminatórias.

34. Compete ao Estado, em parceria com diferentes segmentos da sociedade, através de uma ampla discussão, garantir a inclusão na grade curricular, desde o ensino fundamental, das questões de gênero, raça e etnia, e reconhecer a necessidade de alteração nas práticas educativas, na produção de conhecimento, na educação formal, na cultura e na comunicação com a sociedade.

35. Estabelecer uma política permanente de produção de dados desagregados por sexo, raça, etnia, deficiência quando houver e orientação sexual em todas as áreas de atuação do Estado, configurando um sistema estatístico de dados sobre as mulheres brasileiras, que evidencie salários, jornada e ambiente de trabalho, doenças profissionais e direitos trabalhistas, possibilitando o equacionamento das desigualdades de gênero e a construção de indicadores de gênero para fins de planejamento, formulação e acompanhamento das políticas públicas para as mulheres, considerando as especificidades das mulheres negras, brancas e índias.

36. Garantir e acompanhar a alocação e execução de recursos nos Planos Plurianuais - PPA, nas Leis de Diretrizes Orçamentárias - LDO e Orçamentos Anuais visando atender as políticas públicas para as mulheres, considerando os diferentes programas e projetos dos órgãos governamentais, que concretizam a transversalidade de gênero considerando a diversidade de raça, etnia, classe, geracional, orientação sexual e pessoas com deficiência, nas políticas públicas. 
37. Garantir caráter participativo no processo de elaboração do PPA, LDO, Orçamento anual, visando alocar recursos para políticas públicas para as mulheres garantindo 0 controle social para o acompanhamento da execução do orçamento, considerando os diferentes programas e projetos que concretizem a transversalidade de gênero, raça e etnia das políticas públicas. Cabe ao Estado prover as condições para que 0 controle e o acompanhamento dos indicadores da eficácia das políticas de gênero possam ser feitos pela sociedade civil organizada e movimentos feministas e de mulheres.

38. Implementar instância de controle social sobre o destino dos recursos públicos com a participação paritária das mulheres.

39. Avaliar a adequação de criação de Fundos Específicos que tenham por objetivo atender à execução de políticas públicas para as mulheres e efetivar a análise dos instrumentos orçamentários com o olhar de gênero, considerando a diversidade de raça, etnia, classe, geração, orientação sexual e pessoas com deficiência.

40. Criar, fortalecer e ampliar os organismos específicos dos direitos e de políticas públicas para as mulheres visando à operacionalização da transversalidade das ações e 0 desenvolvimento de programas que reúnam e articulem ações governamentais nos distintos níveis e esferas de poder, executivo, judiciário e legislativo, com desenvolvimento planejado e integrado dessas políticas.

41. Efetivar e revisar, aperfeiçoando e atualizando as diretrizes da Política Nacional para as Mulheres, por meio de debate político na Conferência Nacional de Políticas para as Mulheres, a ser realizada a cada três anos, precedida de conferências municipais, estaduais e do Distrito Federal.

42. Caberá à Secretaria Especial de Políticas para as Mulheres a coordenação das políticas para as mulheres. Nos estados e municípios este papel caberá às secretarias e coordenadorias com papel e atuação equivalentes. 


\section{7 de Julho de 2004}

\section{EIXO 1}

\section{Enfrentamento da pobreza: geração de renda, trabalho, ACESSO AO CRÉdito E À TERRA}

43. Garantir que o Estado promova a independência econômica das mulheres, assegurando seus direitos, o acesso ao emprego, a melhoria das condições de trabalho e o controle sobre os recursos econômicos, com apoio à geração de renda e à economia solidária.

44. Criar mecanismos que garantam a isonomia salarial entre mulheres e homens nas mesmas condições de trabalho e mesmo nível educacional, respeitando as suas peculiaridades locais, com especial atenção às mulheres com deficiência, índias e negras, trabalhadoras rurais e moradoras ribeirinhas.

45. Recuperar o valor do salário mínimo com aumentos reais anuais que permitam elevar a renda das trabalhadoras, bem como diminuir as diferenças sociais de gênero, raça e etnia e classe social.

46. Estimular o compartilhamento das tarefas domésticas através de uma maior liberação do tempo das trabalhadoras que não incida na remuneração e de campanhas institucionais, construindo e reforçando uma nova cultura referente à divisão sexual do trabalho.

47. Ampliar e facilitar as oportunidades e garantir o acesso das mulheres ao sistema de crédito, desburocratizando-o mediante a adequação dos programas atuais; promovendo mudanças nas normas; criando novas linhas e sensibilizando os operadores de crédito; estimulando a capacitação e criando sistemas de acompanhamento e fiscalização; além de incentivar a criação de associações de produção.

48. Promover uma reforma fiscal, a partir do debate com a sociedade civil organizada, de forma a garantir a equidade e a justiça na cobrança de impostos e na redistribuição dos recursos.

49. Promover a ampliação da oferta de emprego por meio de uma revisão na política macroeconômica e estratégias de desenvolvimento que incentivem o crescimento econômico sustentável voltado para o mercado interno de consumo de massas. Re- 


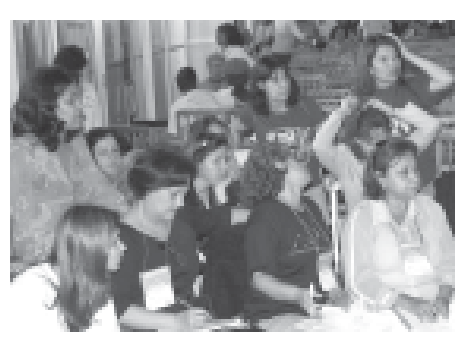

dução da jornada de trabalho, sem redução do salário, para aumentar o acesso ao emprego e favorecer também a divisão do trabalho doméstico, propiciando mais tempo livre para as mulheres participarem de outras atividades.

50. Adotar políticas macroeconômicas e estratégias de desenvolvimento, com a redução da taxa de juros e do superávit primário que assegurem as necessidades das mulheres, garantindo a superação da pobreza e do desemprego.

51. Realizar uma auditoria que permita dar transparência quanto à origem e volume da dívida pública interna e externa.

52. Garantir a implementação de políticas de geração emprego e renda, combatendo todas as formas de discriminação baseadas no gênero, geração, raça e etnia, incluindo as portadoras de HIV.

53. Combater a discriminação de sexo e de raça no mercado de trabalho, a segregação ocupacional e as práticas de assédio moral, simbólico e sexual.

54. Garantir melhores condições materiais e humanas às Delegacias Regionais de Trabalho (DRT) para que essas possam intensificar a fiscalização e o cumprimento da legislação trabalhista, com ênfase no trabalho da mulher, com objetivo de reduzir as desigualdades salariais.

55. Incorporar a questão de gênero, raça e etnia nos programas do sistema público de emprego, trabalho, renda e reforma agrária com ações afirmativas visando assegurar a igualdade de acesso.

56. Que o poder público, envolvendo empresas públicas e privadas, garanta 0 estabelecimento de programas de geração de emprego, associativismo, e empreendedorismo das mulheres jovens, no meio urbano e rural, contemplando a diversidade de raça e etnia e a livre orientação sexual, priorizando as mulheres gestantes, solteiras e pobres.

57. Implementar políticas públicas de escolarização, formação profissional e capacitação, voltadas para a inclusão das mulheres no mercado formal de trabalho, em condições justas e igualitárias. 


\section{7 de Julho de 2004}

58. Implantar e implementar projetos de qualificação profissional que garantam acompanhamento psicossocial, elevação da escolaridade e conhecimento tecnológico, visando a inserção no mercado de trabalho especialmente para mulheres em situação de violência, gestantes solteiras e pobres, empregadas domésticas, mulheres com deficiência, refugiadas e ex-presidiárias. Essas demandas deverão ser incorporadas pelo Plano Nacional de Qualificação Profissional, pelo FAT e pelo SINE.

59. Implementar políticas públicas de geração de emprego e renda e de fomento a projetos produtivos auto-sustentáveis, que ofereçam capacitação e aprimoramento técnico e gerencial, e acesso a tecnologias, que respeitem e se adequem às demandas e às potencialidades produtivas, especialmente das comunidades quilombolas, pesqueiras, ribeirinhas, indígenas e das trabalhadoras rurais.

60. Desenvolver políticas públicas que ampliem e valorizem a participação das mulheres no mundo do trabalho, em condições justas e igualitárias, com mecanismos que incentivem a sua contratação, aumento, escolarização, qualificação e capacitação profissional gratuitos, partindo de diagnóstico das necessidades do mercado de trabalho, das comunidades rurais e urbanas, com condições dignas de trabalho, garantindo a diversidade de raça e etnia, geração e orientação sexual.

61. Implementar políticas de promoção de autonomia financeira de mulheres em situação de violência ampliando o contingente de mulheres atendidas pelos programas de capacitação profissional e geração de emprego e renda.

62. Assegurar às mulheres em situação de risco social e/ou pessoal, inclusive as egressas do sistema prisional, e em medidas sócio-educativas e portadoras de doenças crônicas, vagas em cursos profissionalizantes de gestão de seu próprio negócio, visando facilitar sua inserção no mercado de trabalho e a conquista de sua independência econômica.

63. Garantir capacitação e trabalho para a mulher encarcerada e ex-detentas, e aos seus dependentes, inserindo-os no mercado de trabalho, com direitos legais e trabalhistas.

64. Garantir políticas públicas governamentais voltadas à economia popular solidária com equidade de gênero, raça, etnia e geração, potencializando o associativismo, cooperativismo, micro-crédito e incubadoras, proporcionando a sustentabilidade econômica das mulheres. 


\section{7 de jullho de 2004}

65. Desenvolver a economia solidária estimulando a organização de redes de produção, comercialização e consumo, incentivando, através de recursos técnicos, financeiros e materiais, a criação e manutenção de cooperativas, associações e incubadoras voltadas às mulheres, com deficiência ou não, de todas as idades, raças e etnias das áreas rural e urbana.

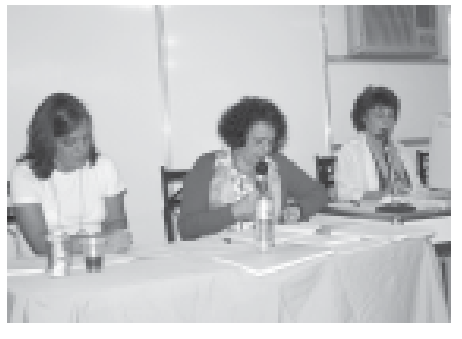

66. Incentivar a criação e implementação de programas de crédito específicos para as mulheres com a desburocratização dos agentes financeiros e acesso facilitado nos programas de crédito existentes, renda e ampliação de convênios federais, estaduais e municipais, para efetivar projetos de capacitação das famílias e geração de renda, com foco no desenvolvimento da mulher, com deficiência ou não, sem distinção de raça, etnia ou idade, visando a implantação e empreendimentos de geração de trabalho e renda no meio rural e urbano, na perspectiva da economia solidária.

67. Incentivar as esferas municipais e estaduais na promoção de programas de inclusão no mercado de trabalho, com ênfase aos grupos auto gestionários, formados por mulheres.

68. Assegurar às mulheres rurais e urbanas a Previdência Social.

69. Assegurar a Previdência Social para as mulheres como fator de integração social. Dessa forma, discutir e apoiar as propostas em tramitação no Congresso Nacional sobre 0 acesso das donas de casa à Previdência Social, bem como as propostas que reconheçam o trabalho de reprodução social (trabalho doméstico não remunerado) como forma de inclusão no sistema de seguridade social, assegurando o acesso das mulheres a todos os benefícios da Previdência Social indispensável ao exercício pleno da cidadania.

70. Estender à empregada doméstica todos os direitos assegurados às demais trabaIhadoras e trabalhadores inseridos no mercado formal de trabalho. Erradicação do trabalho escravo e do trabalho infantil no âmbito do emprego doméstico.

71. Criar mecanismos legais que assegurem o acesso e o direito à seguridade social (saúde/assistência/previdência) à trabalhadora informal urbana e rural, às mulheres donas de casa, agricultoras, índias, ciganas, negras e quilombolas. 


\section{7 de Julho de 2004}

72. Assegurar que a Reforma Agrária garanta qualidade de vida e acesso aos bens e serviços, posse da terra e moradia.

73. Assegurar que a Reforma Urbana garanta qualidade de vida e acesso aos bens e serviços, posse da terra e moradia.

74. Garantir a efetividade das políticas de fortalecimento da agricultura familiar como 0 acesso ao crédito, assistência técnica, diversificação da produção e acesso aos mercados com igualdade de gênero, raça e etnia.

75. Incentivar o acesso das mulheres à titularidade da terra nos assentamentos e programas de reforma agrária, garantindo à trabalhadora rural a inclusão de seu nome nas escrituras de propriedades, independente do seu estado civil, bem como garantir o direito da mulher de ter seu nome no bloco de notas de produtora rural.

76. Estimular a promoção da agricultura agro-ecológica, com a garantia da preservação e defesa de sementes crioulas, como patrimônio da humanidade e soberania alimentar.

77. Valorizar o meio rural e ribeirinho como espaço privilegiado para a implantação de políticas públicas de inclusão social, preservação ambiental prevendo a estruturação de serviços públicos nas comunidades e assentamentos /acampamentos rurais.

78. Construir, garantir e viabilizar políticas públicas que garantam o transporte e a comercialização e os preços mínimos da produção agrícola familiar, possibilitando, ao mesmo tempo, a geração de renda e trabalho para as famílias e o incentivo à diversificação dos produtos agrícolas produzidos.

79. Contribuir para o acesso igualitário aos direitos econômicos, em especial ao crédito, terra e à moradia para as mulheres e populações negras e indígenas como forma de superação das desigualdades de raça e etnia.

80. Promover a simplificação de processo de acesso ao crédito agrícola e ao microcrédito produtivo para as trabalhadoras do meio urbano e rural, em especial as negras, quilombolas e índias, dos meios urbano e rural.

81. Garantir a demarcação, homologação, ampliação e desintrusão das terras indígenas. 


\section{7 de jullho de 2004}

82. Propor a certificação, por lei, da titularidade da casa obtida pela Reforma Urbana, e a titularidade da terra obtida através do Programa de Reforma Agrária para 0 casal.

83. Assegurar a titularidade coletiva das terras das populações quilombolas, assim como a demarcação e regularização fundiária dos territórios indígenas.

84. Assegurar através de orçamentos públicos, espaços públicos coletivos para a produção, comercialização e consumo, priorizando grupos autogestionários constituídos por mulheres e empreendimentos de economia solidária.

85. Garantir a inserção soberana do Brasil no comércio e na política internacional, firmando apenas acordos comerciais que não impeçam políticas econômicas, industriais e agrícolas voltadas para o desenvolvimento sustentável do país e para a promoção da igualdade entre mulheres e homens, negras, indígenas e brancas e combate a todas as formas de exclusão.

86. Rever os acordos com o Fundo Monetário Internacional buscando superar as políticas ortodoxas e restritivas por ele indicadas, objetivando assim o crescimento econômico e social com geração de renda e trabalho que permitam alterações estruturais na divisão sexual do trabalho.

87. Manutenção dos direitos existentes e ampliação de novos direitos na reforma sindical e trabalhista que obedeçam aos princípios da igualdade e equidade de gênero.

88. Criar programas de incentivos a agroecologia, contrapondo os transgênicos e agrotóxicos, e valorizando os produtos orgânicos.

89. A perspectiva de gênero, raça e etnia deve ser contemplada em todos os concursos públicos (federal, estadual, distrital e municipal), de ingresso a cargos, empregos e funções e deverá ser condicionada a assinatura da ciência sobre a interdição das discriminações de gênero, raça e etnia.

\section{EIXO 2}

\section{Superação da violência contra a mulher - prevenção, assistÊnCIA E ENFRENTAMENTO.}

90. Cabe ao Estado combater a violência contra a mulher compreendida como "qualquer ação ou conduta, baseada no gênero, que cause morte, dano ou sofri- 


\section{7 de Julho de 2004}

mento físico, sexual ou psicológico à mulher, tanto na esfera pública como na esfera privada", nos termos do Artigo $1^{\circ}$ da Convenção Interamericana para Prevenir, Punir e Erradicar a Violência contra a Mulher - Convenção de Belém do Pará (1994).

91. Promover políticas públicas que aperfeiçoem e consolidem medidas de prevenção, assistência, punição e erradicação de todo os tipos de violência contra as muIheres baseadas nos princípios da transversalidade, incluindo relações de gênero, diferenças étnicas e raciais, geracionais, mulheres com deficiência (física, visual, auditiva e mental), de diferentes orientações sexuais ou qualquer outra especificidade/ intersetorialidade, para que a questão seja tratada não apenas na área de segurança, mas também de forma interdisciplinar envolvendo diferentes áreas (saúde, educação, trabalho, segurança, assistência social, habitação, justiça, entre outras) na integralidade, para que a prevenção e 0 atendimento perpassem as esferas governamentais (municipal, estadual e federal).

92. Cumprir os princípios expressos na legislação nacional e nos textos internacionais subscritos pelo Brasil, nas recomendações das decisões das Cortes Internacionais e demais mecanismos, em casos de violações dos direitos humanos das mulheres, de maneira a dar efetividade ao cumprimento de tratados e convenções internacionais.

93. Promover política nacional de enfrentamento da violência contra as mulheres, meninas e adolescentes de forma articulada entre os três Poderes - Executivo, Legislativo, Judiciário - no Ministério Público e nos diversos setores públicos dos três níveis de governo, com políticas de defesa social e segurança pública, disponibilizando recursos orçamentários e rubricas específicas.

94. Reconhecer, nas distintas ações, programas e projetos que a violência contra a mulher é uma questão de saúde pública, segurança, educação e justiça. Uma violação de direitos humanos que se manifesta nas relações desiguais de poder, construídas historicamente.

95. Viabilizar a participação eficaz da sociedade civil organizada, principalmente dos movimentos feministas e movimentos de mulheres, em todas as instâncias de controle social, nas definições, implementações e monitoramento das políticas públicas, visando a erradicação da violência contra a mulher.

96. Criar condições para diversificar as formas de coibir a violência, com a promoção do enfrentamento de suas manifestações, com especial atenção à violência

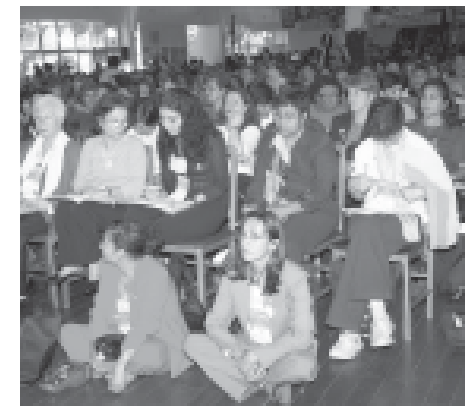


doméstica e sexual, de maneira a garantir a prevenção e a promoção de assistência às vítimas, visando o fortalecimento, a recuperação de sua auto-estima, o fornecimento de condições concretas para sua autonomia e o exercício de sua cidadania.

97. Identificar e analisar os fatores de vulnerabilidade que atingem grupos específicos de mulheres.

98. Aumentar e garantir o acesso das mulheres ao atendimento e informação sobre as formas de prevenção de todos os tipos de violência. Nos casos de suspeita de violência intrafamiliar ou doméstica, os profissionais da rede de saúde, educação, segurança, Ministério Público e Assistência Social e demais envolvidos na rede de atenção, devem prestar informações às mulheres vitimas de violência sobre os direitos e os equipamentos de atendimento à denúncia.

99. Garantir às mulheres, nos serviços públicos de atendimento, a interdisciplinaridade e a integração, de forma unificada e articulada, dos serviços: psicológico, jurídico, social, médico, policial e pericial.

100. Promover a intersetorialidade e o fomento das redes interinstitucionais, na promoção da assistência integral às mulheres, através da estruturação de uma rede de apoio qualificado e eficiente que integre as áreas de educação, saúde, geração de emprego e renda, assistência social, habitação, justiça e cidadania por meio de equipamentos sociais tais como: Juizados Especiais Criminais, Varas Especializadas, Promotorias de Justiça de Defesa dos Direitos da Mulher, Defensorias Públicas Especializadas e Coordenadorias Estaduais da Mulher, Delegacias Especializadas de Atendimento às Mulheres (DEAMS), Casas-abrigo, Centros de Referência, unidades de atenção à saúde física e mental e serviços de preparação para reinserção no mundo do trabalho.

101. Incluir a perspectiva de gênero nos currículos das(os) agentes de segurança pública e da justiça e envidar esforços para a melhoria urgente de suas condições e instrumentos de trabalho.

102. Construir mecanismos nos diferentes níveis de governo, de segurança, amparo legal, psicológico e jurídico para servidores públicos que atendem vítimas ou praticantes de violência intrafamiliar e doméstica, bem como garantir segurança, assistência e treinamento técnico pelo estado aos profissionais que atuam diretamente com situações de violência tipificadas na legislação brasileira. 


\section{7 de Julho de 2004}

103. Implementar políticas que combatam, reprimam e erradiquem o trabalho escravo e o tráfico nacional e internacional de mulheres e órgãos, incluindo ações de formação para profissionais de instituições que trabalham com turismo, garantindo segurança e assistência às mulheres vítimas de tráfico. Promover políticas efetivas no combate ao turismo sexual e exploração sexual de mulheres, crianças e adolescentes, bem como sua associação às redes de crime organizado, na direção da eliminação dessa manifestação de opressão.

104. Garantir a notificação compulsória dos casos de violência doméstica e sexual em todas as instituições da rede do serviço público e não apenas nos serviços de saúde. Produzir e divulgar, de modo sistemático, informações, análises e diagnósticos sobre a violência contra as mulheres, considerando as questões de raça, etnia, de geração, classe social, situação de domicílio (urbana ou rural), orientação sexual, mulheres com deficiência, bem como os tipos de crime e sua distribuição territorial, disponibilizando permanentemente essas informações para a população. Essas informações devem estar integradas aos serviços de atendimento às mulheres em situação de violência e servir para a elaboração de estatísticas nacionais.

105. Garantir nas defensorias públicas dos estados a criação de núcleos de atendimento e acompanhamento específicos às mulheres vítimas de violência.

106. Federalizar e punir na forma da lei, os crimes praticados pelos militares (abuso de autoridade, abusos sexuais, estupros, abandono de paternidade e outras violências), motoristas (incentivo à prostituição), contra as mulheres indígenas, ribeirinhas e principalmente em áreas de fronteiras.

107. Implementar a revisão do Marco Legal para a violência doméstica e de gênero no Brasil. Adotando as normativas internacionais no que tange a elaboração de instrumental eficaz e ágil para o enfrentamento da violência, seu enquadramento legal e as reparações cabíveis.

108. Propor mudança na legislação penal visando o agravamento da punição do agressor, autor de violência contra a mulher.

109. Realizar ações e campanhas educativas interdisciplinares de prevenção, nas diferentes formas de mídia e em todos os espaços públicos, de forma a conscientizar o conjunto da sociedade que a violência contra a mulher é inaceitável. 


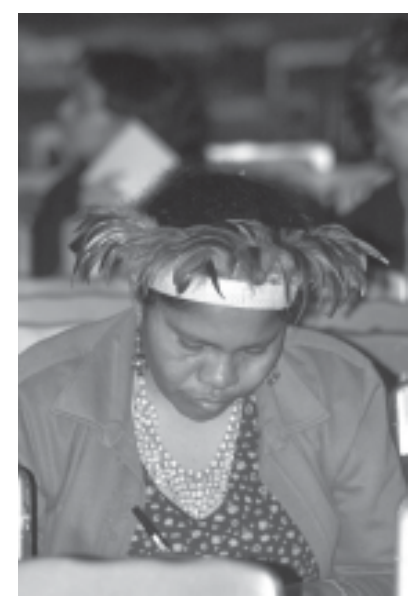

\section{EIXO 3}

Promover o bem-estar e qualidade de vida para as mulleres: uso e ocupação do solo, saúde, moradia, infra-estrutura, equipamentos sociais, recursos naturais, patrimônio histórico E cultural.

Saúde

110. Garantir, efetivamente que o Estado cumpra os princípios e diretrizes da política nacional de atenção à saúde integral da mulher, conforme os princípios do Sistema Único de Saúde - SUS, introduzindo os conceitos dos direitos sexuais e direitos reprodutivos como direitos humanos das mulheres, que se traduzam no direito de escolha e no respeito às diferenças nos aspectos da promoção à saúde, ampliação do acesso aos serviços, humanização e melhoria da qualidade da atenção e recuperação dos agravos e reabilitação, através das seguintes diretrizes:

111. Efetivar o cumprimento do PAISM - Programa de Assistência Integral à Saúde da Mulher - respeitando as diversidades étnicas e raciais seguindo os princípios do SUS de universalidade, eqüidade e integralidade, garantindo orçamento nos três níveis governamentais, a implementação de suas ações e a qualificação, formação e capacitação das (os) profissionais.

112. Garantir a universalidade e integralidade da política de saúde das mulheres, levando em conta todas as diversidades e especificidades, como das adolescentes, jovens e idosas; trabalhadoras domésticas, rurais, urbanas, extrativistas, ribeirinhas e quilombolas; profissionais do sexo; mulheres negras e indígenas; lésbicas e mulheres que fazem sexo com mulheres; usuárias de drogas lícitas e ilícitas; mulheres com deficiência; mulheres do sistema prisional, e adolescentes que cumprem medidas sócio-educativas; mulheres vivendo com HIVIAIDS. Neste sentido, promover também políticas específicas para qualificar e adequar os serviços de saúde nas diferentes comunidades rurais, urbanas e periferias urbanas.

113. Capacitar gestoras (es) e profissionais visando desenvolver sua competência para lidar com as diversidades e especificidades dos segmentos acima referidos, incentivando e criando mecanismos para a produção de pesquisas de caráter étnico/racial neste campo. 


\section{7 de jullho de 2004}

114. Incluir o quesito cor nos sistemas de informação e nos documentos do SUS.

115. Cabe ao Estado viabilizar a estrutura dos centros de referência para garantir 0 atendimento humanizado e descentralizado às mulheres, a partir da perspectiva da interdisciplinaridade e integralidade, interiorizando as ações e serviços, considerando as especificidades regionais, áreas de difícil acesso e sistema de referência e contrareferência, com responsabilidade definida para os níveis de gestão e com recursos definidos e específicos. Neste sentido a I Conferência Nacional de Políticas para as Mulheres recomenda e referenda o reconhecimento da profissão da parteira tradicional, fortalecendo a relação entre parto domiciliar e SUS.

116. Garantir o recorte de gênero, raça e etnia, e demais especificidades das mulheres, nas ações e programas de saúde pública, em consonância com o PAISM, no atendimento primário feito pela rede direta com equipes multidisciplinares e não terceirizadas, atendendo inclusive as comunidades rurais, quilombolas, ribeirinhas e indígenas, profissionais do sexo e soropositivas e o reconhecimento das especificidades de orientação sexual na Política Nacional de Saúde - SUS, considerando os diferentes níveis de complexidade - PSF, atenção básica, de média e alta complexidade - em consonância com as diretrizes e princípios do PAISM (Programa de Assistência Integral à Saúde da Mulher), nas ações do Programa de Saúde da Família - PSF, capacitando as equipes, incorporando assistentes sociais e psicólogas para que se efetive a multidisciplinaridade, reforçando o sistema de referência, e integrando-o com equipes multidisciplinares, incluindo intérpretes e outros profissionais para atender as pessoas com deficiência.

117. Reorientar as ações do PSF, garantindo ao mesmo os princípios da universalidade, integralidade e equidade, previstos no SUS.

118. Implementar o Pacto Nacional de Redução da Mortalidade Materna e Neonatal, reduzindo a morbimortalidade, através da melhoria da assistência, garantindo a investigação de óbitos, considerando a variável cor, incluindo as parteiras para os casos onde houver assistência domiciliar e incentivando a participação do movimento de mulheres no acompanhamento das políticas. Neste sentido garantir cobertura de prénatal, assistência às complicações obstétricas, transporte e referência às mulheres assistidas por parto tradicional indígena e quilombola, divulgando amplamente na mídia seus relatórios. 
119. Implantar e implementar o Programa de Humanização do Pré-Natal e Nascimento - PHPN - em todos os estados, garantindo o acesso e a qualidade da assistência ao pré-natal e parto de baixo e alto risco, no puerpério, ampliando o número de leitos e implantando centros de parto normal. Descentralizar integralmente o PHPN garantindo o acesso e a qualidade da assistência e pré-natal, parto, puerpério e gestação de alto risco e abortamento, ampliando o número de leitos para mães e crianças, implantando centros de parto normal e criando casas casa de acolhimento pré e pós-parto para atendimento das trabalhadoras rurais na sede do município. Garantir a presença de acompanhante, de escolha da mulher e da adolescente, nas consultas ambulatoriais e nas internações de trabalho de parto, aborto incompleto e aborto legal.

120. Cabe ao Estado garantir o atendimento público de qualidade, humanizado, e ágil, para efetivação da interrupção de gravidez nos termos da "Norma Técnica de Prevenção e Tratamento dos Agravos Resultantes da Violência Sexual contra Mulheres e Adolescentes", incluindo orçamento, equipes multiprofissionais capacitadas e tecnologias modernas como Aspiração Manual Intra-uterina - AMIU.

121. Garantir acesso à atenção integral à saúde da mulher, com ações de prevenção, diagnóstico precoce e reabilitação do câncer, destacando-se a necessidade de ação efetiva de prevenção do câncer de útero, pulmão, intestino e mama. Às mulheres mastectomizadas (que tiveram o seio retirado) com seqüelas limitantes, que seja garantida a aposentadoria integral. Garantir o fornecimento de todos os métodos contraceptivos de escolha do casal, inclusive para as(os) adolescentes.

122. Garantir acesso de todas as mulheres à assistência clínico-ginecológica, incluindo as soropositivas, ou vivendo com Aids, nas ações de prevenção integral, diagnóstico precoce e tratamento do câncer ginecológico e de mama e de pulmão, endometriose, miomatose e outros agravos prevalentes nas populações historicamente excluídas (inclusive procedimentos operatórios terapêuticos e concessão de órteses e próteses), mulheres com deficiência - com adaptação dos equipamentos para os exames específicos - nos hospitais públicos, privados e filantrópicos conveniados com o SUS. Expandir a capacidade instalada em termos de equipamentos para prevenção e diagnóstico precoce dessas enfermidades, contemplando não somente centros urbanos, bem como pólos regionais no interior dos estados. 


\section{7 de Julho de 2004}

123. Desenvolver políticas, nas esferas Federal, Estadual e Municipal, de prevenção, diagnóstico e reconhecimento das doenças e acidentes do trabalho para as trabaIhadoras, com deficiência ou não, do meio urbano, rural, indígena, quilombolas e trabalhadoras domésticas, com ou sem vínculo empregatício, bem como garantir e criar legislação específica de prevenção, segurança e vigilância sobre as condições de bem estar da mulher trabalhadora e reconhecer as enfermidades decorrentes do assédio sexual, do assédio moral, e da violência sexual no local de trabalho.

124. Reconhecer, valorizar, validar e regulamentar as terapias tradicionais e implementar os valores da medicina alternativa e tradicional, em especial as de matriz africana e tradições indígenas, integrando essas práticas nos serviços do SUS. Garantir o acesso das mulheres a tratamento com fitoterápicos, homeopatia, acupuntura e outras práticas comprovadamente benéficas à saúde. Reconhecer por parte do Poder Público, os conhecimentos das populações indígenas sobre o uso das práticas tradicionais de saúde, respeitando as especificidades de cada povo, intercambiando estes conhecimentos com o sistema formal de saúde e pactuando a capacitação.

125. Desenvolver ações de informação e educação em saúde reprodutiva que promovam a igualdade de direitos entre mulheres e homens, utilizando inclusive a Linguagem Brasileira de Sinais - LIBRAS.

126. Promover e garantir a formação continuada das(os) profissionais de saúde para atendimento ético, respeitando os valores pessoais, a liberdade individual, a decisão informada, em especial no acolhimento e abordagem de profissionais do sexo, homossexuais, lésbicas e transgêneros, mulheres do sistema prisional, adolescentes, mulheres com deficiência, pessoas de religiões diversas e culturas diversas, pessoas vivendo com HIV/ Aids, mulheres com neoplasia de mama, doenças crônico degenerativas e portadoras de doença do trabalho.

127. Implementar a atenção à saúde das mulheres lésbicas e bissexuais, incluindo 0 quesito orientação sexual nos sistemas de informação e nos documentos do SUS, capacitando gestores e profissionais de saúde no atendimento destes grupos.

128. Ampliar as políticas e serviços de atendimento às mulheres em situação de violência, incluindo as unidades de medicina legal, capacitando as(os) profissionais

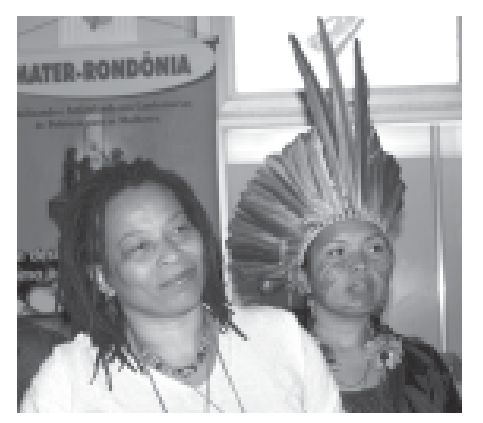




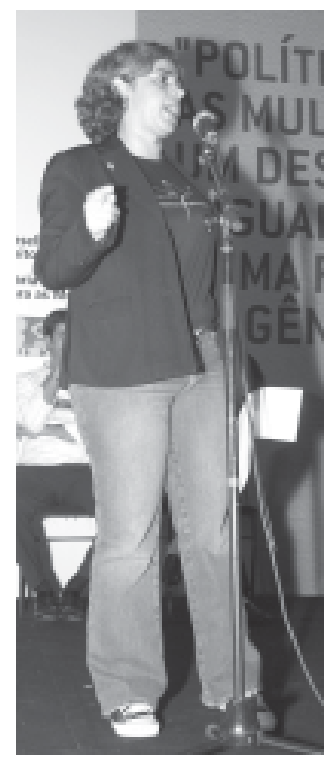

para o cuidado integral garantindo o atendimento referencial e emergencial nos hospitais e postos de saúde da rede pública para mulheres, crianças e adolescentes vítimas de violência física e sexual.

129. Sensibilizar gestoras(es) e profissionais de saúde para tratar o aborto clandestino como problema de saúde pública, incluindo-o nas ações de saúde reprodutiva. Garantir que as mulheres em processo de abortamento tenham atendimento humanizado nos serviços de saúde.

130. Rever a legislação que pune as mulheres que realizam o aborto. A primeira Conferência Nacional de Políticas para Mulheres recomenda a descriminalização e a legalização do aborto, com garantia do atendimento humanizado pelos serviços públicos de saúde.

131. Traçar políticas e programas que cubram toda rede pública de saúde (hospitais públicos, privados, filantrópicos e conveniados com o SUS), para oferecer atendimento humanizado, sigiloso e seguro, e com as técnicas mais modernas e menos agressivas (AMIU) nos casos de mulheres em situação de abortamento, aos casos de aborto previsto em Lei e aos casos de abortos autorizado por sentença judicial.

132. Garantir a prevenção e assistência em DST/AIDS às mulheres, e a suas (seus) parceiras (os), filhas (os), com especial atenção às mulheres negras, Usuárias de Drogas Injetáveis (UDI) e em geral (lícitas e ilícitas), parceiras (os) de UDI, terceira idade, lésbicas, profissionais do sexo, mulheres em situação de prisão, vítimas de violência, incluindo a ampliação e 0 acesso a medicamentos.

133. Ampliar o credenciamento do SUS para especialidades de cirurgia reparadoras para mulheres com lipodistrofia.

134. Implantar e ampliar as redes de atenção à saúde mental que contemplem as ações de prevenção, tratamento e inclusão social, com recorte de gênero e com preparo dos profissionais de saúde para o atendimento das especificidades sociais, étnicas, culturais e biológicas das mulheres.

135. Implementar uma política nacional de acesso aos testes de reconhecimento de paternidade (DNA) pelo SUS. 


\section{7 de Julho de 2004}

136. Responsabilizar o Estado na garantia da efetiva implantação do controle social das ações por meio de formação de Comitês, Conselhos de Saúde, divulgação de índices alcançados e criação de mecanismos de monitoramento e avaliação de políticas, com representação dos movimentos de mulheres e capacitação de conselheiras(os).

137. Garantir que o Estado efetive os registros e estatísticas, com ampla divulgação sobre 0 atendimento à saúde da mulher e óbito, como forma de reduzir a subnotificação, incluindo dados referentes à raça e etnia, deficiências, orientação sexual, local de residência (urbano/rural), violência e gênero.

138. Elaborar diagnóstico do mundo do trabalho e suas conseqüências na saúde e vida das mulheres trabalhadoras, possibilitando que as (os) profissionais do SUS sejam capacitadas (os) para o atendimento adequado, com identificação e tratamento dessas doenças do trabalho.

139. Subsidiar, instrumentalizar e regulamentar os serviços das parteiras tradicionais.

140. Considerar como problema da saúde pública a exploração sexual e violação de crianças e adolescentes, garantindo a implementação de projetos que visem a proteção social, bem como a prevenção da gravidez precoce.

141. Garantir a efetiva implementação do Programa Nacional de Saúde Bucal no SUS. Implementar programas de assistência nutricional a gestantes, lactentes, idosas, portadoras de doenças crônicas Ex: HIV/ Aids, câncer etc.

142. Criar programas que previnam a violência contra grupos de maior vulnerabilidade: crianças e adolescentes, mulheres idosas, negras, indígenas, trabalhadoras sem terra, bissexuais e lésbicas.

143. Investir em pesquisas sobre violência contra as mulheres lésbicas, buscando um diagnóstico para garantir este recorte nas políticas públicas de combate à violência contra as mulheres.

Moradia e Infra-estrutura

144. Cabe ao Estado garantir investimento financeiro que propicie a ampliação quantitativa e qualitativa dos serviços públicos que concretizam os direitos sociais, 


\section{7 de Julho de 2004}

com ênfase no direito ao meio ambiente saudável e moradia digna com posse e titularidade da habitação em nome da mulher.

145. Implementar a reforma urbana de forma articulada com a Reforma Agrária, com acesso ao crédito ou subsídios. Garantir a implantação do Estatuto da Cidade, com ênfase na moradia como um direito humano básico, garantindo o direito a todas e todos à regularização fundiária e que os Planos Diretores incluam as questões de gênero, raça e etnia, orientação sexual, deficiências e faixa etária. Garantia de Programas de Urbanização de Favelas, onde se localiza de 40 a 60\% de mulheres chefes de família segundo o IBGE/2000 (setores censitários).

146. Garantir investimentos em programas de moradia com o acesso prioritário para as mulheres vítimas de violência, encaminhadas pelos serviços públicos de combate à violência contra a mulher, às mulheres chefes de família, às famílias monoparentais, as soropositivas, ou vivendo com Aids, em situação de vulnerabilidade, desempregadas com quadro clínico preocupante e sem amparo da previdência.

147. Incentivar a atuação dos governos Federal, Estadual e Municipal para desenvolver programas de habitação priorizando as populações de baixa renda, prioritariamente chefes de família, viúvas, idosas, deficientes e com necessidades especiais, dotando-os de infra-estrutura e equipamentos comunitários garantindo a titularidade e compra de material de construção.

148. Incentivar, implementar e garantir programas e projetos cooperativos. Desburocratizar o sistema dos bancos federais para famílias de baixa renda, e de mutirão e auto-gestão para a construção de habitação, em parceria ou convênios com entidades de luta pela moradia, equipamentos sociais de apoio ao trabalho doméstico e espaços de qualificação profissional, cultura e lazer para famílias com renda de zero a cinco salários mínimos.

149. Assegurar ações integradas entre os governos federal, estaduais e municipais para promover o saneamento básico, objetivando assegurar moradias em ambientes saudáveis.

150. Aumentar o investimento de recursos em programas e projetos habitacionais que garantam o direito à moradia e à terra urbana e rural, assegurando a infraestrutura urbana e necessária, bem como os equipamentos sociais de apoio ao trabalho doméstico, de geração de emprego e renda, e de espaços de lazer. 


\section{7 de jullho de 2004}

Equipamentos sociais

151. Garantir políticas que organizem os espaços públicos, refletindo a possibilidade de convívio com as diferenças de gênero, raça e etnia, geração, classe social, orientação sexual e deficiência, garantindo equipamentos e serviços adequados às suas necessidades tais como creches, postos de saúde, espaços de esporte e lazer, saneamento, etc, equipamentos de esporte e lazer voltados para a mulher, integrado à realidade.

152. Ampliar e universalizar as soluções específicas para os transportes coletivos que garantam o acesso às mulheres grávidas, idosas, obesas, com deficiência, respeitando sua dignidade e condição física e mental, emocional e social, e mobilidade reduzida.

153. Implantar serviços e equipamentos como lavanderias e restaurantes públicos, centros de convivência (esporte, cultura e lazer).

154. Garantir que o poder público cumpra, e exija dos órgãos públicos e das empresas privadas e conveniadas, a lei de creches, negando alvará municipal aos infratores e promovendo o cumprimento dos direitos constitucionais referentes a creches e escolas.

155. Criar uma política de creches públicas, na cidade e no campo, com universalização do acesso e descentralização, como necessidade social da mulher, da família e direito da criança, remetendo à política educacional e à rede de ensino.

156. Garantir programas de revitalização de áreas degradadas, assim como os sítios que contenham patrimônios históricos e culturais, dando visibilidade àqueles que contemplem a memória das mulheres. Incorporar, nos planos e programas nacionais, estaduais e municipais de meio ambiente, a visão de gênero, raça, classe e etnia, considerando as desigualdades regionais.

157. Criar mecanismos de capacitação e inserção das mulheres de comunidades indígenas, quilombolas, ribeirinhas, das mulheres da agricultura familiar e atingidas por barragens, que garantam seu poder de decisão na gestão ambiental sustentável e comitês de bacias e que reconheçam a contribuição dessas mulheres na produção do viver.

158. Incentivar e garantir as práticas agro-ecológicas e de cultivo de iniciativa das mulheres, bem como a agricultura familiar, garantindo o acesso ao crédito e subsídios, tendo como referência a construção do desenvolvimento sustentável. 
159. Viabilizar e garantir a realização de pesquisas, visando aprofundar o conhecimento sobre o cultivo e comercialização de produtos transgênicos, quanto a seus impactos sobre o meio ambiente e sobre a saúde da população e, em especial, sobre a saúde das mulheres em todas as suas diversidades. Assegurar em lei o princípio de precaução, vetando o cultivo e a comercialização de produtos geneticamente modificados até a conclusão dos estudos sobre seus impactos e a aprovaçãa de lei que regularize esta questão no Brasil. Garantir a rotulagem de produtos de procedência transgênica, mesmo que parcial.

160. Fortalecer os saberes instituídos pelas mulheres que produziram formas mais saudáveis e seguras para a produção de alimentos sem agrotóxicos e sem processos de transgenia.

161. Garantir a preservação de nossa biodiversidade através de uma política de desenvolvimento sustentável, estimulando a pesquisa de tecnologias ambientalmente limpas de desenvolvimento e de fontes de energia renováveis, de particular interesse das mulheres, na medida em que a elas tem cabido o cuidado das doenças e seqüelas resultantes do uso de agrotóxicos e insumos químicos.

162. Formular políticas que proíbam a apropriação privada da biodiversidade, e 0 patenteamento de seres vivos de nossa fauna e flora, dos conhecimentos tradicionais e do saber indígenas, os considerando patrimônio comum da humanidade.

163. Implementar a Agenda 21 em vários níveis com a perspectiva de gênero, raça, etnia e geração.

164. Garantir os serviços de coleta, coleta seletiva e reciclagem do lixo, distribuição e tratamento de água, esgoto e lixo a toda população urbana e rural.

165. Garantir o acesso das mulheres à terra e aos recursos naturais, no meio rural e urbano, beneficiando especialmente as quebradeiras de coco, cortadoras de cana, seringueiras, mineiras, caranguejeiras, ribeirinhas, quebradeiras de pedra, garimpeiras, extrativistas, pescadoras, apicultoras, artesãs, que trabalham com barro, palha e outros recursos naturais, litorâneas e beneficiadoras de produções animais, indígenas e trabalhadoras rurais, quilombolas, assentadas e reassentadas de barragens. 


\section{7 de Julho de 2004}

166. Garantir e promover 0 acesso das mulheres quilombolas e indígenas à terra mediante a demarcação, regularização e homologação das terras indígenas, em especial das terras em conflito, e garantindo a titularização coletiva das terras quilombolas.

167. Assegurar, às mulheres urbanas e rurais, o protagonismo nas instâncias de decisão no que se refere às políticas de segurança alimentar e nutricional.

168. Garantir o acesso e assento das entidades que defendem os direitos das mulheres, nas instituições setoriais formuladoras das políticas públicas ambientais, urbanas e rurais, como os Conselhos das Cidades, Meio Ambiente, Energia e recursos hídricos, nas esferas de poder nacional, estadual e municipal.

169. Apoiar e incentivar programas e projetos de cooperativas de mulheres na área de aproveitamento de resíduos.

\section{EIXO 4 \\ Efetivação dos Direitos Humanos das Mulheres: civis, políticos, direitos sexuais e direitos reprodutivos.}

170. É parte das responsabilidades do Estado, a defesa e promoção do exercício da cidadania pelas mulheres com adoção de medidas para garantir igualdade de acesso às estruturas de poder e aos processos de decisão por meio das seguintes diretrizes.

171. Adotar ações afirmativas não restritas à política de cotas, em diferentes iniciativas, programas e projetos na administração pública dos distintos níveis de governo, assim como nos processos eleitorais e nas práticas de gestão participativa e seus mecanismos, tais como os orçamentos participativos, conferências e conselhos de gestão de políticas sociais.

172. Aumentar o controle público sobre os processos da democracia representativa com o financiamento público de campanhas.

173. Ampliar e implementar ações afirmativas, especialmente para enfrentar a situação de desvantagens e diversidade de experiências e situações vivenciadas pelas 


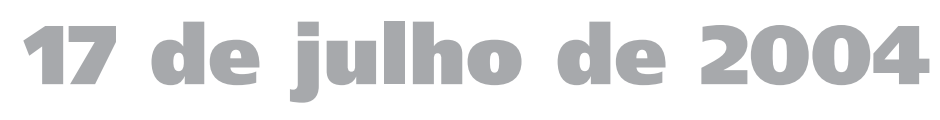

mulheres negras, índias, jovens, adolescentes, idosas, lésbicas, bissexuais e mulheres com deficiência, mulheres privadas de liberdade, mulheres vivendo com HIVIAIDS, profissionais do sexo e residentes em localidades de difícil acesso ou distantes de centros urbanos.

174. Assegurar a promoção e proteção dos direitos humanos das mulheres, traduzindo na legislação nacional, nos planos, nos programas e projetos executivos, seu caráter de direitos universais, indivisíveis, interdependentes e inter-relacionados, bem como reconhecer que violações perpetradas contra mulheres e meninas são violações de direitos humanos.

175. Estimular a implantação e implementação/extensão de defensorias públicas específicas para as mulheres, promotorias de justiça e juizados especiais e fortalecer

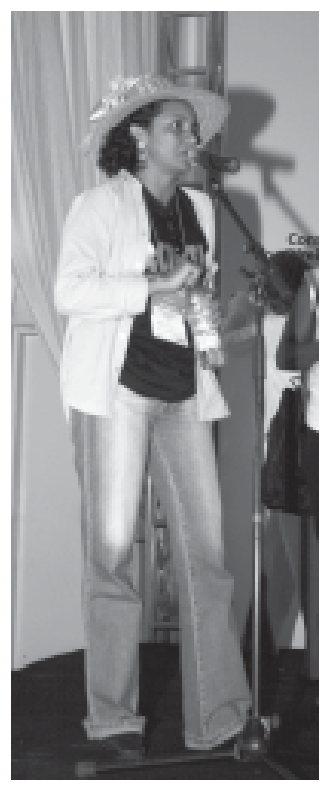
o Ministério Público, como forma de agilizar e garantir a devida reparação nos casos de crimes de violência contra a mulher, de direitos humanos, racismo, sexismo, xenofobia, homofobia, lesbofobia e de todas as formas de intolerância religiosa, bem como promover o controle democrático sobre o poder judiciário.

176. Promover o reconhecimento da diversidade e adotar mecanismos de reparação às populações afrodescendentes, quilombolas e indígenas, intensificando políticas públicas de efetivação de direitos. A Secretaria Especial de Políticas de Promoção da Igualdade Racial - SEPPIR deverá atender com políticas públicas as necessidades e interesses dos povos indígenas, em especial das mulheres índias, e fazer a revisão de suas atribuições definidas na lei que a instituiu.

177. Assegurar às mulheres no sistema prisional ou egressas deste, a dignidade e proteção dos direitos humanos, sexuais e reprodutivos, em especial das regras mínimas para tratamento das detentas, aprovadas pelas Nações Unidas, respeitadas as especificidades decorrentes da orientação sexual e da maternidade. Oportunizar a visitação de seus familiares, especificamente no que se refere à visitação de filhos menores. Garantir a inclusão nas resoluções do Conselho Nacional de Política Criminal e Penitenciárias, a visita íntima para as mulheres lésbicas.

178. Promover a divulgação dos compromissos governamentais assumidos no âmbito dos direitos internacionais, que tratam da promoção, defesa dos direitos e do exercício da cidadania das mulheres, de forma continuada e acessível a toda população, criando condição para o seu monitoramento por parte da sociedade civil. 


\section{7 de jullho de 2004}

179. Garantir que as normas de acessibilidade e segurança sejam implementadas em estabelecimentos, logradouros e transportes públicos, com vistas a efetivar os direitos de cidadania das mulheres com deficiência.

180. Garantir, defender e estender os direitos civis, políticos, sociais, econômicos, trabalhistas e previdenciários previstos na Constituição Federal e na legislação infraconstitucional, garantindo o reconhecimento e defesa das diversas modalidades de famílias e parcerias, independente da orientação sexual.

181. Contribuir para a transformaçãa da relação das mulheres com o seu grupo familiar, independente da orientação sexual, favorecendo a democratização e possibilitando a superação das relações familiares estruturadas a partir do domínio e da violência.

182. Elaborar e implementar legislação e políticas para efetivação dos direitos sexuais e direitos reprodutivos, com políticas de difusão, informação e capacitação junto à sociedade e organismos da administração governamental, em todos os níveis, bem como promover a ampliação dos serviços de saúde sexual e reprodutiva, para jovens, terceira idade e pessoas com deficiência.

183. Promover e garantir o reconhecimento público do direito das mulheres e dos casais quanto à opção da maternidade/paternidade, possibilitando meios para regulação da sua fecundidade, afirmando o caráter laico das políticas de saúde reprodutiva. Neste sentido, a I Conferência Nacional de Políticas para as Mulheres recomenda a descriminalização e a legalização do aborto, com a garantia da assistência ao aborto no serviço público de saúde.

184. Desenvolver mecanismos de promoção de respeito e legitimação à diversidade de orientação sexual, implementando políticas estratégicas e consolidando os direitos civis já constituídos para a construção e efetivação da plena cidadania de lésbicas, bissexuais e demais cidadãs que vivem em processo de exclusão, cumprindo determinação do Governo Federal no Programa "Brasil Sem Homofobia", e garantindo os benefícios de assistência médica e previdenciária, direito à herança, pensão e registro de parceria civil entre homossexuais. 


\section{7 de jullho de 2004}

185. Estabelecer e garantir o direito das mulheres e dos casais quanto à opção da maternidade/paternidade.

186. Fortalecer e ampliar a Secretaria Especial de Políticas para as Mulheres como espaço de formulação, elaboração e articulação das políticas de gênero e combate à discriminação nos diversos níveis de governo (municipal, estadual, distrital e federal).

187. Reconhecer e promover o projeto de promotoras legais populares, como uma política pública, em parceria entre o Estado e a Sociedade Civil, para defesa e promoção do direito das mulheres e garantia do acesso à justiça.

\section{EIXO 5}

Desenvolvimento de políticas de educação, cultura, Comunicação e produção de conhecimento para a iqualdade.

Educação para a igualdade de gênero

188. Assegurar e monitorar ações estratégicas nas instâncias de decisão e execução de políticas educacionais para uma educação e pedagogia não sexista, anti-racista, antidiscriminatória e antihomofóbica, em direção a uma educação para a igualdade, respeitando, valorizando e levando em conta as diferenças individuais.

189. Identificar e atuar com ações afirmativas nas condições sociais que impedem segmentos de mulheres de se alfabetizarem, reformulando e implementando os programas educacionais de jovens e adultos, adequando-os às necessidades das mulheres.

190. Elaborar, adotar e divulgar indicadores sociais, econômicos e culturais sobre as populações afrodescendentes e indígenas para a formulação e implantação de políticas públicas, que combinem ações de saúde, previdência social, trabalho, educação e cultura. Dar especial atenção à implantação do quesito cor nos formulários e registros nas diferentes áreas.

191. Cabe ao Ministério da Educação - MEC introduzir na formação dos docentes, das Instituições de Ensino Superior, disciplinas sobre relações de gênero, raça, etnia e orientação sexual incluindo estágio. Além disso, garantir aos docentes em exercício, 
formação permanente específica subsidiada pelo governo, sobre as mesmas questões em todos os níveis do sistema educacional público. A inclusão de gênero, raça, etnia e orientação sexual deve ser ampliada para todas as áreas do conhecimento, acrescentando conteúdos sobre essas questões nos currículos do sistema Nacional de Ensino. Nessa perspectiva, a reforma universitária em curso deve contemplar essas demandas, com apoio da Secretaria Especial de Políticas para as Mulheres SPM.

192. Propiciar e estimular a abordagem das questões de gênero em suas interfaces com a educação, nos processos de formação continuada na rede de ensino, em todos os níveis, fornecendo informações regulares sobre como tais questões se relacionam com o desenvolvimento do currículo, tornando tais questões pauta permanente do trabalho pedagógico.

193. Realizar em nível nacional uma conferência articulada pela SPM, Ministério das Comunicações, SEPPIR e MEC sobre gênero, raça e etnia e educação escolar formal, não-formal e informal que trate das diretrizes para as escolas públicas e privadas, em todos os níveis, com a participação ativa das (os) trabalhadoras (es) em educação professoras (es), administrativas (os) e estudantes.

194. Rever os parâmetros curriculares e as políticas educacionais sobre a ótica de gênero, raça e etnia, orientação sexual, geracional e pessoas com deficiência considerando outras dimensões além da sexualidade.

195. Atuar para garantir nos conteúdos programáticos e curriculares dos cursos de formação de professores, em todos os níveis, nas práticas de ensino, formação continuada, gestão escolar, as questões de gênero, raça e etnia e orientação sexual, visando a formação teórica e prático-reflexiva de todas (os) aquelas (es) que atuam em educação, enquanto elemento fundamental para uma educação inclusiva e de qualidade.

196. Garantir em âmbito nacional o movimento de reorientação curricular que incorpore a diversidade cultural nas questões de gênero, raça e etnia, e de livre orientação sexual

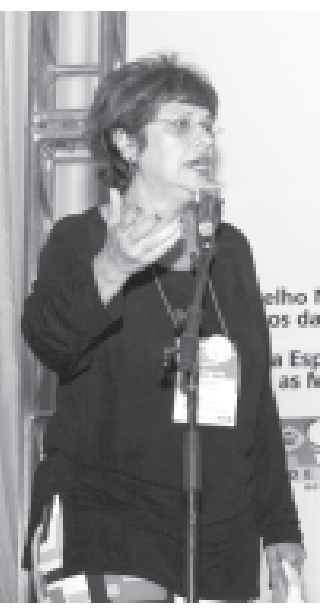
com a participação ativa das educadoras (es).

197. Avaliar os livros didáticos e recursos pedagógicos, integrando a dimensão de gênero, raça, etnia, orientação sexual, de geração, deficiência e regionalidade, visando não só eliminar estereótipos e preconceitos, mas principalmente construir e orientar 


\section{7 de julho de 2004}

parâmetros de análise quanto aos textos e imagens veiculados, respeitando as diretrizes curriculares nacionais.

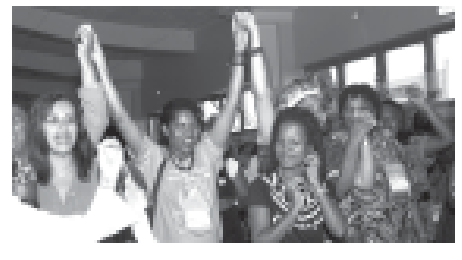

198. Equipar as escolas de ensino fundamental e médio, formando educadoras(es) na utilização de equipamentos audiovisuais nas escolas, incentivando a criação de videotecas e a produção de vídeo e cinema nacional que abranjam os temas transversais, incluindo deficiência e orientação sexual, devendo a responsabilidade de tais medidas ser da União, através do Ministérios das Comunicações e governos estaduais e municipais, além dos recursos já vinculados.

199. Realizar um processo de capacitação e formação continuada de profissionais da educação (professores, orientadores, diretores, psicopedagogos, agentes escolares administrativos etc) e comunidade escolar, no sentido de eliminar atitudes preconceituosas em relação às lésbicas, demais orientações sexuais, as profissionais do sexo e em relação às pessoas com deficiência, sejam alunas (os) ou professoras (es) no ambiente escolar e fora dele.

200. Criar programas de educação que entendam a realidade e as necessidades das mulheres do campo (assentadas, acampadas, sem terra, quilombolas) e trabalhadoras rurais e urbanas em geral que necessitam, por exemplo, de horários e tempo de duração escolar diferenciado, as mulheres indígenas que necessitam de escolas diferenciadas, com educadoras (es) capacitadas (os).

201. Ampliar os programas de educação sexual abordando os seguintes temas: relações de gênero, direitos sexuais e reprodutivos, autonomia sobre o corpo, sexualidade como um direito, prevenção da gravidez na adolescência, prevenção das DST/AIDS, aborto, violência doméstica e sexual e drogadição, assegurando a capacitação continuada de todas (os) as (os) educadoras (es) e demais profissionais da rede envolvidas (os) no programa.

202. Reconhecer, estimular o contato e garantir espaço para a diversidade das práticas educacionais, esportivas e culturais das diversas matrizes culturais, principalmente as africanas, indígenas, quilombolas e ribeirinhas e fronteiriças.

203. Determinar que as escolas garantam acessibilidade física, tecnológica, de equipamentos e de comunicação para receber as mulheres com deficiência (f́́sica, visual, auditiva e mental), promovendo a utilização de softwares (livres) que garan- 


\section{7 de Julho de 2004}

tam a inclusão e autonomia dessas pessoas, em especial as mulheres. Além disso, preparar as(os) profissionais da educação para o trato com a deficiência e profissionais que lidam com a linguagem de sinais (LIBRAS), favorecendo a educação inclusiva conforme previsto no capítulo $V$ da LDB.

204. Criação de uma política de creches públicas, com universalização do acesso, como necessidade social da mulher, da família e direito da criança, qualificando as educadoras (es) infantis, garantindo seu funcionamento em horário diurno e noturno.

205. Garantir a ampliação do atendimento escolar em horário integral para crianças e jovens de 06 a 14 anos, com inclusão de atividades extracurriculares.

206. Ampliar a cobertura da educação infantil em período integral, especialmente as creches, estendendo o horário de permanência das crianças e possibilitando seu funcionamento no período noturno, garantindo a implementação do Fundo de Manutenção de Desenvolvimento da Educação Básica - FUNDEB.

207. Traçar diretrizes para que os cursos profissionalizantes não reproduzam estereótipos de aptidões supostamente naturais para as mulheres e os homens, possibilitando às mulheres, especialmente as jovens, trabalhadoras do lar, terem acesso à formação nas diversas áreas, ampliar o universo profissional das mulheres, bem como romper com a cultura tradicional de que a mulher não precisa estudar.

208. Considerar as práticas esportivas como ações educativas fundamentais, formativa e de saúde, que deverão contemplar ações conjuntas com os profissionais de educação física, com o objetivo de desenvolver metodologias de atividades físicas atentando para a dimensão de gênero, referenciando conteúdos e práticas na área da educação física e esportiva, e de lazer.

209. Criar em todas as Secretarias de Educação (municipais, estaduais e distrital) mecanismos estratégicos voltados para o trato da eliminação do racismo no ambiente escolar da rede pública e privada, expresso nos livros didáticos e nas relações escolares em todos os níveis, visando a formação permanente dos profissionais de educação 0 qual deve ser composto e ou assessorado por educadoras e educadores negros comprometidos com a luta anti-racista e dispor de recursos suficientes para cumprir seus objetivos. 


\section{7 de julho de 2004}

210. Criar em todas as secretarias de educação (municipais e estaduais e distrital) um núcleo específico para tratar a temática indígena no ambiente escolar da rede pública e privada, modificando o tratamento dado à questão indígena e étnico racial nos livros didáticos e nas relações escolares em todos os níveis. 0 núcleo deve ser composto e/ou assessorado por educadoras (es) indígenas comprometidas (os)com a causa indígena, dispondo de recursos suficientes para cumprir seu objetivo.

211. Fazer cumprir a LDB no disposto da lei federal $10.639 / 03$ e as diretrizes curriculares nacionais decorrentes dessa lei que torna obrigatório o ensino sobre a história e cultura afro-brasileira nos estabelecimentos de educação infantil, fundamental, médio e superior público e privado.

212. Formular políticas de ações afirmativas que possam ser desenvolvidas de modo transversal, estabelecendo parcerias com a Secretaria Especial de Políticas de Promoção da Igualdade Racial - SEPPIR.

213. Desenvolver, através da SPM, campanhas educativas na mídia de enfrentamento a todas as formas de discriminaçãa, com ampla divulgação dos direitos da mulher.

214. Promover na escola, em articulação com a comunidade, poder público e ONGs, ações voltadas à prevenção e assistência à violência doméstica, eliminação do trabalho infanto-juvenil, da homofobia e do racismo, informando sobre seus direitos, leis, equipamentos sociais e assistência psicossocial e jurídica.

215. Assegurar aos estudantes do ensino fundamental, médio e superior, o acesso à educação previdenciária, com perspectiva de gênero, raça e etnia, articulando as várias instâncias de governo e da sociedade civil.

216. Ampliar a porcentagem do Produto Interno Bruto - PIB destinado a educação atingindo o mínimo de 7\% (sete por cento).

217. Garantir, em todos os municípios, o acesso à escolarização pública em todos os níveis e modalidades de ensino.

218. Propiciar programas de incentivo a produção científica e cultural das mulheres, questionando 0 androcentrismo da ciência sob a aparente neutralidade com que se apresenta e seus efeitos sobre a educação e a produção do conhecimento. 


\section{7 de Julho de 2004}

219. Assumir o compromisso de construir políticas públicas para a igualdade, resgatando as mulheres como sujeito das práticas culturais e da produção de conhecimento, incentivando e ampliando, por meio das Secretarias de Cultura, do Ministério da Cultura, Ministério da Ciência e Tecnologia e Secretaria Federal de Comunicação, estas iniciativas e objetivos, apoiando e divulgando a produção cultural e científica das mulheres, inclusive estimulando a pesquisa e adoção oficial de livros que contenham a contribuição das mulheres na construção da história da humanidade.

220. Implementar e Incentivar as iniciativas culturais das mulheres, considerando-as como potencializadoras das ações educacionais e comunicativas, introduzindo a perspectiva de gênero, raça e etnia, utilizando as diferentes linguagens e expressões artísticas, aproximando e resgatando o cotidiano da cultura popular e da diversidade cultural de nossa realidade, ressaltando a contribuição das mulheres de todas as gerações.

221. Desenvolver políticas e estratégias de respeito a todas as pessoas: aceitação das diferenças culturais, sexuais, políticas, religiosas, étnicas e raciais, visando com isso à democratização das relações interpessoais e sociais.

222. Divulgar e se pautar pelos princípios do documento da Organização das Nações Unidas - ONU sobre envelhecimento ativo: independência, participação, dignidade, assistência e auto-realização.

223. Criar e viabilizar políticas públicas descentralizadas que democratizem o direito das mulheres ao lazer e ao esporte, para que tenham condições de manifestar seu potencial criativo e tenham acesso aos bens esportivos culturais produzidos pela humanidade respeitando a terceira idade.

224. Fomentar a produção cultural e a pesquisa que trate da temática da mulher, valorizando a produção cultural e cientifica das mesmas, incorporando a dimensão de gênero, raça e etnia.

225. Incentivar a criação de centros de referência que integrem saúde, educação e cultura para as pessoas com deficiência, respeitando o princípio e metodologia de trabalho da interdisciplinaridade no diagnóstico, prevenção e acompanhamento, levando em consideração a relação entre a escola, família e comunidade.

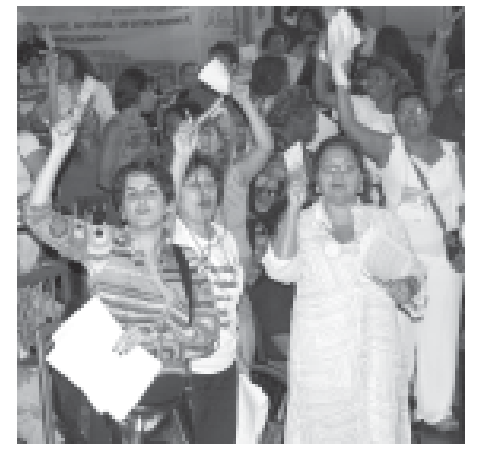

(n)


226. Incentivar a criação de centros de referência cultural que atendam mulheres com diferentes condições de aptidão humana e livre orientação sexual.

227. Incentivar a criação de casas ou centros de cultura que incluam em suas agendas atividades que abordem a temática lésbica. Instituir o 29 de agosto como o Dia Nacional da Visibilidade Lésbica.

Políticas de lgualdade de gênero na Comunicação

228. Cabe ao Estado democratizar os meios de comunicação e promover a implantação de políticas públicas de comunicação de caráter regulador e fiscalizador, e de controle social garantindo o acesso e a representação efetiva dos diferentes segmentos da população à informação e à liberdade de expressão das mulheres.

229. Promover a regulamentação das rádios e TVs comunitárias.

230. Elaborar um código de ética para os meios de comunicação de massa garantindo o controle social dos meios de comunicação para coibir e punir os excessos cometidos, no que diz respeito à violência, racismos, sexismo, pornografia e outros, no conteúdo da televisão, do rádio, jornais e revistas impressas, bem como as novas mídias que se caracterizam pela confluência dos diversos veículos, propiciada pela Internet, sistemas digitais e outdoor. Monitorar os meios de comunicação de massa visando um diagnostico para um processo reflexivo sobre a qualidade da programação numa perspectiva de gênero, raça e etnia, inclusive sobre as lacunas e insuficiências existentes.

231. Exigir mídia gratuita para campanhas de comunicação e serviços.

232. Garantir que os contratos públicos celebrados pelo governo com agências de publicidade, propaganda e mídia em geral, tenham cláusula específica referente à participação de negros e negras, promovendo uma imagem equilibrada e não estereotipada nos meios de comunicação.

233. Regulamentar uma cota de espaço de mídia para campanhas educativas governamentais e não-governamentais no sistema privado de comunicação, com vistas a desconstrução dos estereótipos e preconceitos contra a mulher. 


\section{7 de jullho de 2004}

234. Exigir, estabelecendo cotas mínimas de programação e espaço nos diferentes meios de comunicação de massas, a introdução de mensagens educativas e de serviços sobre diferentes temas de relevância, no que se refere a inclusão e valorização da mulher, como contraparte da concessão pública de transmissão.

235. Elaborar, em conjunto com a sociedade, um código de ética que regularmente e garanta na mídia o recorte de gênero, raça/etnia, sempre incentivando o respeito às diferenças e veiculando apenas o que determinar o referido código, responsabilizando empresas e profissionais da mídia pelo abuso mercantilista.

236. Estimular a elaboração em conjunto com o CONAR, órgão de auto-regulamentação da publicidade, código de ética sobre a imagem da mulher na publicidade, com garantia de controle social dos meios de comunicação, contemplando a diversidade das mulheres negras, com deficiências e lésbicas nas campanhas publicitárias, criando, então, um conselho fiscalizador do qual façam parte a SPM, Ministério da Justiça, Ministério das Comunicações, SEPPIR e movimentos de mulheres.

237. Garantir o direito de acesso às Tecnologias da Informação, através de programas de inclusão digital e o desenvolvimento de capacitação para o seu uso e produção, que vá além da questão instrumental, incluindo a perspectiva da cidadania ativa, com a leitura crítica e a criação de mecanismos de intervenção para alterar os estereótipos dos padrões vigentes. Prever a promoção do uso de software livre, inclusive para acesso de pessoas portadoras de deficiência e a utilização destes na produção de sites inclusivos na Internet.

238. Promover através de campanhas nos meios de comunicação de massa, ações afirmativas que valorizem a estética negra e indígena (cor, cabelo, vestimenta, beleza, maquiagem e etc), estimulando, com isso, o orgulho da identidade étnico-racial.

239. Promover políticas de ações afirmativas, estabelecendo cotas de $30 \%$ para as mulheres negras e índias nas escolas, universidades federais, estaduais e privadas e cargos públicos em todos os escalões. 


\section{Moções apresentadas na Plenária Final}

18 moções atingiram o número de 200 assinaturas exigidas no Regulamento.

1) Moção de Repúdio

Nós delegadas e delegados da $1^{\text {a }}$ Conferência Nacional de Política para Mulheres repudiamos, veementemente a publicação do livro Manual da Incompetência Feminina, do autor Paulo Mundim Prazeres Repudiamos também o procedimento da Editora IBRASA, sendo co-responsável por tamanha violência e discriminação contra as mulheres brasileiras, motivo este que exigimos a imediata suspensão da edição, assim como o repasse das verbas adquiridas pela vendagem do livro para órgãos de apoio à mulher ou a Secretaria Especial de Política para Mulheres.

\section{Essa é a redação que teve 325 assinaturas - Aprovada}

2) Nós, Delegadas de Pernambuco, expressamos nosso repudio ao Governador Jarbas Vasconcelos, que se mostrou indiferente a importância do processo das conferências para as mulheres, descumprindo o seu papel de garantir que todas as Delegadas eleitas na I Conferência Estadual de Políticas para Mulheres pudessem participar do pleno da I Conferência Nacional de Políticas para Mulheres, realizado em Brasília/ DF, de 15 a 17 de julho de 2004. Em seu descaso, o governo de Pernambuco não propiciou condições para que a I Conferência Estadual de Política para Mulheres se desenvolvesse de modo a promover uma eficaz discussão de políticas públicas para as mulheres. A ausência de estrutura adequada comprometeu o debate político e o processo de escolha das delegadas. Além disso, o governo de Pernambuco não viabilizou condições dignas para a viagem da delegação ao oferecer a essas representantes somente a opção de viagem de ônibus, sem a ajuda de custo adequada, dificultando o deslocamento e a presença da delegação completa, impossibilitando que a representação da diversidade pernambucana estivesse presente, de forma a contribuir com a construção de um Plano Nacional que busca a igualdade a partir de uma perspectiva de gênero, não-sexista, anti-racista e nãohomofóbica. Isso comprova a falta de compromisso na sua política e na construção de processos democráticos que incluam as mulheres como protagonistas.

\section{Essa é a redação que teve 200 assinaturas - Aprovada}

3) A I Conferência Nacional de Política para as Mulheres, realizada entre os dias 15 e 18 de julho de 2004, em que estiveram presentes mulheres de todos os estados brasileiros, aprovou no dia 16 de julho a seguinte moção a respeito da liminar do Supremo Tribunal Federal sobre a Argüição de Descumprimento de Preceito Funda- 


\section{7 de Julho de 2004}

mental apresentada pela Confederação Nacional dos Trabalhadores na Saúde, com assessoria técnica da ANIS - Instituto de Bioética, Direitos Humanos e Gênero:

Moção de apoio: Diante do sofrimento das mulheres grávidas de fetos com anencefalia, do direito universal à saúde e do cumprimento aos princípios constitucionais da liberdade e da dignidade, expressamos nosso apoio à liminar do Ministro Marco Aurélio Mello que autoriza mulheres grávidas de fetos com anencefalia a interromperem a gestação. Registramos, ainda, nossa confiança que o plenário do Supremo Tribunal Federal irá referendar tão importante decisão para a garantia da saúde reprodutiva, psíquica e espiritual das mulheres, bem como dos direitos humanos.

\section{1 assinaturas - Aprovada}

4) Moção de apoio à liminar concedida pelo Ministro Marco Aurélio de Mello, do Superior Tribunal Federal - STF, cujo mérito será avaliado em agosto, favorável à realização de aborto em casos de gravidez de fetos anencéfalos (sem cérebro), que não possuem nenhuma chance de sobrevivência, causando enorme sofrimento às mulheres.

\section{3 assinaturas - Aprovada}

5) Moção de Protesto contra a Legalização do Aborto

Nós, abaixo assinadas, protestamos contra qualquer proposta em prol da LEGALIZAÇÃO DO ABORTO, reiterando o princípio legal de que TODOS TÊM O DIREITO A VIDA, conforme previsto no art. $5^{\circ}$ da Constituição Federal, pois a partir da concepção, uma nova vida foi gerada, não cabendo a nós o direito de decidir sobre ela. Alertando também sobre a importância de um programa de acompanhamento de crianças, adolescentes e jovens, que precocemente estão entrando na atividade sexual sem estarem totalmente cientes das suas conseqüências e responsabilidades, gerando um aumento no número de adolescentes grávidas ou com problemas de DST/AIDS.

\section{4 assinaturas - Rejeitada}

6) Moção de defesa da legalização do aborto.

\section{Retirada pelo tema já ter sido debatido e aprovado na Conferência}

7) Emenda Constitucional - PEC 385/2001 - aposentadoria para donas-de-casa Nós, mulheres de várias organizações sociais de todo o Brasil, manifestamos nosso total apoio à proposta de emenda constitucional 385-2001, que dá direito a aposentadoria para Donas-de-Casa. Este direito é de fundamental importância para a diminuição da pobreza e desigualdade de gênero no Brasil.

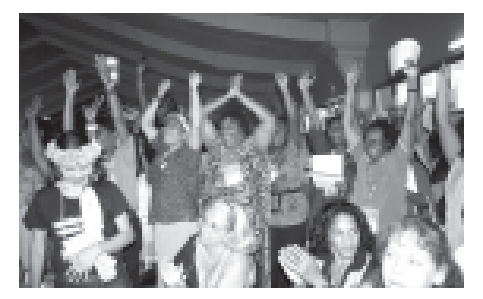

244 assinaturas - Aprovada 


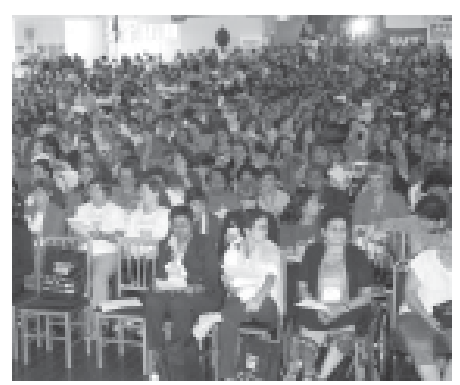

8) Secretaria da Mulher no Primeiro Escalão - Recomendação para candidatas(os) Moção de recomendação às candidatas e candidatos as Prefeituras de todos os municípios brasileiros, pela criação de Secretarias da Mulher, com status de $1^{\circ}$ escalão, em seus futuros governos, pois as experiências existentes, neste sentido, tem tido êxito e tem contribuído para a implantação de políticas públicas que beneficiam as mulheres em diversos setores de suas vidas.

\section{8 assinaturas - Aprovada}

9) Desvinculação de recursos constitucionais - Saúde, Educação e Superávit

Os recursos que a Constituição garante para a saúde e para a educação constituem uma conquista histórica do povo brasileiro. A I Conferência Nacional de Políticas para as Mulheres, vêm, de público, com profundo sentimento de indignação, manifestar seu repúdio à proposta de desvinculação das verbas constitucionais destinadas à saúde e a educação em estudo no Ministério da Fazenda, atendendo as exigências do FMI. É falso o argumento de que é preciso "desengessar o orçamento" para se ter mais recursos para aplicar na área social. A intenção manifesta de acabar com as vinculações orçamentárias, em nome de uma maior flexibilidade fiscal é para a realização de superávit para o pagamento da dívida. De janeiro a maio de 2004, o superávit somou $\mathrm{R} \$$ 29 bilhões $(29.347 .429 .568,37)$ valor que o governo previu para a saúde no ano de 2004. A I Conferência Nacional de Política para as Mulheres exige que o governo cumpra o seu contrato com a Nação e a Constituição, mantendo as regras atuais que vinculam a receita para Saúde e Educação.

\section{4 assinaturas - Aprovada}

10) Promotoras Legais Populares

Considerando que a falta de conhecimento e consciência da condição de sujeito de direitos pela grande maioria das mulheres brasileiras impede a efetivação dos seus direitos civis e políticos, econômicos e sociais; Considerando que no Brasil a experiência de formação de PROMOTORAS LEGAIS POPULARES tem se revelado como importante mecanismo de empoderamento e fortalecimento da cidadania das mulheres e está sendo implementado em 11 estados da federação; Nós, mulheres brasileiras, reunidas na I Conferência Nacional de Política para Mulheres, recomendamos o reconhecimento e promoção do projeto de Promotoras Legais Populares como uma Política Pública em parceria entre o Estado e a Sociedade Civil, para a defesa e promoção dos direitos das mulheres e garantia de acesso à justiça.

\section{3 assinaturas - Rejeitada}




\section{7 de jullho de 2004}

11) Construção de uma Cultura da Paz

"A história está clamando por reconciliação, compaixão, amor, serviço e sacrifício. Os problemas de hoje não podem ser solucionados pela lógica do poder... Nossos problemas podem ser solucionados pela lógica do amor" - Dra Hak Ja Han Moon Presidente da Federação das Mulheres para a Paz Mundial."

Considerando que a Organização das Nações Unidas incumbiu as mulheres de ajudar a concretizar o maior sonho da humanidade: A PAZ MUNDIAL e que uma campanha mundial indicará, coletivamente, ao Prêmio Nobel da Paz 2005, mil mulheres que trabalham pela construção de uma cultura de paz, as delegadas do Estado da Paraíba resolvem apresentar a presente moção, que visa sensibilizar o Governo Federal, através da Secretaria Especial de Política para as Mulheres, na criação de um programa que defina as seguintes prioridades:

a. Reconhecer o papel das mulheres na democratização e na construção de uma CULTURA DA PAZ;

b. Enfocar que cada brasileira possa ser MULHER AGENTE DA PAZ;

\section{4 assinaturas - Aprovada}

12) Mulher Indígena - Terra Raposa Serra do Sol

Nós, mulheres participantes da I Conferência Nacional de Política para Mulheres apoiamos as mulheres indígenas de Roraima que manifestam seu repúdio pela forma como os direitos dos povos indígenas estão sendo violados, especialmente 0 direito ao território tradicionalmente ocupados pelos povos da terra indígena Raposa Terra do Sol, conforme portaria 820/98 da constituição brasileira. Desse modo, exigimos a imediata homologação em área continua da TI Raposa Serra do Sol, que se tornou um caso emblemático da violência e descaso contra os povos indígenas.

\section{3 assinaturas - Aprovada}

13) Homologação das terras indígenas com demarcação continuada

Ao Excelentíssimo Senhor Presidente da República

Luiz Inácio Lula da Silva

Ao Supremo Tribunal Federal

Ao Ministério Público

Ao Ministério da Justiça

Nós, mulheres indígenas, na I Conferência Nacional das Mulheres Indígenas em Brasília de 12 a 13 de julho e também na I Conferência de Políticas para Mulheres que manifestam lutas e vigílias constantes, para que nos seja entregue a HOMOLOGA- 


\section{7 de Jullho de 2004}

ÇÃO DE NOSSAS TERRAS COM DEMARCAÇÃO CONTINUADA NO PAÍS INTEIRO (ninguém deve atravessá-las, nem invadi-las). Partes dessas terras já foram demarcadas pelo INCRA e tem uma nação indígena em Goiás que está vivendo em terra emprestada de outros parentes, eles sentem e estão marginalizados por isso. NÃO QUEREMOS MAIS VIOLÊNCIAS. QUEREMOS VIVER COM DIGNIDADE. Somos um povo resistente e defensor do país.

\section{0 assinaturas - Aprovada}

14) Apoio à candidatura de Silvia Pimentel ao CEDAW

No próximo dia 05 de agosto de 2004 serão realizadas eleições para o Comitê sobre Discriminação contra a Mulher (Comitê Cedaw), órgão das Nações Unidas responsável pelo monitoramento da Convenção sobre Eliminação de Todas as Formas de Violência contra a Mulher. 0 Comitê é composto em sua maioria por especialistas de países do hemisfério norte, com sub-representação do hemisfério sul, especialmente da América Latina e Caribe. 0 Brasil esteve representado no Comitê uma única vez, há mais de 20 anos. Em reconhecido compromisso para reverter esse quadro, o governo brasileiro, por indicação da sociedade civil, apresentou como candidata ao Comitê CEDAW a Professora Doutora Silvia Pimentel, jurista feminista, de histórica trajetória no movimento de mulheres em âmbito nacional e internacional.

A I Conferência Nacional de Política para Mulheres manifesta seu total apoio à candidatura de Silvia Pimentel, reconhecendo sua legitimidade, competência e compromisso na luta pela defesa dos direitos humanos das mulheres, e solicita ao governo brasileiro, no marco do Ano Nacional da Mulher, que dê a máxima prioridade a essa candidatura, a fim de que as mulheres brasileiras possam contar com legitima representante em órgão internacional de tamanha relevância.

\section{1 assinaturas - Aprovada}

15) Atos de violação dos direitos das mulheres nos processos de guerra Moção de repúdio a todos os atos de violação dos direitos das mulheres, nos processos de guerra, nos quais elas sofrem abusos de toda a ordem e têm seus corpos violentados sistematicamente.

\section{9 assinaturas - Aprovada}

16) Casa-abrigo de Juiz de Fora

Nós mulheres, representando todos os Estados do Brasil, queremos APOIAR a iniciativa das companheiras de Juiz de Fora/MG, na sua luta pela continuidade do serviço 
de CASA-ABRIGO, que está na iminência de ser fechada por atos abusivos de setores da Administração Municipal.

Neste ano de implementação de Políticas Públicas de Igualdade de Oportunidades de Gênero, apelam para a sensibilidade do Prefeito Municipal, cuja propalada vocação social é conhecida de todos, para que apóie a luta das mulheres brasileiras, como sempre o fez, pois Juiz de Fora não pode transitar na CONTRAMÃO dos avanços sociais, cujos resultados estão evidenciados nesta $1{ }^{\text {a }}$ Conferência Nacional de Políticas para Mulheres.

\section{8 assinaturas - Aprovada}

17) Moção sobre abuso e exploração sexual de crianças e adolescentes.

Nós delegadas da primeira conferência nacional de políticas para mulheres vimos parabenizar a comissão parlamentar mista de inquérito do abuso e a exploração sexual de crianças e adolescentes pela aprovação do relatório final. Vimos também manifestar nossa indignação com os parlamentares que votaram a favor da retirada do nome do vice-governador do estado do Amazonas da lista dos envolvidos.

\section{5 assinaturas - Aprovada}

\section{8) Caso Maria da Penha}

Em 1983, Maria da Penha foi vítima de tentativa de homicídio por seu então marido, que em Fortaleza (CE), atirou em suas costas, deixando-a paraplégica. Em 2001, a Comissão Interamericana de Direitos Humanos (CIDH) responsabilizou o Estado Brasileiro por omissão, negligência e tolerância em relação à violência doméstica contra as mulheres, pela ineficácia da Justiça em punir crimes dessa natureza. Passados 3 anos dessa decisão, o Brasil ainda não cumpriu integralmente com as recomendações da Comissão.

A I Conferência Nacional de Política para Mulheres protesta contra a demora do Estado em cumpri-las e EXIGE que o governo imediatamente tome todas as medidas para investigar os responsáveis pela demora injustificada que resultou na violação dos direitos e garantias de acesso à Justiça; efetuar o pagamento de indenização a Penha e demais medidas de leis e políticas públicas para enfrentar o problema.

\section{1 assinaturas - Aprovada}

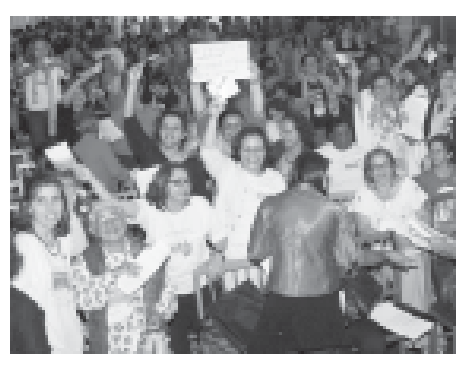




\title{
AnEXos
}

\section{Conferência Nacional de Políticas para as Mulheres}

\author{
REGULAMENTO INTERNO \\ aprovado na Plenária do dia 15 de jullo de 2004
}
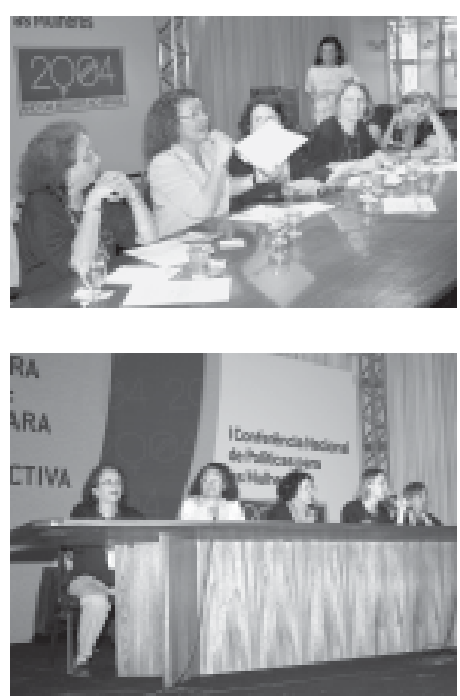

CAPÍTULO I

DA FINALIDADE

Art. $1^{\circ}$ - Este regulamento tem por finalidade definir as normas de funcionamento da I Conferência Nacional de Políticas para as Mulheres (I CNPM), convocada por Decreto Presidencial de 19 de dezembro de 2003, com REGIMENTO aprovado pelo Conselho Nacional dos Direitos da Mulher, em 02 de dezembro de 2003. A I CNPM tem por objetivo "propor diretrizes para fundamentação do Plano Nacional de Políticas para as Mulheres a ser apresentado ao Presidente da República".

CAPÍTULO II

DA ORGANIZAÇÃO

Art. $2^{\circ}$ - A I Conferência Nacional de Políticas para as Mulheres será presidida pela Ministra da Secretaria Especial de Políticas para as Mulheres, e na sua ausência ou impedimento eventual, pela Secretária-Adjunta ou pela Coordenadora Executiva da Conferência.

Art. $3^{\circ}$ - A coordenação das atividades durante os três dias da Conferência estará a cargo da Comissão Organizadora designada pelo Conselho Nacional dos Direitos da Mulher (CNDM), composta por quatro integrantes do CNDM e por quatro representantes da Secretaria Especial de Políticas para as Mulheres, presidida pela Ministra da Secretaria Especial de Políticas para as Mulheres. 
CAPÍTULO III

DO FUNCIONAMENTO

Art. $4^{\circ}$ - A realização da I Conferência Nacional de Políticas para as Mulheres terá a seguinte programação:

a) Plenária de Abertura

b) Painéis

c) Grupos Temáticos

d) Plenária Final

CAPÍTULO IV

DOS PAINÉIS

Art. $5^{\circ}$ - Nos termos de seu Regimento, a I Conferência Nacional de Políticas para as Mulheres terá como tema "Política para as mulheres: um desafio para a igualdade numa perspectiva de gênero" que será abordado a partir de dois grandes painéis:

1. análise da realidade brasileira, avaliando as políticas realizadas e os compromissos assumidos pelo Estado Brasileiro;

2. apresentação de propostas de diretrizes para a construção do Plano Nacional de Políticas para as Mulheres.

Art. $6^{\circ}$ - 0 temário da I Conferência Nacional de Políticas para as Mulheres será abordado por painelistas indicadas(os) pela Comissão Organizadora que disporão de 20 (vinte) minutos para as suas exposições.

Parágrafo $1^{\circ}$ - Ao término do primeiro painel, as(os) delegadas(os) e as(os) convidadas(os) poderão manifestar-se verbalmente ou por escrito, sendo que o tempo de intervenção será de 3 (três) minutos, improrrogáveis.

Parágrafo $2^{\circ}$ - Caberá à mesa definir o número de inscrições considerando-se a programação da Conferência.

Art. $7^{0}$ - As exposiç̧ões serão registradas em fita magnética com vistas a sua divulgação nos Anais da I Conferência Nacional de Políticas para as Mulheres. 
CAPÍTULO $V$

DOS GRUPOS TEMÁTICOS

Art. $8^{\circ}$ - Os Grupos Temáticos se reunirão para debater e definir as propostas de diretrizes para um Plano Nacional de Políticas para as Mulheres, a serem apreciadas pela Plenária Final da Conferência a partir dos seguintes eixos temáticos:

1. Enfrentamento da pobreza: geração de renda, trabalho, acesso ao crédito e a terra.

2. Superação da violência contra a mulher: prevenção, assistência, combate e políticas de Segurança.

3. Promoção do bem-estar e qualidade de vida para as mulheres: saúde, moradia, infraestrutura, equipamentos sociais, recursos naturais.

4. Efetivação dos direitos humanos das mulheres: civis, políticos, sexuais e reprodutivos.

5. Desenvolvimento de políticas de educação, cultura, comunicação e produção do conhecimento para a igualdade.

Parágrafo $1^{\circ}$ - Cada eixo temático será debatido por 4 (quatro) grupos.

Parágrafo $2^{\circ}$ - Os Grupos Temáticos serão constituídos buscando levar em consideração as opções feitas pelas(os) inscritas(os) no pré-credenciamento.

Parágrafo $3^{\circ}$ - Os grupos temáticos deverão abordar os temas numa perspectiva não sexista, não racista, não homofóbica, incorporando a diversidade étnica.

Art. $9^{\circ}$ - Os Grupos Temáticos serão constituídos:

I - Por delegadas(os) com direito a voz e voto, convidadas(os) com direito a voz e observadoras(es) em número de até 100 (cem pessoas por grupo.

II - Por uma coordenadora, indicada pela Comissão Organizadora, com as funções de coordenar as discussões, controlar o tempo e estimular a participação, de acordo com o roteiro previamente recebido. 
III - Por uma relatora, indicada pela Comissão Organizadora e uma sub-relatora indicada pelo próprio grupo, responsáveis pelo relatório do grupo e da consolidação junto aos demais grupos do mesmo eixo temático.

Art. $10^{\circ}$ - As delegadas(os) nos grupos terão direito a aprovar, suprimir, mudar a redação ou incluir propostas em forma de diretrizes pertinentes ao tema, contidas nos relatórios dos Estados, e que não foram contempladas no documento-base.

Parágrafo Único - Serão consideradas aprovadas as propostas que obtiverem 50\% mais 1 (um) dos votos das(os) delegadas(os) presentes nos grupos.

Art. $11^{\circ}$ - A discussão nos grupos temáticos, será realizada tendo por base o Relatório consolidado pela Comissão Especial Temática e de Relatoria, contendo as propostas de diretrizes emanadas das Conferências Estaduais, que deverão ser debatidas e deliberadas no próprio grupo.

Parágrafo $1^{\circ}$ - Estarão disponíveis nos grupos a Memória das deliberações de todas as conferências estaduais, para eventuais consultas.

Art. $12^{\circ}$ - As propostas discutidas nos grupos, depois de sistematizadas, deverão ser entregues à Comissão Especial de Relatoria pelas(os) relatoras(es) dos grupos até as 21:00 horas do dia 16/07/2004.

CAPÍTULO VI

DAS PLENÁRIAS E RELATÓRIO FINAL

Art. $13^{\circ}$ - A Plenária de Abertura terá como função aprovar o Regulamento da I Conferência Nacional de Políticas para as Mulheres e deliberar sobre eventuais recursos. A Plenária Final deverá debater e votar as propostas de Diretrizes já apreciadas pelos Grupos Temáticos e as moções apresentadas.

Art. $14^{\circ}$ - Participarão das Plenárias:

a) as(os) delegadas(os), com direito a voz e voto;

b) as(os) convidadas(os) com direito a voz

c) as(os) observadoras(es). 
Art. $15^{\circ}$ - As sessões plenárias da I CNPM serão coordenadas por uma mesa constituída por integrantes da comissão organizadora ou pessoas por ela indicadas.

Parágrafo Único - Caberá à mesa:

a) informar ao plenário o número de delegadas(os), convidadas(os) e observadoras(es) inscritas(os) na Conferência.

b) encaminhar para aprovação o Regulamento Interno da Conferência.

c) conduzir os trabalhos das plenárias.

Art. $16^{\circ}$ - A sistemática dos trabalhos da Plenária Final da I CNPM se dará da seguinte forma:

a) Apreciação dos relatórios consolidados por eixo.

b) Apreciação das moções.

Parágrafo $1^{\circ}$ - Caberá ao plenário a aprovação das propostas encaminhadas para votação, sendo aprovadas as que obtiverem 50\% (cinqüenta por cento) mais 1 (um) dos votos das(os) delegadas(os) presentes mediante apresentação do crachá.

Parágrafo $2^{\circ}$ - As propostas que obtiveram aprovação nos quatro grupos do mesmo eixo temático, serão consideradas aprovadas pela conferência, mediante referendo do plenário.

Parágrafo $3^{\circ}$ - As propostas aprovadas em 1 (um) ou mais grupos do mesmo eixo temático e as não aprovadas, mas que obtiverem no mínimo de $20 \%$ da votação nos grupos, serão deliberadas em plenário, com o seguinte encaminhamento:

a) as propostas apresentadas em plenário e não destacadas serão consideradas aprovadas.

b) as propostas destacadas terão uma intervenção a favor e uma intervenção contra, com o tempo máximo de 3 (três) minutos para cada. Caso o plenário não se sinta devidamente esclarecido, será aberta uma nova rodada de intervenção, sendo uma a favor e outra contra.

c) após a discussão, serão submetidas à votação no plenário e aprovadas aquelas que obtiverem 50\% (cinqüenta por cento) mais 1 (um) dos votos das(os) delegadas(os) presentes.

Art. $17^{\circ}$ - As moções serão exclusivamente apresentadas por delegadas(os), devendo ser de âmbito ou repercussão nacional e devem ser encaminhadas, por escrito, à 
Secretaria da I Conferência Nacional de Políticas para as Mulheres, até às 19h do dia 16.

Parágrafo $1^{\circ}$ - Cada moção deverá ser assinada por, no mínimo, 200 (duzentas) delegadas (os).

Parágrafo $2^{\circ}$ - A Comissão Especial de Relatoria organizará as moções recebidas, classificando-as e agrupando-as por tema.

Parágrafo $3^{\circ}$ - Em caso de divergência, haverá uma intervenção a favor e uma contra, de no máximo 3 (três) minutos cada.

Parágrafo $4^{\circ}$ - As moções serão apreciadas após a votação das propostas de diretrizes. Serão aprovadas as que obtiverem 50\% mais 1 (um) dos votos das presentes.

Art. $18^{\circ}$ - A redação do Relatório Final, a cargo da Comissão Especial de Relatoria, coordenada pela Secretaria Especial de Políticas para as Mulheres, será elaborada em até 45 (quarenta e cinco) dias após o término da I Conferência Nacional de Políticas para as Mulheres.

Art. $19^{\circ}$ - 0 Relatório Final será referendado pelo Conselho Nacional dos Direitos da Mulher - CNDM, antes de sua divulgação, respeitando-se a aprovação da Plenária Final da I Conferência Nacional de Políticas para as Mulheres.

CAPÍTULO VII

DISPOSIÇÕES GERAIS

Art. $20^{\circ}$ - Será assegurado pelas mesas das plenárias, o direito a manifestações "PELA ORDEM" das(os) delegadas(OS), sempre que quaisquer dos dispositivos deste regulamento não estiverem sendo observados.

Parágrafo Único - As "QUESTÕES DE ORDEM" não serão permitidas durante o regime de votação.

Art. $21^{\circ}$ - Serão conferidos certificados de participação da I Conferência Nacional de Políticas para as Mulheres a todas (os) as (os) participantes: integrantes da Comissão Organizadora, das Comissões Especiais, delegadas (os), convidadas (os) obser- 
vadoras (es), expositoras (es) e relatoras (es), especificando a condição de participação na Conferência.

Art. $22^{\circ}$ - Os casos omissos neste Regulamento serão resolvidos pela Comissão Organizadora. 


\section{Homenagem às mulheres brasileiras}

Na solenidade de Abertura da I Conferência Nacional de Políticas para as Mulheres, quatorze mulheres foram homenageadas. Seis delas (Rose Marie Muraro, Heloneida Studart, Elizabete Teixeira, Ruth de Souza, Ana Montenegro e Mãe Estela) não puderam comparecer por motivos imperiosos.

\section{Perfil das Homenageadas}

\section{Raimunda Gomes da Silva - Raimunda dos Cocos}

Filha de lavradores pobres, natural do Maranhão, Raimunda não estudou e se casou aos 18 anos. Sozinha, criou seus seis filhos trabalhando como lavradora. Conseguiu valorizar as muIheres em uma das regiões mais machistas do país, salientando a importância do trabalho das quebradeiras de coco babaçu para a renda familiar. Fundou a Federação Interestadual das Quebradeiras de Coco e a Associação das Quebradeiras de Coco. É uma grande liderança entre as trabalhadoras rurais.

\section{Gracíliana SelestinoWakanã}

Gracíliana Selestino Wakanã reside na Aldeia Boqueirão, do povo indígena Xucuru-Kariri, da cidade de Palmeira dos Índios - Alagoas, sendo uma das mais atuantes líderes do movimento em defesa do povo indígena, em especial das mulheres indígenas. É uma das primeiras mulheres indígenas a participar do movimento feminista.

\section{Zuleika Alambert}

Zuleika Alambert foi deputada pelo partido comunista nos anos 40. É feminista, escritora e política. Exilou-se no Chile e na França durante a ditadura militar. Em Paris, foi fundadora do grupo de mulheres brasileiras na capital francesa. Recebeu o título de cidadã paulista em 1986 graças à sua militância. Possui livros publicados no Brasil e no exterior, entre eles "Uma jovem brasileira na URSS".
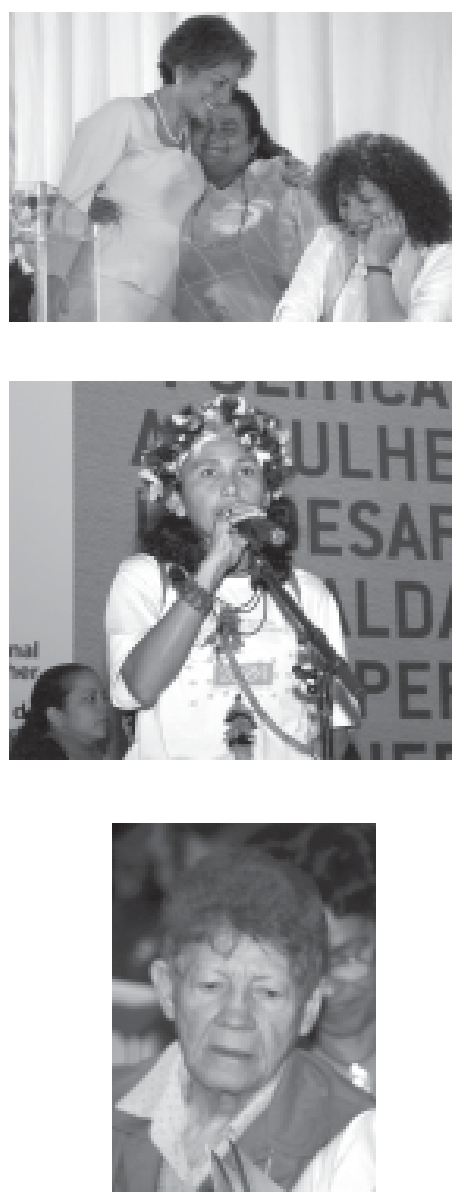

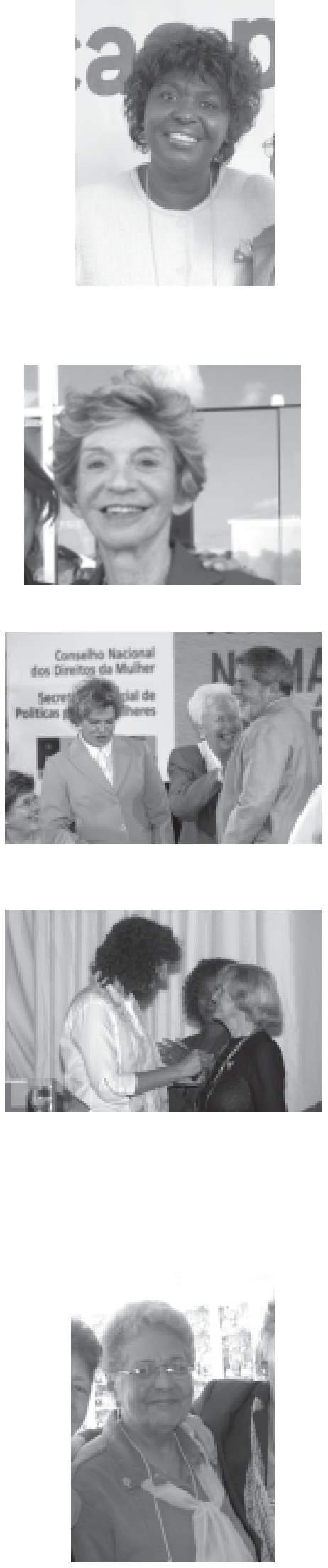

\section{Benedita da Silva}

A primeira senadora negra no Brasil é atualmente um símbolo para mulheres, homens e crianças negros. Benedita da Silva venceu todas as adversidades e, determinada a seguir uma carreira política, foi eleita vereadora, deputada federal, senadora, vice-governadora e governadora do estado do Rio de Janeiro. Foi também Secretária Especial de Assistência Social do governo Luiz Inácio Lula da Silva.

\section{Heleieth Saffioti}

Socióloga, professora, pesquisadora, Heleieth dedicou seu conhecimento a pesquisar e escrever sobre a mulher. Com dez livros publicados e centenas de ensaios no mundo inteiro, é a primeira teórica da questão da violência contra a mulher.

\section{Clara Charf}

Cidadã militante, viúva de Carlos Mariguella, viveu exilada em Cuba por nove anos e hoje é membro do Conselho Nacional dos Direitos da Mulher. Integrante da Secretaria Nacional de Mulheres do PT é também coordenadora do Comitê Brasileiro 1000 Mulheres para o Prêmio Nobel da Paz de 2005.

\section{Enid Backes}

Gaúcha e socióloga, Enid foi militante do movimento estudantil, do movimento feminino pela anistia e de movimentos populares. Atuou também na luta sindical, como dirigente da Associação Gaúcha dos Sociólogos. Participou da fundação da primeira Coordenadoria da Mulher no Rio Grande do Sul.

\section{Lenira Carvalho}

Nascida en 1932, em um engenho alagoano, Lenira tem origens humildes que não a pouparam do destino de ser empregada doméstica.

Por volta de 1962 formou um grupo de domésticas para discutir os problemas da categoria. Durante o Golpe de 1964 teve sua casa invadida e foi presa. Dada a repressão ao movimento, retomou a sua profissão, sem deixar de lado o propósito de ajudar a construir uma associação de empregadas domésticas no Recife, sonho que se realizou em 1979. A Associação das Empregadas Domésticas da Área Metropolitana do Recife virou Sindicato em 1988. Com muita garra pelas reivindicações de sua categoria durante a Constituinte de 1988, chegou-se ao resultado histórico de conquistas trabalhista. 


\section{Rose Marie Muraro}

Rose Marie nasceu em 11 de novembro de 1930, praticamente cega. Formou-se em Física e Economia e graças a sua forte personalidade teve determinação suficiente para se tornar uma das mais brilhantes intelectuais de nosso tempo. Escritora e editora, publicou diversos livros polêmicos, contestadores e inovadores, do ponto de vista dos valores sociais modernos. Nos anos 70, foi uma das pioneiras do movimento feminista no Brasil. Suas idéias se refletem em sua vida pessoal: aos 66 anos, ela desafiou os seus próprios limites, quando recuperou a visão por meio de uma cirurgia e viu seu rosto pela primeira vez. Rose considera o movimento de mulheres o mais importante movimento social do século no mundo inteiro.

\section{Heloneida Studart}

Nascida em 09 de abril de 1932, em Fortaleza, no Ceará, Heloneida, aos 16 anos, já publicava crônicas no jornal "O Nordeste" que provocavam polêmicas entre parentes e amigos. Aos 18 anos veio para o Rio de Janeiro com o seu primeiro manuscrito debaixo do braço. 0 romance seguinte - "Dize-me o teu nome" - ganhou os prêmios Orlando Dantas e o da Academia Brasileira de Letras. No entanto, a Literatura não diminuiu sua militância política e sindical. Heloneida foi presidente do Sindicato de Entidades Culturais, em plena ditadura, de onde saiu presa. Candidatou-se a deputada estadual, em 1978, pelo antigo MDB e foi eleita com 70 mil votos. Heloneida é uma feminista histórica e fundadora do Centro da Mulher Brasileira.

\section{Elizabeth Teixeira}

Elizabeth Teixeira nasceu no município de Sapé, Paraíba, em 13 de fevereiro de 1925, em uma família de sete irmãos. No dia 02 de abril de 1962, quando três policiais, vestidos de vaqueiros, mataram o líder camponês João Pedro Teixeira, seu marido e fundador da Liga Camponesa, Elisabeth sentiu que a organização dos trabalhadores do campo não podia morrer com ele. Após o golpe de 1964, Elizabeth, mesmo perseguida, presa e ameaçada, não desistiu e continuou a luta de seu companheiro, mantendo-se à frente da Liga Camponesa. Sobreviveu como lavadeira e professora na cidade de São Rafael e, na clandestinidade, perdeu o contato com os filhos e foi dada como morta pela repressão políicca. Exilou-se em Cuba, por um período, mas recusou o convite de Fidel Castro para ir viver, com os 11 filhos, na ilha, em nome de seu compromisso com os camponeses no Brasil. Elizabeth hoje é considerada uma das grandes responsáveis pela organização dos trabalhadores rurais. 


\section{Ruth de Souza}

Ruth de Souza, uma das grandes damas da dramaturgia nacional, nasceu na cidade do Rio de Janeiro. Ruth tem mais de 50 anos de carreira artística, vividos nos palcos de teatro, estúdios de TV e sets de filmagem. Primeira brasileira a ser indicada para um prêmio internacional - o de melhor atriz, na edição do Festival de Veneza de 1954, pela sua atuação no filme Sinhá Moça Ruth de Souza disputou, também, o Leão de Ouro com artistas consagrados do cinema mundial. Na época em que começou sua carreira, o fato de ser negra era um grande obstáculo, mas, Ruth sempre foi uma pioneira. Em um período em que não havia atores negros, ela fez parte do primeiro grupo teatral importante do Brasil, o Teatro Experimental do Negro Negro. Lutou contra o racismo e combateu, com intensidade, por melhores papéis para as atrizes e atores negros em todos os meios culturais.

\section{Ana Montenegro}

Ana Montenegro é reconhecida por sua luta em defesa de seu povo e de sua terra. Militante do Partido Comunista Brasileiro (PCB) por mais de 50 anos, Ana lutou bravamente pelo restabelecimento da democracia no Brasil e, em conseqüência disso, teve a sua vida conturbada por perseguições políticas. Foi obrigada a se afastar de seu lar e de sua família por quase 20 anos de exílio. Com participação expressiva nos movimentos de mulheres, ela foi a primeira mulher a ser exilada do país. Aos 90 anos de idade, Ana ainda afirma em alto e bom tom que a sua luta continua sendo por pão, terra e trabalho e diz ainda: - um país que tem isso, tem liberdade!

\section{Mãe Estela}

Mãe Estela de Oxossi, 60 anos, baiana, ialorixá e herdeira do axé do candombléAxé Opô Afonjá, localizado no bairro de São Gonçalo do retiro, em Salvador. Mãe Estela, uma das mais respeitadas mulheres da Bahia, iniciou um importante movimento de rompimento com o sincretismo, que vem sendo seguido por várias casas. Não por sectarismo, mas para resgatar os valores negros e a religião africana e garantir a preservação dessa cultura. A casa de Mãe Estela mantém obras sociais da maior relevância para diversas comunidades na Bahia. 


\section{Perfil das Delegadas e Perspectivas de Atuação}

A SPM e o Instituto Brasileiro de Administração Municipal - IBAM - realizaram uma pesquisa durante a I Conferência Nacional de Políticas para as Mulheres para traçar 0 perfil das delegadas que participaram do evento. Responderam ao questionário $44,6 \%$ das (os) participantes.

Esta pesquisa e seus resultados serão apresentados na íntegra em publicação à parte por constituir um conjunto riquíssimo de informações.

Apresentamos alguns gráficos resultantes do trabalho realizado pelo IBAM no précredenciamento e durante a I Conferência Nacional.

Este trabalho foi elaborado pelo Núcleo de Estudos Mulher e Políticas Públicas, da Área de Desenvolvimento Econômico e Social do Instituto Brasileiro de Administração Municipal - IBAM.

Créditos:

\section{Supervisão}

Alexandre Santos

Superintendente de Desenvolvimento Econômico e Social

\section{Coordenação}

Delaine Martins Costa

Coordenadora Núcleo de Estudos Mulher e Políticas Públicas

\section{Equipe}

Marina Sidrim Teixeira

Consultoria para Metodologia de Pesquisa e Análise de Dados

Antonio Carlos Alkmim dos Reis

Consultoria para elaboração do Banco de Dados e Metodologia de Pesquisa

André Saldanha Costa

Getúlio Sérgio de Jesus Silva

Codificação dos questionários

Afrânio de Oliveira Silva

Marcia Alkmim dos Reis

Digitação dos questionários

\section{Apoio Administrativo}

Flávia da Silva Lopes 
1. Distribuição das(os) inscritas(os) na I Conferência Nacional de Políticas Públicas para Mulheres, segundo origem geográfica ou administrativa da delegação

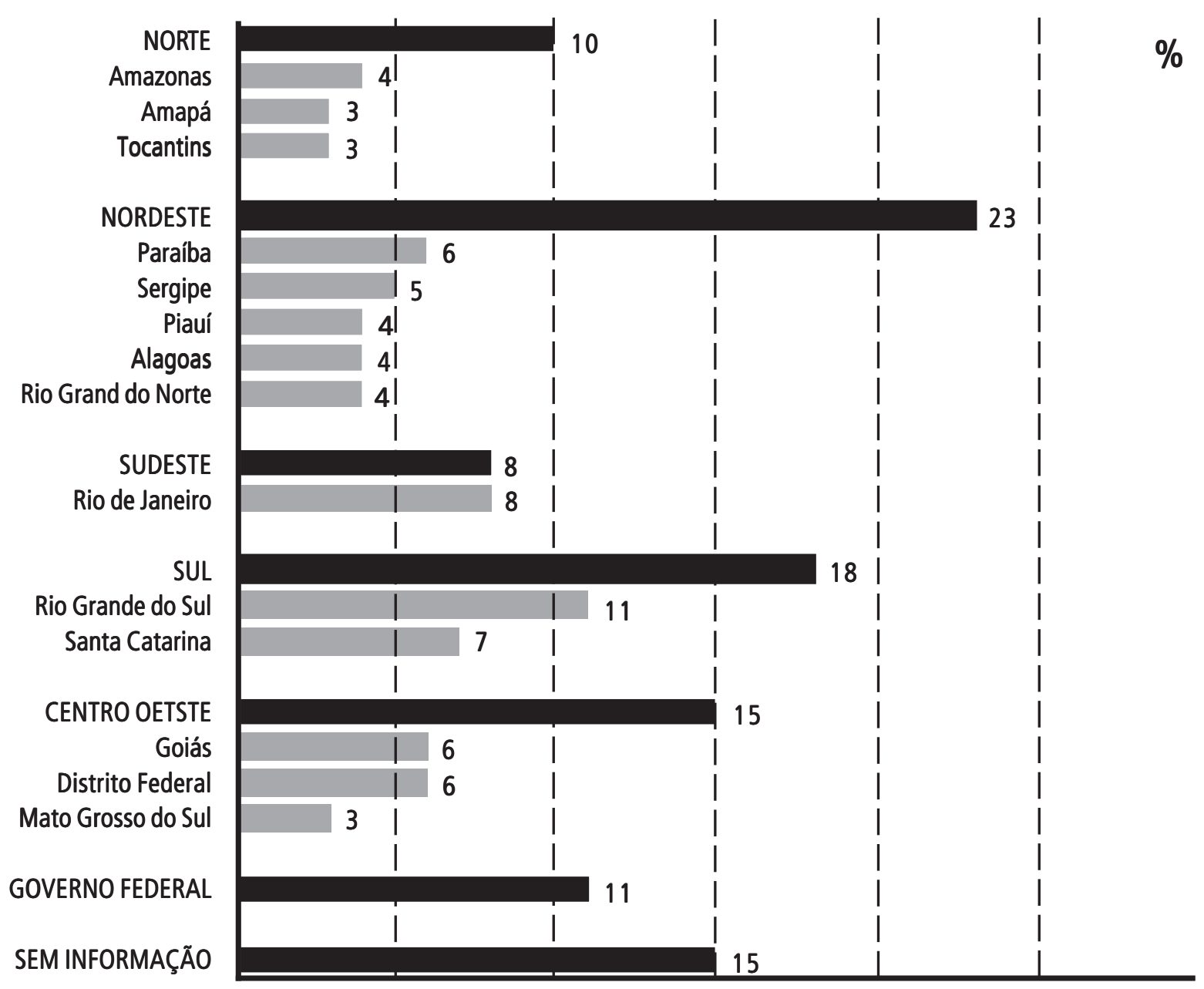


2. Distribuição das (os) inscritas (os) na I Conferência Nacional de Políticas Públicas para Mulheres, segundo características sócio-demográficas

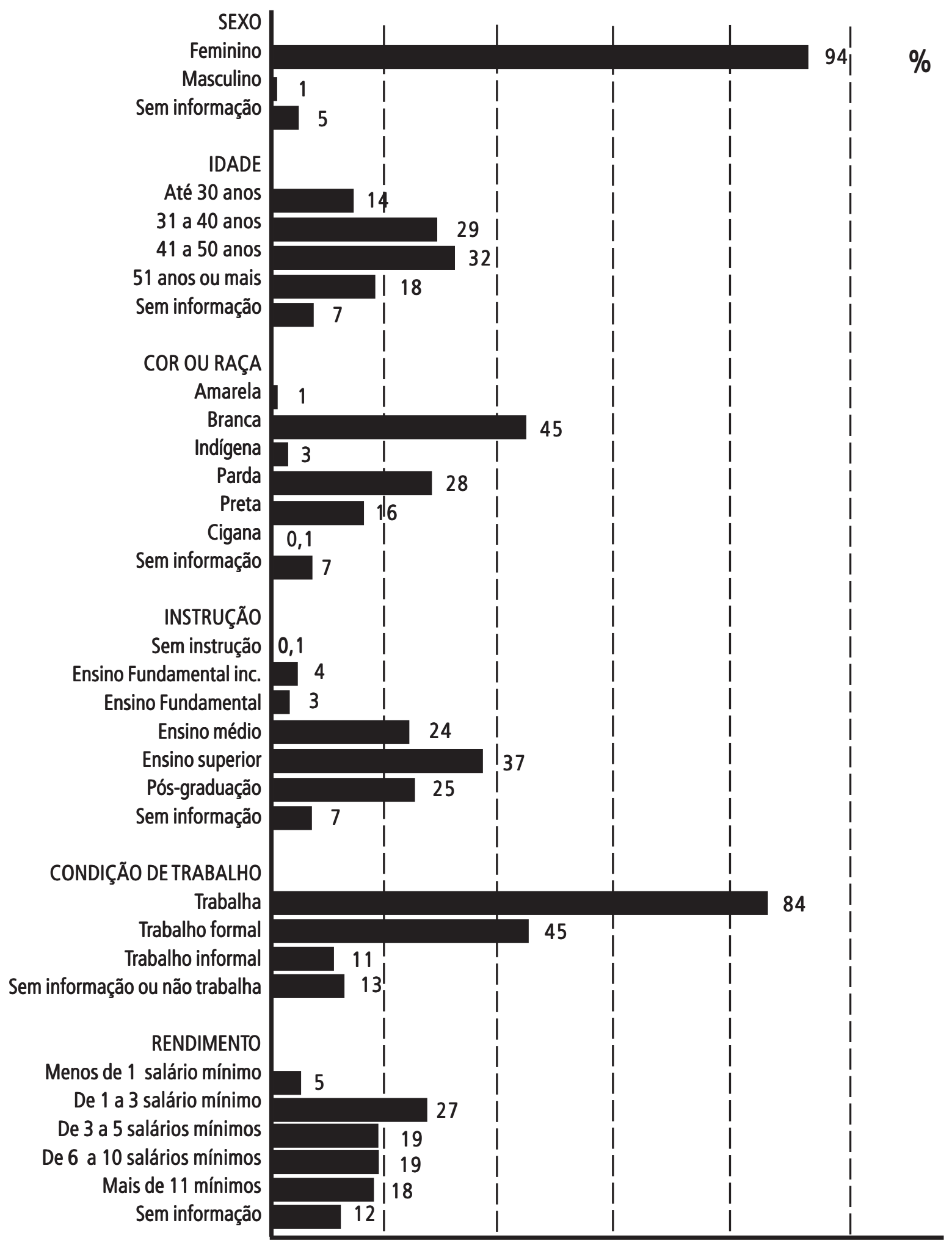


3. Distribuição das (os) inscritas (os) na I Conferência Nacional de Políticas Públicas para Mulheres, segundo características familiares e sócio-demográficas

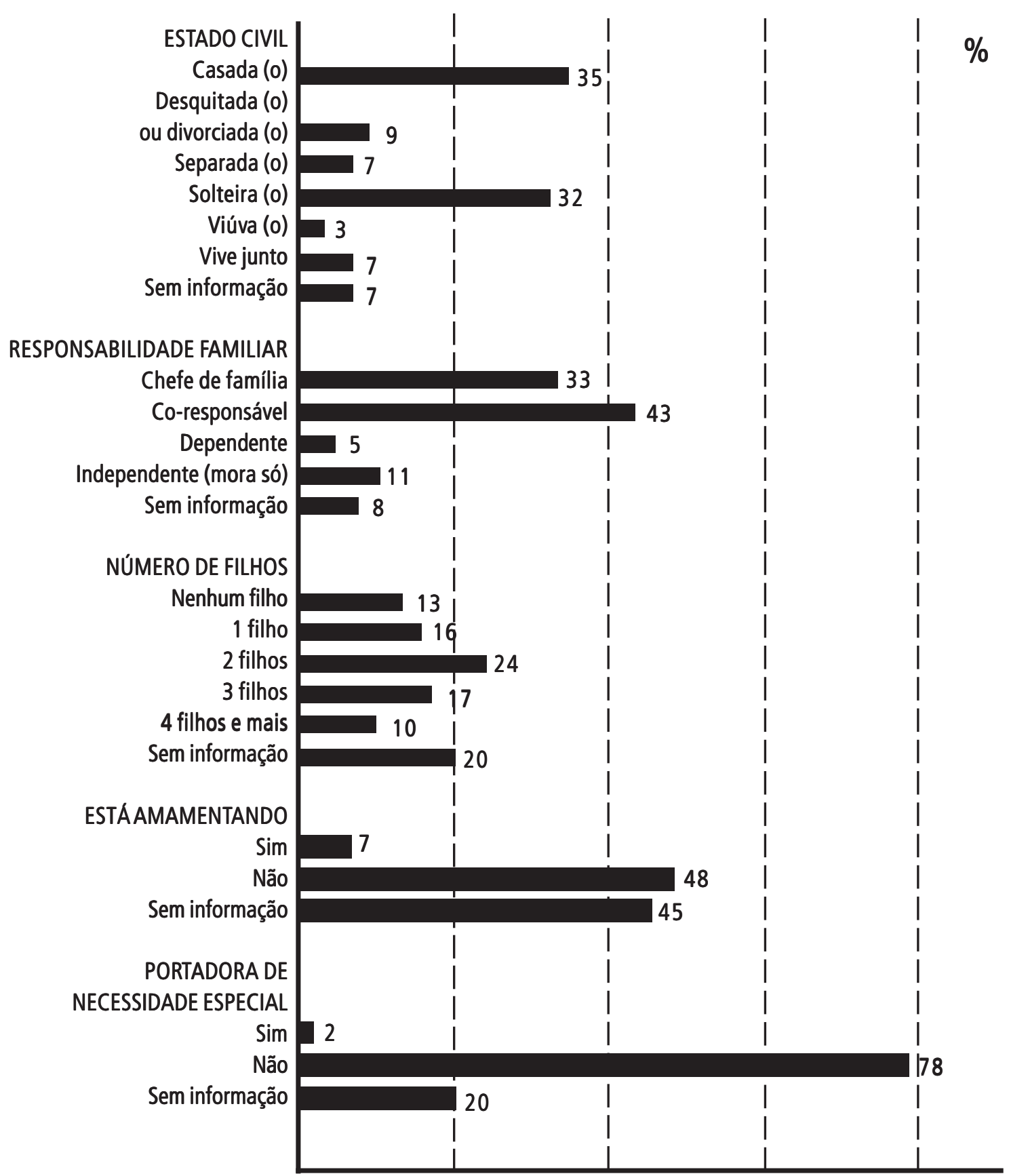


4. Distribuição das (os) inscritas (os) na I Conferência Nacional de Políticas Públicas para Mulheres, segundo características da atuação política e tipo de delegação na Conferência

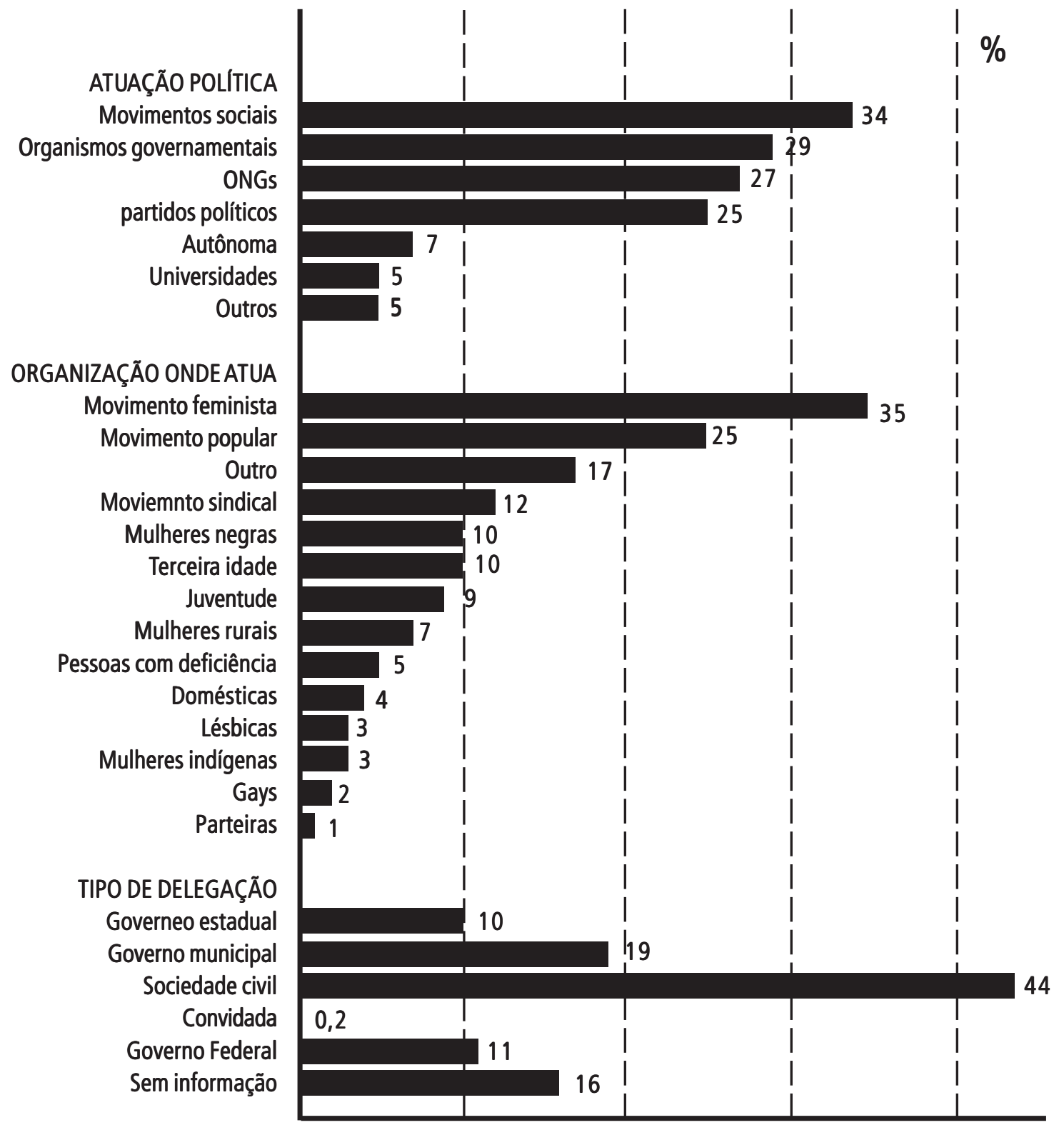


5. Distribuição das (os) inscritas (os) na I Conferência Nacional de Políticas Públicas para Mulheres, segundo a prioridade de participação nos grupos de trabalho

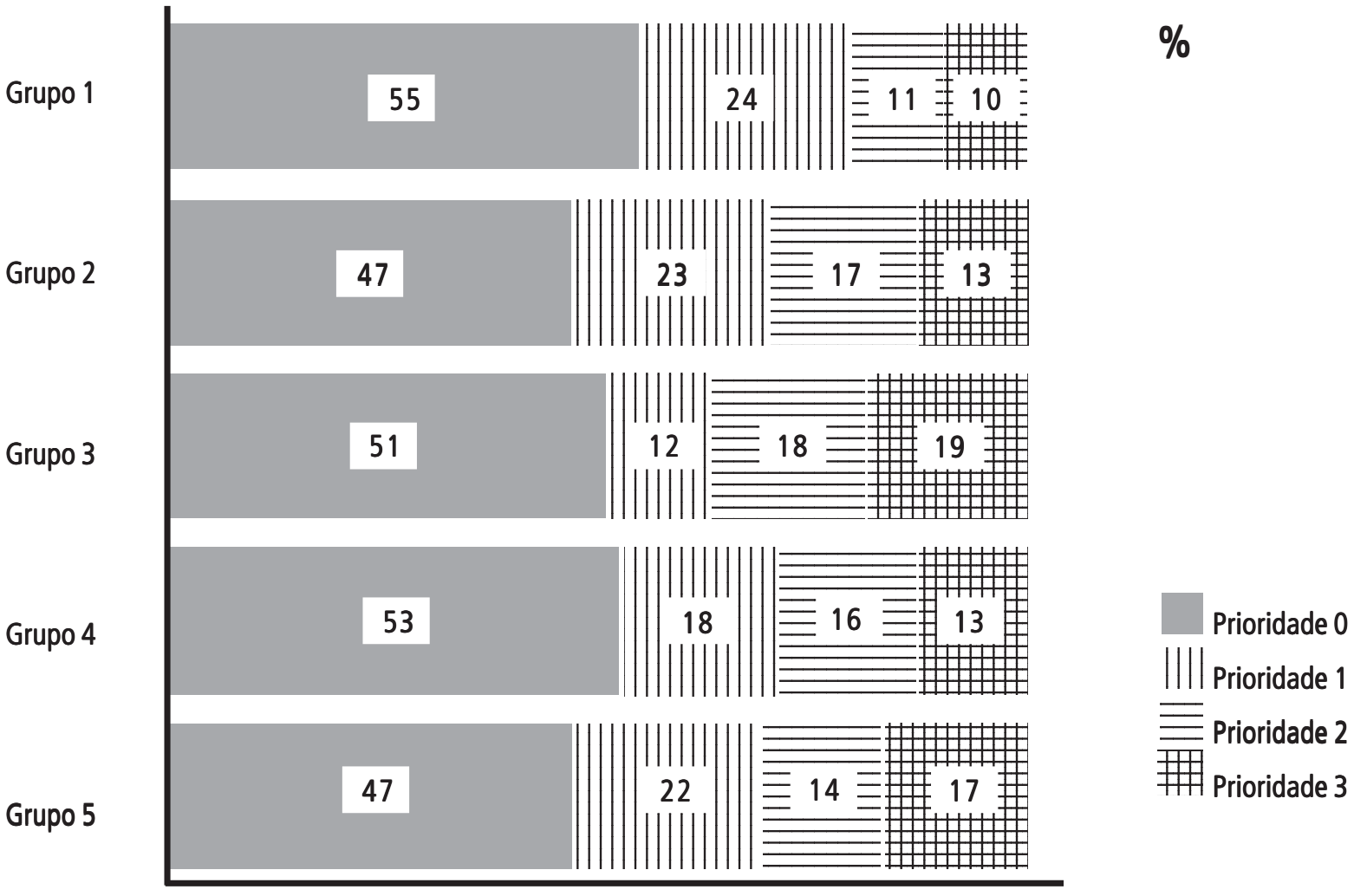




\section{Créditos}

Durante a I Conferência Nacional de Políticas para as Mulheres foi projetado o vídeo Mulheres do Brasil: presente!, realizado exclusivamente para a abertura do Evento.

0 vídeo faz uma homenagem às mulheres brasileiras, em especial a muitas delas que se destacaram na luta por seus direitos, e contou com a colaboração de diversas atrizes emulheres do Brasil.

\section{Mulheres do Brasil: presente!}

Ficha Técnica

Participação Afetiva:

Arlete Salles

Camila Pitanga

Dira Paes

Isabel Fillardis

Natalia do Vale

Ruth de Souza

Tássia Camargo

Agradecimentos Especiais:

Ana Montenegro

Benedita da Silva

Clara Charf

Heleieth Saffioti

Heloneida Studart

Mãe Estela

Raimunda dos Cocos

Rose Marie Muraro

Zuleika Alambert

Agradecimentos:

BMG

Chico Buarque de Holanda

Casa Eliane de Grammont

Cláudia Ferreira

Conceição Nascimento
EMI Music

Eunice Gutman

Fernado Brant

Gilberto Gil

Grupo Edit. Musical Arlequim

Inês Magalhães

Inês Pandeló

Intervídeo Comunicações

Ivan Lins

Maria Luiza Aboim

Miltinho

Milton Nascimento

Nilza Iraci

Universal Music

Universal Publishing

Warner Chappell

Warner Music

Direção Geral

J.A. Medeiros

Roteiro e Direção

Heitor Silva

Locução

Cristiane Vianna
Produção

Adriana Brandão

Irapuan Portugal

Fotografia e Câmera

P.C.Alves

Assistente de Câmera

Gustavo Freitas

Operador de TP

André Oliveira

Maquiagem

Cida Freitas

Edição

J.A. Medeiros

Edição em Symphony

Cláudio Nunes

Finalização

Link Digital 


\section{Patrocínios}

A realização da I Conferência Naciona de Políticas para as Mulheres contou colaborações diversas.

Em especial, destacamos as empresas que patrocinaram a Conferência pela sua sensibilidade e comprometimento com as questões da Mulher. A elas, nosso muito obrigada!

\section{$A \vee O N$}

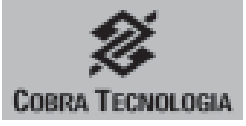

\INFRAERO

GHA PETROBRAS

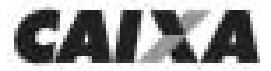

CNI

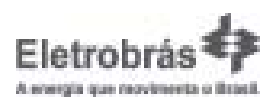

FURNAS ampuan

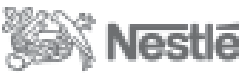

Good Food, Good Liff

senac

$\square$

ITAIPU

Distrito Federal 


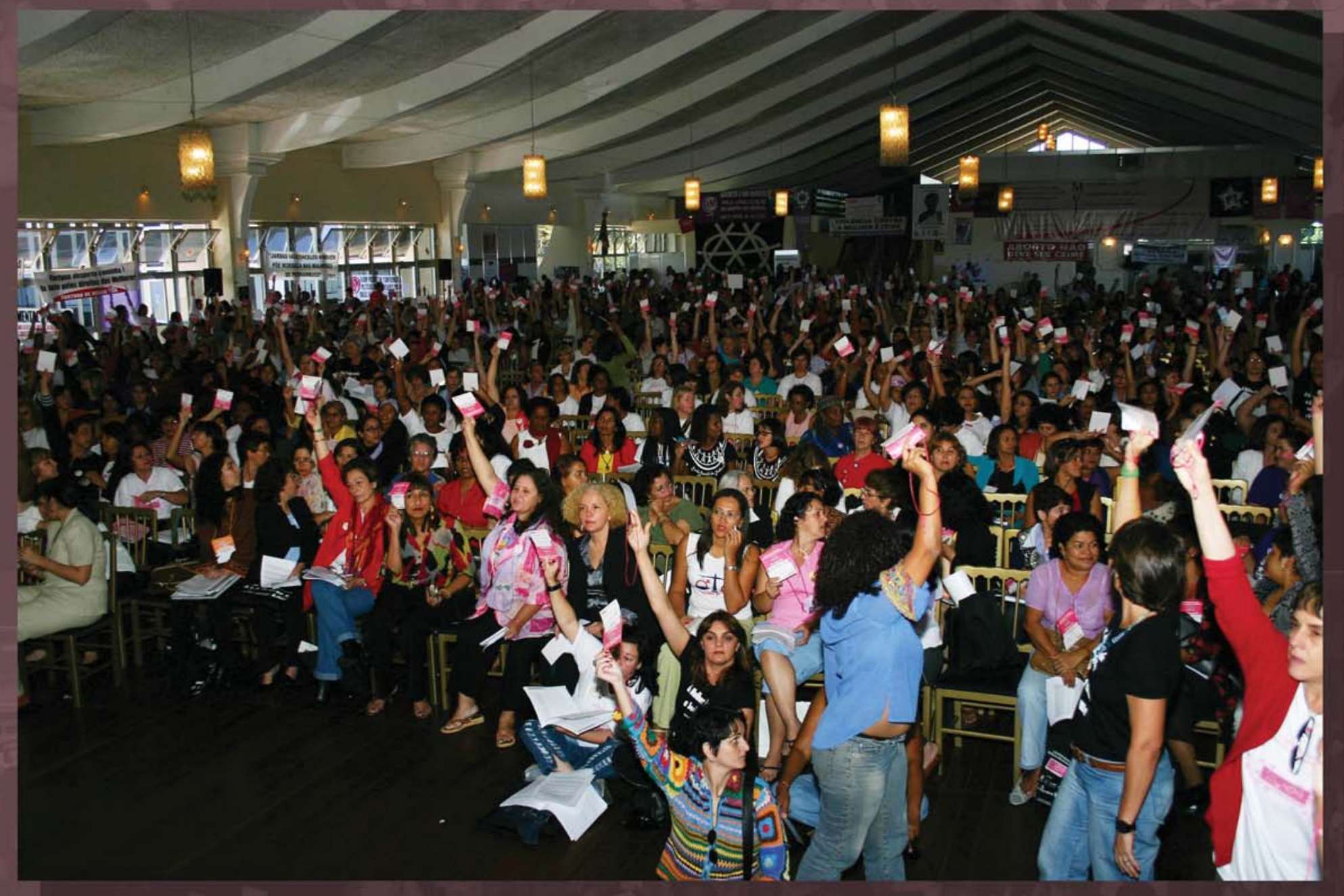

Conselho Nacional dos Direitos da Mulher
Secretaria Especial de Políticas para as Mulheres

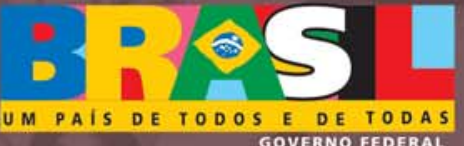

